\title{
The guciontosute.
}

UR

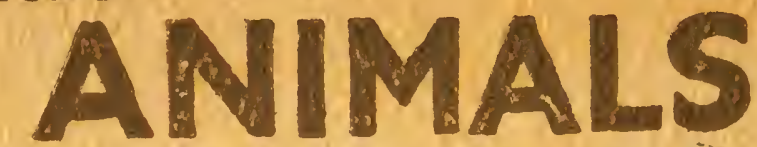

OF L

OUISIA

NA

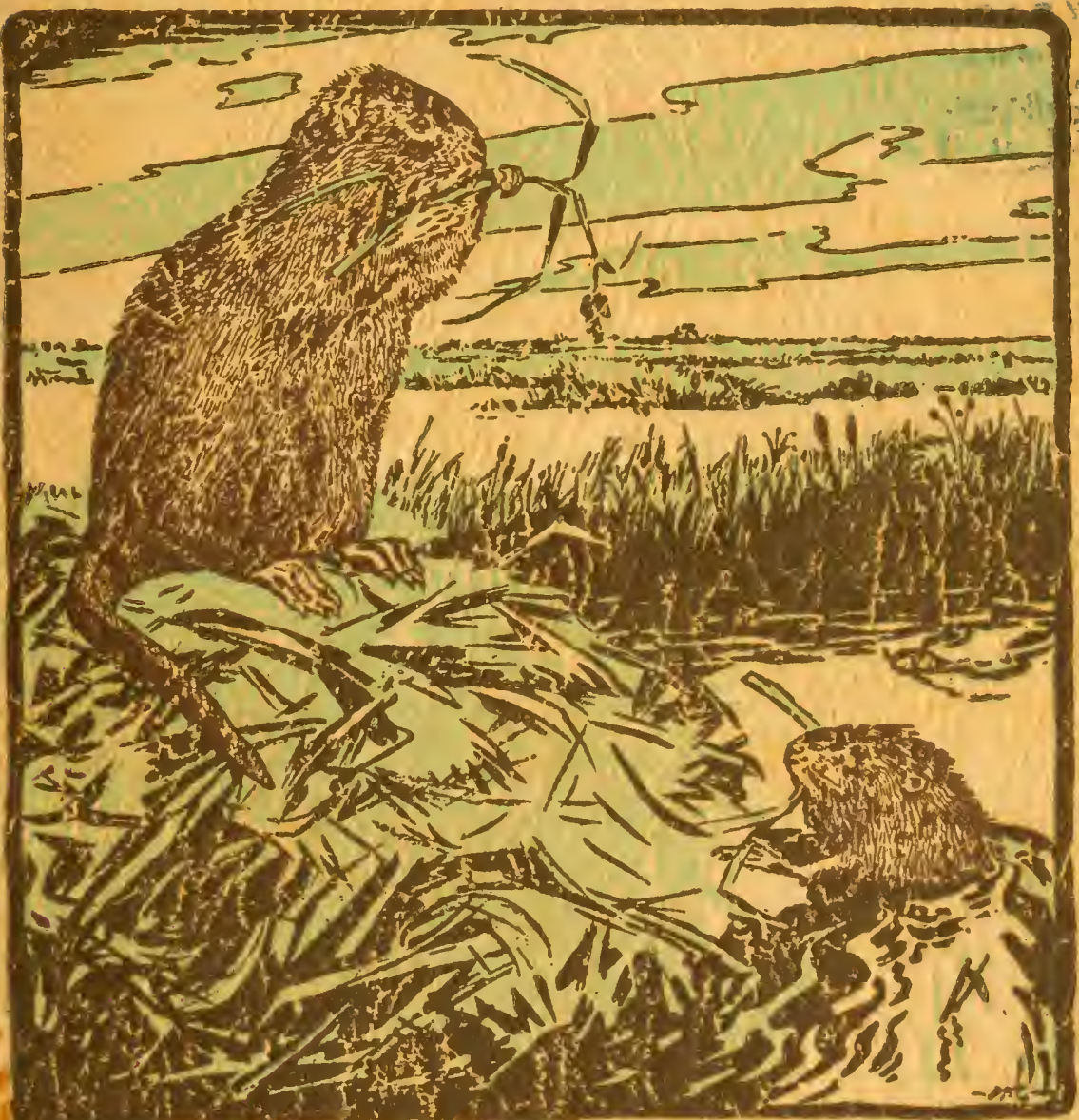

6.

BULLETIN NO. 18 REVISED

Published by the

STATE OF LOUISIANA

DEPARTMENT of CONSERVATION

NEW ORLEANS

JANUARY, 1931 


\section{MARINE BIOLOGICAL LABORATORY,}

Received July 29, 1933

Accession No. 32184

Given by.....Julian P. Scott

Place,

${ }^{*}{ }^{*}$ No book or pamphlet is to be removed from the Laboratory without the permission of the Trustees. 


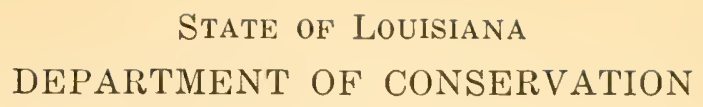

ROBT. S. MAESTRI, Commissioner

BULLETIN 18

(Revised)

\section{THE FUR ANIMALS \\ $\mathrm{OF}$ \\ LOUISIANA}
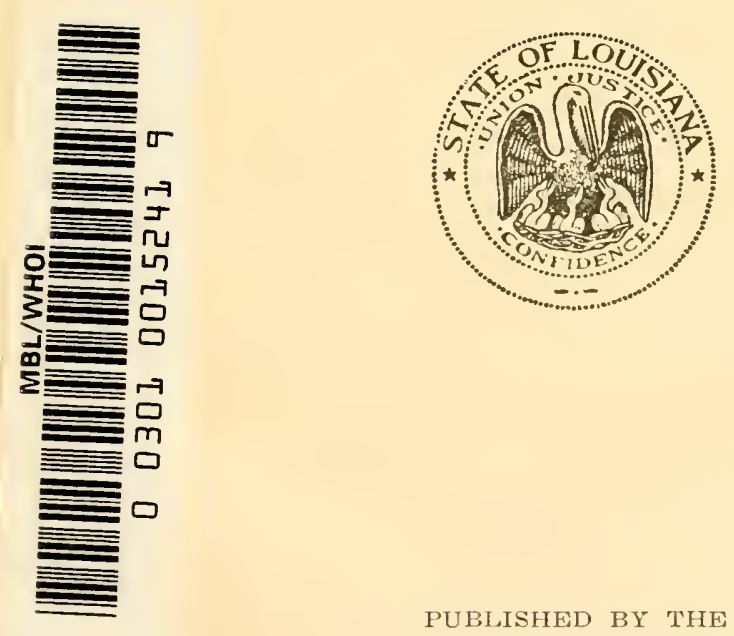

PUBLISHED BY THE

DEPARTMENT OF CONSERVATION

NEN ORLEANS COURT BUILDING

JANUARY, 1931 
THis bulletin has been prepared for free distribution to the citizens of the State of

Louisiana, who may obtain copies at the office of the Department of Conservation, 126 N. O. Court Building.

Owing to the size and expense of printing this bulletin, free distribution by mail cannot be undertaken. Those who wish to obtain copies by mail should send 25 cents in stamps to the office of the Department of Conservation to cover mailing costs. 
PERSONNEL

ROBERT S. MAESTRI

Commissioner

JAMES P. Guillot

Secretary

DR. J. A. SHAW

Director, Division of Mines and Minerals

V. H. SONDEREGGER

Forester and Director, Division of Forestry

ARMAND P. DASPIT

Director, Division of Fur and Wild Life

JAMES N. MCCONNELL

Director, Division of Oysters and Water Bottoms

J. B. Dauenhauer, JR.

Director, Enforcement and Fisheries Division

Philip A. Gehlbach

Superintendent of the Department's Flotilla

RICHARD B. OTERO

Director, Bureau of Education

Mrs. Estelle Cottman

B. A. in Education

Assistant Director, Bureau of Education

JAMES NELSON GOWANLOCH

Chief Biologist of the Bureau of Scientific

Research and Investigation

WM. G. RANKIN

Auditor of the Department

and

Acting Director, Division of Statistical, Biological

Research and Information 
This volume is a revised edition of the bulletin published in the year 1928 by the Louisiana Department of Conservation and compiled under the direction of the Department by Stanley C. Arthur, then Director of the Wild Life Division. 


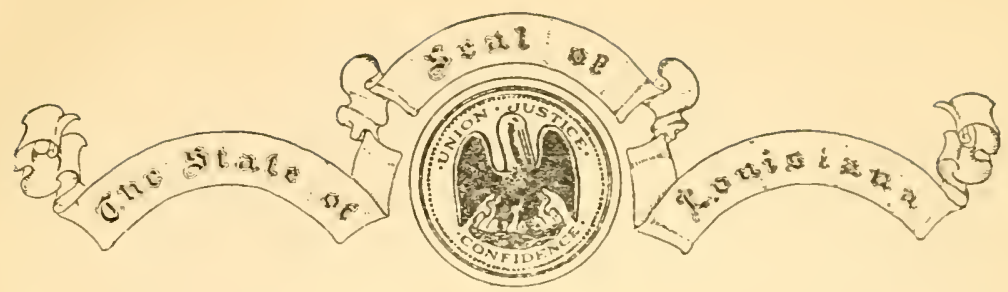

THE FUR ANIMALS OF LOUHSIANA

$\mathrm{T}$

IHE ANNUAL FUR CROP of Louisiana is worth six million dollars and more to the trappers of the state. The taking of fur animals for their pelts is one of the more important vocations of many thousands of our citizens during the winter months. The fur industry is a very important one not alone to the trapper, buyer, dealer and garment manufacturer but to those who wear furs.

Unless the fur animals are rigidly conserved, unless proper laws are enacted for their protection during the reproduction periods of the year, unless suitable habitats and marsh areas are preserved, unless those who take these animals in their traps and those who deal in the pelt, recognize the soundness of open and close seasons, the time is not far distant when most of our fur animals will be exterminated, and furs worn only by the well-to-do.

It is to direct attention to the great commercial importance of our fur animal fauna, and to emphasize the necessity of maintaining the supply, as well as to give those interested a life history of the several species of mammals that go to make up the fur animal fauna of Louisiana.

This bulletin has been in process of compilation for more than three year's and it is believed that the information it contains will aid materially in bringing about $a_{1}$ condition in Louisiana that will make the fur animals found here a constant source of profit.

We are justly proud of the position that Louisiana holds as the chief fur-producing territory on the North American continent for, directly or indirectly, fur contributes to the support and comfort of a large proportion of our population, and the industry is one of the natural resources of the state that the Department of Conservation is charged with, under the constitution, consel'ving, protecting and upbuilding.

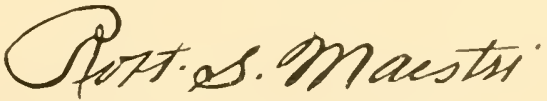

Commissioner of Conservation. 


\section{TABLE OF CONTENTS}

Chapter One

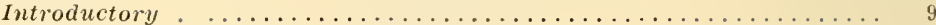

CHAPTER TWO

The Early Fur Trade of America................... 15

Chapter THREe

The Early Fur Trade of Louisiana.................. 19

CHAPTER FOUR

Our First Natural History Writers.................. 33

Chapter Five

Louisiana Indian Animal Stories.................... 39

Chapter Six

The Fur Industry of Today.................... 47

CHAPTER SEVEN

Furs as a Source of State Revenue.......................... 73

CHAPTER EIGHT

The Opossum ................................... 77

Chapter Nine

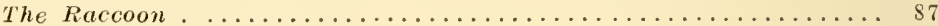

The Ring-tailed Cat........................ $9 \mathrm{~s}$

Chapter TeN

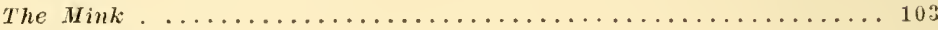

Chapter Eleven

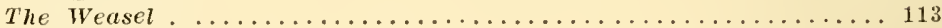

Chap'Ter Twelve

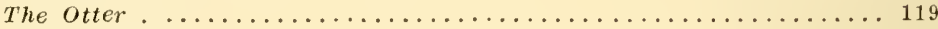

Chapter 'THIRTEEN

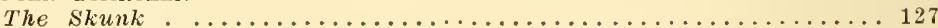

Chapter Fourteen

The Little Spotted skunk "Civet Cat")................. 136

Chapter Fiftein

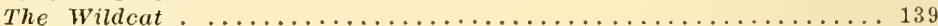

Chapter Sixteen

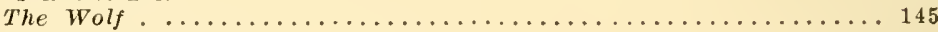

Chapter SEventeen

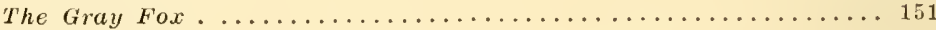

CHAPTER EIGHTEEN

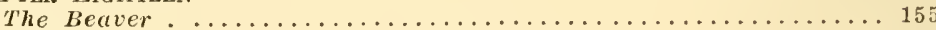

Chapter Nineteen

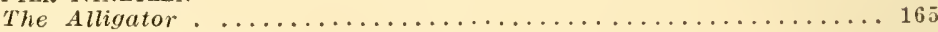

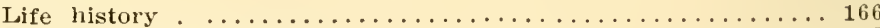

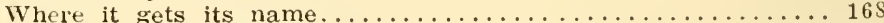

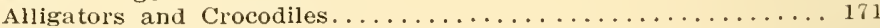

Food $\ldots \ldots \ldots \ldots \ldots \ldots$

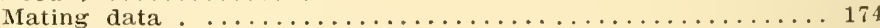

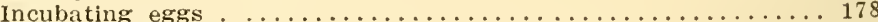

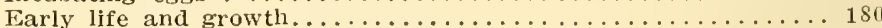

Gator hunting ........................... 184

Chapter T'WENTY

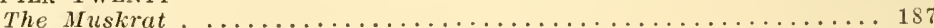

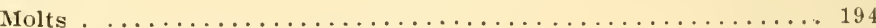

Key to North American Muskrats................... 195

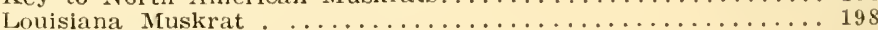

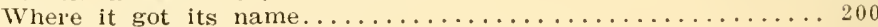

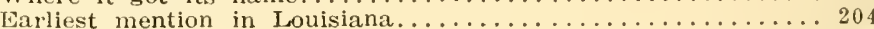

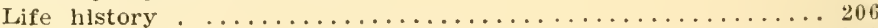

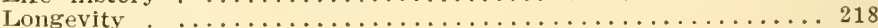

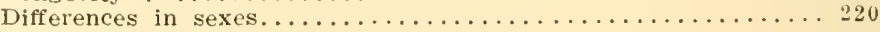




\section{CONTENTS-Continued}

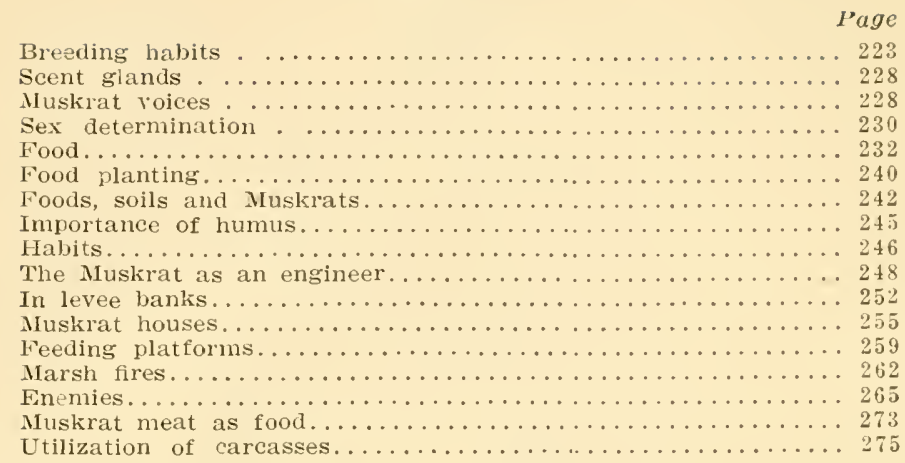

Chapter TWENTy-ONE

The Field Biologist's Report.................... 277

Fighting .............................. 280

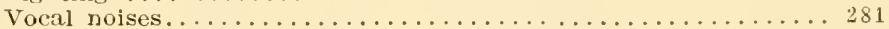

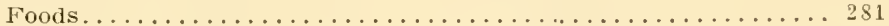

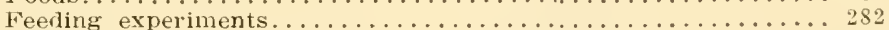

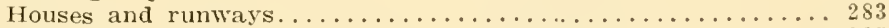

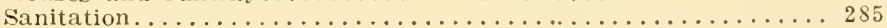

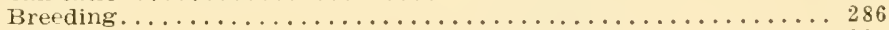

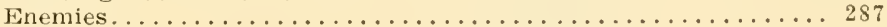

CHAPTER TWENTY-TWO

'Rat Ranching............................ $28 s$

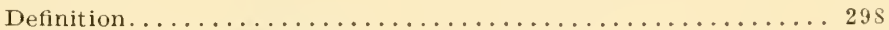

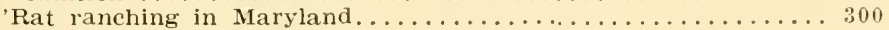

Maryland's "Black" Muskrat...................... 30 2

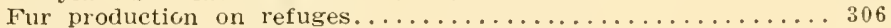

Delacroix Island region........................... 313

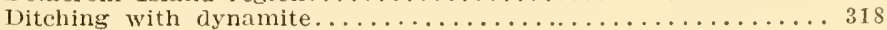

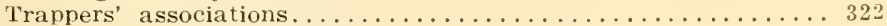

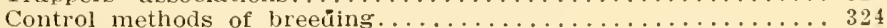

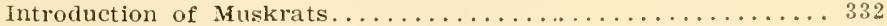

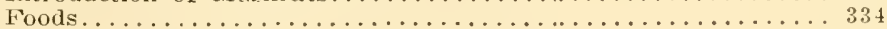

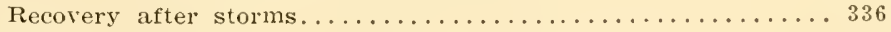

CHAPTER TWENTY-THPEE

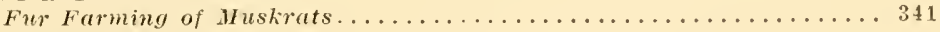

Chapter TWENTy-Four

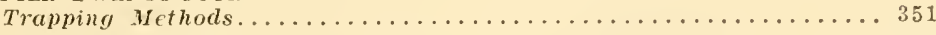

Chapter TWENTY-Five

Ecology of the Louisiana Muskrat lands.................. 365

CHAPTER 'TWENTY-SIX

The Different Huskrat Furs...................... 372

Chapter TwENTy-SEven

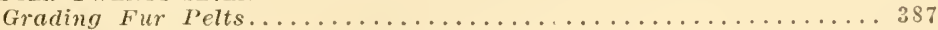

Chapter Twenty-eight

Skinning, Curing and Shipping Furs..................4 403

APPENDIX-

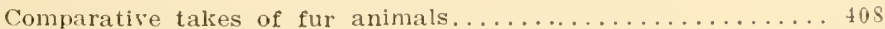

Fur production of Canada...................... 413

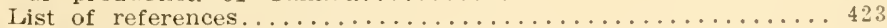

Systematic list of Louisiana fur animals.............. 429

The Creating of Wild Iife Refuges in Louisiana........... 439 


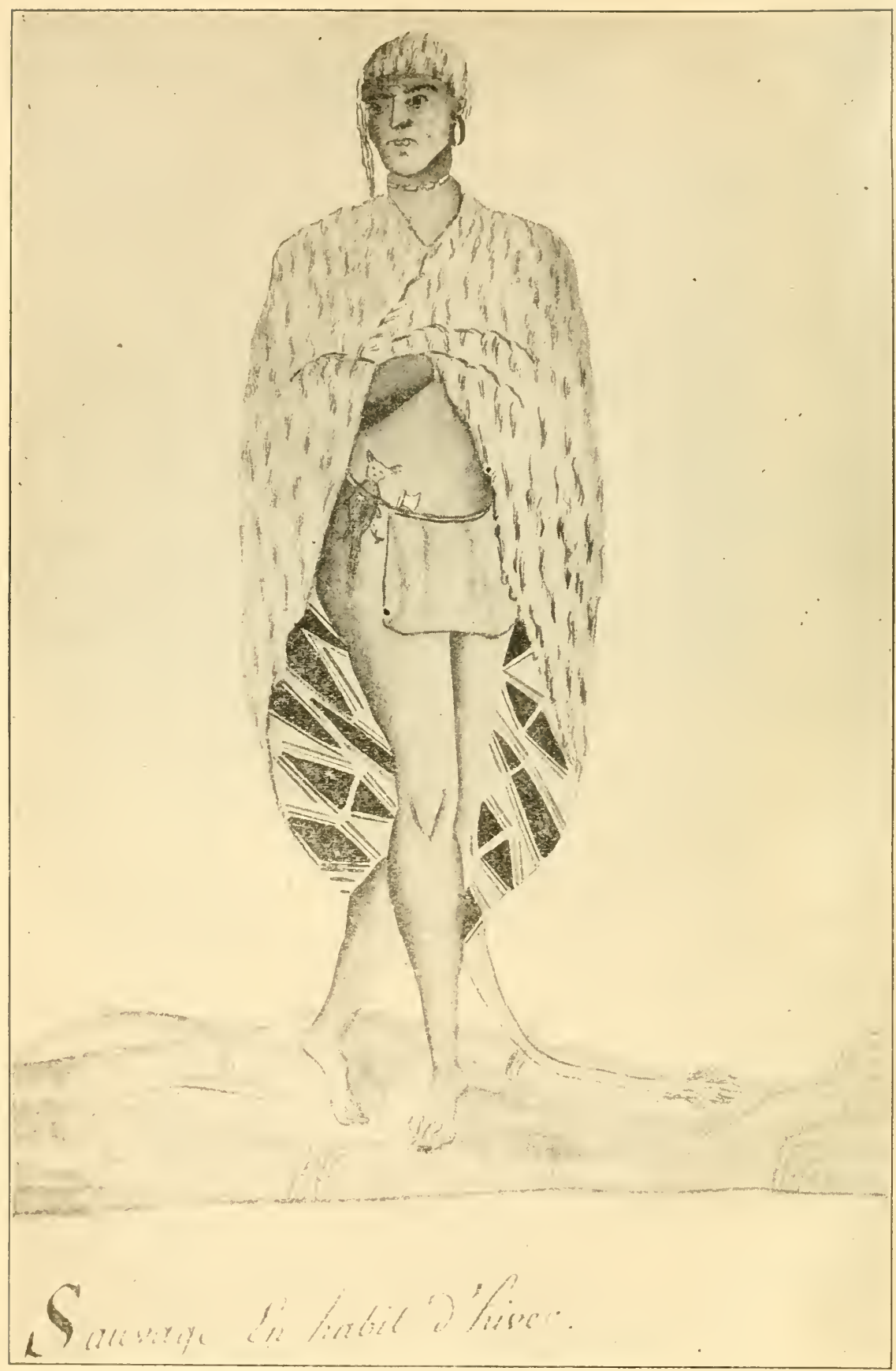

The first Louisiana fur-wearer. An Atakapa Indian wearing a buffalo robe, decorated on the innerside by designs in black and red. From a painting made in New Orleans about 1732 by A. De Batz. Reproduced through the courtesy of David l. Bushnell, Jr. 


\section{CHAPTER ONE}

\section{INTRODUCTORY}

$\mathrm{T}$

HE TAKING OF FURS for clothing and the trading in pelts is undoubtedly the oldest industry in the world. This activity goes back many thousands of years into the dim reaches of the Stone Age when the cave man, crude hatchet or club in hand, killed the beasts of the field so that he and his family could have covering during the rigorous seasons of the year, and one may be safe in claiming that the Neanderthal Woman was the first to choose the handsomest pelt for keeping her flesh warm and for enhancing her physical charms.

It is known from cave pictures, that the Cro-magon people wore animal pelts and, if styles in habiliments were in vogue in that time, undoubtedly our antedeluvian ancestors had their favorites among the variety of haired skins that could be worn. Turning our attention to the age known as the Garden of Eden period, we find in the third chapter of Genesis, twenty-third verse, that Adam and Eve, at the behest of the Creator, wore the skins of the beasts of the field following their expulsion-thus creating a change of style from the vegetable kingdom to that of the animal.

The Babylonians, Assyrians, Greeks, and Romans wore furs, history tells us. Mention is made that Queen Semiramis of Babylon in 2182 B. C. brought 8,000 tiger skins to her country at the close of her campaign in India. Furs were mentioned by Herodotus.

In Biblical and pre-Biblical times, Armenia was the principal fur center, its pelts being sent there from northern Asia and Persia and traded to Greece, and ermine, the fur insignia of royalty, is a word derived from Armenia, so it is claimed by etymologists.

Furs were worn in Egypt, its early records show; Chinese writings testify to the wealth they secured from furs three thousand and more years ago, and the people of 
Western Europe and England wore furs for protection and covering, until the Roman invasion introduced the use of fabrics. After the retirement of the Romans, the Europeans north of Italy returned to the wearing of the skins of wild animals. For a number of generations prior to the Norman conquest in 1066 homespun was worn by the nobility but the poor classes used furs and sheepskin for raiment.

During the middle ages the men of Europe wore furs exclusively, but they were denied to woman, and it was not until the reign of Edward III of England that furs became fashionable for women, and they have remained so ever since.

As native furs were scarce in England and their use confined to the wealthy, and in order to meet the demand for coats made from pelts of creatures of the wild, Prince Rupert in 1670 formed the famous Hudson's Bay Company known then as "The Governor and Company of Adventures of England trading into Hudson's Bay," to export pelts of fur animals from the New World, principally that section of the continent we now call Canada, and this company is still in existence. Other companies preceded and followed the Hudson's Bay Company into the fur business in America and this section of the world became famous for the production of the finest furs worn by the people of the civilized world.

Furs have had their place in myth, song and ancient legend and it may come as a surprise to many to learn that Cinderella's slipper was not made of glass, as many of us were informed by fairy story books, but was, in fact, a fur slipper.

The original of Cinderella and her famous foot-gear, which had its origin in Egyptian folk-lore, was written by a noted French author named Perrault under the title "Cindrillion" (little cinder girl) and although he wrote that the little heroine dropped on the steps of the palace a pantoufle en vair, (fur slipper) the printer set the type so as to read en verre, and verre in French is "glass," while vair, having the same pronunciation, is a fur represented in 
silver and azure in heraldric design and supposed to represent the fur on squirrel bellies worn only by the nobility. So, a typographical error has been responsible for the belief long held by English and American children that the slipper the Prince found, which fitted only Cinderella's foot and not those of her ugly and wicked step-sisters, was made of a fragile substance such as glass and not of a durable material such as fur.

Aside from being the oldest industry known to mankind, the taking of furs has been instrumental, as has no other factor, in the advancement of the world and its people. On the North American continent, the Eskimos and the Indians of the far north, the savages of the central part of the continent, as well as the aborigines of the Gulf Coast, used furs as a covering to keep their flesh protected from the piercing winds and bitter colds of the winter months.

The securing of furs has caused wildernesses to be explored; has led to wars and pillage; and has even changed the maps of the world. There is no more romantic part of our early American history than the winning of the west and the treasure the early trappers, voyageurs, and coureurs des bois, sought to win were the furry coats of many animals that roamed the fastnesses of the forest.

No other industry of North America, whether agricultural, mineral, or forest has been the origin of such wealth as has the fur industry. Before the forest trees were leveled, before an acre of ground was cultivated, before a mine was opened, the fur animals were a source of revenue to the hardy pioneers, whether they landed on Plymouth Rock, settled Maryland, fought the snow and ice of Hudson Bay, or served under Iberville in the Gulf of Mexico that Louisiana might be founded.

The demand for furs in the old World was primarily responsible for the rapid colonization of North America, and the catch of the Indians, eagerly bartered by the first traders, formed the first wealth of the New World that was freighted over the inland waters of the new land and over the ocean to Europe. 


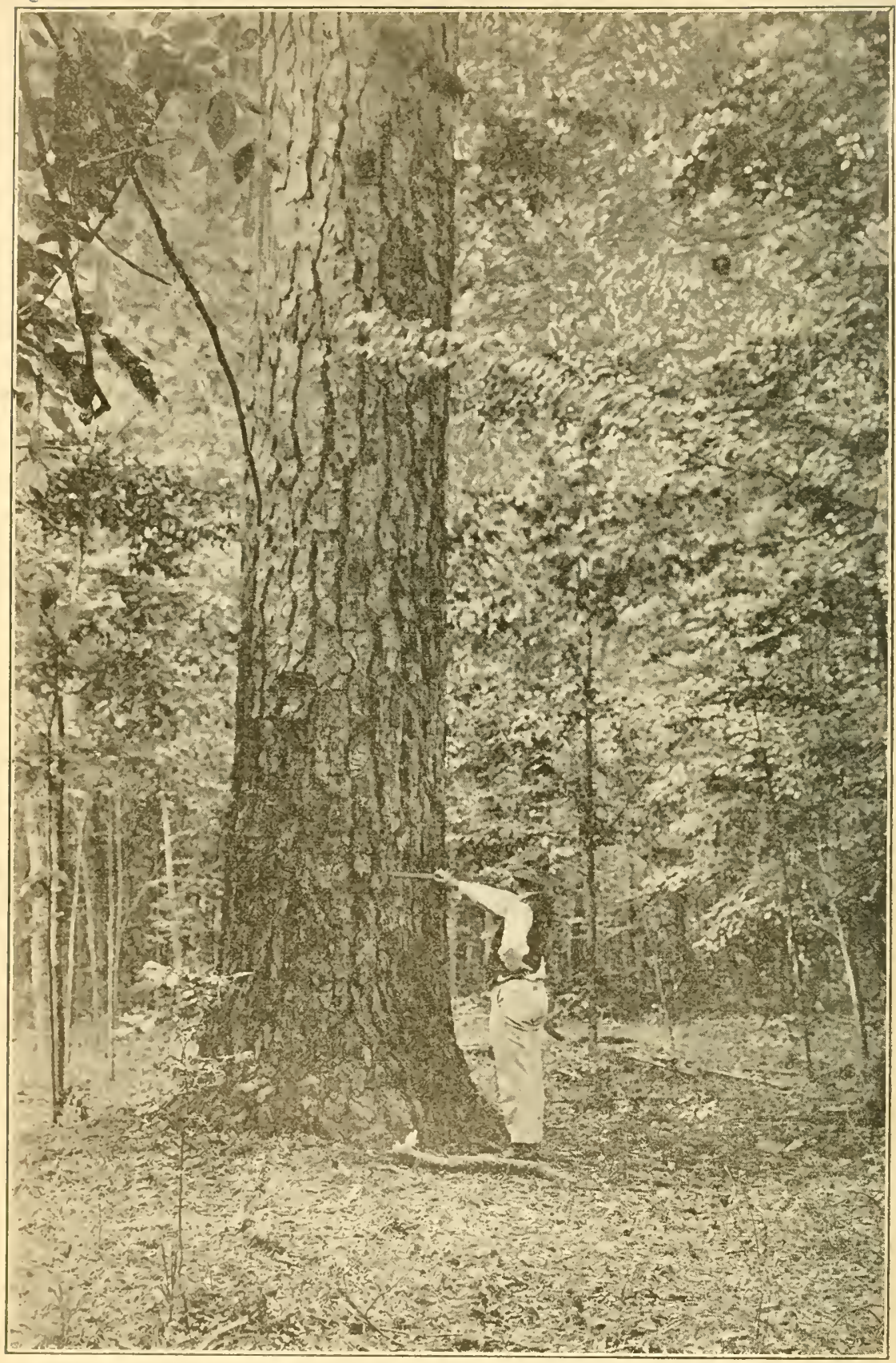

A giant loblolly in a virgin stand of pine in LaSalle parish. Such woods harbor opossums and raccoons. 
Abroad, furs had been the prized possession of royalty, Kings and Emperors gave furs as gifts. They even were used as forfeits in the exchange of royal prisoners taken in war. In the ancient days furs competed with gems and jewelry as articles of adornment for the rich and the fashionable. So great was the demand and so circumscribed the source of supply, it is small wonder that their use was restricted to the nobility and to the rich.

With the discovery of America came the discovery of this wonderful reservoir of fur animals and a seemingly unlimited supply of fur. Trappers and traders flocked to the New World, all animated by the same ambition-to make a fortune in furs-and few failed.

Since the earliest time, the fluctuations of the fur market have been as many and varied as the animals that supplied the commodity. Hundreds of years ago, it was. the greatest speculative game in the world, and today, when the raw fur market is at its highest pitch, the traditional Black Friday of Wall Street is quiet and docile beside it.

No other natural resource of the American continent has been as productive over so long a period as a source of wealth as has the fur of the animals native to our land and-stranger still-the industry is not in danger of extinction in the very face of the fact that hundreds of millions of fur animals have been taken in traps and their covering converted into suitable garments for lovely woman.

Trade monopolies seem to have been invented with the genesis of the fur business and, today, as in distant 1670 when the Hudson's Bay Company was founded to monopolize the fur industry of North America, many modern business organizations endeavor to exercise the same kind of big business control over the pelt of the lowly fur animal.

In view of what has already been set down, we have it demonstrated that the feminine yearning for furs is a natural one-a throwback to the days of prehistoric woman.

Eve's daughters today wear furs to enhance apparel, emphasize natural style and charm, or to satisfy that inherited desire for a touch of barbaric splendor that has. come down from the Stone Age. 
But modern woman has something over her cave sister in the rast range and variety of skins that are hers to choose from. Furs of every kind for every type and for every purpose. Fragile furs and durable ones. Furs that combine beauty of pelage with lasting qualities. Imitation fur's that look well in shops but terrible after a few days' wear. Furs of soft grays, rich and lustrous browns, glistening blacks. Coarse furs and fine furs, long haired and short. Fur's for indoor adornment and outdoor wear. The real problem that the woman of today faces is whether she is buying a genuine or a synthetic fur, whether the fur is exactly what a furrier represents it to be, or merely a sheepskin, rabbit or even the lowly housecat baptized with a trade name and sold for what it is not. For the real demand is for genuine fur's.

Today speculative and wondering eyes have been turned on the State of Louisiana, due to the present feminine demand for genuine furs the world over. Although it has been long known that Louisiana is rich in oil, natural gas, timber, salt, sulphur, game and other bird life and game animals, it has only been in the last few years that word has gone forth that in the annual production of pelts of the fur animals, this sub-tropic state of our's not only leads her sister states of the Union in this regard but actually produces more pelts of fur animals than all of the provinces and territories of Canada combined, with Alaska thrown in for good measure. And, to increase the wonderment, it might be added that Louisiana's annual fur crop exceeds in value the yearly combined gold and silver output of Alaska. 


\section{CHAPTER TWO}

\section{THE EARLY FUR TRADE OF AMERICA}

F Rom the days of its discovery by the Spanish De Soto and its settlement by the hardy pioneers under Iberville and Bienville, Louisiana has held an enviable position in the fur trade of the North American continent and its native mammals, at least those whose pelts found ready purchasers, have been conspicuous in the state's fauna. The pelts produced in Louisiana found their way into the general trade marts with no special designation as being "Louisiana furs," and for this reason, presumably, few of the usually well-informed of the country in general knew that this southern state was a fur producer; fewer Louisianians, for that matter, knew it.

In the early days there were only four important furtrading centers on the North American continent-Quebec, Montreal, Fort James on Hudson Bay, and New Orleans, the first two named being started by the original fur traders, the French, and the third by the renowned English of the famous Hudson's Bay Company. Quebec and Montreal were noted then as fur centers and have continued to be famous for the great number and varieties of fur animal pelts handled in their trade.

With the establishment of Crozat's monopoly, under a grant of Louis XIV in 1712, came the first commercial handling of furs in southern North America, with New Orleans as the fourth fur center of North America, for under the French King's grant Crozat was given exclusive right to handle all peltries, beaver furs excepted, of the then vast Louisiana.

In spite of popular belief to the contrary, the English "adventurers" of the Hudson's Bay Company were not the original fur traders of North America. The French who settled this north land hold this distinction and it was under the French regime that it flourished, fell and rose again.

From the earliest times the Basque and Breton fishermen upon the "banks" had traded for furs. As the French 
court demanded more and more furs, adventurers came for the fur trade exclusively. Pont-Grave and Chauvin built Tadoussac in 1599 as a center for this trade with the Indians of the Saguenay, and when trade routes were discovered further inland, the founding of Quebec and Montreal followed. ${ }^{1}$

The French Government from the first granted monopolies of the fur trade, always on the condition that the Company should take to New France (Canada) a stated number of settlers. But settlement and the fur trade could never go together-settlement, by driving fur animals farther afield, made trading increasingly expensive, and the great profits of the fur trade, together with its freedom and romance, excluded the more adventurously inclined from the rational pursuits of a settler. Trade spread west and south by the river routes, convoys bringing the furs yearly to Montreal and Quebec. The de Caen Company, in the seventeenth century, sent yearly to France from 15,000 to 20,000 pelts. "Beaver" was made the Canadian currency.

In the meantime, English navigators had been seeking a northwest passage to the Orient. By 1632 their efforts came to an end with little practical result. Hudson Bay, however, had been accurately charted, so that when the first English fur-trading ships came some thirty years later, they sailed by charted routes to a safe harbor. The first expedition came at the instigation of Radisson and Groseilliers, two French coureurs de bois who had traveled in the rich fur country north of Lake Superior. They had sought aid in France, but being repulsed, turned to England. The charter of the "Adventurers of England trading into Hudson's Bay" was obtained in 1670 by Prince Rupert, who became first Governor of the Company, whence the name Rupert's Land. In 1676, merchandise costing $£ 650$ was sent to the Bay and the fur's obtained by barter were sent to England and sold for $£ 19,500$. The dividend on the stock of $£ 10,500$ was sometimes as high as 100 per cent. During the struggle with the French, beginning about 1685,

'Coates, Fur Production of Canada, 1923 Dominion Bureau of Statistics, Fur Branch. 
no return was made, but with the English victory, the Company resumed payments, usually amounting to 20 per cent per annum. Forts were built on Hudson Bay and James Bay at the mouths of rivers; the Company, as monopolist, waited for the furs to be brought to its posts.

With the Seven Years' War the fur trade from the South passed out of the hands of the French, and until 1771 the English were busy rediscovering the old French routes to the West. 


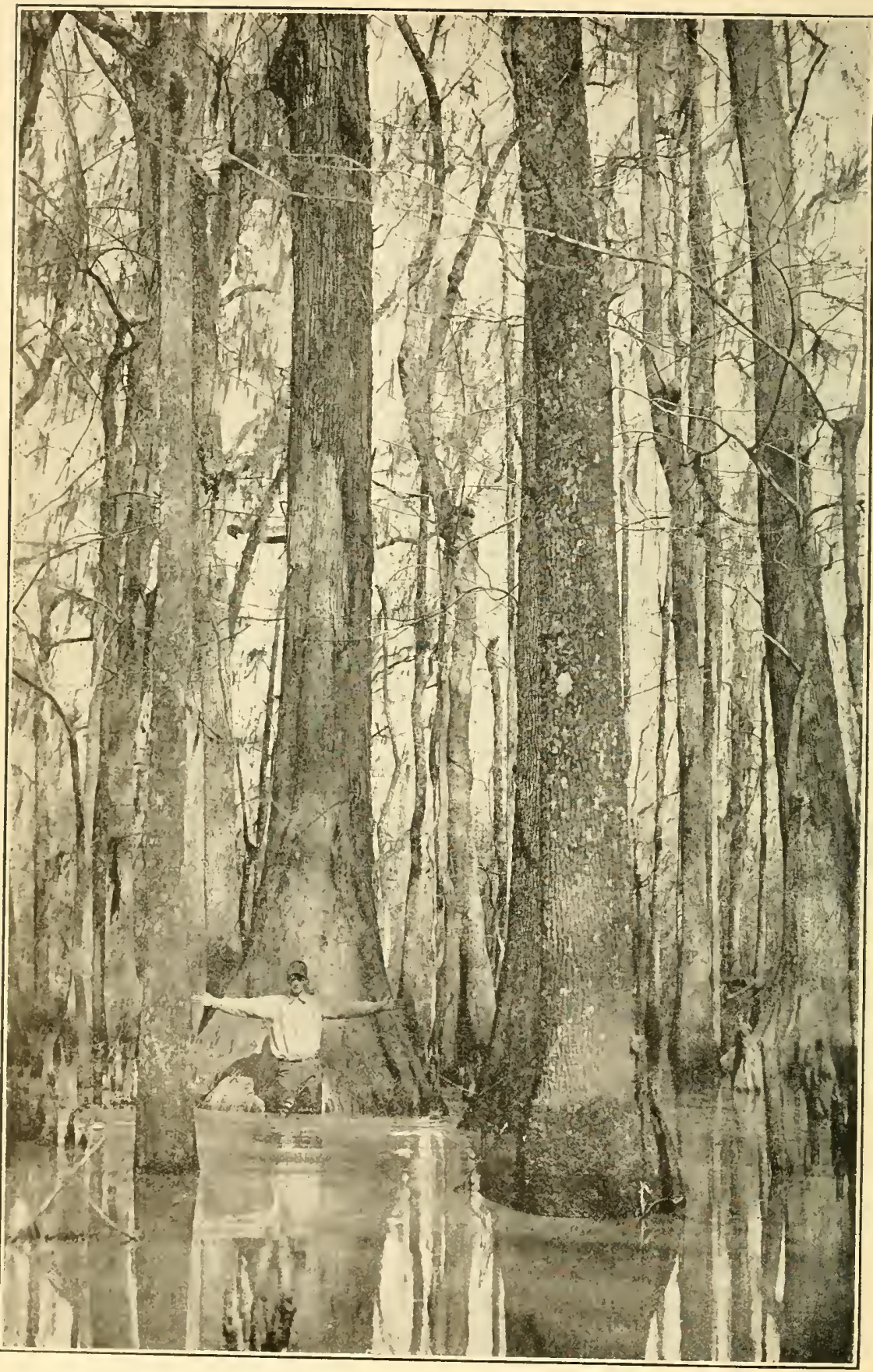

In such subnerged swamps, where tupelo grow to great heights, raccoons, otters, minks and some opossums live. 


\section{CHAPTER THREE}

\section{THE EARLY FUR TRADE OF LOUISIANA}

I

$\mathrm{T}$ IS A difficult matter to give a concise and yet complete history of the carly fur trade of that great section of North America which for many year's was known as Louisiana, for what was done in those pioneer days has remained buried in dusty tomes and archives, and forgotten official records, with no one sufficiently interested to unearth the pertinent facts from their burial grounds and give them a place in printed words available to those seeking such historical knowledge.

One such collection of records has been made, however, and that is the volume issued by the Columbia University of New York, as a part of the printed studies in history, economics, and public law series. This book, "The Commerce of Louisiana During the French Regime, 1699-1763," by N. M. Miller Surrey, Ph. D., is probably one of the most valuable works of its kind for the student who elects to make studies of any phase of the early settlement of this part of the North American continent. The matter that follows, devoted to the early fur trade of Louisiana, has been drawn very freely from Mrs. Surrey's excellent compilation and from the bibliography, followed many other sources of information.

The establishment of the Lower Louisiana colony proved a costly venture to France, Chambers tells us, ${ }^{2}$ and at a time when she was finding her financial resources taxed to the utmost. So the king and his advisors gladly seized upon the opportunity to put the burden of the colony's maintenance on other shoulders and a bargain was struck with Antoine Crozat, a French merchant of great wealth and capacity for business. In consideration of his sending at least two shiploads of settler's yearly to the colony, and his bearing a large proportion of the expenses for the subsequent six years, Crozat was granted seigneurial jurisdiction over Louisiana by Louis XIV, after whom this great inland

aChambers, Mississippi ralley Beginnings, p. 57. 
province was named, which included personal ownership of landed estates, exclusive rights of trade, freedom from taxes and duties, and authority to nominate executive officers of the colony subject to confirmation by the King. Under the charter, Crozat's province extended from New Mexico to "the lands of the English of Carolina" and "from the edge of the sea as far as the Illinois."

The "exclusive rights of trade" included peltries, with the exception of beaver skins, and an immense fortune appeared to be ripe for the grasp of the French merchant, but Crozat's venture ended in failure. "Having a monopoly of trade, he could not resist the temptation to profiteer-to overprice his merchandise and undervalue the furs and other produce tendered him in exchange," says Chambers. "This one-sided advantage led to indifference as to effort, stagnation as to trade, actual loss to Crozat himself." In five years, the merchant was sick of his bargain and asked to be released, and so ended the first attempt to "corner the fur market" of Louisiana.

Next came John Law and his famous "Company of the West," a speculative enterprise of stupendous proportions which also ended in panic and failure of a magnitude that corresponded to that of Crozat. Law's "Mississippi Bubble," as his scheme has been characterized in history, and named by him Compagnie de la Louisiane ou d'Occident, united the already profitable fur trade of French Canada with the proprietary exploitation of Louisiana. Within a short time this prince of promoters united several trading companies, dubbing the association La Compagnie des Indes, which soon acquired a monopoly of the foreign trade of France, including that of furs.

One of the first and most important acts of the company was the restoration of Bienville to the governorship, and one of Bienville's first acts was to found a city on the banks of the Mississippi. So New Orleans sprang into being and from its very incipiency became the "fur centre" for the great fur-producing area of the center of the North American continent. From the far reaches of the continent, drained by the twining fingers of the tributaries of the 
mighty Mississippi, came peltries during the life of the "Company of the West" and even after Law's bubble burst. With the flow of fur through the new port no special distinction came to New Orleans as a fur center, although many of the older firms of the "Crescent City" owed their prominence and accumulated profits to the trade thus carried on in these early days.

Long before the establishment of Louisiana, the French in America were energetic in the fur trade, as has always been pointed out. The first establishment of a fur-trading company came with the operations of "The Company of the Hundred Associates," in 1626, the trader's plunging into the new and unknown lands of westerly sections of New France, as the French possessions in upper North America were then known, for their furs.

The work delegated to the company and its successors after 1663 , and that assigned to the Church, was carried on by the traders in conjunction with the churchmen. As indicated by a letter to Colbert from Governor Frontenac in 1672 , the task of establishing commerce with the Indians and converting of them to the Christian faith did not always harmonize, for the governor said that the Jesuits "think as much about the conversion of beaver" as of souls; for the majority of their missions are pure mockery." ${ }_{1}$ In 1676, Frontenac received instructions that he must not "suffer any person, invested with Ecclesiastical or Secular dignity or any Religious Community" to follow the fur tracle in any wise or even to trade in peltries, a prohibition which was likewise placed on any of the governor's domestics or any other person acting directly under his authority.

The struggle of the Frenchmen for control of the fur trade with the Hudson's Bay Company fell with full weight on the trader's of New France, as difficulties with the Indians began and competition increased. Many of the skins sent to Montreal were not properly cured, while others were of poor quality. Then came the settlement of Iberville and his Frenchmen at Biloxi and the beginning of a new fur

'Surrey, Commerce of Louisiana, from Documents Relating to the Colonial IIistory of N.Y., p. 305 . 
trade movement from the gulf up into the heart of the continent and, before Louisiana was a year old, New France had asked the home government for protection against the encroachments from the colony on the Gulf of Mexico.

\section{Louisiana Enters the Fur Trade}

In order to prevent the traders of New France from carrying their peltry down the Mississippi to the Louisiana market, the "Company of Canada," which succeeded the "Company of the Hundred Associates," proposed to the Crown that all beaver skins shipped to France from Louisiana should be seized at Rochefort and sold at the same price the "Company of Canada" was paying for them at Quebec.

The affairs of the Canadian Company rapidly passed from bad to worse and records show that twelve of the principal trader's had in the fall of 1701 made off with a large cargo of brandy which they exchanged for pelts and sold them in the newly formed Louisiana colony. By the next year the French government was informed that so many of the traders had left their homes in New France for the purpose of entering the Louisiana fur trade that many of the merchants of Montreal and Quebec were being financially ruined. The prayer that the home government stop this practice was answered by the Louisiana officials to the effect that the trouble rested with the merchants of the two northern cities, because they provided the traders with merchandise and sent them into the woods to buy furs "which would have gone over" to the English had the Frenchmen of Louisiana not received the pelts."

So, in 1706, the "Company of Canada" went bankrupt. Each year the profits of the firms succeeding this company fell off, while the traders of the Louisiana territory built up their business and prospered.

Among Iberville's schemes for the development of the province he was to establish was one for the promotion of a trade in skins with the natives. As early as 1700 he had received some buffalo hides from the Illinois country and

3. Nargry, vol. iv, pp. 628-629. 
engaged voyaguers returning to the gulf from the interior to secure more of them so that he could ascertain their possible value in the market of France. For each skin the hunter's were to receive seven livres (a livre was approximately 25 cents) and, to secure the skins as rapidly as possible, they were asked to induce the Indians to abandon the beaver for the buffalo. Iberville proposed to construct a fleet of bateaux plats (flat boats) on which considerable quantities of buffalo robes could be floated down the Mississippi, there to be placed on ocean-going ships and sent to France. ${ }^{*}$

It was Iberville's previous knowledge of the fur trade in and around Quebec and Montreal, as well as his fear of the result of the English activities about Hudson Bay, which led him to the belief that the Indians of the central northern regions could be persuaded to sell their peltry to traders from Louisiana, whom he proposed to station on the upper waters of the Mississippi River. He reasoned that with prices the same and with French merchandise as good as that offered by the English, the Indians would prefer to dispose of their pelts in this fashion rather than to carry them miles over a difficult and dangerous country in order to exchange them for English goods.

Had it worked, the scheme would have completely destroyed the fur traffic of the English of that region, and Iberville believed that if he could establish this traffic, in five year's it would draw from Fort Nelson annually between 60,000 and 80,000 buffalo hides, worth four or five livres each; 150,000 deer skins, worth 2,500,000 livres; and other peltry such as that of bear, wolf, otter, lynx, wild cat, fox, and marten, worth at least 200,000 livres.

But this proposal to the French home government seems to have fallen on deaf ears, and the English, undoubtedly hearing of Iberville's intended operation, strengthened their influence over the Indians by having their agents supply them with guns in trade, and by this means of barter,

Margry, vol. iv, p. $37 t$.

salery, vol, iv., pl). $600-(i) 1$. 


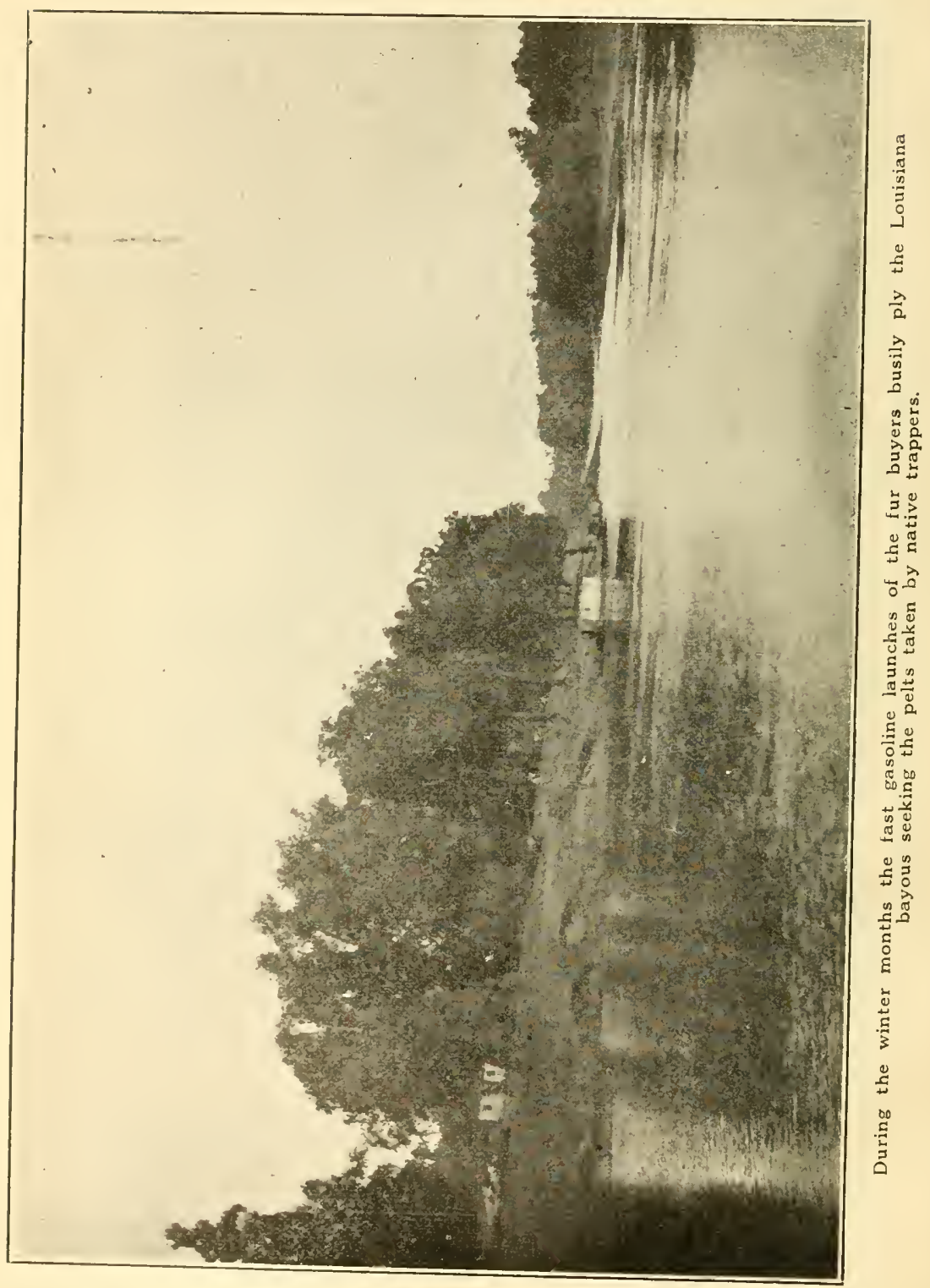


coupled with their energy, the agents of the Hudson's Bay Company kept the French from making any great headway in this field.

In 1700, a former trader with the "Company of the Hundred Associates," named LeSeur, left Biloxi with two boats manned by nineteen men for the country of the Sioux, where, he claimed, these savages "dressed themselves entirely in beaver skins which were soon discarded and replaced by fresh ones, simply because of a lack of market."

Whether or not this was an exaggeration uttered for purposes of promotion of his scheme we do no know, but the trader did buy 3,600 beaver pelts and many other skins of fur animals, although trading in beaver skins was contrary to the grant he had been given. LeSeur justified this purchase on the ground that the Indians had pillaged his canoes and he had taken the beaver pelts in compensation for his losses. The officials of New France (as upper Canada was called) in protesting LeSeur's entry into what they considered their domain, claimed that this robbery had been preconceived in order to have an excuse to seize the skins. ${ }^{6}$

During the first year of the existence of the little French settlement on the Gulf of Mexico, quite a traffic in pelts of fur animals was established with traders coming from the upper part of the Mississippi Valley, and most of this trade was of an illicit sort because all crown grants stipulated beaver skins belonged to the French companies of Canada. Stimulated by the attitude of New France toward the new Louisiana colony, buffalo hides and beaver skins were caught and then found their way down the Mississippi to the new market in prodigious quantity. Iberville had visions of the trade growing to about 45,000 pounds of skins annually.

"The fur of the otter, polecat, the pitois, wood-rat, ermine, and marten are what is called la menue pelleterie, or lesser peltry," we are told by Charlevoix."

- Margry, vol. is, p. 357 .

${ }^{7}$ Charlevoix, Toyage to North America, vol. i, n. 208. 


\section{THE CROZAT GRANT}

Then came Antoine Crozat with his royal patent on the scene, which gave him an exclusive right of trade in all peltry, except beaver, which was still reserved to New France, but the trade carried on by the new regime was not destined to prosper because the officials offered such low prices-fifty sols for bear skins and fifteen for deer skins-and most of the peltry either passed into the hands of the English or were sent up to New France.

Trader's who formerly brought many skins to Biloxi or Mobile did so no longer, and declared that while Crozat remained in control of affairs they would continue to stay away. And they did. The settlers in lower Louisiana, however, continued to receive a few pelts with which they carried on an illicit trade with vessels that chance brought to their shores. For beaver pelts they received three livres each and for deer skins fifty sols, but due to the long waits between the coming of ships with which they could trade the habitans of the lower valley frequently lost a great many furs on account of the damage done them by insect larvæ while they were stored awaiting transportation.

\section{JOHN LAW'S "MississipPI BUBBLE"}

Although the Crozat regime had given a setback to the fur trade of upper Louisiana, it had increased the French influence among the Indian tribes of the lower Mississippi valley and traffic in furs improved when Law's "Company of the West" took over Louisiana. During the first year of control more than 1,000 deer skins were shipped to France, and the company began laying plans to better the fur trade, and to this end entered into treaties of commerce and friendship with the Indians of the upper Missouri and a number of forts were erected.

The acquisition of the Illinois country did not increase the Gulf trade in beaver skins, we are told, because "the animals found there were almost of the straw color, whereas the value of these pelts depended upon the darkness of their hue."s Other skins of peltry, however, were sent down the river to New Orleans in great quantities.

"Charleroix, A royage to North America, vol. I, p. 54. 
It was in 1720 that officials informed the home government that many of the skins received, before they could be shipped to France, were often badly damaged in the warm climate because of the crude system of tanning in vogue, and that while they were able to supply large consignments of buffalo skins, it would be necessary to properly tan them. A tannery on the Wabash River (Ohio) was proposed, with soldiers who understood the process to do the work. This did not materialize, however.

In 1721, "The Company of the West" endeavored to systematize the commerce in peltry by fixing prices at the various storehouses and, according to LaHarpe, the following are prices fixed for Biloxi, Mobile, and Fort Louis; delivered elsewhere, they were diminished by the cost necessary to ship them to the coast:

Kinds

Best Grade

Beaver............... 3 livres a pound

Buffalo..............t livres each

Cow................... lives 10 sols each

Deer skins........... With head and tail:

Large Medium Small

$25 \quad 20 \quad 15$
Good Grade

34 sols a pound

Without head and tail:

Large Medium Small

$20 \quad 15 \quad 10$ sols each

So the fur trade prospered, "but just at the time when the outlook was darkest for the English, the French officials played into the hands of their rivals by trying to persuade the traders to take up agriculture, which they believed was more essential to the welfare of Louisiana than furs." 9 The Louisiana traders it must be admitted, were furthering the English advantage by demanding high prices in pelts for the French goods they distributed in exchange, and this caused trouble with the Natchez, and led to an order from New Orleans suspending all commerce with these Indians. This command only served to widen the breach between the officials and the traders, who continued operations in defiance of the instructions from New Orleans. Indians on the Missouri also went on the warpath, robbing the Frenchmen found in this territory.

Other Indian troubles arose, and the "Company of the West" was thoroughly convinced that it could not carry on

'Surrey, Commerce of Louisiana, p. 347. 
the Indian trade by sending out agents of its own, so the decision was reached to put the valuable fur traffic in the hands of men already skilled in the service. It was estimated that at that time the number of skins obtained in the province annually amounted to about 50,000 pelts, exclusive of the peltry drawn from the Sioux, Missouri, and Illinois Indians. Of this amount, the savages on the Red River, Tonica and the tribes on the Arkansas furnished 1,000 deer skins each; the Yazoo and Ossagoulas, 2,000 of a very good quality; the Alibamon, 3,000; the Chicasaw and Choctaw, 4,000 each; the Talapouche, 5,000; the Abikas, 8,000, and the other tribes in lower Louisiana smaller amounts.

\section{WARS WITH THE INDIANS}

In 1717 , the fur trade in the upper part of the province was greatly disturbed by wars with the Fox Indians, and while the Louisiana traders and troops were confronted with this outbreak an unjust action on the part of the commander of Fort Rosalie, in taking lands of the Natchez for the purpose of making himself a handsome estate, caused these Indians to rise and attempt to destroy this important French settlement in the lower valley.

Five years later the French share in the western fur trade had sunk to a most critiacl condition, as the English were quick to take advantage of the Indian outbreaks against the French and they increased their trade and profits correspongingly. Indeed, within a year or two English traders were among the Choctaws outbidding the Frenchmen for pelts.

In 1744, the year the French and English war started, records show us that Louisiana obtained about 100,000 deer skins, as well as many buffalo, kid, otter, and beaver skins, for which the French traders gave in exchange guns, powder, blankets, knives, needles, razors, vermilion, woolen goods, ribbons, blankets, shirts, and "brandy well mixed with water!"

At the same time the English were exporting about 100,000 hogsheads ( 800 to 900 pounds each) of skins a year , for which they received sixteen shillings, nine pence a pound. 
After the beginning of hostilities, the French were unable to provide their traders with European goods in sufficient quantities to carry on a successful barter with the Indians for fur pelts, and in addition the French prices for peltry decreased by three-fifths of their former value, while the English prices advanced. For instance, a deer skin would sell in England for five livres, while in France one of the same quality would bring but two. This condition, coupled with the fact that the English goods offered the Indians were of much better grade in most cases than those imported from France, placed the Frenchmen of the valley at a disadvantage.

The French had one hold on the faithfulness of the savages of the lower Mississippi Valley and that was that French powder was more easily obtainable and of pronounced superior quality to that offered by the English. The rivals attempted to offset this advantage of French powder and lead by giving the Indians English rum, which threw them into a series of drunken orgies, and while they were in this crazed state, endeavored to turn them against the French. Some success crowned the efforts of the English in this direction for the French were forced to fight the savages, and the English collected the pelts during the upheavals. At times, it is claimed, the English actually bought up the next year's assortment of pelts on a basis of credit for a present supply of rum.

During the four years of the war, 1744 to 1748, notwithstanding a shortage of French goods for trading, the trouble with the Indians, and the keen competition of the English, the fur trade of the Louisiana colony continued; it was far from being destroyed, for it was estimated that there were some 1,600 Frenchmen engaged in the trade, and in 1745 it was said that there was a collection of furs at New Orleans valued at 9,621 livres.

\section{Furs FloAt Down the Mississippi}

With the restoration of peace between England and France the fur trading went forward with the same competition that had marked affairs before hostilities, and by 
1752 the supplies of peltry floated down the Mississippi to New Orleans increased to a marked degree. The fur traffic in that portion of Louisiana drained by the Missouri and its branches was placed under the monopolistic control of one Deruisseau, but the new official was not able to control his trader's, who corrupted the savages by their evil ways; these traders engaged in every excess, even stealing and carrying away Indian girls, which provoked the Indians to a murderous onslaught on one post, which they destroyed.

In addition to misdeeds, "the Frenchmen defrauded the savages most shamefully. For example, for 1,000 crowns' worth of fine beaver skins they paid a small amount of powder which they told the Indians was a new variety that, if planted, would produce all the powder they would want. As soon as the natives discovered that they had been defrauded they were infuriated against the French in general." 10

When hostilities began again with England in 1754, the French were once again without goods for barter, and this situation continued throughout the war period, with the French losing the little hold that they had kept on the Indian fur trade. But they clung to the great Illinois country, and at the end of the struggle between the two countries, the fur trade in this part of the province was not only intact but actually growing.

In 1762, "Maxent, Laclede \& Co." of New Orleans received a per'mit from Governor Kelerec to establish trading operations on the Missouri river and preparations were at once made to make the most of this grant, which included the right to trade in all fur and peltries, excepting beaver skins, and in September of 1763, the junior member of the firm was ready for a trip into the north country.

Two sons of New Orleans, Pierre Laclede Liguest and Auguste Chouteau, by name, left the Crescent City for the upper reaches of the Missouri under a grant that gave their firm the right of exclusive trade with the Indians of that stream, as well as the other savage natives west of the Mississippi river. 
In order to take better care of the beaver skins they secured from the Indians, Leclede (for he did not use his last name) and Chouteau constructed a cache on a bluff where the "Big Muddy," as the Missouri was then called, and the Mississippi met and formed a giant stream. This small fort grew to a settlement, then to a town, and later to a city of great proportions and importance. The Orleanians named the town they founded after the King of France - - St. Louis.

Therefore, New Orleans became the mother, if we may use the simile, of that wondrous city of the mid-western interior which in course of time came to be the great furtrading center of the North American continent and remained the "fur capital" for a number of years until ever-grasping New York City took over the fur industry for its own during the World War period.

In the early days the Mississippi river was the main artery of transportation of the North American continent and down the mighty Father of the Waters floated huge cargoes of bundled pelts consigned to New Orleans, where they in turn were loaded on deep water ships for the journey to the far cities of the Old World, and so New Orleans became the chief port of fur export.

When the Iron Horse superseded the paddle-wheel palaces of the Mississippi river as the chief means of transportation of this country, the change vitally affected New Orleans and its early-day export business. Its position dwindled to comparative nothingness and, as a consequence, New Orleans' former position in the fur and peltries trade was forgotten.

Yet today Louisiana is the foremost state of the Union in quantity production of the pelts of fur animals. It is greater in this regard than any other area of the same size on the North American continent. It produces every year more pelts of fur animals than is produced by all of the provinces of Canada-all this in spite of the state's sub-tropical geographical position, and may be destined, in time, to occupy the niche in the fur trade of America she held two hundred and more years ago. 


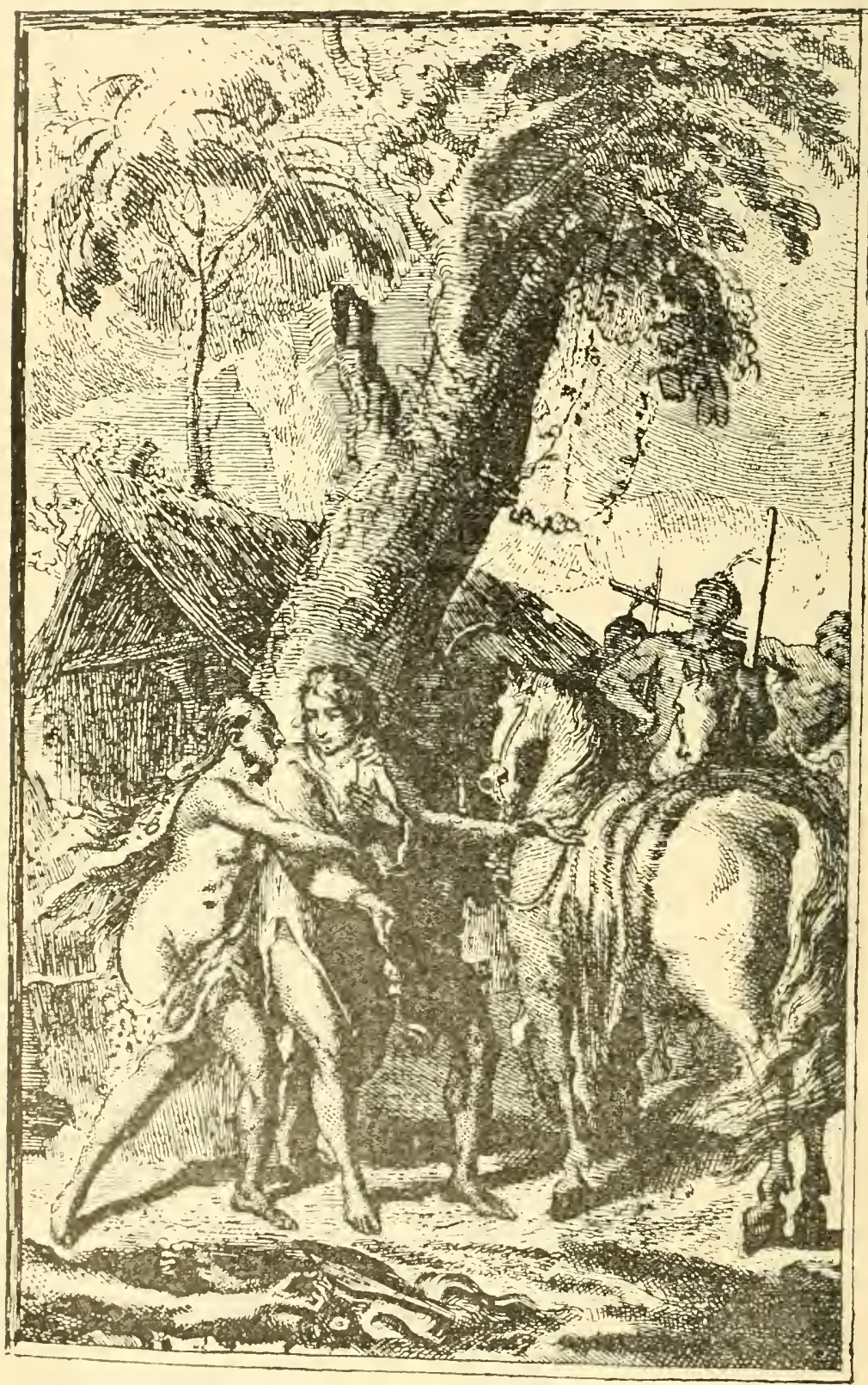

An ancient engraving illustrating the rescue of Simars de Belleisle from the whoke as as wearing the skins of Louisiana wild animals. 


\section{CHAPTER FOUR}

\section{OUR FIRST NATURAL HISTORY WRITERS}

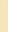

THE first to describe our fauna and write what may be considered a natural history of Louisiana was M. Le Page du Pratz, a Frenchman who came to this country in 1718 and remained in Louisiana many years. His published accounts of the country, the natives, and its fauna and flora are not only interesting but amusing, especially the crude engravings that embellish his works. He described the bison or buffalo, which was designated by the early French settlers as Le Boeuf sauvage; and lays great stress on the very fine wool secured from the skins or robes. "These skins are an object of no small consideration," wrote du Pratz. "The natives dress them with the wool on, to such great perfection as to render them more pliable than our buff. They dye them with different colors and clothe themselves therewith. To the French they supply the place of the best blankets, being at the same time very warm and very light." He said that the cougar, which he called a Pichou, "is a kind of Chatpitois (wild cat), as high as the tiger but not so thick, and his skin is extremely beautiful"; and "that the foxes were numerous" and, while they were like the European species, "their skin is much more beautiful."

The raccoon, which was a new animal to the wondering Frenchman so interested in nature, was named a Chat sauvage (literally "wild cat,") but Du Pratz admitted it had "been improperly called so by the first French settlers in Louisiana, for it has nothing of the cat but its nimble activity, and rather resembles a monkey. It is not above eight or ten inches high, and about fifteen long. Its head is that of a fox; it has long toes, but ver'y short claws, not made for seizing game; accorclingly, it lives on fruit, bread, and such things. This animal may be tamed, and then becomes very frolicsome and full of tricks. The hair of those that are tame is gray, but of the wild is reddish."

The artist who engraved the Du Pratz illustrations was evidently given a free hand, for the reproduction of the 
Chat sauvage shown herewith evidently was calculated to give the reading public of Paris the impression that the raccoon was built somewhat on the lines of a horse.

Two other fur-bearers, the opossum and the skunk, were likewise described and their likenesses shown. The opossum was termed a rat de Bois, and the skunk was aptly named a Bete puante, and its well-known method of defense aptly described. The beavers and the others were noted, but, strange to say, not a word was mentioned as to the mink nor the now justly celebrated muskrat.

The works of M. Bossu, Capitaine dans les Troupes de la Marine, whose entertaining series of letters were written about 1760 and subsequently printed, describes a number of the animals previously noted by du Pratz, but, like the other writer, he failed to make any mention of either the muskrat or the mink.

While du Pratz is recognized as the first historian visiting early Louisiana and setting to paper his early, valuable but quaint impressions of its flora and fauna, there was published in Paris in 1753 a history written by an officer of the Compagnie des Indes who served for 25 years in Louisiana, that takes second place in interest, to say the least.

The writer was Butel Dumont de Montigny and his work written in French, of course, has the impressive title: "Memories Historiques sur La Louisiane; contenant ce qui y est arrive de plus memorable depuis l'anne 1687 jusqu'a present; arec l'establissement de la Colonie Francoise dans cetts Province de l'Amerique Septentrionale sous la direction de la Compagmie des Indes; le climat, la nature \& les productions de ce pays; l'origine \& la Religion des qui l'Habitent; leurs Mocurs \& les Coutumes, etc." It was published in two volumes illustrated with maps and plates of trees, and plans of the new city of New Orleans.

It is in Chapter XIII, "Concerning Terrestrial Animals in Louisiana," that we are interested and so that those who have never had the opportunity of knowing how the early historians of our fauna treated and described the strange mammals found here two hundred years and more ago a 
number of translated passages from Dumont's work, where they treat of the fur animals of Louisiana, are included in this bulletin.

"Of all the ter"restrial animals which live in this Province the most important \& the most useful to the country are the Bears and the wild Oxen. [Boeuf sauvage or the bison or "Buffalo" as we now know this great animal which was found in many places in Louisiana in winter. The Bayou Terre Boeuf section of St. Bernard and Plaquemines parishes was named the French equivalent of "Land of the Beeves" because of the great number of buffaloes, members of what is known as the Southern Herd, that spent the winter months in the lush-green pastures of these reknown marshes.] The latter, instead of being covered with hair, as are our oxen in France, are covered with fleece as fine as silk and quite curly," wrote M. Dumont, "\& it is heavier in winter than in summer, the Inhabitants make great use of it. They [the buffaloes] have near the shoulders a rather high hump \& have very fine horns which serve as receptacles for the hunters to carry their powder. Between their horns \& near the top of their heads, they have a tuft of wool so thick that a pistol shot fired point blank cannot penetrate it, as I have myself experienced. The flesh of these Boeuf sauvage is excellent, as is that of the cow \& of the calf; its flavors \& juices are exquisite."

M. Dumont mentioned our Louisiana white-tailed deer, which he termed a chevreuil, and paid high compliment to its flesh, either boiled or roasted, and devoted considerable space to the Louisiana black bear, describing its hunting and spoke of the trade the colony enjoyed in "bear oil." He mentioned the many squirrels seen and described the antics of the flying squirrels.

"There are also chats sauvage in this region, especially in the lower river region, \& on the islands along the coast," sets down M. Dumont. His chat sauvage, literally translated meaning "wild cat," was none other than our amusing little raccoon. The early French settlers, never having seen such an animal before, decided that it was more like a cat than any other creature, and thus named it. 
"Their silvery skin is very beautiful, \& generally esteemed. These animals live only on small birds when they catch any; but if that hunt is not successful, they have recourse to oysters and other shell fish which they eat. For that they wait until the tide is quite low \& that the oyster opens its shell either to take the air or to receive a fresh supply of sea water; then they put their paw in the shell, then the muzzle, \& they eat the oyster. It is true that sometimes they are not successful, \& the oyster, happening to close suddenly, imprisons between its shells the paw of the chat [raccoon], in which case the animal is patient \& docile, \& is obliged to wait three hours for the change in the tide. The flesh of these chats is neither bad nor unhealthful." It is quite probable that Dumont is the originator of this pleasant little fiction that has persisted even to this day in certain circles.

Like Le Page du Pratz, the opossum and its habits attracted Dumont and he gave considerable space to this lowly fur animal of the Louisiana swamps. Like du Pratz, whose description of the Rat $d u$ Bois will be found in its entirety in the chapter devoted to the opossum, Dumont was very much interested in the marsupial's method of reproduction and it will be noted that he was, practically biologically correct in stating how the young were born.

"That (the flesh) of the rat sauvage (opossum) is much better; they are eaten and they taste like cochons de lait (suckling pigs). These rats are much larger than those in France; they are very hideous to the sight, \& their skin seems always covered with mud. Their long snout is adorned with two great mustaches on either side; there is practically no hair on their ears, \& their tail, which has none at all, is marked like those files which are called queue de rat (rat tails.) Moreover, this animal is so slow that it is easily caught. It is very fond of birds \& poultry; hence it boldly enters the barn-yards and hen-houses; it even goes into the fields to the corn which has been sown there.

"The instinct with which it hunts is very curious. After having caught a small bird and killed it, it is very 
careful not to eat it; it neatly places it in a fine uncovered place near some large trees; then climbs into that tree \&, hanging by its tail to the branch which is nearest the bird, it patiently waits thus until some flesh-eating bird should come to carry it off. Then it pounces upon it and makes a prey of both the one and of the other." (Needless to add, this trait or method of securing prey is 1753 imagination but it probably sounded thrilling to the gay Parisiannes of that period.)

"The female of this animal is none the less admirable for the manner in which she feeds \& raises her young," M. Dumont goes on to tell us, and what he says in his account should be compared to the matter set down in the chapter on the opossum on page 77. "I might even say that she has a double belly, since under her belly she has a kind of pocket, which seems to serve as such, and which is formed by two membranes so strongly attached one to the other that it is impossible to separate them without tearing them; the mother alone can open them when she pleases.

"It is there that, after she has brought forth, she places her young, who, clinging to her dugs, are nourished with her milk, and grow in a sure shelter, where it is always warm; upon seeing the animal in that state, one would be tempted to think that she was still with young. As soon as the young are strong enough to come out and run on the grass, the mother lets them out, so that they may fetch upon the ground some worms to feast on. Should she hear some noise or some suspicious movement, she utters a certain cry, and upon hearing that signal which is known to them, the little ones are seen running to their mother and entering her body from which they have issued. When one of these mothers is killed in that state, the pocket opens of itself, and the little ones come out. They are then rather pretty, and not much larger than the rats in France. The skin of these animals is not much thought of, no use is made of it." (M. Dumont would probably be interested in knowing that the pelts of opossums are worth 
today about a quarter of a million dollars annually to Louisiana trappers or he'd be suprised!)

Rabbits, according to Dumont, were to be found in Louisiana and he called attention to the fact that they did not burrow into the ground but "withdrew into the hollows of trees," which aptly describes the hares to be found in our state, and he, in contradistinction to Le Page du Pratz and Captain Bossu, mentioned some of the smaller fur animals as Dumont said: "Finally, there are renards (foxes), belettes (mink), fouine (weasels), that are not warred upon." Dumont, like the other two writers already mentioned, did not mention the now celebrated muskrat.

The skunk did not escape Dumont's attention, although he gave it but, slight mention in the following words: "There is also a sort of animal, rather pretty, but for which for more than a league around befouls the air with the stench of its urine, that is the reason why it has been called Bete puant (the stinking animal)." 


\section{CHAPTER FIVE}

\section{LOUISIANA INDIAN ANIMAL STORIES}

$\mathrm{T}$ IHE first Indians met by Iberville in 1699, when he came to our shores to establish a permanent Louisiana settlement, were the members of a tribe who called themselves Ta'neks aya, which meant, in their tongue, "First people."

Iberville said the Bayogula Indians called these Taneks "Bilocchy," so has come down the word "Biloxi." The village of this tribe, however, was not on what we now call Biloxi Bay, as has been erroneously stated, but was on the banks of the Pascagoula river several miles to the eastward, near two other tribes, called the Pascagoula and the Moctobi.

It is believed by Dr. John R. Swanton ${ }^{11}$ that the Biloxi Indians were related linguistically to such Siouan tribes as the Tutelo of Virginia; the Ofo, of the lower Yazoo delta; the Dakota, Mandan, Crows, Winnebago, Hidatsa, and other Sioux Indians of the west.

Our present interest in the Biloxi is the legends and folk tales they have left us and, more particularly, in those dealing with the very species we are considering in this bulletin on fur animals.

It must be remembered that the religion of the Southern Indians was zoötheism, their gods being deified men and animals; the heavenly bodies were also personified as men or animals, and were worshipped as such. In their folk tales we find such examples as Xyinixkana, "Ancient of Otters;" Tumotohkana, "Ancient of Wild Cats;" Tumotchkanadi, "Ancient of Opossums ;" Atckahona, "Ancient of Crows;" Aduskana, "Ancient of Wood Rats;" Pestana, "Ancient of Tiny Frogs," etc.

The deified animal, bird or reptile became an "Ancient" and many amusing things are told of them, why the buzzard has a bald head, why the opossum has a hairless tail, why the wild turkey has a tuft of hair hanging from his breast 
feathers, why the Katydid sings all summer and dies when the cold weather comes, and such delightful fancies.

\section{Why THE 'POSSUM TELLS A LiE}

The story of "The Opossum and the Raccoon" tells why the opossum plays 'possum ("always telling a, lie," as the Biloxi put it) and shows that the fondness of both these animals for crayfish was recognized by the first inhabitants of this section. The translation of this legend by Dr. Swanton follows:

"The Ancient of Opossums thought that he would reach a certain pond very early in the morning and catch the crayfish that might be found on the shore, but some one else had reached there first and had gone round the pond and then had started home long before the Ancient of Opossums had arrived there. This unknown person acted thus regularly every day.

"So at length the Ancient of Opossums lay in wait for him. At length he found the person, who proved to be the Ancient of Raccoons. They conversed together, and they agreed to see which one could rise the sooner in the morning and go round the pond. The Raccoon said, 'I rise very early. I never sleep till daylight comes.' The Opossum made a similar assertion, and then they parted, each going to his home.

"The Opossum lay down in a hollow tree and slept there a long time. He arose when the sun was very high and was going to the pond, but the Raccoon had already been there ahead of him and had gone round the pond, devouring all the crayfish. The Raccoon sang as he was returning home. The Opossum stood listening, and then he sang thus: ' $\mathrm{Hi}$ na ki-yu vous-se-di.' He met the Raccoon, who had eaten all the crayfish.

"The Raccoon said, 'I have been eating very long, and I was going home, as I am sleepy.' To this the Opossum said, 'I, too, have been eating so long that I am sleepy, so I was going home.' The Opossum was always telling a lie. The people say this of the Opossum because when one hits that animal and throws it down for dead, pretty soon the Opossum gets up and departs." 
How the Opossum Lost the Hair on His TaIl

In the Biloxi tale of "The Wolf and the Opossum" we learn how the sly 'possum lost all the hairs on his tail. The opossum, known to these savages as Kcixka yoka, which meant "Swamp hog," in its deified form as "Ancient of Opossums" is set down as a very sly and resourceful animal. The legend runs:

"The Ancient of Opossums killed a Wolf, and, after stringing the Wolf's teeth as a necklace for himself, he walked along singing a song:

'Hama yuxku-Hama yuxku.

Insu-na hi wa-ye!

Anixanixye.'

"While he was singing, the Ancient of Wolves came in sight close to him. 'What are you singing?' said he to the Ancient of Opossums. 'Nothing,' replied the latter. 'I was saying, "What very pretty flowers are here".' After this conversation the Ancient of Wolves disappeared, and he and his people went some distance ahead and hid from the Ancient of Opossums.

"Meanwhile the latter walked along singing:

'Xaye pixti-! Xaye pixti-

Hinawa-ye! Hinwa-ye!

Anixanixye!"

"He sang this for some time until he thought that he had gone very far from the Ancient of Wolves. Then he sang about the wolf teeth as he was walking. Just then the Wolf people were coming out of the undergrowth, and appearing before him. When they appeared near him they said, 'This one must be he who has killed some of us.' So they tied the Ancient of Opossums and laid him down; whereupon they searched him and found the necklace of wolf teeth. Then they wished to kill him, but the Ancient of Opossums said, "If you hit me with any sort of stick I shall not die, but if some persons go to a dead tree which has the bark peeled off and dig it up by the roots and bring a stick from that and hit me but once with it I shall die at once and shall not revive.' 
"Then the Wolf people went to dig up the tree. They left as a guard over the Ancient of Opossums a one-eyed wolf, who sat there watching him. Then the Ancient of Opossums in order to play a trick on his guard said, 'Untie me and bring a stick from the dead tree and kill me by hitting me, and be very brave over me as I recline; do so to me and I shall lie dead.' When he had said this, sure enough the one-eyed wolf untied him and was thinking of breaking off the fatal stick when the Ancient of Opossums entered a hole in the ground and thus escaped.

"On the retur'n of the Wolf people just at this time they dug into the ground. While they were digging their foe came in sight at another place. He had painted himself red before he approached them. 'Why are you all acting thus?' said he. At length they replied, 'We ar'e doing so because the Ancient of Opossums killed some of us and entered a hole here.' 'I will enter,' said the Ancient of Opossums, 'and after catching him I will bring him out and you all must kill him.' Then he entered the hole.

"In a little while he emerged bearing a hoe on his shoulder and with his body painted yellow all over. 'What are you all doing?' said he, as if he were a stranger. 'We are doing so because the Ancient of Opossums killed some of us and entered this hole,' replied the Wolf people. 'I will go in and catch him, and when I bring him out you all must kill him,' said the Ancient of Opossums. Again did he enter the hole. When he thought, 'I have gone a very long distance,' he began to call out, 'I am he! I am the one who did it!' But while he thought that he had gone far into the hole, he was in error; for his bushy tail stuck out of the hole in full sight of the Wolf people, who seized it immediately and it slipped off the skin. Therefore the tails of opossums since that day have been nothing but bone."

\section{A Tale Similar to Aesop's}

Although obtained directly flom the Biloxi, Dr. Swanton, in his translation of the legend of "The Brant and the Otter," calls attention to the similarity of it to Aesop's 
celebrated fable of the Fox and the Crane, the "brant" being, in all probability, the blue goose as we know the species today.

"Once upon a time the Ancient of Brants and the Ancient of Otters were living as friends. One day the Ancient of Otters said to the Ancient of Brants, 'Come to see me tomorrow,' and departed. When the Ancient of Brants reached the abode of the Ancient of Otters, the latter being exclaimed, 'Halloo! I have nothing at all to give you to eat! Sit down!' Then the Ancient of Otters went fishing, using a 'leather vine,' which he jerked now and then in order to straighten it. Many fish were caught, and when he reached home he cooked them. When the fish were done, the Ancient of Otters put some into a very flat dish, from which the Ancient of Brants could not eat. So the Ancient of Brants hit his bill against the dish 'Ta!' and raised his head often as if swallowing something. But the Ancient of Otters was the only one that swallowed the cooked fish. Then said he to the Ancient of Brants, 'Have you eaten enough?' To which his guest replied, 'Yes I am satisfied.' 'No, you are not satisfied,' rejoined the Ancient of Otters, taking up more of the fish, which he set down in the flat dish before his guest, and then he, the host, devoured it rapidly.

"When the Ancient of Brants was departing, he said to his host, 'Come to see me tomorrow.' When the Ancient of Otters reached the abode of the Ancient of Brants, the latter being exclaimed, 'Halloo! I have nothing at all to give you to eat! Sit down!' Then the Ancient of Brants went fishing, using a 'leather vine,' which he jerked now and then in order to straighten it. Many fish were killed, and when he reached home with them he cooked them. When the fish were done the Ancient of Brants put some into a small round dish into which the Ancient of Otters could not get his mouth. So the Ancient of Otters had to satisfy his hunger with what dripped from the mouth of the Ancient of Brants. This the former licked up. Again did the Ancient of Brants swallow the cooked fish. Finally he said to his guest, 'Have you eaten enough?' To which the Ancient 
of Otters replied, 'Yes, I am satisfied.' 'Nonsense!' rejoined his host, 'you are not satisfied. I have served you as you served me.' This event ended their friendship."

\section{The RABbit AND THE TAR BABY}

Admirers of Joel Chandler Harris and his Uncle Remus stories should be greatly interested in the Biloxi myth of Tcetkana, the rabbit, and Sunitoniko, the Tar Baby, which the Biloxi called "The Rabibt and the Frenchman," and Dr. Swanton's translation is as follows:

"The Rabbit aided his friend the Frenchman with his work. They planted potatoes. The Rabbit took the potato vines as his share of the crop and devoured them all. The next time that they farmed they planted corn, and this time the Rabbit said 'I will eat the roots.' So he pulled up all the corn by the roots, but he found nothing to satisfy his hunger. Then the Frenchman said, 'Let us dig a well.' But the Rabbit did not desire it. He told the Frenchman that he must dig it alone. To this the Frenchman replied. 'You shall not drink the water from the well.' 'That does not matter. I am used to licking off the dew from the ground,' answered the Rabbit.

"The Frenchman made a tar-baby and stood it up close to the well. The Rabbit approached the well, carrying a long piece of cane and a tin bucket. On reaching the well he spoke to the tar-baby, but the latter said nothing. 'Friend, what is the matter; are you angry?' said the Rabbit. Still the tar-baby said nothing. So the Rabbit hit him with one forepaw, which stuck there. 'Let me go, or I will hit you on the other side,' said the Rabbit. And when he found that the tar-baby paid no attention to him, he hit him with his other forepaw, which stuck to the tar-baby. 'I will kick you,' said the Rabbit. But when he kicked him. the hind foot stuck. 'I will kick you with the other foot,' said the Rabbit. And when he did so, that foot stuck to the tarbaby. Then the Rabbit resembled a ball, because his feet were sticking to the tar-baby and he could neither stand nor recline. 
"Just about this time the Frenchman drew near. He tied the legs of the Rabbit, laid him down and scolded him. Then the Rabbit pretended to be in great fear of a brier patch. 'As you are in such fear of a brier patch, I will throw you into one,' said the Frenchman. 'Oh, no,' replied the Rabbit. 'I will throw you into the brier patch,' repeated the Frenchman. 'I am much afraid of it,' answered the Rabbit. 'As you are in such dread of it, I will throw you into the brier patch.' So he seized the Rabbit and threw him into the brier patch. The Rabbit fell into it at some distance from the Frenchman. But instead of being injured, he sprang up and ran off laughing at the trick he had played on the Frenchman."

\section{Why the Opossum Has a LaRge Mouth}

The Choctaw Indians who lived on the north shores of Lake Pontchartrain and had their villages in the territory now designated as St. Tammany parish had their own myths, legends and folk tales of the various birds and animals found there.

One of these legends deals with the opossum, which they called Sokata, and tells why it has such a large and grinning mouth. David I. Bushnell, Jr., ${ }^{12}$ gives the following translation:

"It had been a dry season and there was very little food for Deer, consequently he had become thin and rather weak. One day Deer met 'Possum and exclaimed: "Why! 'Possum, how very fat you are. How do you keep so fat when I cannot find enough to eat?' And 'Possum answered, 'I live on persimmons, and as they are unusually large this year, I have all I want to eat.' 'But how do you get persimmons, which grow so high above the ground?' 'That is very easily done,' replied 'Possum. 'I go to the top of a high hill and, running swiftly down, strike a persimmon tree so hard with my head that all the ripe persimmons fall to the ground. Then I sit there and eat until I cannot hold more.' Indeed, that is easily done,' answered Deer; 'now watch me.'

${ }^{12}$ The Choctaw of Bayou Lacomb, St. Tammany Parish, La., p. 32. 
"So 'Possum waited near the tree while Deer went to the top of a near-by hill. And when Deer reached the top of the hill, he turned and then ran quickly down, striking the tree with so great force that he was killed and all his bones were broken.

"When 'Possum saw what Deer had done, he laughed so hard that he stretched his mouth, which remains large even to this day." 


\section{CHAPTER SIX}

\section{THE FUR INDUSTRY OF TODAY}

7 odAY Louisiana annually produces more pelts of fur animals than any other State in the Union, it exceeds in this regard any one province or territory in Canada, it leads all States in the production of muskrats and mink, it is approached only by Arkansas in the yearly take of raccoons and opossums, a record of importance and one Louisianians have a right to be proud of.

But the sub-tropical State of Louisiana has even a greater record-during the past several trapping seasons it has produced more pelts of fur animals than have all of the provinces and territories of the Dominion of Canada combined-with Alaska's catch thrown in for good measure.

Noting only the important fur bearers, the Louisiana list comprises the following species and number taken in a representative season, and one that can be compared with other territories for the same year, as well as the value of the catch to the trappers:

\begin{tabular}{|c|c|c|c|}
\hline Species & $\begin{array}{c}\text { 1924-25 } \\
\text { "Take }\end{array}$ & & $\begin{array}{l}\text { Value to } \\
\text { Trapper }\end{array}$ \\
\hline Muskrat . . & $6,236,165$ & $\$$ & $5,177,696.00$ \\
\hline Opossum & 287,180 & & $258,462.00$ \\
\hline Raccoon.... & 145,810 & & $583,240.00$ \\
\hline 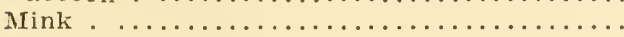 & 84,301 & & $421,505.00$ \\
\hline 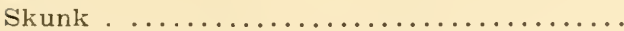 & 14,752 & & $18,440.00$ \\
\hline 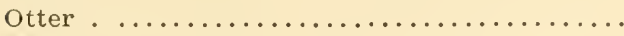 & 2,110 & & $31,650.00$ \\
\hline \multirow[t]{2}{*}{ Miscellaneous pelts.$\ldots \ldots \ldots \ldots \ldots \ldots \ldots$} & 947 & & 947.00 \\
\hline & $6,771,265$ & & $6,491,940.00$ \\
\hline
\end{tabular}

The miscellaneous pelts that go to make up Louisiana's total output include wolf, fox, weasel, etc.

For the sole purposes of comparison, the following fig. ures may be quoted.

Alaska in the 1924-25 season produced 285,545 pelts of all kinds. (Figures from U. S. Biological Survey.)

New York, latest available figures 344,283 pelts. (Conservation Commission of New York figures.) 
Pennsylvania, 1,637,307 pelts, valued at $\$ 2,899,340$. (Estimated by Board of Game Commissioners of Pennsylvania.)

Dominion of Canada, all provinces, 1924-25 season, 3,820,326. (Figures from Dominion Bureau of Statistics, Fur Branch.)

This brings to point, in face of the figures indicating such an exceedingly large annual harvest of the animals comprising the backbone of the fur trade, the question so frequently asked by almost everyone-those interested in the production of furs, conservationists in and out of the trade, trappers and land-owners, as well as those who derive comfort and pleasure from the wearing of the furs. "Is the supply being rapidly, wastefully and insanely depleted" and "When will, at this rate of take, the natural supply of Louisiana be depleted?"

The conservation problem, as it relates to fur-bearers, is in conserving the remnants and in the State seeing that only a decent annual harvesting of the mammals be permitted so that seed stock remains and the species and the industry so perpetuated. At the present time there seems to be no obstacles to stop or hinder such a conservation program being carried out unless the aim of this department and true conservationists interested in the perpetuation be deflected or defeated through a continuation of the practice of taking unprime skins of a too long open season, the disturbance of the breeding season, a continuation of the present practice of purchasing unprime pelts and the skins of immature animals and the buying of pelts taken out of the legal open season for trapping by buyers and the trading of them by dealers.

In facing the fur conservation problem, Louisiana has a number of facts to recognize in finding an answer. The demand for furs is increasing as the population of the world is growing. A number of the rarer fur mammals are decreasing as the world's wilderness is being encroached on by man and turned into account for other activities.

That this presages the ultimate doom of the Carnivoria, or meat-eaters, cannot be denied. On the other hand, Dame 
Fashion has learned, although only quite recently, it is true, that there are many useful, although heretofore considered commonplace, fur-bearers, such as the muskrat, mink, raccoon, skunk, opossum, mole, weasel and rabbit, that not only thrive by depredations on cultivated land, but most of them inhabit lands and marshes that will probably never serve man any useful purpose other than remaining as they are-breeding places for the lowly fur-bearers.

And what other State can approach Louisiana in the area of such lands and marshes? The way seems clear, at least for a sound economic use for our great sea marsh areas, over 2,500,000 acres, for combination 'rat ranches and refuges and resting places for the horde of migratory wild waterfowl that come here each winter.

Attempts will undoubtedly be made to meet the demand by making synthetic furs. All sorts of "beaverettes," "marminks," "coneys," "electric seals," "sealettes" and the like will be fashioned out of sheepskins, rabbits, horses, even the lowly Tomcat will be utilized, but the demand by woman will always be first for real furs, and the muskrat will never be dethroned. It, however, would be an economic mistake to have the prices for muskrat pelts go too highso high that the garment manufacturer would be forced to experiment with near-furs in an endeavor to catch the attention of the modish woman. To meet this, the muskrat industry in Louisiana should be so stabilized that a stearly, profitable supply of pelts annually be delivered to the manufacturer so that he can fashion a garment that will be placed within the range of the average American woman's pocketbook.

Practicable methods of 'rat ranching should be worked out by those most concerned, the owners of large acreages in the coastal belt marshlands. A fair method of paying the actual trappers for their labors in securing the animals during the winter months so that both the 'rat ranch owner' and the laborer can make money. Some sort of an effort should be made by owner, trapper and fur dealer to create a main market for pelts, particularly the muskrat pelts, in Louisiana so that prices can be stabilized. The people 
of Louisiana must be made to realize that there is within the State's borders a great and valuable industry conducted on what is now believed to be waste lands.

The fact that Louisiana possesses a six to seven million dollar raw fur pelt industry is not known to all and unsuspected by many otherwise well informed. The editor of a prominent New Orleans daily when told at a luncheon club gathering that Louisiana produced more pelts of fur animals than all Canada, wrote an editorial on the subject which he headed "Rats!"

The editor said that he "was pleasantly shocked" at the news. "If true, it shatters a legend inherited from childhood and sweeps away the fragments. Nearly every reading man of 40 years was steeped in his youth, one time or another, in the history and romance of the Hudson's Bay Company and the rest of the Canadian fur epic, and the facts and fictions about the fur trappers in the frozen North.

"St. Louis, by force of the circumstances that it was the meeting-place and trading-post for north and west and east, became early the center of our own fur trade. And by force of commercial habit it has held the place. If the supply is at our doors, New Orleans ought to be a great fur market, even if it cannot be The Market.

"Perhaps it is a mistake to agitate for the reclamation of the swampy belt fringing the Gulf, because it now yields great wealth at a minimum of expense, and can be made to produce still more, in skins. These moreover pay the State a severance tax on $\$ 6,000,000$ of value.

"Right or wrong, it is worth thinking about. We should be glad to print informed communications on the subject for either point of view."

No communications were received and the editor hasn't said "Rats!" since.

The taking of unprime pelts can instantly be stopped if those most concerned will support a real conservation program for the fur industry of the State. If those most concerned, the trappers, the fur buyers and the fur dealers, do 
not stop these practices themselves, the various States, through legislative enactment, can. By penalizing those who take unprime pelts and the pelts of infant fur animals. making it illegal not alone to take such skins but to have them in possession, the industry can be economically regulated, but such a stringent action should not be made necessary.

It is recognized that Louisiana possesses some very advanced laws for the protection of fur animals and proof of this seems to be indicated in the consideration and adoption of like laws by sister states. For years the State permitted the trapping of such non-game mammals as constitute our list of fur animals-muskrats, opossums, raccoons, mink, skunks, otter, foxes, wolves, weasels-without regulation. but gradually laws were passed by the Legislature that brought a check to those who would trap at any period of the year.

The entire fur situation, especially conditions pertaining to the muskrat, has received the closest and most earnest attention of the Department of Conservation. From surveys made over a period of years it appeared that when the season opened too early in the fall the furs taken were not prime, and when the season extended too far into the new year the furs reaching the market were "springy," and too many breeding and nursing females were taken. The duty of the Department was plain. It was imperative to shorten the season, with like advantage to the reproduction of the animals and those connected with the fur trapping and selling industry. We had conclusive evidence that the furs taken during the middle of the winter, the latter part of December and during the month of January, were superior as to primeness and brought the best prices.

The first law giving the fur animals of Louisiana a close season, permitted trapping from November 1 to February 1 (Section 6, Act 204 of 1912) and the animals so protected were the mink, otter, muskrat and raccoon; under this law, wildcats, skunks and opossums could be taken at any time.

When the first law protecting the fur animals of the State was passed the legislation said fur animals could 
only be taken by licensed trappers (Act 127 of 1912, Sections 9, 13 and 14) but the legislators failed to specifically fix a trapping license or its cost although it did provide for necessary hunting licenses. This law gave the residents of a parish the right to hunt in their own parish for 50 cents, made hunting free in the ward in which they lived, a state-wide hunting license cost $\$ 3.00$, and the price of "market hunting," those persons who hunt for profit, was fixed at $\$ 10.00$. On the subject of trapping licenses the sections were mum.

Soon after this law went into effect a trapper named Morgan was arrested for having trapped ten minks, six otters and three raccoons without having secured a "market hunter's license." Although the Legislature had failed to provide a trapping license fee, the officers of the conservation commission charged the trapper of "unlawfully taking with traps for profit (market hunting) during the open season ten minks, six otters and three raccoons, without then and there first procuring a license."

When brought to trial counsel for the trappers asked to have the information quashed on the grounds that the Legislature had made no provision for the payment of a trapper's license and that the trapper was not guilty of violating any law. This motion was overruled and the defendant invoked the supervisory jurisdiction of the supreme court of the State and asked for a reversal of the judgment of the district court. The high court held ${ }^{13}$ that even though the Legislature had failed to provide for the payment of license taxes for the taking of certain game by traps during an open season that it followed by necessary inference that this method of hunting or trapping could not be indulged in at any time and that, as the defendant had trapped the animals named in the bill of indictment, he had violated the law.

At the 1914 session of the Legislature, this defect in the law was remedied (Act 293 of 1914) by fixing the cost of trapping licenses at $\$ 2.00$, and the season for trapping 
was lengthened 15 days, viz, November 1 to February 15, inclusive.

Those in the department studying the situation believed that further cutting of the open season was necessary and made this recommendation to the legislature in 1926. The proposal was for a 60-day season starting December 1, and ending January 31. Opposition from trappers and other interests developed and a 75-day season was enacted, starting the season November 20 and ending it February 5.

In 1928 another effort was made to make the open season December 1, to February 15, but the suggestion was not adopted.

It is the mature decision of those having the best interests of the fur industry of the state at heart that no fur animals should be trapped before the first day of December and, if it is necessary to have a 75-day season for the taking of fur animals, that the season should end February 15.

\section{THE FUR SHORTAGE}

According to information gathered throughout the country by the bureau of biological survey in the United States Department of Agriculture there is at present a nation-wide shortage of furs but that this is not due entirely to trapping nor trapping methods. Much of it is caused by our characteristically American wasteful methods of handling important natural resources. Conspicuous among these are the indiscriminate felling of virgin forests, drainage of marsh lands and such activities whereby fur producing areas have been tremendously reduced.

"Trapping out of proper seasons is another cause for the shortage, and the trading of pelts so taken by dealers, too, has contributed to the present day shortage," warns the biological survey. "The defect in most conservation laws is the length of the legal open seasons, and the most serious drawback is that most laws permit trapping before the pelts are prime in the fall. It has been estimated that approximately 45 to 55 per cent of the pelts reaching the raw 
fur markets fall into the unprofitable class. Fur of the more superior quality and more of it would be handled by the trade if seasons were shortened and made more uniform in states having similar climatic conditions.

"Those responsible for the enactment of laws do not always realize that two and one-half months are sufficient open season on muskrats nor that the most valuable skins are those taken late in winter and early spring. As far as the muskrat is concerned, it is acknowledged by all who have made a serious study of this animal that it is an economic mistake to trap it anywhere in the United States before December 1 of any year."

This pronouncement by the Federal bureau seems to be suffcient proof of the soundness of the recommendations we have made as to the open season for trapping of fur animals in Louisiana in the future.

\section{The Fur Take In Past Years}

The trapping industry in Louisiana has grown to proportions that make it not alone a resource of large revenue and a means of livelihood to a considerable percentage of the state's population but a subject for the most careful and extensive conservation consideration so that the industry will become a permanent one.

It is a difficult matter to present accurate comparative takes of past years. It is certain that the survey made by the author of this bulletin in 1914 was the first made tending to compile the actual numbers of fur animals taken by the trappers and handled by the various raw pelt dealers. The catches of various winters, up to the 1919-1920 season were made a part of the department's files, but this collection of statistics was interrupted when the raw fur dealers of New Orleans, who objected to the state's fur severance tax, fought its collection in the courts, carrying the fight to the United States Supreme Court, where they lost, as they did in all of the lower courts.

While this legal affray was on the deparement was enjoined from delving into the business of the raw pelt dealers and at the conclusion of the legal battle the tax for 
the pelts taken was settled by a compromise of $\$ 61,842.47$, and the specified figures as to the number of fur animals taken was not obtained. Again, in 1927, the raw pelt dealers fought the fur tax as unconstitutional when the department saw fit to exercise its prerogative under the law to audit their books. Again the dealers lost, the contest going once more as high as the United States Supreme Court.

The following figures are believed to be approximately colrect as to the fur animals taken, with the exception of the muskrat, for the seasons of 1918-1919 and 1919-1920, as undoubtedly the raw pelt dealers did not report the entire number of pelts taken from the chief fur animals of Louisiana, and there was no law at that time giving the department of conservation the power to examine or audit their books. It has also been necessary to estimate the catch in a number of the other seasons, but it is believed that the figures are, in the main, an accurate compilation of fourteen years of trapping in Louisiana.

THE FUR TAKE IN LOUISIANA

1913 to 1929

\begin{tabular}{|c|c|c|c|c|c|}
\hline & Season & Muskrat & Opossum & Raccoon & Mink \\
\hline $1913-14$ & & $4,254,000$ & 178,000 & 401,000 & 105,000 \\
\hline $1914-15$ & & $5,000,000$ & 180,000 & 420,000 & 112,000 \\
\hline $1915-16$ & $\ldots \ldots \ldots \ldots \ldots \ldots$ & $3,500,420$ & 193,640 & 532,480 & 114,620 \\
\hline $1916-17$ & $\ldots \ldots \ldots \ldots, \ldots$ & $2,125,000$ & 228,921 & 678,821 & 122,480 \\
\hline $1917-18$ & $\ldots \ldots \ldots \ldots \ldots$ & $1,387,220$ & 140,125 & 220,110 & 85,440 \\
\hline $1918-19$ & $\ldots \ldots \ldots \ldots$ & $2,963,110$ & 152,800 & 258,200 & 79,975 \\
\hline $1919-20$ & $\ldots \ldots \ldots \ldots \ldots \ldots$ & $4,073,200$ & 224,100 & 252,800 & 98,700 \\
\hline $1920-21$ & $\ldots \ldots \ldots \ldots \ldots \ldots$ & $4,990,000$ & $144,70 \mathrm{~s}$ & 176,751 & 72,946 \\
\hline $1921-22$ & & $6,000,000$ & 113,385 & 131,041 & 40,573 \\
\hline $1922-23$ & $\ldots \ldots \ldots \ldots \ldots$ & $10,000,000$ & 154,972 & 109,030 & 34,607 \\
\hline $1923-24$ & $\ldots \ldots \ldots \ldots \ldots \ldots$ & $7,000,000$ & 160,000 & 120,000 & 50,000 \\
\hline $1924-25$ & & $6,236,165$ & 287,180 & 145,810 & 84,201 \\
\hline $1925-26$ & & $3,613,765$ & 198,490 & 128,516 & 51,447 \\
\hline $1926-27$ & $\ldots \ldots \ldots \ldots \ldots \ldots$ & $3,036,749$ & 356,184 & 127,882 & 43,896 \\
\hline $1927-28$ & & $2,858,834$ & 339,210 & 103,544 & 67,284 \\
\hline $1928-29$ & & $5,105,374$ & 518,295 & 153,914 & 99,844 \\
\hline $1929-30$ & & $6,269,556$ & 309,363 & 105,381 & 69,680 \\
\hline
\end{tabular}


THE FUR TAKE IN LOUISIANA-Continued

1913 to 1929

\begin{tabular}{|c|c|c|c|c|c|}
\hline & Season & Otter & Skunks & $\begin{array}{l}\text { Mis'c. } \\
\text { Pelts }\end{array}$ & Total \\
\hline $1913-14$ & & 2,860 & 27,280 & 4,500 & $5,002,640$ \\
\hline $1914-15$ & $\ldots \ldots \ldots \ldots \ldots \ldots$ & 2,750 & 25,500 & 3,000 & $5,743,250$ \\
\hline $1915-16$ & n.............. & 3,540 & 23,670 & 6,740 & $4,375,110$ \\
\hline $1916-17$ & $\ldots \ldots \ldots \ldots \ldots \ldots \ldots$ & 2,940 & 25,624 & 3,164 & $3,186,950$ \\
\hline $1917-18$ & $\ldots \ldots \ldots \ldots \ldots \ldots \ldots$ & 1,985 & 25,210 & 3,100 & $1,863,190$ \\
\hline $1918-19$ & $\ldots \ldots \ldots \ldots \ldots \ldots \ldots$ & 2,428 & 22,340 & 3,700 & $3,482,553$ \\
\hline $1919-20$ & ................ & 1,680 & 13,300 & 2,365 & $4,666,145$ \\
\hline $1920-21$ & $\ldots \ldots \ldots \ldots \ldots \ldots \ldots$ & 1,321 & 13,554 & 1,000 & $5,400,280$ \\
\hline $1921-22$ & ................ & 1,044 & 16,934 & 2,491 & $6,305,471$ \\
\hline $1922-23$ & $\ldots \ldots \ldots \ldots \ldots \ldots \ldots$ & 1,530 & 12,430 & 3,037 & $10,315,606$ \\
\hline $1923-24$ & $\ldots \ldots \ldots \ldots \ldots \ldots$ & 1,500 & 15,000 & 2,000 & $7,348,500$ \\
\hline $1924-25$ & $\ldots \ldots \ldots \ldots \ldots \ldots$ & 2,110 & 14,752 & 947 & $6,771,165$ \\
\hline $1925-26$ & $\ldots \ldots \ldots \ldots \ldots \ldots$ & 2,024 & 30,866 & 1,058 & $4,026,166$ \\
\hline $1926-27$ & $\ldots \ldots \ldots \ldots \ldots \ldots$ & 2,554 & 27,671 & 1,095 & $3,596,031$ \\
\hline $1927-28$ & & 1,190 & 22,348 & 1,072 & $3,393,482$ \\
\hline $1928-29$ & $\ldots \ldots \ldots \ldots \ldots \ldots$ & 3,048 & 38,940 & 2,655 & $5,922,070$ \\
\hline $1929-30$ & $\ldots \ldots \ldots \ldots \ldots \ldots$ & 1,447 & 27,034 & 1,877 & $6,784,339$ \\
\hline
\end{tabular}

\section{LICENSED TRAPPERS OF LOUISIANA}

Previous to 1917-1918 season, the possessor of a legal hunting license was permitted to trap fur animals in Louisiana; therefore it is impossible to secure an accurate enumeration of trappers. For the 1917-1918 season the new law requiring all trappers to hold a $\$ 2.00$ state-wide trapping license went into effect and continued up to the end of the 1919-1920 season, when the legislature again removed the special trapping license feature, making it permissible to trap fur animals on a hunter's license.

For the 1922-1923 season a $\$ 1.25$ combination trapping and hunting license law was enacted, providing for all those who trapped to secure the trapping license allowing the legal right of hunting for 25 cents extra. The first year this law went into effect witnessed the high mark in trapping licenses purchased in Louisiana, 28,600 trappers paying the fee. This season also marked the year of the greatest fur take in Louisiana, estimates of those in the fur trade rallging from $10,000,000$ to $15,000,000$ muskrats being shipped out of the state. 
This combination hunting and trapping license remained in effect up to the 1923-1924 season, when a new law was enacted which, while keeping the trapping license at $\$ 1.25$, did not include the right to hunt on it. In 1926 the legislature enacted a new and revised fur law, raised the trapping license to $\$ 2.00$, giving the proceeds of the sale of the license to the various parishes "to be used and expended in said parish in aid of fur bearing animal conservation." Under this regulation a trapper, who must be a resident of Louisiana, is obliged to purchase a license in every parish in which he traps.

The table below will show the number of licensed trappers that have taken the field the past ten years to take the fur animals in Louisiana, as well as the number of buyers, resident dealers and non-resident dealers taking out licenses :

\begin{tabular}{|c|c|c|c|c|c|c|}
\hline & eason & 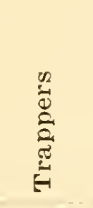 & 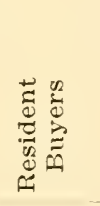 & 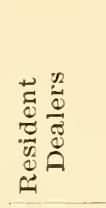 & 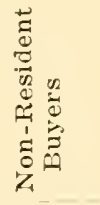 & 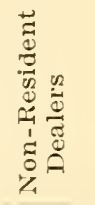 \\
\hline $1917-18$ & $\ldots \ldots \ldots \ldots$ & 6,145 & $\ldots \ldots$ & $\ldots \ldots$ & $\ldots \ldots$ & $\ldots \ldots$ \\
\hline $191 \delta-19$ & $\ldots \ldots \ldots \ldots$ & 6,243 & $\ldots \ldots$ & $\ldots \ldots$ & $\ldots \ldots$ & $\ldots \ldots$ \\
\hline $1919-20$ & $\ldots \ldots \ldots \ldots$ & 9,834 & $\ldots \ldots$ & $\ldots \ldots$ & $\ldots \ldots$ & $\cdots \cdots$ \\
\hline $1920-21$ & $\ldots \ldots \ldots \ldots$ & * & 314 & SS & $\ldots \ldots$ & 3 \\
\hline $1921-22$ & $\ldots \ldots \ldots \ldots$ & * & 537 & 100 & $\ldots \ldots$ & 16 \\
\hline $1922-23$ & $\ldots \ldots \ldots \ldots$ & 28,600 & $\ldots \ldots$ & $\ldots \ldots$ & $\ldots \ldots$ & $\ldots \ldots$ \\
\hline $1923-24$ & $\ldots \ldots \ldots \ldots$ & 26,550 & $\ldots \ldots$ & $\cdots \cdots$ & $\ldots \ldots$ & \\
\hline $1924-25$ & $\ldots \ldots \ldots \ldots$ & 20,149 & 941 & 73 & $\ldots \ldots$ & 29 \\
\hline $1925-26$ & $\ldots \ldots \ldots \ldots$ & 17,344 & 885 & 83 & $\ldots \ldots$ & 26 \\
\hline $1926-27$ & $\ldots \ldots \ldots \ldots$ & 12,973 & 704 & 56 & 12 & 6 \\
\hline $1927-2 S$ & $\ldots \ldots \ldots \ldots$ & 12,628 & 695 & 62 & 4 & 4 \\
\hline $1928-29$ & $\ldots \ldots \ldots \ldots$ & 12,603 & 710 & 61 & 7 & 2 \\
\hline $1929-30$ & $\ldots \ldots \ldots \ldots$ & 12,878 & 634 & 67 & 4 & 6 \\
\hline
\end{tabular}

*Combined with hunting license.

To understand the distribution of the trappers throughout the state the table on page 58, showing the number of licensed trappers by parishes, is included in this bulletin. A study of the licenses sold will show that the bulk of the trappers carry on their quest for the fur animals in the 
coastal section parishes, where the muskrat is found. Terrebonne, largest parish in the state by area, is the leader in furnishing trappers, follow ed by the adjoining Lafourche, with St. Mary which bounds Terrebonne on the west, a close third. Plaquemines, Vermilion, Jefferson, Calcasieu, Cameron, St. Bernard, and even Orleans, contribute their quota to this winter-time army. Just how many farmer boys, as well as those who have an inherited distaste to license buying, are not represented in the following list is problematical, but it is enough to say that each year Louisiana sends about 20,000 trappers into the marshes, swamps and other parts of the great outdoors to take their share of pelts.

\section{LICENSED TRAPPERS IN LOUISIANA}

\begin{tabular}{|c|c|c|c|c|c|c|}
\hline & $1924-25$ & $1925-26$ & $1926-27$ & $1927-28$ & $|1928-29|$ & $1929-30$ \\
\hline Acadia & 163 & 136 & 67 & 76 & 47 & 41 \\
\hline Allen. & 359 & & 194 & 217 & 159 & \\
\hline Ascension $\quad \ldots \ldots \ldots$. & 95 & 104 & 96 & 56 & 60 & 52 \\
\hline & 230 & 275 & 204 & 131 & 139 & 109 \\
\hline Avoyelles $\quad . . . . \ldots \ldots$ & 194 & 340 & 108 & 42 & 52 & 52 \\
\hline & 267 & 196 & 100 & 160 & 231 & 185 \\
\hline Bienville.$\ldots \ldots \ldots \ldots$ & 162 & 117 & 95 & 130 & 102 & 7 \\
\hline Bossier. . & 173 & 131 & 100 & 127 & 117 & 123 \\
\hline Caddo. & 203 & 134 & 96 & 91 & 102 & 114 \\
\hline Calcasieu & 611 & 479 & 267 & 374 & 284 & 306 \\
\hline 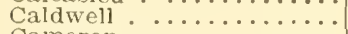 & 225 & 74 & 60 & 64 & 46 & 37 \\
\hline Cameron ............... & 679 & 306 & 274 & 385 & 502 & 763 \\
\hline Catahoula.$\ldots \ldots \ldots \ldots$ & 176 & 97 & 97 & 71 & 41 & 41 \\
\hline$\ldots \ldots \ldots \ldots$ & 79 & 41 & 54 & 63 & 43 & 41 \\
\hline Concordia & 186 & 169 & 124 & 72 & 62 & 165 \\
\hline De soto $\ldots \ldots \ldots$ & 201 & 162 & 145 & 161 & 155 & 169 \\
\hline East Baton Rouge & 110 & 88 & 72 & 55 & 47 & $\begin{array}{r}105 \\
33\end{array}$ \\
\hline East Carro & 196 & 122 & 154 & 217 & 173 & 173 \\
\hline East Feli & 67 & 36 & $\begin{array}{r}104 \\
39\end{array}$ & 45 & 34 & 32 \\
\hline Evangelin & 143 & 123 & 52 & 50 & 61 & 61 \\
\hline Franklin & 190 & 127 & 80 & 70 & 44 & 44 \\
\hline & 17 & 145 & 110 & 128 & 77 & 67 \\
\hline$\ldots \ldots \ldots \ldots \ldots$ & & 141 & 159 & 109 & 119 & 165 \\
\hline ............ & 239 & 298 & 222 & 237 & 90 & 109 \\
\hline$\ldots$. & 155 & 10 & 68 & 86 & 62 & 58 \\
\hline Jefferso & 507 & 651 & 360 & 394 & 392 & 475 \\
\hline Davis & 246 & 196 & 121 & 148 & 100 & 100 \\
\hline Iafa & 57 & 75 & 18 & 6 & & 8 \\
\hline Lafoll & 1,495 & 1,362 & 878 & 918 & 1,044 & 995 \\
\hline & 105 & & 42 & 46 & & 36 \\
\hline Lineol & 61 & 46 & 36 & 70 & 44 & 49 \\
\hline Livi & 192 & 177 & 94 & 46 & 31 & 30 \\
\hline Marison & 243 & 236 & 165 & 239 & 177 & 166 \\
\hline Morehous & 189 & 219 & 181 & 226 & 267 & 252 \\
\hline $\begin{array}{l}\text { Natchitoches } \\
\text { Orleans }\end{array}$ & $\begin{array}{l}492 \\
494\end{array}$ & $\begin{array}{l}393 \\
442\end{array}$ & $\begin{array}{l}292 \\
525\end{array}$ & $\begin{array}{l}297 \\
165\end{array}$ & $\begin{array}{l}312 \\
174\end{array}$ & $\begin{array}{l}308 \\
222\end{array}$ \\
\hline Onachi & $\begin{array}{l}4,94 \\
27 t\end{array}$ & $\begin{array}{l}137 \\
137\end{array}$ & $\begin{array}{l}525 \\
175\end{array}$ & $\begin{array}{l}160 \\
168\end{array}$ & $\begin{array}{l}174 \\
148\end{array}$ & 128 \\
\hline Pla:11 & 85 & 881 & 1,055 & 584 & 868 & 942 \\
\hline Foin & 17 & 215 & 15.9 & 129 & 74 & 71 \\
\hline Rap & 38 & 415 & 272 & 296 & 294 & 313 \\
\hline Rerd River & 16 & 74 & 68 & 89 & 66 & 47 \\
\hline ichis & 24 & & 99 & 87 & 100 & 100 \\
\hline Sabine = . & 39 & 3.34 & 216 & 425 & 307 & 315 \\
\hline St. Bernard & 29 & 301 & 460 & 33 & 388 & 285 \\
\hline St. Fharle & 234 & 241 & 234 & 170 & 255 & 274 \\
\hline St. Mr.lfna & $\$ 4$ & & & & & \\
\hline
\end{tabular}


LICENSED TRAPPERS IN LOUISIANA-(Continued)

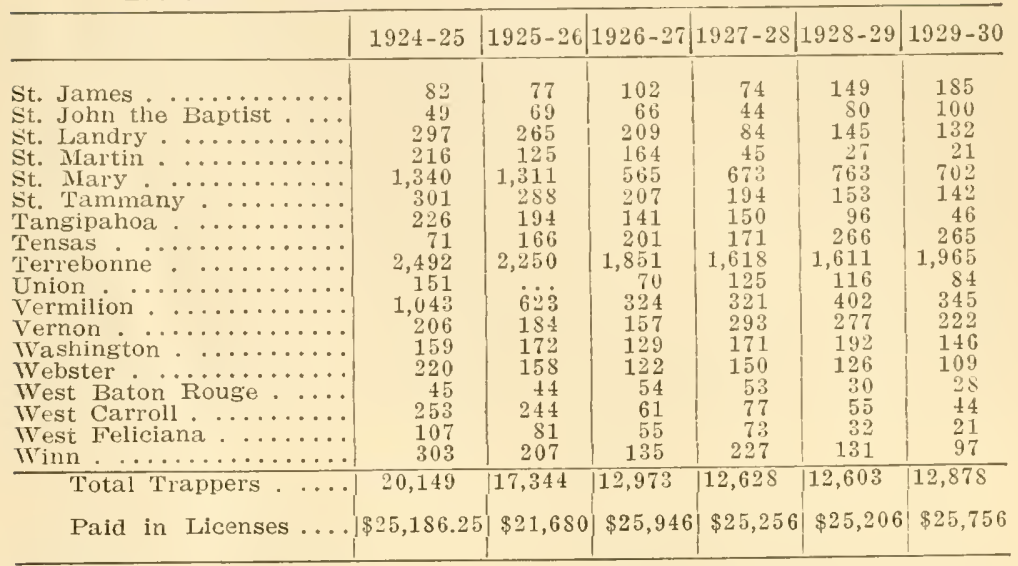

Must Furs Come From the Snow Countries?

Popular and colorful romance has been chiefly responsible for the very general impression that only in the cold climate, where snow and ice and Arctic winds forced the furred creatures of the wild to grow a heavy pelage, are the fur animals to be found. Popular belief, too, has been that only in these northern primal wildernesses do trappers lay their traps so that milady in search of creature comforts or the bizarre may suitably adorn her figure-in winter as well as in summer.

As a mater of fact it is recognized that furs can come from too far North. This is true of the average Canadian muskrat, as fur experts have declared it to be the poorest of all 'rats in wearing quality, this being due, they point out, to the fact "that in cold weather they absorb their own fat for food, which thins the pelt and impoverishes the fur,"

Despite the widespread belief that furs come only from the rigorous sections, the tropics and sub-tropics have long held their important places in the fur world. While it is true that the silver fox, the pet of the fur trade and the highest priced individual pelt in the commerce, is found in the Arctic, on the other hand, the nutria, for by such name does the coypu rat masquerade in the fur trade, comes from the tropics and sub-tropics of South America; and the 
greatest pelt known to the fur world-that is, in the years gone by-was the beaver, and the beaver had a distribution from the hot lands of Mexico to the Actic fastnesses of Hudson Bay. The beaver, now practically gone, has been replaced by the heretofore inconspicuous muskrat as the pillar of the fur trade and nowhere is the muskrat to be found in more prolific numbers than in the State of Louisiana, and in this same state approximately 20,000 trappers go into the vast expanses of the coastal marshlands, the swamps and other woodlands for fur pelts every winter.

\section{WHAT IS FUR?}

Fur is the name applied especially to the covering on the skins of certain animals. The fur lies alongside another and usually longer covering variously called the "guardhair," "overhair" and "kinghair." The fur of an animal differs from its hair in that it is soft, silky, dense, downy, and under the microscope will be noted to be barbed lengthwise. The guardhair is straight, smooth and comparatively stiff.

The fur and the guardhairs on an animal have separate uses. The guardhair on the living animal keeps the fur filaments apart and has its function in preventing the fur from a tendency to mat or felt, and, in addition, the guardhairs protect the fur from injury, thereby giving the animals needed immunity from cold.

In many cases the guardhairs are not utilized by the furrier when making up certain garments, while in other pelts the guardhairs constitute the beauty and value of the pelt.

The fur market and fur wearers are dependent on certain members of the mammalian order for its source of natural supply. Four orders are conspicuous sources of this natural supply, being the Camivora, Rodentia, Ungulata, and Marsupilia.

The two most important orders are the Carnivora, or flesh-eating mammals, which in Louisiana are represented by the wolf, gray fox, lynx or wild cat, black bear, raccoon, mink, skunk, weasel and otter; and the Rodentia, or gnaw- 
ing mammals, represented by squirrels, chipmunk, beaver, muskrat, native rats, hares, and field mice.

The Ungulata, or hoofed mammals, have but one representative in Louisiana, the Louisiana white-tailed deer, while the Marsupilia, or pouched mammals, have a single representative, the opossum, by no means an unimportant pelt in the fur marts today.

The Insectivora, or insect eaters, are represented by the common mole and several species of shrews, but they form an inconsequential group as far as fur trade is concerned.

\section{What Makes Fur Beautiful?}

It has been frequently pointed out that there are two prime requisites for furs which make them, in our phraseology, beautiful-health and youth.

Health of the animal determines the lustre, and youth gives the fur its texture, or that "smooth, silky quality," as it is frequently termed.

A third element (that of cold) is not necessary for the creation of fine furs with such quadrupeds as raccoons, opossums, otters, minks and muskrats. This is very evident from amphibious mammals. Other species of mammals do need cold to give them a firm and prime pelt; in this category can be placed such prized furs as those from the silver fox, marten, fisher, and weasel (ermine) as they, to combat the rigors of a long and freezing winter, put on a thicker coat of fur, but sometimes this is done at a sacrifice of quality.

Therefore, good furs from the sub-tropics are not to be looked upon as strange, unnatural or impossible. The strange thing is that furs can come from too far north, for they are without the quality possessed by pelts taken in more temperate localities.

And, too, it must not be forgotten that in winter, in Louisiana, when the temperature falls to 32 degrees above zero, that the water of the marsh lands is just as cold as the waters of the northern tier of states. If the water would be any colder it would freeze solid and muskrats 
have not, as yet, solved the difficulties in the way of swimming through a solid block of ice.

\section{Is TrapPing CrUel?}

A hue and cry has been started in some quarters against the taking of our native mammals for fur, as a decided economic waste; as a trade that depends on extreme cruelty for its existence; as a pastime, and a profession which is against all the ethics of true conservation. In this regard it might be well to quote one of the foremost champions of our vanishing wild life, Dr. William T. Hornaday, former director of the New York Zoological Park, who, in discussing the status of the fur-bearers, recently said:14

"The real fur-bearing animals of the world stand on a basis apart from most other wild animals of the world. Many of them are fiercely predatory and absolutely require the hand of the human killer to keep them from overrunning and devouring men, beasts and birds. For example:

"Wolves, wherever they occur in large numbers, constitute a nuisance and scourge of the first magnitude. With unparalleled ferocity they devour the wounded and the dead of their own kind, their own pups, and the game of every description, from mice to men. It is true that their slaughter of men is not great, but that is because man is himself a dangerous animal of no mean proportions. The depredations of gray wolves and coyotes on little sheep and colts of the western stock ranges are at all times very exasperating, and millions of dollars have been expended in wages and bounties for wolf destruction.

"In approaching the wolves and weasels, some of our principles against the extermination of species break down, and we note exceptions. There are those who believe that it would be a good thing for the world at large if all wolves and weasels were to be totally blotted out of existence. We believe that their destruction of more valuable wild creatures outweighs their own fur value.

1s The Fur Trade and the Wild Animals, Bull, N. Y., Zoological Soc. vol. iv, No. 2, pp. 36-38. Míar., 1921. 
"All the members of the marten family, in which are the fishers, martens, skunks, weasels and mink, are savage and merciless. Some of them; such as the weasel, mink and skunk, are wholesale slaughterers who murder helpless birds by the dozen for the vicious lust of murder. For example, on two occasions a mink wiped out an entire flock of over twenty gulls, in the New York Zoological Park, in a single killing and without devouring even one. On one estate, in Pennsylvania, one murderous little weasel murdered twenty-four ring-necked pheasants in one night.

"The skunk is the pariah of the class Mammalia, a dangerous and disgusting outcast, and it is a good thing for the world that his pelt is wanted for its fur. May the price of skunk skins never go down until the last skunk has been gathered in! This view, however, will not receive the indorsement of those fur dealers who hold that the skunk is so nearly harmless to man that he should be tolerated and encouraged for the sake of his fur.

"The 'sufferings' of wolverines, weasels, mink and skunk in traps are not so great as they may seem. A marten or a mink will eat a good meal with one foot in a trap. It is a way with the members of the marten family to tear and devour their prey alive, and it is the way of man to catch them in about the only way in which it can be done-in steel traps. We do not believe in any unnecessary cruelty, either in the killing of wild animals or domestic animals, but there is plenty of both. The proper course of human people is to reduce it to an irreducible minimum."

In comment on the balance of nature in relation to the fur-bearers, Dr. Hornaday, too, pointed out, "that ever since the day of primitive man, and according to their needs, the carnivorous fur-bearers have killed and devoured other vertebrates whenever they could be caught; and man has killed the fur-bearers to supply his own needs, and our people should not quarrel with these two fundamental laws of nature for they are as fixed and unshakeable as the Rocky Mountains."

On the other hand, he points out, it is a right good thing that man's needs have caused him to keep down the increase 
of predatory animals by killing them and utilizing the surplus. Had this not been done, he declares, many species of land mammals and birds would have been exterminated, and only the largest, the strongest and the fleetest would have survived.

Even at the risk-or, rather, the absolute certainty-of: arousing resentment and criticism, Dr. Hornaday said that he felt compelled to say that the fur trapper has his legitimate place in the economy of nature, and that he believed in the taking of fur-in moderation. The noted wild life expert and champion, however, sounded a warning, claiming it is easy for the trapper to overplay his hand and leave behind him lifeless wastes, and that in many instances the: world of today is trapping not wisely but too well.

"It is the dity of the fur trade to get together and take steps to regulate the trapping business, to stop waste and abuses, to stop using species that should not be used, and provide for a continuance of the legitimate fur trade," is his summing up of the situation as it presents itself today.

\section{Periodic Fluctuations of Fur Animals}

In the study of creatures of the wild, whether they be: birds, mammals, or insects, the reason for a great abundance one year and a corresponding scarcity another has always been a puzzling study, whether its solution is sought by scientist or untutored student of the ways of the wild. These alternating cycles of abundance are sometimes so uniform that they have been termed "period fluctuations" and in many cases have never been satsfactorily explained or, to be more exact, they have brought forth a number of conflicting theories from those who have declared a solution for the phenomena.

Periodic fluctuations in the fur catch have been known since the early days of the operations of the Hudson's Bay Company among the fur animals of northern North America and, in Louisiana, as well as in the far north, these. cycles or waves of plenty and scarcity have elicited many explanations. The peculiar "year of no rabbits" of the Arctic and sub-Arctic is perhaps the best known and the: 
most studied fluctuation, and Professor V. W. Jackson, in his "Fur and Game Resources of Manitoba," claims that periodic fluctuatoins in the fur catch of that Canadian province can seldom be ascribed to the effects of trapping, but, rather, to natural causes, such as food supply, weather conditions, and widespread epidemics. These go in cycles of plenty and scarcity, of severity and salubrity, and dependent animal life seems to vary accordingly.

Herbivorous animals seem to vary slightly with the vegetation and largely with epidemics of widespread disease, Professor Jackson said, while carnivorous animals seem to die from exposure and sfarvation in winter. The flesh-eaters do not usually seem to have specific epidemics on the same large scale as the vegetable feeders, he states, and in his study of statistical reports extending over a century of fur-trading in the north shows that the peak years of rabbit abundance were 1845, 1855, 1877, 1887, $1897,1905,1917$, and of lesser abundance in 1924. This approximates an eleven-year cycle, according to Professor Jackson, and he cites Elton's suggestion of association of sunspot maxima and the eleven-year cycle with its concomitant effect upon vegetation, tree growth, and water levels and other natural conditions. And, as might be expecteđ, the abundance and scarcity of lynx, fox, and wolf is coincident with that of the rabbit of the north. This study of the almost perfect correlation of the rise and fall of the rabbit population with the animals that prey on them indicates a provision of some kind to maintain a balance of nature.

"This periodic abundance of rabbits and sudden decline is a perfectly normal happening," claims Professor Jackson. "In good or favorable years the fertility of rabbits is much increased, there being eight to ten young in a brood, instead of five or six, and two or three broods instead of one. The district becomes surcharged with rabbits, food fails, epidemies break out, and the population is destroyed in a season."

While those interested in the perpetuation of the fur industry in Louisiana cannot point out any direct connection between the "year of no rabbits" of the north with the 
fur animal supply with our part of the continent, still it is important to point out that there have been what appear to be periodic fluctuations in the muskrat population not wholly attributable to trapping. A matter so important warrants a great deal of local research as to causes, and if depletion by epidemics rather than by trapping is the factor in the periodic and extreme fluctuations in our muskrat crop in the past few years, the causes should be sought out and remedial efforts expended to prevent reoccurrence if it is possible.

\section{California's Plague of Mice}

In January, 1927, scientists and many others interested in rodent reproduction, followed newspaper and other reports of an unprecedented outbreak of mice in the Buena Vista Lake section of southern California. According to some of the stories, "millions upon millions" of the animals swarmed on the highways, and one oil company was credited with killing "four tons of mice."

The outbreak, naturally, was immediately investigated by the California Fish and Game Commission and by the Museum of Vertebrate Zoology of the University of California, Director Joseph Grinnell delegating E. Raymond Hall, curator of mammology, to make the study. Mr. Hall estimated that the affected area was about eighteen miles in diameter, that the rodent outbreak was by the common house mouse (Mus Musculus), and he found as many as seventeen mice per square yard over an area of many acres planted in kafir corn. Computed from the counts made on the measured areas, Mr. Hall arrived at the startling number of 82,280 mice per acre, or 2,468 pounds of mice per acre, doing damage and migrating to other parts.

A very interesting and valuable account of this plague was written by Mr. Hall and published by the University of California, ${ }^{15}$ and the liberty is taken of quoting from the bulletin wherein it bears on the problem of periodic fluctuations of rodents.

${ }^{25}$ Hall, E. Raymond, An Outbreak of House Mice, pp. 189-203, University of california, 1927 . 
The California investigator found no mice less than three-fourths grown. "Since it is commonly known, from laboratory experiments, that shortage of food curtails or stops reproduction in mice," said Mr. Hall, "the exhaustion of food in the Buena Vista Lake basin is suggested as the probable cause for the apparent absence of young mice among the thousands seen. No evidence of disease of any kind that might be expected to destroy the mice was noted. Judging from what has happened during marked increases in the population of other rodents, some epidemic eventually should, of course, be expected to occur here.

"Among animals that are subject to such enormous and sudden increases in population, and equally sudden decreases, it may be inferred that natural selection would operate at an accelerated rate. For instance, with the present scarcity of food in the Buena Vista Lake region, it can be understood how certain individual mice that are able to survive longest without sufficient food would live to produce offspring, whereas the millions less fit in this respect would die and leave no progeny. Assuming that this physiological fitness were heritable, a marked change might occur in this respect within a short series of generations. Perhaps the example chosen is not the most happy one; but it suggests one, at least partial, explanation of the apparently unequal rates of evolution of different descent-lines of animals that come to the attention of the palaeontologist. Certain characters would seem more rapidly to be selected for in a kind of animal that is subject to rapid increases and decreases in population than in a kind whose population remains relatively constant through long series of generations."

In this California plague of mice, Mr. Hall found that a radial migration resulted, at first, in apparently equal numbers of the mice moving outward from the basin in all directions, and, seemingly, no choice of destination was made by the migrants, there being, according to this authority, no stimulus or positive attraction causing all of, or even the majority of, the mice to move in one given direction rather than in another. 
"To assume that the movement of one mouse in a given direction acts as a stimulus for another one near-by to do the same, or that this movement at least discourages the latter from going in a different or exactly opposite direction, explains the movement once it has begun," Mr. Hall tells us. "But, of course, it could not explain the equal movement in all directions from one central point; in fact, if such were the determining factor at the beginning of the migration, a radial migration of the type just described would be prevented.

"Perhaps, then, a mechanical cause starts the migration; after the animals have once gone, for a given length of time, in a certain direction, some sort of impulse is developed to continue. But what the stimulus for guidance may be is not clear."

It must be remembered in the case of the outbreak of house mice in this dry bed of a one-time lake, given over to agricultural pursuits, that the animal causing the plague was an exotic species, an immigrant from the Old World that had not been in that section of California more than fifty years, and that the same relative outbreak in numbers was not observed in the native rats and mice of that section. $\mathrm{Mr}$. Hall found that the conditions of this restricted region were most suitable for the increase of the house mouse, particularly in the abundance of grains, for which they had a great predilection, while the native species of rodents desired more green foods.

Mr. Hall's outstanding observance, was the fact that the farmer-folk of the affected area had kept up an unceasing warfare on the birds and beasts of prey-the hawks and owls of the air and the coyotes, foxes, bobcats, skunks and other carnivorous mammals of the land. Although it is known that several factors besides the natural enemies of rodents, native and exotic, determine their numbers, such as farorable climate and abundant plant growth, the fact that mice are small and easy of prey render them the staple food of every one of the carnivorous mammals, while hawks and owls of many species need the tiny rodents for their subsistence. 
In this California region one of nature's checks on an abindance of earth-bound animals had been wiped out by man when these tiny mammals began to roll up in numbers. And the mice played havoc with agriculture. Indeed, it was estimated that the losses that coyotes, bobcats, skunks and other mammals might have caused the sheepgrowers of that region, and for which they were poisoned, trapred and shot out, were less in value than the damage the plague of mice did to the agricultural interests.

According to Mr. Hall, it should be pointed out "that in the no:mal, or usual, state of population of animals, one given carnivore feeds on several species of prey, but when for any reason one species of prey becomes more numerous than the others, the carnivore naturally, because of the ease and readiness with which the prey can be secured, concentrates upon that one. There is, then, a certain optimum point of population-size for a species that calls forth the maximum effcctiveness of the other animals that prey on it.

"When the usual relative numbers of all the different species, both carnivores and herbivores, are present, this optimum point seldom is passed or even reached, and the condition of an over-population is thus prevented by the anim ls that play the carnivorous role.

"It is known that house mice attain sexual maturity by the time they are three months old at most and that, on the average, under favorable circumstances they produce a litter at least each month. The litters average from five to six. In two year's' time, then, breeding at this rate and assuming that all the mice lived to reproduce their kind, two adult mice producing a litter at the end of the first month, have a potentiality of $3,701,257$.

"Lat us suprose, for the sake of illustration, and not for. the sake of assuming that the number selected is correct as to the actual number produced by one pair here, that at Buena Vista Lake one pair of house mice was responsible for one one-thousandth of this number-that is, 3,701. Four pairs of mice then would, at the end of two years, be re- 
sponsible for 14,804 mice. If, however, predatory mammals, or anything else, should destroy at the beginning, half these eight mice, involving two females, the number at the end of two years would be only half of 14,804 , or 7,402 . It therefore is readily seen that the absence at the present time of natural checks is not the important factor but that their absence when the increase in population began was the important factor that might have prevented or at least greatly decreased the eventual outbreak.

"Although suitable shelter was abundant for the mice, it was not of the kind that would have been impregnable to the enemies of the mice. Although food was abundant, no evidence is forthcoming that it was more abundant than in similar fields elsewhere at times when the weather conditions were essentially as they were in the past two years at Buena Vista Lake. As Hinton has said, 'The weather may be lenient to rodents, the carnivora never.' At Buena Vista Lake the carnivores had been eliminated.

"The causes of this over-abundance of population of house mice may therefore be stated as: favorable meteorological conditions, abundant food and shelter, and removal of the principal natural enemies of small rodents that normally hold their numbers in check. The factor determining the time of the spectacular emigration of the mice was, probably, the destruction of their food and shelter.

"Unfavorable meteorological conditions alone, a lesser amount of food and shelter alone, would have, and the presence of the normal number of carnivorous mammals alone might have, prevented the excessive increase in numbers."

The foregoing comments on periodic fluctuation among mammals, especially applying to the rodent family, to which division our muskrat belongs, have been included for the sole purpose of attracting the attention of readers of this bulletin to this phase of our wild animal life to act as an incentive to those with an investigative turn of mind to make first-hand studies of the phenomenon.

Field studies of the muskrat in Louisiana appear to bear out the fact that our principal fur animal has five-year cycles of abundance. This observation, however, it must be 
pointed out, has not been proved and will need further intensive study, but in view of the present discussion the following is set down:

In 1913 , the New Orleans raw pelt trade handled a very large amount of muskrat pelts and veteran trappers, when it was recalled to them, remember that this animal was very abundant during the fall and winter of that year.

The World War was on in full blast in 1918. Many of our Louisiana trappers were in France, many others who "emained here were busy with other war-time activities, the European fur market was closed, particularly Leipzig, the chief German raw pelt center, and as a consequence few trappers were in the field. While the estimate of the fur catch, especially the muskrat, was not high, it is a fact, however, that this animal was particularly abundant in 1918 and in spite of the fact that a disastrous Gulf hurricane swept the coastal marshes in August of 1915.

The year 1923 will ever be remembered as the year in which the greatest catch of muskrats ever recorded in Louisiana took place. A veteran fur buyer for a prominent New York house, who has kept a check of the muskrats handled by the local dealers for a score of years, says that fifteen million pelts of this fur animal is not too high a figure. At any rate the catch of that year can be conservatively placed at about ten million.

In 1924 and again in 1925, Louisiana was visited by a severe drought. Salt water inundated fresh water lakes and lagoons, muskrats died, the vegetation dried, and fires swept the coastal areas from the Pearl to the Sabine Rivers. Muskrats suffered and it will never be known how many died from the effect of a lack of water, from disease and from fire. A phenomenal and unexpected rise in prices sent an army of trappers into the marshes who "cleaned up" on the 'rats the droughts, fires and diseases did not get. and the muskrat has been slow in coming back. 


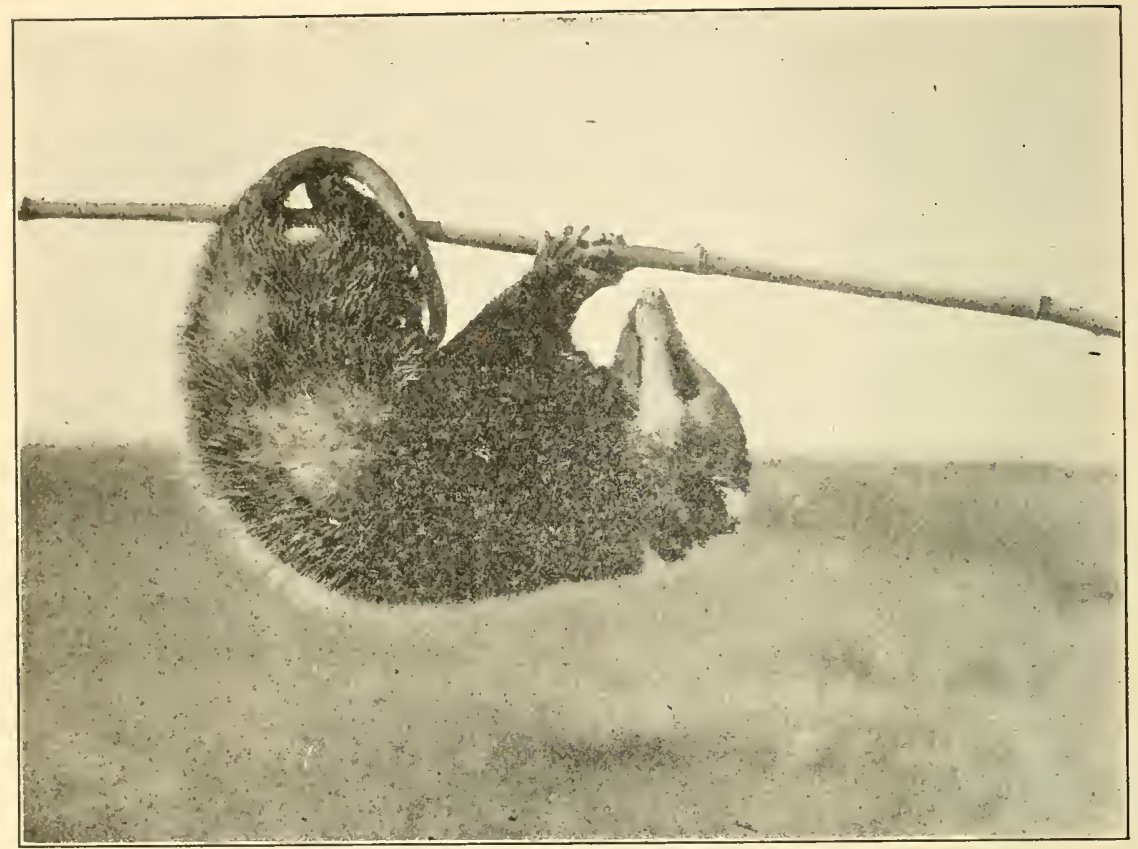

Because of the grasping strength of its toes it is no trick for an opossum to climb about, upside down, like a sloth.

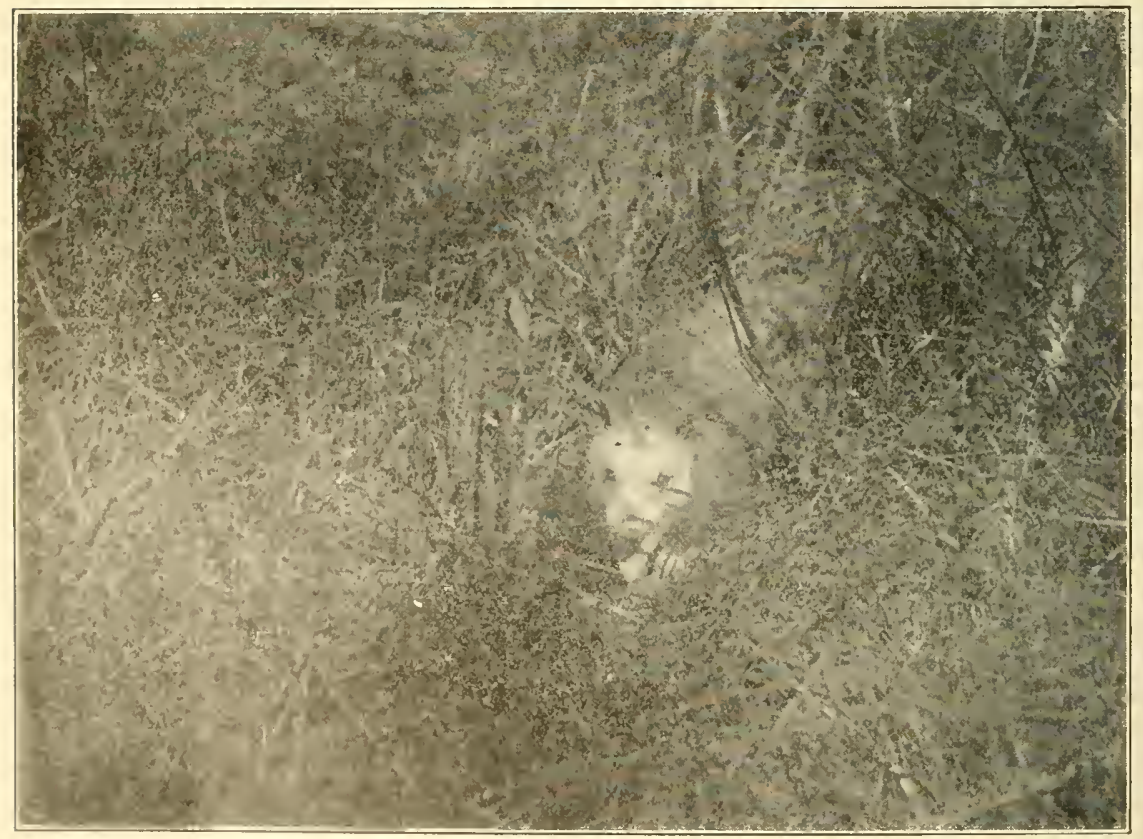

The possum, in search of its prey, moves stealthily about in dense vegetation. 


\section{CHAPTER SEVEN}

\section{FURS AS A SOURCE OF STATE REVENUE}

THAT the fur industry can be made an important souice of revenue for a state is proved by the amount of moneys collected during the trapping season in Louisiana as a tax. This state first enacted a severance tax law whereby 2 per cent of the value of the product severed should go to the stats. The Louisiana legislature several years ago, to facilitate the collection of this tax, placed valuations on the pelts of the various fur-bearers so as to impose an arbitrary tax. Muskrats and opossum pelts were valued at $121 \%$ e cents, calling for a specific tax of $1 / 4$ cent; skunk, civet cat, wild cat, fox, wolf, were valued at 50 cents, with a specinc tax of 1 cent; mink and raccoons were valued at $\$ 2.50$, with a specific tax of 5 cents; otters were given a valuation of $\$ 12.50$, with a specific tax of 25 cents.

In the 1021-1225 scason the wild life division of the Department of Conservation collected $\$ 24,206.10$, which went into the genercl fund of the state, as not one cent of this amount was cincwed the Conservation Dapartment for its collection. Tha severance tax was collested on 5,445,014 pelts of all kinds, which was regarded as only 80 per cent of the total take, as, due to a change of administration, work on tha collection was not started until some time after the trapping season was under way. The auditor reported the following figures:

SEASON $1924-1925$

\begin{tabular}{|c|c|c|c|}
\hline Spe_ies & Number & Tax & Collected \\
\hline 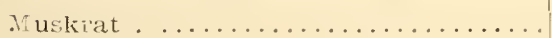 & $4,996,933$ & ${ }_{1}^{1} \mathrm{C}$ & $\$ 12,192.33$ \\
\hline Fisceson.$\ldots \ldots \ldots \ldots \ldots \ldots \ldots$ & 116,648 & $5 \mathrm{c}$ & $5,732 . \pm 0$ \\
\hline Opossum $\quad \ldots \ldots \ldots \ldots \ldots$ & $229,7+4$ & $1.1 \mathrm{C}$ & $.57+.34$ \\
\hline Mink $\ldots \ldots \ldots \ldots \ldots \ldots \ldots$ & 67,441 & $5 c$ & $3,372.05$ \\
\hline Skunk $\ldots \ldots \ldots \ldots \ldots \ldots \ldots \ldots$ & 10,741 & $1 \mathrm{c}$ & 107.41 \\
\hline Otter $\ldots \ldots \ldots \ldots \ldots \ldots \ldots \ldots \ldots$ & 11.658 & $25 \mathrm{c}$ & 422.00 \\
\hline Civet cat $\ldots \ldots \ldots \ldots \ldots \ldots \ldots$ & 1,061 & $1 \mathrm{c}$ & 10.61 \\
\hline Miscellaneous pelts ............. & $75 \mathrm{~s}$ & $1 \mathrm{c}$ & $7.5 \mathrm{~S}$ \\
\hline Collected for species not specified. & $\begin{array}{r}5,425,014 \\
\ldots \ldots \ldots\end{array}$ & $\left|\begin{array}{c}\ldots \ldots \ldots \\
\ldots \ldots \ldots\end{array}\right|$ & $\begin{array}{r}22,718.74 \\
1,487.36\end{array}$ \\
\hline Total collected for general fund... & $\ldots \ldots \ldots$ & $\ldots \ldots \ldots$ & $\$ 24,206.10$ \\
\hline
\end{tabular}


The sum of $\$ 1,487.36$, for which no pelts are specified, was for payments made to the state on the fur tax where certain dealers, buyers and trappers rendered their returns in lump sums without separating the different species of fur bearers. This additional sum, it might properly be pointed out, would be equal to 595,944 muskrats, or the same number of opossums, or 29,747 raccoons, or even a like number of mink, which would swell the 5,425,014 figure considerably.

Escapes from this fur tax law were from a million muskrat pelts or more that were smuggled over the Sabine River into Texas from the rich Cameron Parish marshes; and from the pelts of raccoons and opossums and mink, from the central and northern sections of the state, where a large number of small shipments are made each winter by farmer folk and others not actually in the trapping business, who do not record their catch, nor is the fur tax paid as required by law.

SEASON 1925-1926

\begin{tabular}{|c|c|c|c|}
\hline Species & $\frac{\dot{c}}{\stackrel{c}{c}}$ & $\begin{array}{l}\sqrt{1} \\
-1\end{array}$ & $\underset{0}{\stackrel{0}{0}}$ \\
\hline 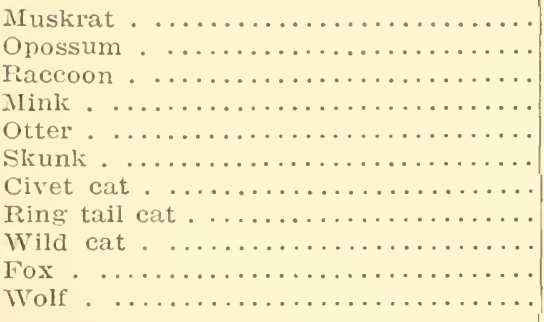 & $\begin{array}{r}3,299,650 \\
180,797 \\
117,239 \\
46,864 \\
1,846 \\
21,814 \\
6,319 \\
8 \\
437 \\
543 \\
19\end{array}$ & $\begin{array}{r}1 / 4 \mathrm{c} \\
1 / 4 \mathrm{c} \\
5 \mathrm{c} \\
5 \mathrm{c} \\
25 \mathrm{c} \\
1 \mathrm{c} \\
1 \mathrm{c} \\
1 \mathrm{c} \\
1 \mathrm{c} \\
1 \mathrm{c} \\
1 \mathrm{c}\end{array}$ & $\begin{array}{r}8,249.12 \\
451.99 \\
5,861.95 \\
2,343.20 \\
461.50 \\
218.14 \\
63.19 \\
.08 \\
4.37 \\
5.43 \\
.19\end{array}$ \\
\hline 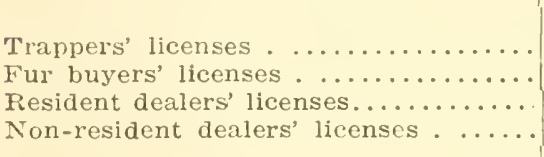 & $\begin{array}{r}3,675,536 \\
16,422 \\
885 \\
83 \\
26\end{array}$ & $\begin{array}{r}\$ 1.25 \\
5.00 \\
25.00 \\
50.00\end{array}$ & $\begin{array}{r}17,659.16 \\
20,527.50 \\
4,425.00 \\
2,075.00 \\
1,300.00\end{array}$ \\
\hline & & & $\$ 28,327.50$ \\
\hline Total $\ldots \ldots \ldots \ldots \ldots \ldots \ldots \ldots$ & $\ldots \ldots \ldots \ldots$ & $\ldots \ldots \ldots$ & $\$ 45,986.66$ \\
\hline
\end{tabular}


'There is now a new tax per pelt law, not called a severance tax; through it the state collects 1 cent on muskrats and opossums, 5 cents on mink and raccoons, 25 cents on otters and 1 cent on all other pelts. This tax we expected would bring the department approximately $\$ 60,000.00$ to $\$ 70,000.00$ yearly in normal trapping seasons.

SEASON 1926-1927

\begin{tabular}{|c|c|c|c|}
\hline Species & $\begin{array}{l}\frac{d}{0} \\
\stackrel{0}{\Xi} \\
\vdots \\
Z\end{array}$ & $\underset{\leftarrow}{\mathscr{C}}$ & $\begin{array}{l}\stackrel{d}{\Phi} \\
\stackrel{ \pm}{0} \\
\stackrel{0}{ٍ} \\
0 \\
0\end{array}$ \\
\hline Muskrat................... & $2,223,957$ & $1 \mathrm{c}$ & $\$ 22,239.57$ \\
\hline 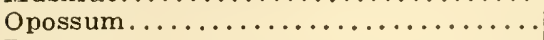 & 323,814 & $1 \mathrm{c}$ & $3,238.14$ \\
\hline 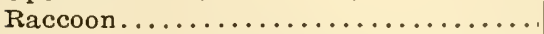 & 116,257 & $5 \mathrm{c}$ & $5,812.85$ \\
\hline 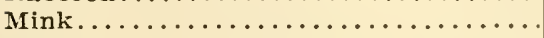 & 43,896 & $5 c$ & $2,194.80$ \\
\hline 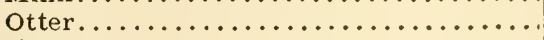 & 1,077 & $25 \mathrm{c}$ & 269.25 \\
\hline skunk ................... & 22,578 & $1 \mathrm{c}$ & 225.78 \\
\hline 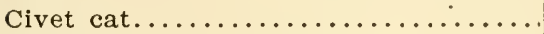 & 5,093 & $1 \mathrm{c}$ & 50.93 \\
\hline 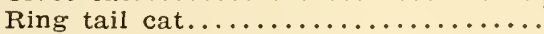 & 44 & $1 \mathrm{c}$ & .44 \\
\hline 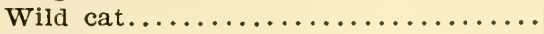 & 569 & $1 \mathrm{c}$ & 5.69 \\
\hline 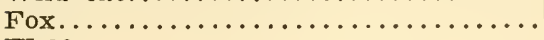 & 396 & $1 \mathrm{c}$ & 3.96 \\
\hline Wolf $\ldots \ldots \ldots \ldots \ldots \ldots \ldots \ldots \ldots$ & 24 & $1 \mathrm{c}$ & .24 \\
\hline \multirow[t]{2}{*}{ Miscellaneous pelts.$\ldots \ldots \ldots \ldots \ldots \ldots$} & 62 & $1 \mathrm{c}$ & .62 \\
\hline & $2,737,767$ & . & $\$ 34,042.27$ \\
\hline Resident buyers' licenses ......... & 704 & $\$ 10.00$ & $7,040.00$ \\
\hline Non-resident buyers . ............. & 12 & 50.00 & 600.00 \\
\hline 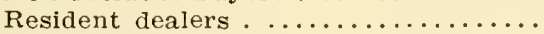 & 56 & 50.00 & $2,800.00$ \\
\hline Non-resident dealers...$\ldots \ldots \ldots$ & 6 & 250.00 & $1,500.00$ \\
\hline Total ... & $\ldots \ldots$ & $\ldots$ & $\$ 45,982.27$ \\
\hline
\end{tabular}

In the season 1927-1928 licenses were sent to the sheriffs of the different parishes who sold them and the money collected from the sale of these licenses was used by the different parishes and not sent in to the department. According to records, there were 12,973 licenses sold, which amounted to $\$ 25,946.00$. 


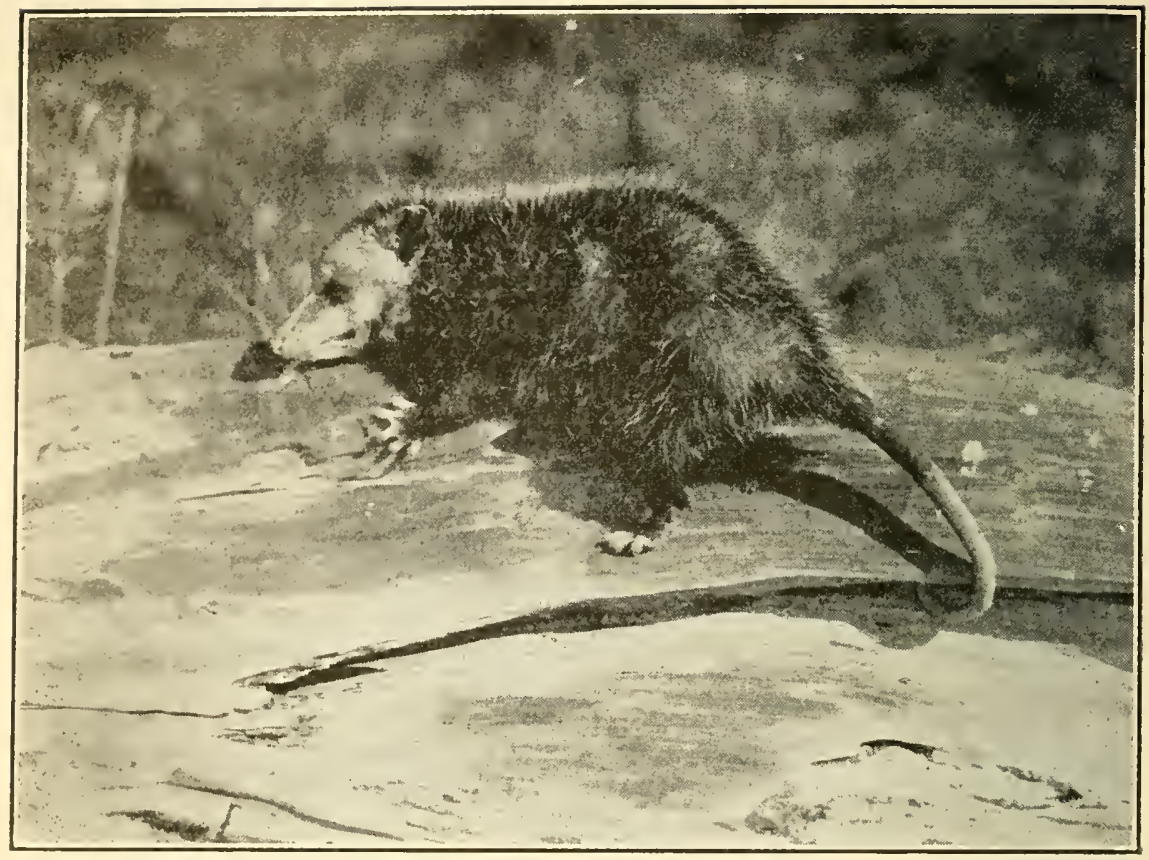

The opossum, next to the muskrat, is the most abundant fur-bearer in Louisiana, over a quarter of a million pelts being taken annually.

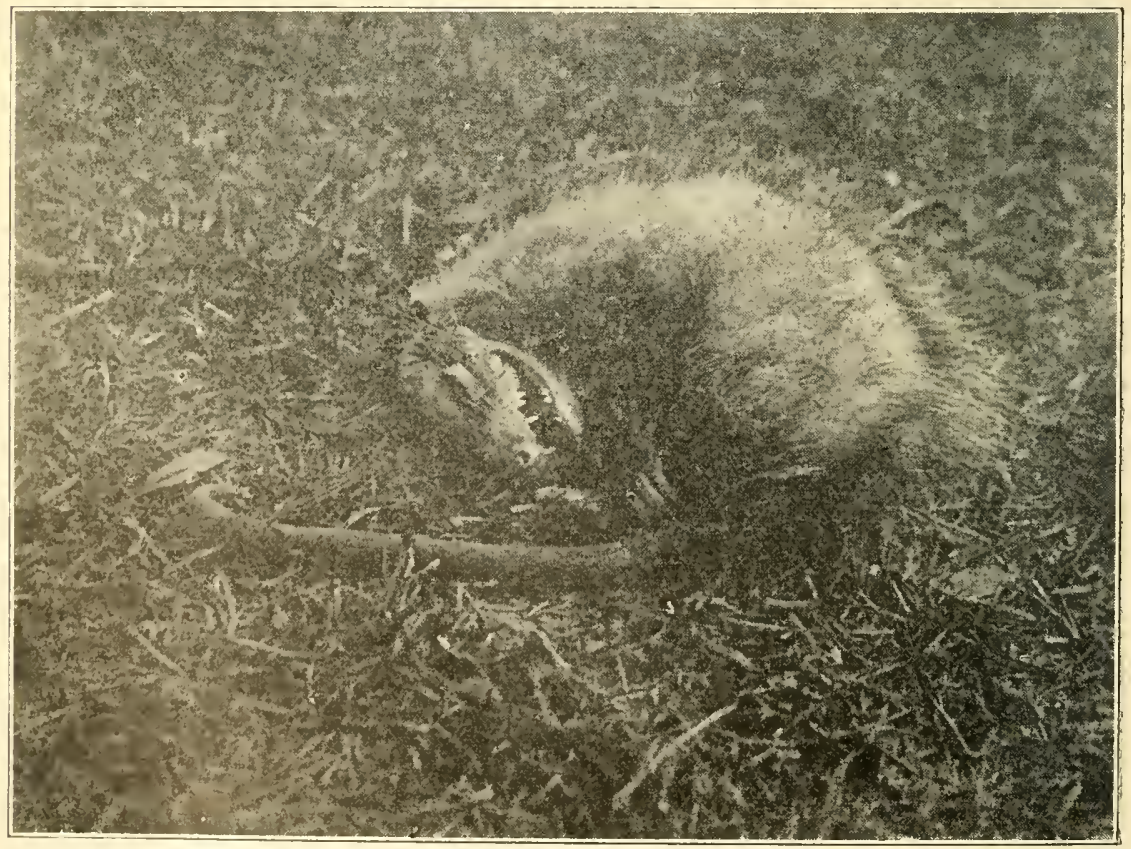

An opossum playing 'possum. The take of this fur-bearing animal is increasing every year in spite of hard trapping. 


\section{CHAPTER EIGHT}

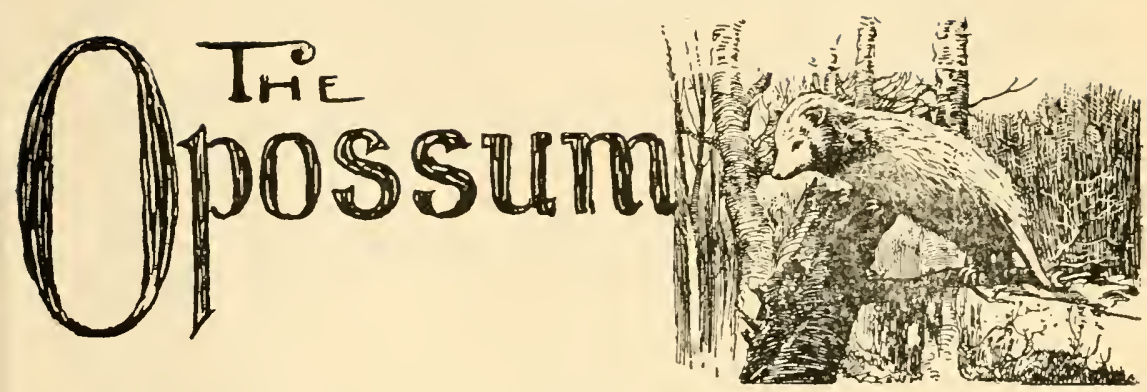

T THE cpossum, we will consider a fur animal that is not only a native of this continent but one that has for its common name a designation wholly American, for the 'possum, as we frequently term it, was first named opossum by the North American Indians along the Atlantic seacoast where the early settlers elected to carve a new home out of the wilderness.

It was the doughty Captain John Smith who gave the beast the spelling we now use. In his History of Virginia, the warrior whose life was saved by Pochahontas set down with his quill pen these words: "An opossum hath a head like a swine, a taile like a rat, and is the bigness of a cat. Under the belly shee hath a bagge." A laconic but wholly encompassing description that does indeed describe this queerest of all mammals.

We have two, possibly three, forms of opossums: The Louisiana or Gulf opossum (Dideiphis virginiana pigra), a small dark opossum with a long tail ; found from Georgia, Florida, along the Gulf coast through Louisiana and, undoubtedly, into Texas. In the northern, eastern and central parts of Louisiana is found a much larger animal, the typical Virginia opossum (Didelphis virginiana virginiana); where it occurs it is very numerous, much larger than the Gulf form, tail smaller, usually uniformly whitish, with the white guard hairs longer than the black. The Gulf subspecies has two color phases, some are whitish, others decidedly blackish. Long-tailed opossums, with black guard! 
hairs longer than the white, have been taken in south-western Louisiana and may prove to be the Texas opossum (D.m.texensis) or an undescribed form.

The French-speaking trappers call this fur animal, aside from opossum and 'possum in common usage, rat de bois, meaning "rat of the woods," perpetuating the name given this animal by the puzzled first settlers to Louisiana. The Spanish-speaking trappers of the Delacroix Island region of St. Bernard and Plaquemines parishes term the opossum a topo or raibua.

Naturally, this queer animal was well known to all Gulf tribes, but we have been unsuccessful in locating all of its names. The Ofo Indians named it feska tci-nki, "little pig;" while the Biloxi called it kcicka, "hog," and the Choctaws called the animal shukata. It is recorded that the eastern Indians called this animal whoapink, meaning "white face," and that it was even a more common name among the aboriginals than opossum.

Placed by naturalists in the lowest position in the order of mammals the opossum, for this reason, is usually named and described first in any systematic work on natural history.

Being physically such an oddity of nature, it might be well to describe the animal before considering some of its habits or how it appeared to the early Louisianians.

As was pointed out by Captain John Smith, opossums are small mammals varying from the size of a very large cat to larger proportions. Opossums have long noses, ears and tail, the latter being naked and prehensile-which means that the animal can grasp things with its tail.

The first toe on the hind foot is so fully opposable to the other digits or toes, so as to constitute a functionally perfect "hand." Therefore, one does not exaggerate when this queer creature of our woods is described as "four-handed." This opposable first toe is without nail or claw, but the tip of the toe is expanded into a broad, flat pad, of great use to each hind foot when the animal is climbing about among the trees-these two "hind-hands" making it sure-footed. 
The five toes of the two front legs are provided with long, sharp claws and the first toe, or thumb, is not at all opposable and, as far as its anterior pair of legs go, the opossum is very much like many other mammals.

The opossum has a mouthful of teeth all crowned with minute and sharply-pointed cusps, with which to crush the insects on which these animals delight to feed, although it has many other articles of diet on its nightly menu for it is almost wholly a nocturnal prowler.

But it is the pouch that the female possesses that has given this animal a popular place in natural history. Belonging to the Order Marsupialia, a natural history division which includes all of the pouched mammals, or as they are more commonly termed, Marsupials, the opossum is related to some other remarkable and destructive animals mostly confined to the Australian region, the kangaroo being a noteworthy example.

This order takes its name from an external abdominal pouch found only on the female, in which the young, after birth, are carried and nursed until the progeny attain some size.

As has been pointed out by Stone and Cram, ${ }^{16}$ marsupials, are in fact, the survivor's of an ancient population. of animals which was spread over the earth before the superior beasts of the present era made their appearance. Today marsupials are restricted to the United States (with one example, the opossum), South and Middle America, and Australia. The variety of pouched mammals found in Australia is quite large, the largest and best known being the kangaroo, but this fauna also contains the thylacine or Tasmanian wolf, the dasyure or Tasmanian devil, the small bandicoots, the wombats, flying phlangers, counterparts of our flying squirrels, and marsupial moles have also been found. The teeth of marsupials are more primitive than those of most of the other mammals and are generally more numerous. Some marsupials are carnivorous, other's hibivorous and others are, like our opossum, omnivorous.

${ }^{16}$ Stone and Cram, American Animals, pp. 3-4. 
When first born an opossum, a kangaroo and a mouse are about the same size-about half an inch in length, and weigh about one to eighteen and twenty grains.

The opossum's peculiar method of carrying the young has given rise to a host of peculiar folk tales as to how the birth of the young occurs, tales so outlandish and so far from the actual facts, it is deemed necessary to set down here the correct story of reproduction. A deeply rooted tradition has it that the female opossum copulates through the nose and that she blows the fruit of conception into the pouch.

The young, ranging from six to twelve in a litter (sometimes as many as fourteen), are born in a manner usual to most mammals except for the fact that the little ones are dropped from the usual organ in a very immature state. They are blind, helpless, hairless and very, very small, weighing scarcely more than two grains each. One scientist placed 16 of the extremely minature young in the bowl of an ordinary teaspoon which they just filled. ${ }^{1}$ Although it has been claimed they are picked up by the mother and placed in the pouch, this is incorrect. The true facts about the reproduction of the opossum have been known since 1823, when Barton of Philadelphia, in a paper sent to a European philosophical journal on "Facts, observations and conjectures relative to the generation of the opossum of North America," set down the following findings, which have been recently proved as correct by two later day investigators. ${ }^{17}$

As to the manner in which the young reach the pouch, Barton combats two ideas as prevalent today as in 1823 . He first touched on the "opinion very generally adopted in many parts of the United States" that the young are produced in the pouch.

He recorded: "The young opossums unformed, and perfectly sightless as they are at this period find their way to the teats (of the mother) by the power of an invariable,

\footnotetext{
"Hartman, Brocling Season of the Opossum. Jour. Morp. \& Physiol.,

17Heauser, Chester H. and Hartman, Carl G., Dept. of Embryology, Carnegie Institution of Washington, Baltimore, Md., Journal of Mammalogy, sol. 9, P. 62 .
} 


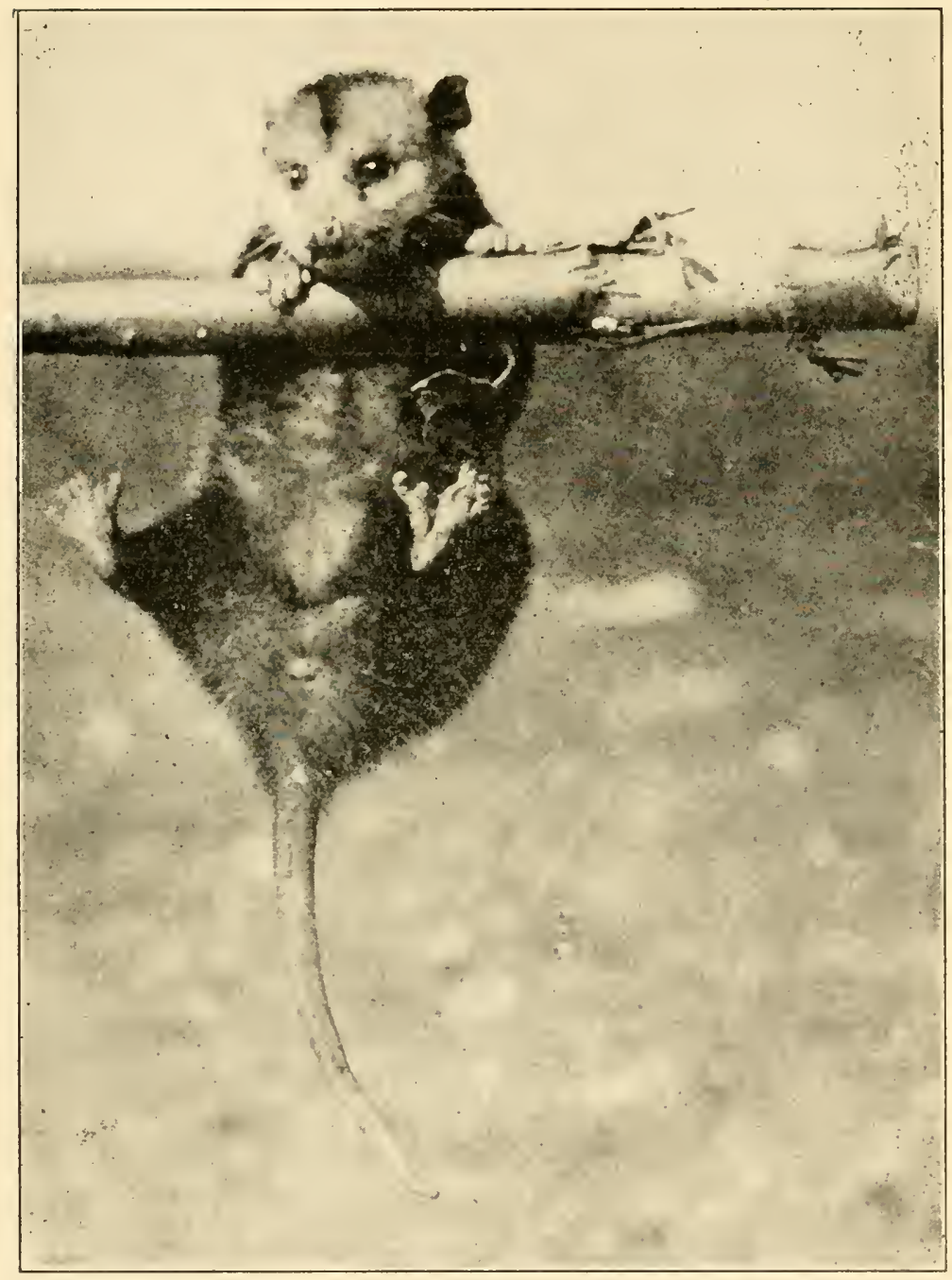

This opossum is demonstrating its ability to hang on with its forefeet. the photograph shows the opposable big toe of the hind feet which is characteristic of this animal. 
a determinate instinct, which may, surely, be considered as one of the most wonderful that is furnished to us by the science of natural history."

Those who are aware of the manner of reproduction of the opossum frequently err in claiming that the parent picks up her tiny, immature babies and places them in the pouch, some claiming this is done by the mouth, while others maintain this act is performed by the paws. More than one hundred years ago, Mr. Barton set down: "It is not true, as has been often asserted, that the mother, with her paws, puts the young ones in the pouch."

When the young are expelled from the female's body, after a gestation period of 11 days, the babies are not much more than embryos. They weigh about two grains each, but are very much alive and active, for they instinctively crawl about the mother's body until the abdominal pouch is found and entered. Each member of the litter seizes a teat and by a provision of nature the mouth of the baby opossum adheres to the lactate appendage of the parent, and, being in a very imperfect form of development and unable to suckle for the first few weeks of this period, the mother injects her milk into her offsprings' mouths by a special muscle, which compresses the lacteal glands. In other words, she "pumps" sustenance into her young.

When about six weeks old the eyes open, the mouths of the young become detached from teats, after which they venture out and survey the world into which they have been so strangely born. The first excursions are made usually from the pouch to the mother's back, the young climbing to her hair and scrambling around her body. The family presents a droll sight when the parent animal arches her tail over her back and the little ones twine their prehensile tails about the mother's, hanging head down with fore feet grasping the hair of the parent animal's back. A week or two passes before the young leave the mother's back for their first excursion on land. As the opossum litters more than once a year, it has been demonstrated that she will receive attention from the male before she has fully raised her first litter. 
The opossum is polyæstrus, having more than one œstrus or heat period during a given breeding season. The breeding season begins in January in our section of the South and the females usually have young in the pouch by the middle of February.

The period of gestation averages 11 days, the young remaining attached to the teats for approximately 65 to 70 days, and then for 30 days move freely about the mother, entering the pouch for food, or, when alarmed, for protection. Hartman fixes the longevity of the opossum at seven years. ${ }^{1}$

\section{Rat de. Bois}

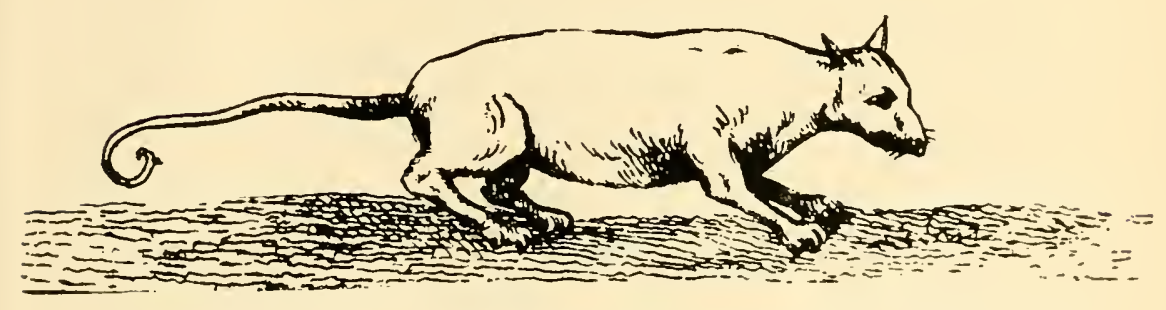

The Rat de Bois of the early French settlers to Louisiana was none other than our opossum and this is the way that the illustrator for Le Page du Pratz claimed it looked in 1735 .

Le Page du Pratz, the earliest Louisiana historian, wrote a very entertaining account of the opossum, which he called the Rat de bois, the name applied to this animal by the early French settlers. du Pratz's account of this "rat of the woods" is here reproduced merely to show the manner of natural history writings of 1730 , and, therefore, some of the habits attributed to this animal must not be taken seriously by the present reader.

His engraving of the rat de bois, which is herewith reproduced, is quite as amusing as his account which, translated, follows:

"The 'rat de bois" ' head and tail is like a rat's $\mathrm{He}$ is as big and long as an ordinary cat. His legs are

Hartman, Breeding Habits, Development and Birth of the Opposum, Smithsonian Institute Annual Report, 1921, pp. 347-363. 
shorter, his paws long and his toes armed with claws; his tail almost without hair and made to hook, because when taken by this place he winds himself at once around the finger. His hair is grey and although fine is never smooth. The Indian women spin this and make garters of it which they dye red.

"They hun' fowl at night and suck their blood but never eat them. Ordinarily no animal is seen to walk so slowly, and I took one often walking at my usual pace. When he sces lee is about to be caught, his instinct leads him to play off dead, and it is so well carried on that if you were to kill him and cook him he would not move or show sign of life. It is only when at a great distance. or well hidden, that he starts off to quickly hide in some corner or among some brus'?wood.

"I have always been surprised at the great numbers of this animal seen everywhere, when everything seems to conspire to their destruction, for this animal is of an extraordinary slowness, defenseless, and even though able to climb well, his little ones are born on the ground. It is believed that no other animal fights him.

"When the female is about to give birth to the young, she, in company with the male, go in search of fine dry grass. After accumulating what is nezezsary. the female lies on her back, the male puts the grass between her paws and drags her by the tail to her nest. She never leaves her young after they are born and takes them with her wherever she goes. Nature provides her with a pockct or double skin, under her stomach, and stretches from the stomach to the thighs. This skin covers her udders and is split its full length, but the two ends are joined so well that it would be impossible to discover this split if not acquainted with this fact, and it can only be opened by tearing it, so fine and tight is this skin. It is in this pocket that she conceals her young when she leaves her nest, and she transports these without harm in this 
soft, warm carriage where they can sleep and suck at their ease. If taken while carrying her young, s'e suffers without giving sign of life; if hung by the tail or put over a fire, the tail wraps itself and the mother dies with her young without anything boing able to open the skin of this pocket.

"The meat of this animal has a very good taste, and very much like that of the suckling pig, when it is broiled. It is said that the fat is used to appsase the pains of rheumatism, sciatica, and other ailments."

The opossum is prized, first of all, for its fur, but many in Louisiana esteem the animal for its flesh, and among the colored folk, 'possum and sweet 'taters is considered as choice a dish today as in du Pratz's time.

The pelage of the opossum, which finds a ready sale in the fur marts, is distinctive for having two coats, an underfur that is short and white with its upper parts covered with a frizzle of black and white hairs, the white one being the longer, thus giving the animal a greyish appearance. Its use in the fur trade for other things besides trimming is rapidly gaining favor among women of fashion, and, with the decline of other furs, it seems reasonable to expect the value of the opossum raw pelts to rise.

Approximately a quarter of a million opossum pelts leave the state annually, making Louisiana the largest opossum fur-producing state of the Union.

The opossum is distributed generally throughout the state, being found in numbers in every one of the sixty-four parishes, including Orleans. It seems to center in greatest numbers in Terrebonne, Lafourche, Calcasieu, Jefferson, Natchitoches, Plaquemines, Beauregard, Assumption, Rapides and Allen, and the parish quantity production seems to be in the order named. 


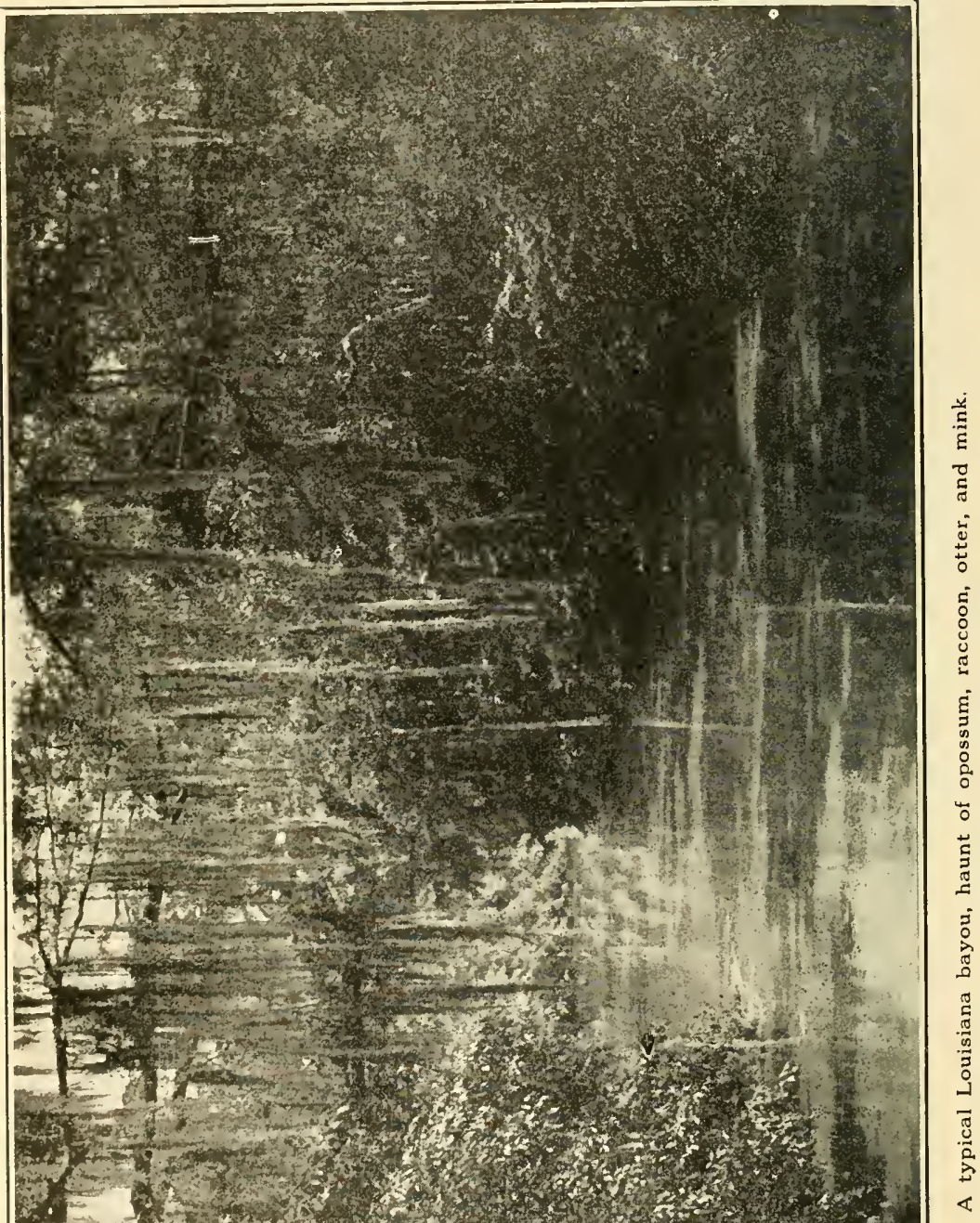

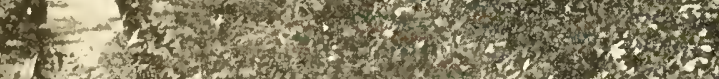
1.

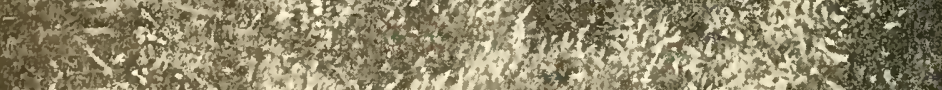

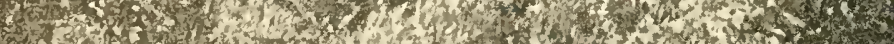

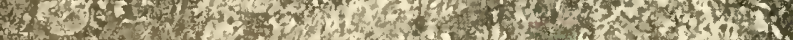

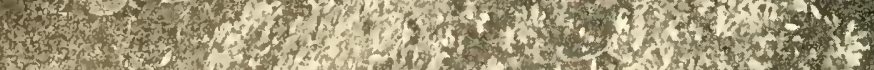

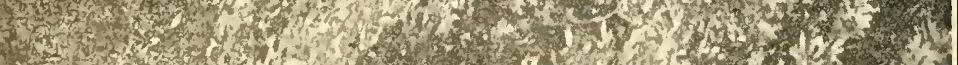

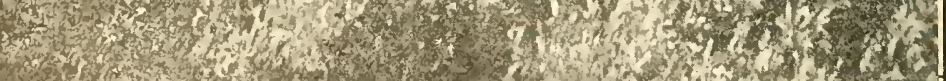

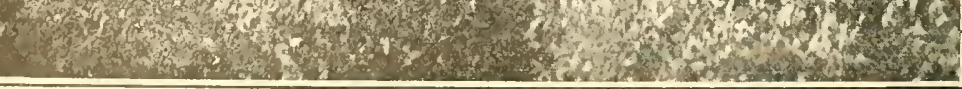




\section{CHAPTER NINE}

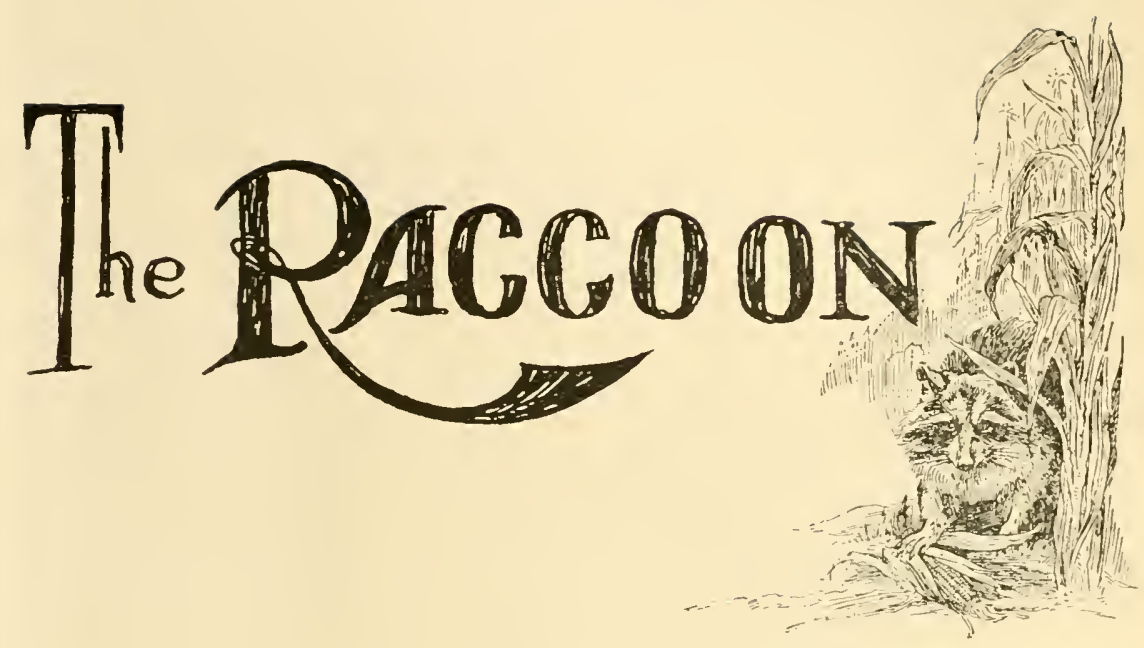

$\mathrm{O}$

F ALL typical American mammals no animal, big or little, is better known than the raccoon, or " "coon," as it is so frequently called.

A scientist would tell you probably that the raccoon is a typical representative of a group of American arboreal placental mammals belonging to the order Camivora, but ask someone who really knows this animal in its native habitat and he will, in all likelihood, say that it is a little cousin to the bear, because in truth it is bear-like in form and has the same characteristic habit of the ursine family in that it shuffles about the ground in a lumbering manner, has the same bear-like agility in climbing trees, eats anything that comes its way-fruits, bugs, reptiles, shellfish, bees, honey, nuts, berries, fish - in fact, it is just as partial to an animal diet as it is to vegetable matter; being plantigrade or flat-footed, the raccoon leaves a foot-print similar to the track of a bear. It has the same build that makes its hind quarters higher than its fore parts, but, when walking, the entire sole of the foot is not applied to the ground, as it is when the animal is standing at rest, while the toes, especially those of the forefeet, can be spread out very widely. 
The raccoon is a thickly built animal with a coat of long, rather coarse, greyish-brown hairs, black at the tips, underlain by a fine fur characterized by its length, softness and thickness; it has short ears, and a bushy black-and-white ringed tail. In length it averages 32 inches. The raccoon possesses a long, pointed snout, and a white face with a characteristic black area on each cheek surrounding the eye.

While found in its most plentiful numbers in the Southern States, the raccoon has an extensive range, being found as far north as Ontario and as far south as Louisiana and Florida. A considerable number are trapped every year in the Pacific Coast states of California, Washington and Oregon, but it does not inhabit the Rocky Mountain region.

The raccoon provides man with one of the most practical and serviceable furs, which is used today extensively in the manufacture of ccats for both women and men. It is a splendid wearing fur and very warm and comfortable. With the advent of the automobile and the call for a fur garment that would stand hard outdoor usage, the raccoon peit has proved itself ideal.

For many years Missouri was one of the principal 'coon producing centers of the United States, but with the reclaiming of the swamp lands in the New Madrid section, the animal disappeared or sought new habitats. Arkansas has long been an important producer of tinis fur animal, but Louisiana is the largest 'coon producing state of the Union.

In the early days of the fur trade of the Mississippi Valley, raccoon skins were a recognized circulating medium in the Valley states, just as beaver pelts were used as currency in the northern states and Canada.

So strange was this animal to the first French settlers of Louisiana that they called it a Chat sauvage, and Cat Island, off the Mississippi coast, gained its name because of the strange "cats" Iberville's pioneers found inhabiting the place. 


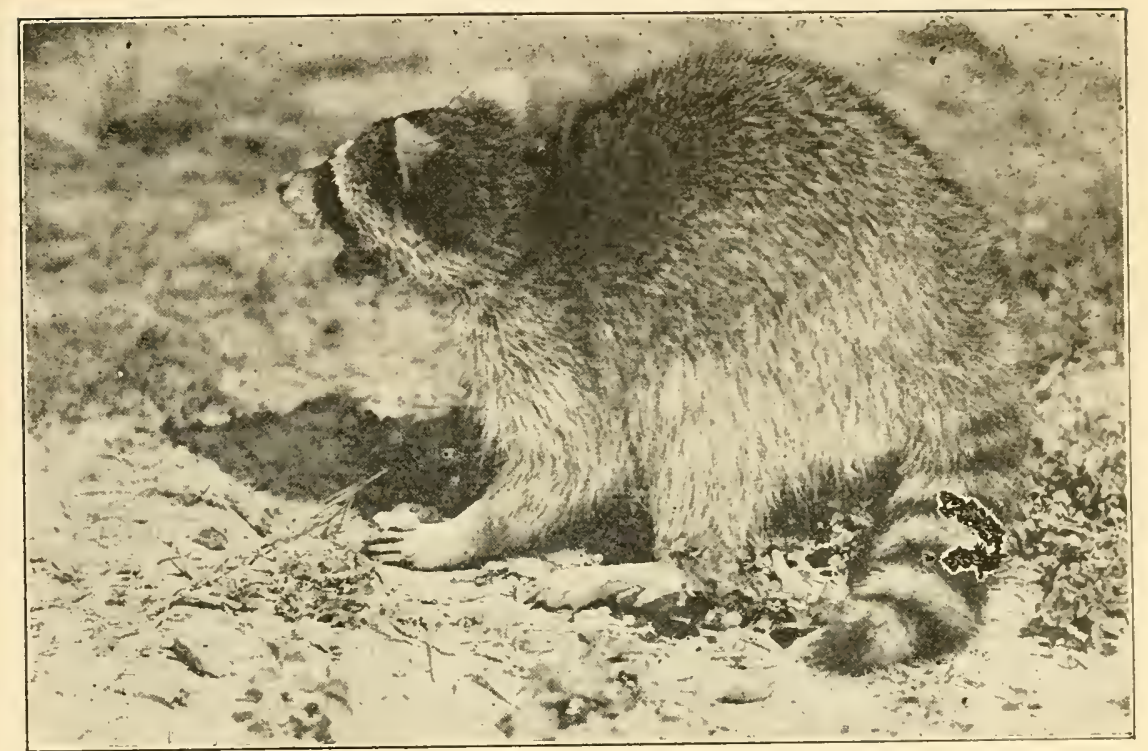

A raccoon at bay with the animal exhibiting its humped back, plantigrade feet, ringed tail, and grizzled gray pelage.

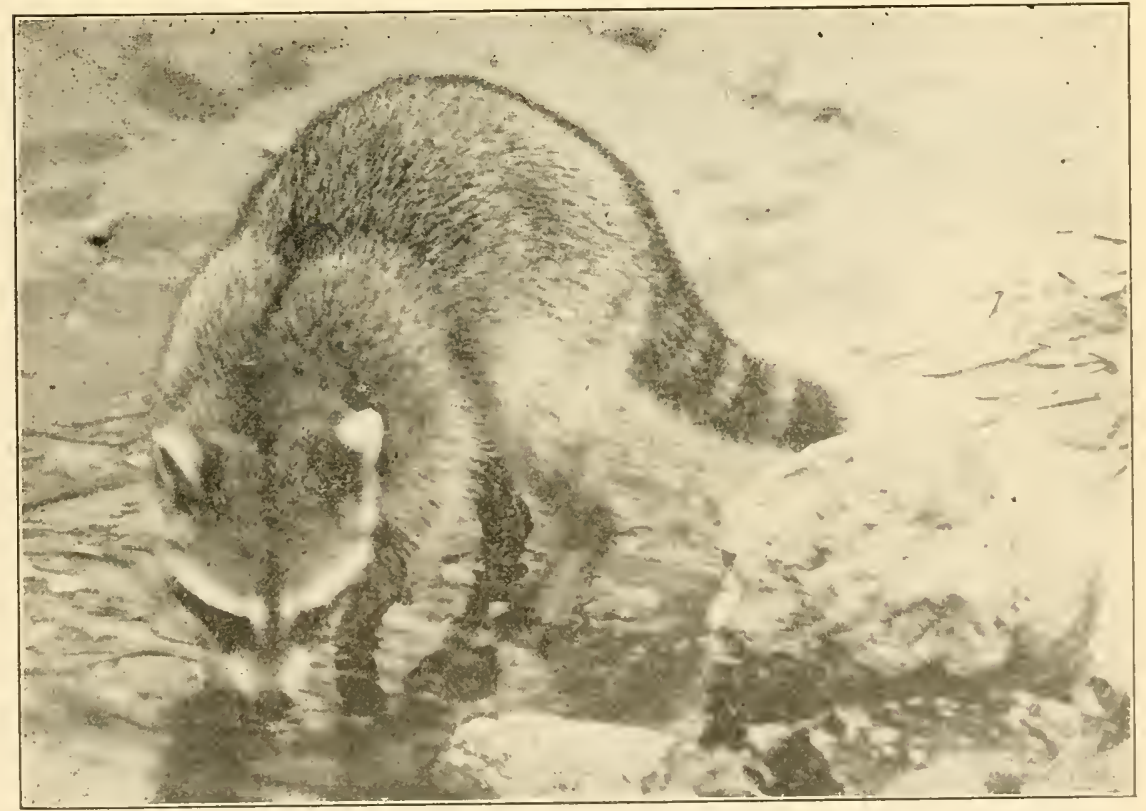

The coon is not afraid of water. It swims streams without effort and is very fond of animal and fish food found in wet p'aces. 


\section{Chat Sauvage.}

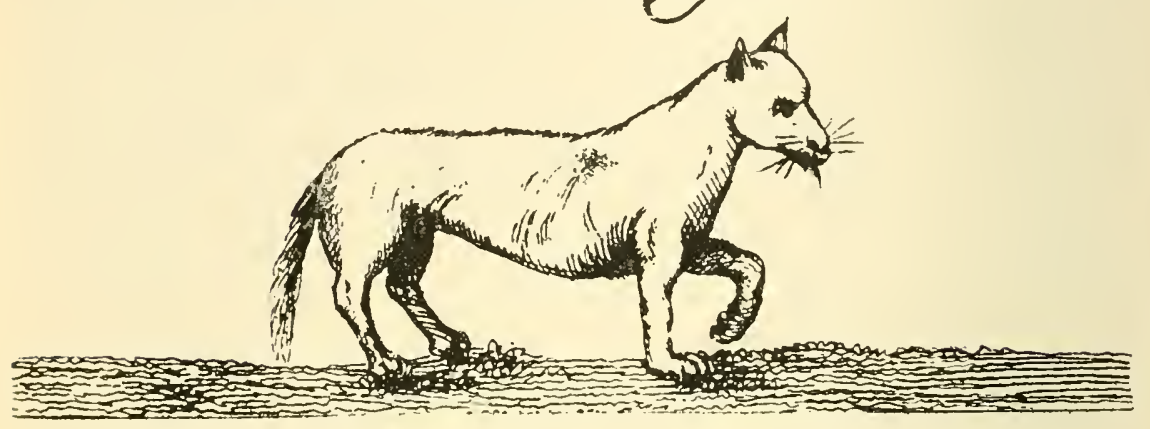

The illustrator of the historic volumes of Le Page du Pratz made the raccoon appear more like a horse than any other animal. The name Chat Sauvage, which was French for wild cat, was applied to Brer 'Coon by the settlers of Louisiana in 1730 , and because there were so many of these fur animals found on an island off Bay St. Louis in the Mississippi Sound, lberville named it lsle de Chat or, as it now appears on our maps-"Cat Island."

This is what M. Le Page du Pratz, whom we have already quoted, wrote about the raccoon he found in Louisiana in 1718:

"The Chat Sauvage was improperly named by the first Frenchmen to come to Louisiana, for the only likeness they have to the cat is their suppleness. They mostly resemble the Marmotte. He is not more than eight or ten inches high and about fifteen inches long, his head is somewhat like the fox's. His paws have long toes with small claws not so well suited for seizing game, and too he lives only on fruit, bread and other like things. His hair is of a lighter color than that of the fox; however, a distinction must be made of the one that is tame and the wild one (because this animal familiarizes himself, becomes very playful and performs a number cf tricks). The hair of the tame one is grey, and of the wild one russet, but the skin of either is not as beautiful as the fox's. He becomes very big. His meat is good to eat. I'll not speak of the ordinary cat, although wild, for it is entirely similar to ours."

The name raccoon, now in such common usage, is a corruption of a North American Indian name "arrathkune" or "arathcone," but the Choctaw Indians of the Gulf Coast 


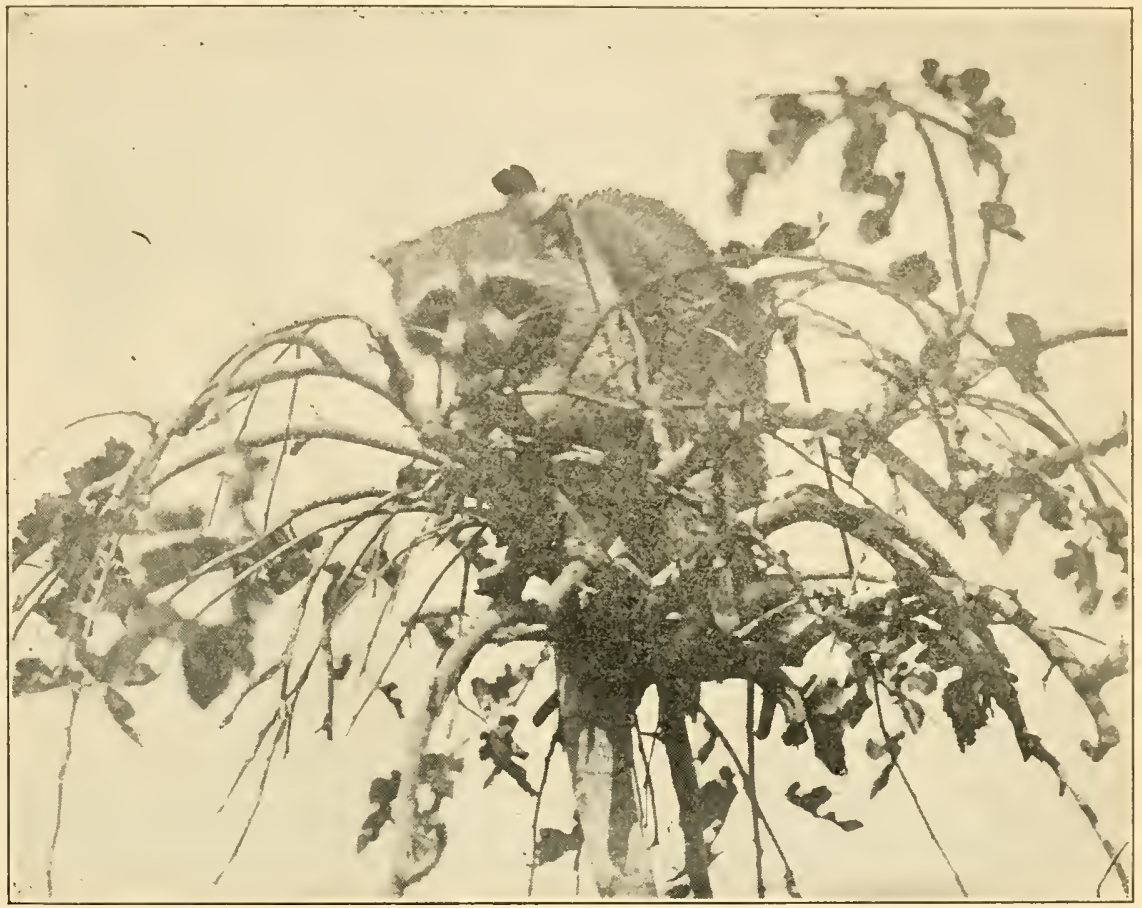

The raccoon is one of our fur animals whose numbers have decreased during the past few trapping seasons.

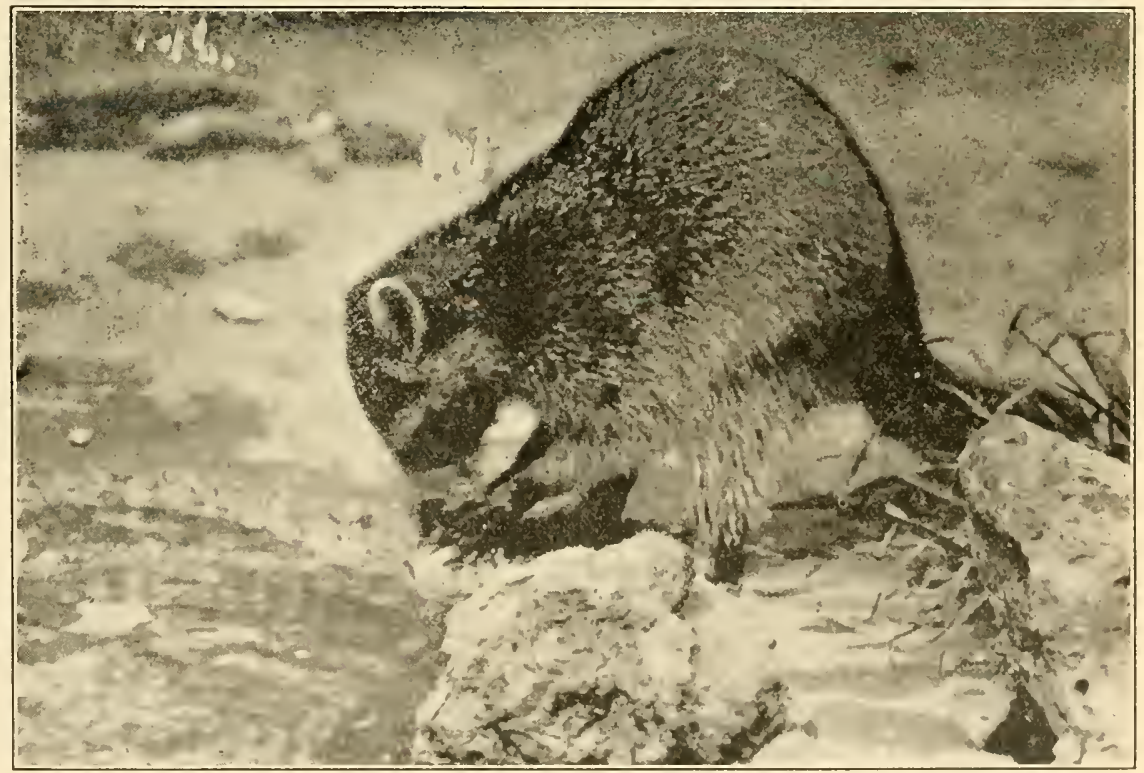

The raccoon has a characteristic habit of washing its food before eating it. 
called it a Shoui, a name heard today among the Frenchspeaking trappers of the Louisiana lowlands. It is, for that matter, so much in use that many people believe that Shoui is a French word. The Biloxi Indians termed it atuki and in their folk lore there is a very interesting story of "The Opossum and the Raccoon," in which these two native American animals staged a crayfish-eating contest. The Ofo Indians called the 'coon iya.

Scientifically, the raccoon has been christened Procyon lotor, a designation given it by Linnaeus in recognition of its curious habit of dipping or washing its food before eating it. This habit has earned for it the French name of roton laveur and the German name of waschbar.

This valuable fur animal is a night wanderer and it delights to prowl about wet places. For that reason, the swamps and marshes of our state are favorite habitats of this queer animal. A fallen tree seems to have a great temptation for Brer 'Coon, and on his nocturnal wanderings in search of food he mounts the log and clumsily ambles along it from one end to the other. This habit has long been recognized by our native trappers, and an experienced 'coon-trapper simply sets his trap on the top of a prostrate log without bait or other lure and can be sure of skinning his animal the next morning-provided, of course, a 'coon elects to promenade the log during the night.

Curiosity is one of the raccoon's pronounced habits, so much so that a piece of bright tin or other shining metal is frequently hung over a trap so that it will be seen by this prowler in the moonlight, and the raccoon examines it to the cost of its life and pelt. Other trappers will wrap the pan of the trap with tinfoil and place the trap under an inch or two of clear water near the bank of a stream so that Mr. 'Coon will reach for it with one of his forepaws-and remain there until the trapper appear's the next morning and adds another skin to his collection of raw pelts.

The track of a raccoon is easily recognizable in soft earth and as it has a habit of wandering up and down the banks of waterways it always leaves visible evidences of 


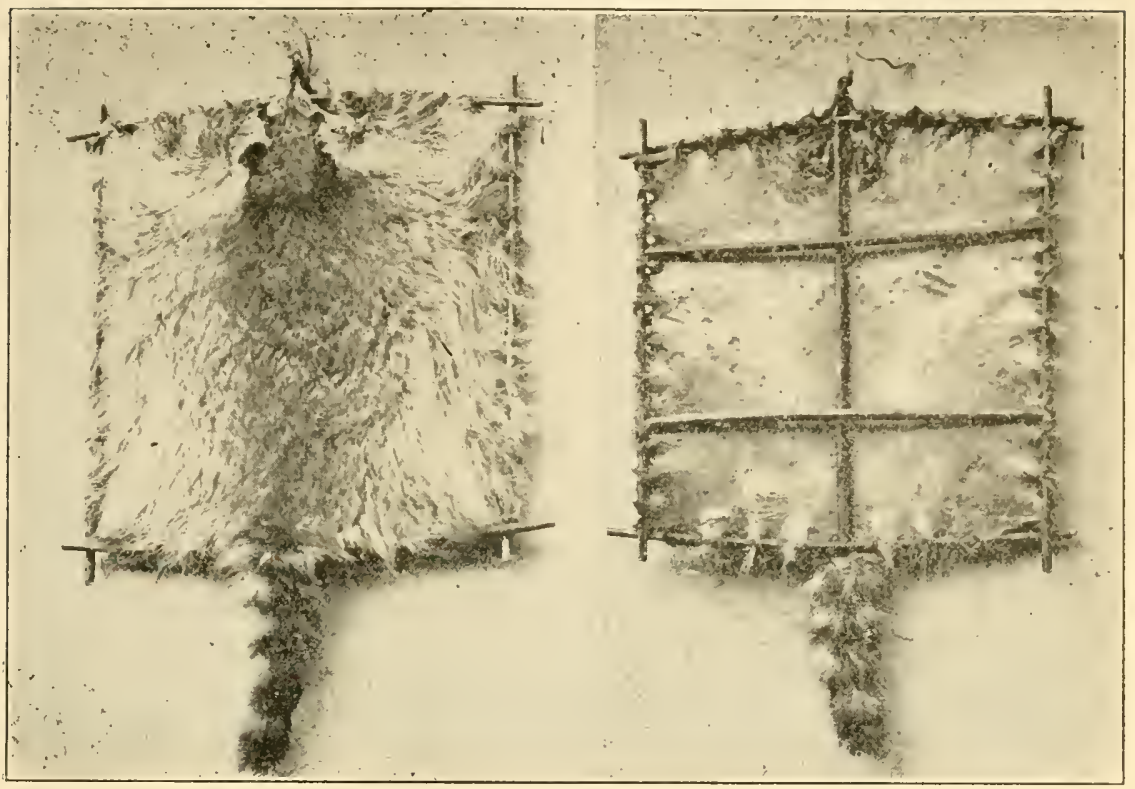

One way of stretching a raccoon peit, useful wher the:e are no nails or boards around.

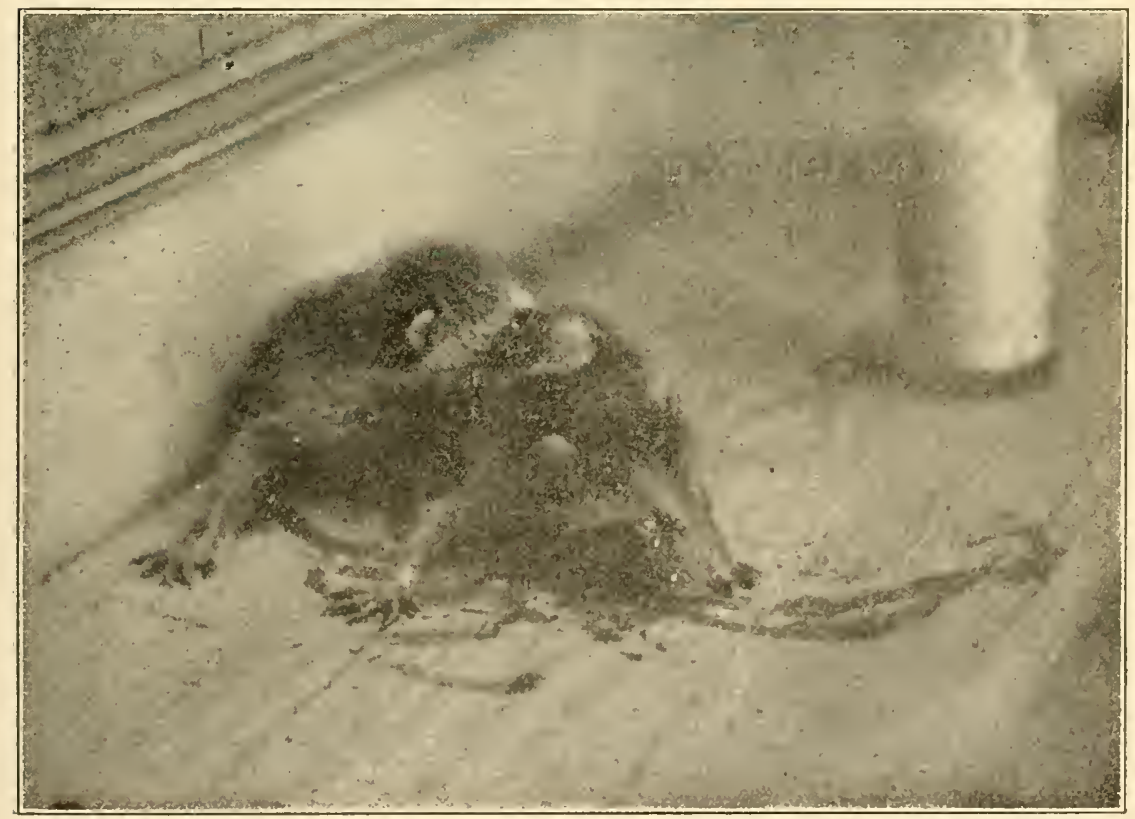

Young raccoons raised on pet cream in a coca co'a bottle. 
its nightly meanderings. These footprints are long with a narrow and quite distinct heel pattern, if it has not been traveled too rapidly, and resembles to a certain degree the mark of a human foot. Such footprints are usually in pairs, one foot a trifle in advance, while the pairs are separated about 30 inches, although this varies with the variation of its speed. While the skunk leaves a similar heel pattern, the larger size of the 'coon's track, coupled with the fact that its toemarks are separated while the skunk's are not, will distinguish between the two impressions.

Raccoons are polygamous. The female gives birth to one litter a year, the mother usually inhabiting her den with her little ones during the latter part of February and the month of March; some young are dropped as late as the first part of April. The period of gestation in one of our cooperative experiments proved to be 62 days. A trapper who took a female raccoon near Boutte, St. Charles parish, February 9, found it to be carrying four wellformed young. This would indicate breeding activities about the middle of December in Louisiana.

The size of the litter varies. Sometimes there are only three young, but more frequently there are four, five and six produced. The babies are as blind and helpless as kittens, and are tenderly cared for by the mother practically throughout the summer. Even after the nursery period has ended the family will remain together, and when the weather turns chilly the young and old will curl up together and enjoy a long and undistubred sleep. Raccoons, too, will frequently climb a tree and have its sleep perched in the crotch of a branch.

The raccoon takes very kindly to captivity and it makes a very satisfactory pet. For this reason it has proved very adaptable to fur farming, and many in this state are now experimenting with this animal to test out the practicability of fur farming. The cost of feeding this animal, however, militates against any large profits in this direction unless the price of its pelt should rise even higher than it has been cluring the past few years. An economical vegetable diet, 


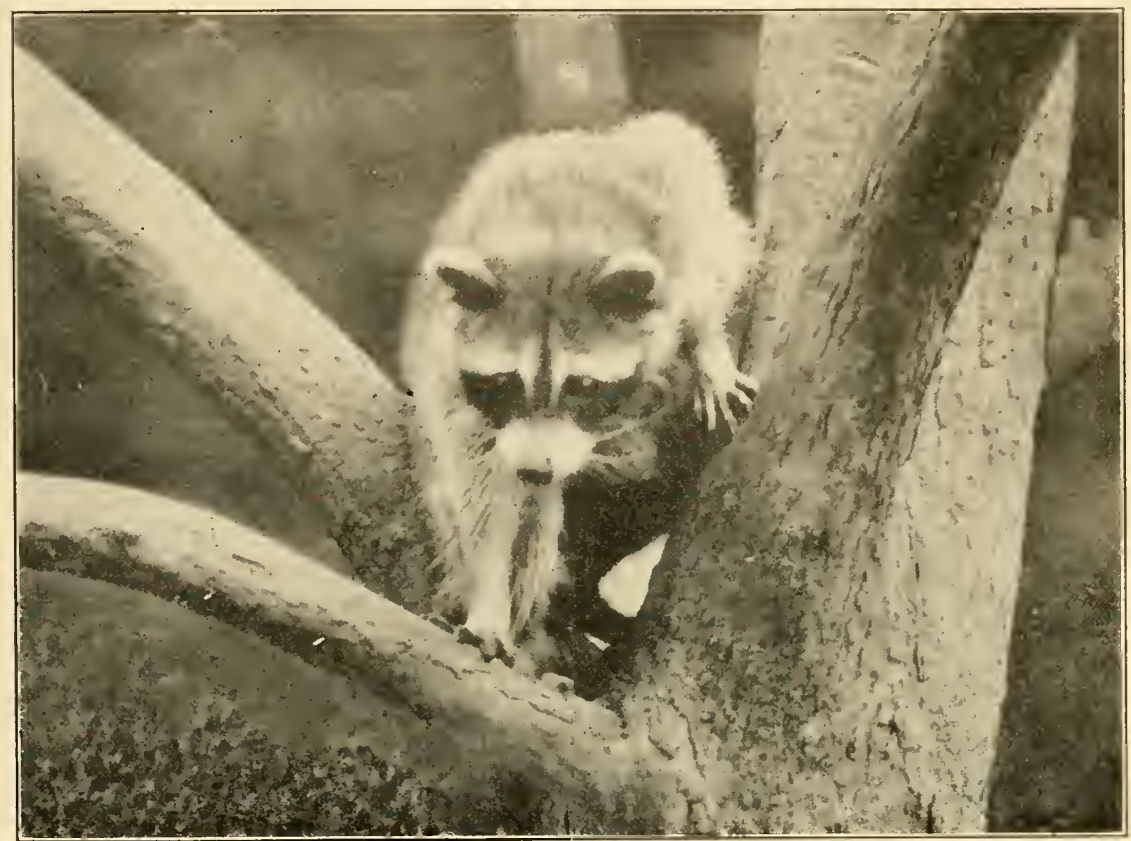

As a climber few anima's surpass Brer 'Coon. A crotch of a tree is a favorite sleeping piace

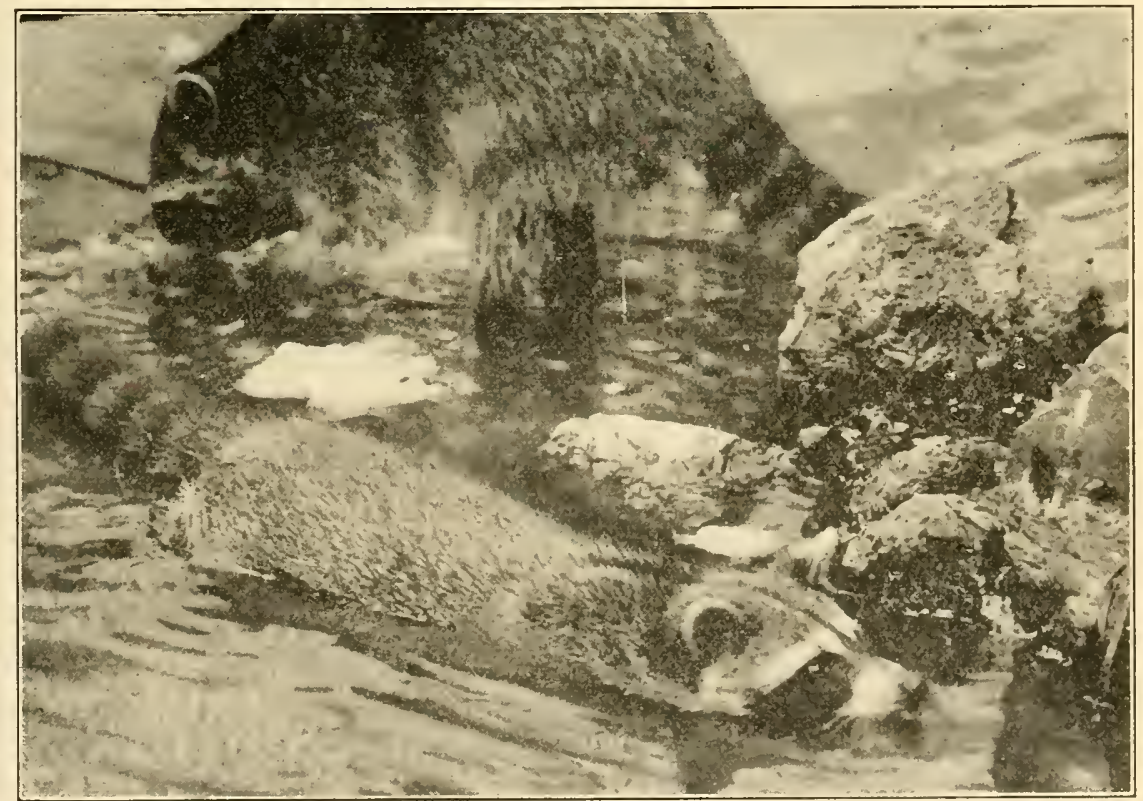

The coon is playful and delights in playirg tricks on another, and splashing about in shallow water furnishes a great deal of amusement to the splasher. 
consisting of cornmeal mixed with lard and baked in flat pans, has been used with success by several fur farms in the east and north, and this diet is said to have produced animals with very fine pelts. Experiments along this line should be worth trying by those interested in raising fur animals in captivity.

Treeing a coon at night with dog and flambeaux has long been a sport in the South, and in Louisiana, especially, "cooning" has been a favorite out-of-door recreation of our farmer-folk. However, with this animal's rising value. in the fur marts, trapping is practiced more and more. In a 'coon hunt, the quarry is usually brought down from its refuge in a tree top with a shotgun, and this lessens the value of the skin considerably, and when a treed 'coon is shaken from its perch for the dogs to finish, its coat of fur' is so ripped and torn by dogs' teeth as to make it practically worthless.

Although agile and expert at tree climbing, the raccoon must not be considered a wholly arboreal animal, for it. does not hunt its prey in the treetops, but, rather, utilizes. the trees as sleeping places and refuge when pursued by man or other foes. With the coming of night, Brer 'Coon descencls from his lofty perch to search for food on the ground or capture a luckless crayfish from the edge of a watery depression. Water is no hindrance to this animal, for it is capable of swimming long distances and is frequently trapped on low-lying islands in the Gulf of Mexico off the Louisiana coast, miles from the mainland.

In Louisiana the raccoon is of uniform distribution throughout the state. It is as plentiful in the marshes as it is in the vast hardwood lands and the cypress and tupelo swamps. The marsh animal is known to the trade as: "Louisiana tide water" or "salt water" coon, and is reddis' or yellowish as compared to the darker inhabitants of the wooded swamps. The darker raccoon brings a much better. price than does the marsh animal.

The cause of the reddish or yellowish color of the marsh 'ccon has been attributed to a lack of shade enjoyed by the swamp 'coon and most trappers securing a blackish raccoon 
in the marshes, miles from tree growth, will claim it to be a "woods 'coon," the theory being that the sun's rays have a tendency to bleach the guard hairs. As a matter of fact, this appears, according to investigations, to have very little to do with this color condition. Tidal marshes, and especially salt-encrusted grasses, cause the yellowing of the raccoon's coat. Mother 'coons, with "salt water" pelage have been found with young that were as dark as the young of woods 'coons. Marshes that have an excess of fresh water have a very high percentage of black 'coons that never saw a woods or enjoyed the shade of a cypress swamp. Note what du Pratz said.

Although indigenous to every parish of the state, the raccoon is found in greatest numbers in the coastal belt. Terrebonne parish leads in production, with St. Mary second, Lafourche third, Cameron fourth, and Plaquemines, St. Bernard, Assumption, Natchitoches, Rapides, Vermilion, Beauregard, Calcasieu, Iberville, Livingston, West Feliciana. Allen, East Baton Rouge, Iberia, Richland, East Carroll and Sabine, in the order named, are the principal producers of this fur animal.

\section{The Ring-TaIled Cat}

The "Ring-tailed Cat," or Bassarisk, or "Civet Cat," or "Cat Squirrel," the Cacomiztli or Cacomistle, a "Raccoon Fox," a Ring-tailed Bassaris, "Coon-Cat," to say nothing of a dozen other local names, as well as Bussuriscus astutus, according to scientific nomenclature, is a fur animal of Louisiana according to law, but whether or not there has ever been one taken alive and wild in this state is to bring up an argument.

Up to this time no one has received indisputable evidence of a single specimen of this fur animal being taken in Louisiana, although this mammal of many names is supposed to wander over our border line occasionally from Texas and, according to some, Arkansas.

The Ring-tailed Cat is a strange little creature, nearly allied to the raccoon, but it has a far more slender 


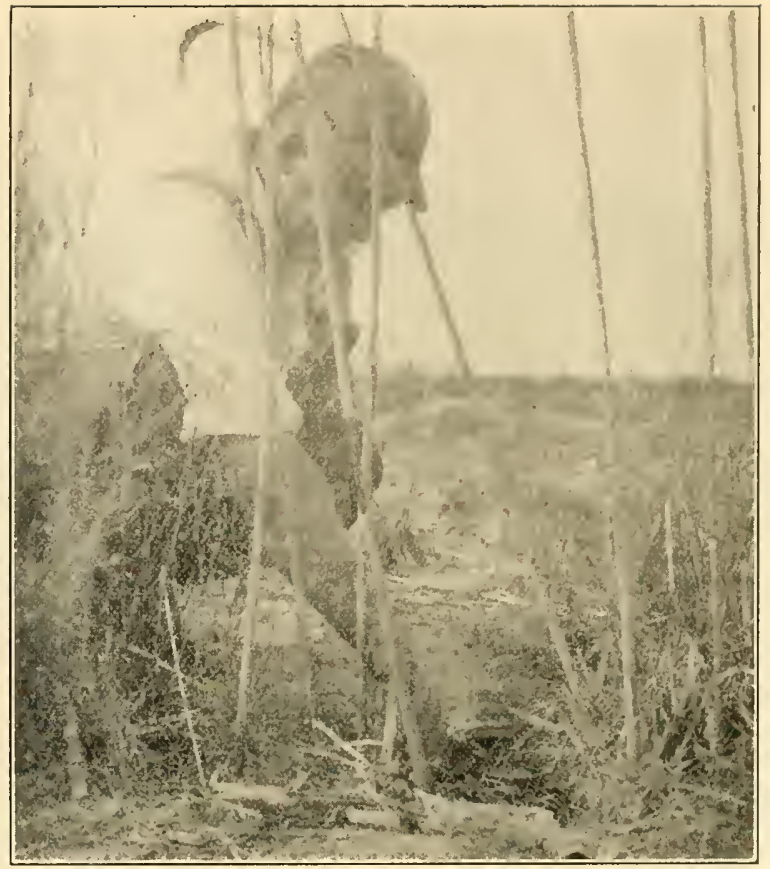

Setting a trap for a raccoon on high land next to a kayou. The trapper has placed his canes so that brer coon will be forced to walk through the opening where the trap is being set.

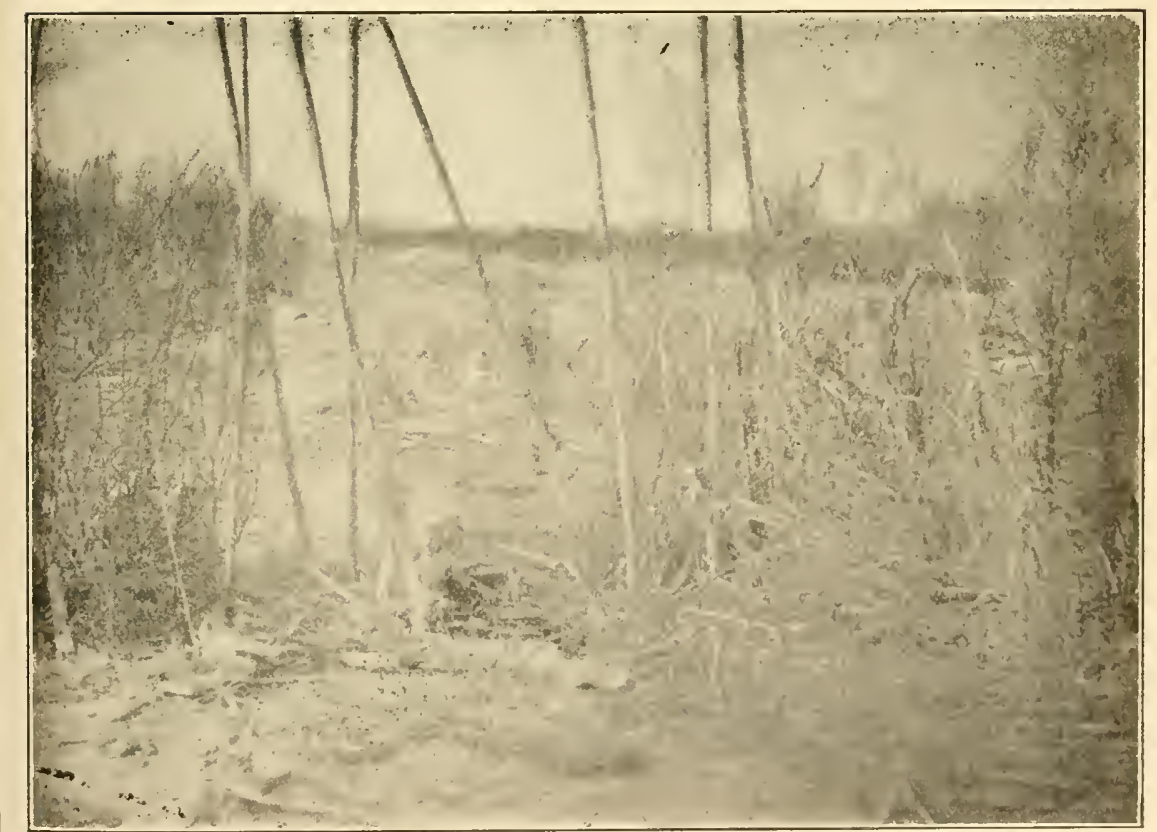

When set properly, the trapper will sprinkle dried grass stems lightly over the trap so that it will be hidden from the prowling raccoon when it passes through the opening. This is a "blind" set-no baiting being necessary to catch the animal. 


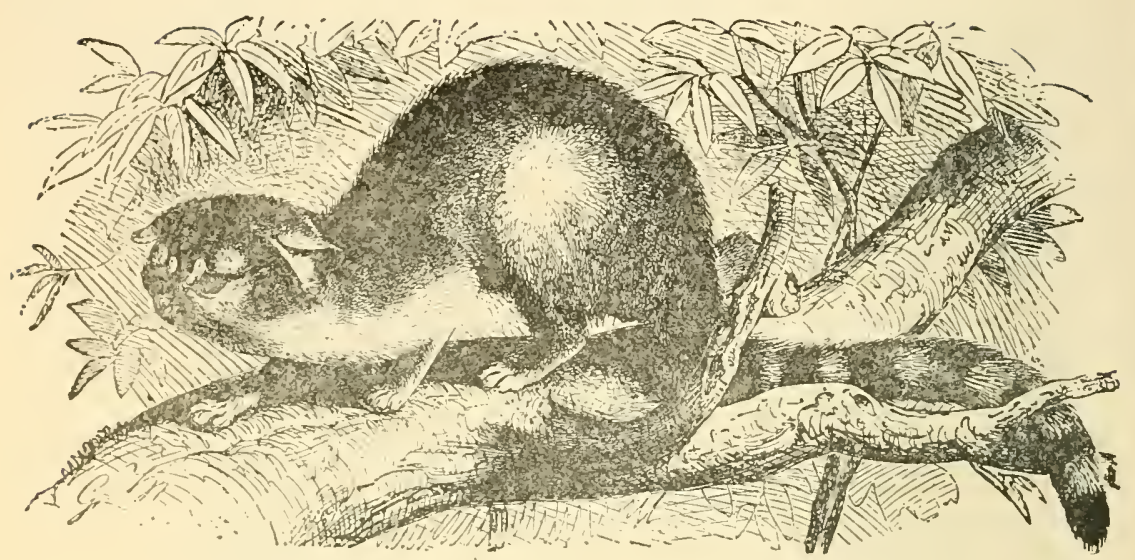

Drawing of a "Ring-tailed cat" or Bassarisk, a fur animal said to occur in Louisiana.

build, a sharper muzzle, a much longer tail, which is alternated with black and white rings; its feet are not so "bearlike" as are those of the 'coon, and the short claws are partially retractile, while the ears are broad and scantily haired. In size this animal can best be compared to an average sized slim housecat, the body and head measuring approximately 16 inches, and the length of the tail, to the end hairs, is about one inch less.

The general color of the pelage is brownish-yellow mixed with gray, blending to whitish on the underparts; the ringed tail is bushy, but it is much more slender than the raccoon's appendage. The Ring-tailed cat has a narrow black ring about each eye, which in turn is almost surrounded by a ring of white hairs.

It climbs trees, nesting in hollow branches like a squirrel, and can scratch and bite and catches rats, mice, and small birds just like an ordinary cat. It is supposed that flom such activities this animal received its most common name "Ping-tailed Cat," although it is not a "cat" of any kind, as it does not resemble the feline in structure or habits.

"Civet Cat," as Dr. Joseph Grinnell has pointed out,* is a doubly unfortunate choice of name, first because it is in no

* irimull, Joseph and storer, Tracy Irwin, Animal Life in the Yosemite. p. S1. Univ'rity of California. 


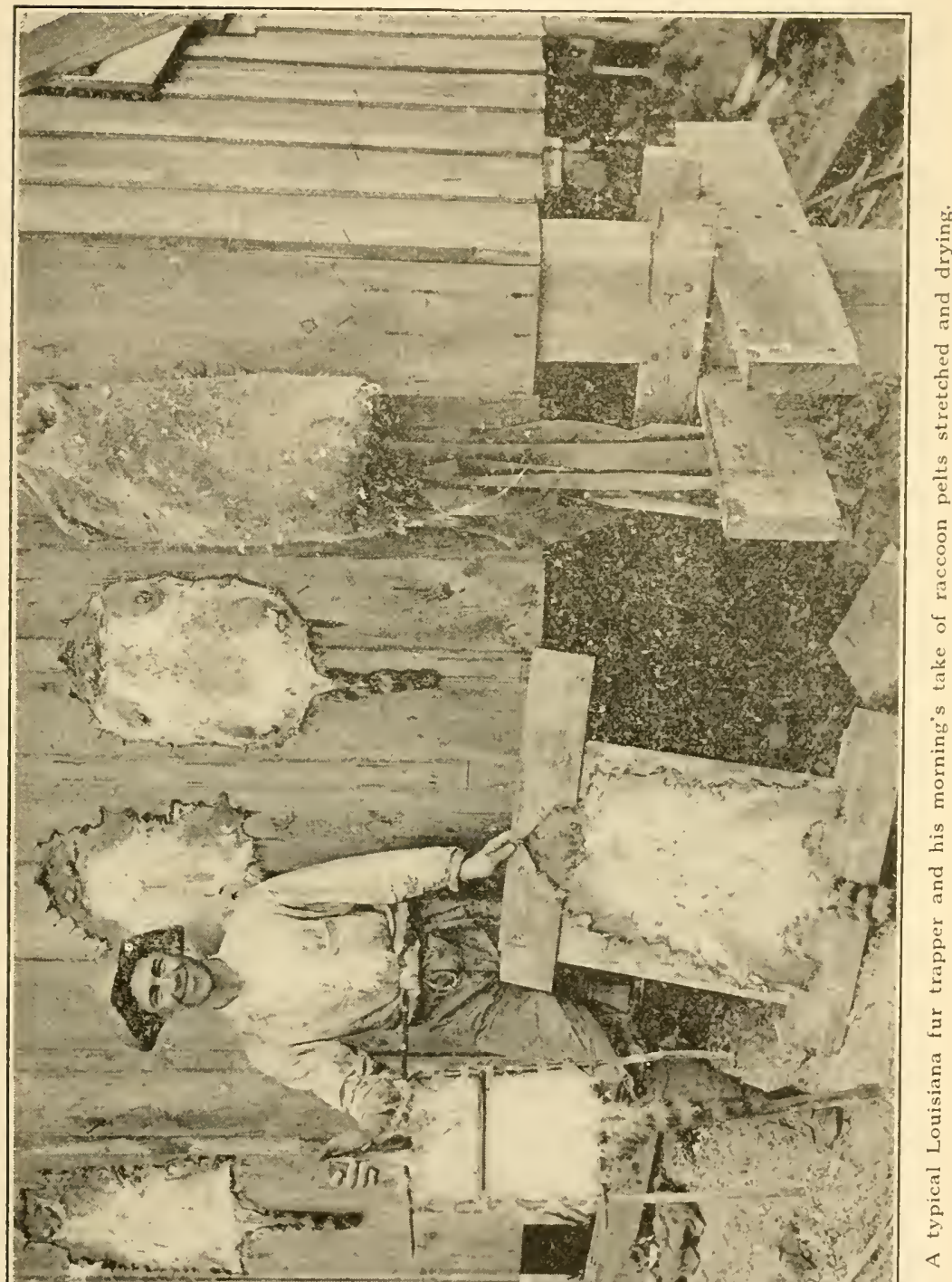


wise related to the true Old World civets; second, because this particular mis-naming (civet) has been so universally applied by trappers and dealer's to the Little Spotted Skunk.

"Raccoon fox" is not a good name for this pretty little animal, either, as there is nothing of the fox abcut it, although the general resemblance to the 'coon is most apparent.

Dr. Elliot Coues once proposed for this fur animal the name Bassarisk, a baptism heartily endorsed by Dr. William T. Hornady, who claims that the original Mexican term, Cacomiztli, is so ill adapted to our wants that such a name will never be generally used. However, in the matter of names, people in general pay no attention to the dictation of wise scientists and contentedly go on mis-naming the wild creatures without a blush or twinge of conscience, such as calling the migratory thrush a "robin," persisting in naming a bison a "buffalo," or referring to the little spotted skunk as a "civet," and it is doubtful if this animal will ever be known as a Bassarisk.

Therefore, in all probability, the Ring-tailed Cat will remain a "cat" until the last one is gone and, if it is eventually found that it really does inhabit certain sections of this state, it undoubtedly will be dubbed the animal a "Louisiana Ring-tailed Cat."

While a few Louisiana dealers receive a scattering of these pelts in consignment shipments every year, it appears that they are mixed with other pelts from trappers carrying on their operations near the border of Texas. The question of this animal's appearance in Louisiana can be best worked out by trappers sending specimens or information direct to the Department of Conservation. It is only because of the allegations of a few that it does occur here, and the fact that the state laws on fur animals name the Ring-tailed Cat as coming within the provision of fur tax, that this animal has been given a niche in this bulletin. 


\section{CHAPTER TEN}
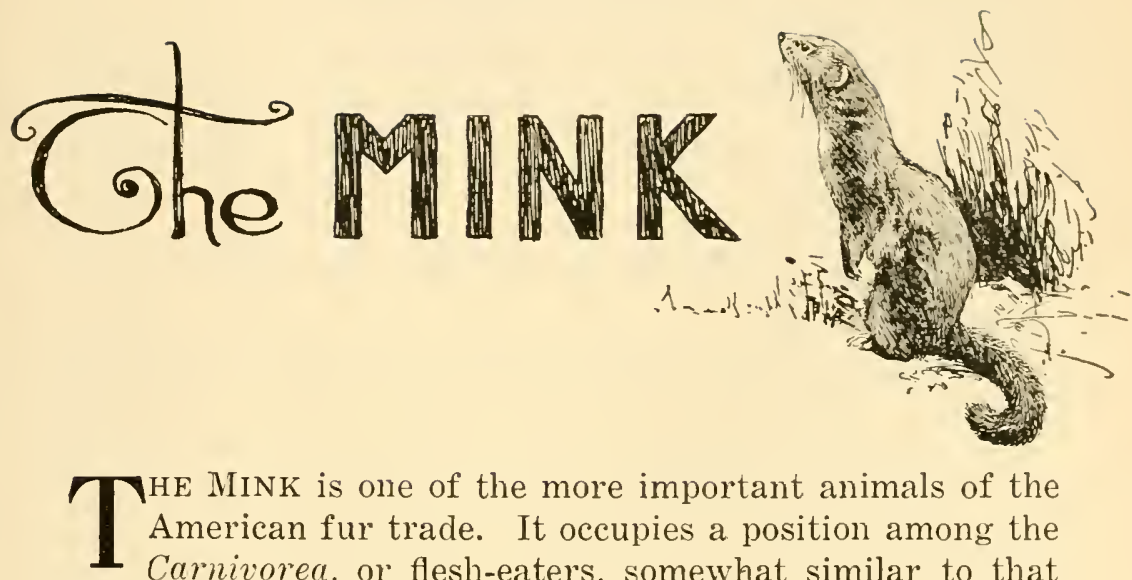

THE MINK is one of the more important animals of the American fur trade. It occupies a position among the

Carnivorea, or flesh-eaters, somewhat similar to that held by the muskrat among the vegetable feeders. In numbers it is found in larger quantities in Louisiana than in any other state of the Union.

This small but prized fur animal is an inhabitant of North America, but it has relatives in other parts of the world, the nearest being the Norz or Sump fotter (march otter) of eastern Europe, particularly Finland, Poland and a considerable portion of Russia. Asia has another form, the so-called "Siberian mink," which is believed by some scientists to connect the true mink with the polecats of the Old World.

The name mink originated from the Swedish maenk or mank, applied to the European form, and this name was carried to America by the first settlers. The native American name for the animal seems to have passed with the disappearance of the aborigines. However, Captain John Smith, in his History of Virginia, written in 1626, sets down that among the animals inhabiting the country were "Martins, Powlcats, Weesels and Minkes," clearly indicating that this particular animal was distinguished from the other mammals it resembled by a vernacular appellation. Two later historians in 1709 and 1784 referred to the mink as a "minx." In spite of its abundance in our part of the South, we find no particular mention of this fur animal in 
the works of du Pratz, Bossu, or the other descriptive writers of early Louisiana, Dumont excepted.

The Gulf Indians knew it and named the animal in their own tongue. The Choctaws called it a toni; the Biloxi named it iskixpa. The early French settlers termed it bclette, a designation very frequently heard among the French-speaking trapper's of the state today, while the Spanish-speaking trappers of the Delacroix Island region give this animal, at times, the Spanish designation of yarduna.

Scientifically, the Louisiana mink has been named Mustela vison vulgivayus, our animal being given a sub-specific rating because of certain physical differences between it and its relatives in various parts of this continent. The American minks inciude several different geographic forms, distributed over the northern part of North America from the Atlantic to the Pacific, and from the mouths of the Yukon and the Mackenzie rivers to Florida, Texas and Louisiana. but they are not found in the arid southwestern states.

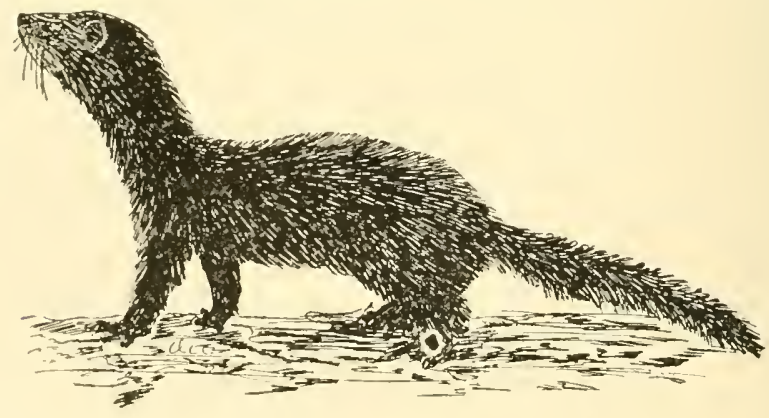

The mink is an inquisitive animal.

The mink is small, when compared to the majority of fur animals, the length of its head and body being from 15 to 18 inches, with a tail measuring 8 to 9 inches. The seres are alike except that the smaller size of the female will readily identify it. The mink's tail is bushy. tapering at the end, and its ear's are quite small, scarcely projecting beyond the adjacent fur of the head.

The pelage is of a rich dark brown in color, the underparts being slightly paler than the general upperparts. It 
ronsists of a dense, soft, matted under fur, mixed with long, stiff, lustrous hairs on all parts of the body and tail. 'The coloration of the tail shades off to black at the tip. The gloss of the coat is greatest on the upperparts, while bristly hairs predominate on the tail. Coues claims that northern mink have the finest and most glistening pelage and that the long hairs are the stoutest, and adds that "in southern specimens there is less difference between the under and over fur and the whole pelage is coarser and harsher."

While brown is the predominating color of the mink, the underjaw of the Louisiana mink is light yellowishbrown and spots on the chest and underparts are pure white, although frequently stained yellowish. In all species of mink the whitish chin is a characteristic mark of the species. These underparts spots are very irregular. On the chin it is sometimes prolonged as an irregular streak down the throat, and in many individuals it is indicated by a few spccks, while in a few cases these white markings are entirely absent. This white marking seldom invades the upper lips. The white spots on the underparts, particularly those on the chest, between the fore legs, are indeterminate in extent and contour and in no wise detract from the value of the mink relt, be it from Louisiana or elsewhere.

As a mink spends a great deal of its time in the water its pelt has become adapted to this mode of living in that it has the longer bristly hairs and felting of the close under fur which best resists the water. Mink pelts are due to maintain a conspicuous place in the fur trade, as few furs of other animals can surpass them in richness of color, gloss and fineness.

Belonging to the Mustelidae, the mink possesses perinacal glands and emits the peculiar odor which the animals of this genus have in common. As Dr. Coues has pointed out, "no animal of this country, except the skunk, possesses so powerful, penetrating and lasting an effluvium. Its strength is fully pre-perceived in taking an animal frcm a trap or when the mink is irritated. Ordinarily the scent is not emitted to any noticeable degree; it is under roluntary control and the fact that the mink spends so much of its time in the water is another reason why its 
proximity, even in numbers, is not commonly perceived by smell."

Both sexes possess the scent bags. They lie in the perinaeum, one on each side of the rectum, and open upon a papilla on either side of the anus just within the edge of the external orifice. Coues also points out that, as usual, the apparatus pertains primarily to the sexual relations and can have no other duty of consequence, since the scent is not powerful enough to deter pursuit on the part of an enemy, as in the case of the skunk, and its service, therefore, can be set down to that of attracting sexes.

Owing to its short legs and unusual length of body when compared to its slim build, the mink walks slowly and rather clumsily with its back arched, but when it desires to travel rapidly, it moves swiftly in a series of bounds, a gait it is able to keep seemingly without tiring. It is perfectly adapted to a double mode of life, being equally at home searching out its prey in thick undergrowth on land or seeking it in the water, its swimming ability being scarcely exceeded by the otter. The mink is a restless animal, being active by day as well as by night, but it is mainly nocturnal, and it is usually at night that it is taken by the trapper.

The mink is solitary. It is a renowned wanderer and its hunts take it over considerable territory when on a food foray. The only time it seems to seek companionship is during the early spring mating season, as the oestrum, or heat period, occurs but once a year. This duty over, the pairs separate, the rearing of the family devolving wholly on the female. The nursery is usually a nest in a hollow $\log$, a stump, or a cavity among the roots of a tree. The den is lined with dried grasses, leaves, feathers, hair or other soft material procurable. There is only one litter a year and it numbers from three to eight. The young in Louisiana usually being born during March and April. A pair of mink, in captivity, mated January 29 and the litter of five was dropped April 14, according to Svihla, giving a period of gestation of 75 days, but it is believed that this period is not longer than six or seven weeks.

A log cutter for a lumbering concern in St. James parish on April 10, 1926, found a litter of seven baby mink in a hollow log not far from Lutcher. His attention was at- 


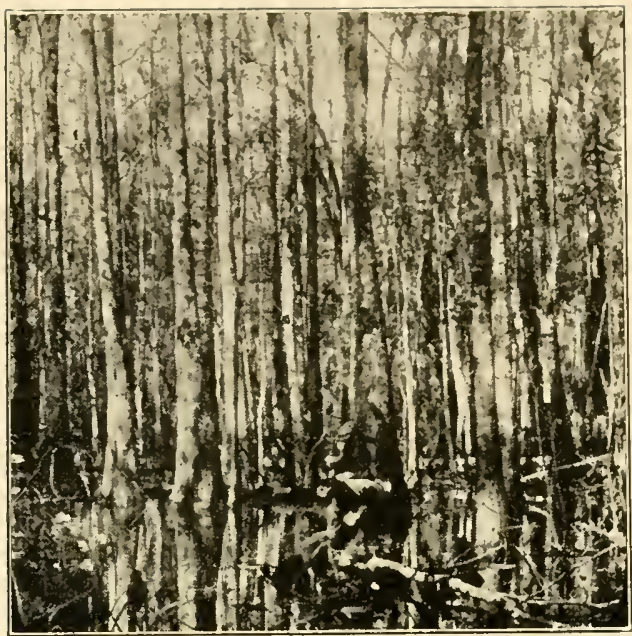

The mink does not mind wet feet for it inhabits such swampy places as pictured above.

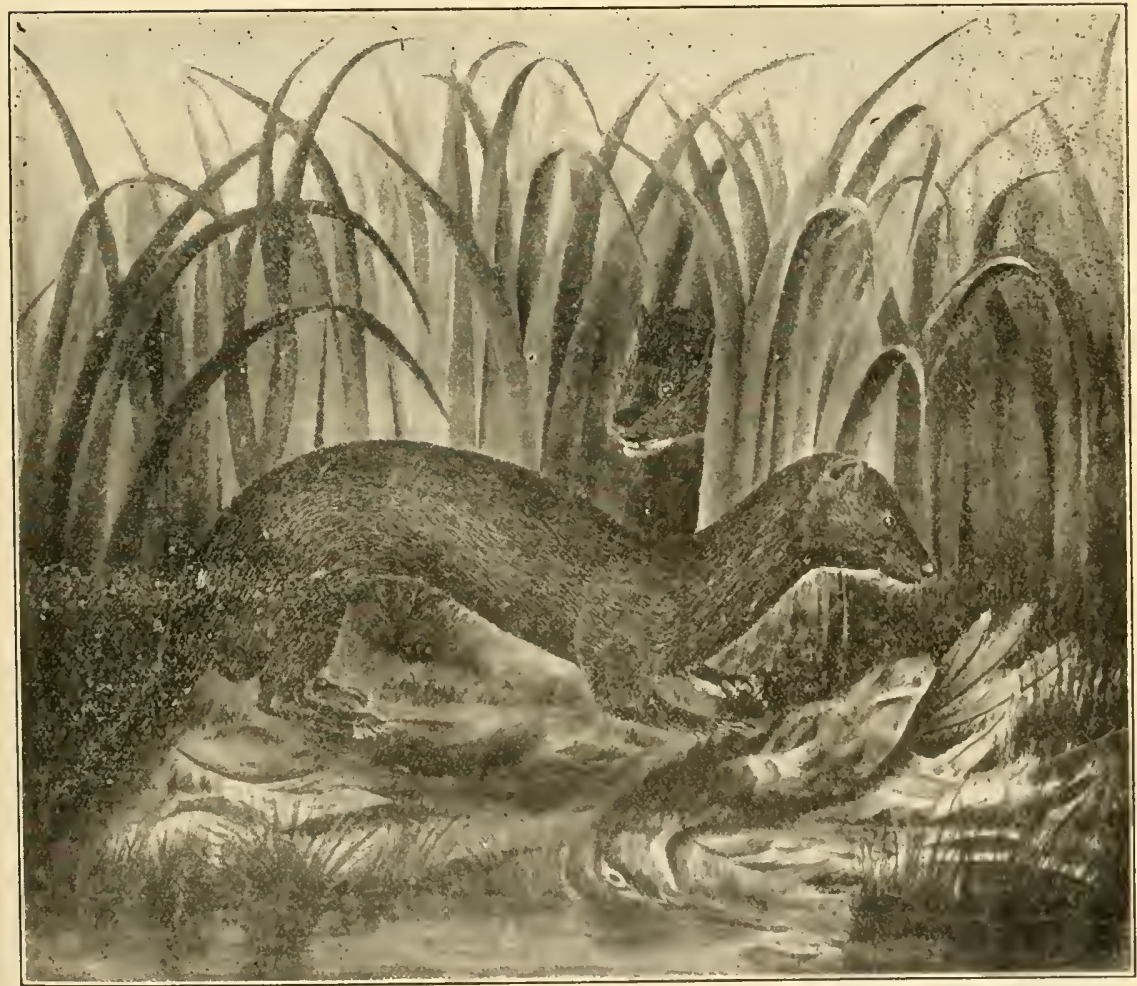

A Louisiana mink feasting off a summer mallard.

-From a uater color painting by G. L. Tiavant. 
tracted to the family by hearing a whimpering or mewing, something like the cries of kittens. The seven young had been born since the cutting of the log, some two weeks previously, the woodsman said. The litter of young mink, none of which had their eyes open, were taken to the finder's home and fed milk, but two of them died within a day of their discovery.

The remaining five were taken to the Avoca Island experimental fur farm and given to a common housecat to suckle. The foster mother was very partial to her new family, refusing to go back to her own kittens, and cared for the little creatures of the wild very tenderly. Two of the youngster's engaged in a ferocious fight when being transported to Morgan City and afterwards died. The remaining three were successfully raised, but afterwards died from causes that were not determined.

The finding of this family would indicate that the young were born approximately April 5. If the period of gestation is 50 days, this would indicate a mating season about the middle of February.

The mink is known not only for its bold and courageous demeanor toward other animals, but for its frequent bloodthirsty proclivities. While it hunts and kills mostly for food, still at times it seems to be animated by a desire merely to kill and gratify this lust. It frequently destroys a bird and a smaller animal by severing its throat and, after a sip or two of its victim's blood, leaves it to continue a sanguinary quest for other victims.

Trailing its prey by scent, the mink destroys mice, rats, chipmunks, squirrels, and even muskrats heavier than itself. If likes bil'ds' eggs and does considerable damage in this regard to all ground-nesting species. In the water this fur animal pursues and captures fish, snakes and frogs, and varies its diet by eating insects and various kinds of crustaceans and shell fish.

According to Audubon, who devoted considerable attention to mammals during his residence in Louisiana, the mink subsists principally on clapper rails, seaside sparrows, and sharp-tailed sparrows which feed on minute shell fish. The famous naturalist-writer-artist describes the mink "wading stealthily through the grass, pausing to take ob-. 


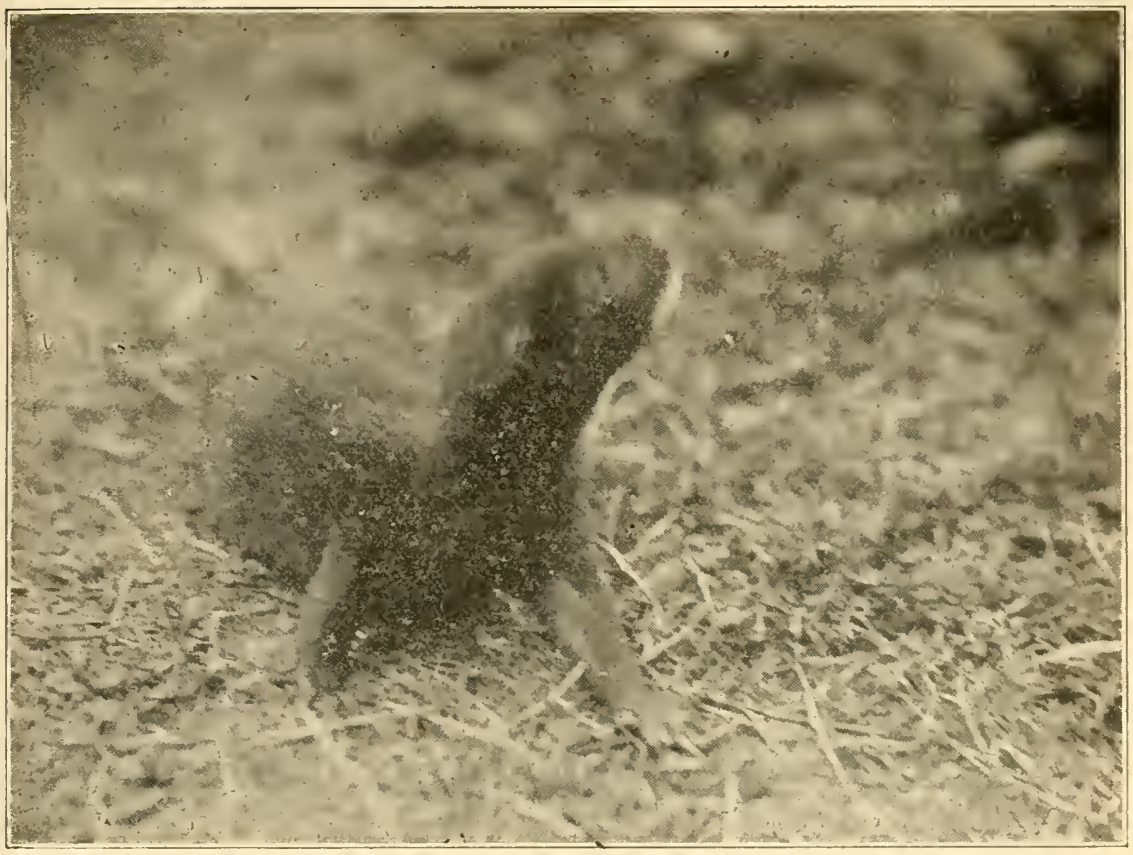

Young mink on department's experimental fur farm.

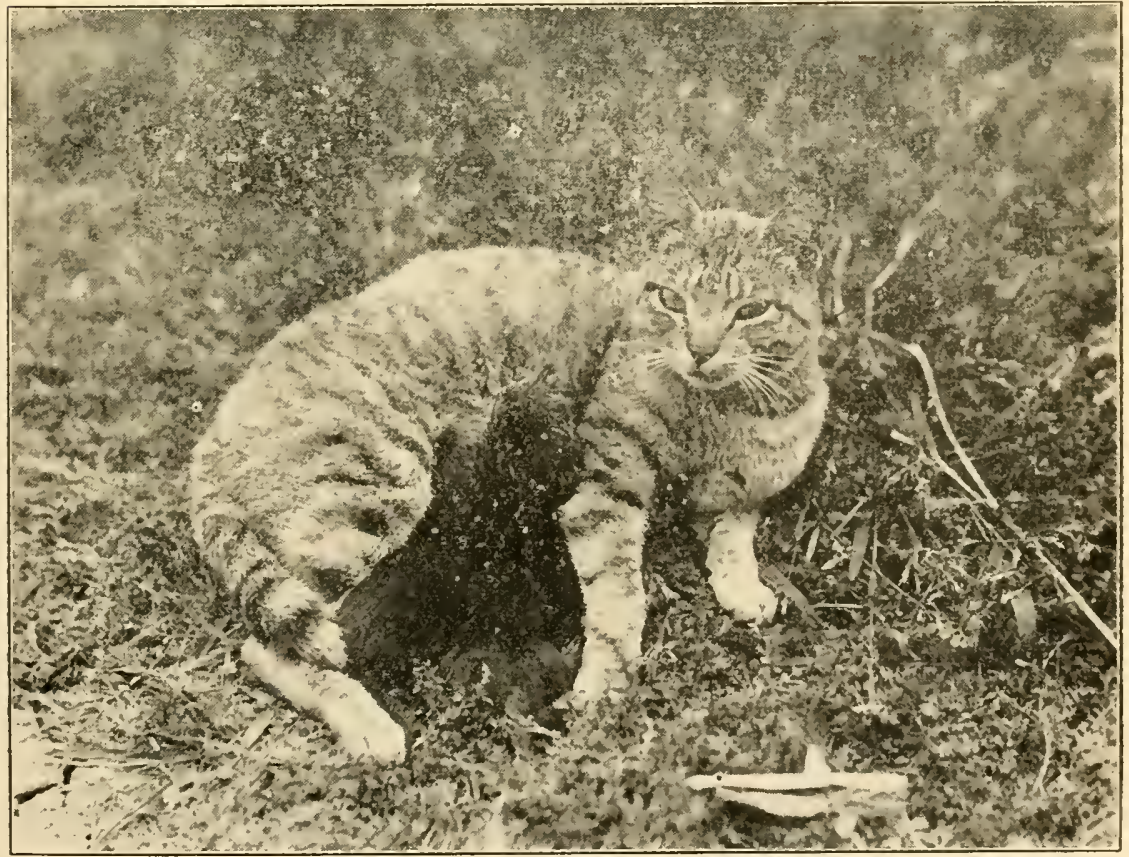

An ordinary tabby cat and her adopted family of baby minks. 
servation, sometimes lying for the space of a minute flat on its belly, hugging the mud. At length it draws its h.nd feet far forward under its body, like a cat, its back arched, tail curled then makes its sudden spring."

The mink is perfectly at home in the water, where it swims like an otter-so much so that scientists have proposed that it should be given a Latin name, Luiresla, sgnifying "little otter." The mink swims with most of the boly submerged, sometimes with only the nose above tie surface of the water, and it can progress uncler water with marked ease and rapidity, and it is said that it can remain completely submerged a very long time without coming to the surface to breathe. This ability to swim under water, undoubtedly, stands the mink in good stead when it races to surprise such prey as ducks or other water fowl or other animal life frequenting water.

Auclubon declared that a mink shot while in the water sinks when killed, "as the bones are heavy and have litt.e buoyancy." He also asserted that minks release their characteristic odor when fighting.

When on a killing expedition, the mink frequently slacks its blood-thirst on young muskrats. Selecting an inhabited muskrat house by means of its keen scenting powers, the mink digs and bites its way through the grasses of the structure until it reaches the muskrat family, then through the small tumnel it makes it gains entry to the nursery, puts the mother to flight, and with rapid darts of its triangularshaped head destroys the mice with its sharp teeth.

Therefore. the mink is the enemy of the 'rat rancher, and all muskrat producing areas should be persistently trapped for mink during the regular open season. This should be corne in mind by those who have taken up marshlands for the production of muskrats. Although it may be desirable to refrain from muskrat trapping for a season or two to allow the 'rat population to build up, trapping for mink should be carried on persistently.

Aside from otter skins, the pelt of the mink is the most individually valuable fur taken in Louisiana. It occur's throughout the state, being found in greater numbers, however, in heavily wooded waterbottoms and in cypress and tupelo swamps. The minks found in these sections are 
more valuable than those inhabiting the coastal marshes, as the "woods mink" has a darker coat and the fur is finer. The best No. 1 large pelts brought $\$ 9.00$ and more during the 1927-1928 season.

A mink known in the fur trade as the "French Settlement Mink," found in that section of the state covered by the parishes of Ascension, St. James, Livingston, Tangipahoa and St. John the Baptist, and in the general vicinity of Lake Maurepas, brings the highest price in the raw pelt market. The reason for this is not alone because of its rich dark-brown pelage, but because these animals grade evenly, and, when using French Settlement mink, furriers do not have to spend time in matching tanned skins when making up a garment composed wholly of mink fur. The French Settlement mink gained its trade name because so many of these skins were shipped by boat from the small community of this name on the Amite River in Livingston parish.

Louisiana exceeds all the other states of the Union in the production of mink pelts, and in Canada is only exceeded by the province of Ontario. In the 1924-1925 season, when that northern fur section produced 68,138 skins, the Louisiana output was 67,441 pelts.

One of the principal markets for Louisiana mink is the city of Winnipeg. While the province of Manitoba produced approximately 13,000 pelts in the season of $1924-1925$, still the manufacturing furriers of that Canadian city are active purchasers of mink from our sub-tropical section of the continent, particularly the French Settlement mink, which appears very much like carrying coal to Newcastle!

The leading mink-producing parishes are, their importance in numbers taken being in the order named: Terrebonne, St. Mary, Lafourche, Cameron, Vermilion, Assumption, Plaquemines, Calcasieu, Jefferson, Livingston, Tangipahoa, Natchitoches, De Soto, Iberville, Rapides, Bossier, Caddo, Richland, and there is not a parish in the state where this fur animal is not taken.

The success mink trappers have had in past years, due to the large number of minks they have taken, has caused some to declare that the supply is inexhaustible, but with increasing demand for fur and the spectacular rise in prices; 
of Louisiana skins (mink sold for $\$ 1.33$ average in 1915), the numbers of mink must surely decrease. In those sections of the state where the muskrat does not occur, the cpen and close seasons on mink should be scrupulously observed. However, while the mink is, in itself, valuable as a fur animal, it is an enemy of the muskrat, and on those areas now being taken over for muskrat ranches the few mink to be found should be systematically eradicated, making way for the increase of the more valuable muskrat crop.

To insure a prime skin, one that will command the highest market value, the mink should not be trapped in Louisiana before December 1 nor after February 15. Mink in captivity at the department's experimental fur farm at Morgan City began shedding before the end of March, the hair of the head around the nose first became darker, then the back, and finally the rest of the pelage. By the first of June summer pelage was attained.

Minks are peculiarly adapted to "fur farming" in confinement and the prevailing price for good fur is sufficiently high to make an investment for proper mink-raising enclosures worth while. This, coupled with a growing demand for mink fur and a corresponding decrease of tho animals in the world, leads authorities on the subject to recommend this phase of fur animal breeding. That returns are to be earned in rearing breeding stock for sale seems certain, but what can be earned from a "minkery" on a purely pelting basis $\mathrm{s}$ something that $\mathrm{I}$ as not yet been determined. It is suggested that the field be experimented with by those anxious to invest in fur farming on small acreage.s.

Those interested in this phase of fur animal breeding may obtain a great deal of practical knowledge by reading "Mink Raising," leaflet No. 8, by Frank G. Ashbrook, biologist in charge of the division of fur resources of the bureau of biological survey in the Uuited States Department of Agriculture, which can be secured from the superintendent of documents, Washington, D. C., at 5 cents a copy. It is probably the best information now obtainable on the subject and contains a world of information and knowledge on mink raising in a very few pages. 


\section{CHAPTER ELEVEN}

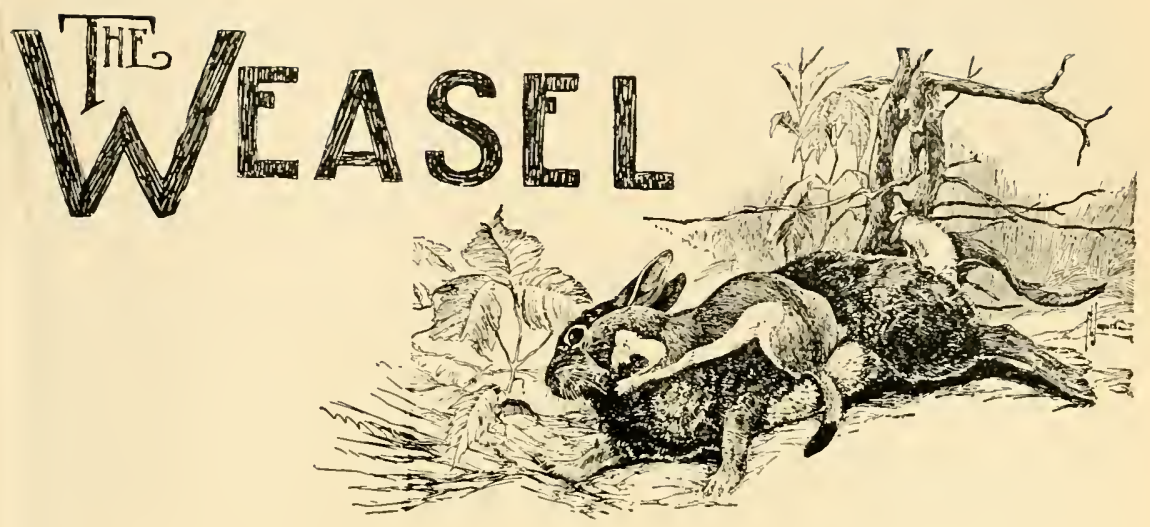

The Weasel, or ermine, as it is usually called in the North and East, is a member of Louisiana's fur animal family. That it does occur here comes as a surprise to those who have made extensive and systematic studies of the mammals of North America, as well as to those who have but a cursory knowledge of our mammallian fauna. While it is not at all plentiful, nor does its pelt or numbers of them taken make it important as a fur producer here, suitable attention should be paid it in this bulletin.

The few specimens secured and sent to biologists for identification were the first to be scientifically recognized from Louisiana. E. Raymond Hall, curator of mammals of the Museum of Vertebrate Zoology of the University of California, who has made a revisionary study of the weasels of North America, found that our weasel so differed from the other geographic forms of the so-called "New York weasel" (Mustela noveboracensis), that he gave it a sub-specific rank and named it according to scientific nomenclature. ${ }^{1}$

But whether it is to be known by the Latin name, or as the Louisiana weasel, this animal has been named, and

${ }^{1}$ Hall, E. Faymond, A New Weasel from Louisina, Proc. Biol. Soc., Washington, D. C. 
many years ago, by the French-speaking population of that section of the state where it appears to be most numerousSt. James parish and those lands adjacent to it east of the Mississippi river.

Here the weasel is a fouine (pronounced foo'in) meaning "sneak," a name applied to this animal by the early settlers in recognition of its skulking, stealthy habits, as fouiner means "to sneak away," steal or slink off. Such Old World mammals as the true pole-cat, fitchet and beechmarten have also been given this name, and, in some parts of France, fouine means a pitchfork.

The usual Old World French translation of the word weasel is belette, but our early French-speaking Louisianians gave the name belette to the mink, and the mink, in Louisiana, is so known to many of our lowland trappers who still speak the tongue of their ancestors.

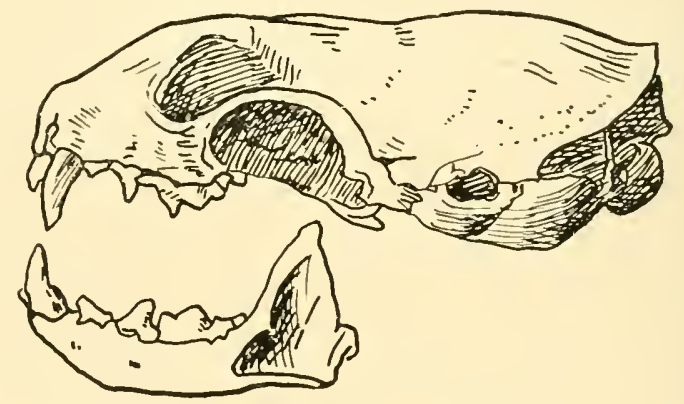

Skull drawing of a weasel showing the canine, or flesh-tearing front teeth characteristic of all meat-eating mammals.

The signification of the word weasel is obscure. Some believe it was derived from the German wiese, meaning a meadow. The early English name was weesel; the Swedes calling it wersla and the Dutch wezel. The Biloxi seem to be the only Gulf Indians to have given this animal a name, calling it iskixpa, a diminutive form of the name given the mink. 


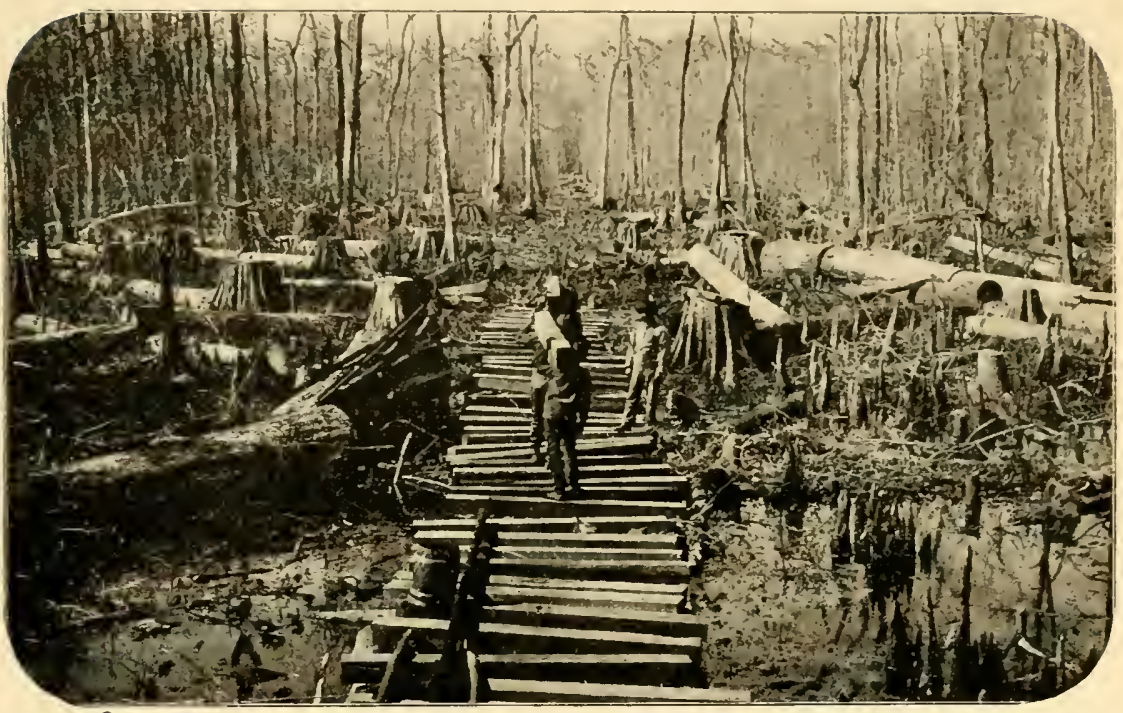

In the cut-over swam? land. where the tupelo and cypress have been removed, are found suitable hab:tats for the murderous little weasel.

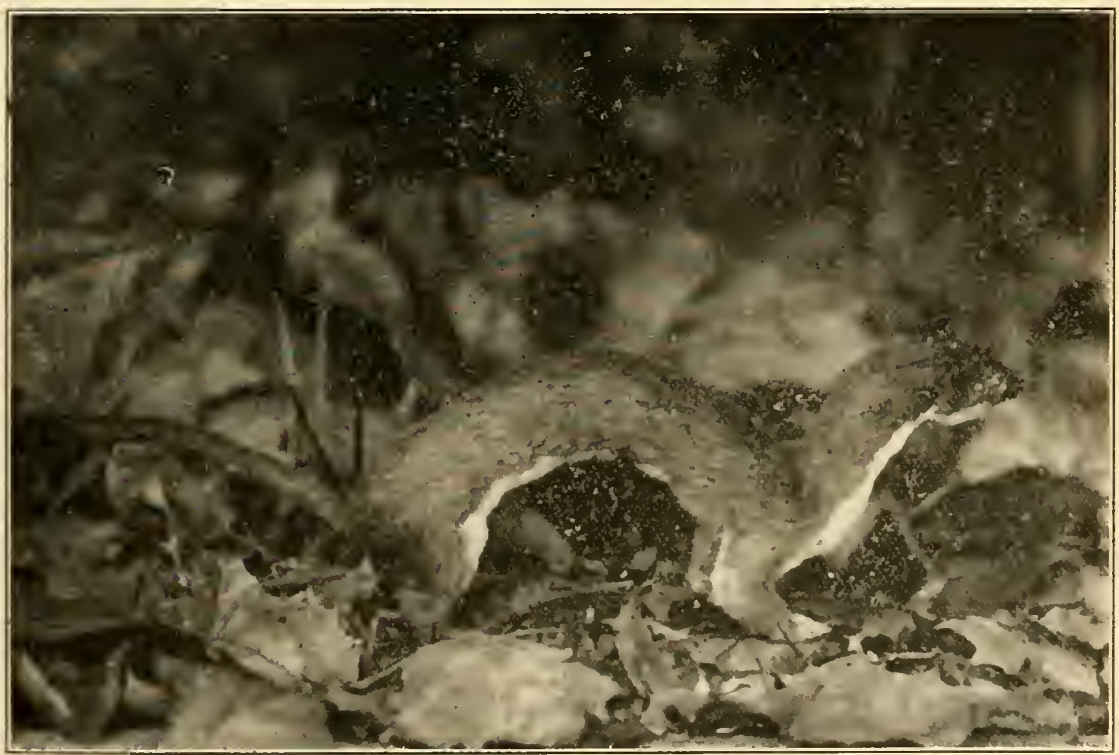

A Louisiana weasel, photographed from a specimen mounted by E. S. Hopkins. 
The Louisiana fouine does not differ in any of its bloodthirsty or predacious habits from the well-known actions of the weasel in other parts of North America. It is bold and inquisitive, fearless and ferocious, alert almost to the point of nervousness and a hunter without a peer. Belonging to a group of animals that bears its common name, the Weasel family, or Mustelidue, it is a close relation of such important fur animals as the mink, otter, skunk, badger, marten and wolverine, and, like the others of its race, is small as to size, fierce and bloodthirsty in habit, endowed with remarkable endurance and, possessing a long and slender body, is quick and graceful in all its movements.

While the weasel is the diminutive member of its family, the animal found in Louisiana is larger than some of the species found in other parts of North America, such as the least weasel that occurs in the northern sections of the continent from Alaska to Hudson Bay and south to Minnesota and Montana. The least weasel is about 7 inches in length, while the Louisiana species is double that size.

In the north the weasel is called the ermine because while in summer its coat is of a dull brown color, in winter this color gives way to a wholly and pure white pelage excepting the very back tip of the tail, and it is this white fur, set off with the black tail tips, that has long been the "ermine of royalty."

The Louisiana weasel does not turn white in winter as do its cousins of the snows and from the live specimens observed, the coloration does not seem to change with the seasons. It is of a reddish-brown above and white, tinged with yellow, on the underparts, with a white chin spot. Our weasel possesses the black-tipped tail and there seems to be a darkish, if not black, dorsal stripe extending along the back and down the upper part of the tail.

While there is no sexual difference in color, the female: is always smaller than the male, and measurements of two. weasels taken in St. James parish are: 


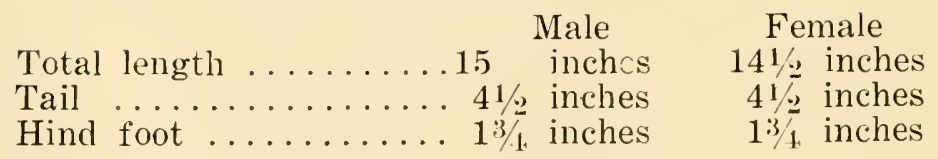

The first weasels noted were a mother and three young that had been trapped alive at Kentwood, Tangipahoa parish, in 1918. The family remained on exhibition in the Audubon Park Zoo for several years. Specimens of weasels have been identified from Greensburg, St. Helena parish; Braithwaite, Plaquemines parish; Geismar, Assumption parish; Laurel Hill, West Feliciana parish; from French Settlement and several other points in Livingston parish, but the greatest number secured have come from St. James parish in the vicinity of Remy and Convent. These all preesented the same uniform size and coloration and information from Remy was to the effect that school children were in the habit of trapping a number of them along the sides of ditches and other waterways.

During the month of December a very large pelt of a weasel was found in a collection of skins being sold in Morgan City and inquiry developed the information that it had been trapped in the neighborhood of the souther'n end of Lake Verret, Assumption parish. According to skin measurements, this was a very large animal and quite light in its reddish-brown color, but retaining the dark dorsal stripe and black tail-tip.

It is quite possible that the Louisiana weasel has a larger distibution than my meager findings have shown and may be more plentiful than researches to date disclose, and assistance from trappers and others interested will be appreaiated in the way of specimens, pelts and skulls and skeletons. Those who would cooperate in this biological investigation are asked to communicate with the department.

A weasel answers the following description: A small and very slender and long-bodied mink-like animal, 13 to 15 inches in length, with very short legs; the tail is covered with brown hairs and always has a black tip. The general coloration is dull reddish-brown on the upper parts of the body, while the under parts are white with a sulphur-like 
tinge. A patch under the chin is pure wite. The share of the head is triangular and the whiskers are long, biacand prominent.

It is nocturnal in its hunting habits and preys on native and introduced mice and rats, young rabbits, birds, grasshoppers, snails, beetles and other insects, and has been found preying on chicken houses in two parts of its rang? in Louisiana.

On its hunts the weasel darts here and there, with the nimbleness of a squirrel and its elongated body, which is almost snake-like in its twisting and turning, reminds one of a powerful but graceful assemblage of muscle. Courageous to a high degree, it will not hesitate to attack animals twice its size and it will take its prey in a shrub, a tree, on the ground or in the water.

Keen of scent, it tracks down its prey in open chase and its lithe and slender body stands it in good stead when it makes its fatal leap and severs the backbone at the neck with one crunch of its sharp teeth or gnashes a jugular vein and satisfies its lust with the blood of its victim.

Devoted to her young, the female weasel of the north is said to bear from four to six in a litter. Although we do not yet know the breeding habits of the Louisiana weasel, it is safe to presume that this may be the average here. The young are born in either a den, in a log, or in a pile of leaves and the mother can be counted on to defend her little ones courageously, and when angered, the characteristic penetrating and disagrceable odor, common to the members of the family to which it belongs, can be quickly detected. 
underparts and inner surfaces of the legs are brownishgrey.

Individual otters vary considerably in size, but the average total length of the Louisiana otter-that is, the measur ment from tip of the nose to the tip of the tailis from $31 / 2$ to 4 feet, with a tail measurement of approximately 1 foot 3 inches. The male otter is considerably larger tnan the female both in length and in weight.

The otter is a mammal having a low elongated body; short legs, broad feet with five toes on each foot, connerted with webs, each toe having short, strong, curved, pointed claws. The head, which is practically the only part of the animal visible when it is swimming, is broad and flat and rather small in relation to the size of the body. The broad muzzle is adorned with thick prominent whiskers. The black eyes are small, and the ears diminutive and rounded. It is a shy animal of pronounced solitary habits and quite generally distributed over North America in localities adapted to its mode of life.

As might be expected of a mammal spending so much of its time in the water, the otter lives almost exciusive on fish, and is rarely met with far from streams, lakes or ponds. Being an expert swimmer and diver, it has no dificulty in pursuing and overtaking fish far beneath the surface. When it has captured its prey, the otter returns to lana to devour its finny meal. Lying on the bank on its belly, the otter holds the fish between its forepaws and begins its meal by first devouring the head and then eating its way down the body of the fish until nothing remains but the tail which, according to some authorities, is never csten. When fizh are plentiful, otters scmetime catch more thin they care to eat; on these occasions they merely take a mouthful of each fish, usually that section just back of the head, leaving the remains on the bank, or the feeding shelf that has been thus used as a dining room. It is in the water leading to this banqueting place that a wise trapper usually places his trap-and catches his otter.

Never abundant anywhere in their range in North America, which is from the northern limit of trees on our 
The Fur Animals of Louisiana

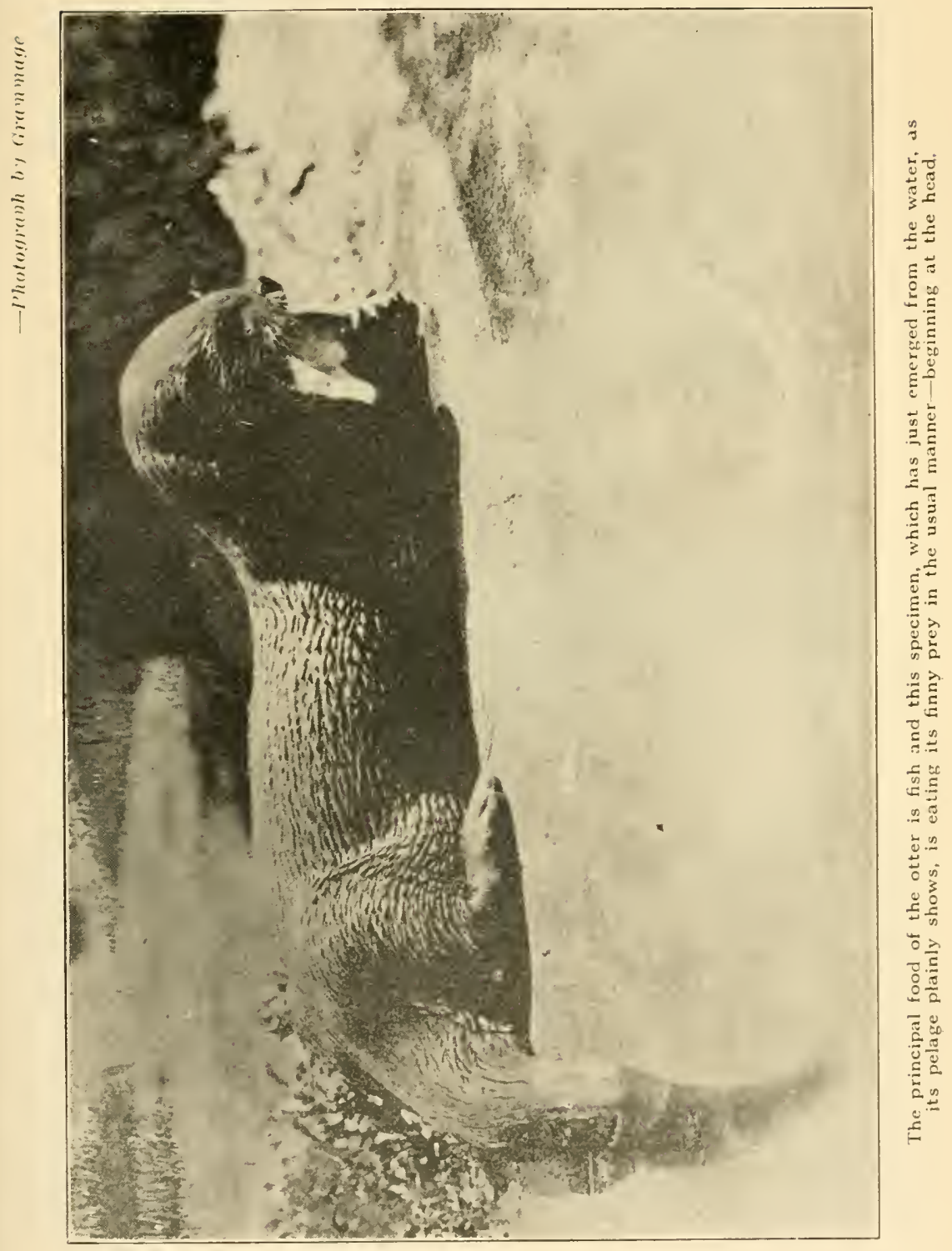


continent to southern South America, these shy creatures of the wild are so solitary in their habits that they have managed to retain their original range and numbers in spite of increassd population, an increased army of trappers and an unbelieveable increase in the value of their pelt. The number taken each season in Louisiana exhibits a remarkable uniformity.

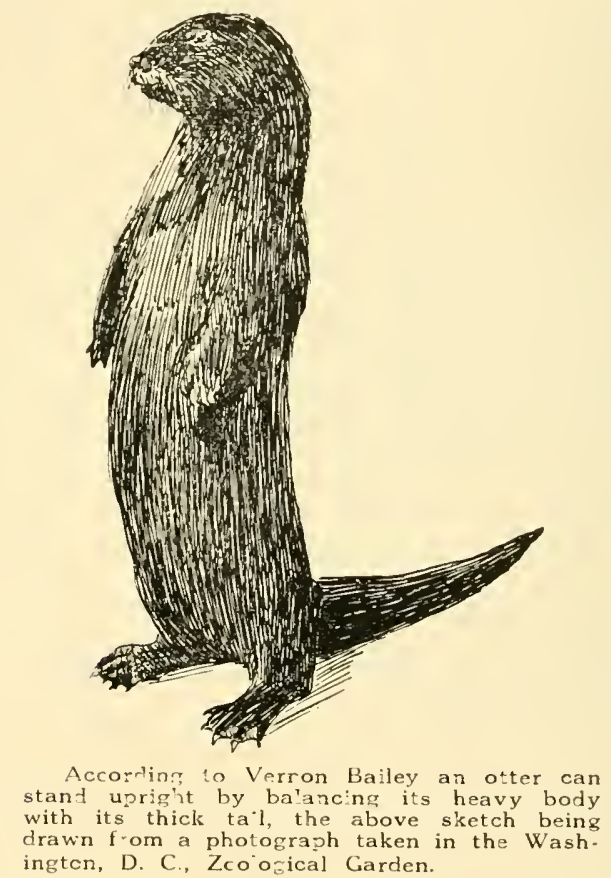

A sight of an otter in its native habitat is rare, even among trappers. The animal's tracks and "signs" are seen frequently, and once in a while, even in Louisiana where low banks line the streams where the otter lives, are seen otter "slides," slick places on the bank where the otters have amused themselves by sliding down the earth into the water so repeatedly as to form a chute. Frequently a flat slick shelf or bench along side some bayou will be noted. This is a so called "feeding shelf," on which the otter lies when derouring its fish or when it desires to nap in the sun. 


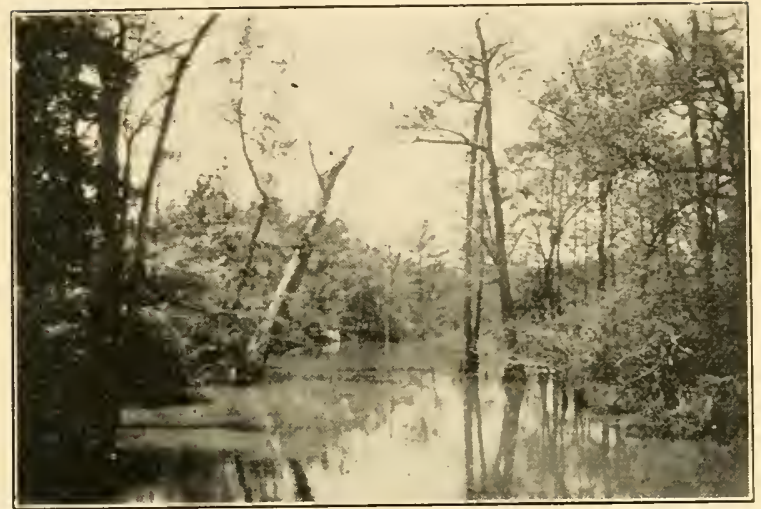

Otter country in Natchitoches parish.

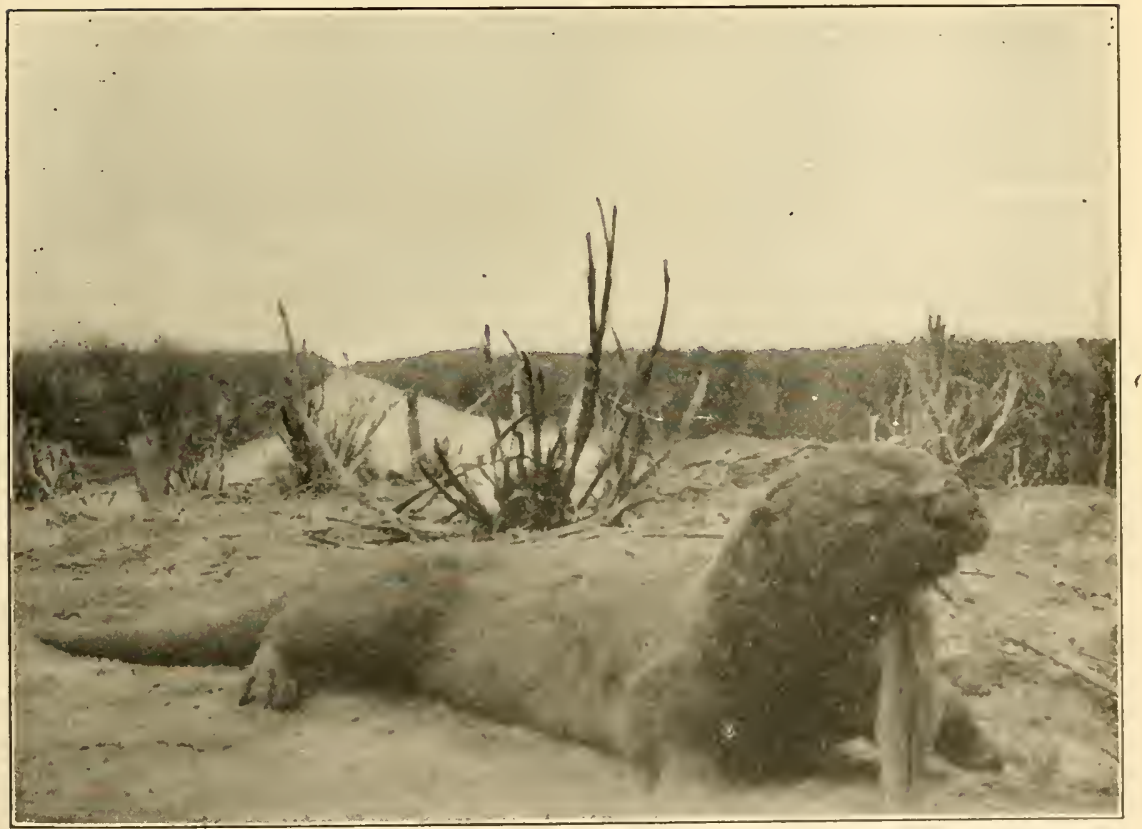

An otter just taken from the trap showing the shape and appearance of the head. 
When the mating season is on, the male makes long journeys in search of a mate. While too short legged and ungainly to move about easily or gracefully on land, in marked contradistinction to its admirable grace, agility and swiftness when crossing any body of water, the bull otter covers remarkable distance when this love hunt is on.

The pairs do not remain together long; in the early spring, in Louisiana, the mother otter produces from two to five young in a litter, but two or three seem to be the arerage; the period of gestation being unknown. The young remain with the mother until nearly grown, which is synonomous with the ammual fall mating season, and then they shift for themselves; at what age they become sexually mature is not known, but it seems certain they grow in size after attaining puberty.

Of all the fur animals, with the possible exception of the raccoon, the otter makes the most satisfactory pet. It is a very intelligent animal, in captivity it has a gentle disposition, and, being very playful, is interesting to watch.

The Lousiana otter is known scientifically as Lutra canadensis lataxina, and, while its pelt has not commanded the price in the fur marts that the northern skins have, still in late years our otters have earned from $\$ 15$ to $\$ 25$ for the trapper lucky enough to catch one. The pelts from the waters in the wooded areas of the state are darker and "furrier" than those from the coastal marsh, and, in consequence command a better price from the fur buyer.

The unplucked and undyed pelt of the otter is the most durable of all furs and is ranked by the fur trade as 100 per cent in the scale of durability; beaver follows with a rating of 97 per cent, the Louisiana muskrat being third in durability.

The principal otter-producing parishes of Louisiana, in the order of importance of annual production, are: Terrebonne, St. Mary, Cameron, Plaquemines, Iberville, Acsension, Livingston, East Carroll, Iberia, Vermilion, Lafourche, Assumption, Pointe Coupee, St. Martin, Washington, and West Feliciana, but there is scarcely a parish in the state where this valuable fur animal does not occur. 


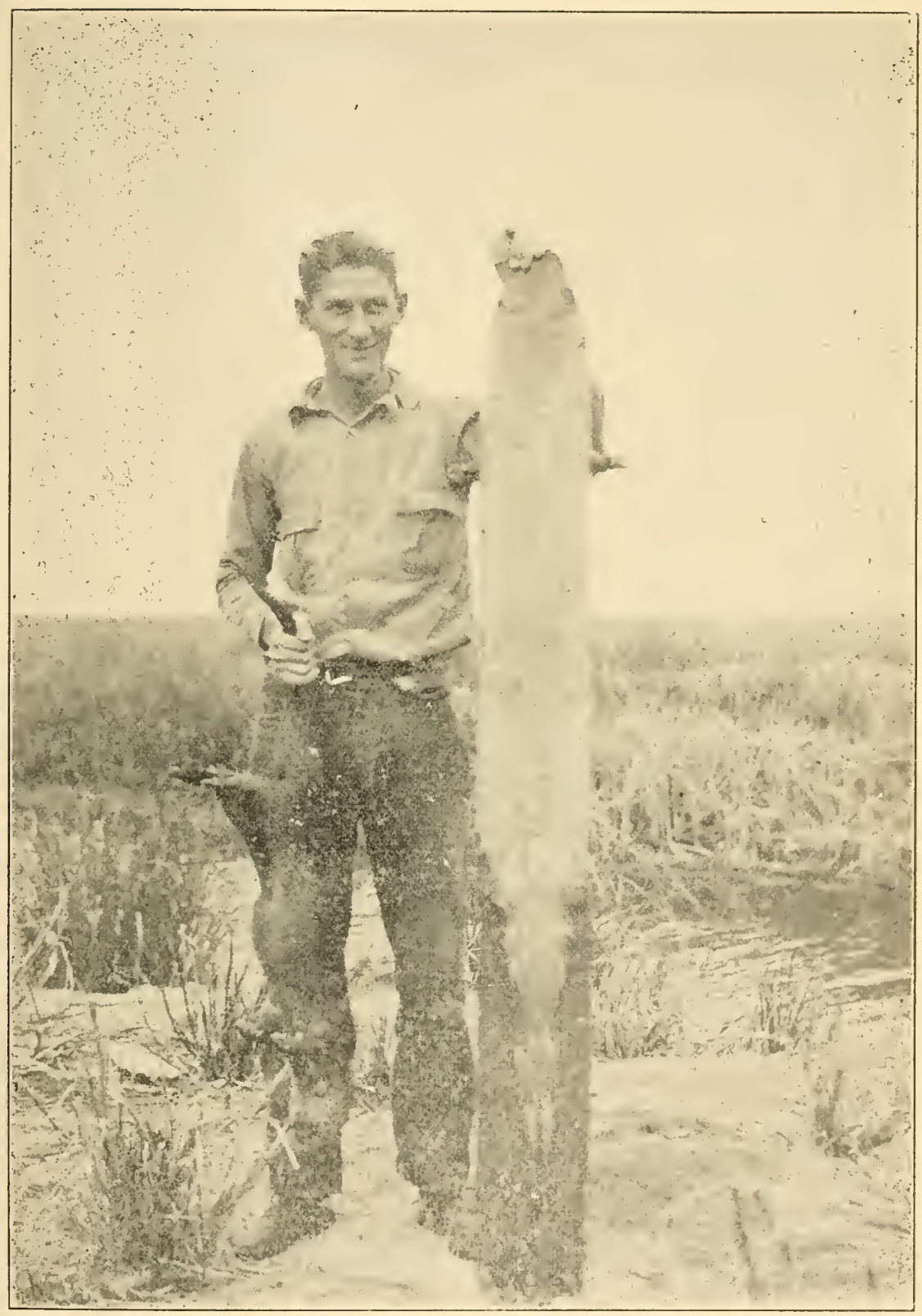

This Cameron parish trapper has had two good days after otter. He has skinned and is drying the pelt of a big male and is getting ready to do the same to the female otter he has just taken from the trap. 
The otter take in Louisiana is slightly more than 2,000 pelts a year, which means about $\$ 35,000$ annually to the trappers securing them. Two otters, trapped in Ascension parish, near McElroy, were very fine examples of dark pelaged animals frequently secured in Louisiana and earned the trapper $\$ 35.00$ a pelt. When these skins entered the fur trade via buyer, dealer, etc., and reached New York they became "Labrador otters," because "fine black otters never come from the South" and "they looked like Labradors!"

The usual run of otters from Louisiana range, however, from $\$ 25.00$ to $\$ 15.00$; pelts not grading up to a No. 1 or for those taken when the pelts are not prime, are, of course, lower in price. 


\section{CHAPTER THIRTEEN}

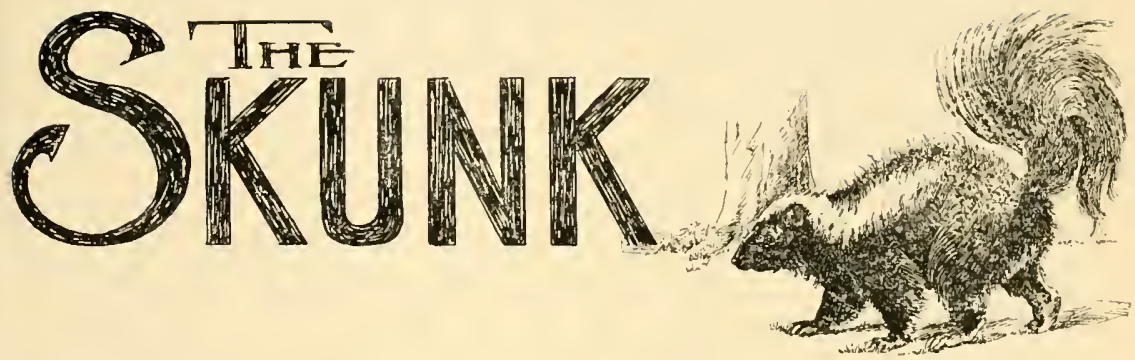

I

$\mathrm{N}$ ALL probability there is no better known land animal in this country than the common skunk and, for that matter, no other American mammal is less popular than this black and white "woods pussy." But, in spite of its almost universal unpopularity, this harmless creature is a valuable and noteworthy member of the group of animals that has given Louisiana such an important standing as a fur-producing state.

The fact that the skunk possesses a scent sac secreting what may be insufficiently described as "a malodorous fluid," which it can dispense with acrid accuracy when annoyed, has long been known. This characteristic method of defense was first made known to the world in 1636, when Sagard-Theodat wrote an account of Canada; this French naturalist described the animal as "Enfance due diable, que le Hurons appelé Scangaresse . . un bête fort puante."1s

And from that time until today the "child of the devil" has held a reputation which has become so notorious that the mere mention of the world skunk has become one of opprobrium.

The name skunk, now in common usage, was derived from the Cree Indian seecawk, although another form, that of seganku, is sometimes given as the derivation. The animal was quite well known to the Indians of the Gulf Coast, the Choctaws calling it Koni; the Biloxi, inska, while the Ofo Indians termed it ataxoska.

18" Child of the deril, whom the lluk on Indians call srangaresse, is ont strong stinking animal." 
The term "polecat," frequently given to all kinds of animals possessing a common means of defense such as has been described, is a misuse of a name given certain Old World mammals belonging to the marten family and a small animal from South Africa, known as the "Cape polecat," which in coloration, markings, and plume-like tail bears a resemblance to our small Little Spotted Skunk.

The skunk, although it differs to a marked degree from its near relatives, belongs to the same important fur family which includes the otter, weasel and mink. It is a really beautiful animal, a triflle larger than a house cat, with lustrous black fur, marked on the back by a patch or streaks of white. The muzzle is long and pointed, the black eyes alert and gleaming, and the plume-like tail usually divided cqually black and white in color by an abundant growth of hair.

The skunk is distinguished physically not alone by its bu hy tail but by the disproportionately large size of the posterior half of its body. Seen from the side, the elevation of the hindquarters is most apparent. In its walks about the countryside, the skunk is slow of gait. It seems to have a measured walk, from which it is loath to deviate, but when pressed, either by an enemy or a desire to capture some disappearing prey, it has a peculiar, shuffling gallop that defies description. A skunk walks on the soles of its feet, instead of on its toes, as do most other mammals. When mildly annoyed it has an amusing way of stamping its forepaws on the ground, like a petulant child.

Slow in movement and deliberate in most of its actions, it is not strange that this animal is hard to intimidate. Nor does it exhibit the same dread of man that most other animals do: and for this reason it seldom runs away when encountered in the wide open spaces. Most wild creatures shun man. To the contrary, one of the skunk's marked characteristics is its fondness for man's company, especially his habitation, for frequently dens and sleeping quarters are established under outhouses or even under dwelling houses. Thickly settled Pennsylvania and New York State today are the principal skunk-producing areas of the United States. 
The skunk was well known to the early French settlers of Louisiana, who gave it the distinctive name of Bete puante, or "Stinking animal." One would scarcely recognize the animal from LePage duPratz's illustration, but he was a little more successful in his written description. This French naturalist-historian wrote of it:

"The 'Bete Puante' is as small as an eight-months' cat. The male is a beautiful black and the female black and striped with white. Its eye is quick; its ears and paws like the mouse's. I believe they live on fruit and grain. It is well named puante, for it has a stinking odor that can be smelt twenty-four hours after it has passed a place. They walk slowly when they know they are followed, turn toward the hunter and expel a urine so offensive that neither man nor beast dare approach it. One day I killed one, my dog caught it, and on bringing it to me some of this fell on my hunting suit. I was obliged to go home immediately. Cleansed myself from head to foot and my clothes after having been scoured had to be exposed to the air for several days before this detestable odor disappeared. I had intended examining this animal closely, but this beginning caused me to decide that I did not care to make a further study of it."

Of the ordinary skunk, two sub-species have been recognized by scientists to be common to Louisiana. They are the Louisiana skunk (Mephitis mesomelas) and the Florida skunk (Memphitis elongata). The latter is said to have a distribution extending from the state for which it is named west along the Gulf coast to the Mississippi river. It is of a medium size, with a very long tail marked with white on both sides, and possessing a white "pencil," as the end hairs are termed, the white stripes on the sides of the body being usually very broad. The Louisiana skunk's range is the territory west of the Mississippi river to the coast of Texas, to Matagorda Bay, and up the Red River Valley to Wichita Falls. It is a small skunk, with a short tail, usually wholly black, but when marked with white the stripes are relatively narrow. 


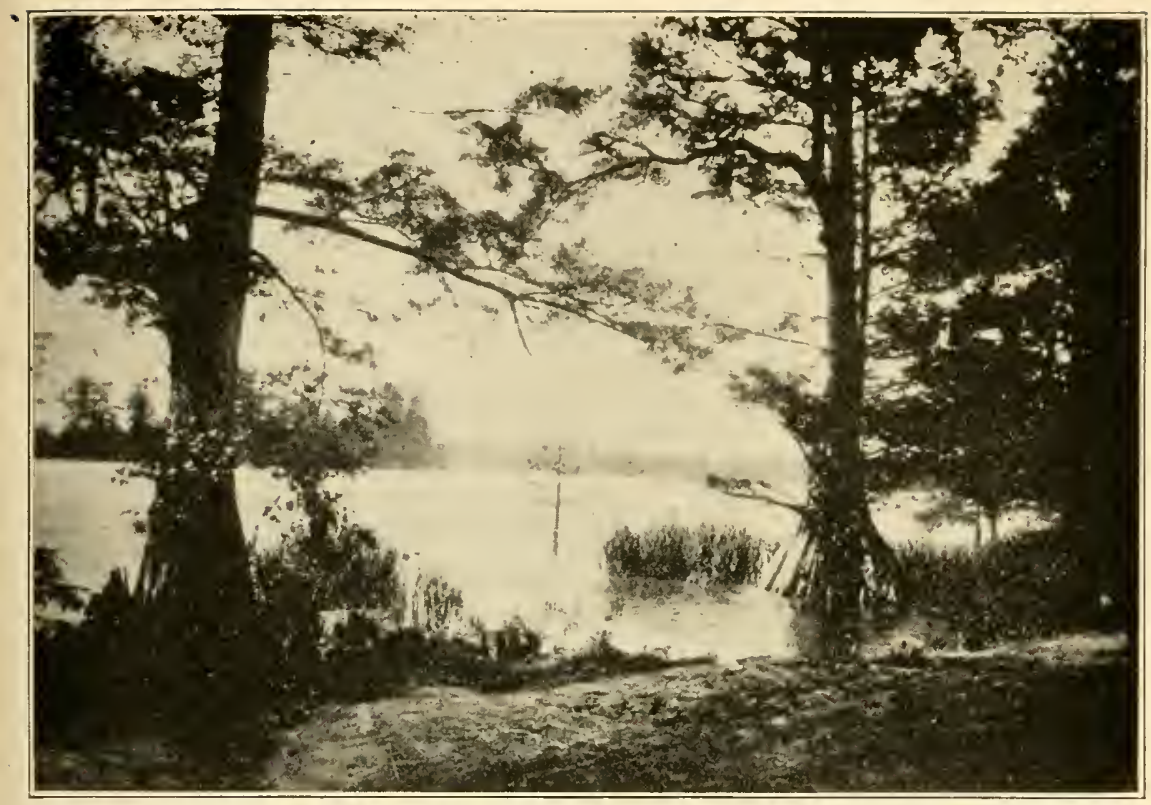

A type of lowland conditions especially suitable for the occurrence of skunks.

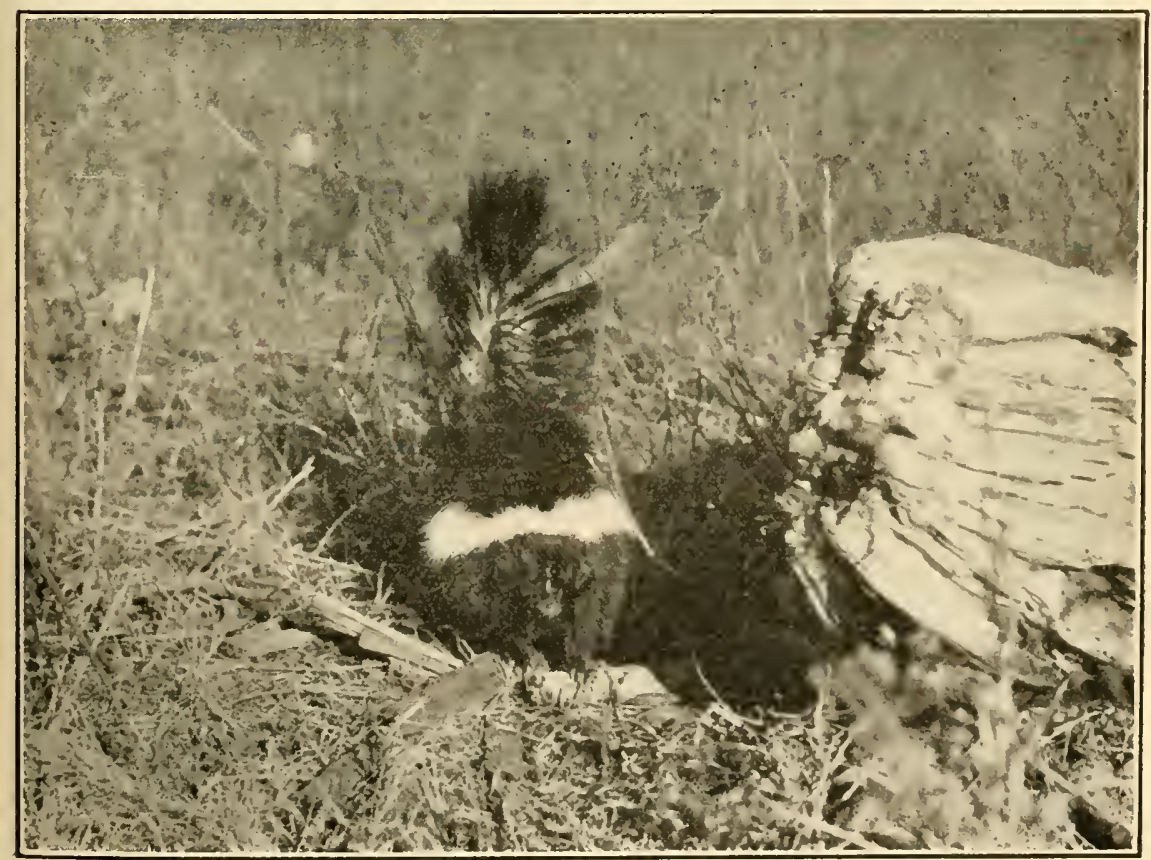

A typical Louisiana broad-striped skunk on the Cameron parish marshlands. 
The common skunk, with its many geographic forms, ranges over the greater part of the North American continent from Hudson Bay, Canada, to Guatemala. It is mainly nocturnal, spending the daylight hours sleeping in its den. Moonlight nights are favored for long strolls whether in search of food or merely in just perambulating around. In the mattor of food, the skunk is omnivorous-that is, its food is a little of everything. It eats a very large quantity of insects, grasshoppers, crickets, beetles, wasps, cicades, June bugs, and grubs and larvae of many kinds. Rodents injurious to man find an acceptable place on its bill of fare, but it also preys on the eggs of ground-nesting birds, as well as on the birds themselves. Lizards, turtle eggs, frogs, fish, and small fruits are also devoured. Sometimes chicken houses are visited with resultant damage to the fowl.

The female skunk produces a single litter during spring, early in April in Louisiana as a rule, and when the young are old enough to leave the den, which is usually a hollow log or subterranean burrow dug by the parents, the young follow the mother in single file on her nightly forays for food, the youngest keeping close to one another like elephants in a circus parade. The family keeps united through the winter months, until the mating season arrives, and then they pair off. The period of gestation is almost nine weeks, 60 to 62 days.

of the animals valuable for their fur the skunk is important in Louisiana raw pelt trade, although this state does not produce as many skins as the more northern and eastern commonwealths. Our crop of 15,000 to 20,000 seems insignificant when compared to Pennsylvania's annual production of 117,000 pelts.

The common skunk is found and trapped in every parish of the state, Terrebonne, St. Mary, Lafourche, Livingston, Cameron, Caddo, Claiborne, Plaquemines, Richland, Pointe Coupee, Natchitoches, Rapides, Tangipahoa and Vermilión bciro the leaders in the order named.

The price paid for skunk averages $\$ 1.00$ per pelt, the prevailing low price being due to the failure of Germany to absorb as large a number of skins as has been taken by 


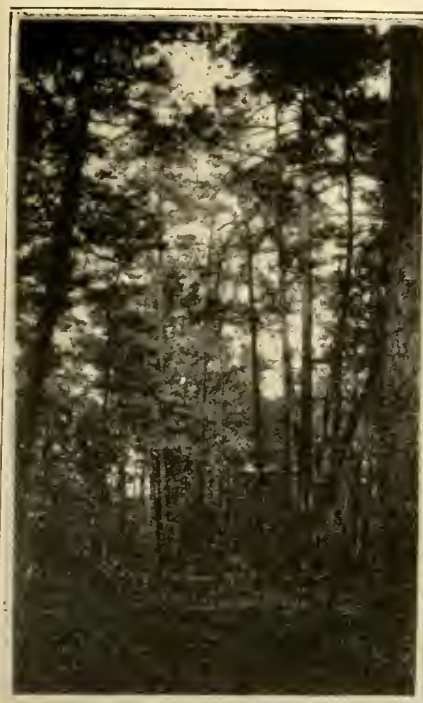

HIGHER LEVEL in SHORTLEAF PINE HILLS

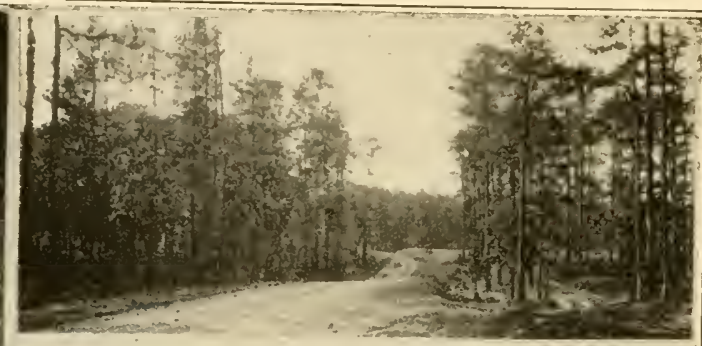

$\angle O N G \angle E A F$ PINE HILLS

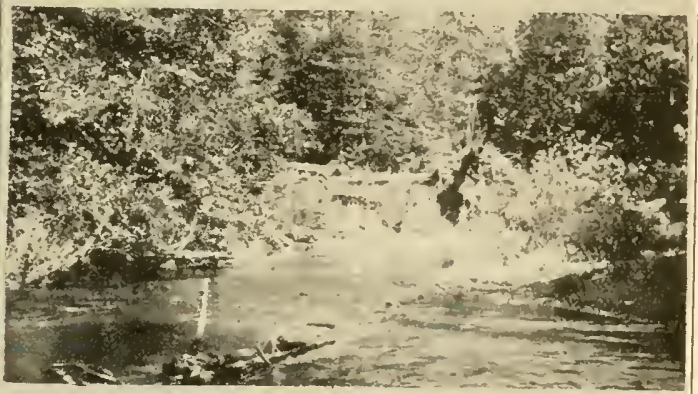

CREEK BOTTOM IN LONGLEAF PINE HILLS D
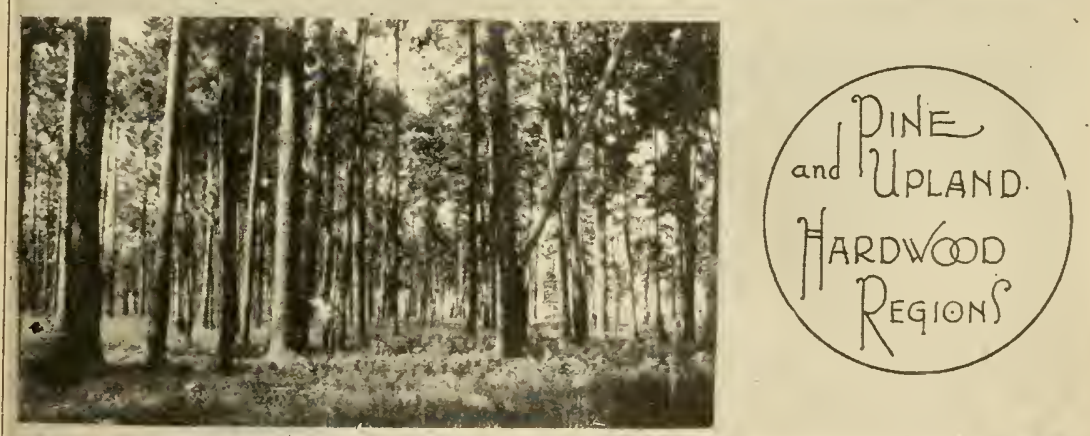

LONGLEAF PINE FLATS
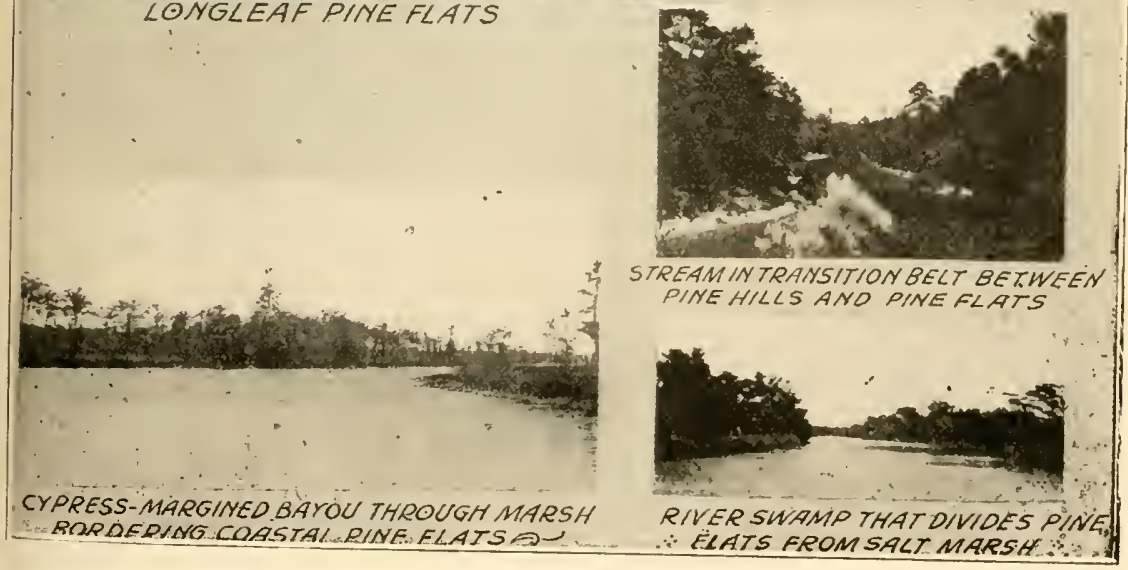

Typical habitats for the striped skunk in Louisiana. 
that country in the past. However, skunk is becoming more and more fashionable in this country; it is expected that the prices on skunk will rise, and within a short time.

Attempts have been made to raise skunks for their fur in captivity and on a commercial scale since 1885 , but it has never proved successful because of the low price of the fur. Most of these activities were confined to developing a strain of wholly black animals by selective breeding. The high prices that have prevailed in recent years and the signs of a renewal of Germany's interest in this fur has led to renewed discussion of skunk raising. That the skunk can be raised successfully in breeding pens in Louisiana there is no doubt, but whether or not the pelting will pay for the care, plant and food is another matter.

If the price of pelts ever go high enough there are excellent reasons for believing that skunk farming in this state will pay. There is scarcely any problem to be faced in fencing, the diet of skunks is varied and the animal is less wild than other members of the musteline family. The odor of the skunk may be disregarded as the breeder can remove the scent glands, rendering his animals harmless in this regard. If the breeding animals are not annoyed there is no need even for this operation, as they soon become tame in captivity and the keeper may handle them with impunity.

There is some danger to the animal in removing the scent glands in mature animals, although it may be performed on the young animals without endangering their lives. The best time for this operation is when the young are four or five weks old. According to information furnished by the Bureau of Biological Survey in Farmers' Bulletin 587, the skunk should be held between the knees of the operator by means of a gunny sack wrapped about the animal's body and feet and an assistant is needed for the operation.

To remove the glands a short incision on each side of the anus through the skin and enveloping muscle is necessary, as shown in the accompanying illustration $\mathrm{A}$. The cuts will expose the round, hard gland and duct. Care 
should be exercised at this point not to cut the duct or other organs. A clamping forceps should be placed over the duct close up to the gland, as indicated in the illustration marked $\mathrm{B}$. The gland is then cut out and the duct severed just beyond the clamp. The gland, with the clamp attached, is then lifted out. The wounds should be brushed with a weak solution of carbolic and need no other dressing. No anaesthetic need be used for this operation on a young skunk, but the older the animal the more difficult it will be because of the larger glands, the sacs in mature animals being approximately three-fourths inch in diameter.
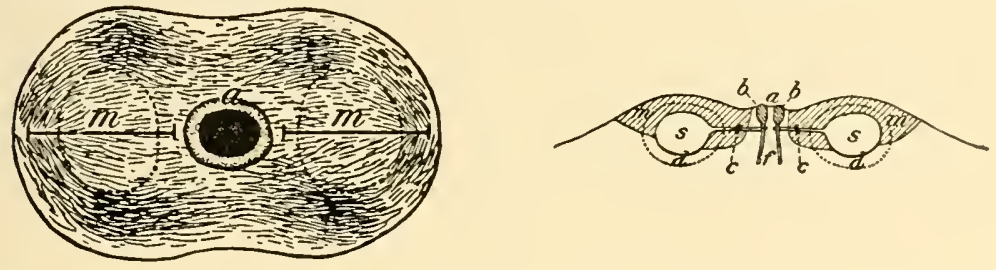

The figure on the left shows the scent sacs of the skunk by dotted lines. The anus and sphinster muscles are indicated by $a$, and the lines for making the incis on to expose the sacs and ducts are marked $m$. The figure on the right shows a section through the scent glands. a. Anus; b, sphinster muscle; c, position for clamps; d, muscle about scent sacs; s, scent sacs; f, rectum; m. depth (shaded area) of incision to be made. Care must be taken not to injure the sphinster nor to cut into the sac or duct. Length of ducts exaggerated. (Diawing from Biological Survey.)

Another operation to deodorize a skunk has been proposed. It consists of cutting the skin over the glands so as to expose a section of the duct leading from the gland and cutting out a portion of it. In healing, the duct is permanently closed and the animal is powerless to use the secretion and the gland dries up. The removal process is the surest and safest operation. 


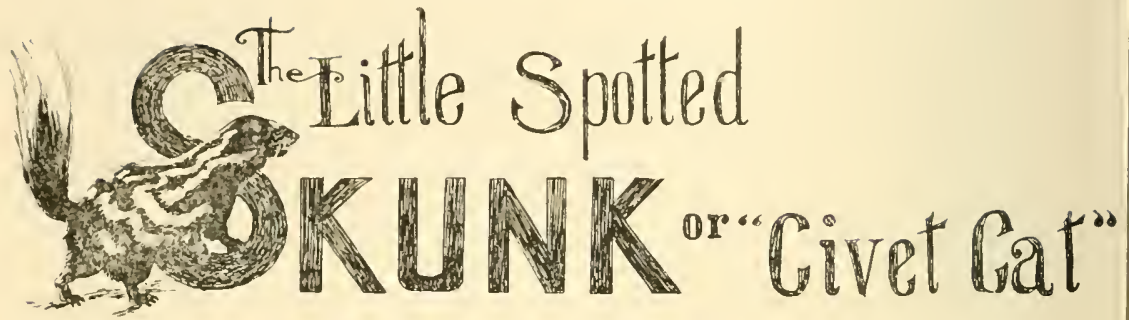

7댇 little spotted skunks, "civets" or "civet cats," as they are called by the fur trade, are diminu'ive an I mals related to the larger skunks and tinof have all tho ill-smelling attrikutes of their larger relatives.

The little spotted skunk is a strikingly-marked black and white animal which, when full grown, is only about half the size of the ordinary skunk. In form it is thick-set, with a broad, triangular-shaped head, set with small ex s The tail is long and bushy with very long, drooping hairs.

In the ordinary skunk the white dorsal stripes are regular and extend from the back of the head down the body to the tail. The little spotted skunk, while of the same general coloration as its relative-black and white-has four white stripes, frequently interrupted by black hairs, along the back which run from the ears to the middle of the back and then continue to the rump in a series of white spots or squares, the two central stripes being usually narrower than the outer. Another spotted stripe is to be found along the side from behind the foreleg to where it curves upward near the hindleg. A white spot is usually found on the hips and another on the head between the ears. In the species found in Louisiana, the tail is black, but with a conspicucus white patch at the hip, which occupies about onefourth of the upper length.

The pelage of this animal makes a very beautiful and striking fur when fashioned into a garment or used as a collar or trimming for other skins, as the black is richlooking and glossy and the white a decided one, as pure in color as snow. It is this contrast of color that has made it a popular fur with the woman who wears furs. The guard hairs are hard and glistening, while the underfur is soft and yielding. 
There are about fourteen different species of this fur animal found in the United States, confined to the southern sections of this country, upper Mexico, and the Pacific Coast States.

The Louisiana spotted skunk is called by the scientists Spilogale indianola, and is confined to the coastal parishes, where it finds suitable highland for its habitat.

The little spotted skunks are very interesting animals, resembling the common skunks in their serene manner of ambling about the countryside after dark, paying very little concern to those they meet on their nocturnal perambulations. These animals are far more agile than their larger relatives, and, unlike the better known species, often climb bushes and sometimes small trees.

They select for dens hollow logs, stumps, and patches of dense brush and, where the nature of the soil permits, they will dig shallow burrows. In Louisiana dens of spotted skunks have been located in shallow depressions scratched from under the roots of trees.

Very little is known regarding the reproduction habits of this animal. Both sexes are alike in pelage and there seems to be no variation in size. Four, five and six young are produced in the spring and the youngsters remain with the mother until nearly grown.

The food of the "civet" consists of insects such as grasshoppers and beetles, harvest and field mice and other small native rodents, lizards, crayfish and water insects and even birds' eggs and birds themselves are found on their menu.

The little spotted skunk has the same manner of defense possessed by the common skunk-the ejection of a vile, foulsmelling liquid.

This little furred animal is, as has been already explained, the "civet" or "civet cat" of the fur trade. This is not a correct nor an appropriate name, but it seems bound to stick. The true civet is a member of the cat family and does not resemble our little skunk in the slightest.

The principal parishes of Louisiana in the production of the little spotted skunk are Calcasieu, Jefferson, Jefferson Davis, Terrebonne, Lefourche, Livingston, Iberville, Ascension and Cameron. 


\section{CHAPTER FIFTEEN}

\section{THE WILDCAT}

CALL it what you will-wildeat, lynx, bob-cat, catamount, bay lynx - the animal under consideration has an appearance that is unique among the wild mammals. Once very common in all of the thickly wooded sections of the state, wildcats have been so persecuted by man that they are to be found today in the thinly settled districts only.

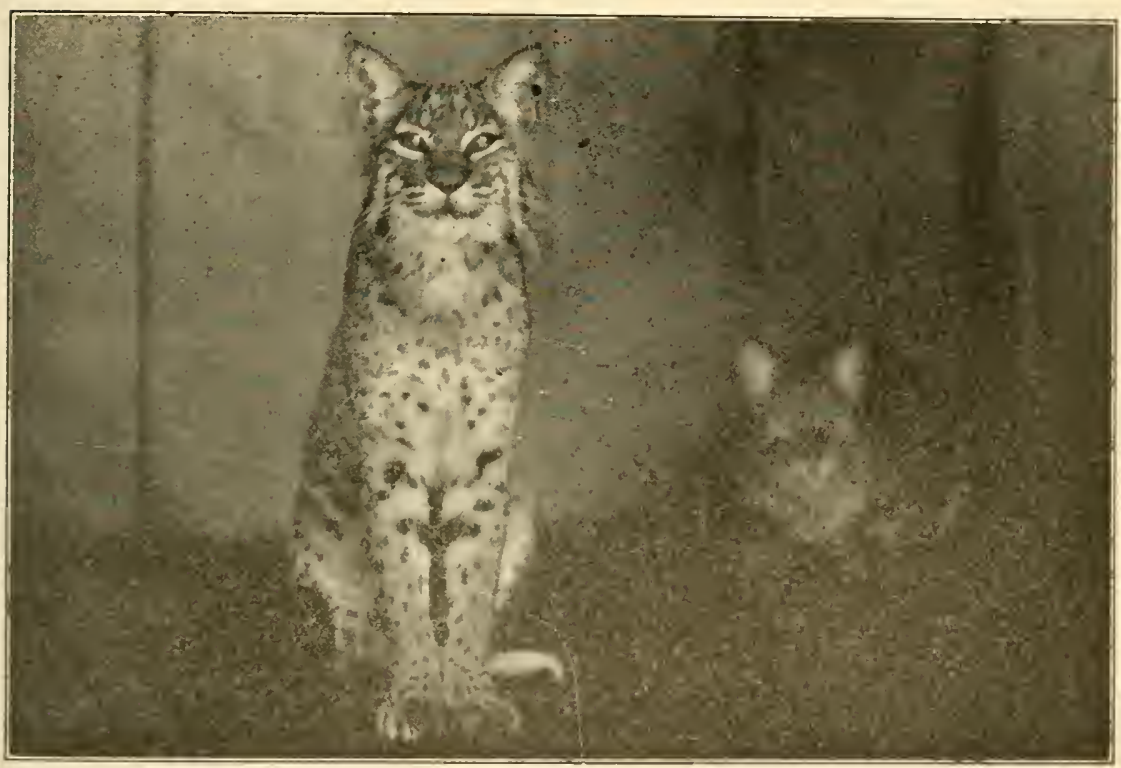

The Louisiana lynx, "bob cat," wild cat, or whatever you choose to call it, is a beautifu! animal.

The bay lynx, as it should bo called, is a heavily-furred, short-bodied, longlegged, bobtailed animal of a reddish brown color, the under surface of the body and the inner sides of the legs are white, spotted, or barred with black. The ears carry a "pencil" or tuft of black hairs. Its long side-whisker's grow about the jaws so as to give the animal the appearance of wearing an old-fashioned ruff. 
Its scientific name of Lynx ruffus was given in recognition of this "ruff" of elongated hairs surrounding the throat and which is more pronounced in the tom than in the female. The face of the lynx is really very beautiful and as it possesses a lithe and graceful body, it can be considered one of the handsomest mammals in our fauna. The tail is short, slender, and slightly turned-up, this abbreviated appendage being barred with rufus and black, with a broad band of black at the extremity.

This stub-tailed wildcat is a lone skulker of our wild lands, as it is only in the mating season that two or more of these animals will be found together. Prowling about on soft, furry paws, it stealthily seeks its prey of rabbits, birds, or native rats and mice in the tangled undergrowth. While the lynx lacks the skill, ability, speed and perseverance of a mink or fox in following a scent or trail, it makes up for this by the ability it possesses of lying well hidden in some retreat, and the lightning-like manner in which it can spring on whatever small game passes within reach.

The lynx is a very skillful still-hunter and lives on a wide variety of birds. Because of its diurnal activities, being a day hunter while most of our other mammals are more nocturnal in habits, its menu is quite raried. Being also an adept climber, it puts this ability to good use in feeding on birds and small mammals nesting in tree cavities. Along the Atchafalaya river bottoms in Pointe Coupee and St. Landry parishes the bay lynx preys on kids and lambs.

Quiet in all it does and possessed of a very keen sense of hearing, the bob-cat will instantly crouch with all four feet under its body, remaining tense and motionless, listening and watching, when it detects any movement in the undergrowth. If it is an enemy, it will creep off without a sound betraying its retreat from the danger zone. If it proves to be some living thing it can make a meal of, it will creep on its victim with the utmost caution. 


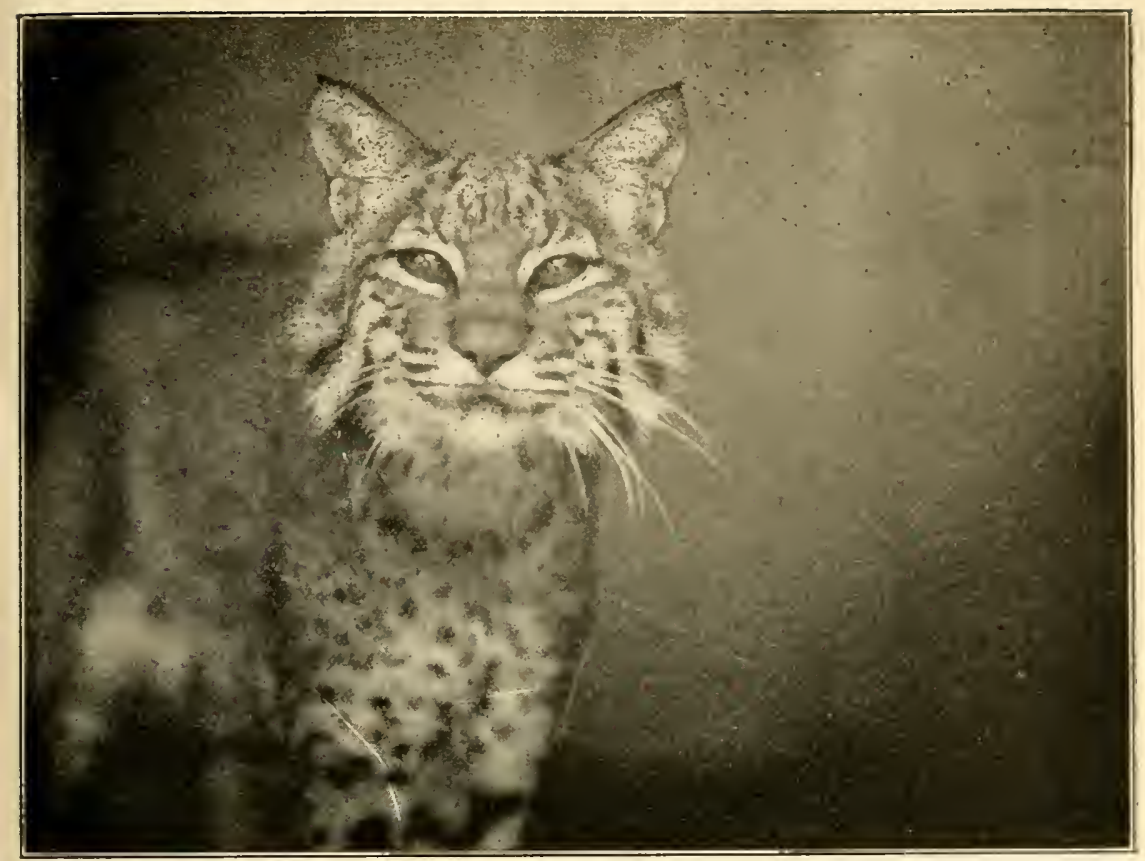

Showing the ruff that gave the lynx its scientific name.

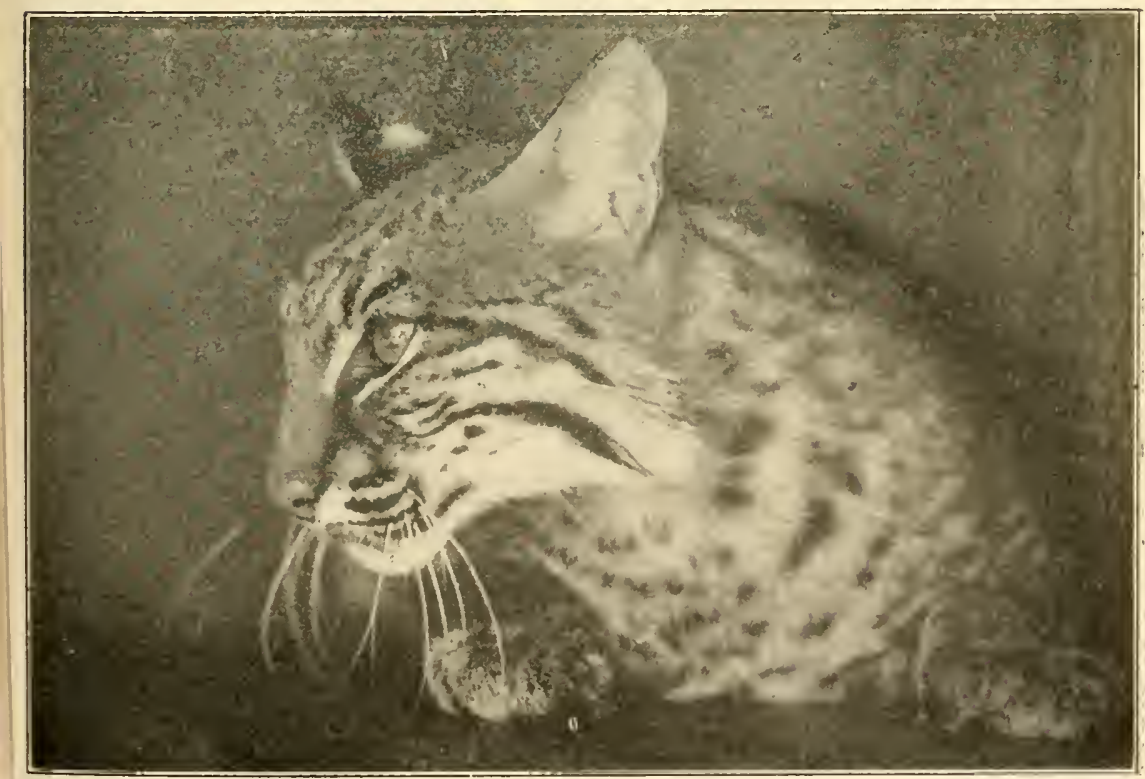

The male bob-cat, or lynx is a handsome fellow. 
Audubon ${ }^{19}$ found that the lynx is fond of concealing itself in canebreaks and frequently sleeps in broom grass. When pursued by dogs, he claimed, the wildcat "takes to clayey bottoms so as to cover the bottom of its feet with this adhesive soil to better destroy the scent that the dogs follow in the chase".

When on a hunt the bay lynx is noted for its habit of uttering wild screams at intervals. This sound, frequently referred to as a caterwaul, is most uncanny, and the theory of many naturalists regarding it is that it is uttered with the object of startling any creature that may be hiding nearby into action so that the cat may more easily locate it by the sound of its prey scampering through the grasses to escape.

Shy and exceedingly cautious about showing itself, and making off quickly at the approach of man, the bay lynx is a savage and dangerous fighter when cornered or held in a trap, and the female proves a tough customer when defending her kittens. It is this fierceness that has been responsible for the saying that a man has marked ability as a scrapper when he is reputed to be able to "whip his weight in wildcats".

The name lynx is derived from a Greek word meaning "to see," and is in recognition of the animal's extraordinary powers of vision. This, too, has been recognized, popularly by the saying "lynx-eyed".

The Choctaws called this animal Shakbatina and different names were given it by the Indian tribes of the Gulf region. The Tunicas called it tcumu; the Atakapas named it cirion. while the Chitimacha Indians called this animal tcewa histamon, which means "animal that hides under trash". The Ofo Indians named it atxanta. The Biloxi designation was tmotcka.

Not as much is known about the reproduction habits of this animal as might be desired. Its mating season is said to occur during the winter in Louisiana, and the kittens,

${ }^{10}$ Audubon, J. J., and Bachman, John, The Triviparous Quadrupeds of North America, vol. 1. 
four and often less to the litter, are nursed during the early spring.

As a fur animal the bay lynx is not very valuable, but during the trapping seasons from 300 to 500 of them are skinned and sent to the fur market. The pelt, if well furred and not damaged, will average $\$ 1.50$ each.

As the bay lynx is of uniform distribution throughout the state and not many of them are taken by professional trappers, no particular location can be pointed out as a leader in the production of this fur.

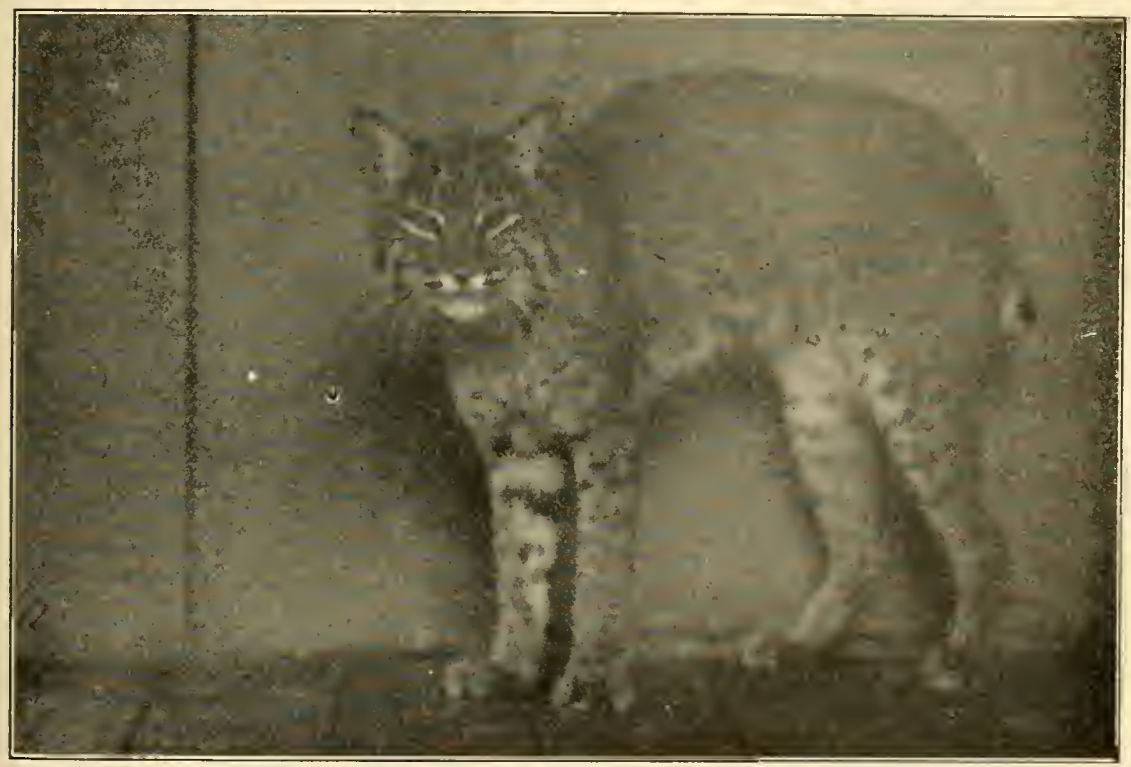

The characteristic standing attitude of the lynx with the hindquarters higher than the head. The abbreviated tail with its black spot is noticeable in this pose of a female photographed in the Audubon Park Zoo, New Orleans. 


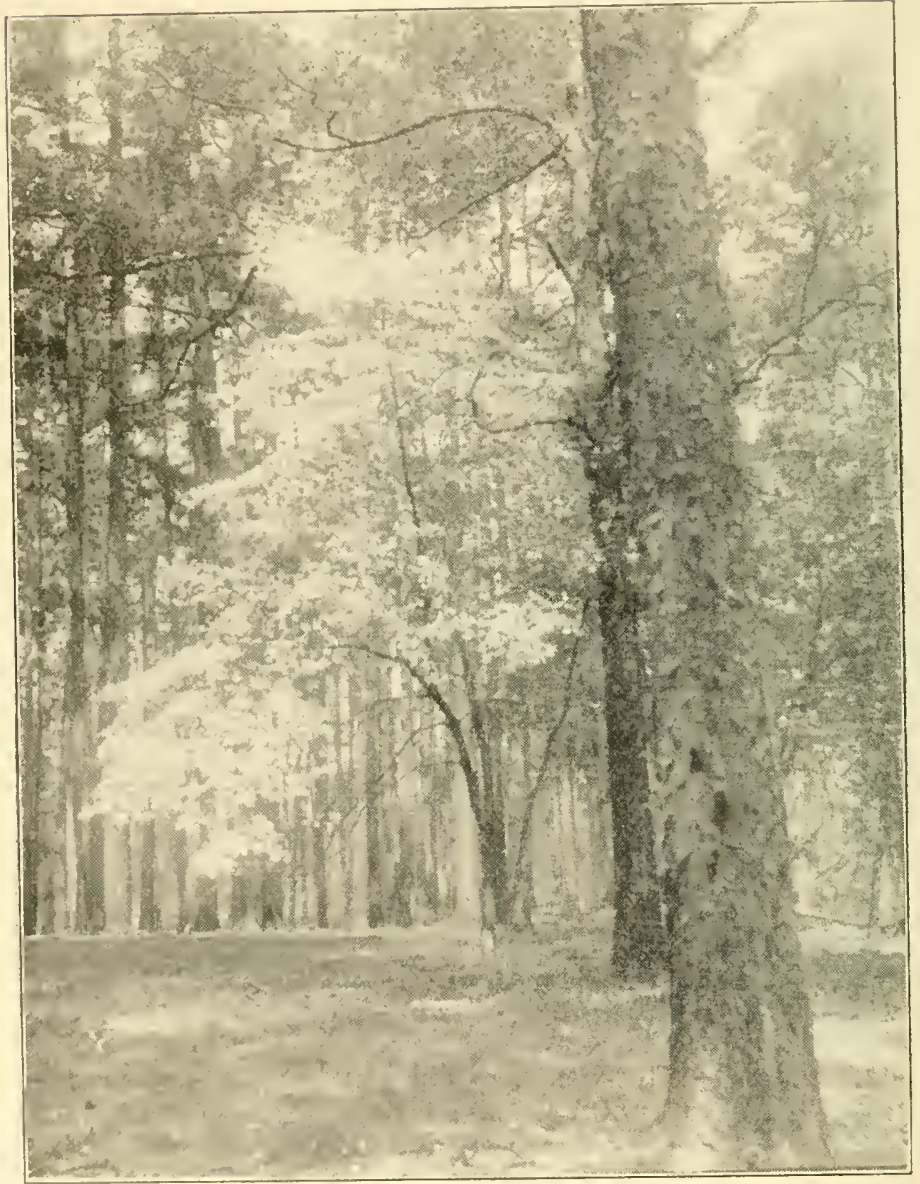

In the hill parishes, where the flowering dogwood blooms in groves of huge yellow pines, the Louisiana wolf treads his stealthy way. 


\section{CHAPTER SIXTEEN}

\section{THE WOLF}

T T IS probably as surprising to most folk who have not studied the subject of fur animals and their distribution

to learn that the wolf is an important and numerous member of Louisiana's mammalian fauna as it is to be told that this southern state is the leading fur-producing state of the Union.

This dog-like animal, however, is as much at home in the unfrequented sections of this state as it is in the northern fastnesses of Canada. A ranger of the Great Plains region of North America, the wolf is also found in our prairie and coastal marsh sections and has proved a scourge and nuisance to the cattle-raisers of Calcasieu and Cameron parishes, w'ere packs have made inroads on calves.

The wolf is a meat cater, preying on almost all of the other mammals inhabitng the region where it hunts. Its principal diet is comrosed of rabbits, native rats and mice, squirrels, ground-nesting birds, and fawns. Its habit of preying on calves, sheep, and hogs has caused it to be "outlawed" not only in Louisiana but elsewhere, and nowhere on the North American continent is this animal given the protection of game laws.

The wolf found in this state is the ordinary gray wolf, the timber wolf or "buffalo wolf" of literature. It is scientifically called Canis floridanus, according to Dr. Hartley H. T. Jackson, of the U. S. Biological Survey. However, any scientific identification of a wolf in the status of present knowledge of the group is only provisional. There are so many variaticns in respect to shape, size, and color existing among the wolves inhabiting the North American continent that it has led to a confusion as to species. This animal was known to the Gulf Indian tribes, for the Choctaws called it nashoba, the Chitamachea knew it as kamakic, and the Atakapa called the wolf caine. The Natchez knew the wolf as utteruah. 
Investigations are now underway to determine whether or not the wolf found in Louisiana may be a separate species or subspecies of the ordinary wolf of North Ameirca, and the Federal biologists are planning a revision of this important genus and it may be found by them that the wolf found in Louisiana may prove to be a separate form. The wolf described as Canis floridanus seems to run through Louisiana into Arkansas.

The young are born early in the year, the mother seeking a den while the male stands guard. The pups vary from three to a dozen in number, but six to a litter is the average. The pups arrive in January, sometimes during the last of February and are "blind", the eyes not opening until they are nine days old. The old wolves prove to be devoted parents, the dog assisting the mother in securing food for the young and in rearing them.

In Louisiana there is very frequently found a wholly black wolf, pupped in a litter with ordinary gray brothers and sisters, which prove this phase to be merely a color variation and does not make the animal a separate species. In the Audubon Park Zoo, New Orleans, a male black wolf with a gray bitch from the same litter taken in Evangeline parish, and kept in captivity for a number of years, bred three times, and in each litter there were black pups as well as gray. The first litter was composed of five, three of the young being black, the other two taking the pelage of the mother. The second and third litters consisted of four young each, there being two black and two gray pups in each litter. The coloration did not follow the sex, as in the first litter, the blacks being bitches and the grays were dogs. In April, 1928, this same gyp pupped a litter of seven, but the dog made a meal off the young before he could be removed and the coloration of the pups could not be ascertained.

The black Louisiana wolf is not wholly black, as it usually has a light-gray breast patch that appears pure white in contrast with the rest of the pelage.

It has been in recent years only that the wolf skin has been taken up by the fur trade; the pelts bringing the 


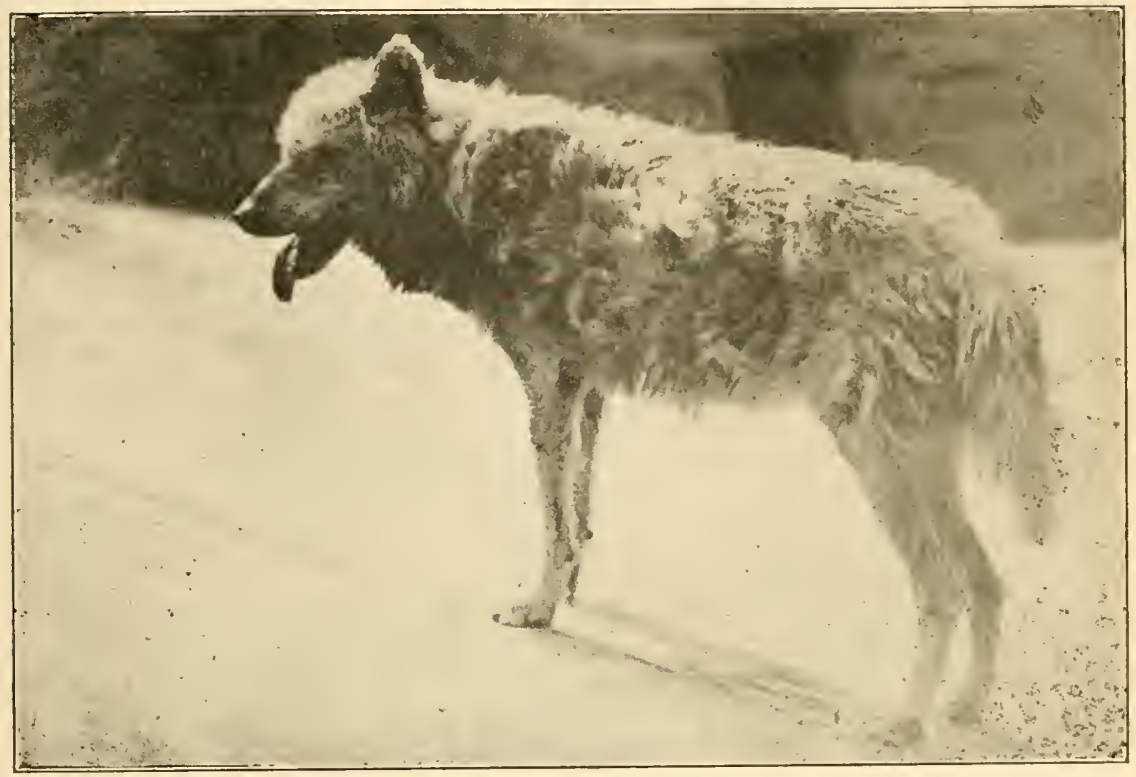

The typical gray wolf of North America which is also found in Louisiana, and in increasing numbers in late years.

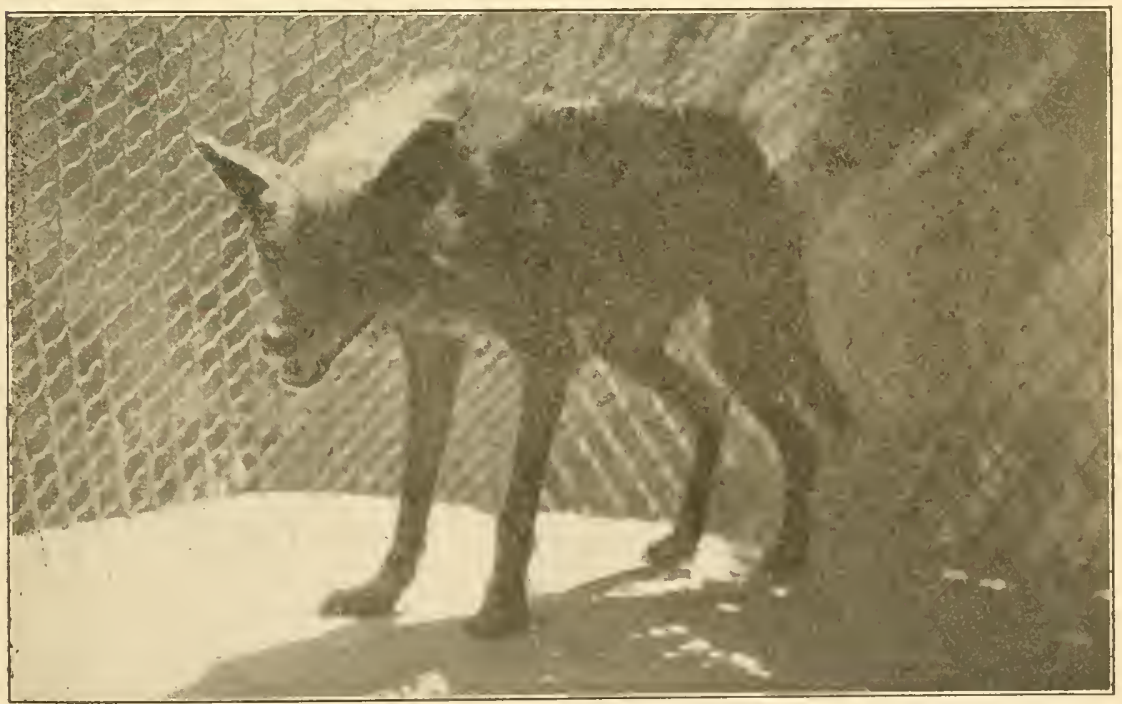

A typical Louisiana black wolf taken in Evangeline parish and exhibited in the Audubon Park Zoo, New Orleans. 
better prices are those possessing a soft, silky pelage, which are dyed and used as trimmings. As the fur is a natural light gray, it takes the various dye shades nicely, and many color creations are thus secured. The pelts possessing a flat, coarse pelage are valuable for automobile robes and like uses.

While the wolf has been persistently hunted by man in Louisiana, as it has been in other parts of this country where its destructive habits make it an outlaw, it appears to be on the increase, and, slowly but surely, extending its range in the state. In some localities war is declared on this outlaw because it is destructive to domestic animals and sporadic raids have been made on it by cattle men and others.

The tales that have prevailed for years as to ferociousness of the wolf, and its alleged habit of hunting in packs after man, tales that have come from Russia, Canada and the wilderness regions of the northern tier of the states, have their counterpart in Louisiana, but, as elsewhere, their attacks on man have been grossly exaggerated.

One story of an alligator hunter who was surrounded by a pack of wolves in the Wild Cow Range section of Cameron parish in the summer of 1926 was investigated and found to have some foundation. Dave Moore, an aged trapper and alligator hunter, was interviewed the morning following his experience at Cameron Farms ranch. He had been out in his pirogue shining for alligators and had taken several of the saurians he had killed to a dry knoll and was skinning them by the aid of his carbide light. He had been hearing the wolves howling, at a distance, throughout the early part of the night, but paid no attention to their noise. While he was engaged at his skinning task his carbide light went out about 2 a. m., and, while refilling the lamp in the darkness, he was surprised and made quite uneasy by hearing the wolves howling close to him. He declared he could also hear their feet pattering through the shallow water all about him and was positive the pack was circling the knoll. 
He endeavored to relight his lamp, he said, but his hands so shook with fright that he did not succeed. He lighted match after match, according to his story, and from the faint illumination could see the gleaming eyes of the wolves as they trotted about him. Thoroughly unnerved, he fired charges from his shotgun until he had used up his last shell, and then took his paddle and slapped it vigorously on the water and against the side of his pirogue in an effort to imitate shots from his gun.

Keeping this up until daylight came and the wolves made off, Moore paddled his pirogue into a waterway and made his way to the Cameron Farms ranch, where he was found by Adam Deville, cattle foreman, in an unnerved condition as a result of his experience of the night. His death a few months later has been attributed to this experience.

The probabilities are that the wolf pack was attracted by the odor of blood from the alligators Moore had been skinning and that the members of the wolf pack had no intention of attacking the aged and experienced hunter, as the Louisiana wolf is, as are the wolves elsewhere, cowardly to an extreme.

A wolf litter found in La Salle parish was dropped soon after the first of the year and of the four young, one was a male. Even in this piney woods section of the state the wolves have become very obnoxious because of their depredations on live stock, and cattle men in West Feliciana parish now fear an increase of their number as the cattle and sheep raising business in this former cotton-raising territory is growing in importance, as in Louisiana, as elsewhere, the wolves and coyotes seem to expand in numbers with the growth of civilization. It is not unlikely, therefore, that in a few years stringent and systematic campaigns against wolves in this state will have to be planned and carried out. 


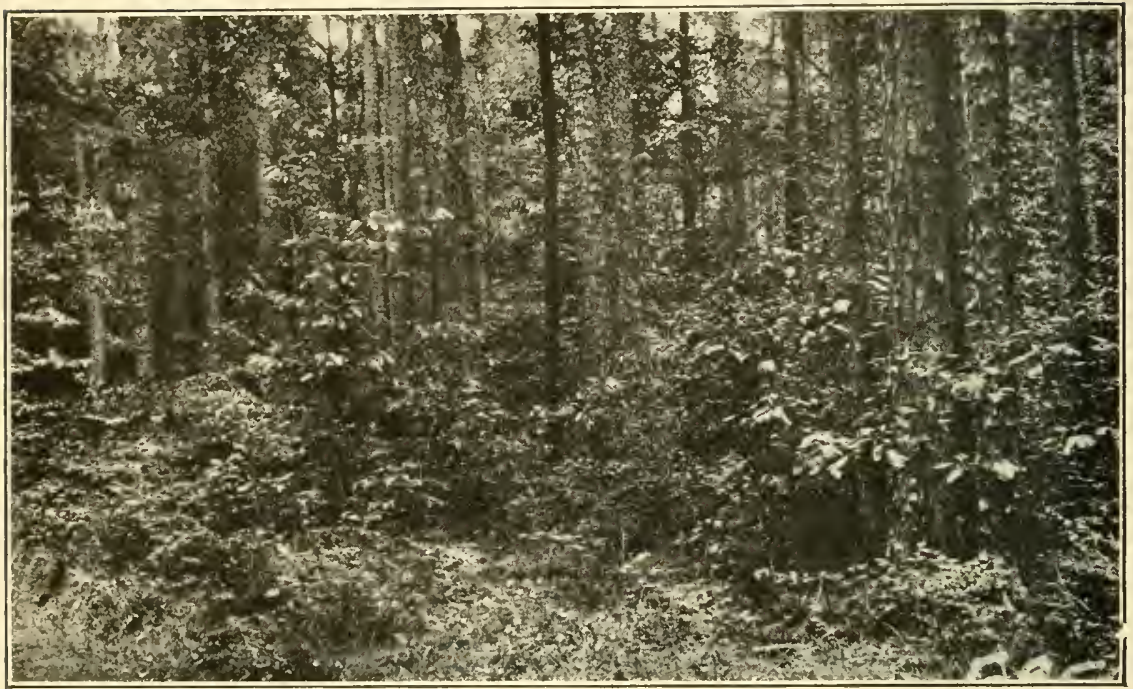

Where the underbrush is thick in the pine hill flats of Louisiana the sly gray fox's thin bark is heard.

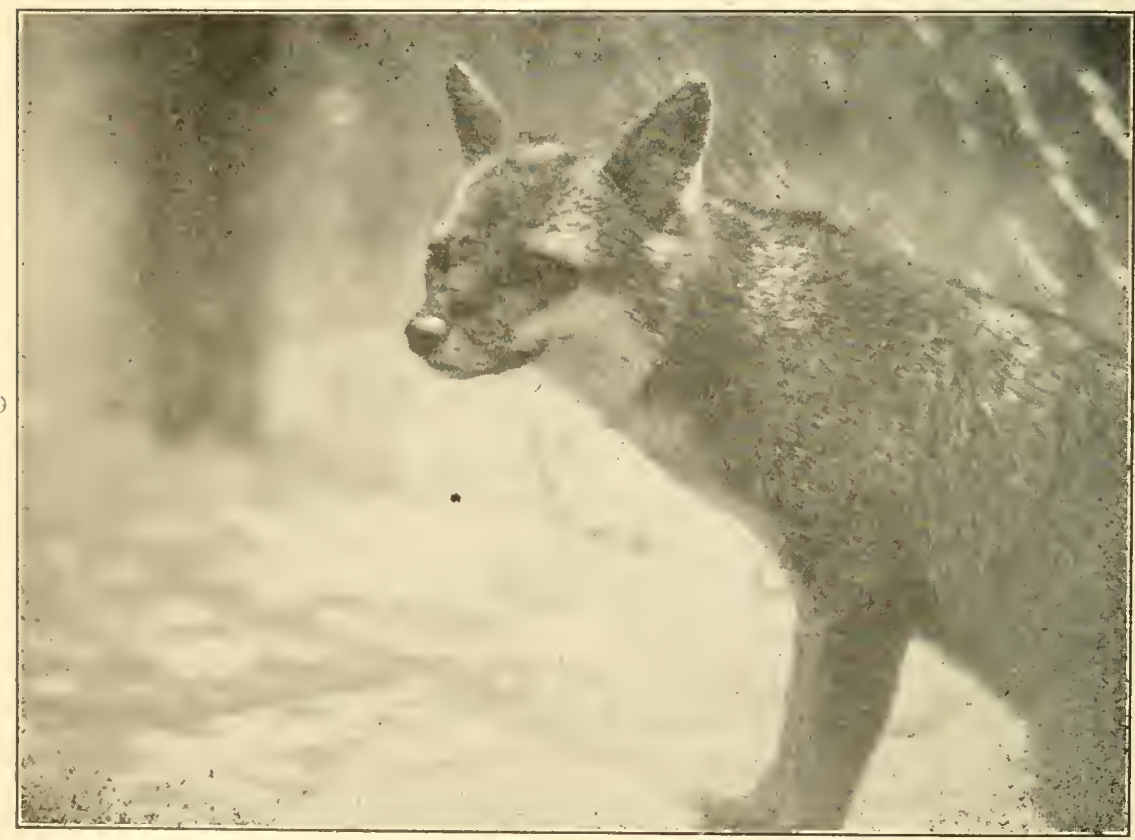

An adult gray fox in the Audubon Park Zoo, New Orleans. 


\section{CHAPTER SEVENTEEN}

\section{THE GRAY FOX}

7 HE fox of Louisiana is the typical fox of the South, the gray fox, a small, sly, cunning, agile mammal with a coat that is pepper-and-salt gray above, rusty-brown beneath, with a red patch on each side of its neck.

Scientifically it has been dubbed with a long and practically unpronouncable name, Urocyon cinereoargenteus. (If you must pronounce it do it in this wise: U-ro-cy'on cin-e're-o-ar-gen'te-us.) There is no characteristic folk name for this animal in Louisiana and a fox, as it is everywhere, is a fox. The Indians of the Gulf regions had their own name for this animal, chula was the Choctaw designation, and toxka, the Biloxi name.

The word fox is of doubtful origin, but is supposed to have come to us from the Teutonic languages, the Dutch vos or the German fuchs. Some have suggested that there may be a connection between the Sanskrit pucha, which means tail, and the presently and widely used name, but this seems to be far-fetched.

"Crazy as a fox," seems to be a part of our present-day speech that will persist and the slang adequately describes this shrewd gray skulker of our wooded sections of Louisiana, although it must be admitted that this animal does not live up to the sly and cuninng reputation of the red fox of the North and East, an animal by the way, that does not belong to our fauna, although a number of them have been brought here and released by fox hunters.

The Louisiana gray fox seldom, if ever, lives in burrows; it shows a decided preference for refuges in hollow $\operatorname{logs}$, or it will rake together a bed of dry leaves in a tangle of bushes and undergrowth and here it will sleep in the open air, and, frequently, the vixen, as the female fox is known, raises her litter of puppies in such a bed. The litter is usually three to five and the puppies are born blind and helpless, and are blackish in color. Audubon is the 
authority for stating that the period of gestation is "about three months," but W. B. Graham of Winn parish, who has bred them in captivity, says this period is 63 days, "the same as a dog."

This fox is a clever hunter and feeds on almost everything that haunts the forest-birds, small mammals, insects, reptiles, berries, mushrooms, acorns. When the young are old enough they are taught the ways of the wild by the parents, for the gray foxes, like other members of the $\operatorname{dog}$ family, are devoted to their offspring and the family remains together until the young are old enough to care for themselves.

The thin bark of the fox, or "yap," which is heard mostly in the early spring months, is a mating call. This fox seems to well deserve its title of "tree fox," for it has a marked ability to climb to the upper branches of small trees, but it usually performs this feat only when chased by dogs. Swift and tireless when running, the gray fox can lead the dogs a merry chase, and because of the sport involved his pelt and brush are eagerly sought by the fox hunters of the state.

The gray fox is not particularly valuable for its fur, but quite a few are caught every winter by the trappers, as the catch ranges from 550 to 500 . Its coat of gray hair and underfur is not to be compared with the much finer red fox, nor does it equal any of the red fox's color phasesblack, silver, or cross fox. The tail or brush of the gray fox is much coarser then the red fox, and is not as highly prized as a trophy.

Tha highland and timbered regions of the state provide suitable habitat for this mem'er of Louisiana's fur animal family, it being entirely absent from the coastal marshes and the wetter swamp lands. The Parish of Allen seems to lesd in the production of fox pelts, with Bienville and Rapides second and third respectively. Assumption, Caddo, Bossier, Calcasieu, De Soto, Franklin, Grant, Natchitoches, Sabine, Union, Vernon, West Feliciana, and Winn are only a few of the parishes where the gray fox roams and where native trappers take his pelt for fur purposes . 


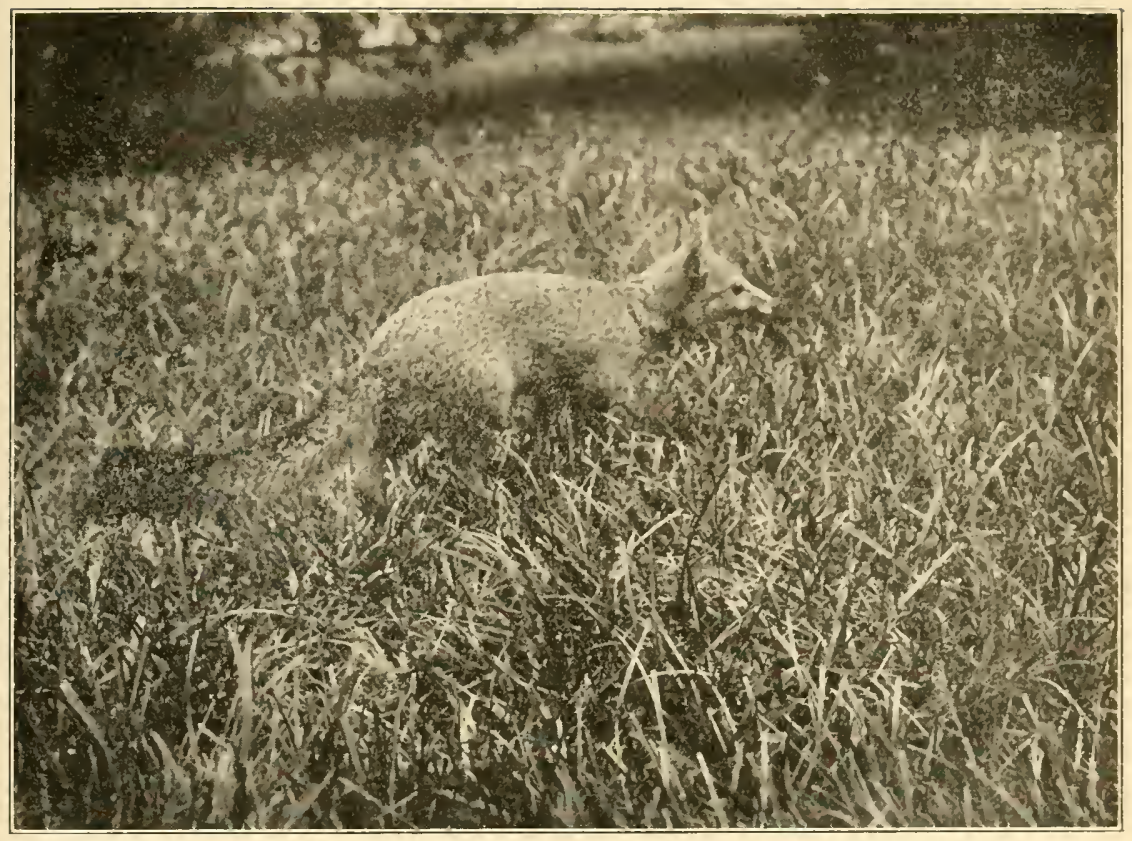

The grey fox is the only representative of the fox family tound in Louisiana. This is a specimen mounted in the Louisiana State Museum.

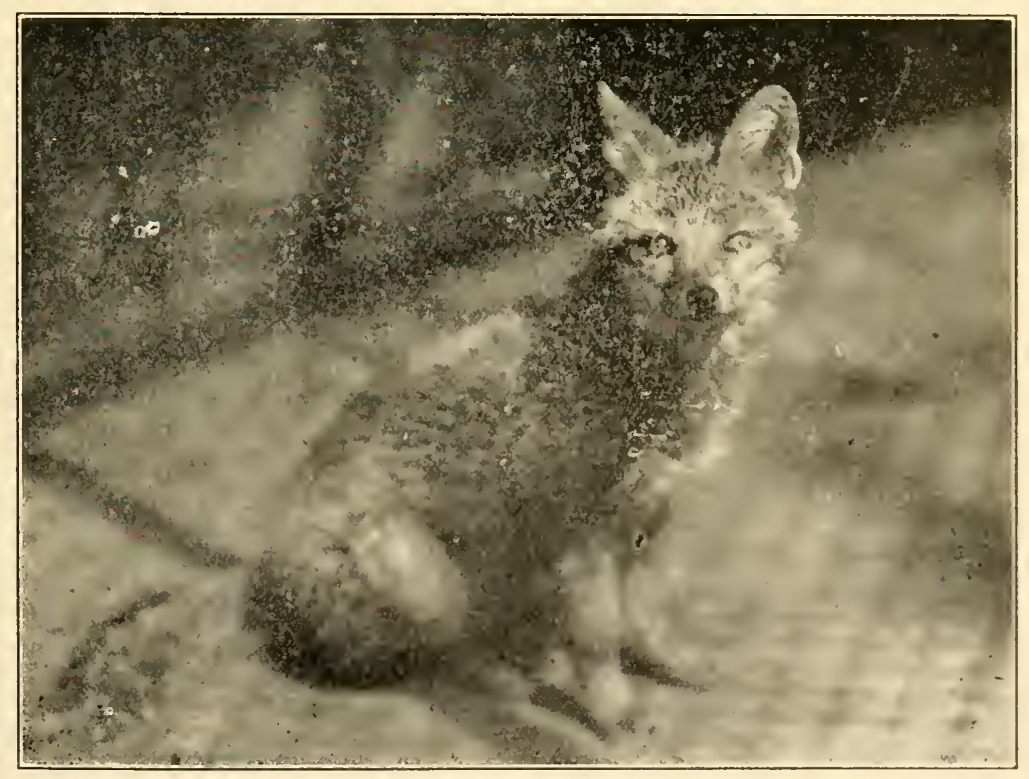

The young grey fox is an alert little fellow and becomes quite tame in captivity. 
The Louisiana law provides that "foxes used in the sport of fox hunting" are protected. Therefore, it is up to the trapper to first ascertain whether or not the fox that is unfortunate enough to put his foot in the trap is used for that purpose or not. As this animal is unquestionably a depredator, it would seem wise to continue it, along with the wolf, bob-cat, and cougar, in the "outlaw" class and not give it the protection fox hunters desire. 


\section{CHAPTER EIGHTEEN}

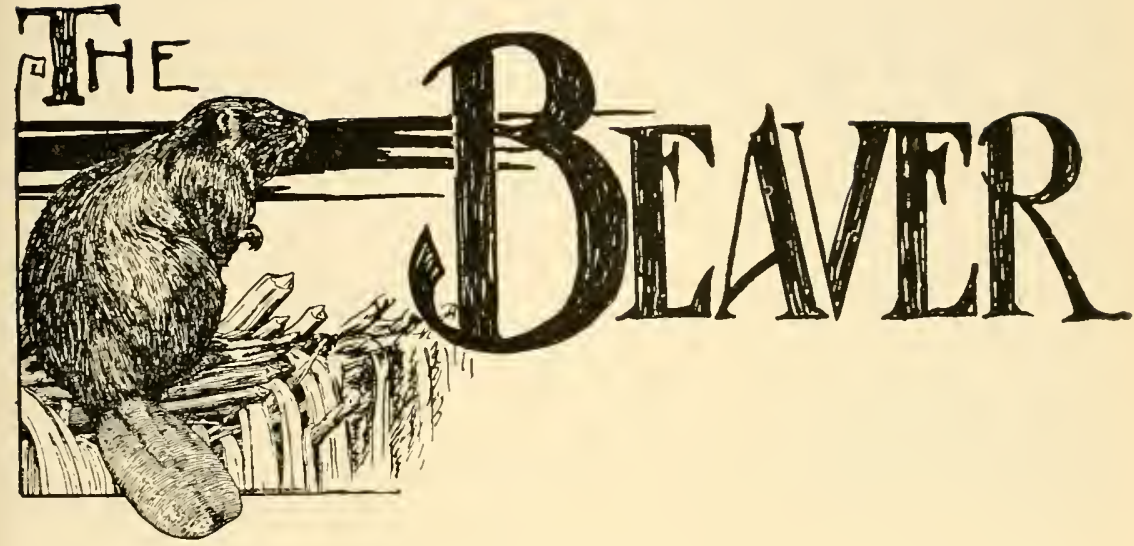

TT WILL be surprising to many who perhaps will learn for the first time that Louisiana is the leading fur-producing 1 territory of North America, to be told that Louisiana fauna not only once included beaver but that we still have colonies of these very peculiar mammals. Today the Louisiana beavel is rigidly protected by state laws, and in the one locality of the state where this mammal exists, in spite of man's usurpation of its habitat, the inhabitants observe the ban against trapping religiously.

LePage du Pratz wrote of the beaver in Louisiana and rave the readers of his quaint volumes an idea as to the looks of the beaver in the engraving that embellished one of the pages. Another early Louisiana writer, Father Charlevoix, in his "History of New France", said: "We had heard that the Beaver was formerly found neal New Orleans, but we never saw one in Louisiana". ${ }^{20}$

In this brief life history of the beaver the liberty has been taken of drawing freely on what Vernon Bailey, chief field naturalist of the bureau of biological survey, has published in his bulletin on this very peculiar rodent, ${ }^{21}$ as it is

"Charlevoix, Nour, France, vol. iii, p. 133.

"Bailey, Beaver Habits and Experimfnts in Beaier Culture, Tech. Bull.

No. 21, U. S. Dept. of Agricul. 
quite certain that the Louisiana beaver does not differ materially in habits from the beaver found elsewhere on the North American continent.

In the fur history of the new world, the beaver holds first place. The beaver trade has had a great deal to do with the development of our country, and in the adventure and pioneering of the early days, it occupies a niche that will never be filled by another animal.

"Originally beavers inhabited the greater part of North America," writes Dr. Bailey, "and at one time produced fur of greater value than that of any other fur-bearing animal of the continent. They were to the native people an important source of focd and warm clothing, and the beaver skin became a unit of barter with the Indians. Beaver fur soon attracted white trader's and trappers, and traffic in the skins became an important commercial factor in promoting the early settlement of the country. Through the generations of intensive trapping that followed, beavers were greatly reduced in numbers and restricted in range, until now they have been exterminated over much of their former area."

The beaver belongs to the extensive and important lodent family, three members of which have been long noted for their value to the fur trade, $i$. $e$, the beaver, which is the largest of the three, the muskrat, which is the smallest, and the coypu (pronounced koy'poo), a South American rodent, intermediate in size between the beaver and the muskrat, which produces the fur known as nutria.

The beaver is a compact, heavily-bodied mammal that is as aquatic as the muskrat and the coypu. Its pelage is a dense coat of fine, soft, waterproof underfur, overlain by coarse guard hairs. The soft underfur is brownish in color, varying from yellowish to a brownish black, while the guard hairs are either light brown or a rich dark chestnut in color.

The most characteristic thing about a beaver is its broadly-flattened, hairless tail, the use of which for hundreds of years has been the source of much speculation and has given rise to many odd folk tales. Like the muskrat, 


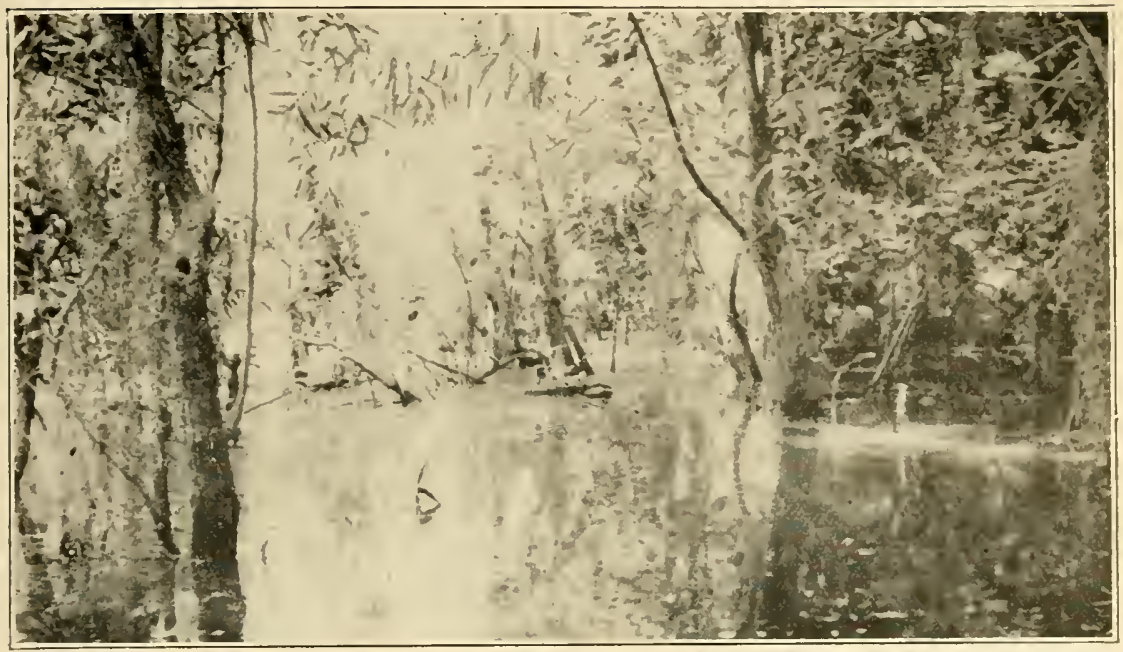

This type of submerged woodland occurs over a large part of alluvial lands in the southeastern section of the state, and is the home of the Louisiana beaver.

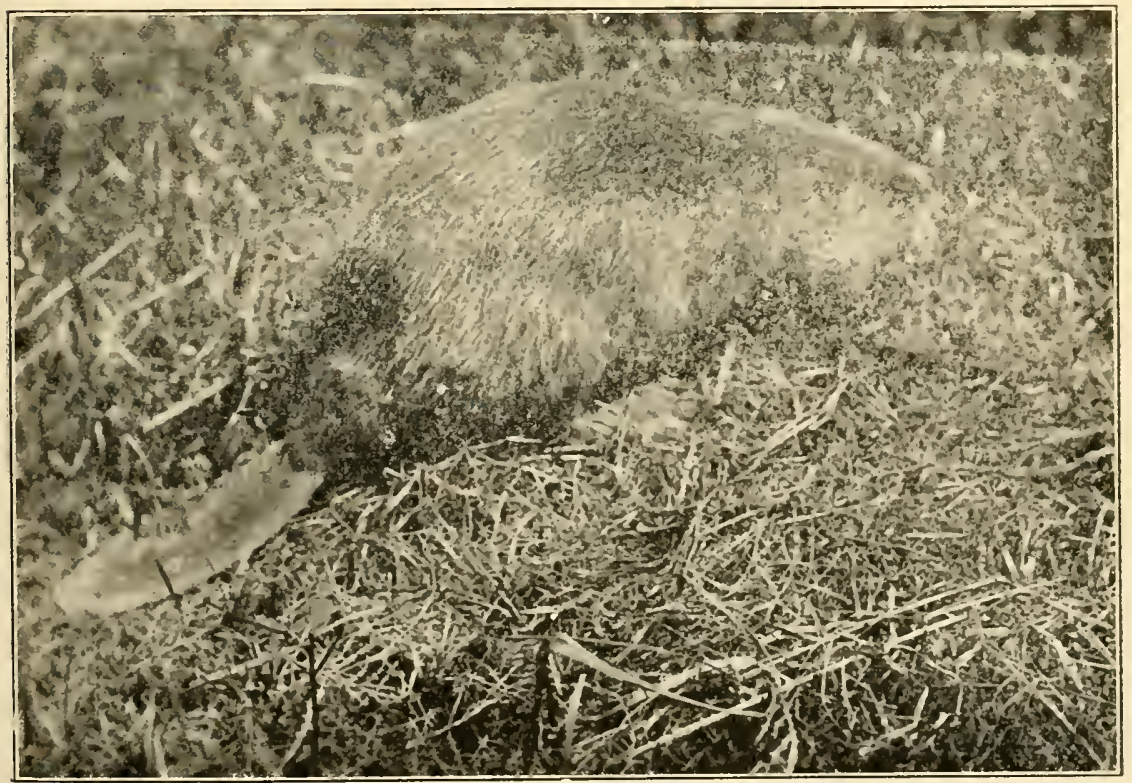

A Louisiana beaver from a mounted specimen in the Louisiana State Museum. 
the beaver has hind feet much larger than the fore feet, and the five toes are fully webbed for swimming. The smaller front feet are unwebbed, and again like the muskrat, their main use is as hands for holding food and they give invaluable service for carrying or holding buildir.g material when dams are being constructed.

The eyes are small and the vision, Bailey believes, evidently is not very keen except under water. The ears are short, lined with fur, and valvular, closing as the animal dives under the water and opening the moment the animal puts its nead above the surface. The sense of hearing possessed by the beaver is remarkably keen, Bailey declares. It has a keen sense of smell, according to the same authority, although the nostrils are small and valvular. Like the ears and nostrils, the mouth can also be shut so tightly that water cannot enter while the long front incisor teeth are being used to gnaw on roots beneath the surface, and the molars, or grinding teeth, used for chewing.

Beavers weigh from 25 to 45 pounds, some older specimens attaining a weight of 60,70 and even 100 pounds. The sexes are so alike in weight and external appearances that it is not an easy matter to distinguish one from the other; adult females, however have four conspicuous mamae arranged in a perfect square, two being borne on each of the elongated mammary glands lying between the front legs.

Before referring to the broad flat tail which has given the beaver its position in popular fancy, it might be of interest to call atention to the double combing claws it possesses on the two inner toes of each of the webbed hind feet. The animal uses the claws for combing out and keeping its fur smooth. These "combing claws" are to be found immediately beneath the nail of the two inside claws.

The flat wide tail is not used as a trowel to plaster mud on its house and dam, as has been claimed by fanciful writers, but let us ask Vernon Bailey, who probably knows the beaver better than anyone else, to answer the question: "Why is a beaver's tail flat?"

"It is only necessary to see it in use, tilted up, steering nne way or the other, or striking downward as the animal 


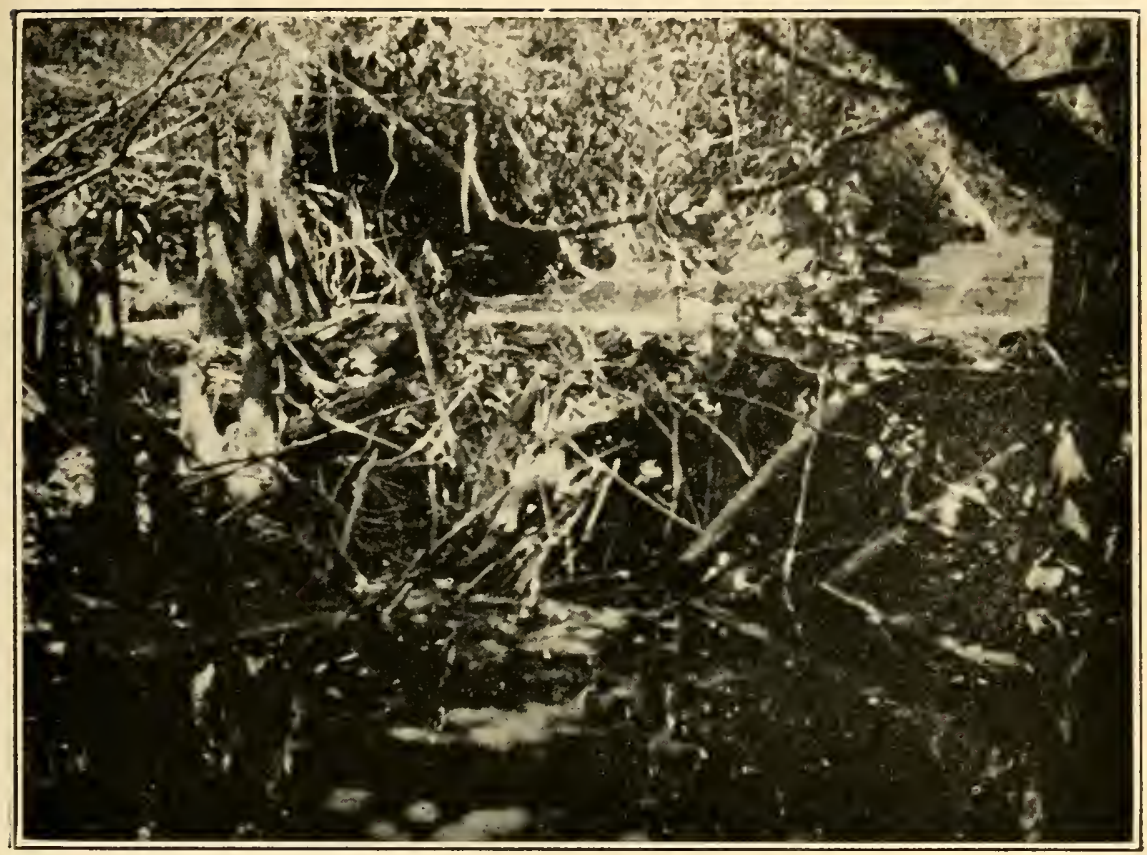

A typical beaver dam on a tributary of the Amite River in St. Helena Parish. The beavers have so increased in this territory that they are reported as doing damage to adjacent corn fields.

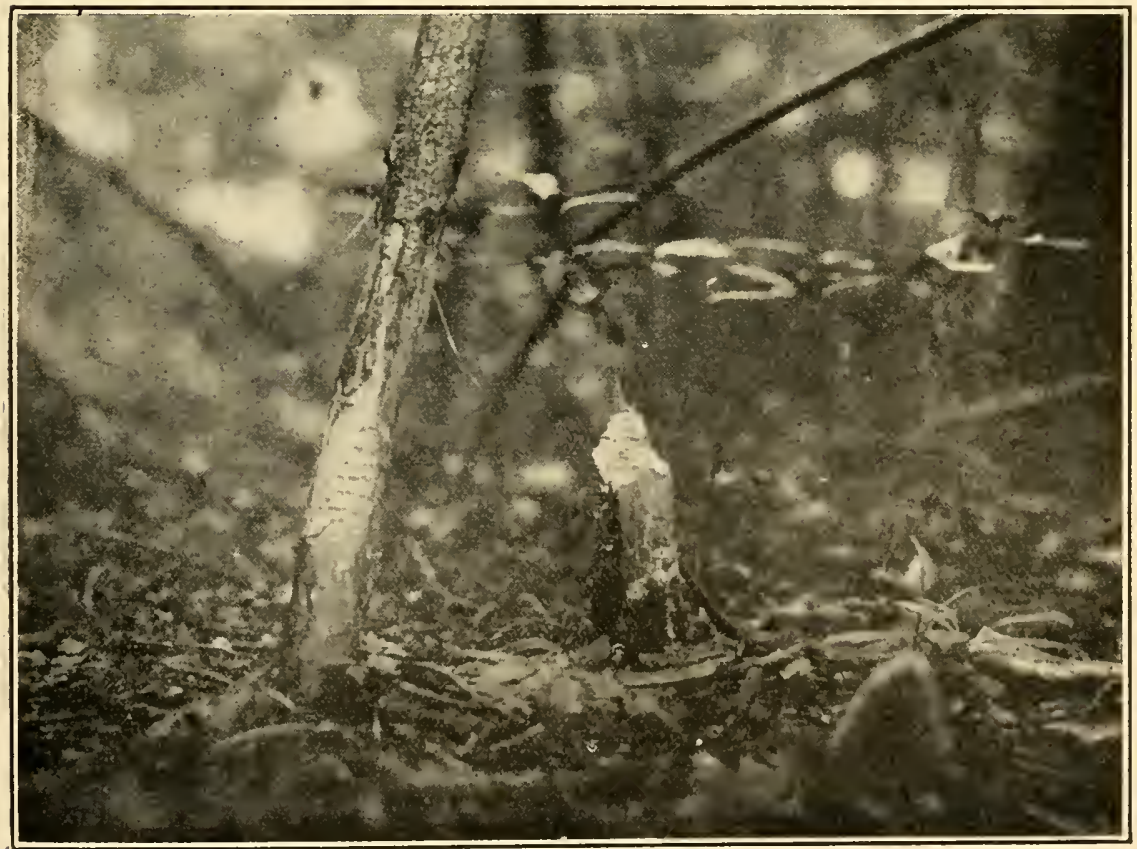

Beaver cuttings near streams in St. Helena, where this fur-bearer is increasing in numbers due to the State's protective laws that prohibit it from being trapped at any time. 
dives from the surface, to understand its aquatic use. Especially is its full width and steering power taxed to the $\lim t$ as the beaver swims, tuglike, by the side of a pole or log that it is towing to the house, dam cr food cache, with only the tail thrown out sideways to keep the swimmer from progressing in circles. On land the tail has other uses, but in the water it serves variously as rudder, propeller, and signal gun, its loud slaps on the surface of the water serving as warnings to friends or enemies.

"In diving, beavers swim downward or in any direction under water. They swim long distances, half a mile or more, without appearing at the surface and commonly remain submerged four or five minutes at a time, but much longer if alarmed."

While beavers are powerful, graceful and easy swimmers, they ordinarily do not progress rapidly through the water, preferring to paddle with their large, webbed hind feet while the front feet are held motionless to their breasts. However, when alarmed they can swim under the water with the speed of an otter, "and with a somewhat similar undulatory motion of body and tail, an appendage that appears to be as effective as a high-speed propeller," Bailey found.

The beaver has been famed the world over for its ability as a woodcutter and as a house and dam builder, but this animal is not endowed with the intelligence ascribed to it by many of the early writers. However, it is an expert among the mammals in damming up streams to obtain a higher water level; it can gnaw through a tree trunk and fell a sapling, although it does not possess the ability to cause a tree to fall in a certain predetermined direction, the tree falling in the direction it happens to be leaning, which, when growing by the side of a stream, is generally in the direction of the water.

In Louisiana the beavers do not seem to confine their food to poplars and cottonwoods, which are the favorite foods in the north, but exercise their incisors on a large and varied menu. When attacking a tree for food the 


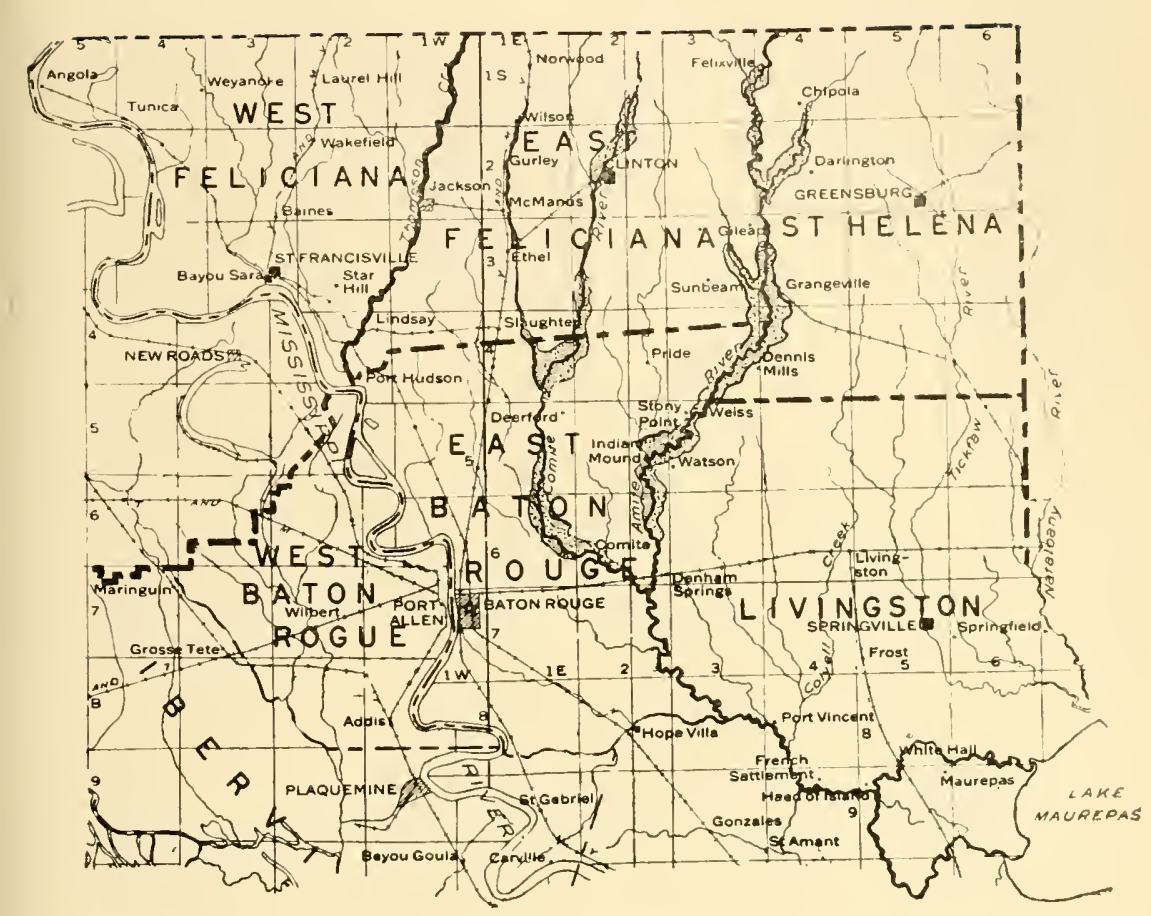

The dotted areas show the location of colonies of beavers in Louisiana along the Comite and Amite Rivers in the four parishes of East reliciana, St. Helena, East Baton Rouge and Livingston.

animal cuts or "rings" the tree by cutting off chips, and the bark is usually eaten from the chips before they fall. It is believed that an adult beaver can fell a poplar tree 3 to 4 inches in diameter, cut it into sections from 4 to 8 feet, each, and drag it to water, and that it takes several nights' work to cut down a larger tree.

While he was under the impression that beavers did not attack pines, Vernon Bailey was shown a number of yellow pine trees that these animals had "barked" and cut down along the Amite river in Louisiana. These animals had also fed on wild blackberry vines, as well as a variety of hardwoods, and several members of the colony had made excursions to nearby cultivated corn fields, in proof of which we found stalks entwined among the sticks and branches that formed the dam. 
In building dams, beavers work from the upstream side, Bailey says. Sticks, leaves, grass, sods and mud are laid across the stream, and are added to until a water flow is checked and the level begins to rise. Then, as it rises, sticks are pushed over the top and allowed to lie criss-cross on the lower slope, bound and securely held by mud and earth added to the top and upper slope until the dam is high and strong enough to hold water in the pond at the desired level, impervious to leaks.

inat the beaver is endowed with sufficient mechanical and engineering knowledge to build its dam in a perfect semi-circle calculated to resist water pressure, theoretically as well as practically, is not true. It possesses no such ability. It car, and does, lay a haphazard structure across a stream and while the site is usually selected at a logical place for such work, the dam is sometimes a successful accomplishment and sometimes it is not.

Besides building dams, the beaver of the north also builds houses, but the Louisiana beaver appears to neglect this activity and confines its home-building to making excavations in the banks of the streams where it lives. The entrances to these subterranean quarters are below the surface of the water and extend upwards so that the living chamber and nursery is above the water level.

As very little research work and study has been done on the beaver colonies in Louisiana, it is necessary to presume a great deal as to their habits. A desire to leave the colonies undisturbed to allow the population to increase has been responsible for the fact that so little scientific atter. tion been paid to this very interesting animal.

It is presumed that our beaver breed earlier than do the beavers of the northlands. The time of mating and the period of gestation are not known, but the young appear in May, and a few as late as June. Therefore, it is not unlikely that the young should appear in March and April in Louisiana. There is no evidence to show that there is more than one litter a season. Bailey finds that in the north beavers apparently begin breeding when they are a year 
old. The usual number in a litter is four, although he has records of six young and even eight embryos found in a large, old female. As the females have only four teats, more than four young must take turns in nursing. As a rule, the sexes are equally divided in a litter.

The Louisiana beaver is known as Castor canadensis carolinensis under the belief that it is related to the subspecies first described from North Carolina. A study of specimens and skulls may show that our beaver is entitled to a subspecific rank all its own.

That it was known to the first inhabitants is shown by the fact the Biloxi called it tama and they called a beaver pelt tama abi. The Choctaws knew the beaver as kinta, the beaver dam was a kinta oktabli, while a pelt was called linta oktapa.

The early French settlers called it Castor and this name and its early distribution is reflected in the numerous Castor Creeks, Beaver Dams retained in the geography of the state. The quaint illustration of a beaver found in Le Page du Pratz's work is sufficiently interesting to be here reproduced.

\section{Cirestar}

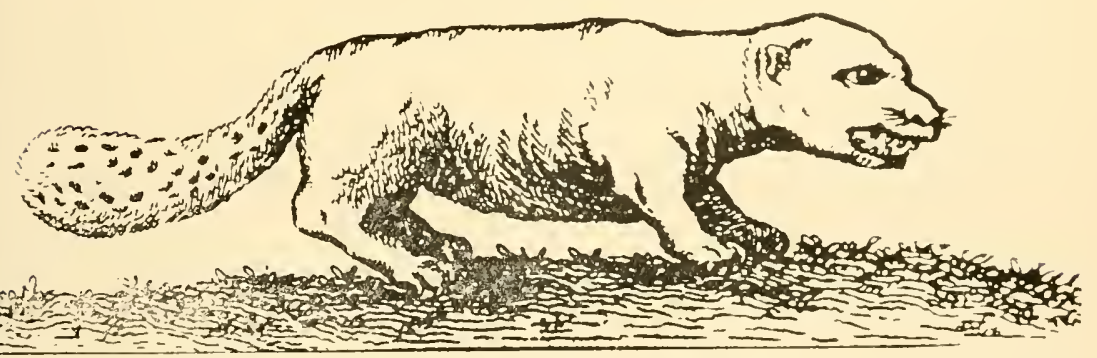

The beaver was a fearsome beast, according to the engraver of the illustrations in Le Page du Pratz's history of Louisiana. It is quite evident that the artist had in mind that the animal's tail was unique but it is hardly the spotted plume-like appendage that was exhibited to Parisians of 1735 .

Today the few beaver colonies remaining are to be found in St. Helena and East Feliciana parishes on the 
numerous tributaries of the Amite River. That these colonies have increased in the past 10 years of conservation activities is most apparent, and it now seems that the time is at hand to break up some of the colonies and restock localities where this most interesting mammal has been extirpated. Whether the beaver in Louisiana will ever become numerous enough to again become a fur-animal of commerce is problematical. 


\section{CHAPTER NINETEEN}

\section{THE ALLIGATOR}

W

HILE not a fur animal, information concerning the Louisiana alligator cannot be out of place in this bulletin, as this reptile, once so common in our marshes, swamps, rivers, bayous and other wet places, has long been an important article of our commerce and has given many thousands of our people of the lowlands an occupation and a livelihood in hunting the giant saurian for its skin.

It is very necessary, too, to call attention to the very alarming decrease in the numbers of our alligators. From toll taken of this saurian during the past half dozen years, particularly during the drouth summers of 1924 and 1925, it seems at this writing that this giant and characteristic reptile is doomed to disappear from our fauna-and within the next few years.

During the muskrat and other animal surveys we have been repeatedly told by trappers that the alligator is the enemy of the muskrat and that "every 'gator killed means the salvation of from 10 to 100 muskrats, or even more!"

Many tales are told as to the number of muskrats found in alligator stomachs; even of one 'gator bull-eyed at the mouth of the Mississippi river that had the remains of two full-grown raccoons, a mink and several muskrats in his stomach. Surveys, made in the field during the past three years, however, do not bear out all the crimes this great, scaly creature is accused of perpetrating on the fur animals.

According to the records of the Department of Conservation, a tax was paid on more than 21,885 belly skins purchased by raw pelt dealers and shipped out of the state for 1925, which, if placed end to end, would measure 197,295 lineal feet, or 30 miles and a trifle over. The year following tax returns were made on 36,041 skins and the audit is not complete for the 1927 season. 
At his rate the 'gator is doomed to certain extinctionand soon-as the demands of the trade now call for the very small skins as well as the larger ones and, to hasten this saurian's departure from our fauna, the State of Louisiana has "outlawed" it, and it can be killed at any time and in any manner and by anybody in any of the coastal parishes-and is!

\section{Life History of the Alligator}

The Louisiana alligator belongs to the order Crocodilia: family Crocodilidae. The alligator differs from a like animal known as a crocodile; the physical difference seems to be based mainly. on the shape of the head and is the one used by Ditmars in his "Reptiles of the World," in classifying the Crocodilia, which, he says, are all included in a single group of that name. The members of this peculiar reptile order are found in all parts of the great continental areas, except Europe, and mainly in tropical or subtropical regions.

There are four forms and 20 species recognized; the crocodile, the gavial, the caiman, and the alligator. The crocodile is the largest of living reptiles, the most numerous in species and the most widely distributed of the group. It is characteristic of the fauna of Madagascar and Africa, where is found the famous Nile crocodile of history. Crocodiles abound also in Mexico, Central and South America, the West Indies, South Asia, the East Indies, Australia, and, in the United States, only in the southern part of Florida. Crocodiles of existing Old World forms are known to attain a length of 30 feet, but the average length, inclucling the big Nile crocodile, is about 16 feet.

The gavial is found in India and some of the islands of the Orient, particularly Borneo and Sumatra. Its name, pronounced ga'vi-al, is a corruption of the Indian word "ghargial," which means "fish-eater," as fish is the gavial's main item of food.

The caiman occurs in southern Mexico and in Central and South America. The name, pronounced ka'man, is 


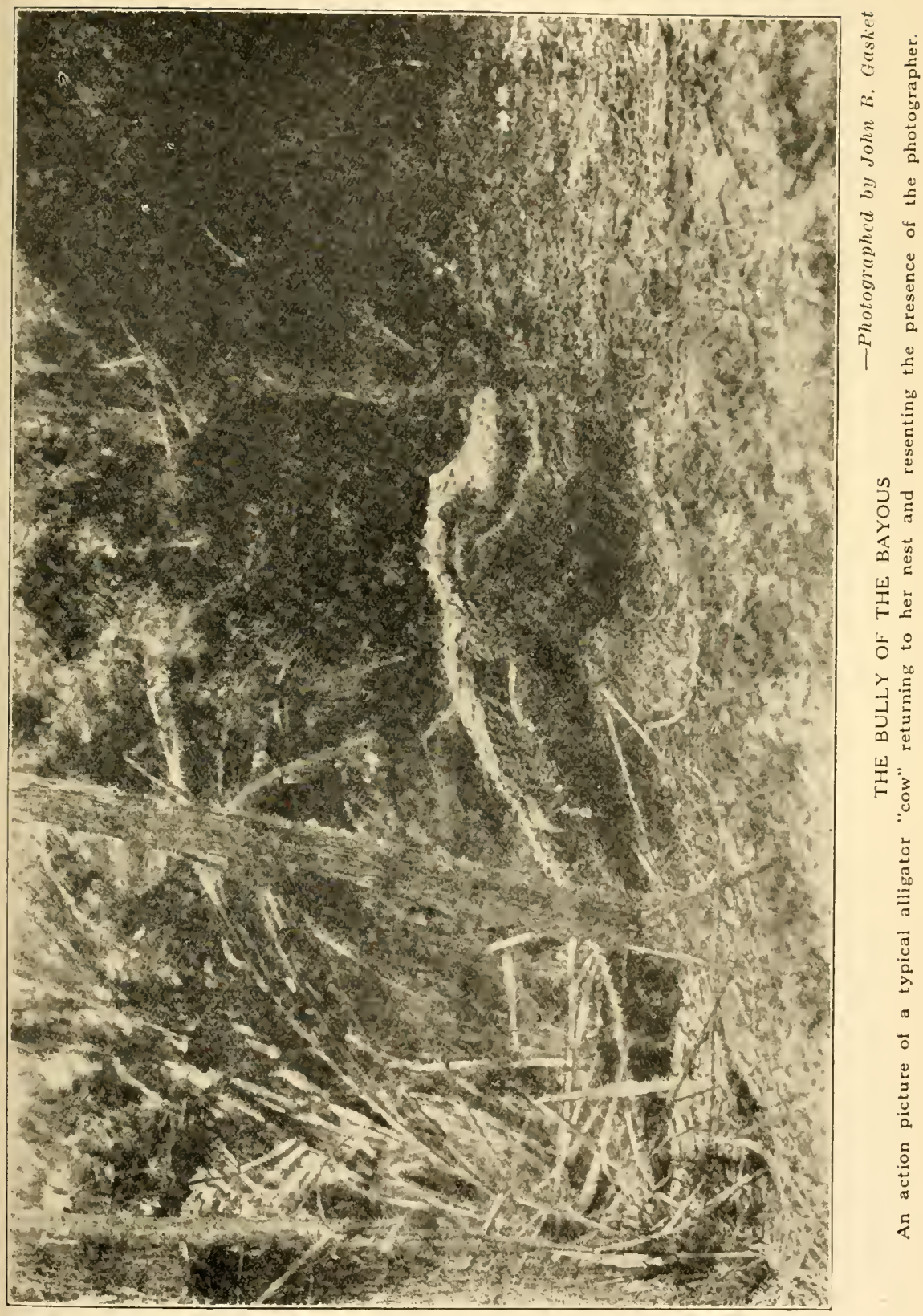


from the Spanish, although the natives of the Amazon region know it as a jacare or yacare. The black caiman of the Guianas and Brazil reach a length of 20 feet, but the rough-backed caiman of the upper Amazon vary from 4 to 6 feet in length at maturity.

The alligator is found only in the southern states of our country, but a small species, about 6 feet in length, is found in China. It is a greenish-black in color, dotted with yellow, and even scientists agree that it is more than strange that the nearest living relative of the Mississippi river alligator should live in the Yangtse-Kiang river, in China.

\section{Where the Alligator Gets Its Name}

The reptile has been given the scientific name of Alligator Mississippiensis and is the form that occurs in Louisana, where it is of quite some value to commerce on account of its hide. The name alligator in its early form, alligarta, was derived from the Spanish El lagarto, meaning "the lizard."

While the Spanish-speaking inhabitants of South and Central America called the alligator a lizard, and its present popular and scientific name is derived from that source, it is very interesting to learn that the early Spaniards inhabiting Louisiana called this characteristic inhabitant of our swamps and marshes a cocodrile, pronounced ko-kodree', which is, probably, merely a Spanish imitation of the name given the alligator by Iberville's Frenchmen. This Spanish pronunciation is responsible for the many Cocodrie bayous and the Cocodrie lakes found in St. Landry, Evangeline, and Rapides parishes.

The first French settlers, likening our reptile to the crocodile of the Old World, called it by this name, but they pronounced it, according to their own tongue, viz.: kro-kodeel', and, as such, is the alligator named by the Frenchspeaking inhabitants of the Louisiana lowlands today.

The Ofo Indians of the delta of the Yazoo called the alligator akshoti; the Biloxi called the saurian nuxwoti, 


\section{Crocodil.}

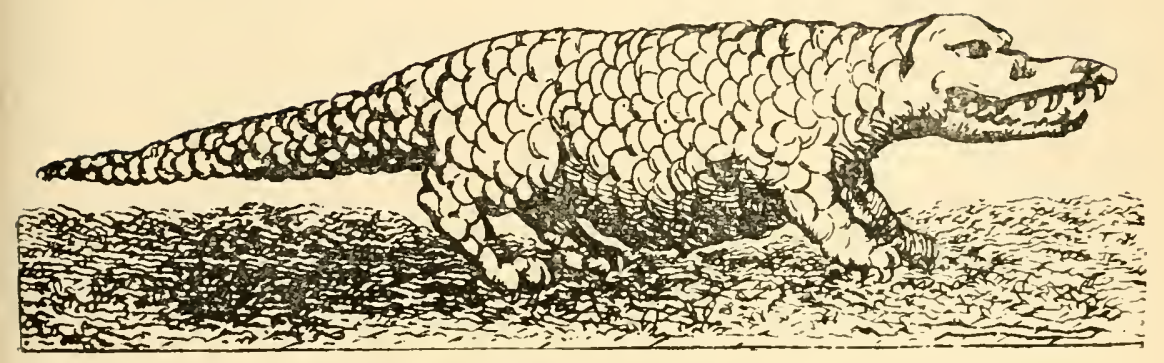

Naturally, the artist who furnished the steel engravings of Le Page du Pratz's historic took on Louisiana's natural resources and wild life did not neglect to depict the alligator, although he made it a more fearcome reptile than it really is.

and any stream or bayou where the reptile was found in large numbers was termed a nuxodapayixya. The Choctaws called the alligator hachunchuba, meaning "without hair," and that is why we have so many "Chinchuba" towns, creeks and bayous in this State and Mississippi.

The alligator was held in reverence by a number of the different tribes inhabiting the Gulf region and it became the distinctive badge or totum of the Bayougoulas, an Indian tribe that had their main village about where the present town of Donaldsonville is situated and had other villages along the Bayou Lafourche.

It is also learned from these early primitives of Louisiana that the skins or hides of the alligator found many usages, and the Natchez Indians, in order to play a certain ball game they were very fond of and in which the ball had to be thrown through a ring, used three musical instruments to incite the players to their utmost. The musical instruments were a hol'n, made of a cane or reed; a drum, constructed from a deer skin stretched over the top of a large clay pot (sometimes a short hollow log was used), and an alligator skin.

To prepare the alligator skin for its use in this aboriginal jazz band, the skin of the dead reptile was first exposed to the ravages of a colony of ants, so that the softer 
parts would be eaten away, and the skin was then hung in the sun to dry. The music furnished by this part of the band consisted in the player scratching the back of the dead 'gator with a stick.

\section{The Alligator 200 Years Ago}

It may be interesting to know what Orleanians in 1718 thought of this monster of the river that crawled about the streets of the newly established city. Again we turn to M. Le Page du Pratz's Histoire de la Louisiane and find his interesting life history of the saurian, together with an engraving of the alligator that must have filled the purchasers of his book with fear and trembling.

"The crocodile is to be found in great numbers in the st. Louis (Mississipjoi) River, but even though this amphibian is well known I cannot refrain from speaking of it. Without giving a description of it, which is to be found everywhere, I will say that he follows the banks of the river frequented by man. They lay their eggs in the month of May, when the sun is already lot in this country, and deposit them in the most secluded spot they can find, between the grass exposed to the midday rays of the sun. These are usually as big as goose eggs, but longer. When broken there is most the white to be lound, the yolk being no bigger than that of a young pullet's. I have never seen one newly hatched.

"The smallest I saw, which I judged to be three months, was the length of an ell with a diameter of $1 \frac{1 / 2}{2}$ inches. I killed one 19 feet long and $3 \frac{1}{2}$ feet in width at the widest part. One of my friends killed one 22 feet long. The little crocodile that I just mentioned had paws no longer than that of a frog three months old; he moved them with difficulty and it appeared to me that the large ones could use theirs no better. The two larger ones just cited had paws no longer than a foot which they moved with difficulty, but all in the water are exceedingly active.

"This animal has his body always covered with slime, like all fish found in muddy waters, and when be comes on land he leaves a slimy track; he drags his budy and this causes the ground where he passes to be very slippery and to return to the water he follows this slippery track. He does not go in search of fish, but conceals himself and catches them as they pass. On the sirle of the river where the current is greater, he digs a hole beneath the surface of the water with his claws, and is careful to make this hole narrow at the opening and large enough at the bottom so that he is able to turn. He places himself here and waits for the fish who are exhausted from the strong current to go in search of still water to rest and coming from the light do not see the crocodile hidden in obscurity so retire without fear. His eneny, who has the advantage of seeing the fish in the light, quickly seizes his prey. 
"I"ll not contradict the renerable antiquities on what it teaches us of the crocodiles of the Nile who throw themselves upon mankind and devour him, who leave a slime along their path to the water so as to make the passerby fall and slip into the river, and who imitate a child's voice to attract and trap them. I'll neither say a word against the travelers who, sure of hearsay, have confirmed these stories, but as I profess to tell the truth and advance nothing of which I am not certain, I may affirm that the crocodiles of Louisiana are without doult a different species from those of other regions. In fact, I have never heard one imitate the cry of a child. Their voice is as loud as that of a bull.

"It is true that they attack men in the water, but never on land, where they are harmless. I gave a convincing example in the first part when I mentioned the one killed by my slave which was 5 feet long. I also spoke of the manner in which I killed the one 19 feet long. Furthermore, there are nations (Indians) who do not fear this animal, the children kill them and their mothers and father's go to get them. What can be believed of what is said of the crocodiles? Besides, I killed as many as I met and they are little to be feared, as they cannot run nor rise against man.

"The slimy path spoken of is nothing more than the slinpery" track which they make to and from the river. They are, as I have said, only dangerous in the water, where they are very active."

\section{The Difference Between Alligators and Crocodiles}

To anticipate an obvious question, "What is the difference between an alligator and a crocodile?" it may be stated that there is, perhaps, no absolute distinction between the groups but that the two are easily distinguished by the outline of the head; the alligator has a broad, rounded snout, while that of the crocodile is narrowed and more pointed. According to Raymond L. Ditmars, curator of reptiles of the New York Zoological Park (to whom I am indebted for a great deal of my information regarding the scientific position of the alligator), the crocodile has in addition to the differences already pointed out, as a rule, larger and more exposed teeth than the alligator and is usually quicker, more active and more vicious than the denizen of our swamps.

A popular theory, not borne out by facts, however, is that only the upper jaw of the crocodile is hinged, while the alligator can only work its lower jaw. This is not true. The most reliable method of identification is by the teeth- 
the fourth lower tooth, which is enlarged and fang-like in all members of the order, fits into a pit inside the margin of the upper jaw in the alligator. With the true crocodile this tooth fits into a notch at the side of the upper jaw and, when viewing the reptile's head from the side, with the mouth closed, this enlarged tooth is hidden in the alligator but can be seen when looking at a crocodile, as indicated in the accompanying pen drawing.

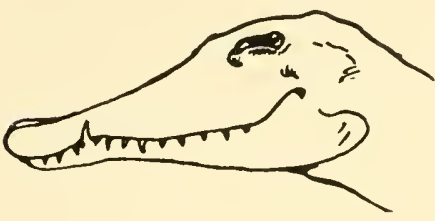

CROCODILE

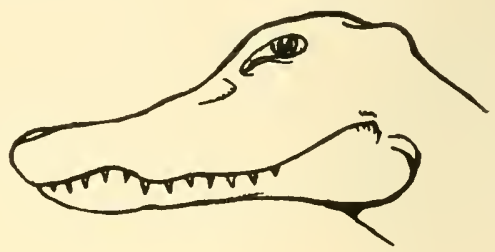

ALLIGATOR

The fourth lower tooth of both the crocodile and alligator is enlarged and fang-like. This tooth, in the alligator, fits into a pit inside the margin of the upper jaw and when viewed from the side, with the mouth closed, this tooth cannot be seen. It is seen when looking at a crocodile with the mouth closed. Therefore, if you don't see the tooth the reptile is an alligator.

The alligator is found in the rivers and swamps of our southern states from the southern part of North Carolina to the Rio Grande.

\section{The Alligator Disappearing}

Years ago, before the rifle of the sportsman appeared on the scene and before the value of their hides was recognized in the marts of trade, alligators were very abundant. Today, the 'gator is surely on the decline and it seems that some sort of prompt legislation will be needed for its protection if this animal is to be preserved to our fauna.

Whether the wholesale destruction by the hide-hunter will eventually exterminate this giant reptile, as has been the case with the buffalo, it is impossible to say, but that the decline in numbers has been rapid will be vouched for by almost anyone familiar with it or its habits. While in the past a number of alligators were killed by the sportsman, few today die from this source-that is, few in com- 
parison to those killed by the alligator-hide hunters. This latter trade in hides tends to complete annihilation if it is not curbed or governed in some manner. The collection of eggs for hatching in curio stores so that the tiny 'gators may be taken North and allowed to starve or freeze to death, must be counted as another medium of destructionnot a serious one, however. Crows, so our agent guarding Marsh Island reports, frequently prey on the eggs-probably those forming the top layer of the nest.

The food of this characteristic marsh and swamp diweller is shown by the following reports:

\section{ALLIGATORS KILLED ON RAINEY REFUGE}

\section{June 27, 1925}

\begin{tabular}{|c|c|c|c|}
\hline & Sex & Length & Stomach Contents \\
\hline No. 1 & Female & 5 feet & 1 full grown muskrat, crabs. \\
\hline No. 2 & Male & feet & crayfish and crabs. \\
\hline No. 3 & Female & 6 feet & 1 full grown rabbit. \\
\hline No. 4 & Female & $41 / 2$ feet & crayfish and crabs. \\
\hline No. 5 & Female & 7 feet & $\begin{array}{l}2 \text { pieces salt pork (no doubt thrown } \\
\text { out of some boat). }\end{array}$ \\
\hline No. 6 & Female & feet & crayfish. \\
\hline No. 7 & Male & $51 / 2$ feet & muskrat fur and bones. \\
\hline No. 8 & Female & 6 feet & 1 fish 6 inches long, crabs. \\
\hline No. 9 & Female & $41 / 2$ feet & crayfish. \\
\hline
\end{tabular}

Six smaller 'gators opened at the same time, ranging from 3 to $4 \frac{1}{2}$ feet, all contained crabs and crayfish.

June 29

\begin{tabular}{|c|c|c|c|}
\hline & Sex & Length & Stomach Contents \\
\hline No. 1 & Male & $61 / 2$ feet & muskrat fur and bones \\
\hline No. 2 & Male & $51 / 2$ feet & muskrat fur, crabs. \\
\hline \multirow{3}{*}{ No. 3} & Female & 5 feet & muskrat fur. \\
\hline & \multicolumn{3}{|c|}{ July 4} \\
\hline & sex & Length & Stomach Contents \\
\hline No. 1 & Female & $i$ feet & stomach empty. \\
\hline No. 2 & Male & $61 / 2$ feet & fish bones. \\
\hline No. 3 & Female & 4 feet & muskrat fur. \\
\hline No. 4 & Male & feet & small mullet. \\
\hline
\end{tabular}




\section{SOME 'GATOR FOOD}

This department has been informed by a manager of a large land company that the alligators in their canals and on their 'rat lands are not only very numerous but very large. Many of those killed in March, 1926, were 10 and 11 feet long and one of them had a girth measurement of 40 inches. The following records are interesting: An 8-foot 'gator had been eating a marsh owl; a 7-foot had 3 ducks and 4 coots (poules d' eau); another, slightly larger, had 9 coots; a 10-footer, with the 40 -inch girth, had eaten 7 coots; an 11-footer had 2 ducks and 5 coots in its stomach; another, slightly larger, had been feeding on owls, coots, ducks, rails, etc.

In this collection of 44 alligators not a muskrat trace was found in any of the stomachs. The taking of coots cannot be looked on as harmful, as these game birds, the poules d'eau of Louisiana, are increasing faster than ducks, because the hunters will not shoot them, and are monopolizing many of the best duck-feeding grounds in the state and cleaning them of foodstuffs. Owls, as surveys have demonstrated, are very harmful to the muskrats, so the taking of these birds cannot be counted against the alligator. Eating ducks, however, is a black mark.

Vernon Bailey believes that the alligators must, through their well-known habit of snapping up anything swimming in the water, play havoc with muskrats when they leave the marshes, and the 'gators, he believes, are partially responsible for the Louisiana muskrat leading the terrestial life it does. That this fur-bearer would shun the water if it was inhabited thickly by alligators, stands to reason, and, in this particular, it might be well to call attention to the fact that gar fish would also eat muskrats found swimming. As yet no scales or bones of gar fish have been found in alligator stomachs.

\section{Mating Data}

According to information gathered while making surveys of the alligators of our state, it has been ascertained that the alligators mate during the latter part of February 


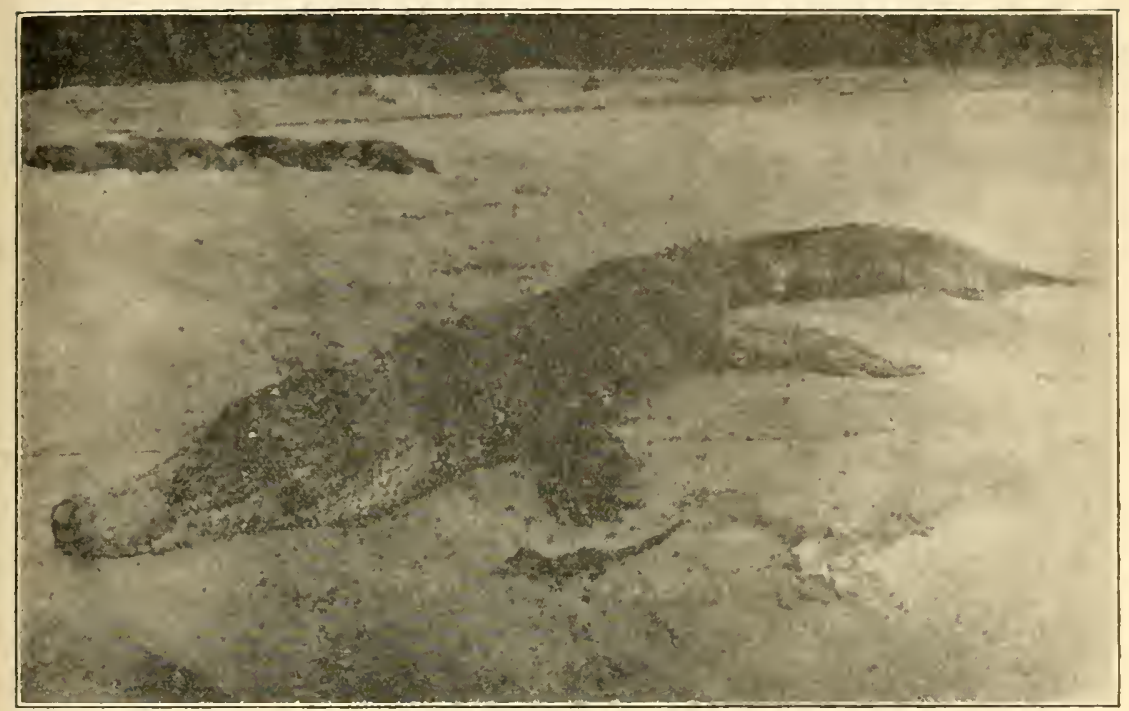

Relative sizes of a newly-hatched baby 'gator and an ancient member of the familyage unknown.

and the first of March. This, of course, depends a great deal upon the state of the weather, continued warm days, and whether or not it has been a cold or mild winter. The Louisiana alligator, however, does not hibernate all through the winter, as has been popularly supposed. Any warm day during December or January will find these reptiles, especially the larger bull specimens, out sunning themselves on a "shelf" alongside some bayou.

The mating takes place on the ground and during this season the mating notes, a bellowing something between a moan and a roar, can be heard a considerable distance. The bull bellows most constantly during this period of the year, the cow answering, although it has been stated that bellowing is confined to the male. The bellow of the bull, being heavier in timbre, is easily recognizable. Mating is acompanied by a great deal of fighting on the part of each, slapping one another with their long, heavy tails; the cow using not only her tail but jaws, even if the attentions of the bull are not distasteful. Missing or mutilated legs and 
tails, and scars, seem to prove these fierce encounters do take place. According to many of our marsh-dwellers and hide hunters, cows do not mate every year, and young cows, those of about 5, 6 and 7 feet, do most of the fighting. Old cows do not appear to be so pugnacious. The bull stays with the cow only two or three days, then leaves for virgin territory. The copulating period extends through March and April to some time in May.

It has long been supposed that it required from twentyfive to thirty years for the alligator to reach sexual maturity, but, from investigations, it is quite likely that the cows may lay eggs as early as five or six years, although this remains to be definitely proved.

These reptiles, when they do not choose bayous or other large bodies of water, make their homes in what are known as "gator holes." These holes are of varying sizes and depths, but always there is a cave constructed below the surface running at right angles to the sides. These caves are sometimes fifteen to twenty feet in length, and, while they are constructed in "holes," they are also made in the banks of bayous and lakes. Above such caves, and on the surface of the ground, is always to be found a smooth place where the vegetation is worn away. This is where the 'gator regularly has its sleep in the sun. When the habitat is in a bayou this sleeping place takes the form of a "shelf" on the side of the bayou. The 'gator uses the subterranean cave as a retiring place during the cooler winter months when it hibernates.

The alligator perpetuates its race by laying eggs from which the young emerge. Nesting starts by the first week in June. This work is done entirely by the female, as the male, after the mating season, takes no interest in the puragaticn of his species. The nesting site is in most inwrances a dry piece of ground, sometimes an acre or two, rrom the "hole," at other times but twenty feet away, or right on the edge of the watery hole. This seems to be controlled wholly by the nature of the adjacent ground. 


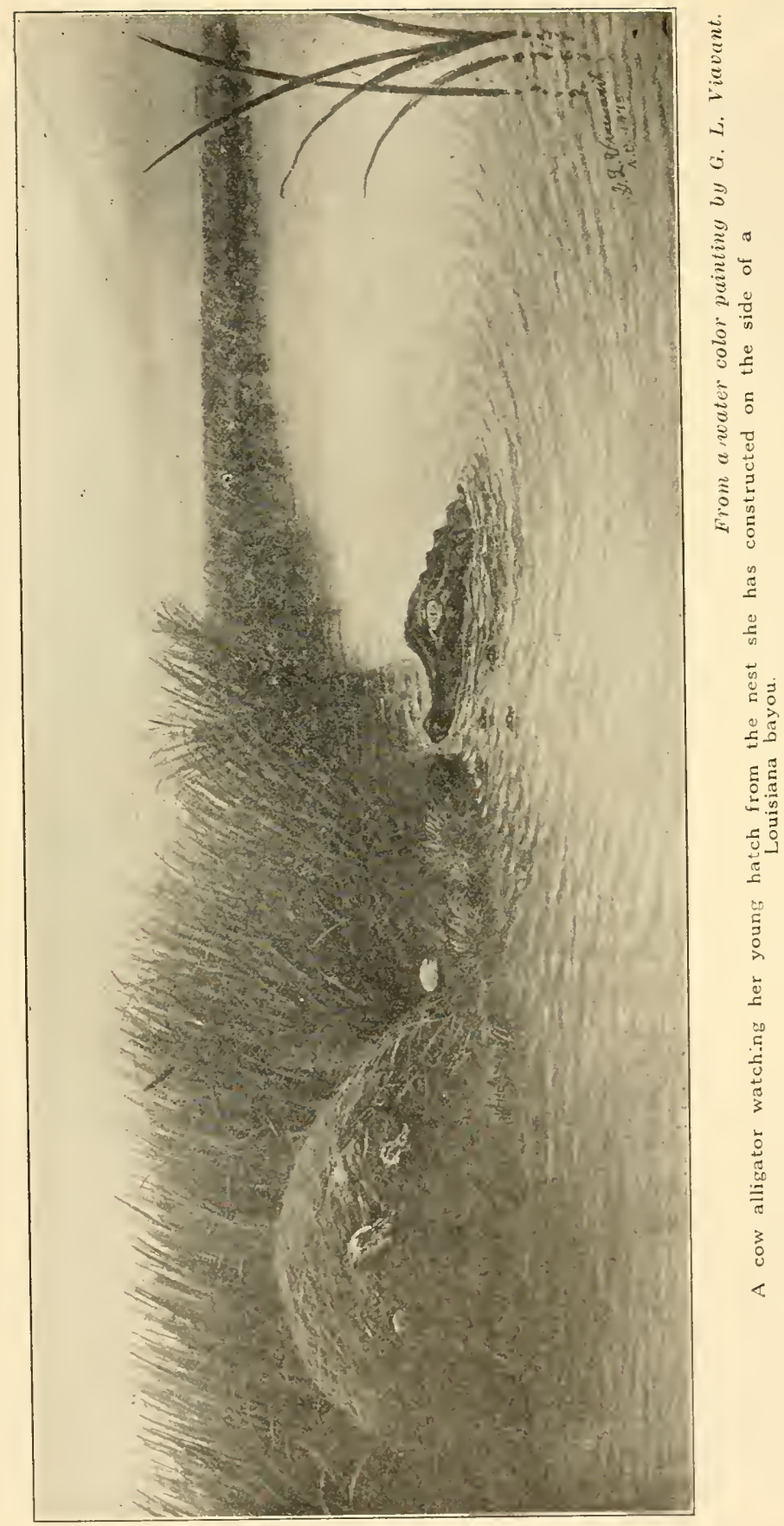




\section{INCUBATING THE EGGS}

Having selected the location of the nest, the cow proceeds to collect, in all likelihood biting it off with her teeth, a great mass of whatever vegetation is most abundant in her immediate vicinity. She carries the paille fine, bulrush, three-cornered rush, cat-tail, saw grass, or other marsh vegetation in her mouth and piles it into a rounded heap from 18 to 20 inches high, and from three to four feet across. This first layer completed, the first eggs are laid and then grass is added and more eggs laid, until the nest reaches a height of three feet. A seven to eight foot alligator will build to this size. The eggs are incubated by the heat of the sun, inasmuch as the sum helps in the decomposition of the vegetable matter of which the nest is composed, as the interior is always damp and the heat generated remains quite constant. The bottom grass is always wet, as are the first layers, then comes dry grass, forming a sort of "fireless cooker." The top layer is sloped so that rain will run off rather than wet the contents.

Observations tend to show that a five-foot alligator wiil lay about 25 eggs; a six-footer will lay about $35 \mathrm{eggs}$, and a seven-footer will lay up to $40 \mathrm{eggs}$; this seems to be the maximum number laid, although a trapper in the Atchafalaya River country reports having taken 72 eggs from one nest on a small island in the river.

The precise period of incubation has not been worked out. Figures show that a nest was first observed July 5 , when the eggs had not been laid more than a few days; the hatching commenced September 7, making the incubation period about nine weeks. Eggs taken from the nest and hatched away from the place where laid take longer. The percentage of fertile eggs is as a rule very high, most of the infertile eggs being found in the nests of the five-and sixfooters.

Cows from 4 feet 9 inches to 5 feet have been found making nests and laying eggs. The maximum length of cows seems to be about nine feet, rarely over. All of the big 'gators are bulls and, while the largest seem to be 


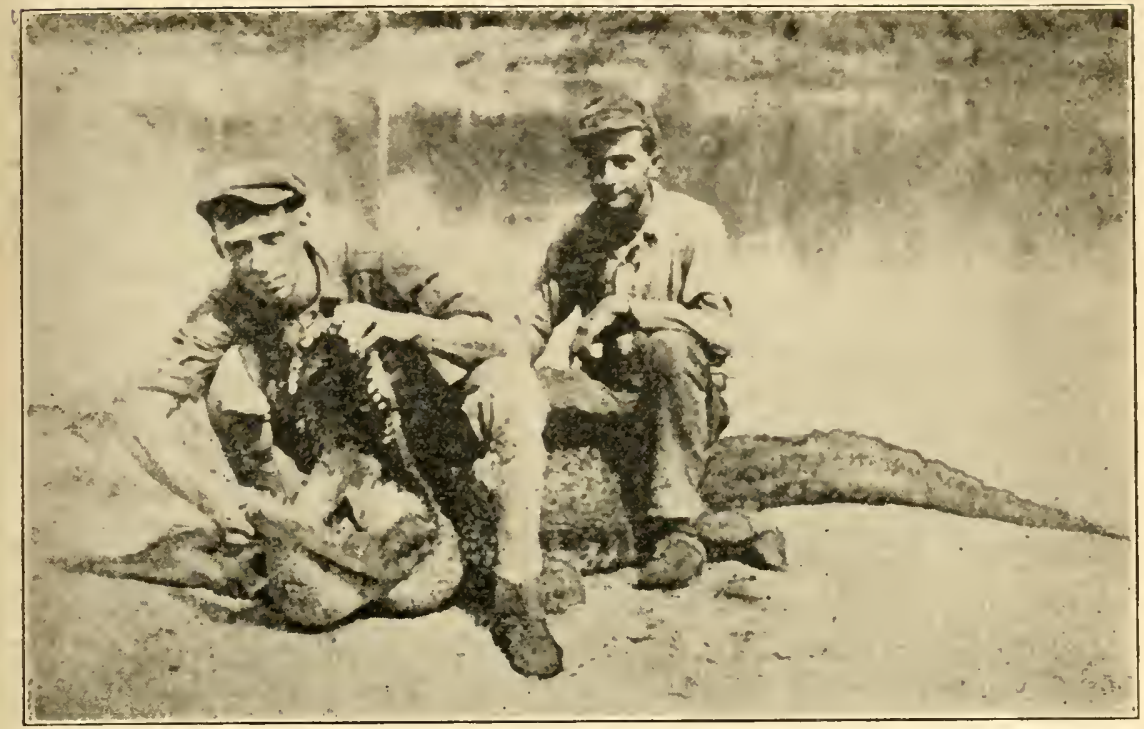

Gaitor hunters demonstrating the capacity of the mouth of the big fellow they have just secured.

about 14 feet, they are now becoming very rare. A number of 15 -footers have been recorded in Louisiana, one "big one" captured, that I measured, proving to be 14 feet 11 inches in length. Hornady reports a Louisiana skin 16 feet 3 inches and du Pratz accounts for one 19 feet long and another 22 .

One noteworthy thing reported by alligator hunters is that there are two color phases in Louisiana-black and yellow. They seem to hatch in these colors and hold the phase almost to maturity and the two phases come from the same nest. A test for sexual differences as an answer to the difference in coloring failed, as both sexes were found in the darker and lighter coloration. It is said by native hunters that one cow will occupy the nest of another cow that has been killed and they have noted that two sets of little 'gators take up with another cow after the death of their own mother. 


\section{EARly Life OF BABY 'Gators}

If the little 'gators hatch irregularly, the first hatched lie in the nest until all that are to hatch are out of the shells. The mother, which does not stay about the nest during the incubating period of nine or ten weeks, hears the little ones "holler," as an old-time 'gator hunter puts it, and answers their call by giving a little, sucking-like "umph," many times repeated. The little 'gators clamber dowl from the grass heap and the cow leads the brood over land to water. She clears the way, constantly calling, "umph, umph, umph," and the little fellows follow, answering her cries. All the little ones take readily to water, the cow forming a black mud bank or "shelf" where the young sun themselves and eat the mud worms, and other insect life that forms their first food. As they grow they eat minnows, crayfish, bugs, and the larvae of water insects. The little 'gators are preyed upon from the time they leave the nest. Bullfrogs eat a great many, while the male alligators eat them up to the age of two and three years.

At the time they hatch, the alligators are from 5 to 7 inches in length. They grow from 4 to 6 inches the first year; in two years they are from 16 to 18 inches in length. From three years and up they grow rapidly until they reach the length of five feet; then they grow only about $11 / 2$ to 2 inches a year. On their native marsh they grow much faster than they do in captivity, it is believed, but figures as to their length in relation to the time they have been in captivity are the only accurate data we have as to the relationship of age to total length.

By combining notes on three series of alligators in captivity in the reptile house of the New York Zoological Park. Curator Raymond Lee Ditmar's arrived at the following conclusions regarding the age and growth of the alligator. This table, opposite page, it should be remembered, is based upon reptiles in captivity, where some suppose they grow much more slowly and believe that they probably mature later than they would do in their natural habitat. Dr. Ditmar's table indicates that the alligator grows faster than we have supposed it did. 


\section{GROWTH OF THE ALLIGATOR}

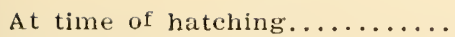

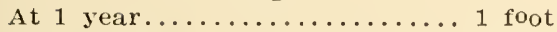

At 2 years................. 2 feet

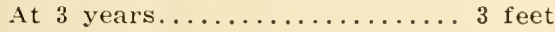

At 4 years............... 4 feet

At 5 years...............4 feet 10 inches.

At 6 years.............. 5 feet 4 inches. Weight 50 pounds.

At 7 years..............6. feet 2 inches.

At $s$ years...............6 feet 11 inches.

At 9 years............... \& feet 2 inches.

At 10 years.............. 9 feet 3 inches.

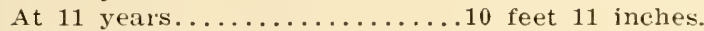

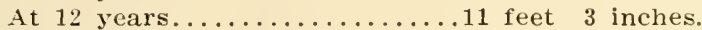

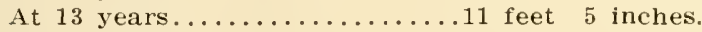

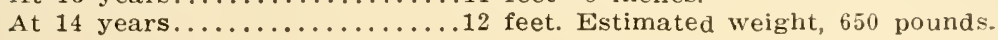

\section{(Maturity)}

Dr. William T. Hornaday, when director of the New York Zoological Park, recorded the growth of a large alligator captured in the wilds and sent to the Bronx zoo for exhibition purposes. ${ }^{22}$ When taken the 'gator measured exactly 6 feet 11 inches. In one year it grew 1 foot 3 inches, or to 8 feet 2 inches; during the second year in captivity it grew 1 foot $1 \frac{1}{2}$ inches, or to 9 feet $3 \frac{1}{2}$ inches; during its third year in captivity it grew 1 foot 7 inches, or to 10 feet 11 inches. Dr. Hornaday said that he believed that his captive specimens grew as rapidly under restraint as they did in the wild state and that he had reached the conclusion that, in ordinary circumstances, a wild alligator is about 10 years in reaching a length of 12 feet. He believes that the average rate of growth up to 12 feet is 1.4 inches per month. After this length has been attained the rate is much slower, being approximately 2 inches a year. His largest captive 'gator' measured exactly 12 feet in 1899, and in 1903, four' vears later, measured 12 feet 5 inches.

It has been pointed out by the U. S. Bureau of Fisheries that "there are several varieties of alligator hides on the market, the most important being the Floridian, Louisianian and Mexican; each differs from the others in certain well-defined characteristics, and owing to these differences each variety has its special uses.

${ }^{2}$ Hornaday, $\mathrm{T}$. T., American Natural History, F. 320. 


\section{Best Skins Come From Louisiana}

"The Florida skins are longer in the body-measured from the fore legs to the hind legs-than those from Louisiana or Mexico and consequently are largely in demand by manufacturers of large handbags. They also have a larger number of so-called 'buttons' or 'corn marks' on the inside or under-surface of an equal number of scutes resulting from imbedded horn-like tissues in the center of those scales. These increase the difficulty in tanning the skins and detract somewhat from the appearance of the finished article, and for this reason the Florida skins are ordinarily the cheapest on the market. The farther south the skins are secured in Florida the greater the number of 'corn marks' and those from the vicinity of Key West are almost valueless for this reason.

"The Louisiana skins differ from those of Florida in the absence of the 'corn marks,' and from both the Florida and Mexican skins in being more pliable and having the scales more artistically curved and shaped. Consequently Louisiana skins are preferred for such small articles as cardcases and pocketbooks and usually sell at the highest prices. Skins secured in Mississippi and Texas are similar to those secured in Louisiana, while those from Georgia and South Carolina are similar to those from Florida, except that the 'corn markings' are not so numerous. All of the Louisiana skins show greater uniformity of coloring, being of a bluish black on the upper surface and a peculiar bluish whi'e on the underside." The tanning and finishing processes rive the commercial article its yellowish color, it m ght be explained.

Only the "bellyskin" is used. The skin is removed soon after the killing, as putrefaction sets in almost immediately in our warm climate, and the value of the skin is thus depreciated. The "bellyskin" is removed by two longitudinal incisions just below the horny portion of the back; and the flesh side of the skin thoroughly rubbed with salt and rolled up with the salted side inside, and shipped to the market. Care is taken not to cut the hide since small cuts not noticed in the raw skins become conspicuous when it is tanned and dressed. Louisiana skins obtain the highest price in the markets and those from Florida the lowest. 


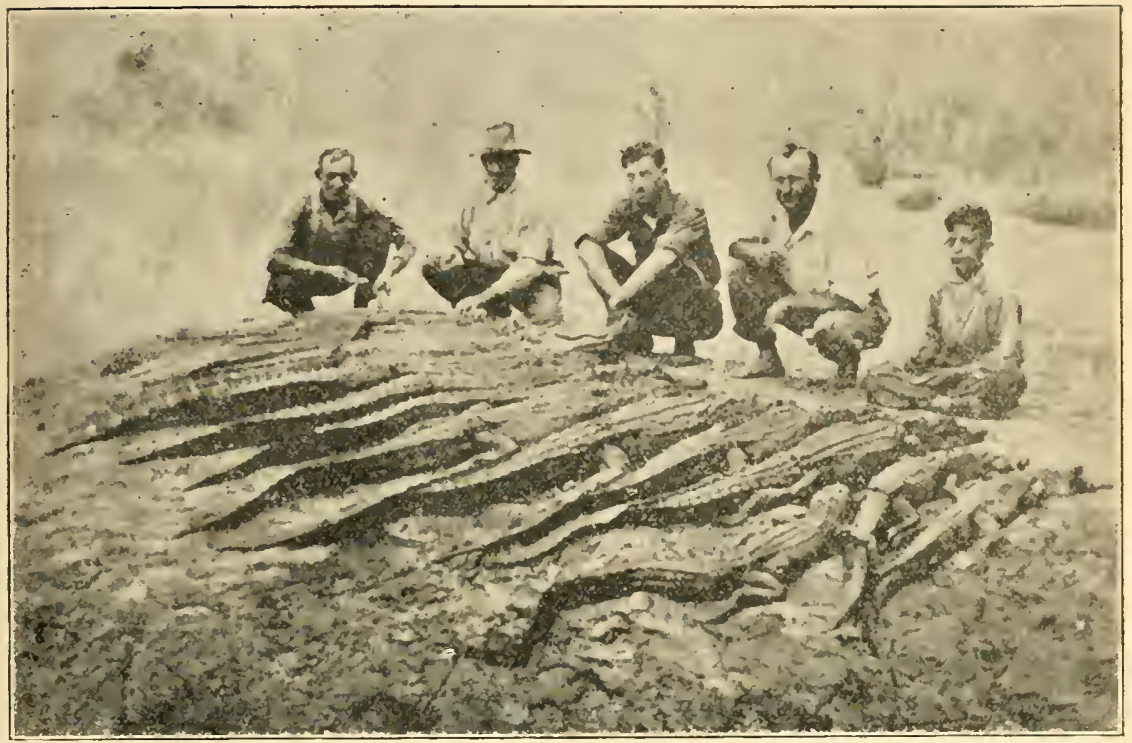

Alligator hide hunters and one night's take. While this characteristic inhabitant of the Louisiana marshes has been charged with being the muskrat industry's worst enemy, field investigations to date have not proved the charge.

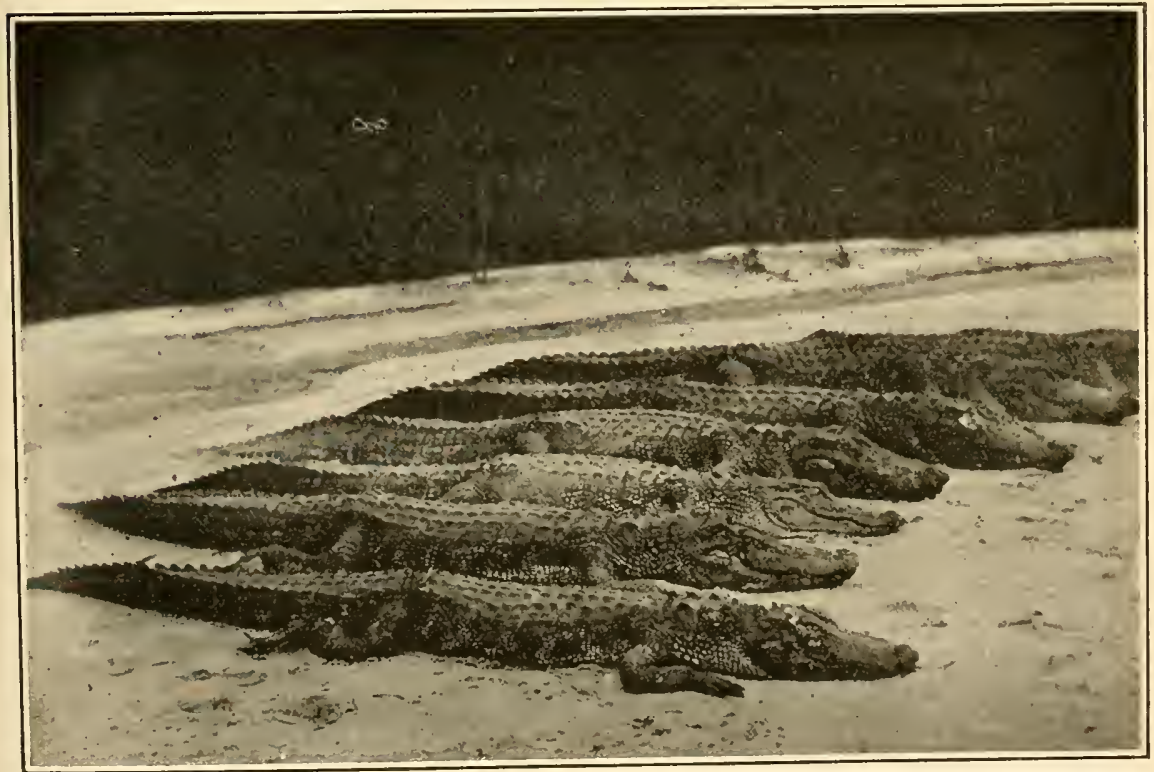

Over 21,000 alligators were taken for their hides during the 1924 season and, as it has been outlawed in the coastal parishes, its numbers have been alarmingly decreased. 


\section{Alligator Hunting}

'Gator hunting is carried on in this state from the first of March to the first of October. Two methods are in vogue: "shining" at night with a carbide lamp, or by "poling" in the day time. In shining, the hunter or hunters paddle along some bayou or other stream, throwing the beam of their powerful light from one bank to the other until the eyes of an unsuspecting 'gator reflect the rays. A shotgun, at short close range, kills the reptile, which is seized before it can sink out of sight in the water and is either dragged on board or on the nearby bank to be skinned by morning.

Poling is pursued in the daylight hours. Anyone can shoot a 'gator at night, but it is not every one who can pole one. A pole, about seven or eight feet in length, of twoinch dressed pine with an iron hook at one end is used. An alligator hole is found and the hunter proceeds to "feel" for the 'gator by sounding the ground around the hole to locate the cave. If "felt" the hunter leaves the hole a short distance and calls the reptile by imitating its sucking cry of "umph, umph, umph." As a rule, the 'gator responds and crawls out of the hole; if it is the size wanted, the hunter, with a well-aimed throw of his hand axe, stuns the 'gator and with additional licks finishes it. If the first blow fails, and the gator retreats to his cave, it cannot be coaxed out again, so the hunter must dig into the cave from the back and vigorously prod the 'gator until it seizes the hook in its mouth and the 'gator is pulled out by main strength, which is usually considerable of an undertaking if the reptile is at all large.

It is scid by experienced alligator hunters that the pole method is the only propor method, as commercial-sized alligators can be secured in this manner, while in shooting at night all sizes, particularly small ones, of not much commerial value, are killed. Skins from 4 to 8 feet are conidered best by the hide buyers and smaller or larger ones wrre not wanted a few years ago, but today the demand appears to be for any size skin a dealer can get. 


\section{Grading Alligator Hides}

Alligators are graded according to size, the measurements being from tip of under jaw to tip of tail, a skin measuring 6 feet 11 inches being considered only a 6 -foot skin and so on. The prices for these skins were not very high until 1926 and 1927, when good prices were secured, as the following table, giving the average prices paid in New Orleans, shows. The 1928 prices as existing at the end of May show a sharp decline, with the dealers not wanting those skins measuring 2 feet and under.

$\begin{array}{cccrrrr}\text { Size } & 1916 & 1917 & 1926 & 1927 & 1925 & 1929 \\ \approx \text { 7- oot } & \$ .90 & \$ 1.35 & \$ 4.00 & \$ 1.65 & \$ 3.25 & \$ 350 \\ \text { 6-foot } & .60 & .90 & 3.00 & 3.25 & 2.25 & 2.00 \\ 5 \text {-foot } & .40 & 65 & 2.00 & 2.25 & 1.25 & 1.50 \\ 4 \text { - oot } & .20 & .45 & 1.75 & 2.00 & .65 & 1.00 \\ \text { 3-foot } & .10 & .25 & .05 & 1.15 & .35 & 1.00 \\ \text { 2-foot } & .05 & .15 & .40 & .50 & * * & 1.00\end{array}$

* Hides above seven feet bring the same price no matter the length.

* Not wanted.

To show how the various sized skins come into the market, the following figures from one New Orleans fur dealer's establishment are interesting. This shows the manner in which the alligator hides were offered for sale, and bought during the summer of 1917 :

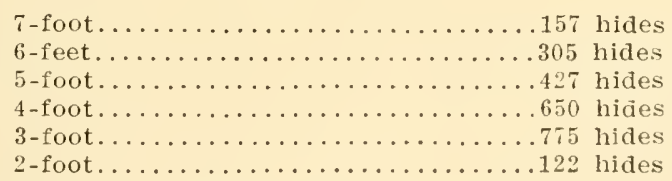

The dealers say they are reluctant to buy the smaller hides, those under 4 feet, but they claim that when a hunter brings in his skins for sale they must buy his whole catch, as he will not sell a part of it, so they are forced to market the small skins, although they are practically useless.

That there is a great deal of waste in securing merely the hide of an animal is evident. There is absolutely no use put to about 95 per cent of the living thing that is killed. That there can be use made of the alligator flesh is quite likely. It is said by those who have eaten the meat of the 'gator, in spite of the notion that it is said to be too strong in flavor to be palatable, that it has no rank taste, but is 
decidely agreeable, being, as might be expected from so amphibious an animal, somewhat like both flesh and fish, yet not exactly like either. It is perhaps the idea of eating a reptile that makes the meat unpopular. It may be that experiments along the line of salting or smoking would be worth while.

\section{New Protective Laws Needed}

In view of the rapidly diminishing numbers of the alligators, suitable laws for its protection should be enacted. It is claimed by some that the enormous increase of the gar fish that depredates $\mathrm{cn}$ our valuable food fishes has been caused by the unrestricted killing of the alligator. Cattlemen in the lowlands count the alligator as one of their most valuable allies. Its habit of making "holes" for a hiding place at the same time provides places for the cattle to drink when the prairies and marshes are feeling the effects of a long drought; especially has this been so in past years, when Louisiana has experienced such dry seasons.

The minimum for alligators to be taken and for skins to be sold should be 4 feet at least; and a maximum of 8 feet. As has been pointed out, a hunter does not get any more for a 10, 12 or 14 foot hide than he does for a seven-footer, and a number of alligator hunters claim that there is more harm in hunting alligators when they are big than when they are small, and that it is the larger alligators that will propagate more successfully. Such assertions are usually made on the strength of opinions and are not founded on scientific or other study and should carry just that much weight and no more.

That a five-foot cow alligator will lay eggs seems to be certain. That they will reproduce when six feet long is a fact shown by our investigations. At just what length the bull alligator reaches sexual maturity has not been established, but it seems safe to presume that a five or sixfooter will properly function.

That some state law is needed to restrain the killing of so many small alligators seems necessary at this time, and a new life history survey should be made, which will very materially add to our sum of knowledge regarding this picturesque inhabitant of our swamps and prairies. 


\section{CHAPTER TWENTY}

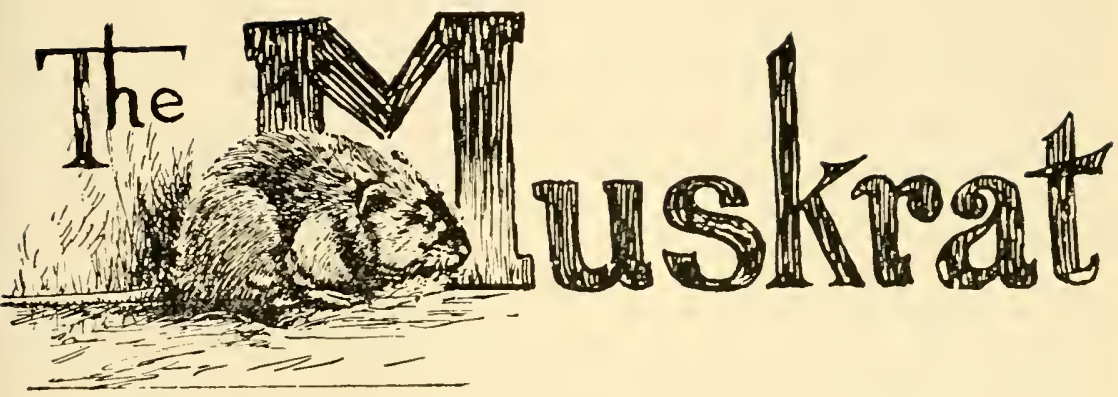

N He muskrat, occupying the position so long held by the beaver, is the bulwark and mainstay of the fur 1 trade of America today and its pelt is one of the most popular furs worn by women.

This animal is exclusively North American, belonging to the extensive rodent family and occurring over the greater part of this continent from the northern limit of trees in the Arctic regions south to the Mexican border. Muskrats are absent from the lower Atlantic seaboard, south of northern North Carolina, nor do they occur along the entire Gulf region with the exception of Louisiana and in a very limited section of western Mississippi and eastern Texas. They are unknown on the Pacific Slope, south of central Oregon, with the exception of a colony that has become established in the Imperial Valley of California due to man's irrigation activities in this once sandy desert.

In Louisiana it is an animal peculiar to our state's circumscribed coastal marsh area and is found here in greater numbers than in any other section of North America.

The muskrat is a small, massively built animal, with a head and body attaining an average length of a little more than 12 inches and a 10-inch tail. The head, which is unusually wide and rounded, is not separated from the body by a distinctively constricted neck, as is the case of many other mammals. Its ears, which are rounded, project 
above the fur of the head and are distinctive features, although most writers have stated to the contrary. The muskrat's eyes while bright and beady, are relatively small, and in spite of this animal's nocturnal habits, do not seem to mean as much to it as does its pronounced sense of smell and very acute hearing. It is very thickly furred and, with the exception of the small area surrounding the nostrils, its muzzle is completely covered with hair and in addition to long, pronounced "whiskers."

The legs are short, with a marked difference in size and appearance between the fore and hind members. The fore legs are rather thin and diminutive when compared to the other pair. Each has four toes and a rudimentary thumb, all furnished with claws. In use. the fore paws are rather hand-like and it is interesting to watch a muskrat pick up a stalk of its favorite food grass, turn it end to end until the white, tender, juicy rooting part can be brought in reach of its yellowed incisors. The hind legs are larger and stouter, each leg having five distinct toes, united by short webs at their bases. The feet and toes are fringed by short, stiff hairs, which are undoubtedly an aid when the animal is swimming.

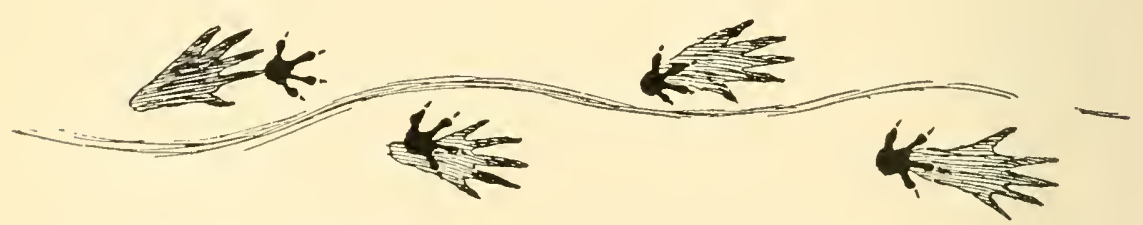

Drawn showing tha chara=teristic foot-prints of a muskrat. The smaller are the front and the large: the back foot impressions. The waving line indicates the mark left

The tail of the muskrat is most odd. While long and tapering, it is not round like that of most of its near rodent relatvies, but is laterally scaly and compressed, and nearly naked, being only thinly covered with hair. Usually the tail is carried on its edge when the 'rat is swimming or walking, but when at rest or sitting on its haunches, the tail flops over on its flat side. The tail's use seems to have been the subject of much controversy. It has three uses-as a sup- 


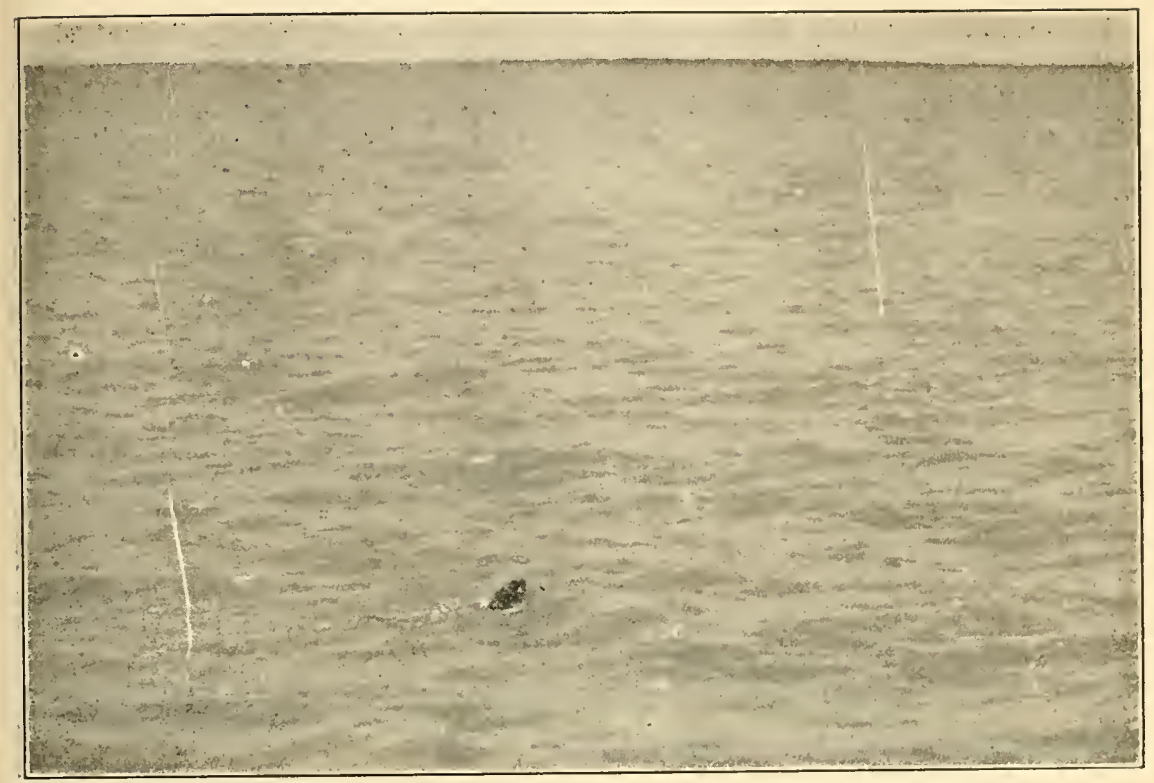

When normally swimming the head and neck of a muskrat are vis.ble as well as the center section of the top of its tail.

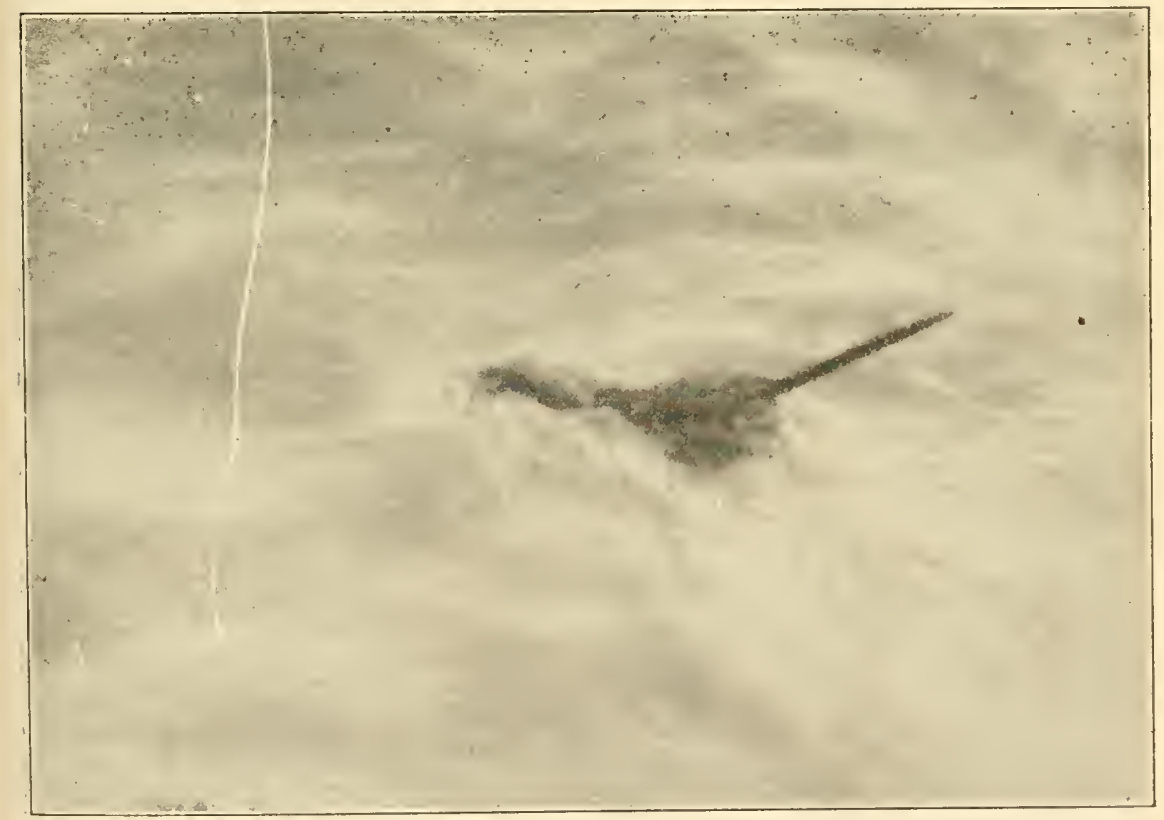

When the muskrat is alarmed and plunges into the water, it hits the surface of the stream with tail stiffened and as it disappears under the surface this appendage strikes ithe water with a resounding "whack!" 
port when sitting erect and feeding; as a sort of scull or oar when swimming, and as a rudder. Its use in sculling, however, is only called into play when it desires to progress through the water rapidly; therefore, as an adjunct to its webbed feet, it has considerable value. The tail is used to help the animal make short turns in the water. See note page 282.

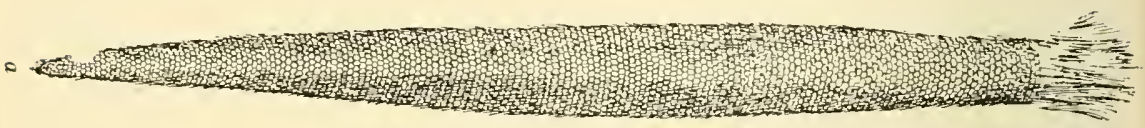

-After E. A. Mearns:

The upper drawing (a) of the tail of a muskrat shows the appendage when viewed from the side. The muskrat normally, carries its tal on edge and the lower drawing (b) shows how the tail looks when looking down on it fon above. The tal of the mus'krat has two functions, it is used as a sort of rudder, when in the water, and the animal can bring it into play as a sort of oar or scull when it wishes to accelerace its swimming.

It is the pelage of this animal that constitutes its value; its soft, velvety texture much resembles that of the beaver. Muskrat fur, however, while shorter, has much more beauty. The pelage consists of a thick, soft under-fur, interspersed with long, stiff, glistening guard hairs, which overlie and practically conceal the fur on the upper surface and sides of the body. The general color is a dark brownish-black, with reddish or golden tints on the sides, and a whitish or silver belly fur, not as thickly inter'spersed with guard hairs as the back and upper sides.

The late Ned Hollister, formerly assistant curator of mammals of the United States museum, and biologist of the Biological Survey, in his Systematic Synopsis of the Muskrats, ${ }^{23}$ said that the Louisiana muskrat, "while like the common muskrat of the eastern United States, averaged slightly smaller, had duller colors, and underparts that were darker." 


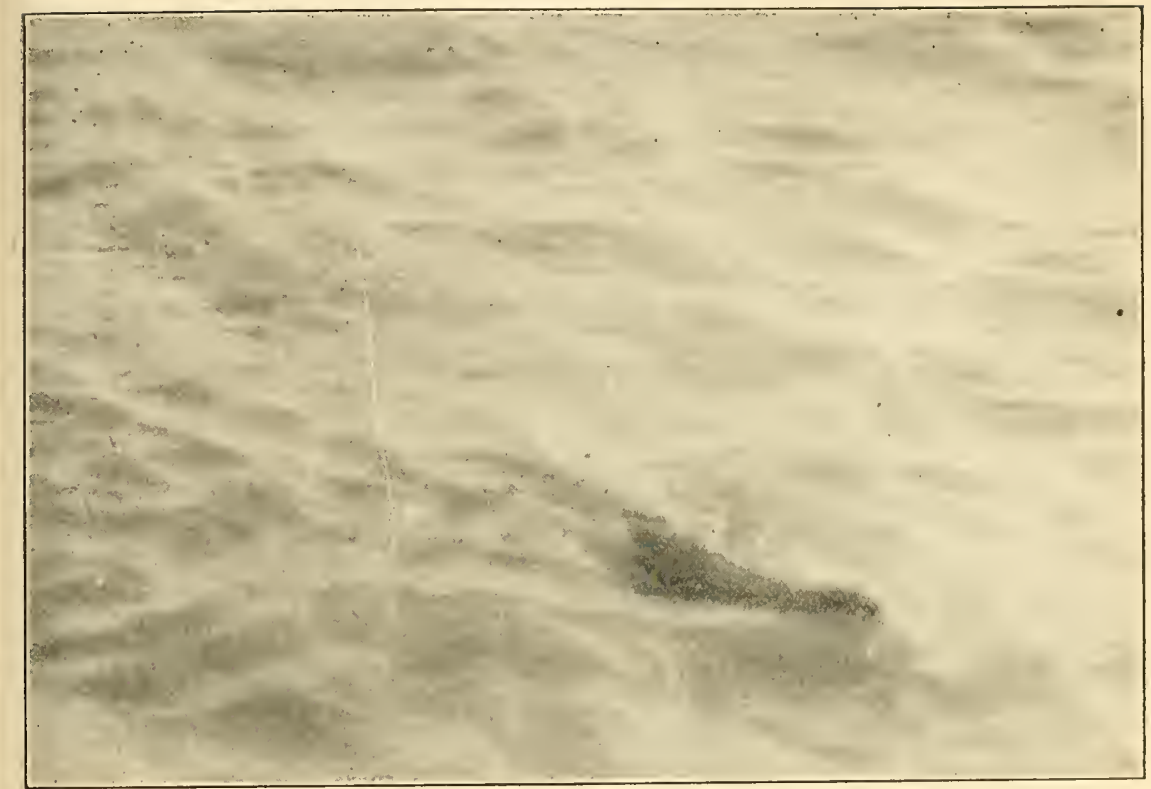

Breasting a stiff current the muskrat uses all four feet and brings its tail into play as a sort of scull to aid in its progression through the water.

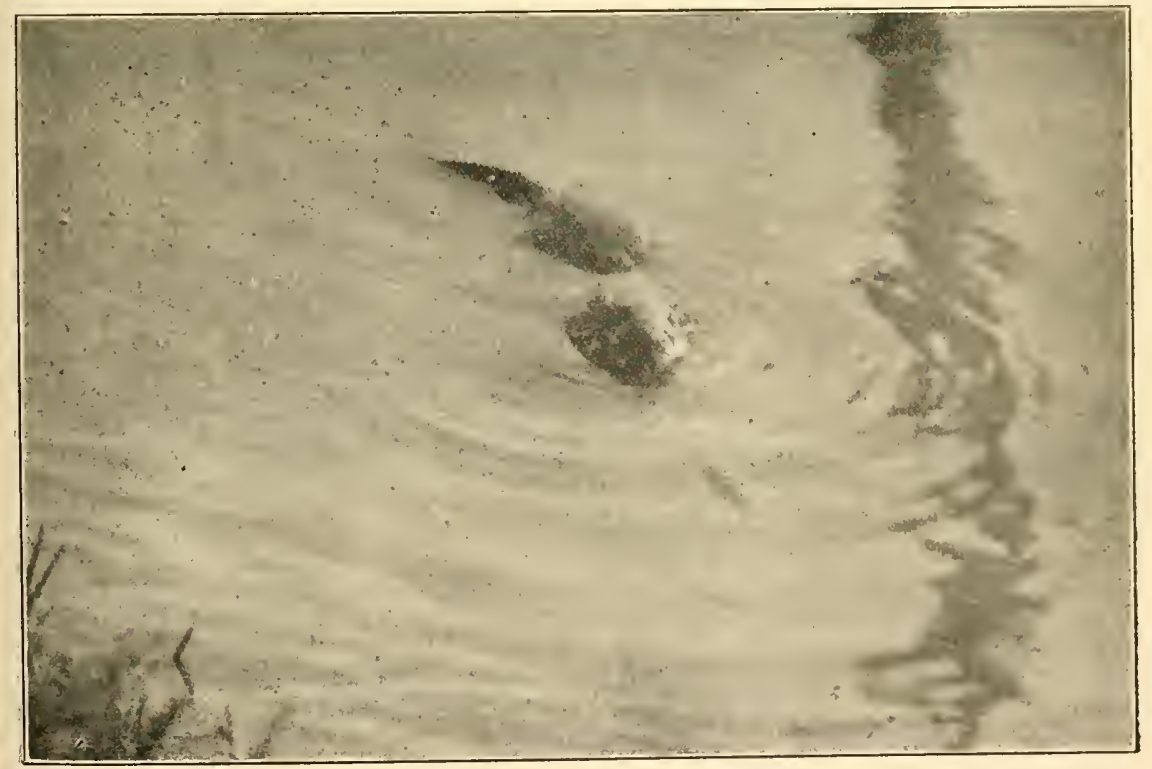

The muskrat using its tail as a rudder in making a turn. 
His messurement and description may be correct, but it is quite evident that he did not have a representative collection of fresh pelts, either dried or tanned, for comparison. In comparisson of the live Louisiana muskrat with live specimens from Michigan, the silver under-fur of the Louisiana muskrat stands out distinctly frcm the more yellowish belly skin of the Michigan 'rats. Skins from Manitoba, Labrador, Minnesota, and Maryland, when laid alongside skins from Louisiana animals, all show derker on the underparts.

And it should be remembered that it is from the under-. parts of the Louisiana mukrat that the "silver muskrat" garment of the fur trade is secured. Nor is Hollister's assertion that our muskrat has duller colors borne out by our comparisons of a representative lot of dressed and undressed pelts from different sections of the country; to the contrary, our muskrat has brighter colors and it seems to. take second place in darkness or blackness of dorsal pelage. to the so-called "black muskrat" of Maryland only.

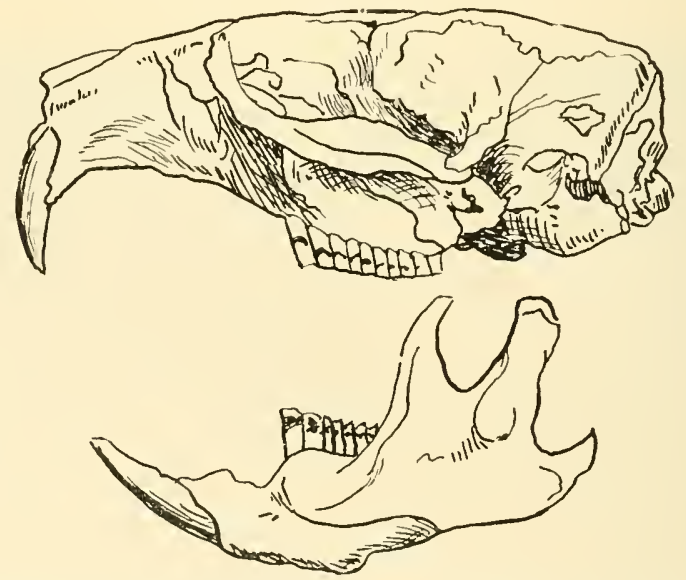

lllustrating the incisors, or front gnawing teeth, of the muskrat typical of all rodents that subsist on vegetable food.

It does not, seemingly, attain either the length or weight. of fully adult northern and eastern specimens, and in this matter Hollister's deductions are evidently correct. But, 


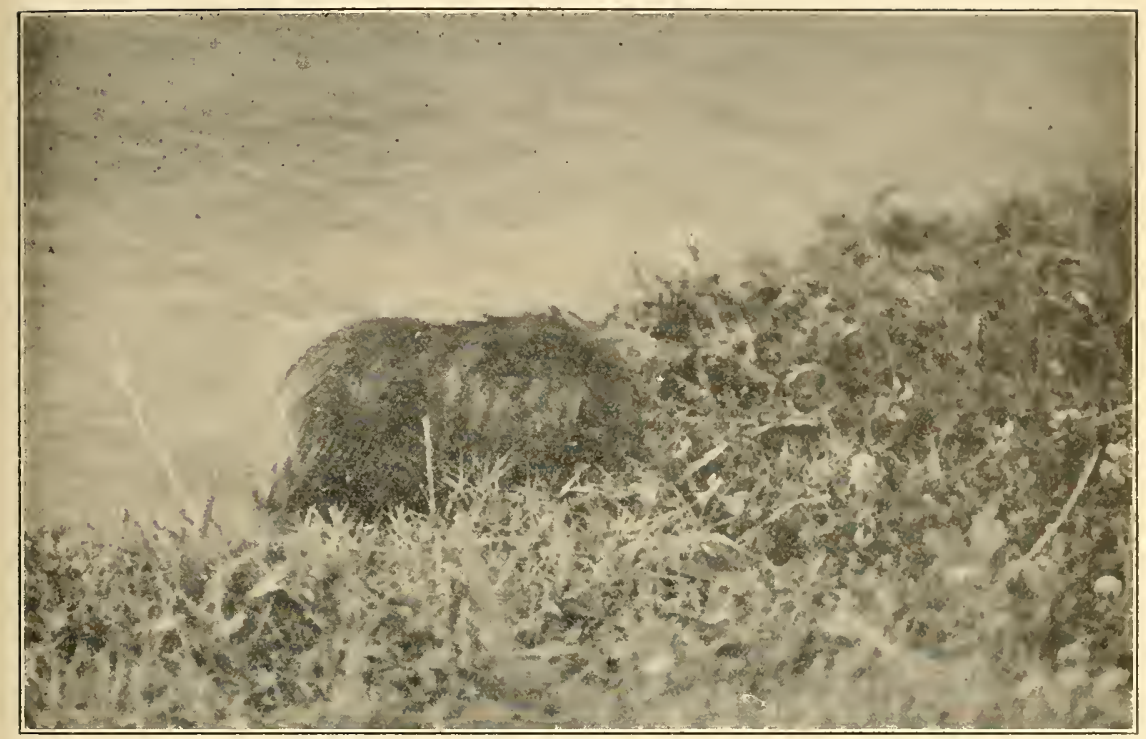

After its swim the muskrat reaches the shore with its pelage sopping wet.

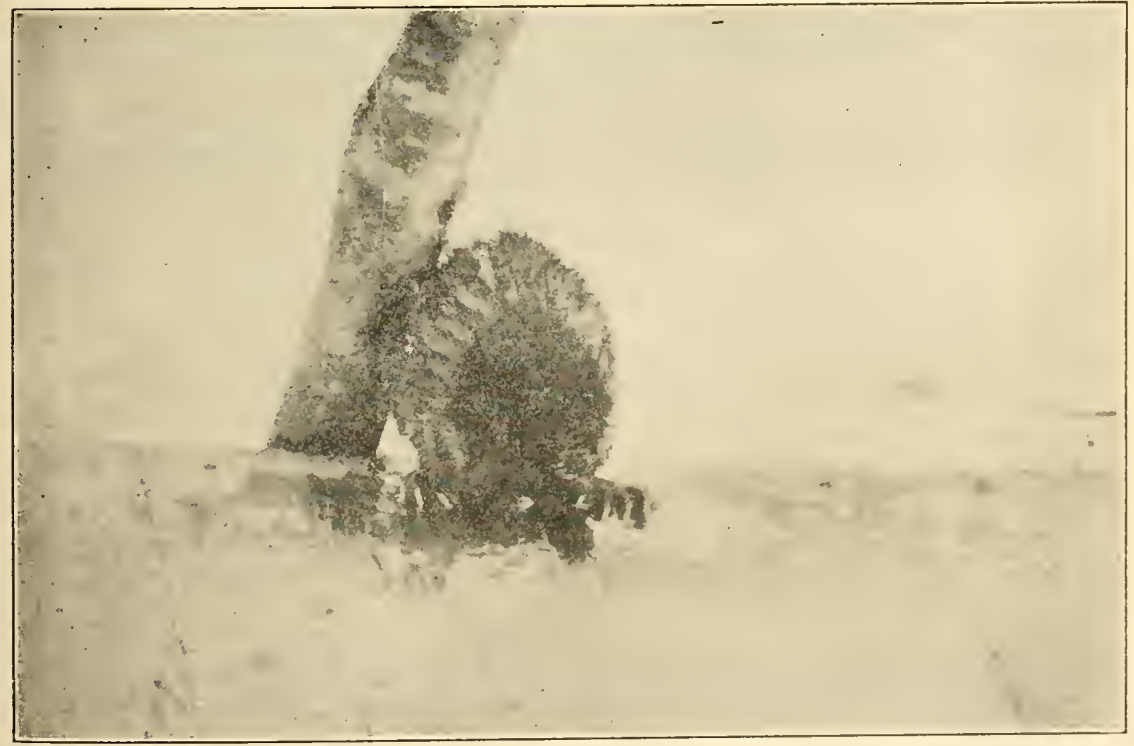

Its first duty is to dry off and, starting at the ears, it energetically combs the hair of its head with its claws, and then attends to the rest of the body with its comb-like toes of the small front feet. 
while smaller than the common eastern muskrat, the Louisiana species exceeds in size the Newfoundland, Northwestern, Alaskan Peninsular, Arizona, Pecos, and Great Plains species, being exceeded in size only by the Rocky Mountain muskrat, Maryland black, and the common eastern species. It averages about the same size as examples from Labrador and Nevada.

The sexes are identical, it being rather difficult to tell the boar from the female; when handling adult live animals the determination of sex is not an easy matter, even when using a "sexing box," as a conical instrument for holding the muskrat upside down, so that the posterior parts can be examined, is called.

\section{MoLTS}

According to Hollister, the Louisiana muskrat "apparently molts twice a year, approximately spring and fall." This is a very important matter if proved to be so, but, it must be freely confessed no evidence has been found that this is so, but we are continuing our investigations.

The authority on the muskrats of the North American continent in general goes on to say, when discussing the muskrat's pelage, that "Aside from conspicuous cases of dichroism [that property of being differently colored], the color of all specimens in comparable pelage from any given locality is remarkably uniform. The great variation frequently noticed in a large series from one region is due mainly to age and season and the degree to which the black overlying hairs have appeared. Sexual variation is so absolutely wanting that it was found useless to distinguish between the sexes in skin or cranial measurements.

"Skulls in a large series from any particular water are remarkably alike in shape and size, but a slight variation between series from nearby localities is frequently noted."

This distinguished biologist and authority on muskrats said that since no two forms occur in the same locality and that the characters separating the geographic races are frequently relative, it was obvious that an artificial key to the 
subspecies would be of little value in identifying specimens, but, realizing that such a key would have important uses as a means of ready reference to characters, and in other ways, he prepared the following, which is reproduced from his "Systematic Synopsis of the Muskrats," published in 1911:

\section{Key to Adult Muskrats in Fresh Pelage}

Size large; hind foot averaging over do $\mathrm{mm}$.

Coloration darker; blackish or blackish brown.

skull with high, sharp interorbital ridge; nasals broadly spatwate anteriorly (Puget sound region and Rocky Moun-

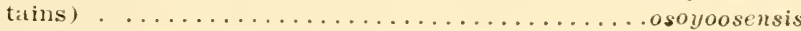

skull without specially developed interorbital ridge. Largest in the genus: twoth ruw averaging over $17 \mathrm{~mm}$; coloration blackish (Atlantic coast, Delaware Bay to North Carolina). Black phase of . ..................................

Size less; tooth row averaging under $17 \mathrm{~mm}$; coloration dark brown (s. E. Canada and N. E. Enited States)... . sibethicus Coloration lighter; reddish brown or grayish brown.

Interpterygoid fossa narrow, with borders nearly parallel (Westeln Oregon) . ..................... ocitalis

Interpterygoid fossa, much widened posteriorly, upperparts grayish brown, with darker dorsal arta (Great Basin

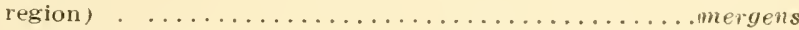

Inderparts bright reddish brown: size very large (Atlantic coast, Delaware Bay to N. C.). Formal phase of... macrodon

Size small; hind foot averaging less than $80 \mathrm{~nm}$.

Coloration dark; black or blackish brown.

skull with high, sharp interorbital ridge.

Zygomata broadly spreading anteriorly (Alaska and $\mathrm{N}$. $\mathbb{W}$.

British America) ................................ Zygomata not bruadly spreading anteriorly.

Hind foot averaging $75 \mathrm{~mm}$. : colors darker with more rusty tinge (Kewatin and eastern saskatchewan) . ... albus

Hind foot averaging less than $70 \mathrm{~mm}$; colors lighter with iittle rusty tinge (Alaskan Peninsular)....... salophus Skull without distinct interorbital ridge.

Coloration glossy blackish.

Tail long (averaging over $260 \mathrm{~mm}$ ) ; skull large (I abra-

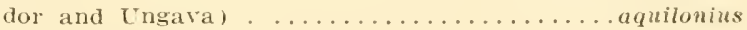

Tail short (avelaging less thin $230 \mathrm{~mm}$ ) ; skull small and

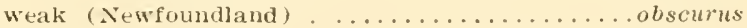

Coloration dull blackish brown: underparts dirk (coast region

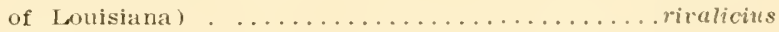
Coloration pale; reddish or pale brown.

Larger (tail averaging $240 \mathrm{~mm}$; hind foot orer $73 \mathrm{~mm}$ ) (great

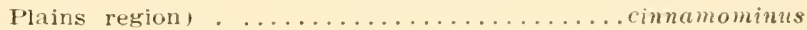

Smaller (tail averaging less than $205 \mathrm{~mm}$; hind foot less than $70 \mathrm{~mm}$ ). Lpperparts cinnamon rufous (Colorado River east to Rio Grande in New Mexico [now in Imperial Valley, Ca]i-

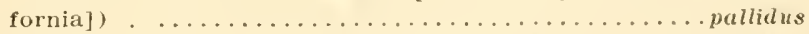

Lipperparts Vandyke brown (Pecos Valley, Texas, and New

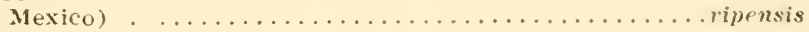


The map on page 197 will show the general distribution of these several species and subspecies of the North American continent and the range of the various forms can be ascertained from the caption beneath the distribution map.

Thoroughly designed by nature for an aquatic life, muskrats are found in the greater part of their range in the vicinity of ponds, brooks, swamps, marshes, and streams of all kinds. The Louisiana muskrat is an inhabitant of the extensive coastal-mar'shes of the state and is found nowhere else in Louisiana. Its range is adequately portrayed by the shaded portions of the outline map of the southern half of the state on page 199. Its geographic relation to the other species and forms of muskrats of North America is shown by the map on the opposite page.

The Louisiana muskrat is recognized as a distinct species and separated from other members of its genus by wide stretches of country. As Hollister ${ }^{24}$ has pointed out, all existing forms of muskrats are closely related. The majority are geographic races of one species, and blend in character from one to another. The type is Fiber zibethicus zibethicus, with eleven subspecies or geographical forms distributed quite generally over the continent. The two other separate species are the muskrat of southerm Newfoundland, Fiber obscurus, and the muskrat of southern Louisiana, Fiber rivalicius.

The scientific name of our muskrat is derived from two sources. The name of the genus, Fiber, is from the Latin word which means "beaver", and was given the muskrat by a French scientist named Couvier, in 1800, who pointed out that Linnaeus, in 1758, had confounded the muskrat with the desman of Asia when the earlier naturalist gave our animal the generic name of Castor.

It may be noted by some that many authors use the name Ondatre as the generic name of the muskrat, viz, Ondatra rivalicius, but as Hollister in his revision used Fiber as the name for the genus, it is so used in this bulletin.

2Hollister, A Systematic Synopsis of the Muskrats, p. 11. 


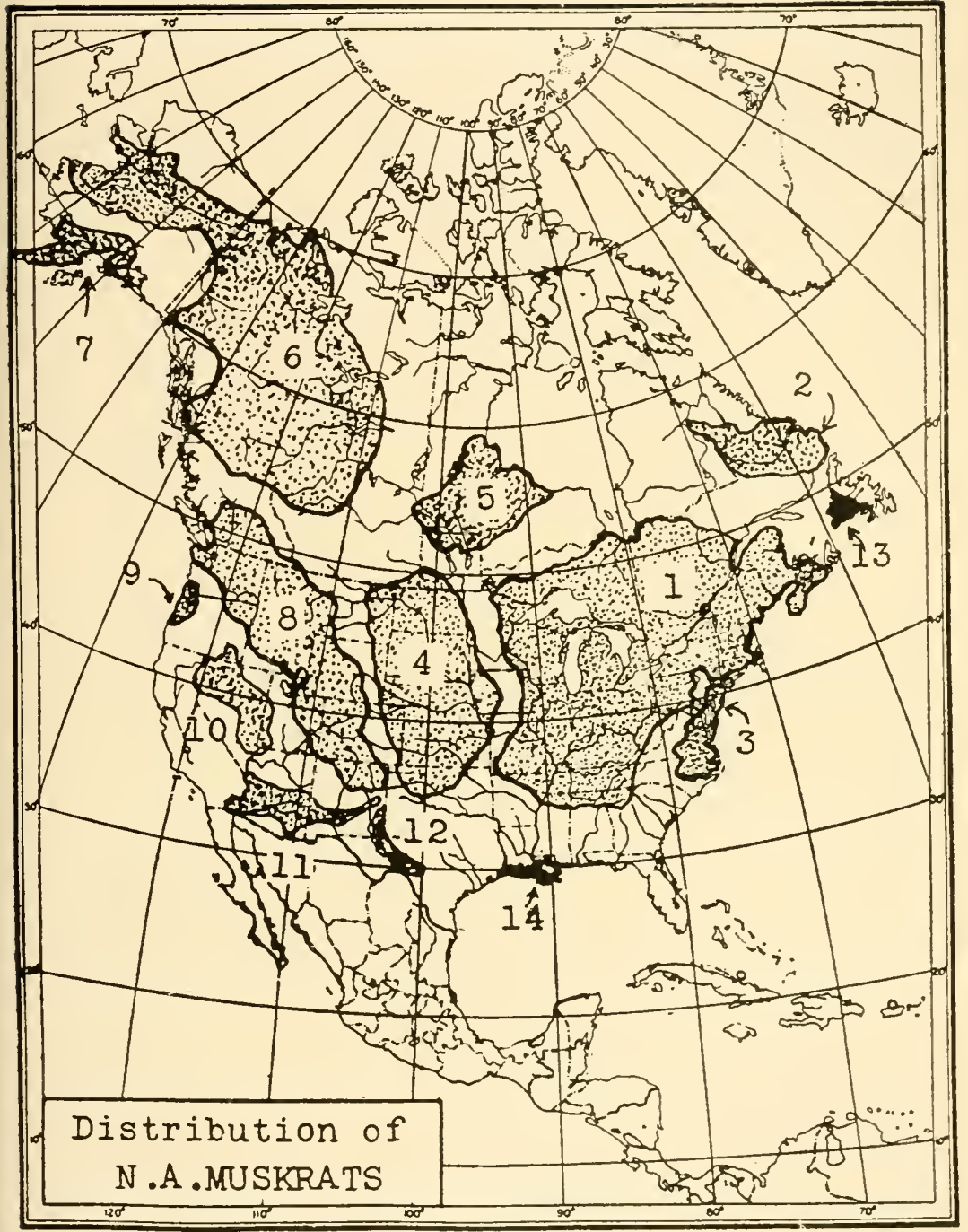

\section{NORTH AMERICAN MUSKRATS}

Their distribution and species according to Hollister. The muskrat is indigenous only to North America, being found nowhere else in the world. The Louisiana muskrat is the most southerly form and the most abundant. Only three species are scientifically recognized, the common muskrat, which has twelve geographic forms or sub-species; the muskrat found in the southern part of Newfoundland, and the Louisiana species, which is also sparingly found in Texas and Mississippi. Their common and scientific names, with the key to their distribution on the chart above, are:

1. Common American muskrat (Fiber zibethicus). 2. Labrador muskrat (F. $z$. aquilonius). 3. Middle Atlantic coast or "black" muskrat. (F. z. macrodon). 4. Great Plains muskrat (F.z. cinnanominus). 5. Hudson Bay muskrat (F. z. albus). 6. Northwestern muskrat (F. Z. spatulatus). 7. Alaska Peninsula muskrat (F. z. . 8. Rocky Mountain muskrat (F. z. osoyoosensis). 9. Oregon Coast zalophus). 8. Rocky Mountain muskrat (F. Z. osoyoosensis): 11. A rizona muskmuskrat (F. z. occipitalis). 10. Nevada muskrat (F. z. mergens). 11. Arizona muskmuskrat (Fiber obscurus). 14. Louisiana muskrat (Fiber rivalicius). 
Until 1895, the Louisiana muskrat was suuposed to be identical with the muskrat of the eastern United States, but Dr. Outram Bangs, of the Museum of Comparative Zoology, of Harvard University, Cambridge, Mass., in that year described the specimens collected on Burbridge plantation, near Belair, Plaquemines parish, as differing from the common muskrat and named our race Fiber zibethicus rivalicius, giving it a subspecific rank. Later investigations proved that it differed from the other muskrats of the North American continent in such a degree that it was entitled to a full specific standing, and then became Fiber rivalicus, the specific name meaning "river loving."

\section{The Louisiana Muskrat}

The Louisiana muskrat is the most southerly distributed species or form in North America, being found only in the southern part of the state, as has already been pointed out, with a few in eastern Texas in an area bounded on the east by the Sabine river, on the north by a line 20 miles south of the Southern Pacific railroad tracks, on the west by a line 40 miles west of the Sabine, and on the south by the Gulf of Mexico. The few found in the state of Mississippi are located in the marshy stretches adjacent to Pearl River, although it appears they once inhabited the Pascagoula Bay marshes in some number's.

Being the most southerly distributed muskrat is the reason, perhaps, that its pelt is known to the fur trade as "Southern Rat," but considering the enormous production of this animal by this state, it should in the future carry the more correct designation of "Louisiana Muskrat," by which it was known to the fur trade fifteen years and more ago.

Although handicapped by a common name that is a misnomer-for it is not a rat, if we liken all animals bearing this designation to the common house rat-it has gained popular favor among the fur wearers. While sporadic attempts have been made to rename it, the name muskrat continues and so popular has become its fur that even the name "muskrat" is becoming stylish. 


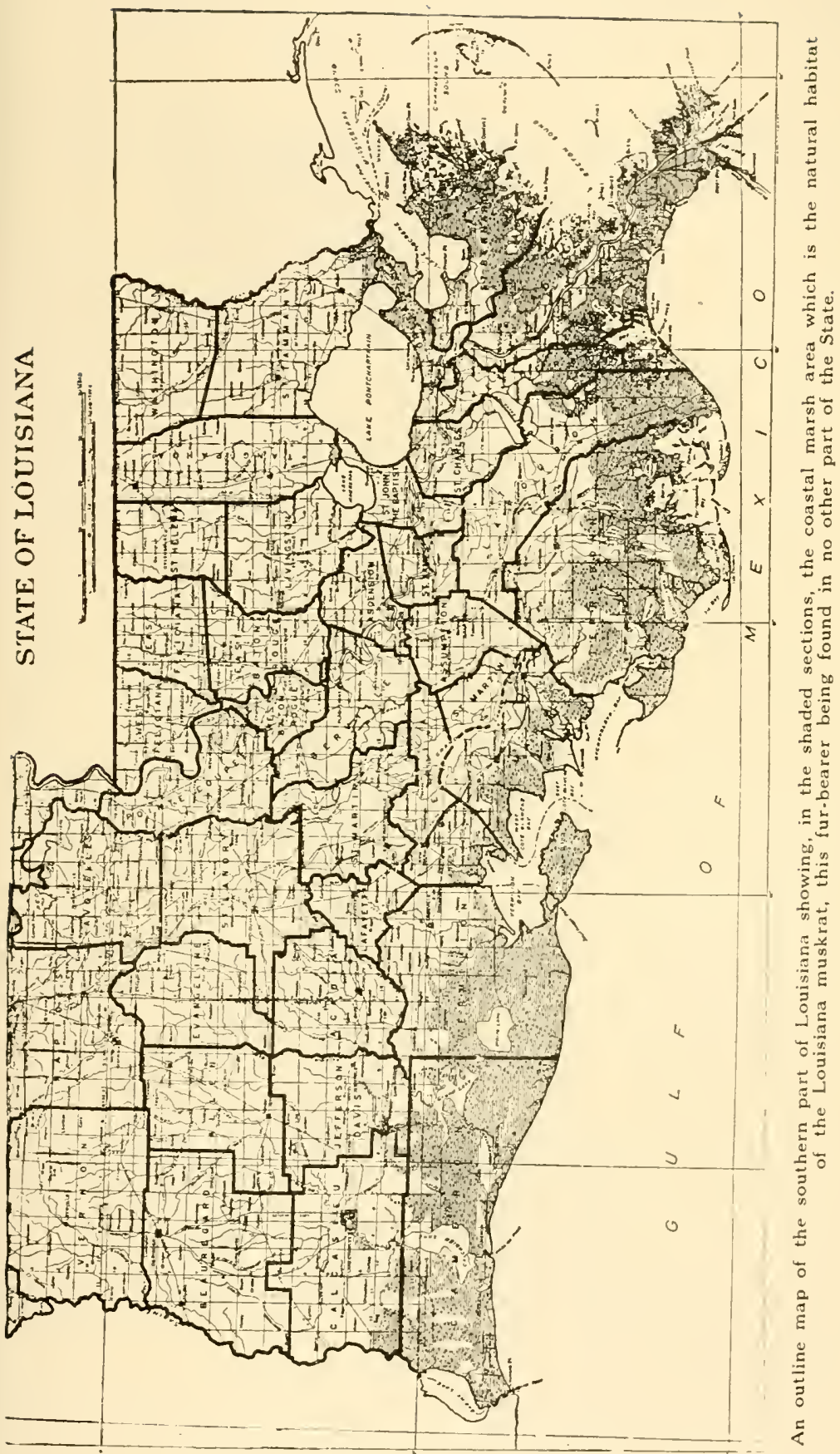




\section{WhERE IT GOT ITS NAME}

The animal gains the musk part of its name from its strongly developed perineal glands which secrete a powerful musk which both male and female discharge in the form of an odor when sexually excited.

It was not originally called the muskrat, and even today the London fur market persists in calling this fur animal by its Cree Indian name of Musquash. The first published description of the muskrat is to be found in "A map of Virginia, with a Description of the Countrey, the Commodities, People, Government and Religion Written by Captaine Smith, sometimes Governour of the Countrey." The author was none other than Captain John Smith whose name is so dramatically associated in early American history with that of the Indian maiden Pocahontas.

The doughty captain, writing in 1612-and the description will be found on page 14 of that historic work-said: "Mussacus is a beast of the forme and nature of our water Rats, but many of them smell exceedingly strong of muske."

But where he got mussacus or why he used it is not known. The probabilities are that this name was the Cree Indian designation, or, at least, the captain's way of spelling the word the savages of Virginia used in indicating this animal.

The "Musk Rat" was so named as far back as 1635. It was apparently christened by one of the Jesuit fathers who pursued his holy vocation in the neighborhood of Quebec. While Father LeJeune appears to have been the first of the early Jesuits to mention this fur animal by the name which has since become its common designation, there may have been others who also applied this French term to the little animal. As he wrote in French, the term was Rat musqué, the free translation into English being the common name it bears today.

From Father LeJeune's diary, for $1635,{ }^{25}$ we translate the following:

${ }^{25}$ Jes. R+1. $\$-45$. 


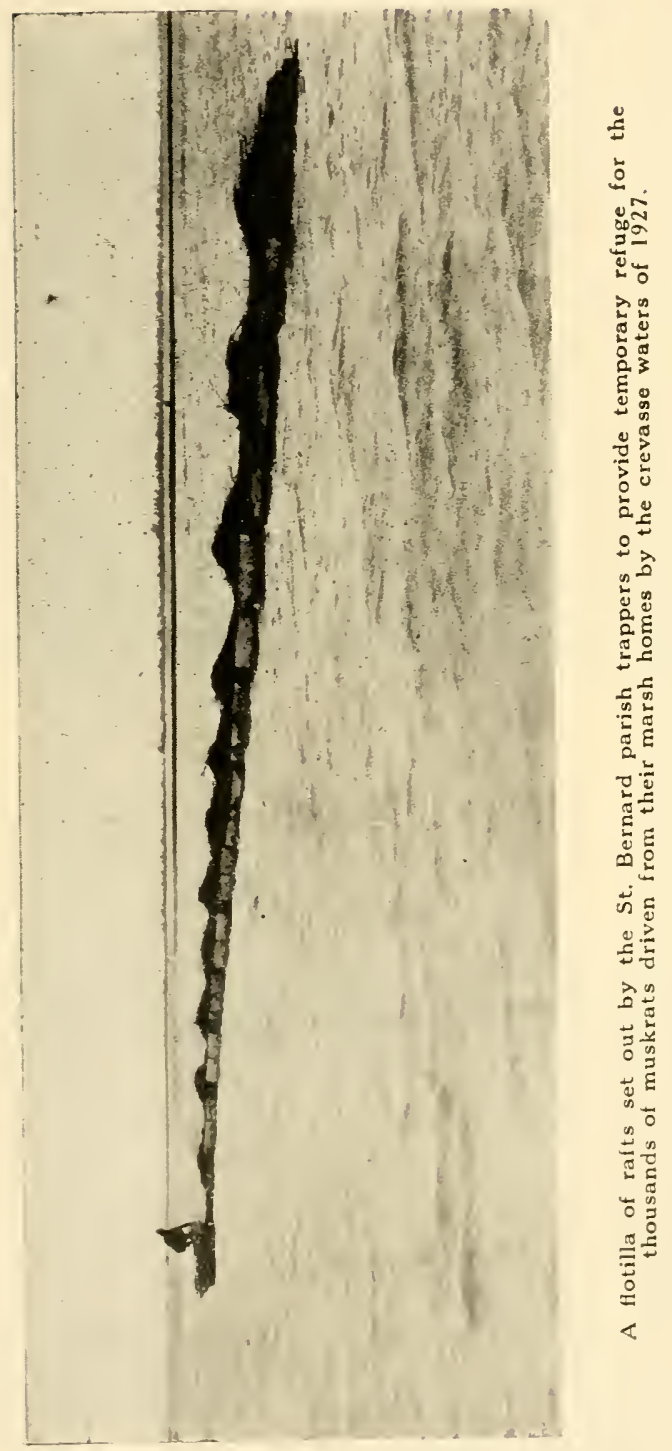


"On the way I saw a Musk Rat hunt. Some of these animals are as large as rabbits; they have very long tails. When they appear in the water the Savages follow them in their little canoes; these rats, upon seeing themselves pursued, immediately dive into the water, their enemies hurrying quickly to the place where they expect them to come up again to take breath; in short, they pursue them until they are tired out, so that they must remain above the water for a little while, in order not to suffocate; then they knock them down with their paddles, or kill them with arrows. When this animal has gained the land, it usually saves itself by hiding in its hole.

"It is called Musk Rat because, in fact, a part of its body smells of musk, if caught in the Spring-at other times, it has no odor."

Or, as expressed in French:

"On l'appelle Rat musqué, parce qu'n effect une partie de son corps prise an Printemps feut a musc, en autre elle n'a point d'odeur."

It was the same Jesuit, it is believed, who set down, in about 1656 , the following passage:

"There are found in these regions of America, animals to which the French have given the name of Musk Rats, because in truth they resemble the rats of France-except that they are much larger-and smell of musk in the Spring. The French are very fond of this odor; the Savages dislike it as if it were a stench." ${ }_{26}$

In order to prove that the French-speaking inhabitants of Canada were responsible for the designation of "Musk Rat," it might not be amiss to quote from La Honton, 1687, who, in his "Travels in Canada," set down:

"In the same place we killed some Musk Rats (Rat Musqué) or a sort of animals which resemble a rat in their shape, and are as big as a rabbit. The skins of these rats are very much valued, as differing but little from those of beavers." 


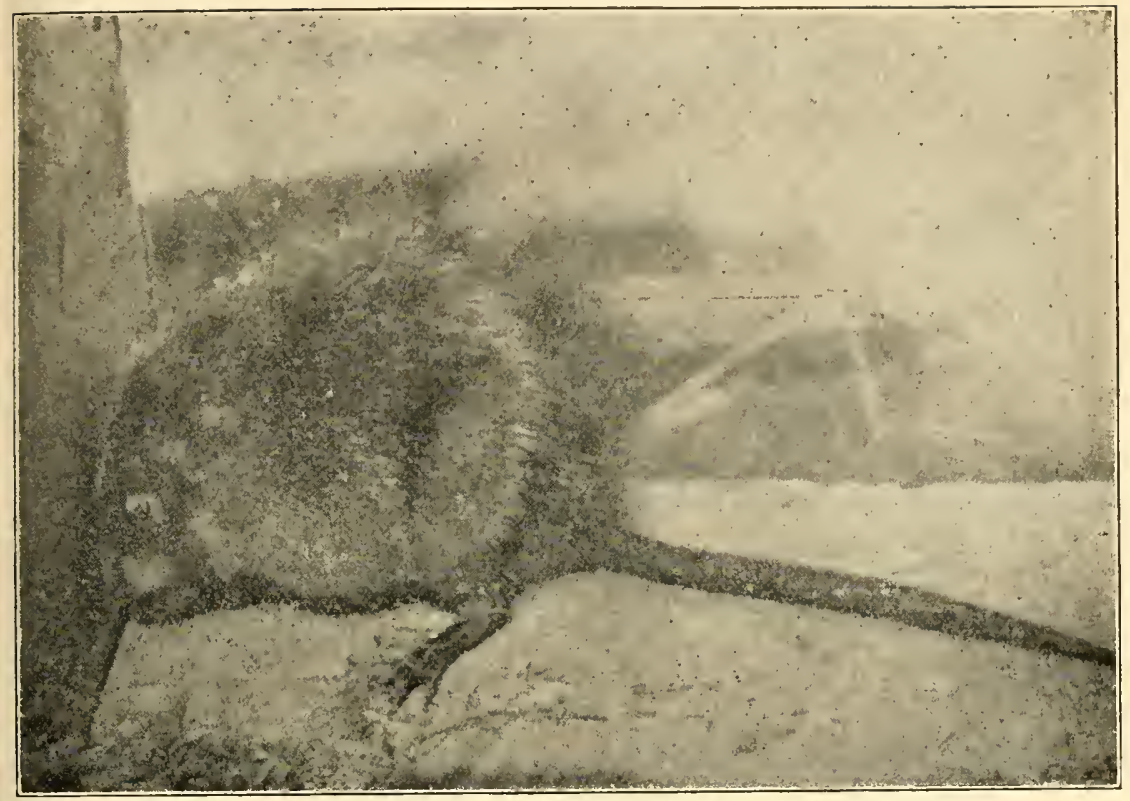

- Mhotoririph Wy Ternon Briley

The Louisiana muskrat, whose pelt is worth approxmately five million dollars to the trappers of the State annually.

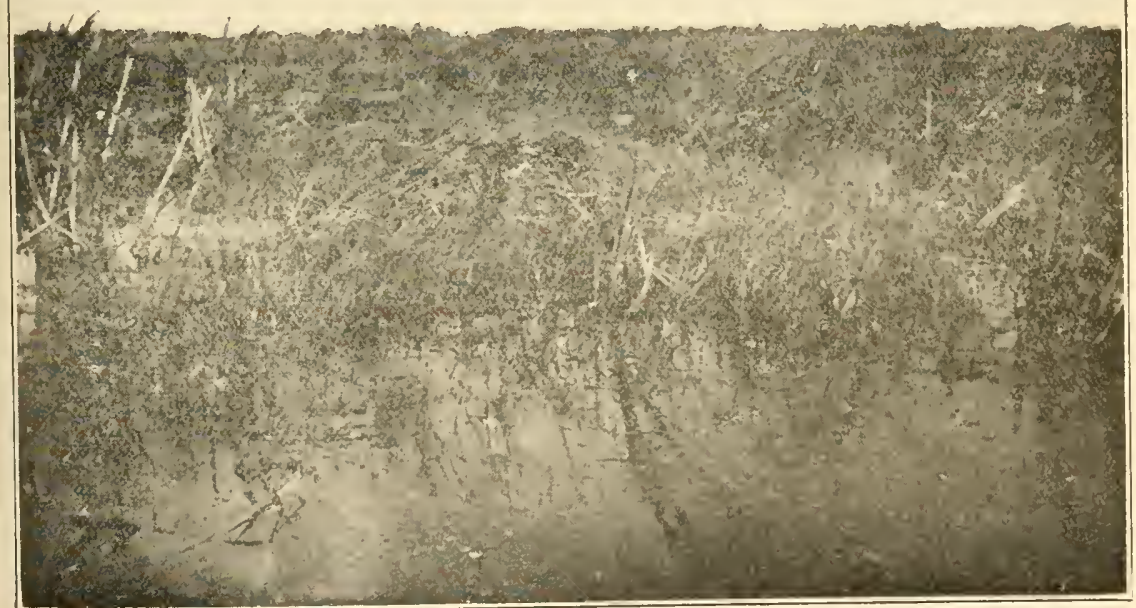

A muskrat "house" in the marshy coastal flats. 


\section{The Earliest Mention of the Louisiana Muskrat}

Short, interesting observations on the dress of the Indians, containing the earliest references to the Rat musqué in Louisiana, are those found in the journal of the voyage made by Father Gravier in the year 1700, and many other valuable data may be gathered from the rare and littleknown but monumental work, "The Jesuit Relations." In it we find what is evidently the earliest printed reference to the Louisiana muskrat and the use of its pelt as a garment.

In 1700 Jacques Gravier, S. J., left what is now called Chicago for a voyage down the Mississippi river to visit. Iberville's new fort, being the first Jesuit to descend the great Father of the Waters to its mouth. This journey is. described by him in a letter, under date of February 16, 1701, to Jacques de Lamberville, in which the missionary describes his different adventures while on the perilous canoe trip.

When describing the dress of the Tunicas, an Indian tribe whom Father Gravier visited in November, 1700, the Jesuit wrote:

"Most of the men have long hair and have no dress. but a wretched deerskin. Sometimes they, as well as the women, also have mantels of turkey feathers or muskrat skins well woven and worked." 27

On December 3, 1700, Father Gravier recounted what. he had observed when he visited the Houmas (more properly, the Oumas, an Indian tribe who settled the land now known as East Baton Rouge and West Baton Rouge parishes). After stating that the children, the men and the young men "are ragged like the Tounika Indian," he goes on to say:

"The women wear a fringed skirt, which covers them from the waist to below the knee. When they go out of their cabins they wear a robe of muskrat skins or of turkey feathers." 28 


\section{leur Cabane}

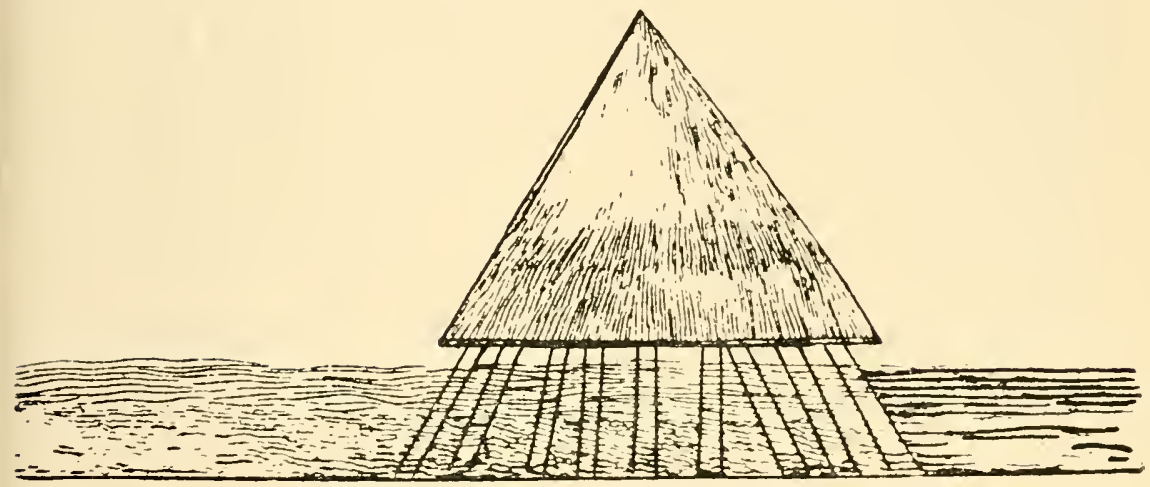

The early writers of Louisiana history in describing the life of the Gulf Coast Indians made frequent references to the Catane of the aboriginals, leading many to believe that they lived in "cabins." As the illusiration in Le Page du Praatz's history shows, we would term the Cabane a "wigwam" or a "tepee."

The original French version being:

"Ouand elles sortent de leur Cabanne elles se couvrir d'une Robe de Rats musquez ou de plumes de cocqs d'Inde."

[A cabanne is French for what we now call a "wigwam" or "tepee."]

We are told that the Cree Indians of the Atlantic Coast called this rodent musquash or vatsus or wachush. [Was this what Captain John Smith meant by his mussacus?] and that musquash meant: "The little animal that sits on the ice in a round form." Quite a description of one guttural two-syllable word. The Huron Indians called the muskrat ondrata, a word that has been proposed by some naturalists as its scientific generic name instead of Fiber.

Our own Gulf Coast Indians called our muskrat by several names, the Choctaws naming it pichali; the Ofo Indians terming it ani oklose, and the Biloxi calling it xanaxpe, but the original names bestowed on it by the Tunicas. Chitimachas and Atakapas seem to have been lost. 
Today, when using the French tongue, the Acadian and Creole trappers of the Louisiana lowlands refer to this animal as a rat musqué, but when speaking English call it a "muskrat." In the Delacroix Island section of Louisiana, in St. Bernard and Plaquemines parishes, where Spanish is the tongue that has prevailed for generations, the trappers call this animal rata, which is, of course, merely the Spanish translation of the common and objectionable word rat. Sometimes these Spanish-speaking trappers will call the muskrat rata almizcle, which means "muskrat," but more frequently this expression is contracted to something that sounds like "meeth quin."

\section{The Life History of THE Muskrat}

Designed by nature for an aquatic existence, the muskrat is clothed with a fur that is dense and waterproof, and it is this provision of nature that has made its pelage valuable in the fur marts. It is an excellent swimmer, and is without a peer as a diver, for it is able to remain under water for a remarkably long time without being forced to come to the surface for air. When disturbed and suddenly affrighted, it leaps into the water, and, diving, makes a loud noise by striking its tail against the surface. It is not strange, therefore, that the Indians called the muskrat "a little cousin to the beaver."

The world-wide and ever-increasing demand for furs, the decrease in the supply throughout the globe, and the discovery that the natural pelage of heretofore inconspicuous herbivorous mammals not only equals but often excels the beauty of fur found on meat-eaters, has conspired to raise the value of Louisiana pelts from the 5 cents average of 1914 to the $\$ 3.00$ valuation quoted by the New York Fur Auction sales of the autumn of 1927.

While this exceptionally high price was not to be maintained, it is possible that its brief ocupancy of a niche in the nouvecu riche class may bring about a proper, if belated, appreciation and recognition of the beauty of this 
subtropical fur in its natural state and assist the animal in living down the ratty termination of its popular name.

The rapid and alarming extermination of the rarer fur animals, especially those species which must give way before the advent of man and the changes he has wrought in the settlement of the country, means the heretofore inconspicuous muskrat has become the most important fur animal of the New World, if not the Universe itself, and it has been aptly described as "the short and simple animal of the poor."

Although its numbers have been depleted in certain sections of this country and Canada-in some places to an alarming extent-the muskrat lends itself, under the protection of the proper state laws, sane and conservative trapping operations, honest and economic handling of the pelts by the raw pelt dealers or middlemen, to the development of a great industry through the utilization of virgin marsh lands for the natural rearing of this fur animal. Such marsh utilization will mean the immediate estoppel of illconsidered drainage of lands for "development schemes." A comprehensive investigation into this animal's life history in the various parts of its range is needed so the musklat may furnish a constant supply of choice fur, add to the creature comforts and styles of our womenkind, and become an important factor in the wealth of our state and country for generations to come.

The muskrat is known to be a prolific breeder when food and water conditions are suitable. Proper food, plus water, is the very important factor in raising muskrats in the wild state; in semidomestication, such as on rat ranches of 100,000 acres or more, or in confinement such as on fur farms. The ranching or farming of these animals will not be gone into here, as it is fully treated in separate chapters in this bulletin.

We do not know all we should about this animal's breeding habits. This holds as good in Louisiana as in Manitoba, in Maryland as in Alaska. One is inclined to 
agree with Hollister and Lantz that breeding habits doubtless vary with climatic conditions.

Ernest Thompson Seton, ${ }^{29}$ in 1909 , gave the period of gestation of the muskrat, in the north, Manitoba, for example, at 20 days. In 1927 Professor Jackson, of the Manitoba Agricultural College, says: "We have as yet no positive record of the one pair breeding three times [in a season], although it is possible with a gestation period of 30 days and a first brood in May, a second in July and a third in September."

On the other hand, as Professor D. E. Lantz ${ }^{311}$ seems to have become the mouthpiece for those who have declared that the period of gestation is only 21 days, it may be well to quote his very words and ascertain how he came to the conclusion that the period of gestation is three weeks. He wrote: "The period of gestation is possibly no longer than twenty-one days, as with the common rat and probably with the field mouse." This indicates he jumped at a conclusion based on researches and first-hand studies of other animals.

But as Professor Lantz adds to this assumption: "The young are blind and naked when born, but develop rapidly," one may be excused from accepting his statement as to gestation too seriously, for neither the Louisiana nor the Labrader muskrat are born naked. To the contrary, it was found, from handling young just born that they are covered with a fine, silky covering of hair which develops rapidly. The muskrat "mice" are, however, born with their eyes closed and they do not open for a number of days.

To indicate the difference between the muskrat and the common house rat, it may be in order to quote Mitchell's observation" that the young of the house rat "which are born naked and blind, are covered with hair on the eighth day and are able to see on the thirteenth day."

\footnotetext{
557.

${ }^{29}$ Seton, E. T., Life Histories of North American Animals, Vol. 1, p. 538p. 15 .

${ }^{30}$ Lantz, D. E., The Muskrat, U. S. Dept. Agr., Farmers' Bulletin No. 396, siMitchell, P. C., The Childhood of Animals p. 4647.
} 


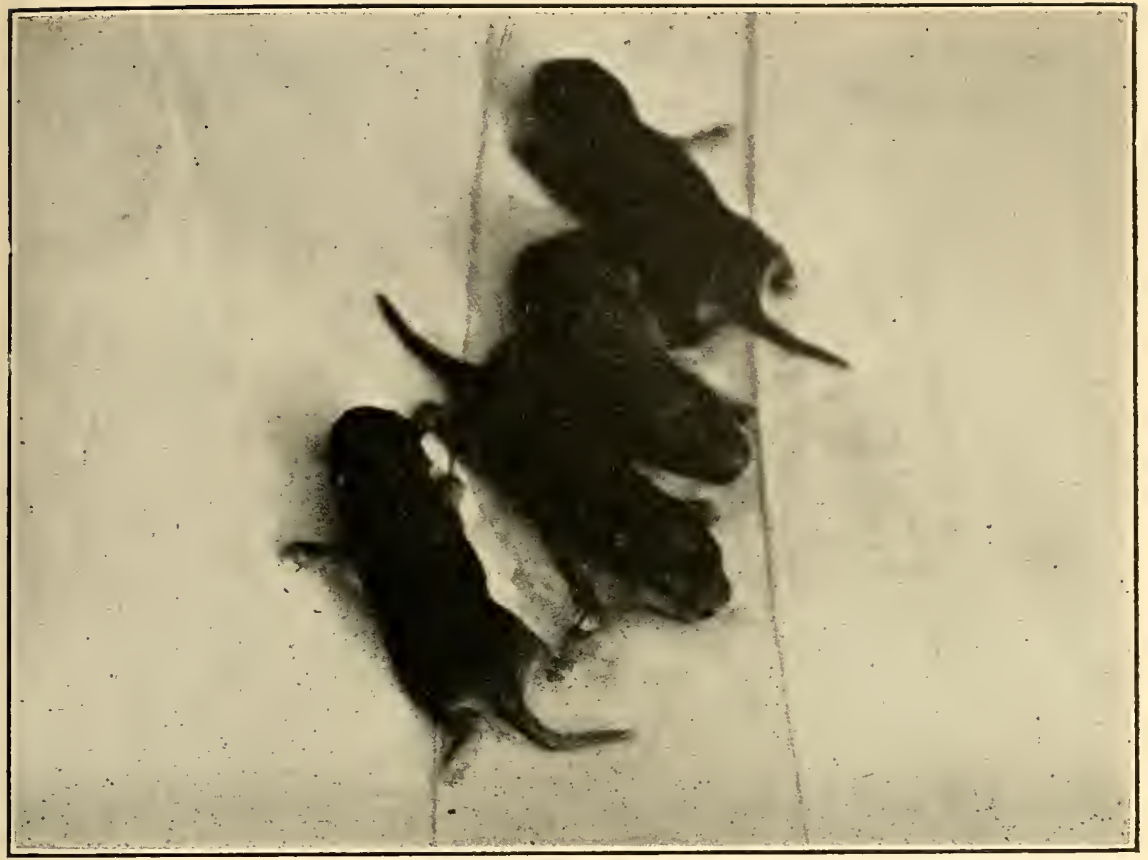

Baby muskrats, known as "mice," a few days old and all from one litter taken from a hill on Marsh lsland in July. Note that the tiny fur-bearers are well furred even this early in life.

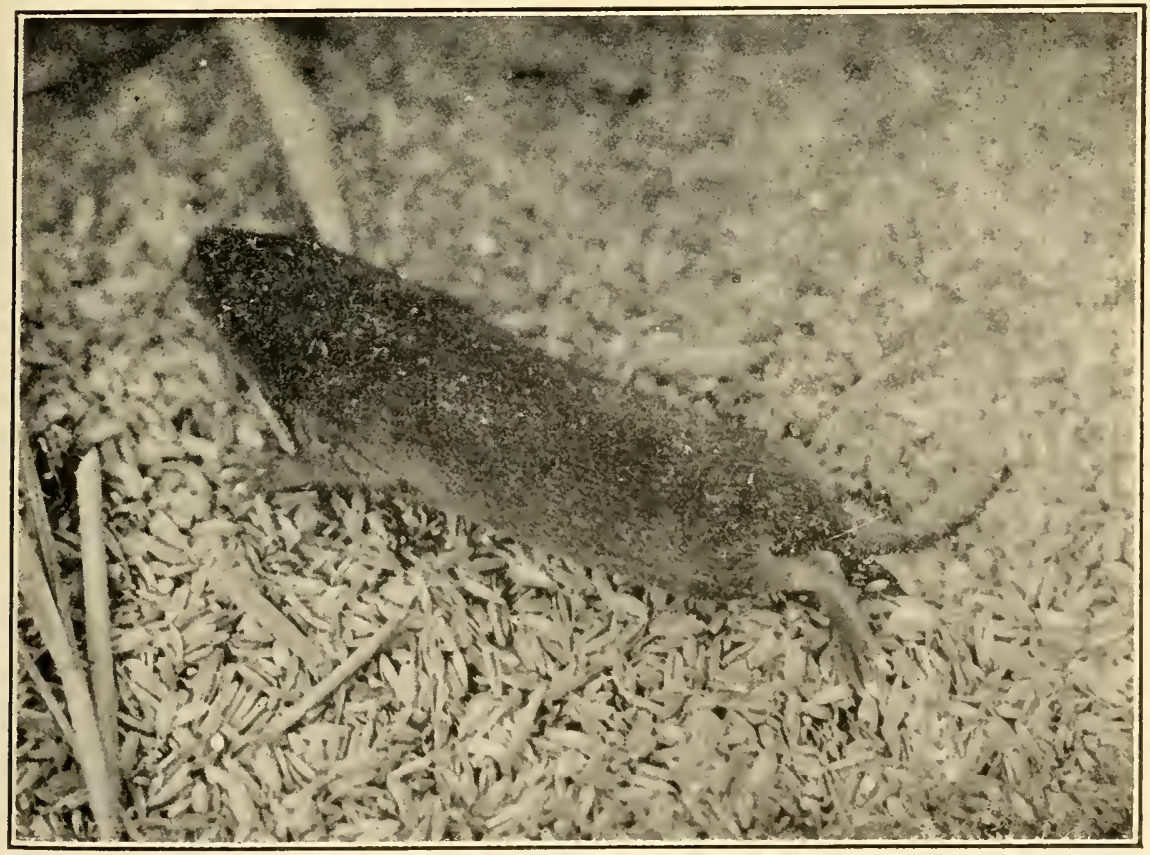

Baby muskrat about five days old. Not only can its fur be noted in the photograph, but the guard hairs are well out. 
As most of the literature on muskrats states that the young are born "naked, blind and helpless," our field biologist was asked to make a special study of this phase of the muskrat's life history, as it had found that they were not "naked" when very, very young, and during his field investigations Mr. Svihla collected a series of embryos of varying sizes. He reports that "some of the largest had a distinctly sparse covering of their hairs, particularly evident under a low-power lens. The hair covers most of the muskrat with the exception of the top of the head, where internal development is still going on. Evidently this is the last portion to be covered with hair. In still smaller embryos no hair can be seen, but the hair folicles are clearly visible. A very young mouse, evidently recently born, was taken which had a thin covering of hair, even on its head. It was no larger than the largest embryo we have.

"Further investigation of young mice showed that the sex can be easily told before the guard hairs have developed on the bellies. A fine gray down was found to cover the bellies and the mammae of the females are plainly discernible. By the time the eyes open the fur begins to get darker, larger and thicker, and the mammae are soon covered.

"During the investigation of the external appearances of the muskiats when young, two cases of females with ten mammae were found-six pectoral and four inguinal."

It seems very evident that many writers, noting the close relationship between the muskrat and the so-called meadow mouse (Microtus), and, having proved out the period of gestation of the meadow mouse in captivity, blindly accepted the 21-day gestation period, because the muskrat is in reality only a highly specialized enlarged meadow mouse, or vole, as it is sometimes called.

While we in Louisiana, in spite of our researches, have not as yet proved the gestation period of the Louisiana muskrat, it would appear at this writing that it is longer than 21 days and nearer Mr. Seton's estimate of 30 days. 


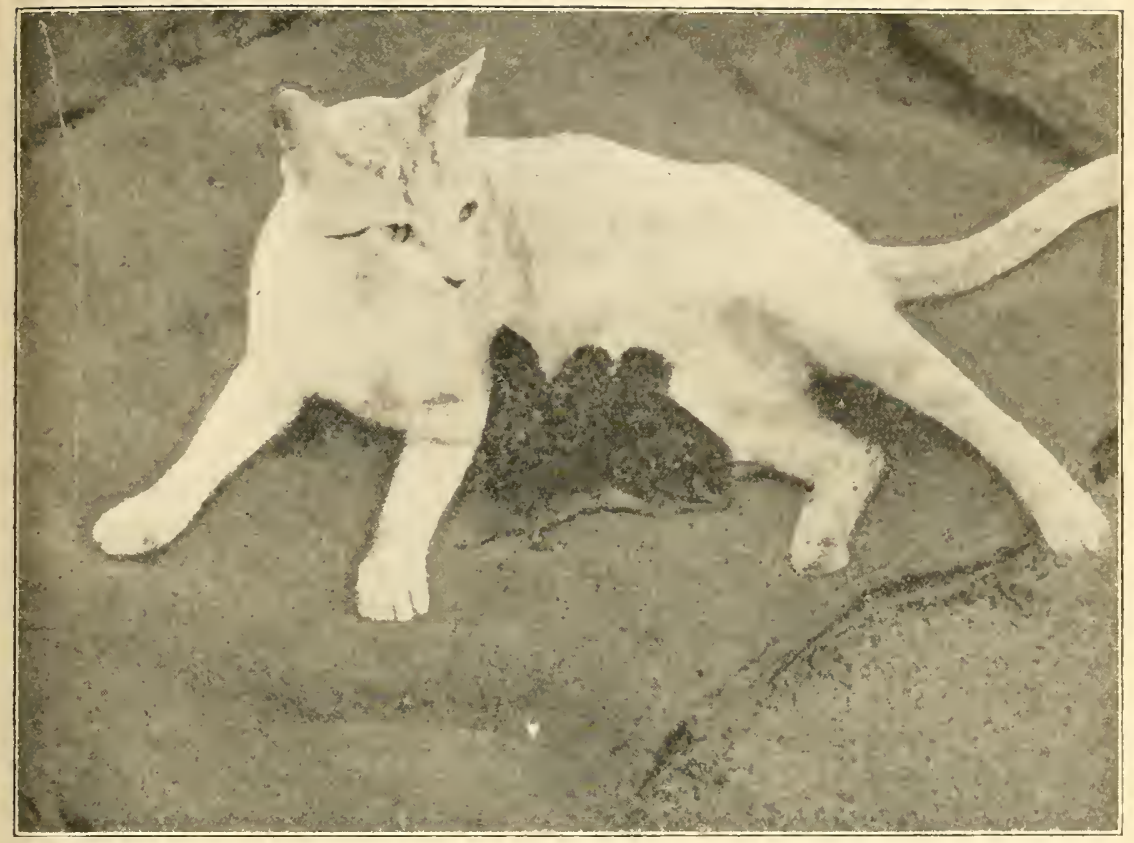

A contented tabby actin as toster mother to mice (baby muskrats) and disproving the oid tale of $\mathrm{uhat}$ cats will do to mice. The cat was pressed into service during the Department's survey of the muskrat injustry in an attempt to rear the baby fur-bearers artificially.

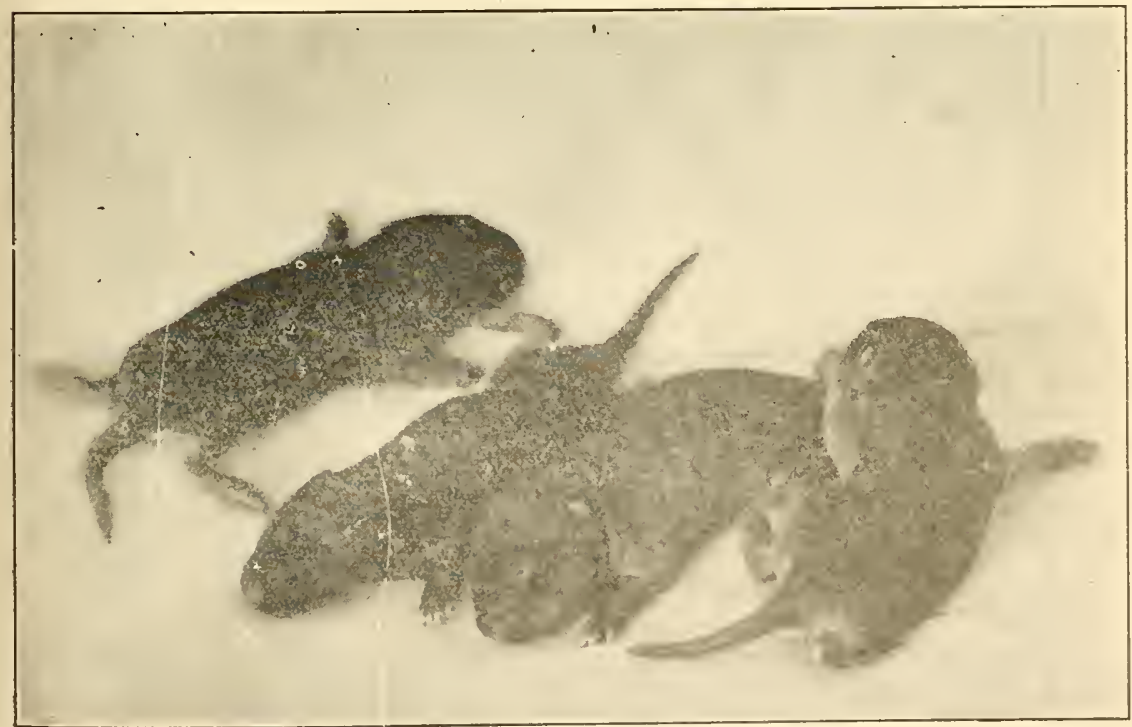

- The baby muskrats, "blind," yet fully haired. 
This, too, would indicate that our muskrat does not have the number of litters a year that has been attributed to the species, and as the matter of reproduction is of such importance because of its direct relation to the future supply, considerable attention needs to be given it here.

From experience and field studies it appears as most probable that the Louisiana muskrat breeds throughout the year with the exception of the hotter months of the late summer. This may be the reason our trappers secure such a large number of "mice" and "kits" when the trapping season begins and is but another reason why the state's lawmakers should forbid trapping before the first day of December of each year and, if it is necessary to have a 75-day open season, the trapping of muskrats should be allowed to continue to February 15.

Because of the subtropical climate of Louisiana in the winter months, there is no cessation of sexual activity among the muskrats here such as prevails in the north when the winter cold makes this animal inactive in almost all matters.

In Louisiana the exact opposite condition prevails. Ask any experienced 'rat trapper and he will tell you that a cold, snappy, frosty night means that the muskrats have been active, on the go, and his round of the traps in the morning will prove this by the large number of animals he will dislodge from the traps.

Following a warm, muggy night the trapper will know that his traps will be unsprung when he makes his rounds in the morning, as the animals he is after had been most inactive when darkness shrouded the marshlands.

Investigations during the past fifteen years indicate that very little breeding is done during the months of August and September, and that a large percentage of the females taken during the winter months will show breeding indications, either by the appearance of the mammae which have been suckled, or by the fetuses found in the uterine horns.

As the fur is prime only in the winter months, we cannot, economically, arrange the trapping seasons at that 
period of the year, when these animals are not breeding at their heaviest, for furs taken during August and September are unprime, destitute of fur and guard hairs"barebacks" the trappers call such animals. "Trash" would be a better word.

Counts of females containing embryos have r'un as high as $37 \%$ during cold winters to $26 \%$ during mild winters, and the catch of kits has been in ratio to the early or late fall the state experienced.

It is evident that being born blind (but not hairless) is a wise provision of nature to keep the young with the mother until they may venture from the nest site prepared, in a measure, to protect themselves by scampering away from such natural enemies as hawks by day and owls by night. Just how long the little "musk mice" (to quote an enthusiastic but unscientific correspondent from Cleveland) remain blind has not as yet been satisfactorily determined. It is a mistake to refer to the house rat, by way of analogy in this or any other regard when considering the muskrat, but, as the muskrat is so closely related to the meadow mouse, it may not be out of place to compare this period in the muskrat to that of Microtus. Vernon Bailey shows this to be "approximately 21 days," and his bulletin"3* on this member of the rodent family is a most valuable and interesting contribution to our knowledge of this tiny inhabitant of the marshlands.

That the young of the Louisiana muskrat does not open its eyes before the twelfth day seems to be amply proved. One specimen, fed on artificial milk, and kept alive for 17 days, never opened its eyes. The specimen was possibly one, two, or more days old when taken. This umatural feeding was undoubtedly responsible for the failure of the eyes to open. It seems quite definitely established that parental care devolves on the mother wholly, but the exact duration of the suckling period is as great a mystery as that of the time of gestation. It is quite probable, however, that the young are a month old, at least, before they begin

\footnotetext{
32Vernon Bailey: Breeding. Feeding and other Life Habits of Meadow Mice, Journal of Agricultural Research, vol, xxvii, p. 528.
} 
feeding for themselves off the tender roots of threecornered grasses, although our field biologist fed them on such artificial foods as rolled oats and corn. One trapper in February, 1927, fed two captive "blind" mice on sweet potatoes four days before their eyes opened. They were released a few weeks later.

Just how many young the Louisiana muskrat has in a litter is as moot a question in our part of the continent as it is in the more northern sections. It is a fact that has never been definitely fixed by any who have written on the muskrat. As has been pointed out by Dr. Charles E. Johnson, ${ }^{33}$ the most reliable data as to the number of young produced at a time are furnished by records of embryos contained in the uterine horns, but the same author wisely points out that the number of intra-uterine young in some species of mammals may exceed the number of young found in a nest, as in the wilds there is a toll taken of all young, this being unvaryingly true of those animals producing large litters.

Seton $^{34}$ estimates the number of young from 4 to 9 in Manitoba, while Jackson, ${ }^{35}$ in the same province, gives the average as 5 young. Dixon ${ }^{36}$ averages the young of the California Imperial Valley muskrat at 6, with 3 and 9 as extremes. Johnson says trappers give 5 to 7 and 5 to 9 to a litter in New York and quotes one trapper as finding 11 embryos in a trapped female. Vernon Bailey found a muskrat in Montana with 13 large fetuses, and Warren in Colorado shows 8 embryos in a specimen he captured.

A typical day's catch of muskrats in Louisiana mar'shes, with the number of mice, kits, damaged, females with and without young, taken is shown in the following table, furrished by Alfred Stark, in charge of one of the trapping camps. It shows the percentage of females in a breeding condition that may be expected in a catch of muskrats during this part of January.

R3ohmson, The Wuskrat in New York, p, 227.

"seton, Life Histories of Northem Animals, 1. 550.

Jackson, liat Ramehing in Vanitoba. p. 2

sildixon, Rodents and Firelamation of Imperial T'alley. Journal of Mammalogy, wol. 3,1 , $1+1$. 
The Fur Animals of Louisiana
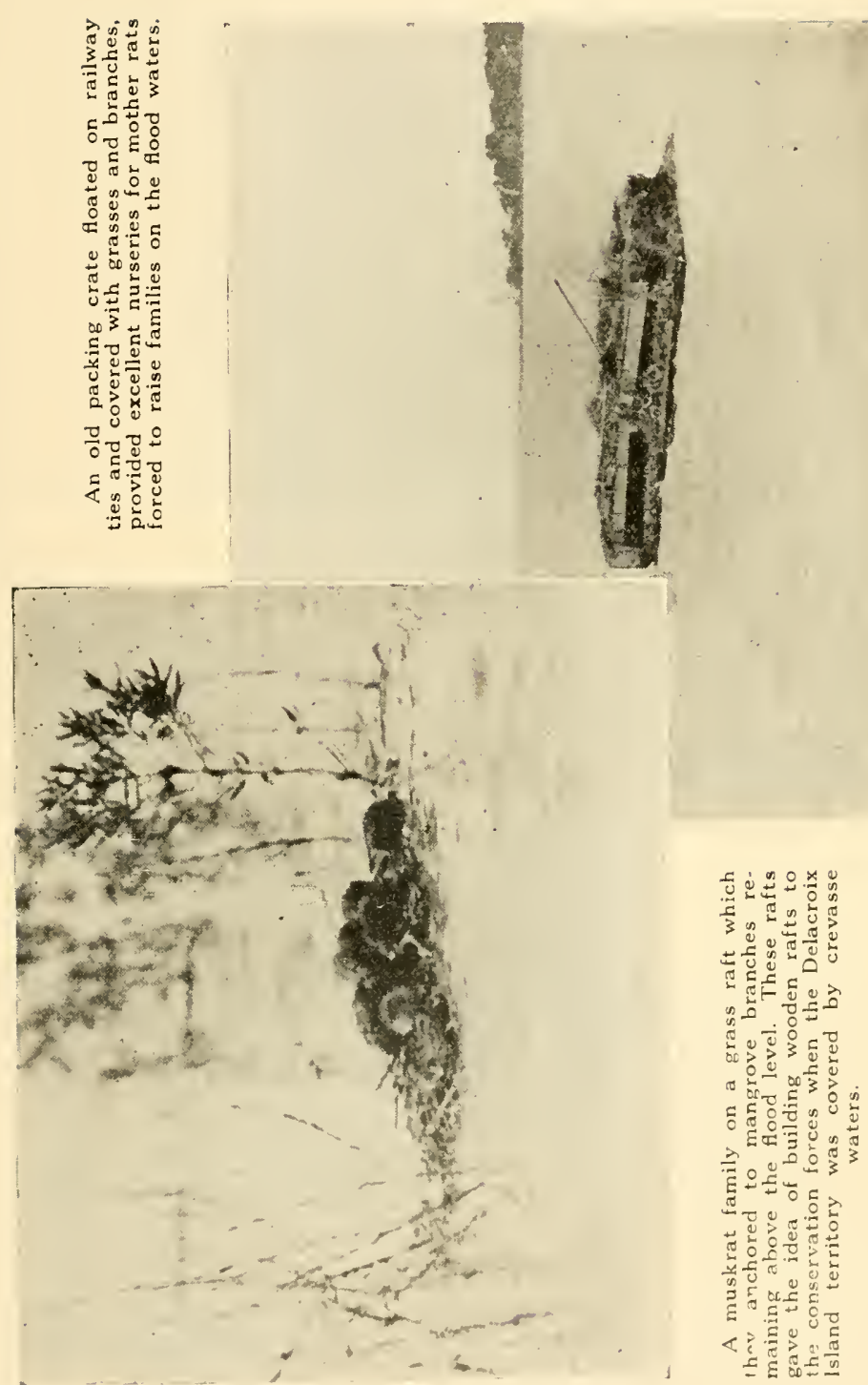
Catch of January 2:, 1028. East Cov =, Camcron Parish.

\begin{tabular}{|c|c|c|c|c|c|c|c|}
\hline Trapper & 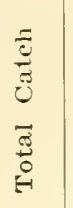 & $\stackrel{巳}{ٍ}$ & 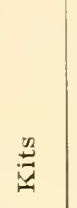 & 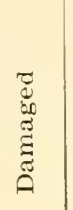 & 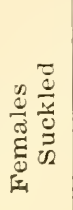 & 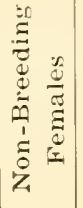 & $\begin{array}{c}\text { Females with } \\
\text { Embryos }\end{array}$ \\
\hline 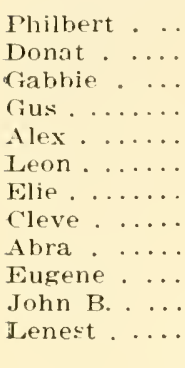 & $\begin{array}{l}45 \\
23 \\
44 \\
73 \\
33 \\
26 \\
34 \\
33 \\
66 \\
56 \\
44 \\
38 \\
\end{array}$ & $\begin{array}{l}\cdots \\
\ldots \\
\cdots \cdots \\
\cdots \cdots \\
\cdots \cdots \\
\cdots \cdots \\
\cdots \\
\cdots \\
\cdots \cdots \\
\cdots \cdots \\
\cdots\end{array}$ & \begin{tabular}{l|}
2 \\
2 \\
3 \\
6 \\
5 \\
1 \\
1 \\
2 \\
5 \\
-1 \\
2 \\
2 \\
\end{tabular} & \begin{tabular}{r|}
8 \\
3 \\
6 \\
7 \\
4 \\
5 \\
1 \\
1 \\
7 \\
11 \\
3 \\
8 \\
\end{tabular} & $\begin{array}{r}\cdots \cdots \\
\cdots \cdots \\
\cdots \\
1 \\
1 \\
2 \\
1 \\
\cdots \\
2 \\
2 \\
1 \\
\end{array}$ & $\begin{array}{r}15 \\
2 \\
9 \\
1 . \\
12 \\
6 \\
5 \\
-4 \\
\vdots \\
17 \\
4 \\
12 \\
\end{array}$ & $\begin{array}{l}1 \text { had } 3 . \\
1 \text { had } 3 . \\
1-4 ; 1-1 ; 1-5 \\
1-1 ; 1-1 ; 1-4 \\
1-4 . \\
1-5 ; 1-3 ; 1-3 ; 1-3 \\
1-5 ; 1-3 ; 1-3 \\
1-5 ; 1-5 ; 1-7 . \\
1-4 ; 1-4 . \\
1-3 ; 1-3 ; 1-3 ; 1-3 .\end{array}$ \\
\hline & 515 & 2 & 33 & 64 & 11 & $11:$ & $\begin{array}{l}25 \text { females contained } 97 \\
\text { embryos, an avearge } \\
\text { of } 3 . \& 8 \text {. }\end{array}$ \\
\hline
\end{tabular}

Suckled females . ........... 11 or $7.3 \%$ of catch

Females with embryos......... 25 or $16.7 \%$ of catch

Non-breeding females . ..........114 or $76.0 \%$ of catch

Total females.

.150 or $29.1 \%$ of catch

The embryonic count is interesting as it shows that our estimate of, practically, 4 to a litter is normal, and that the extremes in the middle of winter are 3 and 7 . In this count 11 females contained 3 embryos, 8 had $4 ; 5$ had 5 ; and 1 had 7.

The "damaced" 'rats reported in the tabulation included only those muskrats whose backs were punctured by birds or other animals. If cnly the belly skin was lacerated it is not ccunted as a damaged. According to Alford Stark, "these domages are caused by a rat which looks like the common old house rat. They cut and eat the flesh of the muskrat, although we know muskrats themselves cut each other when trapped as we frequently find old lacerations on the pelts." 


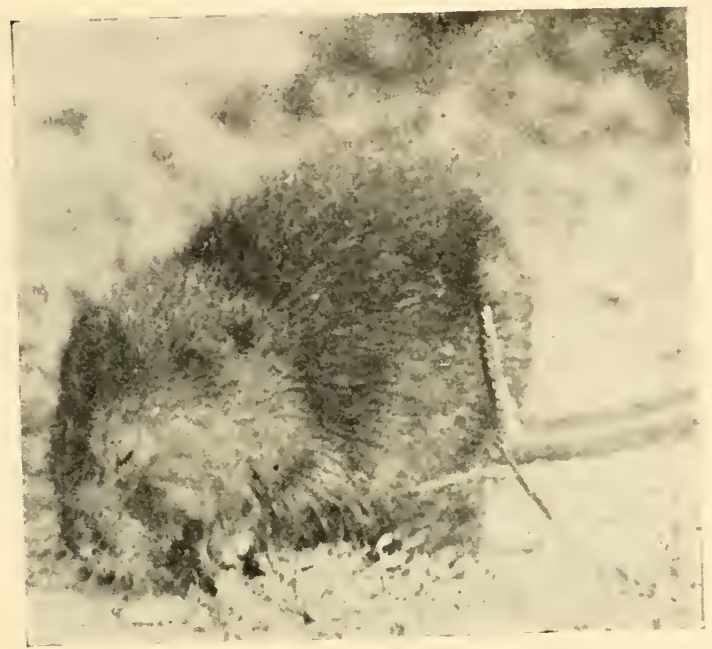

Adult muskrat feeding.

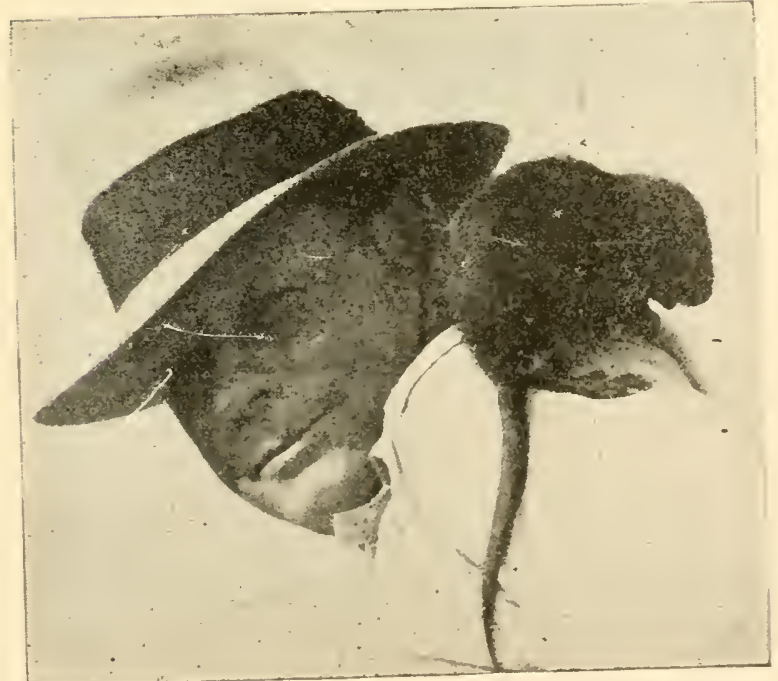

Rescued muskrats soon forgot their inherited fear of man when they were saved from the flood waters. 
A specimen being secured, it was identified as Mus norvegicus, the Norway or common house rat. It was a female and contained 16 embryos.

It is quite probable that the damage done was from the beaks of grackles and blackbirds. It has been found that the common meadow mouse (Microtus) does considerable damage by nibbling on the skins of dead trapped muskrats, but the ordinary house rat has never been considered an enemy until Stark's report was received.

Observation in Louisiana indicates the Louisiana muskrat averages four young to a litter from the following embryonic count:

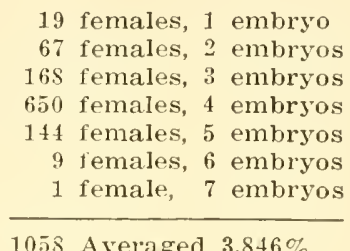

This count, which covers several years, has been made in the so-called highly productive seasons, but it is only fair to point out that the majority of examples cited are from examinations made in the low-production years, and it is noteworthy that the count since 1923-24 and 1924-25 has been decidedly low, and scarcely averaged three to a litter. That this low production a litter may be directly attributable to the drought years of 1924 and 1925 does not appear unlikely, but it certainly does prove that this is a phase that needs investigation; if it does indicate that the years of plenty mean happy and contented animals with large families, then we will have progressed on our search to the reason for mammalian periodic fluctuations.

\section{LONGEVITY}

Investigating the habits of any mammal, particularly a fur animal, calls forth many questions from those engaged in trapping for a livelihood. One of the principal questions that has been asked from one end of the state to the other is: "How long does a muskrat live?" 
The Fur Animals of Louisiana

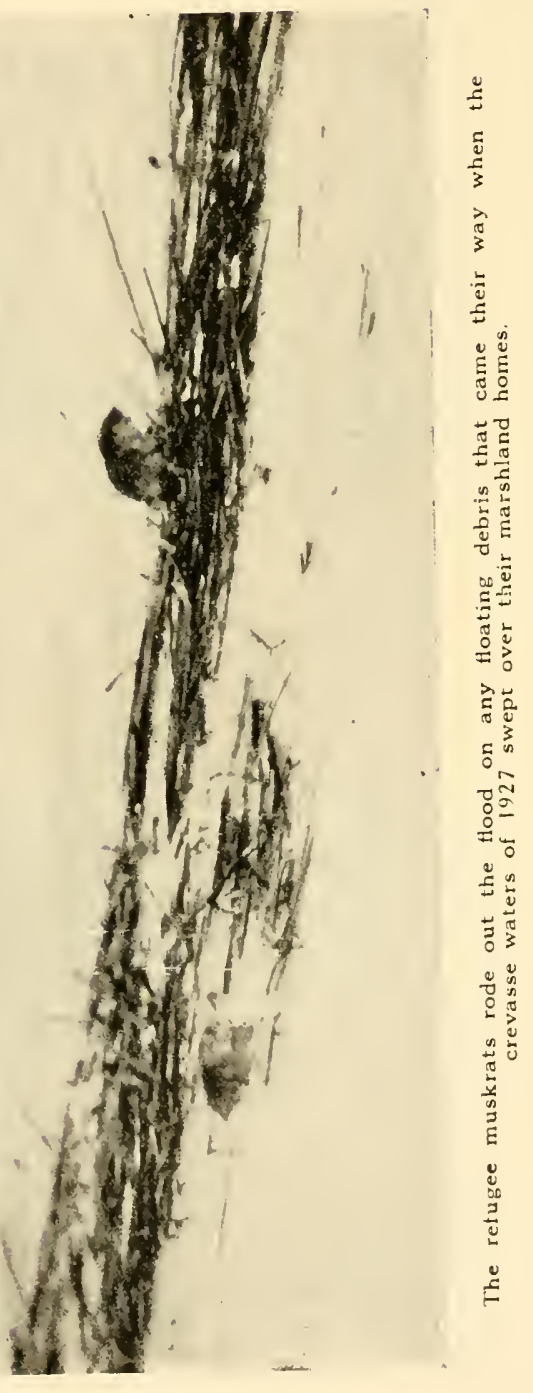


Who knows? Surely not those who have studied this little animal here or elsewhere, for printed literature contains nothing beyond conjecture. Dr. Johnson, after studying the muskrat in New York, admits the difficulty of answering the question, but adds that it is probably within reason "to say that a muskrat may live as long as 10 year's or more."

Close study of the Louisiana muskrat permits several definite statements that approximate exactness in claiming that our animal, at least the females, become sexually mature in six months, although they do not attain physical maturity in less than a year or fourteen months. The number of undersized females, showing indications of having been suckled or containing embryos, seems to prove this.

The so-called oversized muskrats taken are not necessarily very old specimens, or "grandpas," as the trappers sometimes dub them, but merely fully matured specimens that have taken on a great deal of fat.

\section{DifFERENCE IN SEXES}

Sexual differences in coloration or in size are not evident when examining a collection of live muskrats; in fact, sexing a live animal is a difficult matter, and a "sexing box" is necessary to tell a boar from a sow unless one has little regard for gnashed fingers. Scientific study of the muskrat fails to show sexual differences in the skulls.

There are, however, differences of pelage, size, and market value of skins from various sections of this animal's range in Louisiana. Muskrats from the southwestern coastal marsh, Cameron parish, for example, are larger and darker and command the best prices paid by dealers. The animals, too, are known in the local raw pelt trade as "Texas 'rats" and sold on the New York market as such, although taken in Louisiana. The Lone Star State's production in the 1926-1927 season was 30,000, while Louisiana's output of muskrats the same year was in excess of $3,000,000$. 


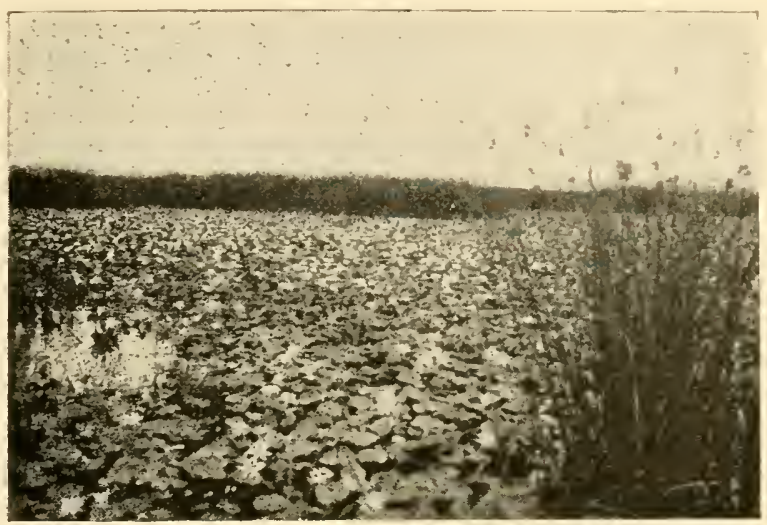

Water lilies in myriad appear in summer in the shallow ponds surrounded by muskrat marshes.

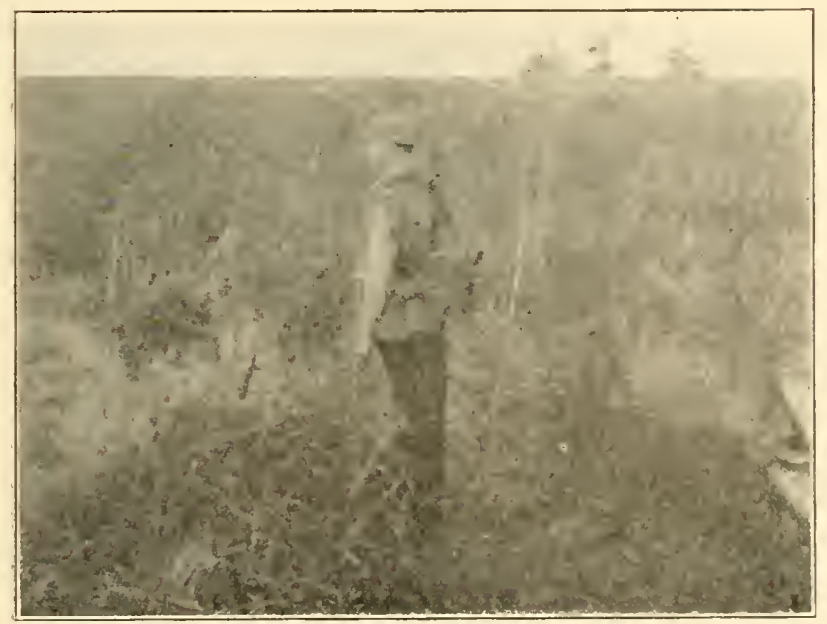

A trapper starts his morning trap run. 
Muskrats occurring in the pronounced saline marshes of Louisiana average smaller than 'rats taken from sweet water marshes and are of a more reddish coloration. These animals do not bring as good a price when offered to the buyer. The Marsh Island 'rat has always commanded a good price, although not as high as the Cameron parish animal, and for this reason muskrats taken in Vermilion, Iberia, and St. Mary parishes are generally sold as "Marsh Island 'rats." The Terrebonne, Lafourche, and eastern St. Mary parish muskrats show marked variations as to color and size and other characteristics of pelt, and these differences, due to local habitats, foods, and water, affect the prices the trappers receive for their catches. Some of our best muskrats are found in the celebrated Delacroix Island section of St. Bernard and Plaquemines parishes, due to the abundance of sweet water and three-cornered grasses.

It is because of these variations that experienced buyer's, trappers, and other handlers of raw furs can readily distinquish the pelts sent in to them, and, unerringly and uncannily, designate the section of the state in which they were trapped. Some of the buyers claim that these differences are regular, and a test given some of these "experts," using skins raw and tanned, seem to indicate that these differences do exist.

Measurements made in the field of freshly taken animals show that the Cameron parish muskrat averages larger and its darker and richer colored pelage is superior to the arerage muskrat of other sections of Louisiana coastal marsh, with the exception of one section of St. Bernard and Plaquemines parishes, which is almost equal in quality, but, acre for acre, far more abundant.

Food does not make this difference, it appears positive, as the same vegetation that cover's the Cameron marsh is to be found in St. Bernard and, if anything, the heavy stands of "three-cornered grass" in the Delacroix Island sections of St. Bernard and Plaquemines are superior to the mixed flora of Cameron. This would indicate that a soil survey is as necessary in this branch of the study as a survey of the food plants. 


\section{Breeding Habits}

It is quite evident from field experiences that the muskrat is polygamous and this conclusion is in accord with the beliefs held by all of the experienced trappers.

While a number of writers have stated that the muskrat is monogamous, and seemingly base their conclusions on evidence that these animals work in pair's when constructing houses, both carrying the building materials and foods, it does not seem to be the case in Louisiana. Ernest Thompson Seton in his life histories of Manitoba animals sets forth that this trait of the male in assisting in bringing up the young is characteristic only of monogamous animals.

In this state careful investigations indicate that, while pairs, a male and a female presumably, do work on a single house or "hill" at the same time, other observations show that pregnant females will construct a house alone and unaided, and several cases of a solitary male making himself a very large and commodious dwelling place have been noted. In each case, the animals were trapped to make sexual identification positive and the house kept under daily observance to obtain data as to rate of construction.

Trappers know well that it is the habit of the boar to travel a great deal, forcing his attention on all females encountered while on his nocturnal love foray. Two males meeting on these quests fall to fighting, they believe, and these combats are the cause of cut and gnashed pelts frequently found on trapped specimens.

The fact that the fur animal we are so interested in is largely nocturnal, even in sections where its domain is not subject to intrusion by man or inquisitive scientists, makes a study of its life history in the natural state difficult. As it is not given to extensive or prolonged daylight activity, we have to arrive at a number of our conclusions a la Sherlock Holmes, by deduction; therefore, a number of conclusions that follow are set down as a result of study of things seen and things deduced from the evidence presented. 
Johnson in his very interesting and valuable bulletin on the New York muskrat quotes two trappers of western New York as saying: "After mating, the male muskrat seems to go into hiding or retirement. These men make it a practice, they said, in their spring trapping, never to set traps near the muskrat houses, and for that reason catch few females, since the males alone travel about in search of mates. When the females have mated they become more active, wandering about a great deal more than at other times, and are taken in traps in numbers. This is the signal for these men to take up their traps."

This observation is quoted for two reasons: the mating season, following the winter quiscence, begins in western New York during the month of March, depending, naturally, on the lateness of the spring; therefore, a decided mating movement animates the species as a whole at one and the same time, while in Louisiana the sub-tropical winter has evidently no deterring effect on mating performances. Here. it should be pointed out, we have not seen any evidences of the male going into retirement or "hiding" after carrying on his mating forays. To the contrary, the boar seems to be continually on the go, except when he is busy fixing up his bachelor quarters.

In spite of the attention that naturalists have given this valuable, widely distributed, and very prolific little fur animal, we do not know everything we should regarding its reproduction. This important information is yet to be secured, and we are placed in the position of setting down positively the things we do not know. To illustrate: the exact period of gestation is unknown, we have no conclusive evidence as to the number of litters one female will normally bear in a twelve-month season, and we do not positively know that the young of the first spring litter will produce young by fall, although we are able, from the meagre information at hand, to deduce something at least approximating the facts.

Fertility has been associated with climatic conditionsthe milder regions of our continent have been credited with larger breeding seasons and on this assumption the Louisi- 


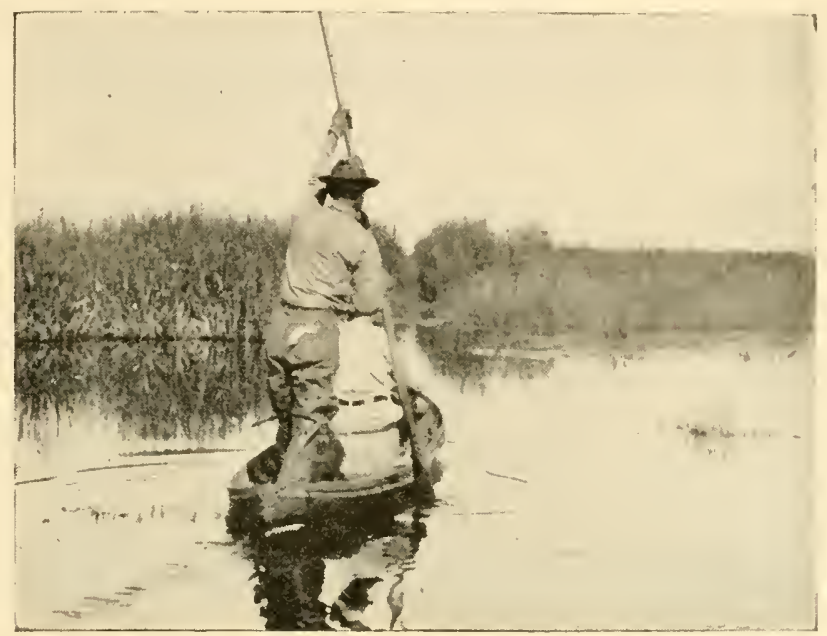

A push pole aids the trapper when he sends his pirogue over shallow waters.

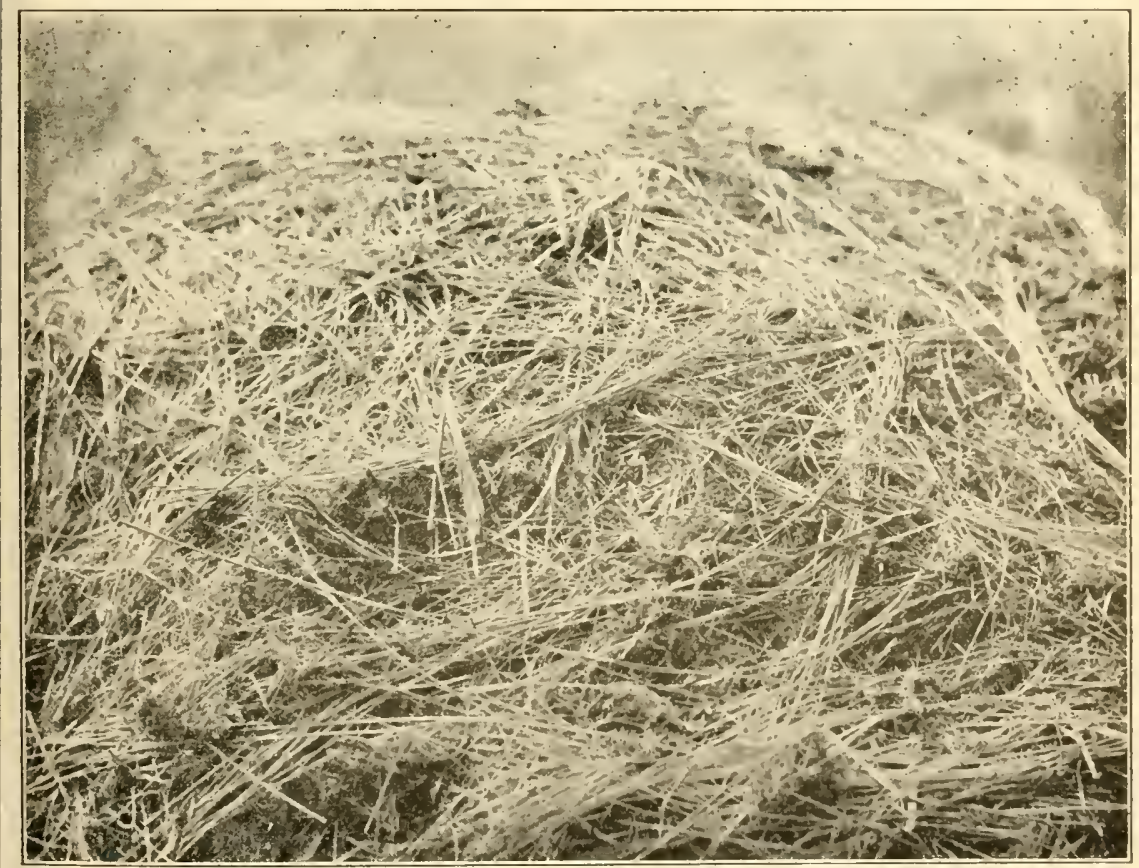

Detail photograph showing how the muskrat piles grasses on the top of his house. 
ana muskrat has been designated as the leader in the number of litters and the number of young in each litter produced. The enormous output of the Louisiana marshes each year is attributed to this by writers on the subject who evidently have not taken into consideration the large area of marsh habitat.

A mature study of the breeding habits of the muskrat in Louisiana indicates the necessity of recognizing a number of points not usually considered germane to the subjectmatter by many who have more than a passing interest in this fur animal. Periodic fluctuations in fecundity are known to be common to a number of mammals, particularly rodents, and the increases in some years and the decreases in others may be attributed to this phenomena of seasonable variation and not to trapping.

The question of mating seems to have been answered. While it is true that there was some doubt that the male muskrat mates with more than one female, our researches and the records from those who have bred this animal in pens on fur farms indicate that the boar is polygamous; therefore, there is no reason for longer believing that the muskrat of the wilds is ever strictly monogamous. This has an important bearing on the rate of increase, for it means that more females will produce young than if it were necessary to have paired parents to insure the stock for the next season's breeding.

While it does seem certain that the female Louisiana muskrat has from three to five litters of young a season, we have yet to prove that one individual mother 'rat has produced that number of litters in one twelve-month. We do not know that females here can produce more than seven young to a litter, four seems to be the normal number, and how great the mortality is among the mice out in the marsh we do not know.

This lack of definite information on a very important phase of our study of the muskrat indicates the necessity of a continuance of the research already begun. 
The Fur Animals of Louisiana

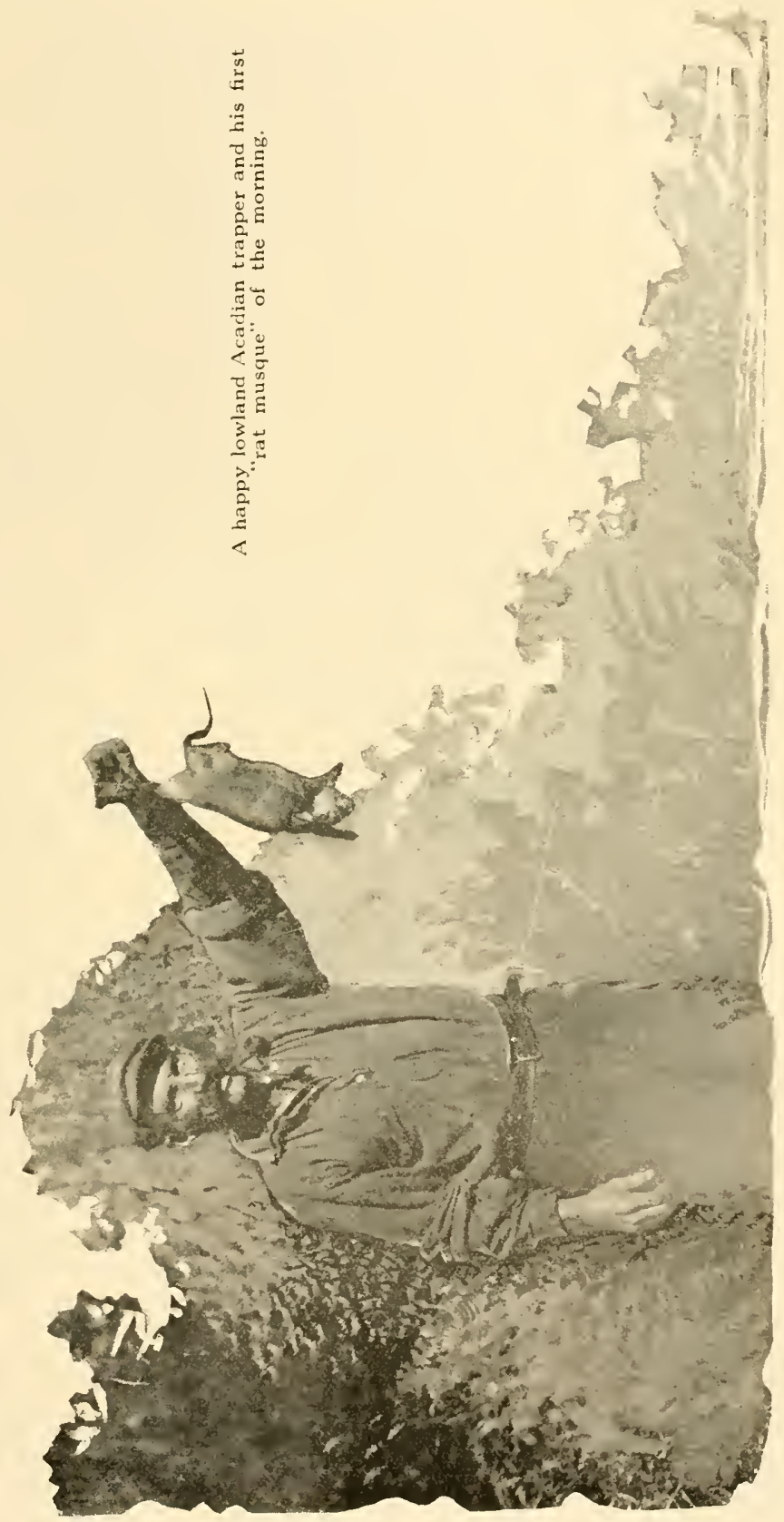




\section{SCENT GLANDS}

Many of the fur animals have special scent glands in modified portions of the skin, often involuted to form a shallow recess or deep sac with narrow openings, and secreting odorous substances. Such scent glands are to be found in the muskrat, mink, skunk, weasel, and otter, and it is from such scent glands, secreting a musky substance, that the muskrat obtained its common name.

It is believed through the aid of an odorous scent that wild animals are able to become aware of the presence of other member's of the species, even at great distances. Very generally these glands are common to both sexes, and it is in such cases that their function as a means of mutual recognition is most evident. It has been long stated that when these scent glands are confined to the male animal their function is without doubt sexual, and that the secretion forms part of the attraction stimulus to the other sex. Recent research seems to prove that this is true also when scent sacs are possessed by both sexes, and in the case of the muskrat, the musky odor is detected at its strongest when the mating season is on, for both the male and the female have the sacs.

\section{Muskrat VOICES}

Muskrats are generally supposed to be without a voice, but this is not the case, as the young are quite vociferous, and captive animals occasionally show vocal powers. One that had been caught in a trap was too far exhausted to be revived and made a pitiful moaning little cry as if in pain and despair. On several occasions Vernon Bailey has heard a querulous little quarreling note from one or two females kept in a large cage together, but occupying one nest box, a little "quer, quer" note of scolding at the other, who may have taken up more than her share of the room or bed.

They often make a chattering noise with the teeth, sometimes a threatening sound or sign of anger, and again a sliding, squeaking sound of the molars rubbed together in chewing or to sharpen and clean them, but these are not vocal sounds, as Bailey has pointed out. 
The Fur Animals of Lonisiana

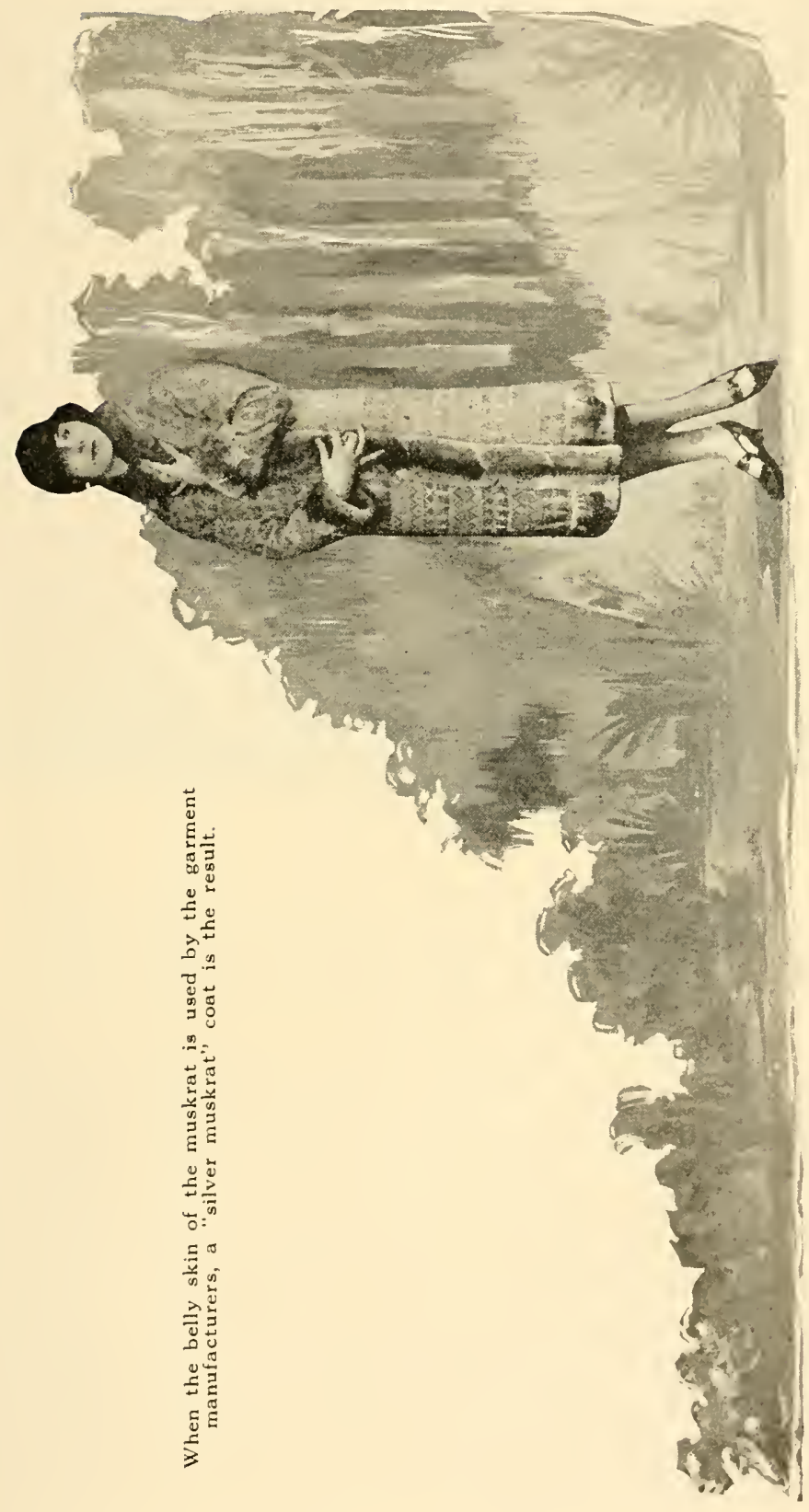




\section{SEX DETERMination}

It is necessary to make a close examination of the exterior sexual organs of a live muskrat to determine the sex absolutely, as the boar and sow resemble one another in all other respects. The best method yet devised for holding the animal so that such an examination can be made, without unnecessary struggling on the part of the subject, and gnashed fingers on the part of the examiner, appears to be the "sexing box," or examining funnel. One such is a commercial apparatus called the "No-bite Examining Funnel," which is shown in the accompanying illustration. It is made by the Flat Creek Fur Farm, Huntington, Ind., and sold for $\$ 1.50$, postage prepaid.

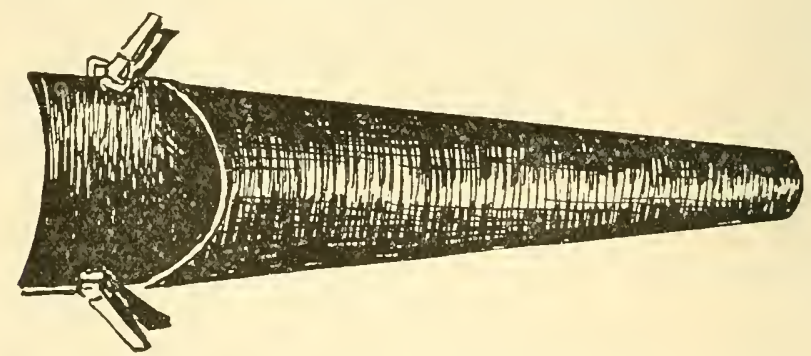

One style of sexing box sold commercially for examining muskrats to determine a male from a female without injury to the examiner. The animal is placed in head first and the hind legs are secured by the spring clothes-pins so they cannot scramble out.

In using a sexing funnel to determine the sex, hold the funnel in the left hand, have the muskrat to be examined hanging by the tail in the right hand, insert the animal head first into the funnel, and, if the No-bite is being used, fix the clothespins to each hind leg so that the animal cannot struggle out backwards. If the animal, being held by the tail before being inserted in the funnel, attempts to double back and bite, make a dropping motion (still holding fast to the tail), and the muskrat will immediately straighten out. It does this involuntarily, as it expects to be dropped to the ground. 


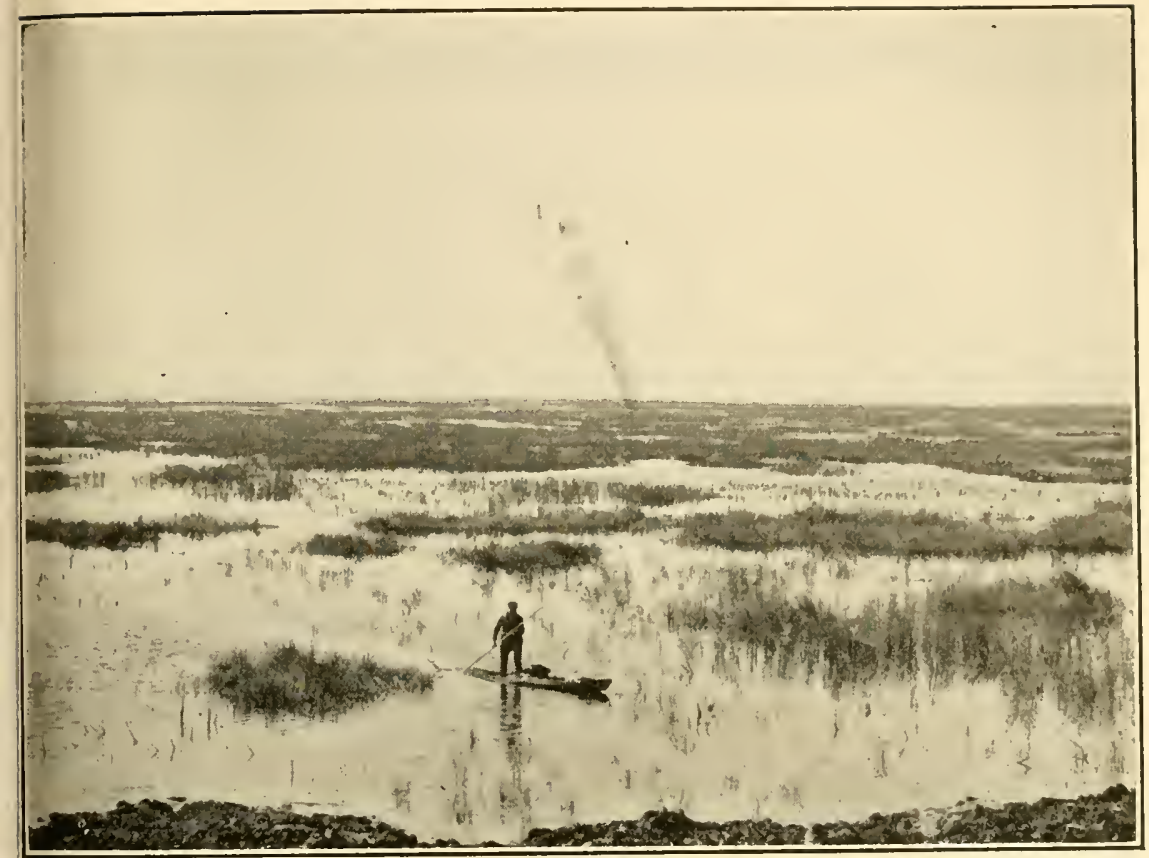

A typical Louisiana muskrat and wild duck marsh in Cameron parish. This area was highly productive of the fur-bearer and here a large 'rat ranch' is being operated.

The integument, a protuberance or sheath, which contains the outlet of the urinary system, near the tail, will be seen. By pushing back the flesh of this sheath the penis will be exposed, if it is a male. The sexual organs of the female are in the opening at the base of an integument which resembles the protuberance of the male. It will be noted that a female is void of hair or fur between this protuberance and the anus, while a boar muskrat is furred. The integument is furred and carries a pencil of hairs on the apex. On a young female the bare spot may be small.

It should be borne in mind that the muskrat being examined should not be handled roughly. Jerking the animal by the tail is liable to cause a swelling at the base of the tail, indicating a dislocation of the tail vertebrate, and frequently the hind legs become afflicted with paralysis. 
The following will be found to be an excellent and infallible guide: Hold the muskrat securely so that it cannot bite and immediately in back of the tail, on the belly, will be found the opening known as the anus. If the subject is a female, there will be found the opening of the reproductive organ, known as the vagina. Next will be found the external opening of the urinary system known as the meatus urinarius. In a young female, at least until she has had a litter of young, the vagina will be found closed, but the position of the organ will be quite discernible because of the fact that it is, at all times, bare of fur or hair. It must be remembered, however, that until the female has been bred that this organ is quite small, only slightly larger than a wheat grain, but, in breeding season or out of it, this bare spot shows quite plainly.

The male muskrat, to the contrary, is well furred up to and around the urinary protuberance. Therefore, the sexing rule should be: two organs (anus and urinary integument) identify the male; three organs (anus, vagina and urinary integument) identify a female in addition to the lack of fur between the two organs already referred to above.

\section{FOOD}

Muskrats are predominantly vegetable feeders. While it is true they will eat animal matter, and at times they devour the flesh of such individuals of their own kind as they may find dead or wounded or helpless, this does not take away from the fact that we should consider them herbivorous mammals like the beaver and the corpu, the other two important fur rodents, that subsist on vegetable matter.

The muskrat's food consists of the root systems of a variety of plants growing in or about water; and as a vegetarian they have a remarkable menu to choose from on the coastal marshes of Louisiana. And while in Manitoba, in New York state and elsewhere in the north and east two species of cattails stand out preeminently as the food, in Louisiana three species of Scirpus, the so-called threecornered grasses, are the principal foods relished by these animals. 


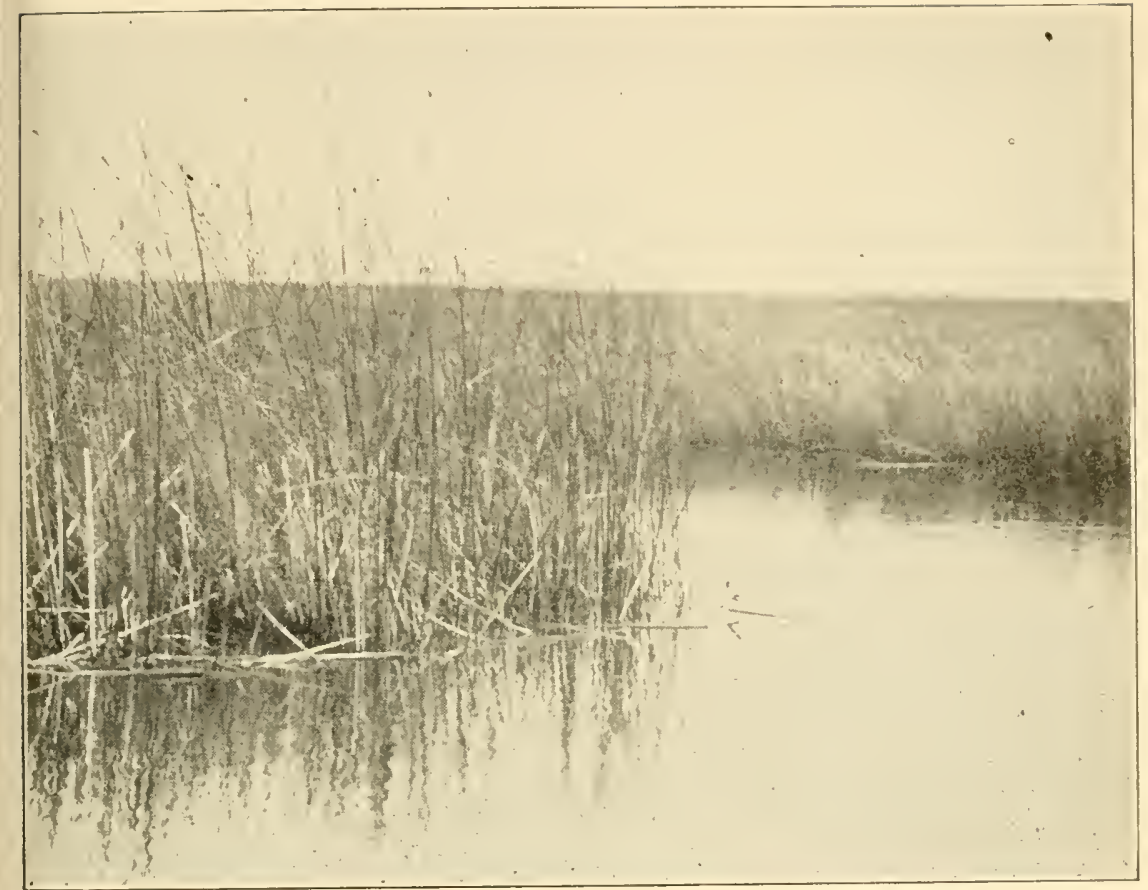

The bulrush (Scirpus validus) is one of the important muskrat foods and occurs throughout Louisiana.

These plants, the three-square club rushes, are the predominant flora on the greatest muskrat-producing areas, and veteran trappers know that where these grasses grow they will find their prey.

These are the leafy three-square (Scirpus robustus), the bayonet three-square (Scirpus olneyi), and the maritime or salt water three-square rush (Scirpus americanus).

These sedges or grasses are well known to our native trappers, but not by the book or scientific names we give them. All three are called "three-cornered grass," because of the triangular shape of the stems; or "goose grass," because of the fondness the great flocks of blue and snow geese have for the basal parts of the stems and the rooting systems. A French-speaking trapper calls the "goose-grass" paille des oie, merely a translation of the term, which is sometimes shortened to paille d'oie. 


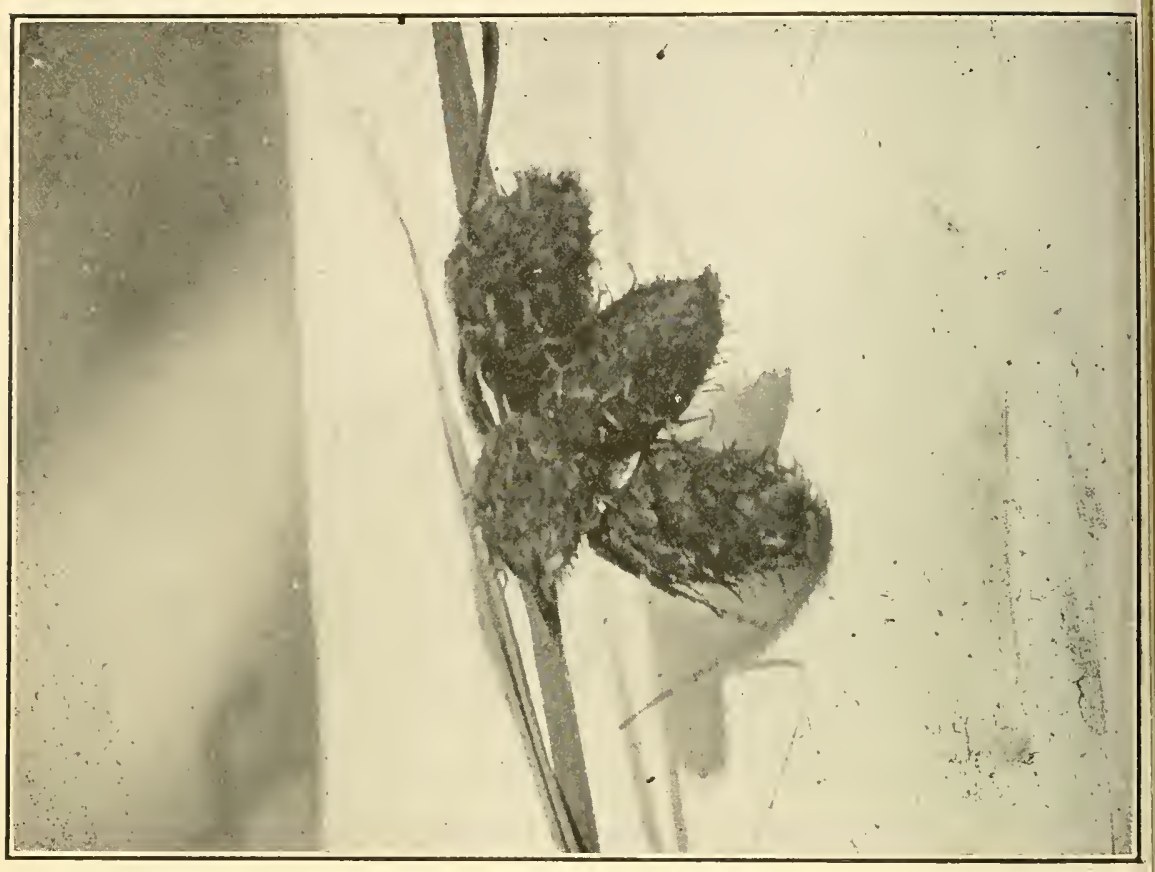

A cluster of seed heads on a stalk of leafy three-square rush (S. robustus), in which the seeds ripen during the late summer. It is believed the most economical way to plant an area with this favorite 'rat food is to harvest the purplish-red heads and broadcast the seeds on wet lands.

While the native trapper knows the difference between the three species as a rule he does not distinguish one from the other, but calls them all "three-cornered grasses." However, he has folk or French or Spanish names for the different species, such as, for the leafy three-square: La canne trois-quarts, "Cocoa grass," coco doux, and "sweet cocoa," this last designation being given this species because of the small black protuberances or "cocoanuts" found growing on the running root stalks of the perennial plant.

The bayonet three-square club rush, considered by many trappers to be the muskrat grass, carries the additional French designation of Le jonc trois-quarts, while in the Delacroix Island section the Spanish name of Yerba tres filos is frequently used. 


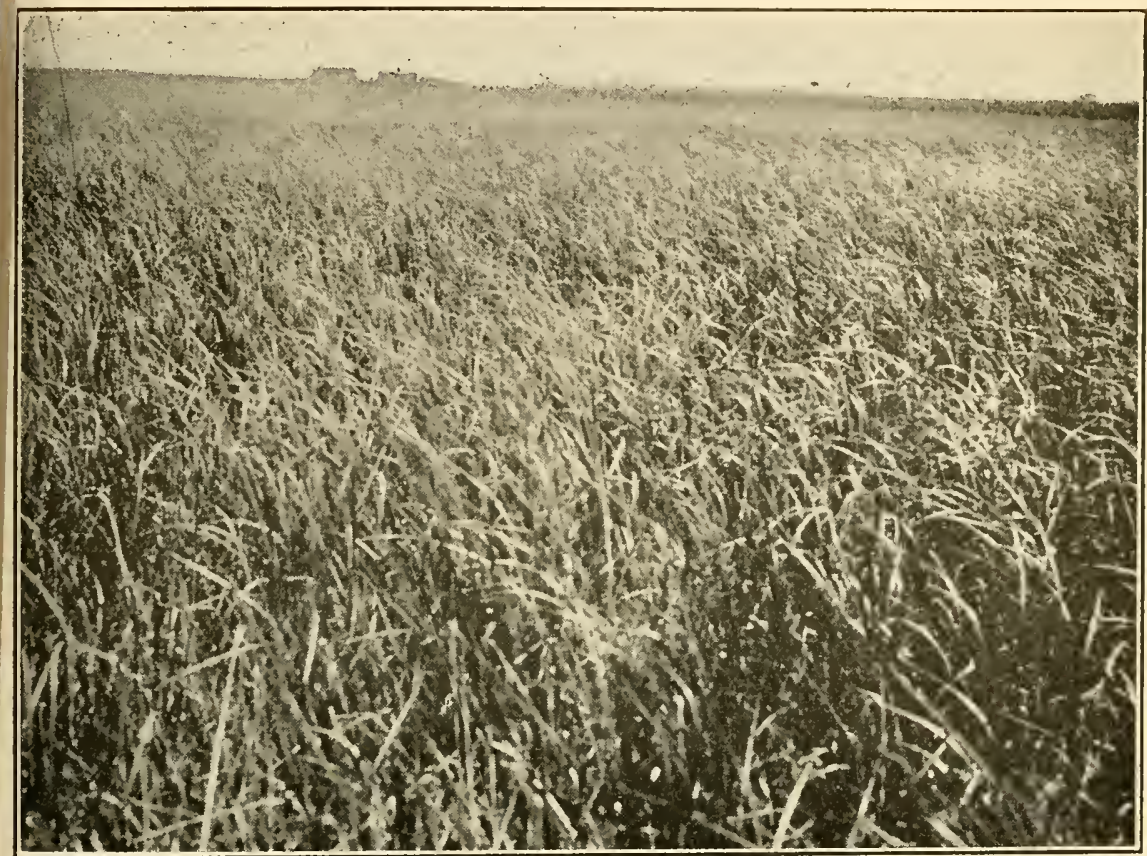

A heavy stand of "three-cornered grass," the three-square rush, Scirpus robustus, a favorite muskrat, wild duck and wild goose food.

The giant bulrush (Scirpus validus), which grows profusely in all known muskrat-producing marshes, is next in importance as food. This plant is known as "bull whip," Jone rond, and sometimes, even in these Ford days, as "buggy whip."

Cattail is also an important food for the muskrat in Louisiana and these animals feed on it freely, especially during the summer months. Both the broad leaf (Typha latifolia) and the narrow-leaf (Typha angustifolia) species are to be found in our marshes, although the narrow-leaf is far more abundant. The cattails are known to the trappers by various names, both English and French, such as "Flag grass, Jone plat, and Jonc au baril."

Marsh grass (Panicum virgatum and Panicum hemitomum), one of the common Paille fine of Louisiana (French for "fine grass"), but dubbed "Payfeen" by most of the 


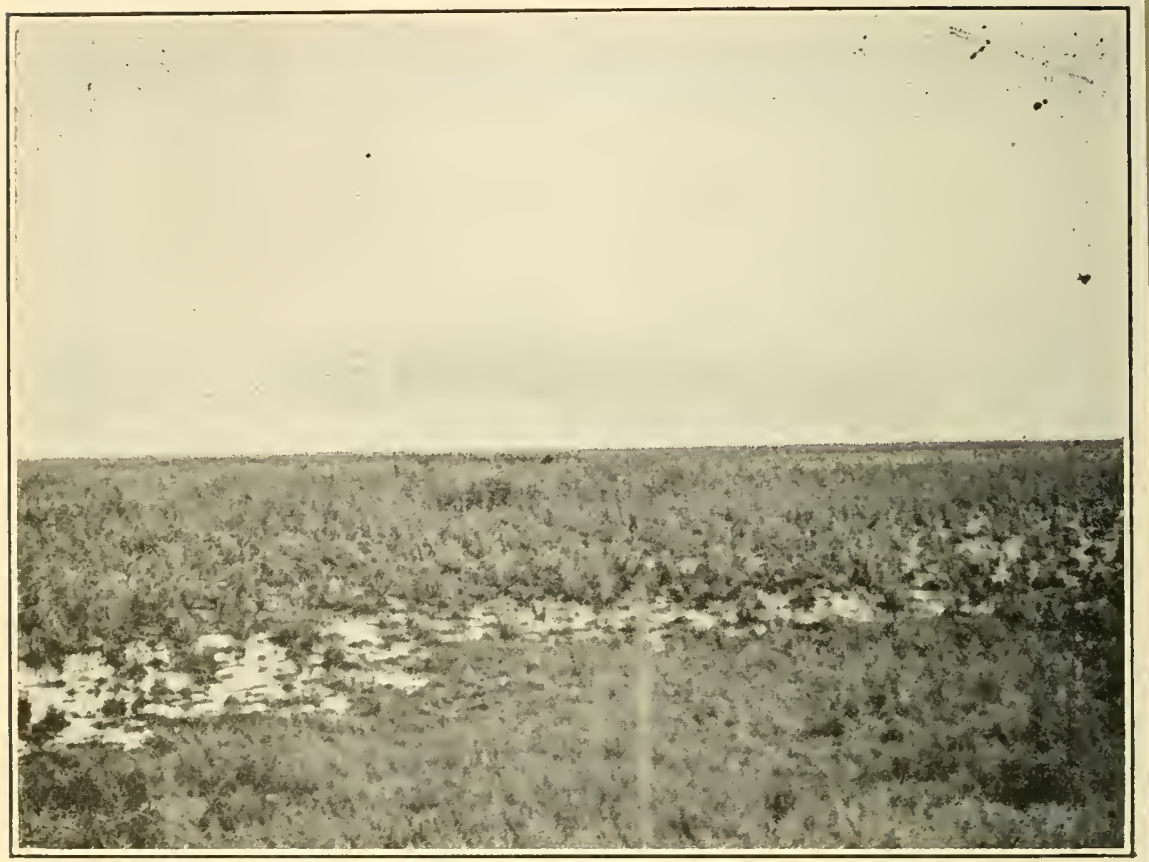

A mixed flock of blue and snow geese rising from the marshes. In the foreground can be seen the places where they have eaten out the rootstalks of three-square rush, or "goose grass," leaving puddles of water. In such marshes muskrats abound.

inhabitants of the marshlands, is another food of the muskrat and where it occurs in abundance is used for house building by these fur animals in preference to other grasses. It is also called "Switch grass" and "Meadow grass."

The so-called couch grass (partina patens var. juncea), another Paille fine, is an important food and house-building grass. This is the common "hay grass" of the Louisiana marshes. To some it is a "salt meadow grass," to others a "wire grass," or a "needle grass."

The quill cane (Spartina glabra) is also eaten by these mammals. The French-speaking trappers call this vegetation Cannes de cochon, or "hog cane," and sometimes Roseau de cochon. Other's refer to it as Herb d'huitre, or "oyster grass," and the name "small rozo" is also applied by English-speaking trappers. 


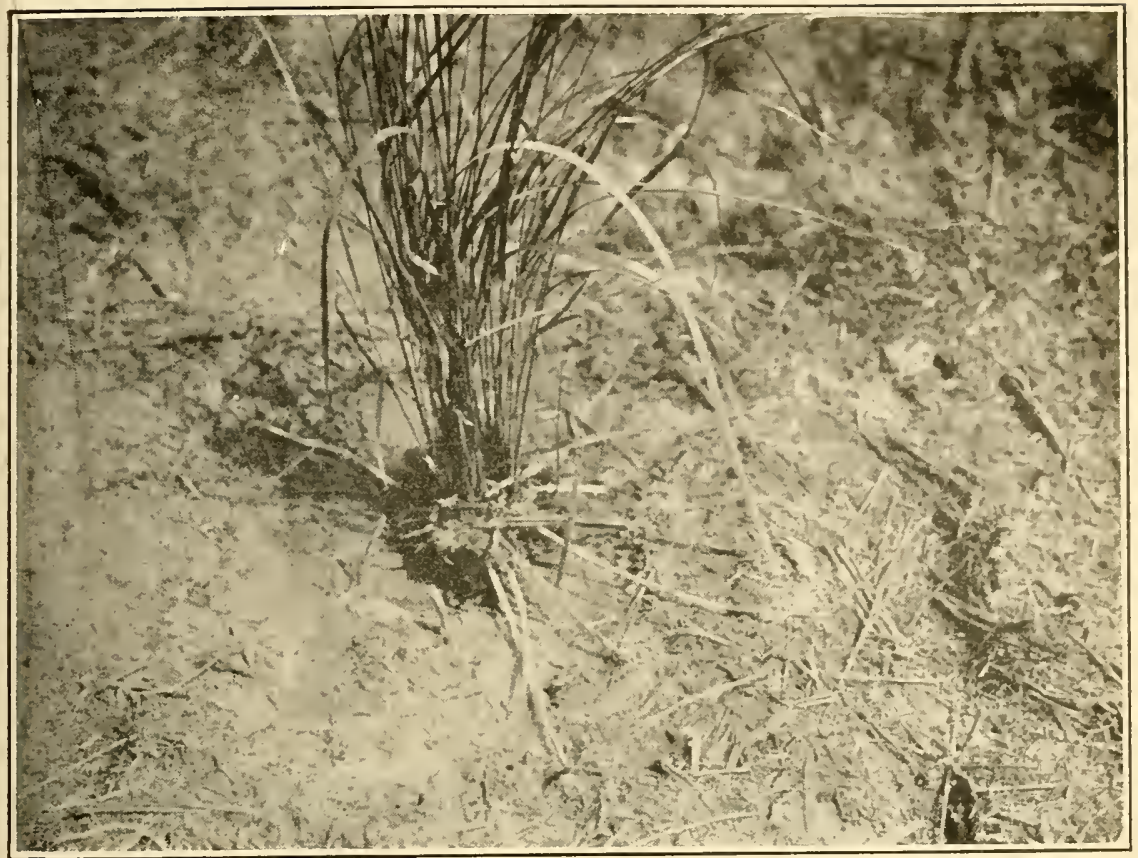

To restock a piece of marsh area with "three-cornered grass," two methods are at hand for the rat rancher. He can plant the seeds of this plant or transplant clumps of the rush to his land. Note the long, white running root-stalks shown in the photograph. These underground shoots send up new plants and are eagerly eaten by the muskrats. The sedge pictured is Scirpus robustus, probably the best of all 'rat foods.

The needle grass (Juncus roemerianus) is better known as Paille chat tigre, or "wild cat grass," and sometimes called "black grass." It is in some localities, especially in the western sections of the coastal marshes, a very important food and building grass of the muskrat.

Saw grass (Cladium effusum) occurs on many of the muskrat marshes in great solid stands. Few practical trappers believe that this grass is of any value to the animals they trap, and frequently bur'n it off. Researches, however, prove that the muskrats find refuge in these stands and frequently build houses of it and do feed off of the basal stalks. When this plant has its tops covered with seeds in the fall inhabitants of the marshlands call it "Red top." Another name is "ruffage."

The common cut grass (Onyza sativa), the Jonc coupant of the French-speaking trappers, finds some value in musk-. 
rat-producing marshes, for the little fur animals feed on its bases and root system.

Marsh cane (Phragmites communis) is characteristic of the Louisiana lowlands. It is usually called "Rozo" by the English-speaking trappers; properly, it is Roseau, a pure French word. Some call it "Sea cane," others "Switch cane," and to many it is "Small rozo." It finds some value as a muskrat food.

The well-known Feather grass (Panicum virgatum), with a number of other names, such as Cannish, "Switch grass," Paille jaune, and "coontail"; as well as "Wild duck millet (Echinochloa walteri), also called "jungle rice," riz de long, and "wild rice" (not the true wild rice of the north, however), and Giant foxtail (Chaetochloa magna), better known as "jungle millet," find places on the muskrat's menu.

Some claim that at times the muskrats eat the roots of the common saw grass (Cladium effusum).

The above list does not mean that the animal under consideration does not eat other vegetation, but it does include the more important natural food grasses.

The two three-cornered grasses, the leafy and the bayonet, the bulrush and the cattail, as well as the Paille fine grasses, will prove to be the valuable species to those seeking real good productive muskrat marshlands in Louisiana.

There seems to be a division of opinion among a number of practical trappers as to the relative merits of the leafy three-square and the bayonet species. The majority place the bayonet first. It is agreed, however, that the "three-cornered grasses" provide the best food and that the basal parts of the stems and the succulent rooting systems have much to do with the conditioning of the fur, for it has been proved without a doubt that when muskrats find a habitat where these sedges are growing in profusion animals of a superior quality are to be trapped. These plants contain a protein of a high value, are rich in starch, and contain a high saccharine content.

The term "three-square club rush," so frequently found in books on our flora, is a misnomer, for to be "square" requires four equal sides, and our common and important 


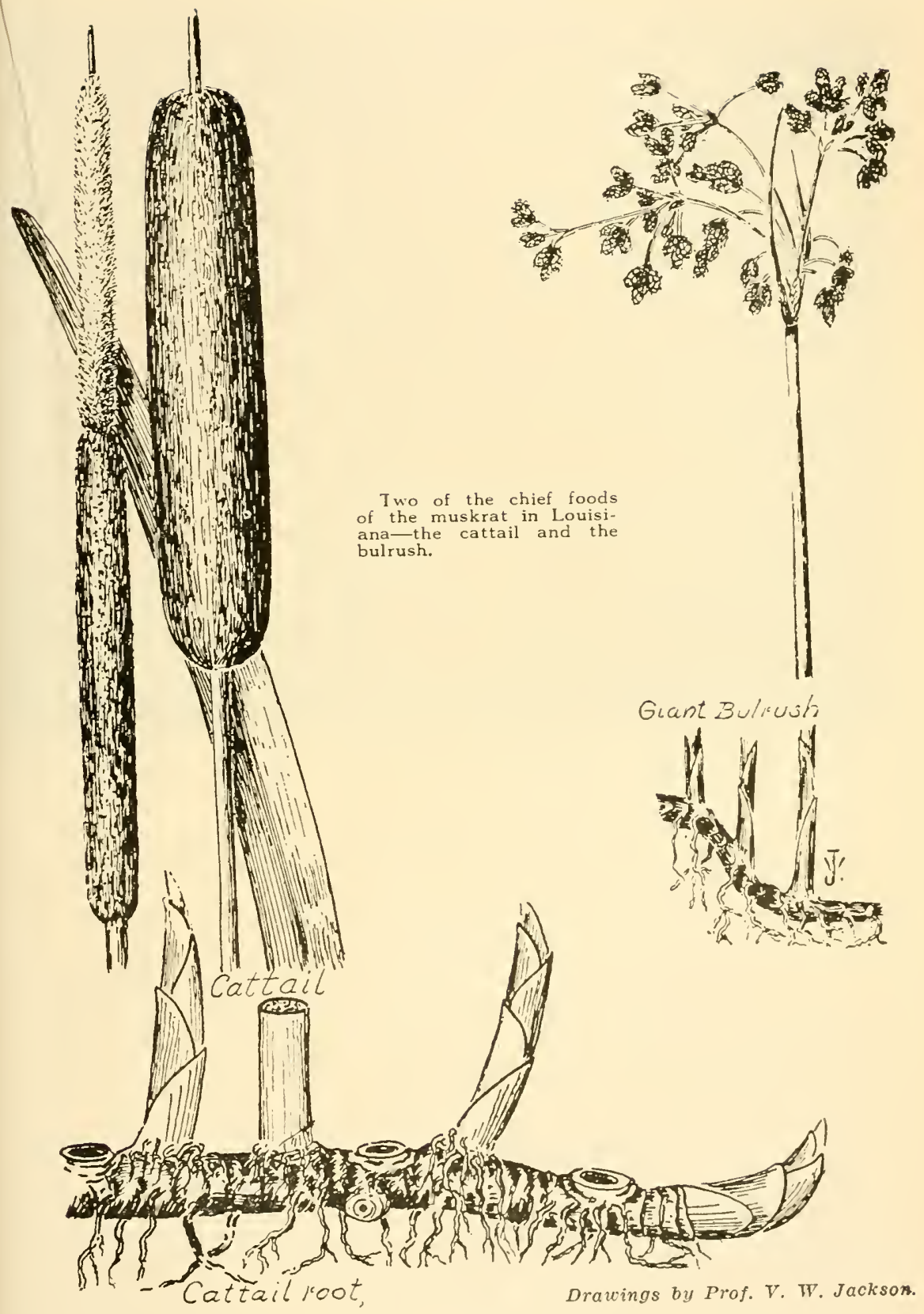




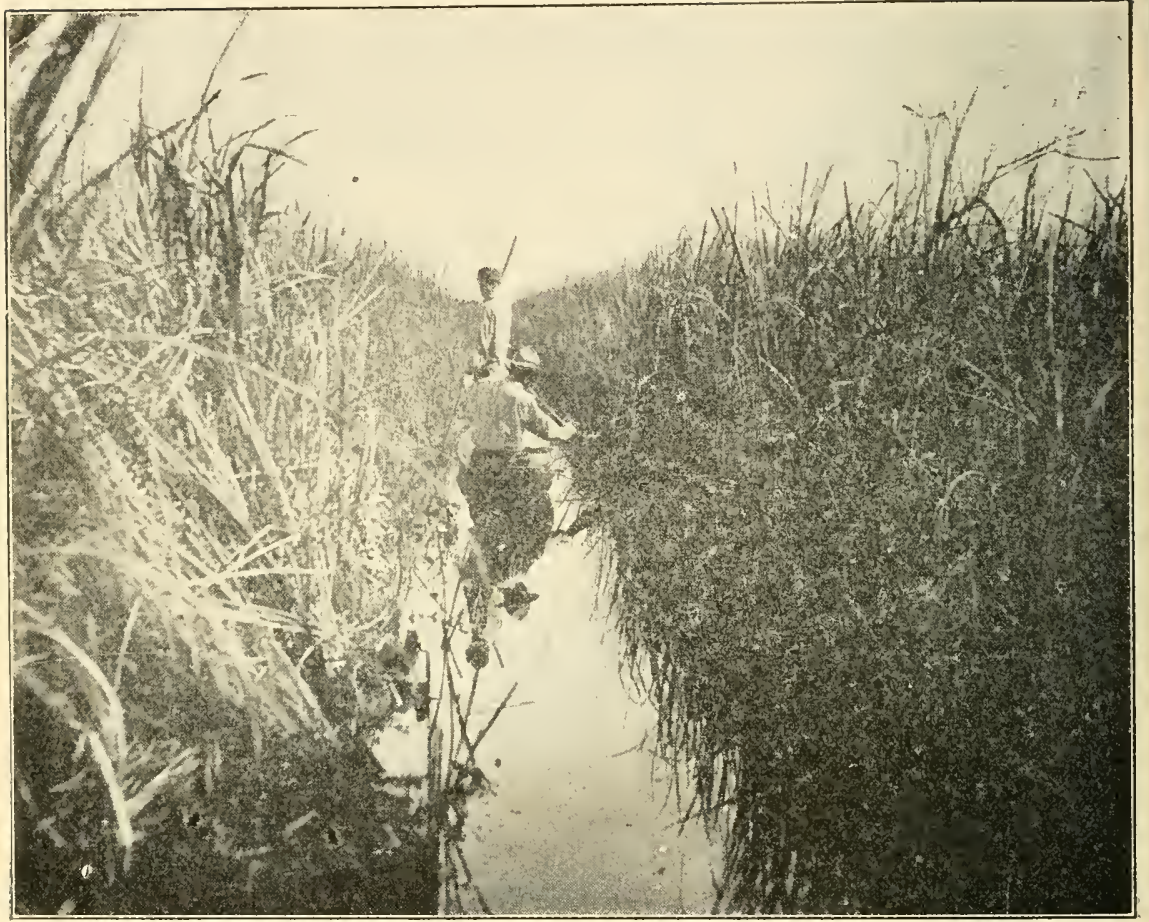

A typical pirogue trail through the marsh used by trappers in making their trap rounds.

muskrat grasses have three sides, and the common designation of the marshes, "three-cornered grasses," comes nearer being a correct term.

\section{Planting}

To replant an area with the known and proved muskrat food grasses would call for a great amount of labor if the replanting were done by transplanting and it is doubtful if it would prove an economical plan.

It would appear that such planting could be best done by sowing seeds of the three-cornered grasses and cattail. To find out the germination periods our field biologist was directed to make the proper experiment. Seeds of the leafy three-cornered grass (Scirpus robustus) and the broad and narrow leaved cattail (Typha angustafolia and T. latifolia) were placed in germinating bottles set in a sunny window. 


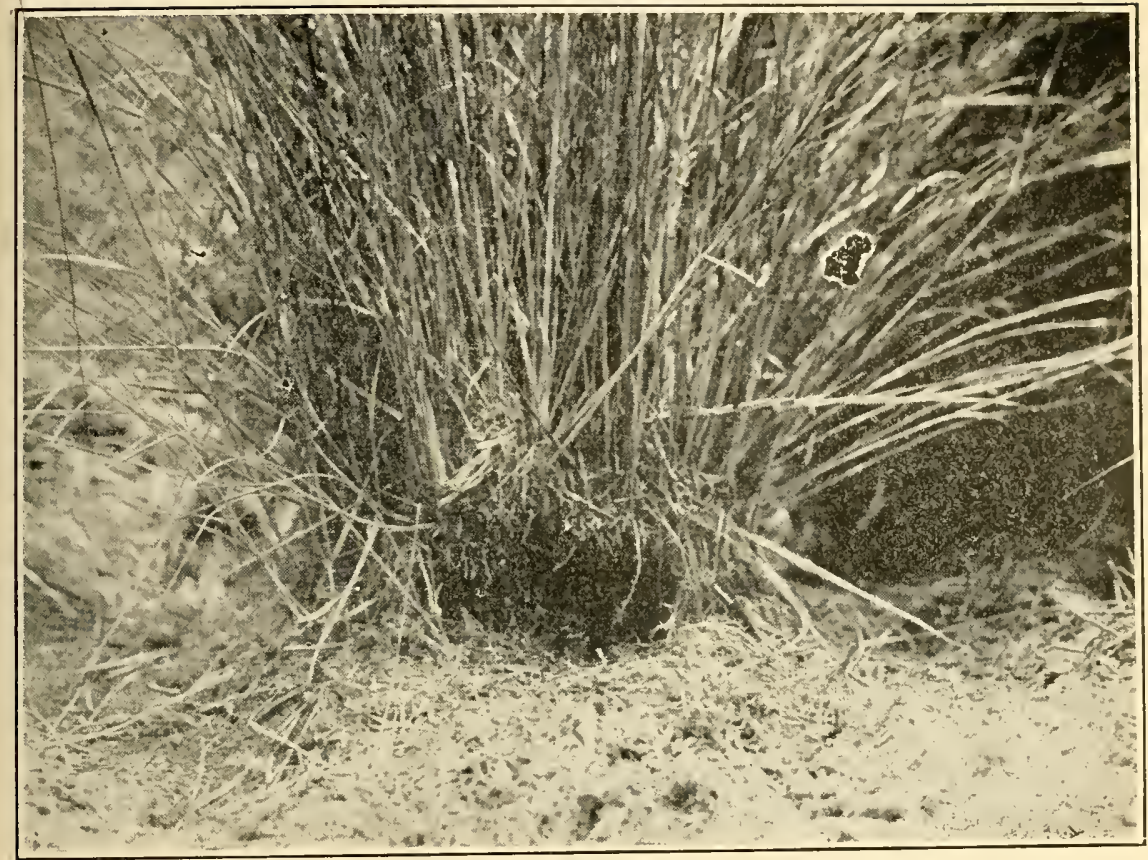

A clump of paille chat tigre or "wild cat grass," (Juncus roemerianus), showing the manner in which muskrats feed on the root systems of this marsh plant.

Cistern water was used and the seeds thoroughly immersed. The data obtained by Mr. Svihla follows:

\begin{tabular}{|c|c|c|c|}
\hline Scirpus robustus ( 1926 maturity) & $\begin{array}{l}\text { Date } \\
\text { Sown }\end{array}$ & $\begin{array}{l}\text { Germi- } \\
\text { nated }\end{array}$ & Duration \\
\hline $\begin{array}{l}\text { Seeds not removed from spi } \\
\text { Seeds removed from spikes. }\end{array}$ & $\begin{array}{l}7-25-26 \\
7-26-26\end{array}$ & $\begin{array}{l}8-24-26 \\
8-8-26\end{array}$ & $\begin{array}{l}20 \text { days } \\
13 \text { days }\end{array}$ \\
\hline
\end{tabular}

Scirpus robustus (1925 maturity)

sefids not removed from spikes. 7-19-26

Seeds removed from snikes...... 7-19-26

Typha angustafolia (1925 maturity) ... 7-19-'26

Typha latifolia (1926 maturity) ..... 7-26-'26

$\begin{array}{lr}\text { S- } 2-26 & 15 \text { days } \\ 7-24-26 & 5 \text { days } \\ 8-7=26 & \text { 12 days }\end{array}$

In the case of the leafy three-cornered grass, as might be expected, the removal of the seeds hastened germination, as the husks and chaff impeded speedy inhibition of the water and encouraged mold and bacterial growth. The germination experiments proved that these plants germinate quickly and that propagation by seeds should prove an easy matter. 
No experiments were made of the bayonet three-cornered grass. While the seeds of this species are carried in husks, the envelopes are much smaller and contain fewer seeds than do the containers of the leafy three square. It is believed that they will germinate as quickly, but it should be borne in mind that the harvesting of such seeds will be very much slower and far more costly.

The leafy three-cornered grass is very prolific when it comes to seeding. The seed envelopes range from seven to fifteen on a stalk, and sometimes more, and an individual pod contains from 40 to 60 seeds each. One count of seeds on a single stalk of Scirpus robustus showed it to have 798 seeds.

\section{Foods, SOILs AND Muskrats}

The muskrat is a prolific breeder "when food and water conditions are right," says Professor V. W. Jackson, of the Manitoba Agricultural College, in his bulletin, "Rat Ranching in Manitoba," and this finding agrees in every particular with local field surveys.

When food and water conditions are right, the muskrat has shown startling increases in population. There has been known place after place in Louisiana marshes that were prolific beyond belief in the number of muskrats taken during a certain winter season, yet the next year they were as scarce as the proverbial hen's teeth. Investigations indicated an absence of food plants, or not enough water, or again too much water seemed to be the rule, although it is still a debatable question with some if a muskrat can get too much water. But, in almost every case where there was a "mysterious" disappearance of 'rats, absence of water was a contributing factor, and drought is, in the opinion of most of the practical trappers, the greatest enemy the muskrat has-alligators and minks to the contrary notwithstanding.

In Manitoba, at one time a remarkable muskrat-producing area, but now facing a steady decline in the numbers taken each trapping season, Professor Jackson, in the bulletin already quoted, claims that the muskrats of that northern province have three litters annually, "plus the grandchildren from the spring brood, which are mature in Aug- 


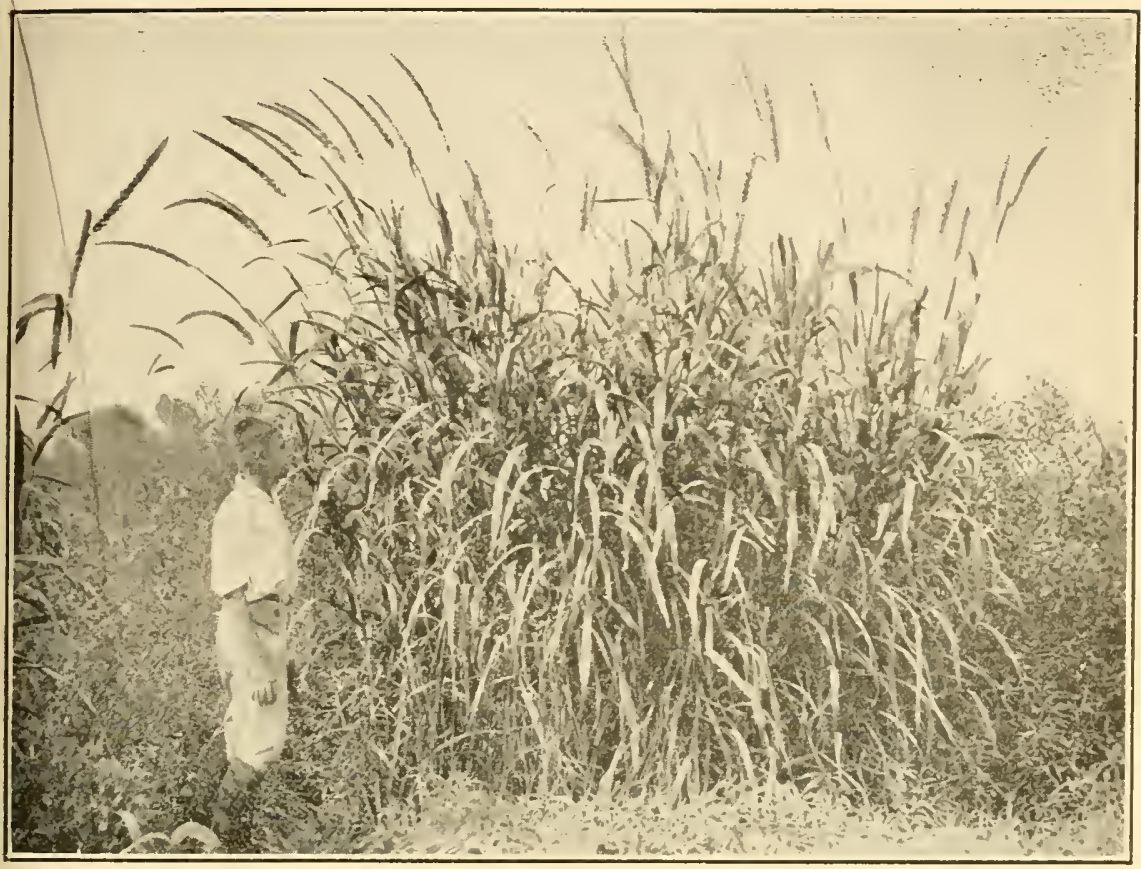

Typical growth of giant fox-tail grass (Chaetochloa magna) sometimes called "jungle millet," a foodplant of some value to muskrats; wild ducks are fond of its seeds.

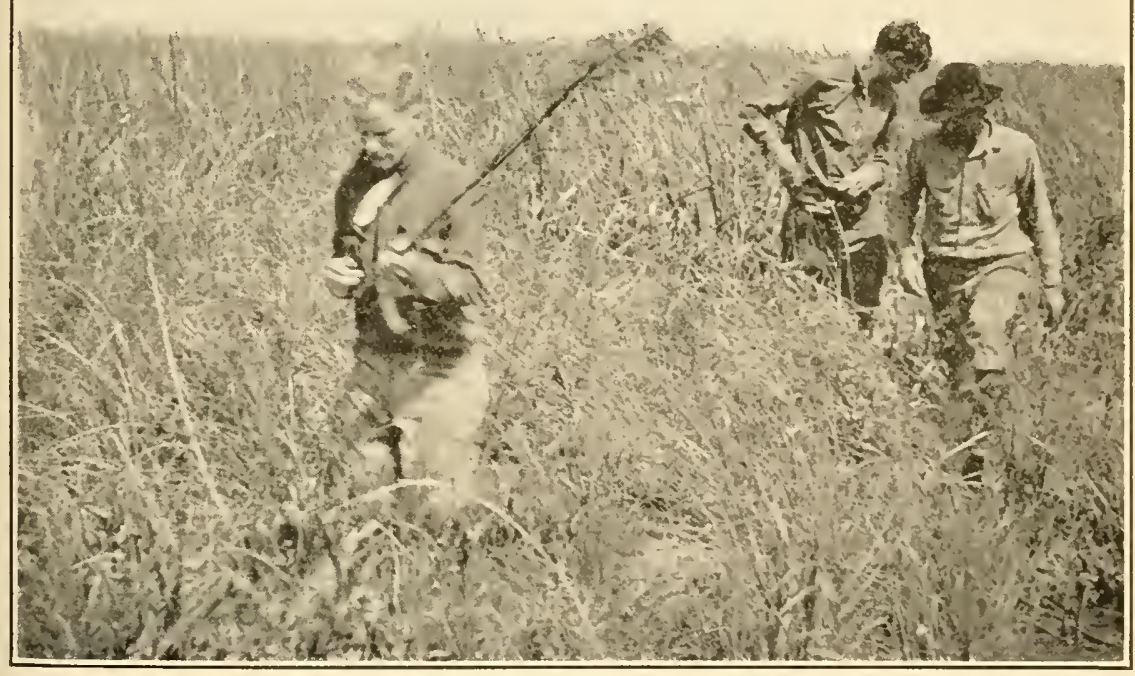

Botanists of the Bureau of Biological Survey examining wild duck foods on Marsh Island. 
ust. The average brood is five, making 25 per pair per season under natural conditions." To illustrate his point, he devised a very illuminating chart of this twelve-month life cycle, which is reproduced on these pages with permission, which presents the matter as he views it in a very interesting manner.

In Manitoba this same authority claims the cattail is the mainstay of the muskrat-the thick, starchy root furnishing two-thirds of its food, and the long reeds and leaves furnishing most of its building material, in addition to the shelter furnished in the winter time, when the animal feeds on the fleshy roots. When this is plentiful the muskrats remain near it, but "when the food gets scarce the whole tribe migrates."

Therefore, there is here the direct relationship between food and reproduction, and a seeming proof of the claim that when food and water conditions are suitable the muskrat is a prolific breeder.

There is another problem connected with Louisiana muskrats, their food and the soil of their habitat, that has long been a puzzling factor, making it appear that there is a third factor: type of soil.

There are many marshland areas in Louisiana that have water in abundance, the recognized muskrat foods, such as the three-square, the cattails, the bulrush, the paille fine, and such vegetation that the muskrat thrives on-but no muskrats.

Or it may prove that there are but a few muskrats in such an otherwise favored section.

There are other marshland areas in Louisiana, the Delacroix Island territory, for instance. Here is the three-cornered grasses, the cattails, the bulrush and the other herbage and millions of muskrats.

What makes these amazing differences in muskrat population? The marshes look the same. We find the same birds in them, ducks and geese in winter, herons, rails, savannah sparrows and all the other marsh-loving birds the year round. 


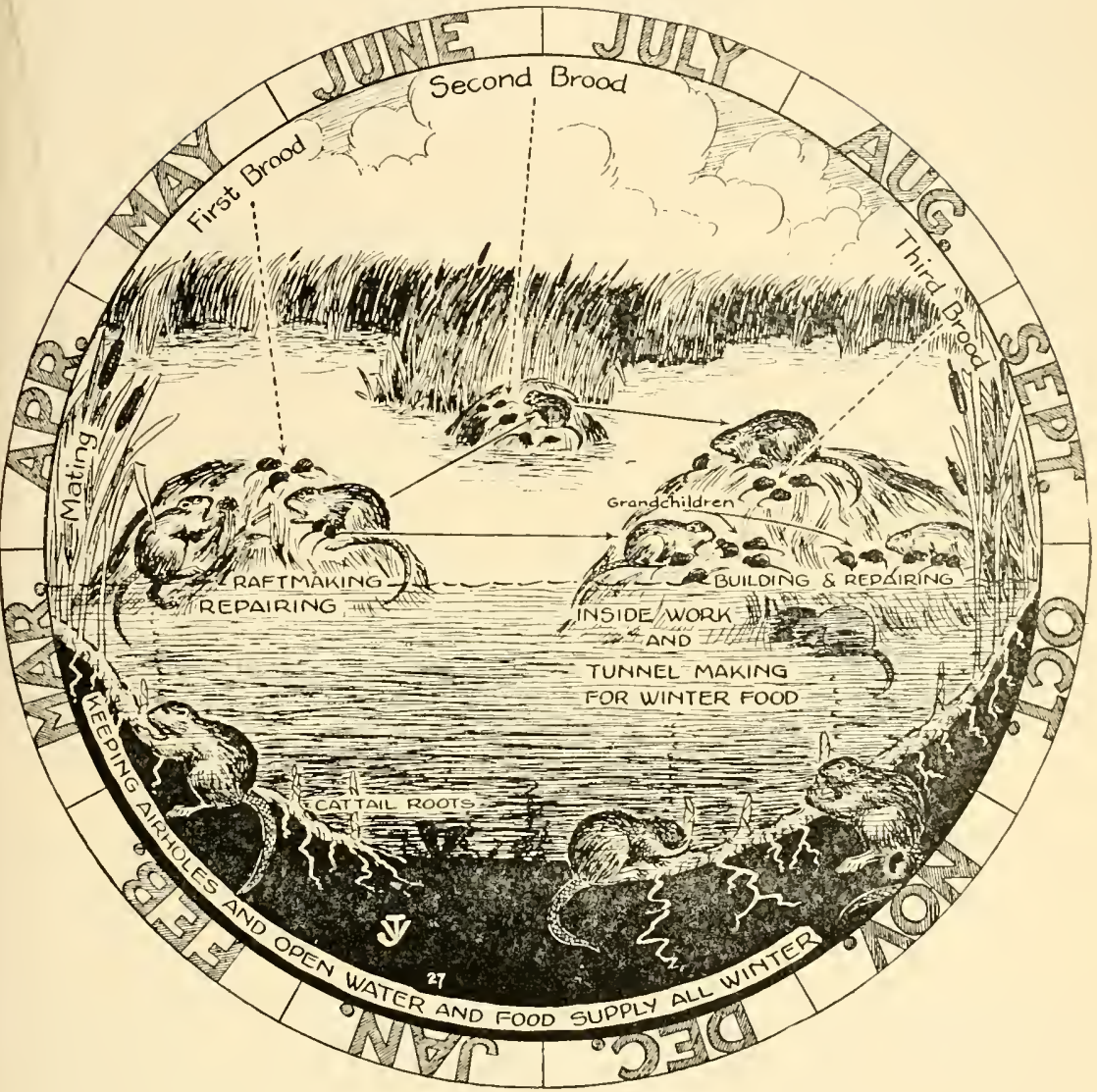

-Reproduced by courtesy of the Northern Fur Trade

THE TWELVE MONTH CYCLE OF THE MUSKRAT

The annual cycle of the Manitoba muskrat as drawn by Professor V. W. Jackson of the Manitoba Agricultural College, who claims that, in Manitoba, there are three litters, plus the grandchildren from the spring litter, which are mature in August. He finds in his section of Canada the average litter is five, making 25 young, per pair, per season, under natural conditions.

\section{THE IMPORTANCE OF HUMUS}

It has appeared that the peaty humus that overlies our coastal marshes has a great deal to do with the muskrat population. We had arrived at our conclusions independently, at the same time, and we are now jointly giving the subject-matter more detailed attention and are gathering further evidence to back up our contention. 
It has been found that wherever muskrats are normally present in the greatest numbers the peaty humus is several leet in thickness. This overlay, which consists of about $90 \%$ vegetable matter, consists largely of accumulated dead remains of the sedge and grasses of the region. The Delacroix Island region has such a humus; a depth of 17 feet has been found in some places.

This humus layer is of importance to the muskrats in that its food plants intermingle their rooting systems with the decaying vegetation. In it the fur animals dig their dive holes and subways through the soft mass far more easily and faster than if they had to tunnel through clay. We find the peculiar structure of the peaty humus allows these tunnels to remain open without caving; this would not be if the muskrat dug through sand.

Areas examined with this in mind showed:

Marshlands with thin layers of peaty humus were deficient in muskrats.

Marshlands where the peaty humus was very thick, the muskrat population proved to be very heavy and a better grade of fur came from the animals taken on such areas.

It is suggested that those interested in this subject read the chapter on the "Ecology of the Louisiana Muskrat Lands," chapter 25 of this bulletin.

\section{HABITS}

While muskrats are classed as nocturnal mammals, they are frequently seen during the daylight hours, either swiming or traveling about. So pronounced are their nighttime activities, however, that there is frequently met a trapper of a score of year's' experience in the marsh who has never seen a free live 'rat and his acquaintance with them is confined to the animals he finds in his traps.

Muskrats, it seems, are subject to migratory fancies, or "fits," as one Acadian trapper expressed it. When animated by this desire, they frequently move in bands, through fields, along and across roads, and are found far from water or usual marshy habitats. When encountered on one of 


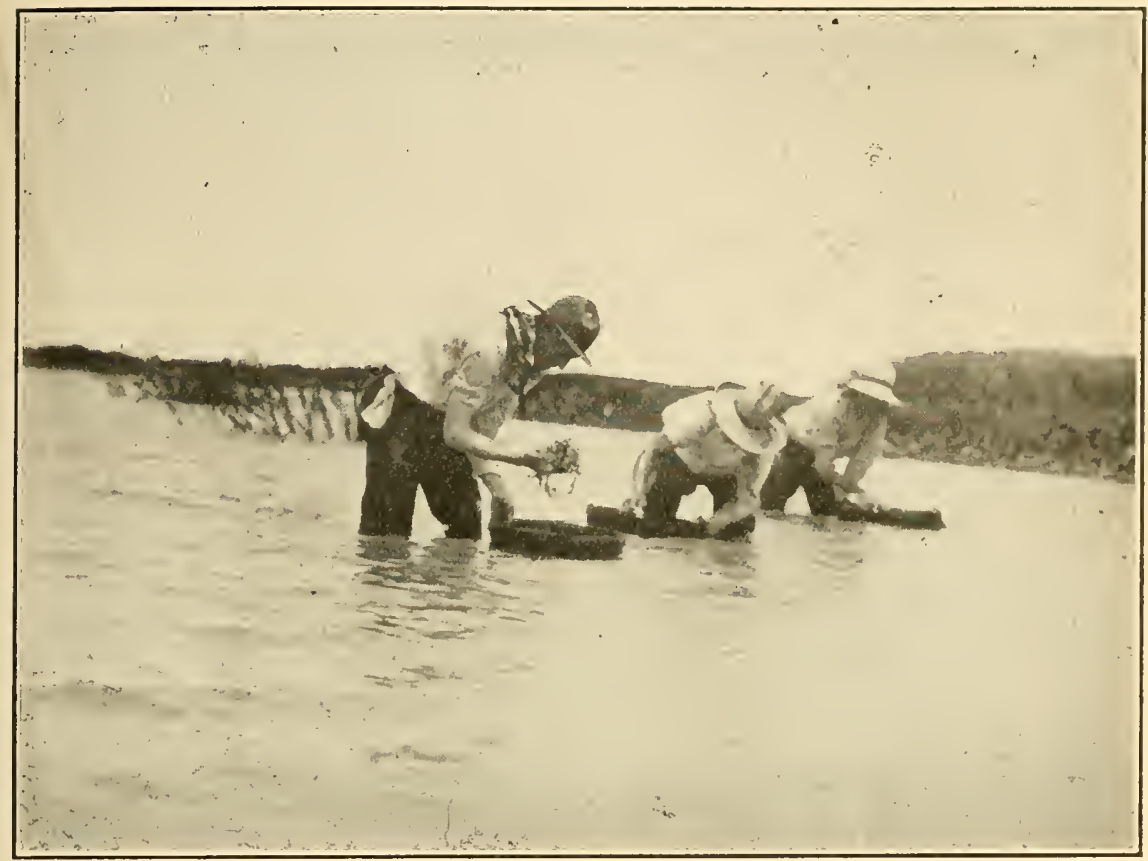

Planting wild celery roots on the bottoms of waters in the Marsh lsland Wild Life Refuge.

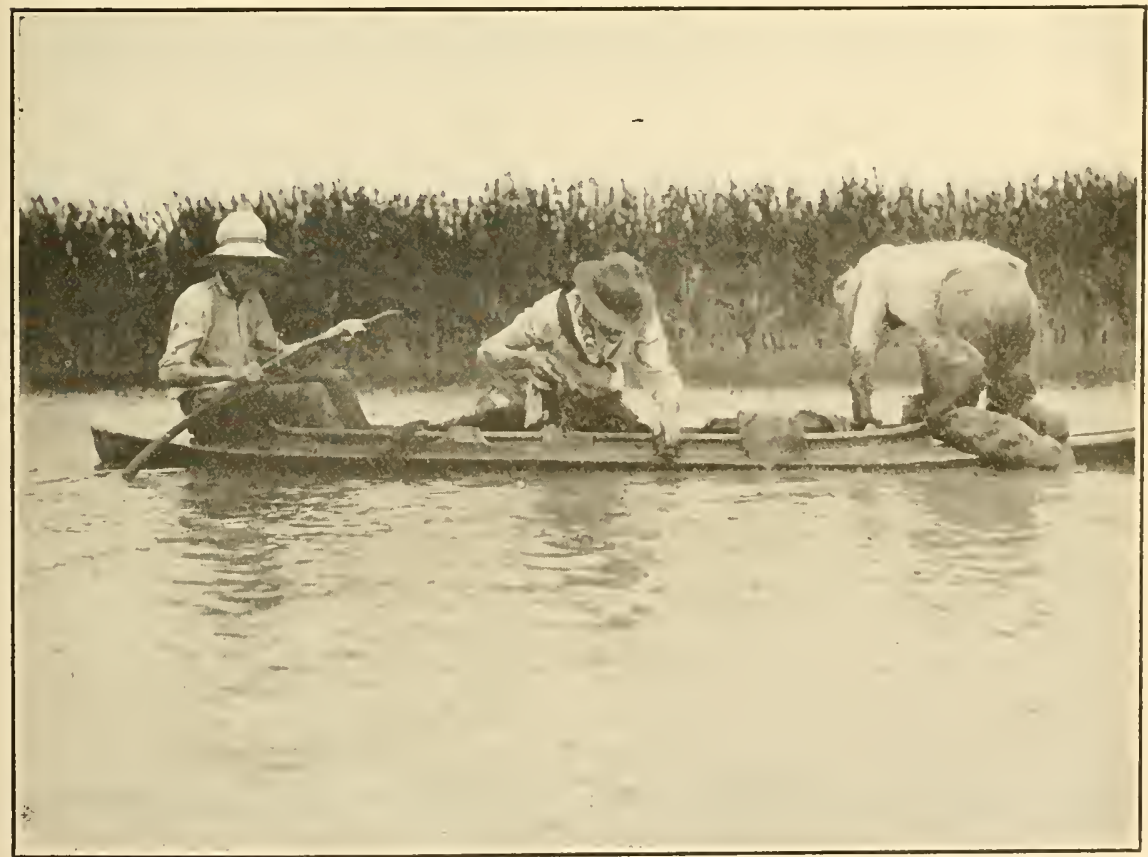

A view of the food planting work done on the State wild life refuges during the summer of 1925. 
these wanderlusts, the individual muskrat is not the docile, scary inhabitant of the marsh, but is rather an irrational rodent with a disposition to fight it out with the man who cloosses its path.

In May, 1927, a fur buyer for a Baton Rouge raw-pelt dealer, driving a truck between Gonzales and Sorrento, Ascension Parish, ran his auto through such a migration of muskrats crossing the gravel road in an east to west direction. One of the migrants was run over and the buyer skinned the animal as a curiosity and reported the occurrence to his employer. According to this man's story he saw from a dozen to 20 of the muskrats crossing the highway.

\section{The Muskrat an Engineer}

Muskrats are decidedly amphibious in their habits, and no animal, even the beaver, is more aquatic than the Louisiana muskiat. Neither is the celebrated beaver a batter builder or engineer.

On the general habits of the Louisiana muskrat Vernon Bailey reported his observations as follows:

"In habits, the Louisiana species differs from other muskiats only in adaptation to unusual environmental and climatic conditions. On the rather dry marshes they dig for water and food and have acquired almost the burrowing ability of pocket gophers. Many of their burrows do not reach water, but merely extend under the tough sod for long distances among the roots of the sedges, grasses, canes, and cattails, on which they feed. At times of heavy rains or high tides these burrows usually fill up with water, but at other times they stand dry or merely moist and muddy. When the burrows are made the ground is often dry, but the muskrats burrow indifferently through dry or wet ground, both in search of food and as a means of safe travel from place to place, and even of communication between neighboring houses.

"In walking over the marshes one is constantly caving into or feeling the give of these burrows below the sod. In places the marshes are honeycombed with them. The burrows open out to the surfaces in numerous places under cover of the tall grass, and some of these doors are regular 


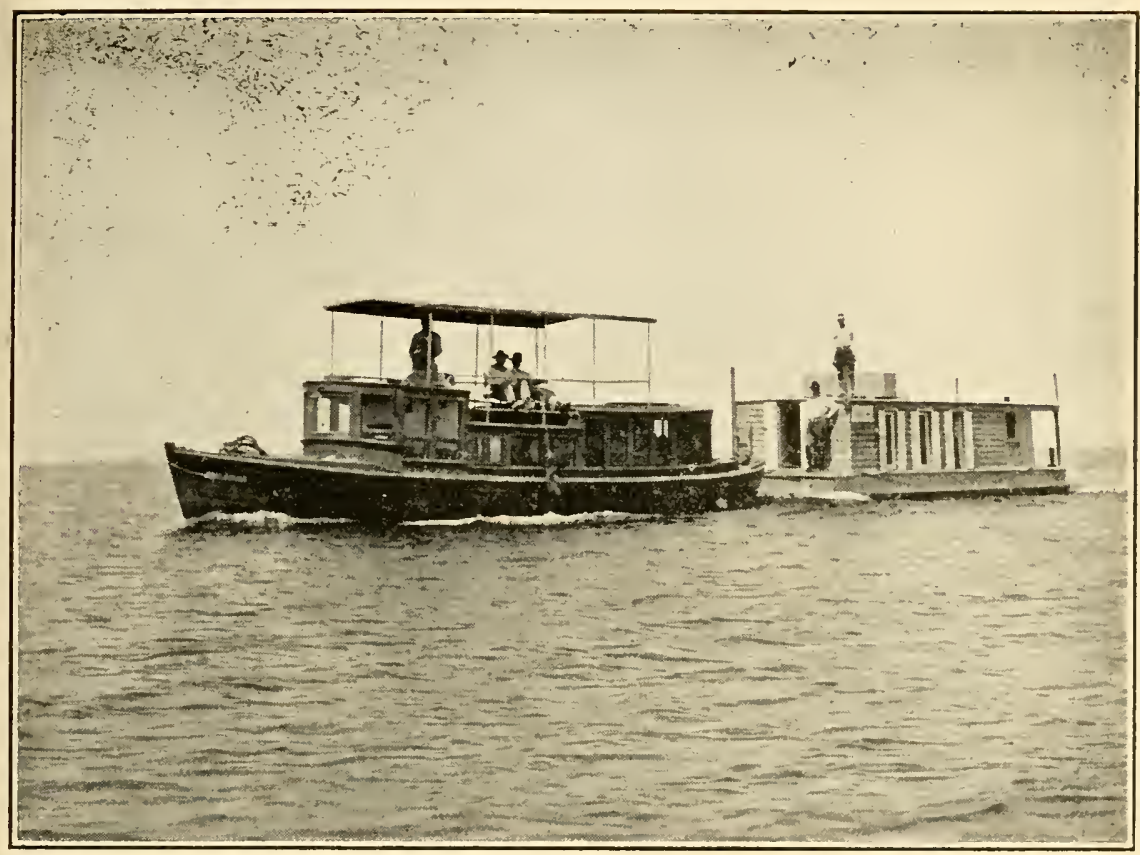

The Department's patrol boat "Opelousas," towing the houseboat "Russell Sage," to Marsh lsland and the other refuges for the food planting campaign.

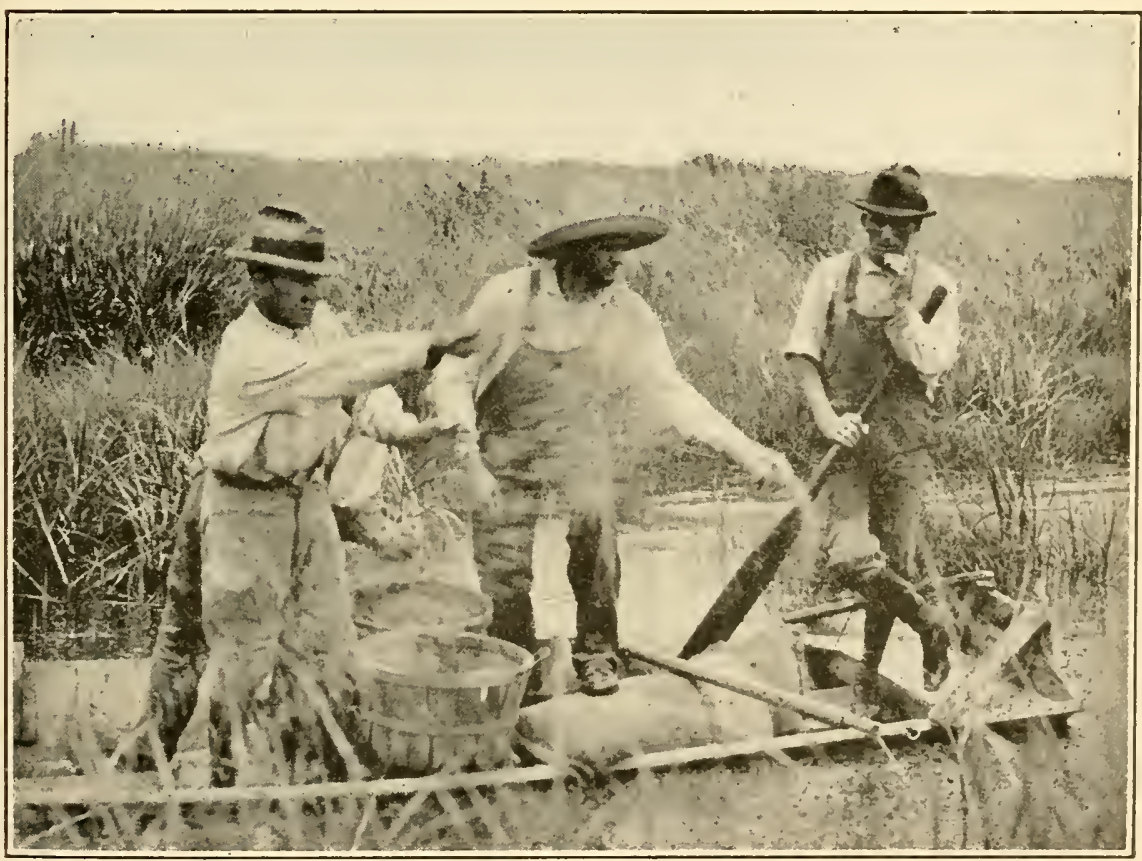

Sowing wild duck's millet on Marsh Island. 
feeding spots where the grass or sedges are cut and eaten, or roots brought up to be eaten. Other openings are used in bringing out mud for plastering up the houses, and still others are exits to cool beds of grass or sods under a dense cover of vegetation, which, at least in summer, take the place of houses.

"In many cases the burrows are closed from within, definitely plugged up with mud or turf to keep out light and enemies, but this habit has not become so firmly fixed as in the pocket gophers and many other rodents. The burrows opening into the light, or exposed, places are more oftell closed than those under a good cover of grass.

"The muskrats are exceedingly timid and cautious, quickly leaving any place that is disturbed or trampled, or a house that is opened or injured. Still they are so numerous that they soon come back, or others come in where some are scared away, and even after a house had been opened up for examination, they sometimes return to it and make repairs on the second or third night. In other cases they do not return for a long time, if at all. They seem never to come near any trap that is not under water and show surprising intelligence for any rodent in avoiding traps."

The designation "bank muskrat" is frequently heard in discussing certain of these animals. This is supposed to be in contradistinction to the "marsh" or "house" muskrat, and some people believe that there are two species of muskrats with different modes of living. This is not borne out by investigation, which shows conclusively that these little fur animals use home building materials that are most easily secured. If they inhabit a marsh they gather the stems of various species of vegetation. This is because the habitat is where there are no banks and a preponderance of vegetation. When these same animals inhabit a country where there are streams and high banks, they will excavate a hole and construct a den if vegetation is scarce.

In Louisiana there are few streams of this character in the lowlands of the coastal territory and as has been pointed out before, our muskrats are confined to the marshes bor- 


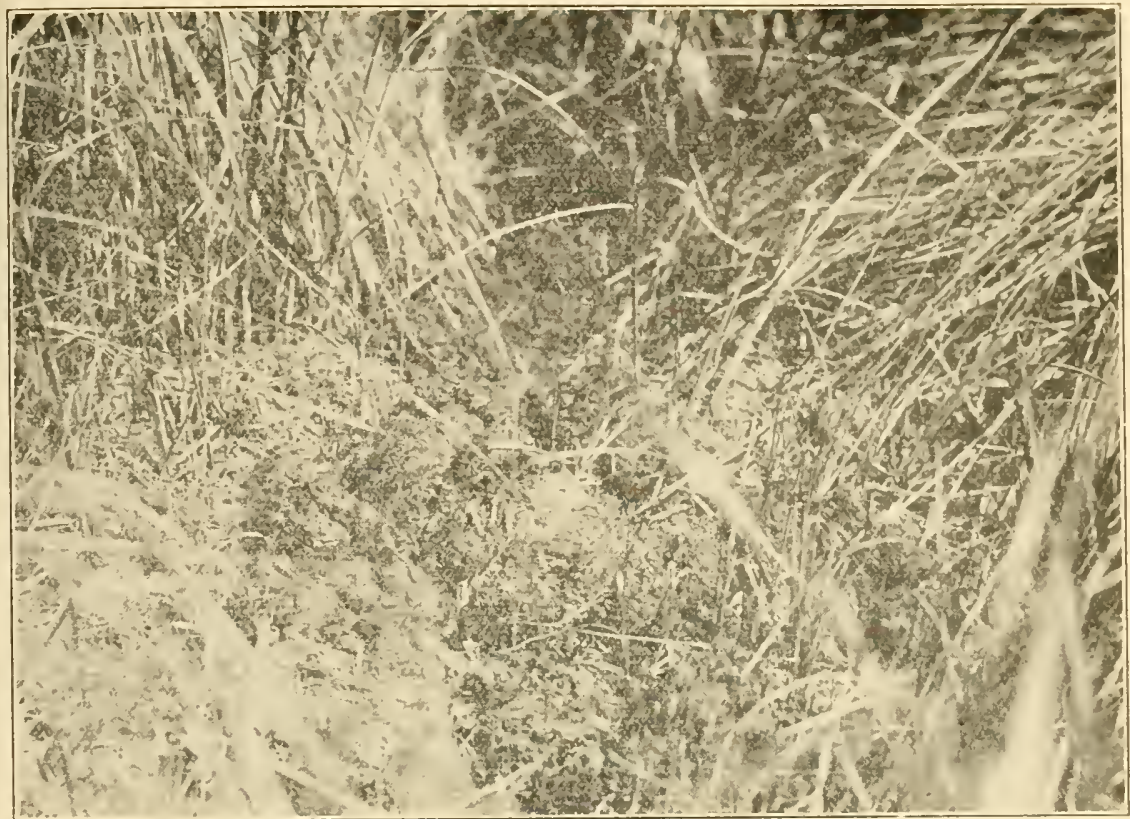

A dive hole leading to an underground runway. The balls of peaty humus excavated by the muskrat are shown in the foreground.

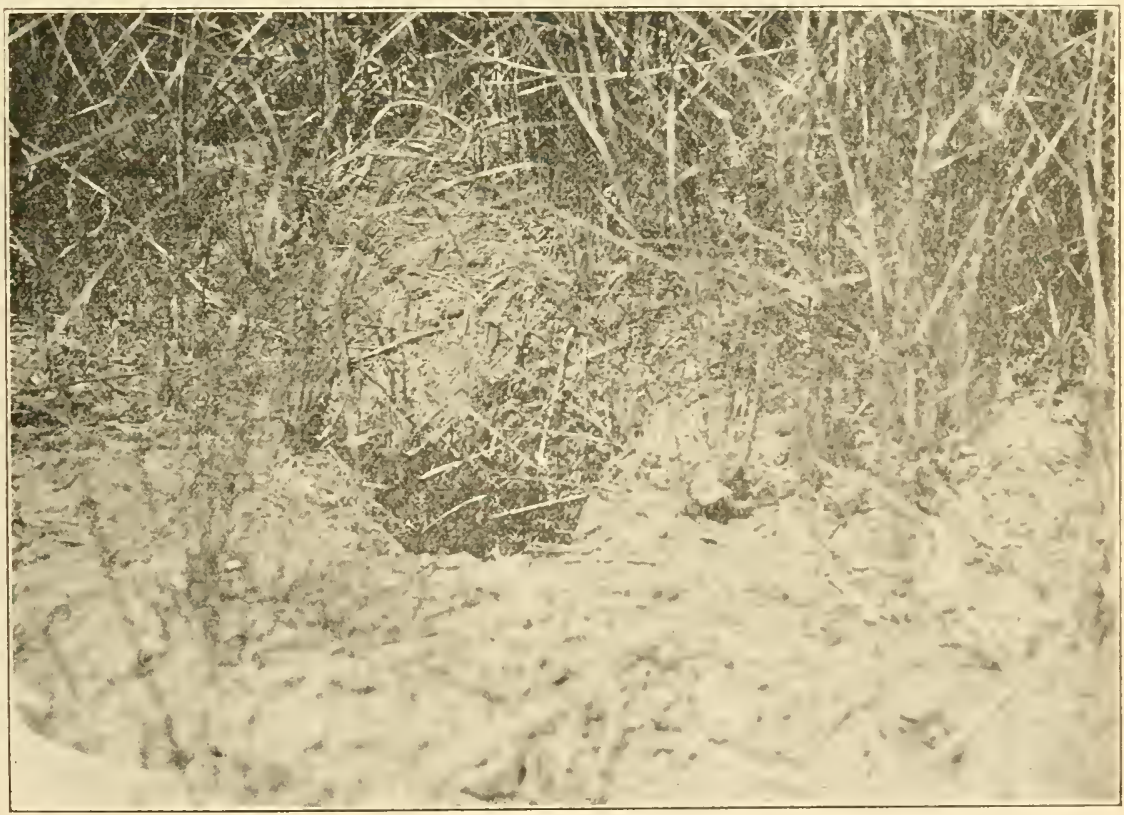

A dive hole dug in a drought period to reach water 26 inches below the surface of the marsh floor. 
dering the Gulf of Mexico. However, in certain sections of the coastal area rice growing has been introduced. To do this successfully, canals have been dug and by the aid of high levees the irrigation waters raised above the marsh floor. These levees have attracted many muskrats that normally are "house" builders and, forsaking this habit, they have dug their burrows, tunnels and dens in the banks thus erected for them by man, as the following observations show.

\section{Muskrats in Levee Banks}

While engaged in experimental work in blackbird control in southern Vermilion Parish, Louisiana, in March and Apiil, 1926, E. R. Kalmbach, biologist of the United States Bureau of Biological Survey, had opportunity to take notes on the habits of muskrats in the rice fields, and reported as follows :

"Learning that those now engaged in a study of the Louisiana muskrat had seldom noted the presence of muskrat burrows in the hard banks of irrigation canals in the rice belt and made observations that were at variance with the statements of certain rice growers who (at least formerly) experienced considerable trouble in ridding the levees of these burrowing rodents.

"My notes were taken in the vicinity of Gueydan, where my attention was called to the levee burrowing habits of the muskrats and the measures that are taken to prevent the undermining of canal banks. It is generally conceded that the extent of this damage today is slight compared with that which occurred in former years, but even under present-day conditions a certain part of the work of canal crews is in connection with the repair of muskrat excavation.

"The prolonged drought of 1924 and 1925, which had increased the salinity of most of the inland waters of the Gulf Coast area, resulted in some of the canals being drained of all or most of their water. There had been no need to refill them up to the time of my observations in March and April, 1926. With only a few inches of water in the beds 


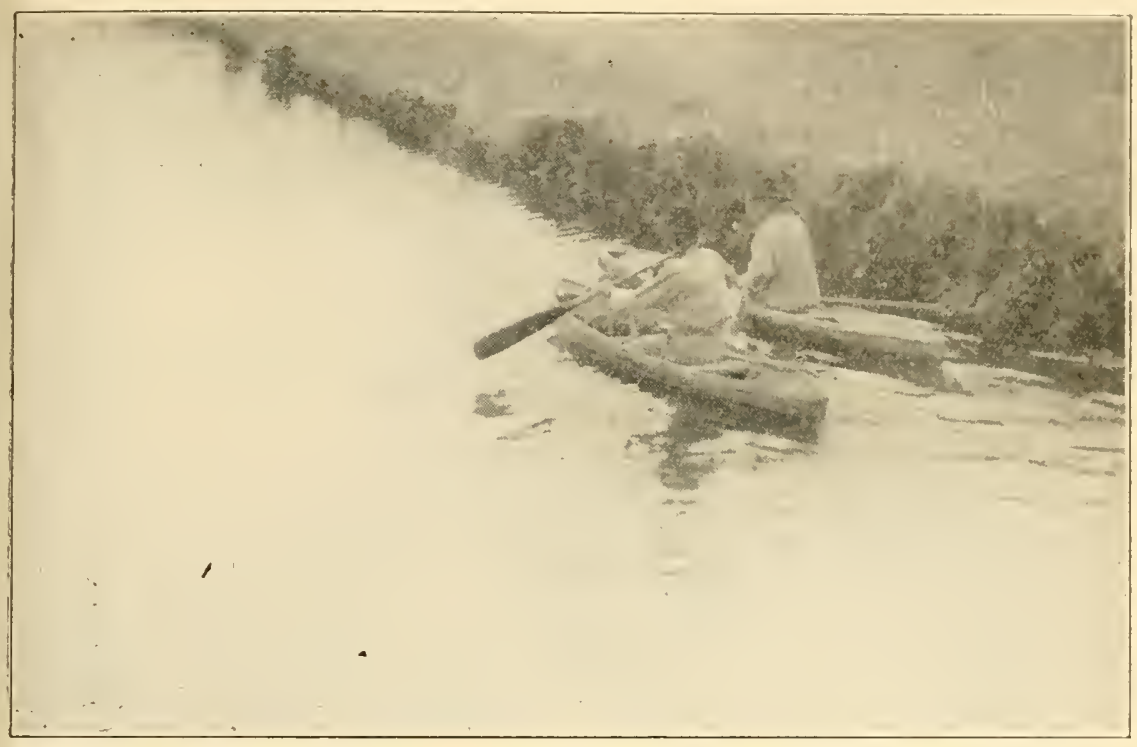

Louisiana trappers in their pirogues. The pirogue is termed the "flivver" of the lowlands. The craft is hewed and burned from the solid trunk of a cypress and by many would be called a "dugout." It is light and draws very little water. Some trappers claim they can paddle one over "a heavy fall of dew."

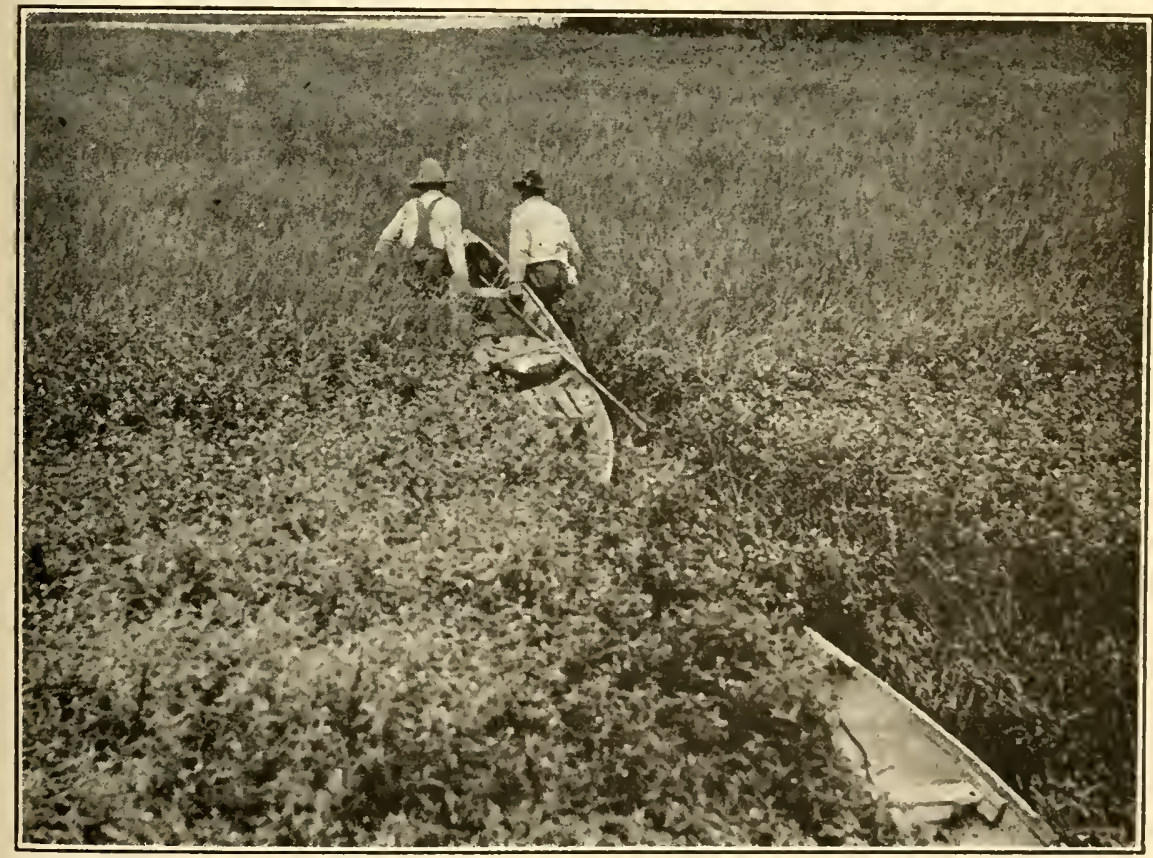

Hauling pirogues over a "trainasse," or grass trail, to reach open water on the other side of a marsh. 
of these canals, the runways and holes into the levees made by muskrats could be easily seen. Many of the latter, of course, would be under the surface of the water in times of normal water level. Availing themselves of the low water level canal crews were engaged in making necessary repairs, including the digging out of these burrows and rebuilding of the canal banks at those points. On five different days (March 13, 17, 18, 27, and April 9, 1925) I accompanied these crews and watched the operations. In one instance no muskrats were unearthed, but in the others a total of 12 were secured, $(2,5,3$, and 2 ).

"The crews engaged in this work become expert and seldom fail to locate and dispose of the offending 'rats. The first step involves the closing of all visible openings at the base of the bank which, under the conditions then presenting themselves, were just about at water level. To make certain that all openings at water level had been closed, a semi-circular dam is thrown up in front of one of these openings, making a barrier against the influx of canal water at that point. Then the water contained in the small pocket behind the dam is baled out with shovels. If a decrease is noted in the level of this impounded water and no flow occurs out of the burrow it is a sign that all subaquatic passages have been blocked.

"When this is accomplished, digging starts at one end of the tunneled area. Each lateral as it is reached is followed to its end and when there are several branches all but the one on which work is being done are temporarily closed to prevent escape of the rats. It is surprising how succesful the rats are in eluding their captors until the last. blind runway has been reached.

"On the several occasions that I accompanied these canaI crews four to six men were engaged and it usually meant the work of several hours. The most extensive piece of digging I witnessed involved the excavating of probably 100 linear feet of runway that cris-crossed 40 feet of canal bank. This work yielded three 'rats. Thereafter the bank had to be repacked before water could be put into the canal. 
"In no instance did I note a muskrat nest in these canal bank burrows. A female skunk heavy with young was unearthed from an enlarged passageway which she had lined with grass. A litter of young muskrats of about the size of meadow mice were dug out, however, by another crew whose operations I did not witness. They were killed and the canal bank rebuilt before I learned of their discovery."

\section{Muskrat Houses}

Muskrat houses, or "hills," as they are sometimes called, are characteristic of the Louisiana coastal marsh. During some seasons these fur animals are more energetic in building than in others. Just why this is is not satisfactorily fathomed. Some experienced trappers and observers believe that the severity or mildness of the winter has something to do with housebuilding activities, but this does not check out, and it is evident that more study to this phase of the muskrat's life must be given.

As shown in the accompanying illustration of a typical house, these domiciles are built out of marsh vegetation and of a number of species of grass, usually of the predominant flora in the habitat-three-cornered grass, cattail, bulrush, roseau, paille fine, needle grass, paille chat tigre, saw grass, et cetera, are utilized, the animal seemingly having no marked preference for any one kind.

These houses rise to a height of several feet, usually from two to four feet high, with a basal diameter of four to six feet, and sometimes even 10 feet. The entrance is always below the surface of the ground. If the house is built in a low spot and surrounded by water, these tunnels are filled with water and the animal is forced to swim through its aqueous subway to gain admittance to the interior of its domicile. These tunnels are usually many feet in length and the entrance is termed a "dive hole." In some instances the dive hole is close to the base of the house. There are more than one such entrances to the house, sometimes as many as five or six, and the tunnels are of varying length, radiating from the house like the spokes of a wheel. 


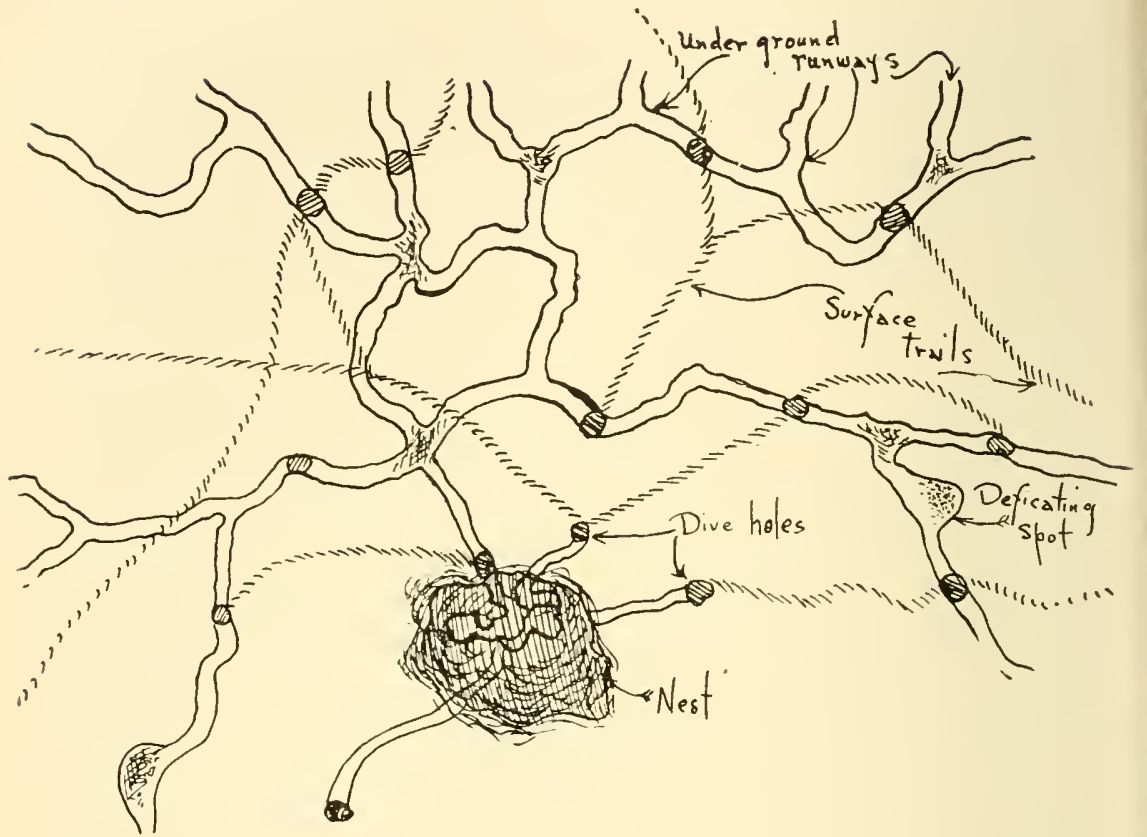

Ground plan of a typical muskrat house, with underground runways and surface trails. The surface trails are shown by barred lines, and the many dive holes of the underground system indicated. Widened parts of the underground passages with cross. hatched lines show beds or sleeping quarters in use when the subways are not filled. with water.

The accompanying sketch indicates the ground plan of a typical muskrat house, the dive holes, entrance tunnels, surface trails and the cleared area which surrounds, as a rule, all such habitations. The Louisiana trapping laws forbid the setting of a trap within ten feet of these houses and it is a most excellent conservation provision, for it preserves in no small way the young and the mother 'rat. Our law, too, forbids the molestation of the houses in any manner, and gigging, pitchforking, or the tearing apart of the houses in any way is punishable by fine and imprisonment.

Houses are built by the adult animals. Pairs, if it is true our muskrats actually pair, build them. Females build them unaicled by the boar. Males build themselves bachelor quarters and it seems to be proved that such quarters are among the smallest houses found in the marsh. Records are: 
available, however, of substantial living quarters being built by the males, so size is not always a definite index as to the marital status of the inhabitant.

House building activities are very apparent. Houses that have been contsructed for some time have a weatherbeaten appearance, while it is very easy to tell houses that have had new roofs laid on them the night before owing to the greenness and freshness of the muck and grasses piled on top of the structure during the previous night, for housebuilding is a nocturnal activity, as are most of the animal's other habits.

The mouth is used in transporting building material. The muskrat does not use its forfefeet in such operations, as does a beaver, although Charles Livingston Bull, the ace of animal artists, for instance, has so delineated this act. The building of houses calls for a great deal of tireless energy when once the muskrat is animated by an "own your own home" desire. Dragging the plant, including the basal parts of the stalk, a quantity of the root system to which adheres a lot of marshy muck and earth, with its mouth, the little animal scrambles up the side of the house, pushing and tugging, arranging and rearranging the material to its liking with the aid of its fragile-appearing hand-like front feet.

With the structure practically completed, tunnels and dive holes are excavated and from below the animal virtually "eats" its way into the interior to fashion one or more chambers, recesses, hallways or whatever one may choose to call the several "rooms." In some of the chambers bedding material is laid and it is here that the animal, or animals, as the case may be, rests during its sleeping hours. These chambers are always above water level. When there are two or more chambers, they are invariably connected, but, like other phases of the habits of the muskrats, there are exceptions to the rule for houses with individual rooms that were connected with outlet tunnels, but not with each other, have been examined. 


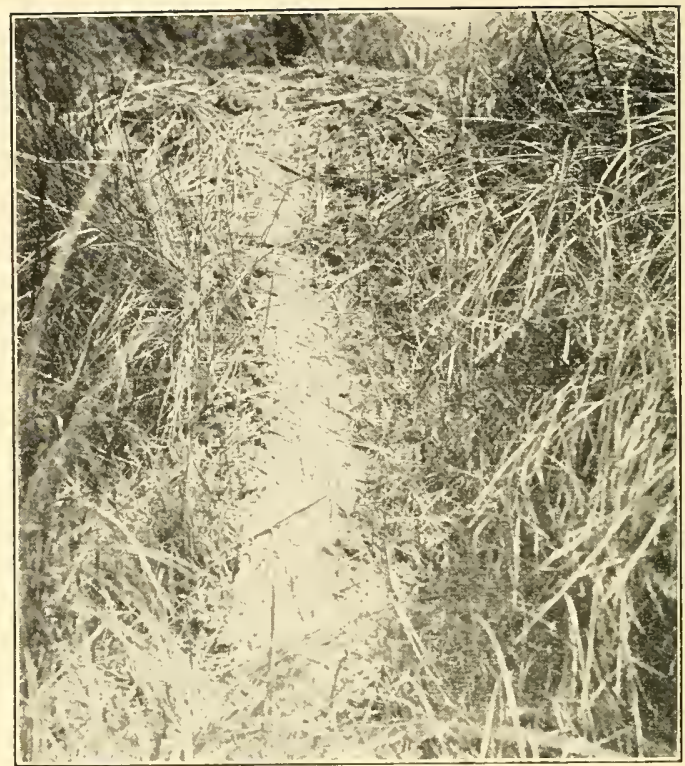

A muskrat "slide" on the side of a house which indicates that at times the muskrat indulges in the sport of "sliding down hill" somewhat after the manner of the otter.

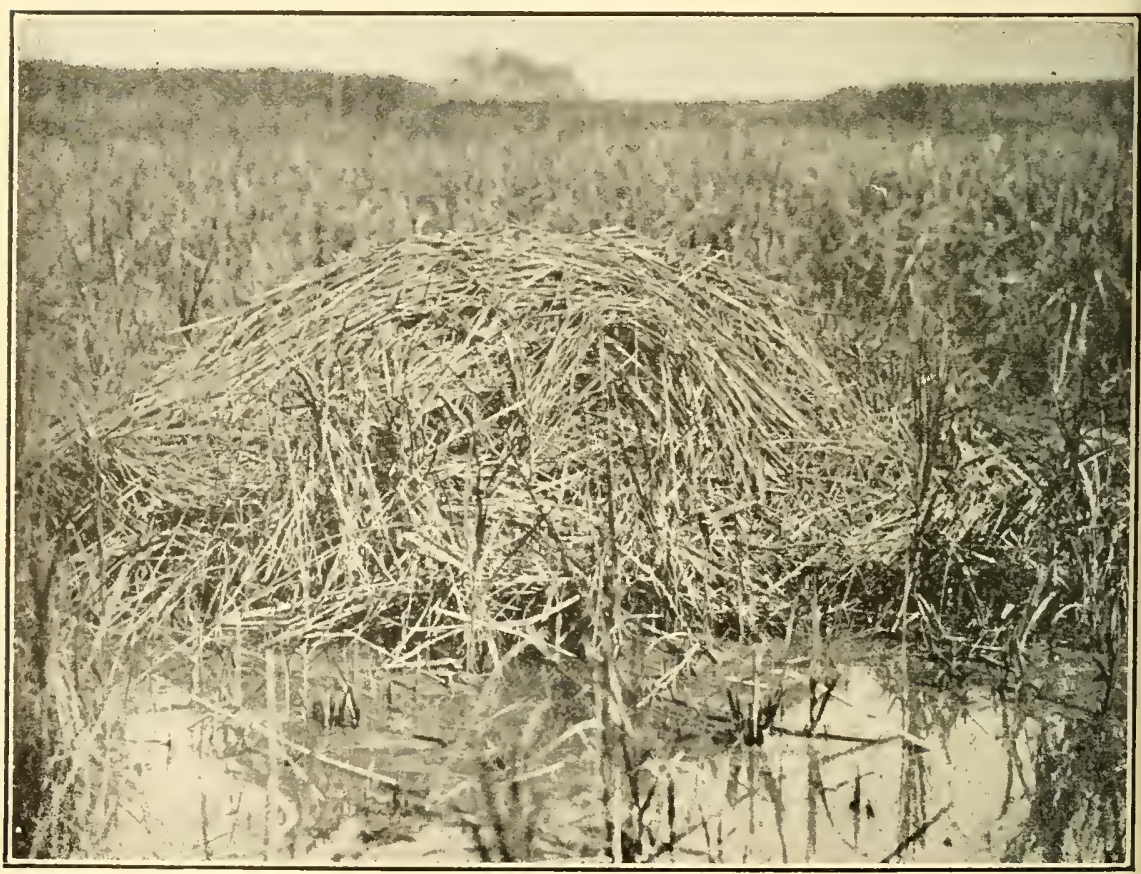

A typical muskrat house on the Cameron Parish marshlands where some of the finest muskrat pelts are taken each winter. 
The interior of these houses are always damp, if not actually wet, due to the admixture of muck and green vegetation used for building, and the interiors have pronounced thermic qualities. Thus, when the weather outside is cold, the interior is warm, and, in contradistinction, when the weather is warm the interior is cool. Therefore, the similarity to a thermos or "icy-hot" bottle is apparent.

The house has these various uses: as a sleeping place, as a retreat from natural enemies, and a nursery when reproduction time is at hand. A pair of adults may occupy the same house, two females, each with a litter have been found under one roof, but it seems quite likely that when the time for young arrives, the male is driven from the domicile, and the mother isolates herself from the boar for a matter of two weeks, possibly longer. Not until the young are able to seek their own food will the female accept the services of the male and the cycle of reproduction goes on until the coming of the hot weather of late summer-July, August and September-marks a cessation of breeding activities.

There seems to be no definite season for house building, but it is evident that these activities are more pronounced in the fall than at any other season of the year.

\section{FeEding Platforms}

As a builder the muskrat does not confine its abilities in this direction to the erection of houses. In the so-called deep marsh, where there is plenty of water on the ground, one will find many "feeding platforms," places where the animal will cut and lay a haphazard criss-cross of grass stems to which it will swim with food held in its mouth and, sitting on its haunches on the platform, will devour its favorite food. These feeding platforms usually span a water-covered runway, and the 'rat can gain its dry top from one of two directions.

When the water does not cover the marsh floor the muskrat calls into play its skill as a subway engineer and the terrain of humus is then netted with these under-the- 


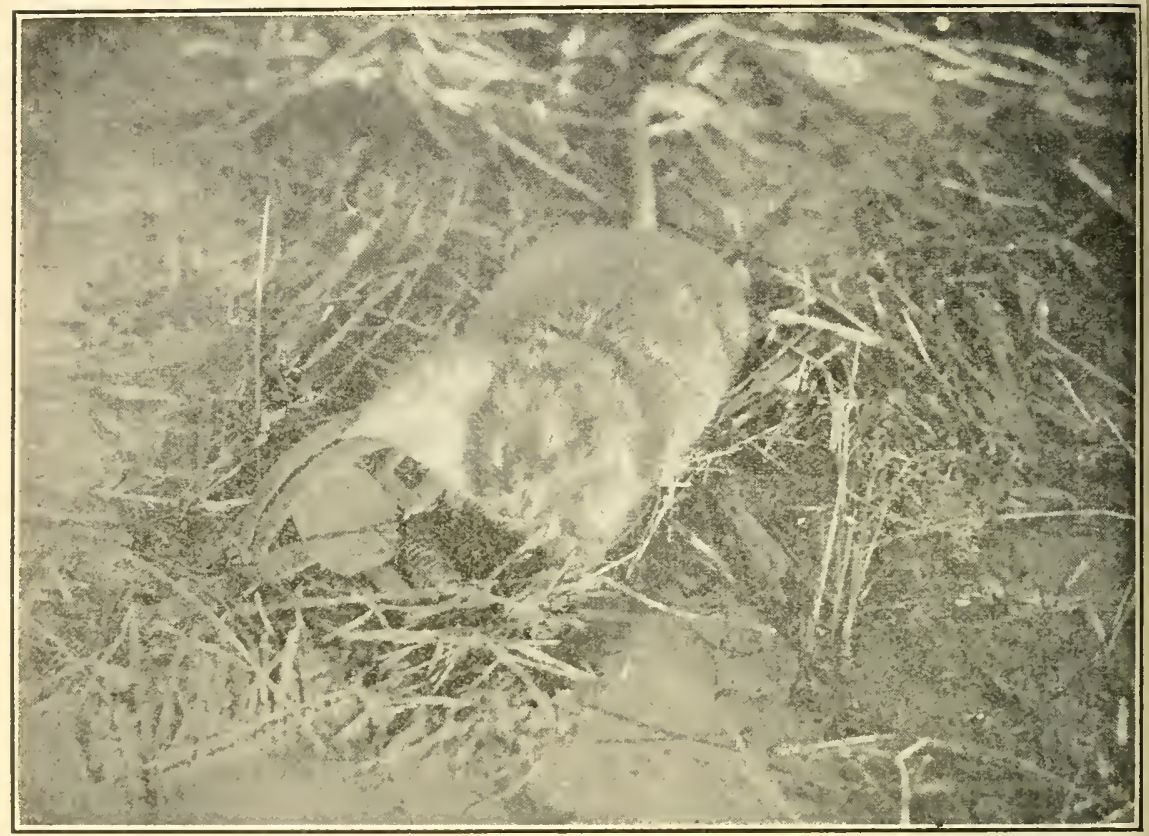

Killing traps are in use exclusively in Louisiana, as elsewhere, in harvesting the annual fur c:op. To meet the demand that has arisen for a so-called "humane" trap, the Department has been experimenting with a variety of traps designed to take the animals alive and unhurt so that those having unprime pelts, as well as the immature animals, can be released unhurt when caught. As yet, no 100 percent "sure fire" trap has been devised.

surface runways, zig-zagging here and there and everywhere. Laterals, short blind runs, and main travelways are dug. They all connect and an examination of such a labyrinth under acres of land shows conclusively that they are the work of many individuals. A sketch of such a work is reproduced on page 257 and shows surface trails as well as the many underground routes and the dive holes which connect the subways, often from 12 to 18 inches deep, with the surface.

These tunnels dug are not wholly for the purposes of travel but to allow the animals to feed on the white, succulent running root systems of the food plants that cover the surface. 
When extra dry weather comes and the surface waters of the marsh evaporate, water is necessary and the animals become virtually well-diggers, going two feet and more beneath the top of the marsh floor for moisture. When digging, the fore paws do the greater share of the excavating, the broader and stronger hind legs pushing out of the hole the dislodged dirt and muck.

While it is quite evident that the muskrat is a hard, indefatigable worker, it is equally apparent that there is a great waste of energy in what it does in tunnel digging and in a number of other activities and one wonders why it does a number of things. But it does them just the same.

Cleanly in what and how it eats, the muskrat is very clean in a number of other habits. Excrement is seldom if ever voided in the houses, in sleeping nests, or on the feeding platforms. In going through the heavily populated marshes frequently there is found defecating spots used by one or more individuals and possibly through many seasons.

In its building and tunneling activities the muskrat has been compared to the beaver. This latter rockent has been recognized as one of the most intelligent of animals and many tales have been told of its engineering skill. "Shall not the muskrat be credited with an equal display of intelligence?" asks Dr. Charles E. Johnson, author of that very valuable "The Muskrat in New York," who believes when the relative size of the builders is kept in mind, the energy, industry, and intelligent behavior of the muskrat appear in every way equal to those credited to the beaver. "The muskrat does not build dams," he observes. "If this one feat had been added to its accomplishments the muskrat would doubtless have been the object of the same amount of attention, wonderment and admiration as has been bestowed upon the beaver."

Our field biologist recites an interesting occurrence relating to the mother instinct of the muskrat and her young in the nest. He found a house which contained two young and, hoping to catch the parent, placed a live trap in the nest, using the babies as bait, with the expectation that the mother would come to her young and be thus caught. 


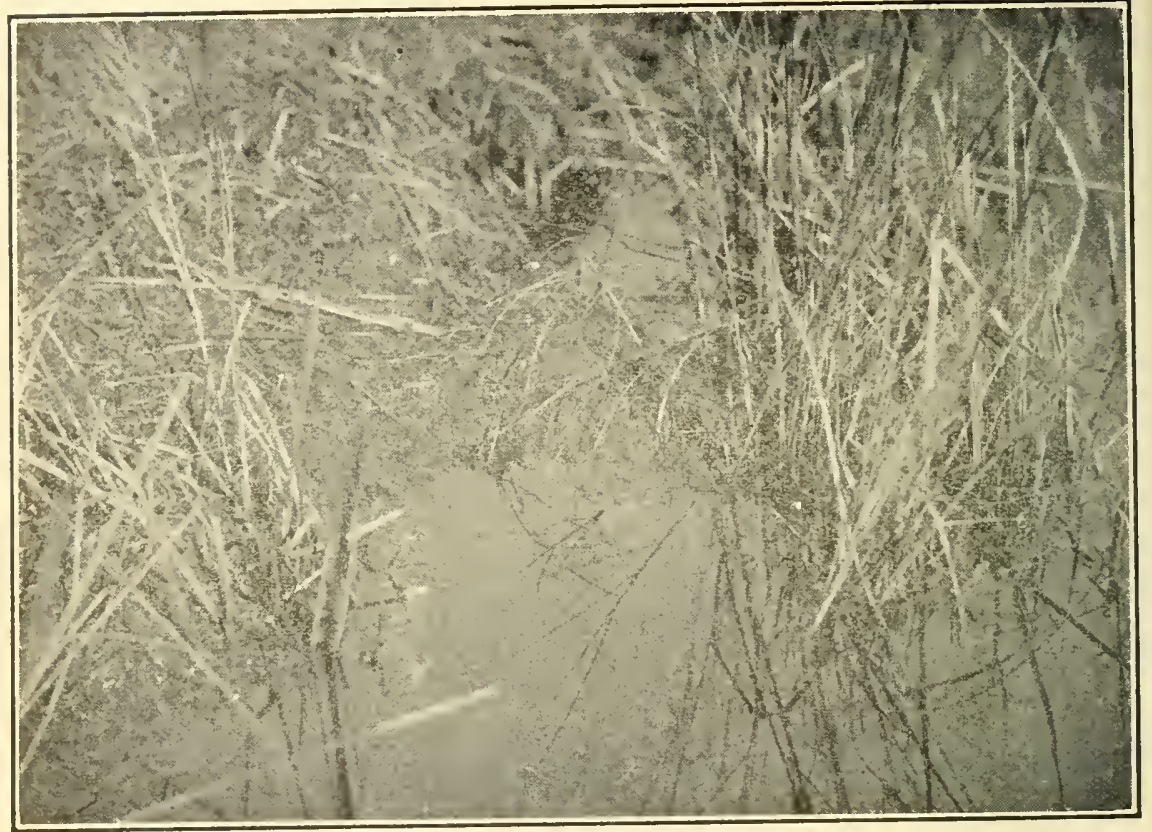

A muskrat "feeding platform," in a marsh. The muskrats carry the root stalks they cut off to such "platforms" by swimming, and devour the food out of the water. They sometimes, when the water is very high, break down grasses to construct their feeding platforms.

When he visited the house the next morning "the trap was sprung and the material surrounding the trap was plugged in all around it, making it impossible for anything to get in the trap. To one side of the old nest with the trap, a new nest was found, in which the young were peacefully sleeping. The same trick was done again and the same results were discovered the next morning."

\section{MARSH FIRES}

One of the problems that the 'rat rancher, the trapper. the land owner-in fact, anyone interested in the muskrat industry-has to face is the question of fires on the marshes.

If all of the fires were accidental, the problem would not be of any great consideration, but, unfortunately, 90 per cent of the fires are set by trappers and alligator hunters. Firing of a marsh by a trapper is done under the 
mistaken impression that it "improves," or that is sometimes his excuse, the food conditions of the marshland. Mostly it is fired so that he can more easily locate the scamper trails of the muskrats, set his traps in them and collect his toll of pelts with a minimum of physical effort.

Does a fire benefit the vegetation of the marshes? Opinions among trappers are almost equally divided on this subject, the slight majority of real trappers are against fires at any time, it should be stated.

Observation would indicate that a fire on a muskrat marsh is not as disastrous as many maintain. Surveys have shown, in many instances, that fires set at the proper time and in favorable seasons do benfit the marsh. In considering fires, this should be borne in mind: when the first cold weather comes the annual grasses dry and yellow, the new grasses of springtime struggle up through the matted dead growth, and in time add their dried and withered stalks and leaves to the growth of the year before. As a result, a tinderous mass of dry herbage is on the marshes awaiting the spark that will ignite the mass into a roaring and devastating conflagration. Once such a fire is started, nothing can stop it, and great damage is liable to be the result.

On the other hand, should the 'rat rancher fire such dead grass growth at a time when the ground is soaked from rainfall, the fire will sweep over the area he selects for burning, burn off merely the dead grasses on top of the ground, and a minmum of damage is done. Should such fires be started when the earth is dry not only is the matted grass burned but the fire also burns into the peaty soil, not only are underground runways burned out but the muskrat houses suffer as well.

Firing of marshes under personal supervision and at the favorable time outlined above proved conclusively that practically no damage was done to the muskrat houses and the animals seeking refuge underground were not harmed in the least, and after the fire had passed on emerged none the worse for the experience. 


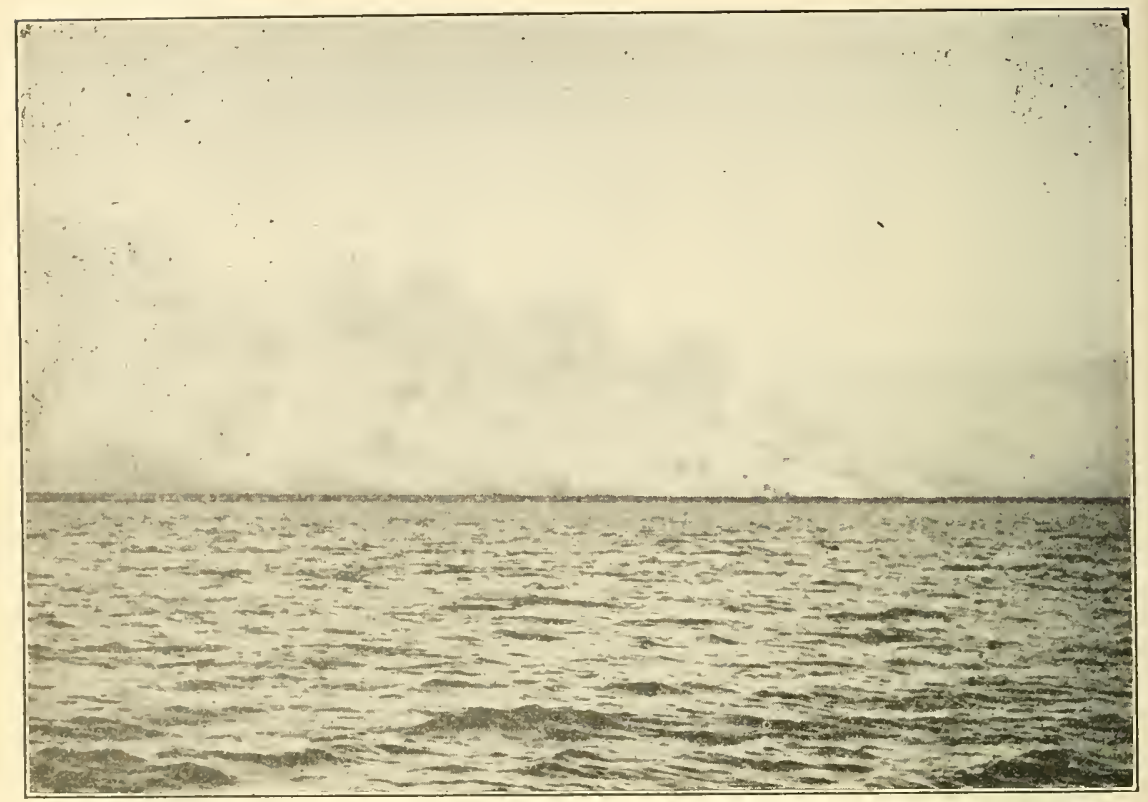

A typical marsh fire seen at a distance.

The firing of the marshes is no new thing. Witness the testimony of M. LePage du Pratz, who, writing of conditions in 1719 in Louisiana, said:

"We set out in the month of September", which is the best season of the year' for beginning a journey in this country; in the first place, because, during the summer, the grass is too high for traveling; whereas, in the month of September, the meadows, the gr'ass of which is then dry, are set on fire, and the ground becomes smooth, and easy to walk on; and hence it is that at this time clouds of smoke are seen for several days together to extend over a long tract of country; sometimes to the extent of between twenty and thirty leagues in breadth, more or less, according as the wind sets, and is highel or lower. In the second plane, this season is the most commodious for traveling over those countries; because, by means of the rain, which ordinarily falls after the grass is burnt, the game spread themselves all over the meadows, and delight to feed on the new grass, which is the reason why travelers more easily find provisions at this time than at any other." 
Under the state laws the firing of marshes or other lands is strictly forbidden, but owners of lands may set such fires for the purpose of improving food conditions for wild life, but only under permit and supervision of the department of conservation officers, and then such authorized burnings shall not be done during the breeding season of wild bird life.

In marsh fires two things are to be considered: damage to wild life from burning at unpropitious times, and the hazards of allowing accumulations of dead grasses to remain on the marshlands waiting to be fired by agencies over which there can be no control.

All marshland fires are not from human agencies. Lightning, during the late summer months, frequently strikes masses of dead vegetation and the marsh is soon ablaze with a fire that cannot be stopped. When such a bolt ignites the marsh grasses it is usually during a protracted dry spell and damage to the muskrat population invariably results.

An economic solution to the marsh fire problem, therefore, remains to be worked out.

If the marshes are fired when the ground is wet, the growth of many of the best muskrat food grasses is almost instantly renewed. Especially is this true of the threecornered grasses. The rooting systems, when they are covered by wet earth, are not harmed, but appear to send up stalks with renewed vigor.

It seems to be the consensus of opinion among practical trappers that it is impossible to kill out certain grasses that are not valuable as muskrat food by firing. Great stands of cut grass (Zizaniopsis communis) have been burned regularly in Cameron parish in an effort to rid the land of the growth, but after several regular firings it seemed that the cut grass came back thicker than before.

\section{ENEMIES}

There are many natural enemies to the muskrat in Louisiana, which is not strange when one realizes that this animal is so abundant and that its marsh habitat is the haunt of so many other forms of wild life. 


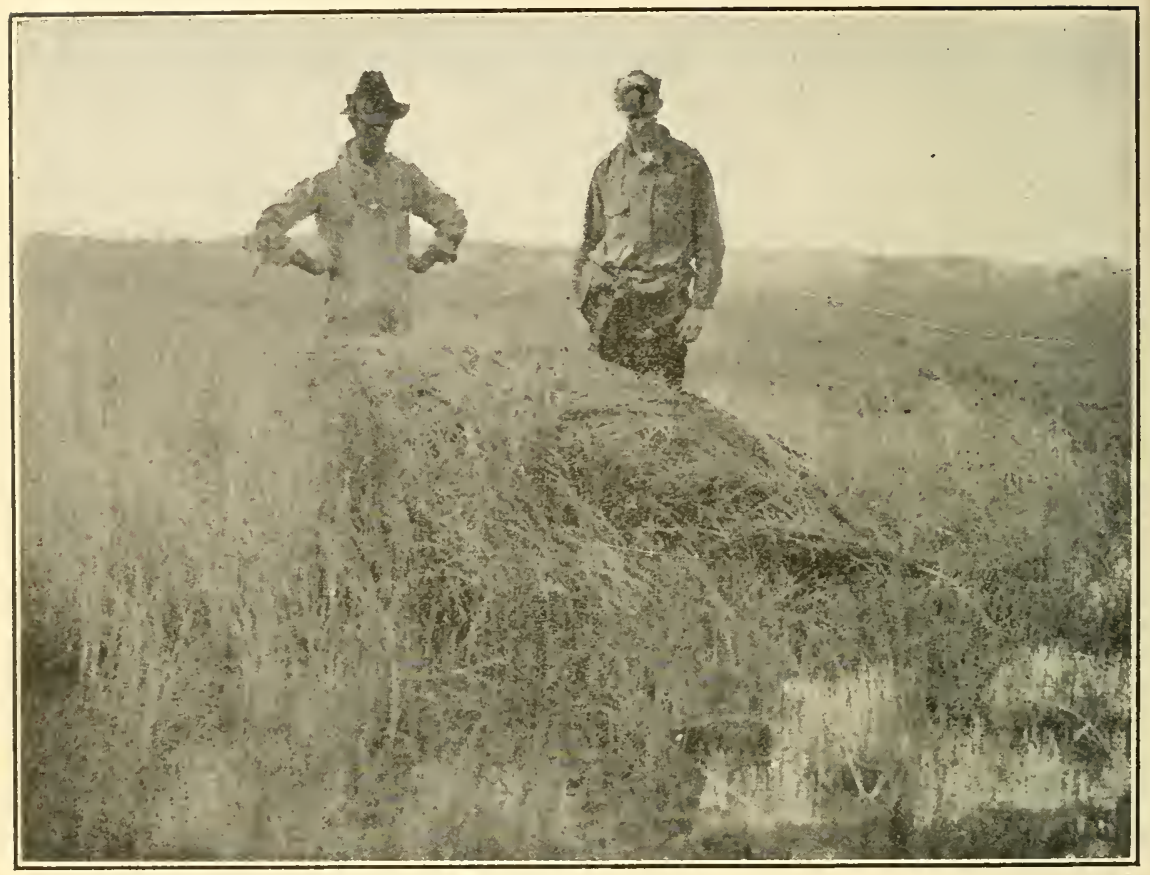

The result of controlled burning of the marsh on muskrat lands. With water on the ground and a fresh wind blowing the fires swept over the muskrat houses without setting them afire. As a result of the burning off the rough dead grasses new growths of threecornered rush appeared. A fire set during a dry spell would cause a great deal of damage, it has been demonstrated.

Mature conclusions are that the enemies to the muskrat, named in the order of the destruction they cause, are: minks, moccasins, snakes, garfish, owls, hogs, alligators and raccoons.

Few of our Louisiana trappers appear to realize the fact that the mink is an enemy to the muskrat, but those who have discovered the fact testify to the amount of damage this sly, murderous little animal does in the coastal marshes and such trappers make mink sets a part of their activities.

A number of investigators have noted the mink's predilection for muskrats. Dr. A. K. Fisher of the U. S. Biological Survey, claims that the mink is indefatigable in its search for meadow mice, muskrats and other marsh-loving rodents, and "it is very fond of muskrats, and one of the 
mink's most important services to man is the destroying of these pests about milldams, canals and dikes, where their" burrows undermine the embankment and cause overflows." William E. Cram is of the opinion that "the mink seems to prefer muskrat flesh to any other food, and hunts and kills muskrats, both old and young, at every season of the year.", 37

Surveys have demonstrated that the mink prey on the helpless young frequently. It has been discovered that countless muskrat houses exhibiting small, round holes on the outside and high on the structure that the mink had made in gaining an entrance directly into the nesting chamber. It is quite evident that the toll taken is very large.

In the high-producing area in the Delacroix Island section of St. Bernard and Plaquemines parishes the minks were at one time very plentiful, but the trappers of that section, through a persistent trapping campaign that has gone on for years, have virtually wiped out these flesheaters and the present-day production of muskrats, is very high.

It has been an old adage in the Louisiana marshes that wherever the poisonous moccasin snake is plentiful one is certain to find many muskrats. On the other hand, some experienced and practical trappers will tell you that the moccasins become so plentiful and take such a toll of young that muskrat population is kept down.

During the disastrous crevasses of 1928, which covered the Delacroix Island marshes large numbers of these snakes feeding on the mice have been found that had sought refuge on the rafts and a photograph of one swallowing a small muskrat is reproduced in these pages. The crews of trappers engaged in rescue work kept up an incessant warfare on these reptiles and thousands of moccasins were killed.

Our field biologist during the month of April found a four-foot moccasin at the foot of a muskrat house swallowing a muskrat kit head first. At the time of discovery the cotton-mouth had swallowed the entire forequarters of the kit and was slowly making advances with the remaining portion by distending its jaws and sinking its fangs further

${ }^{37} \mathrm{Cram}$, W. E., Journal of Mammalogy, vol. 4, p. 22. 
along the young muskrat, in this manner pulling in the kit. After killing the snake, Mr. Svihla found pieces of unchewed paille-fine grass in the mouth of the victim, proving that the kit had been attacked while feeding. Dissection showed that the snake had another muskrat kit the same size in its stomach.

When Vernon Bailey, chief field naturalist of the Biological Survey, was in Louisiana studying the muskrat, he was impressed with the fact that our animal did not swim about in the many streams nearly as much as did this fur animal's cousins in the north, and he became convinced that, through constant and age-long persecution by enemies in the water, such as gar fish, turtles and alligators, that the Louisiana muskrat had abandoned a natatorial habit and confined itself to land, entering the water only when forced to by enemies.

Studies seem to indicate there is a great deal to this surmise and that one of the chief enemies is the big, powerful and rapacious gar fish. Just what damage the gars do has not been worked out, but the several species of this fish inhabiting our Louisiana bayous, from the small needlenose gar to the tremendous alligator gar, which reaches a maximum of six feet, undoubtedly play havoc with any swimming muskrat found in the waters.

Of the damage raptorial birds of prey do to muskrats, the owls are to be counted on as doing the most, and, while the hawk, especially the harmless marsh hawk, has been given a bad name in this regard, it appears they prey on the living muskrat very slightly, if at all. The short-eared owl and the barn owl, from an examination of their pellets picked up in the marsh, prey on the mice to a considerable extent and this is not to be wondered at when we consider that the muskrat is a mammal of pronounced nocturnal habits. The great horned owl undoubtedly destroys many. While marsh hawks, very common raptores of our marshlands in winter, have been seen time and again feeding on muskrats, they only prey on the dead animal-on the skinned carcass left in the marsh by the trapper, or on a dead 'rat held by a trap. 


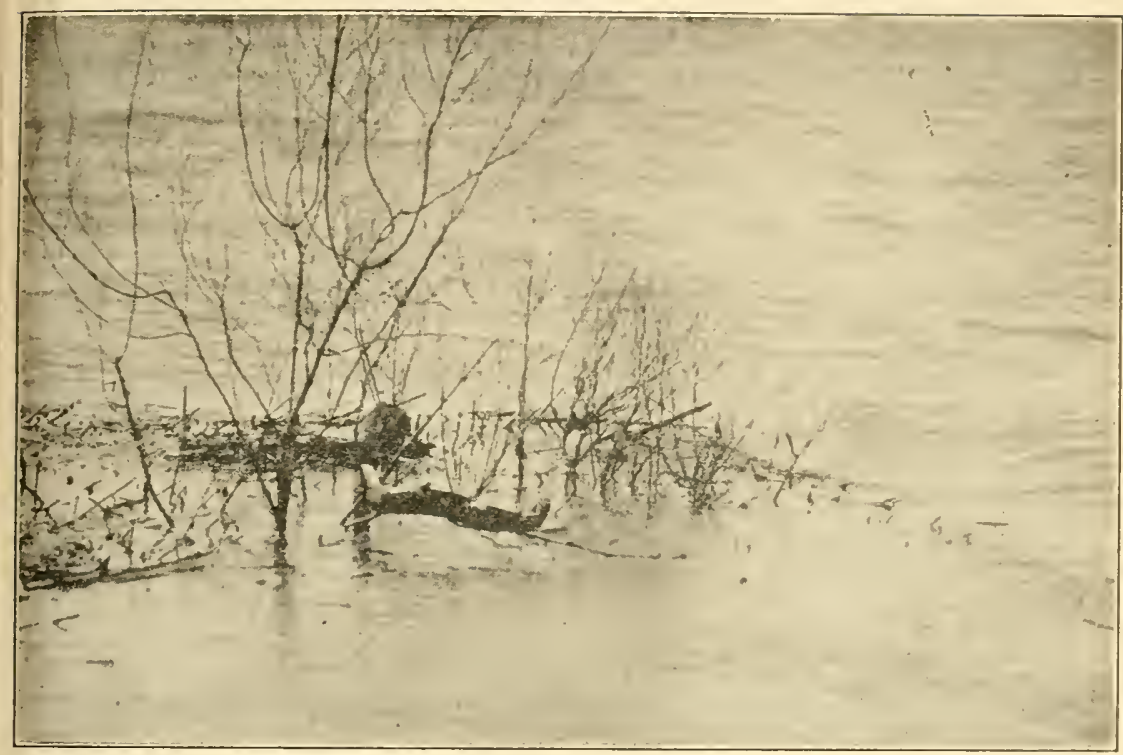

One of the principal enemies of the muskrat is the moccasin snake. One is photographed here making its way toward a young muskrat seated on a raft of dry grasses.

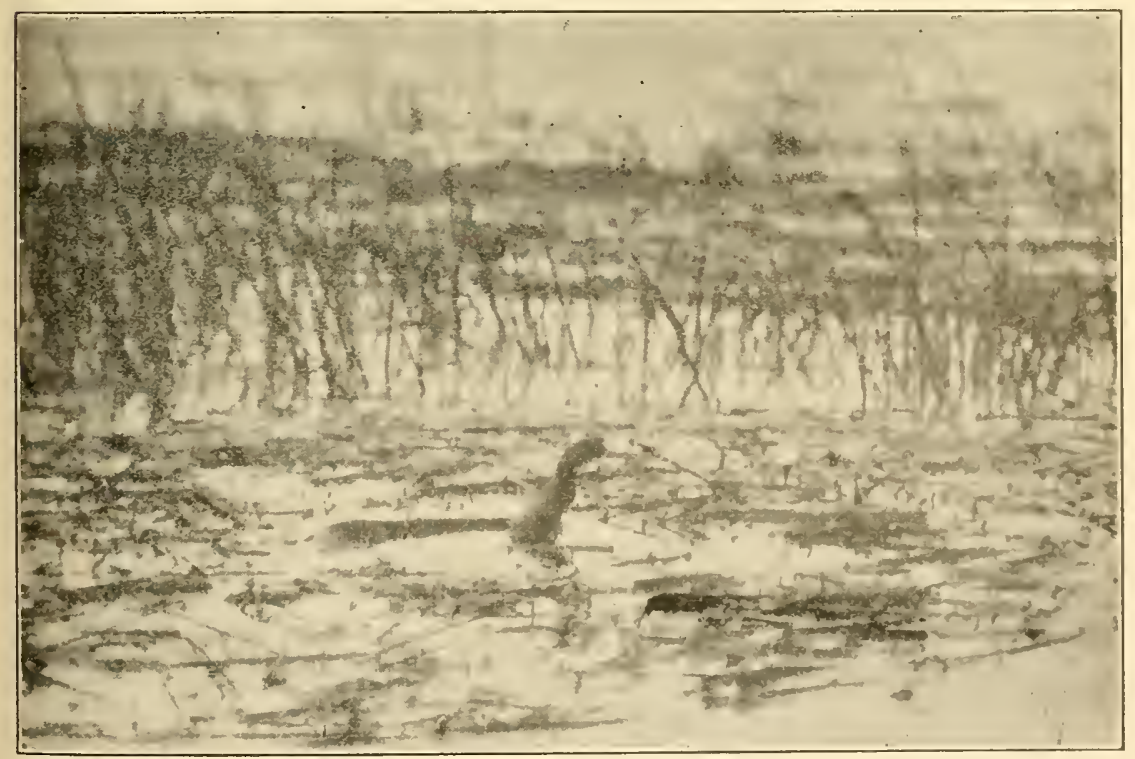

The greatest toll taken by the moccasin is of the mice, or very young muskrats. The snake has been photographed in the act of swallowing a baby muskrat. 
The chief damage done by the marsh hawk is in tearing large holes in the pelt of a dead trapped muskrat before the trapper gets to it, but this damage is matched, if not exceeded, by the grackles (chocks or crow blackbirds) that. have the same bad damaging habit.

There is proof in plenty of the damage done muskrat marshes by droves of "wild" hogs. The swine have a habit of rooting up muskrat houses and it is evident that many litters of young are thus wiped out. C. E. Ward, in charge of a 'rat ranch, claims that "when hogs once taste muskrat they will continue their forays on hills until the muskrats are killed out."

There is no "enemy" of the muskrat that has more imprecations of the trapper hurled at it than the alligator. While it is true that this characteristic saurian of our Louisiana marshes does take its toll of muskrats, both big and small, still field surveys and stomach investigations do not bear out the oft-repeated assertion that it is the enemy of our champion fur animal. Details of what has been found in this regard can be studied in the chapter given over to the alligator in this bulletin on page 165 .

An illustration of the widespread prevalence of the belief that the 'gator plays an important role in the destruction of the muskrat is found in an assertion by David C. Mills, director of the National Association of the Fur Industry, who said "the muskrats in Louisiana have multiplied as the alligators have been reduced in numbers." 38

Mr. Mills believes that the smaller fur animals have been able to hold their own by reason of, first, their fecundity, and, second, the extermination of their larger natural enemies, and, while there is undoubtedly a great deal of truth in this, we cannot wholly subscribe to his alligator theory alone.

Brer 'Coon is another muskrat enemy. There is evidence in plenty of his tearing into muskrat houses in search of helpless young, but the wily raccoon cannot be counted a factor in muskrat destruction. Its forays are sporadic and almost inconsequential.

${ }^{38}$ Milis, D. C., Journal Home Economics, vol. 18, p. 625. 
While the snapping turtle is unquestionably a menace to the muskrat in the north, there is very little evidence pointing to it as an important natural enemy in Louisiana.

Floods take their toll of the muskrat young frequently. By this is not meant the infrequent crevasse inundations, but the high waters that cover the coastal muskrat lands from the gulf tides. There seems to be no guarding against catastrophes of this kind and the fact that the adults are not adversely affected by such floodings means that breeding is not unduly interrupted, although the mice suffer.

Droughts, when they come to the Louisiana marshes, do great damage. Prior to the 1924 and 1925 exceptionally dry spells, the state had not had such a visitation in over twenty years.

The more or less serious consequences that come with and follow exceptionally dry periods include the drying up of fresh water ponds and shallow bayous, and excess of salt water in normally fresh streams; the killing of vegetation and the disastrous fires that sweep the marshlands not alone burning off the vegetation but burning deep into the humus or peat of the marsh floor.

At such times the muskrats roam about in large numbers seeking wet spots, which become unduly crowded, and the mortality becomes very high. These drought spells, with their lack of food and water, have a tendency to stop breeding activities and a short fur crop the following winter trapping season is an inevitable result.

The damage done muskrats by domestic animals is practically nil, save, of course, that done by hogs. As one trapper put it: "Oh, dose hogs. She do ten times more damage than all the belette (mink), alligator, hawk and h'owl, put togedder in one."

Trappers, when they are in the marsh during the three winter months given over to trapping, have a habit of carrying out with their families, one or more cats. Such cats frequently "go wild" in the marsh and prey on the muskrat mice, but our biologist made a noteworthy observation on feline reaction during one of his experiments. 
A cat-none too tame-was found prowling around some trappers' cabins and was caught and taken to the experimental farm, but in a few days disappeared. Later Mr. Svihla found the tabby, very fat, lying in one of the experimental pens, and, suspecting such circumstantial evidence, she was placed in an observation pen with three muskrat kits. Although the cat watched the young muskrats with interest when they ran close to her, she made no move to attack them. The cat was then placed in a cage with three full-grown wood rats (Neotamas) and the reaction was instantaneous and only quick action on the part of the observers saved the wood rats from death. Later, when the cat was given ether, she was found to contain two kittens about to be born, and a large woodrat, which she had eaten, evidently very recently.

In securing muskrat mice in the marsh and endeavoring to feed them, they have frequently been given to cats with suckling kittens. When the cat's own kittens were all taken from her, the feline was always content to play wet-nurse to the mice. Another cat, given five baby minks to raise, refused to have anything to do with her own kittens, preferring the baby minks, although their sharp, pointed teeth would make her wince when they were feeding.

The natural enemies enumerated above, of course, are not all that take a toll of the muskrats in our marshes, but it is believed that all of the important ones have been named. The field for further investigation of enemies, especially parasites, is a wide one, and much is yet to be learned.

Vernon Bailey's views on the subject of enemies follow:

"The Louisiana muskrat, unlike any other species, seems to avoid open water and to be restricted to the broad marshland away from the edges of the lakes, bayous, ditches, and canals which cut these marshes into irregular sections, but this distribution may be more apparent than real. All of these open waters abound in alligators, many large and carnivorous turtles, great numbers of huge garfish, often five or six feet in length, and numerous sharks. Of these, at least the alligators and turtles range back into the marshes along the low places wherever a foot of water is 
available, and the muskrats are noticeably scarce in even these wet places. It seems more than probable that the muskrats are simply devoured wherever this host of enemies can reach them, and that those occupying the marshes are merely what are left from a very prolific species, and that as they increase and spread to the shores, as they are known to do, they become food for the reptiles and fishes. But for surpassingly favorable food and living conditions, and the fact that they breed during almost if not the entire year, they would have been exterminated or kept back as they have been from the marshless stream country immediately northward of the marsh country. A wide belt seems to separate the range of this species on the north from the southern known limit of range of Fiber zibethicus zibethicus."

\section{The Muskrat as Human Food}

The muskrat's flesh, although it is an excellent and palatable food for human beings, is not so recognized in Louisiana. 'This in spite of the fact that it was used by the first white men who came to this country, who learned the Indian methods of cooking it, and the further fact that many people of refined tastes today, especially in Baltimore and Washington, D. C., buy the muskrat carcasses in the markets of those cities and use it on the table just as many of us prepare and eat rabbit meat.

There are two things that militate against the use of this animal's flesh as human food; the first, and foremost, being the designation of this animal as a "rat;" the second being the fact that sometimes the musk glands are cut and the meat thus becomes impregnated with a musky flavor. To overcome the second objection care should be exercised in skinning the pelt, the musk glands should not be cut into, as they can be removed whole when the skin is taken off and the animal's hair should not be allowed to come in contact with the flesh.

The first objection, unfortunately, cannot be so easily removed. The fact that the animal has a "ratty" designation means that mind will always overshadow matter. If the old Indian names of musquash or pichali could be used, 
and the offensive and misleading designation rat avoided, it might be easier for the public to become educated to make more use of this wholesome meat.

At several of the trapping camps Vernon Bailey visited during his many surveys of the muskrat marshlands, muskrats were dressed and cooked in an endeavor to get the trappers, many of whom were complaining of a lack of fresh food, especially meats, to eat the flesh. As savory as the meat smelled when it was sizzling in the pan, on a cold, frosty morning, the trappers declined the feast until they watched the "queer" scientist devour the meal with gusto. Then they would gingerly try a piece.

It was much easier to get others than trappers to eat the muskrats so prepared, although the trappers, to a man, were agreed that this little animal was the most cleanly animal in their food habits and that there was, really, no good reason for not eating the meat-but!

A few of the trappers who did eat the muskrat meals declared that the meal was delicious and far superior to rabbit and squirrel, which is a fact, as the meat is not unlike some of the dark-meated ducks and just as tender and wellflavored when properly cooked.

Vernon Bailey gives the following directions for preparing and cooking the muskrat:

The usual method of skinning the muskrats and leaving a strip of the skin across the back edge of the belly does not disturb the musk glands, which lie at the sides of the penis, and the carcass then can be hung up by the head, and this strip of skin, with the musk glands and the entrails removed and the feet, tail and head cut off. Then it is ready for market or for cooking. There is about a pound to a pound and a half of solid meat on the bones of one fullgrown animal.

For cooking in the simplest way, the meat should be cut in pieces, consisting of hams, shoulders and short sections of the back. The neck and head also have considerable thick and excellent meat. The ribs contain little meat, and are generally thrown away. The liver is large and healthy, and especially delicious, if the gall bladder is carefully removed. 
Roll each piece of meat quickly in flour or fine cornmeal, containing salt and a little black pepper, and drop in a pan of hot grease. Keep it very hot, so the meat will cook rapidly, without losing its juices or flavor, and serve before the last traces of red have left the inside of the pieces. Let the grease drain from the meat for a minute, but serve quickly while hot.

A dry stew in a covered pan with bits of bacon gives excellent results.

Cut up and broiled over the coals in a wire toaster, with thin strips of bacon on top after one side is done, is an excellent camp method of cooking musquash.

The whole carcass laid on the coals of a campfire has furnished many an excellent meal.

\section{Utilization of MUSKRAT CARCASSES}

It has long been realized that there is a tremendous economic waste in trapping muskrats. When an animal is taken in the traps its pelt is skinned off and the carcass thrown aside.

In studying the particular phase of the whole trapping question, from investigations and weights taken in the field, it appears that 13 per cent of the gross weight constitutes the pelt, which is saved for some useful purpose, but 87 per cent of the animal is wasted.

What is to be done with this wastage? Is the wastage of any value? Can it be commercially utilized?

It has already been recited that the flesh of this remarkable little fur animal of our marshes is fit food for human consumption, but the time seems remote when it will be used, as are the Maryland muskrats, for meat in markets of Baltimore and Washington, D. C.

That the millions of carcasses that go to waste annually in our marshes are of value, some way, some how, some where, it is very evident, but nothing has ever been done, it would appear, to determine what the muskrat, sans fur, contains. To obtain such information eleven muskrat carcasses, skinned and with viscera removed, were turned over to Cassius L. Clay, state analyst with the Bureau of 
Foods and Drugs in the Louisiana State Board of Health, for anaylsis. Mr. Clay's report follows:

"The report is of a composite sample, taken after grinding eleven muskrats, received January 5, 1928.

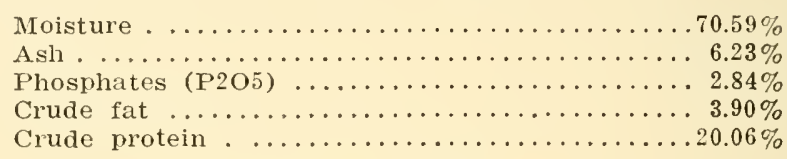

\section{Analysis on Dry Basis}

Ash . ..................................

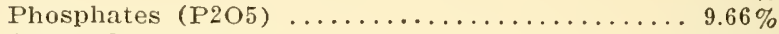

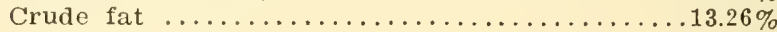

Crude protein ......................68.20\%

"The chemical analysis indicates the composition of muskrats to be such as to make their carcasses valuable either for the manufacture of fertilizer or as a component part of mixed animal feeds.

"There is a considerable amount of mineral matter present in the form of phosphates, a valuable plant or animal food.

"The greater part consists of protein or nitrogenous substances, also a very valuable ingredient. The fat substances could probably be extracted and utilized to advantage.

"The actual value of the muskrat carcasses, would, of course, depend on the availabilty of the supply."

To ascertain what chemicals, fats and proteins could be recovered in quantities sufficient to make the business of gathering carcasses a practical one, it would be necessary to make such experiments on a very large scale, and this could be done best by one of the very large rendering plants. 


\section{CHAPTER TWENTY-ONE}

\section{THE FIELD BIOLOGIST'S REPORT}

$\mathrm{A}^{\mathrm{s}}$

THE muskrat is the chief fur animal of Louisiana, the source of the state's greatest revenue through the sale of pelts and the tax on them, as well as the most important animal of the fur trade of the country today, it was deemed imperative early in 1925 that the Department of Conservation conduct a thorough and intensive survey of the life history of this rodent.

To this end, after consultation with members of the fur trade of Louisiana, marshland owners, and others interested in our furs, there was established contact with the Bureau of Biological Survey in the United States Department of Agriculture, and Dr. E. W. Nelson, who was then its chief, and asked that this federal bureau, which was as interested in the subject as we in Louisiana were, obtain the services of some young student of zoology and have him come to Louisiana and study the muskrat first-hand and at close range.

The biological survey, enthusiastically cooperative in the matter, not only selected the biologist to essay the field work but also sent Vernon Bailey, chief field naturalist of the bureau, to Louisiana to assist in laying the groundwork for the investigation and to direct its scope. The field biologist selected was Arthur Svihla, a graduate of the University of Illinois, who, at the time of his employment by the Department of Conservation, was taking a postgraduate course in zoology at the George Washington University in the national capital.

The biologist began his field work in June of 1925, and carried on his investigations up to and including June 30 , 1927. His main work was to secure, as far as it was possible to do so, a complete life history of the Louisiana muskrat, and he was directed to confine his studies to the reproductive end of the problem, determining periods of gestation, number of young in litters, number of litters per year, and when the muskrat became physically mature and when it became sexually mature, as it was believed that 
these were the more important matters to be learned of this very prolific mammal of the south Louisiana marshlands.

In spite of his opportunities and length of employment, Mr. Svihla did not accomplish all of the work mapped out for him and his services were terminated in the summer of 1927. In the course of his field work the biologist learned a number of facts of interest, if not of any great importance, as to some of the habits and life of our muskrat, and the matter that follows is an abstract of the report that he made the department at the conclusion of his employment:

"The Louisiana muskrat, due, no doubt, to constant persecution, has an intelligence and cunning, which, if accounts in literature be true, far exceeds that of his northern brother. He has a certain cautiousness in approaching traps which has often proved his salvation. During cold, still nights, muskrats work industriously, building on their houses, digging runways, and searching for palatable bits of food. A very windy night or warm weather results in little activity in the marsh. During the summer months, when the weather is hot and dry, signs in the marsh and also in pens where 'rats are known to be, are exceedingly scarce. Plenty of water and cool weather are the most favorable factors for muskrat activity. They are quite adaptable, however. Extremely high tides do not trouble them, and in the summertime when the marsh is dry and the days very hot, they often plug up the surface holes of their runways, thus retaining the coolness and moisture within. In all the southern marsh districts these muskrats live entirely in the marsh proper. There they build their houses and runways and raise their young. They are never found in the bayou banks.

"The muskrat is a social animal in the sense that it likes company of its own kind. In several places in the marsh we have built pens of wire netting wherein pairs of rats are kept. By placing live traps alongside these pens, we have caught a surprising number, considering the extreme scarcity of signs in the adjoining marsh. In one pen a pair of rats was placed and after several days, caught again. To our surprise, not only the original pair was captured, but three additional adult rats. They had evidently climbed up over the two-1oot wire with a foot overhang, and, having gotten in, were unable to get out.

"We have had three-legged rats escape from a wire pen two feet high with a six-inch band of galvanized iron along the top. Rats have also escaped from pens two and one-half feet high with a foot overhang. They will often jump when it is impossible to climb. They have been observed to balance on the edge of their water pans on their hind legs, and when stretching was of no avail, have jumped up onto the overhang and scrambled over.

"That water is the muskrat's natural element is evidenced by the speed and grace with which it swims, not only in and under water, but also when partially submerged. Rats have often been observed swimming under water, and only a slisht ripple on the surface indicated where the rat was. When frightened, a muskrat will plunge into the nearest water immediately with a startling splash, and the ripples from 


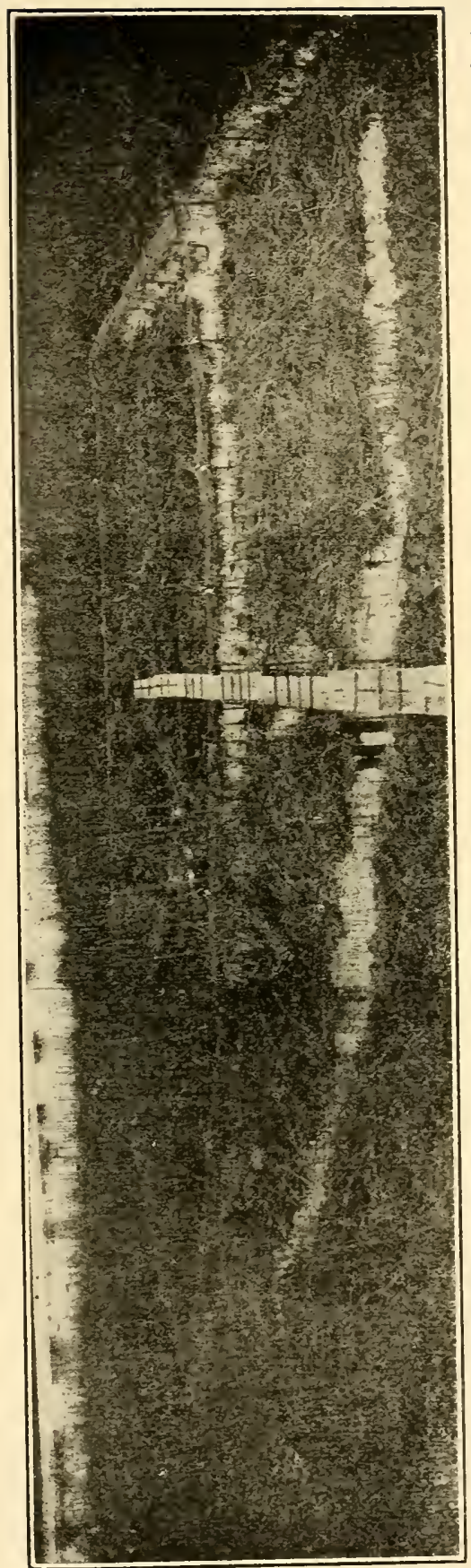

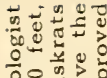

응을

叫

和恣

गั

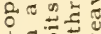

$\circ$ 등은 3

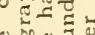

낭

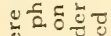

월

$\therefore .52$

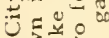

₹

त्र $=2 \frac{2}{3}$

응

एँ

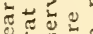

צ⿻

ट्च

ल) ₹

든 오

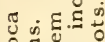

도을

ธ들

द्ن

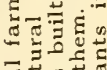

उอ

ᄃ. द

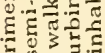

is 3

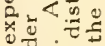

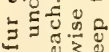

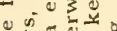

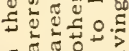

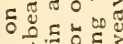

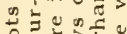

口-

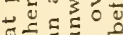

5 ०

o 0.0

है हٔ

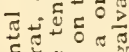

द

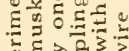

व 23

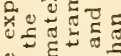

\&.

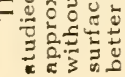


the splash serve to conceal any slight ripples made from swimming under water; hence, it is often impossible to tell where, or even in which direction, the muskrat has gone. In swimming, both the front and hind feet are distinctly used alternately and not simultaneously, as has been suggested by Dr. Johnson in his 'MIuskrat in New York.'

"Muskrats are able to remain under water for an astonishingly long time. In one instance, a rat was observed to plunge into a small canal. In lieu of a watch, counting was begun slowly and continued until the nose of the muskrat was seen to emerge near some floating grasses; 678 slow counts were made before the rat appeared. These counts later translated into clock time approximated eight minutes.

"The use of the tail has been the subject of much weird speculation by authors as well as trappers. In all our observations we ound the muskrat, like other rodents, using this organ merely for balancing."

[Mr. Svihla's conclusions on the use of the muskrat's tail, in that he says that the muskrat used this organ merely for balancing, is not at all borne out by my observations in past years, especially during that time the trapping grounds in the vicinity of Delacroix Island were inundated by the artificial crevasse created at Caernarvon in May of 1927.

During the week trappers, conservation agents and others were busy rescuing swimming muskrats unequaled opportunities were presented of watching thousands of these animals in the water and the following facts were observed:

When the muskrat is leisurely swimming, either in still water or with the current, when it is not necessary for it to exert any extraordinary swimming power, it uses all four feet in progressing through the water. During this leisurely method of swimming it was noted that both the front and hind feet were used, sometimes alternately, and at other times simultaneously.

When swimming with the current or in slack water, the tail, apparently, is not used for any purpose whatsoever, either for sculling or for use as a rudder, as has been frequently stated, but this appendage merely trails behind the body that is being propelled through the water by the animal's feet. When not hurrying through the water the rump is submerged, as well as the basal section of the tail, but the mid-section of the tail, due to being held in an arching curve, is partially out of the water while the tip is submerged.

But when it was necessary for the animal to buck a current, not only were the fore feet used with great energy, but the tail was called upon to aid in its progression, and this flattened and sinewy member was given a writhing, sculling motion, somewhat akin to the swimming motions of a snake, that evidently was of much use to it as an auxiliary motor and propeller are to a sailing vessel.

Not only were these observations made but motion pictures and graflex photographs were fortunately secured of many swimming muskrats showing just how it uses its tail for propulsion power-which should end "weird speculation."]

\section{FIGHTING}

"Muskrats fight desperately when caught or cornered, jumping and striking at their opponents, regardless of size. The incisor teeth are long and extremely sharp and capable of inflicting considerable damage. only during breeding seasons have we found them fighting among themselves. In one case, two males were in a pen with only one female. The defending male put up no fight at all. Escape was impossible, so 
when the fight was intermpted and the injured male captured, the pelt on his back had been so torn by the other male that a wound three inches in diameter resulted. Upon another occasion a small male was killed by a larger one. Other than these few cases we have witnessed no fighting among the rats and we have kept as many as seren males and females in one small pen.

\section{VOCAL NOISES}

"Muskrats have several different vocal noises. The young mice squeak when cold, hungry, or otherwise uncomfortable in no uncertain tones. The sound is similar to other mouse squeaks but can be increased considerably in volume. The adults often quarrel over their food when they are kept in close quarters and then the sound is a highpitched 'n-n-n-n-n-n.' When breeding, and sexually excited, both the males and females emit the same sound, but taster and more emphatic, so that it is not dissimilar to the noise made by a lot of very young and hungry pigs. Sometimes, when badly injured in a trap, a rat will give a low, moaning sound of great suffering, but most often they endure pain in silence. Besides these purely vocal sounds, muskrats have a chattering noise made with the teeth when they are nonplussed, frightened or excited. This is occasioned most often when they are captured or cornered.

"An evicient sign of affection is a habit the rats have of chewing and combing each others' necks and backs. This has been observed most 1 requently during breeding seasons, and is done by both males and females.

"Never have these muskrats been found to indulge in any sort of game or play. They work most industriously and spend a great deal of time washing and combing themselves, but refuse to run wheels or invent any play of that kind.

"From observations of rats in the field and in captivity, their senses of hearing and smelling far exceed that of sight. Although they are active chiefly when it is dark, yet when in captivity they have little objection to artificial light and can be easily watched with a flashlight. They like plenty of range and when kept in small pens spend most of their time trying to escape, gnawing both wire and wood. We found that they need hard foods, for when kept for any length of time on a soft diet, their incisors grow out too long. They are curious animals 1or the most part, and frequently test an unknown object by nibbling it. In fact, muskrats which have escaped from pens in the house have nibbled at almost everything from Christmas cards to shotgun shells.

\section{FOODS}

"The marshes contain a great abundance of grasses and sedges, the seasonal growth of which is such that there is plentiful and continuous supply of vegetable food for muskrats all the year round. These occur more or less abundantly in different sections of the state, but always to such extent in each marsh section as to form a conspicuous part of the vegetation. In fact, most of then grow in pure stands of considerable areas. The leaves, tender bases, young shoots, growing tips and underground runners of these are eaten.

"Although muskrats occasionally nibble and eat many other" marsh plants which are not of much abundance or importance, the threesquares, needle grasses and paille fine are the plants which compose the muskrat's staple food supply in the marsh where he conducted most of our investigations. The favorite foods eaten in captivity are, in order 
of preference: rolled oats, corn, apple, fresh lettuce, fresh carrots, wheat, rice, and oats.

"The muskrats are prone to taste many things and will nibble on a great many plants and food which they will not eat as a steady diet. They are also quite individualistic in their tastes, for some rats refuse to eat carrots or apples, while others eat these eagerly. In captivity we have found that they thrive very well upon a diet of corn and marsh plants such as the paille fine and three-squares.

\section{EXPERIMENT I.-MUSKRATS FED PAILLE FINE}

Total number of ounces consumed by 1 muskrat over a period

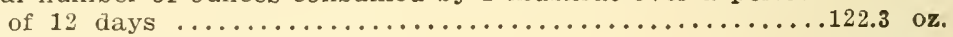

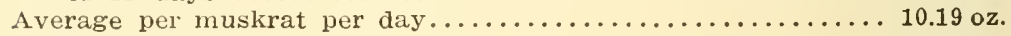
Average weight of 7 muskiats...................... Percentage of weight consumed per day.....................

\section{EXPERIMENT II.-MUSKRATS FED PAILLE FINE AND CORN}

Total number of ounces of paille fine consumed by 1 muskrat

over a period of 14 days...........................

Total number of ounces of corn consumed by 1 muskrat over

a period of 14 days...............................

Total amount of food consumed .......................

Average weight of 9 muskrats.................... 26.1 oz.

Average amount ố paille fine per muskrat per day........ 7.3 oz.

Average amount of corn per muskrat per day............ $1.47 \mathrm{oz}$.

Average amount of food per muskrat per day........... $8.77 \mathrm{oz}$.

Per cent of weight of paille fine consumed per day.........27.9\%

Per cent of weight of corn consumed per day............ $5.7 \%$

Per cent of weight of food consumed per day............ $33.6 \%$

"An ample portion for a pair of rats is 20 ounces of paille fine (Panicum hemitomum), underground runners and leaves, and three ounces of corn per day. Experiments extending over a period of twenty-six days have proved that each muskrat consumes on an average $33.7 \%$ of its own weight per day. When fed green food only (paille fine) each rat eats on an average of 10.19 ounces per day. When fed green food and corn, each rat consumed on an average of $\$ .75$ ounces per day.

"Muskrats are similar to a great many other rodents in that they occasionally eat animal matter. While live crabs cause consternation in their pens, yet we have seen them eat raw and boiled crabs, as well as small dead fish. The animal matter consumed is evidently very little.

"It is a byword among trappers that muskrats habitually wash their food before eating it. They do like to sit in the water while eating, and any muck clinging to their foods naturally falls off. Intentional washing, however, has never been observed. Their front paws are very convenient as hands, and are used to hold the food while eating. Sitting upon their haunches, they take a piece of grass in their front paws and, biting it off at the required length with their incisors, eat it while still holding or turning it in their paws.

"In marshes where the water is constantly high, muskrats build 'feeding rafts' where they sit while eating. These consist of platforms of debris, accumulated from feeding, and are really muskrat 'kitchen middens.' 

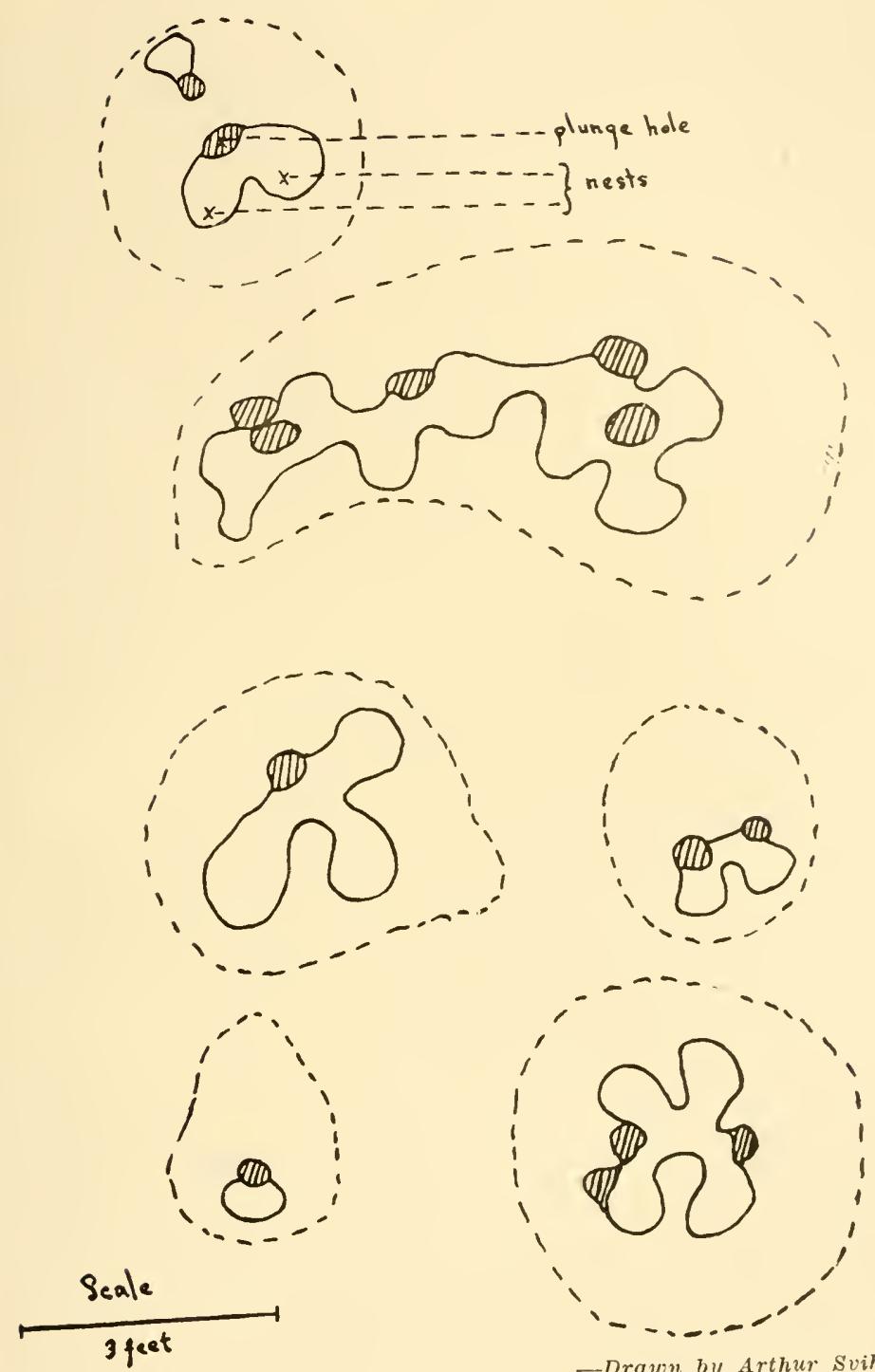

-Drawn by Arthur Svihla.

Diagrams of muskrat hills showing location of nests and plunge holes.

\section{HOUSES AND RUNWAYS}

"The houses, hills, beds or nests, as they are called in various parts of the state, are used as nests for the young, as safe feeding places, and as sleeping quarters. Both the male and female work to build the house. Usually an old feeding platform, with its approach, forms the 
first step in the construction of a new house. The approach develops into the plunge hole and the feeding platform forms the basis for the inside of the house, which is then built up and around the plunge hole. The muskrats here make use of the old houses, so much so that most of the occupied houses are made over from the previous year and even the year before.

"The materials used are those closest at hand and include the green vegetation interspersed with muck. Houses indicate that building is in progress by the bunches of fresh material dragged up onto the house during the night. The building material is carried, dragged or pushed while the muskrat still holds it in its mouth. It is placed in a seemingly haphazard manner, yet a well-packed, matted roof results. This mixture of muck and regetation, which is always wet, except for the sun-baked outer layer, forms a veritable thermos bottle. In the hottest of weather the inside maintains a cool, even temperature, while during the coldest snaps the warmth from the body heat of the muskrats is liept constant.

"The size of the house varies. Some are quite small, only a foot high and a foot in dianeter at the base, while others may be as large as three to lour feet high and eight to ten feet in diameter. Usually, the small houses are made by a single rat, perhaps the male, while the larger ones are built by more than one rat, perhaps a pair. It has been our experience that a single male, placed in a pen, will build only a small house with a single nest, but when a fenale is placed with him, they both work until the house is greatly enlarged. As the size of the houses varies, so does the number of houses to a given area, for naturally some areas contain more rats than others. In many regions, even though the marsh vegetation is thick and water plentiful no hills occur, while in other places hills may be as frequent as six to an area of 20 by 50 feet.

The number of hills to an area is usually the means of telling how good a piece of rat land it is. It is assumed by trappers that houses with many nests contain many rats. Houses have been found with as many as seven nests, with plunge holes easily accessible. Only an approximate estimation of the number of rats which occupy a house can be made. From field observations, it appears that when breeding is in progress but one pair of rats occupy a hill. During other seasons, the inhabitants may vary in number.

"In digging canals or runways, the muskrat digs with its front feet, casting the material up between its hind legs. Then, taking a step forward, it pushes the material farther out with its hind feet. This is done on the surface, as well as underground. Marshlands which harbor muskrats are netted with runways, both on the surface and underground. When walling through the marsh one is constantly sinking into these runways, which often form regular labyrinths. The under ground runways are often quite deep, measuring in some cases as deep as 16 inches. During the hot, dry summers, the openings to these are often plugged mith muck to preserve the moisture.

\section{ASSOCIATIONS WITH OTHER ANIMALS}

"Muskrats are not the only animals which occupy muskrat houses. The damp, warm house material harbors ants and other insects, skinks, frogs, toads and snakes. The snakes include the small garter snake and the southern king snake, which have been found during cold weather under the top layers of material.

"Moccasin snakes and blue runners have often been seen basking on top of the muskrats' houses. Skinks (Leiolopisma laterale) ${ }^{20}$ aro

s"Identifled by G. K. Noble of the American Museum. 
frequently found between the layers of the materials and even lay their eggs there, the damp, warn surroundings no doubt proving very conducive for incubation. Frogs and toads, especially the narrowmouthed frog (Englostoma extensis) and Bufo valliceps bury themselves in this material during cold snaps. Ants and beetles are always numerous, especially the former, and, although, when disturbed by opening the hill, they have been seen to swarm over very young muskrats in their nest, yet they evidently nevel bite them. When opening a hill, the bites from these enraged inhabitants often prove excruciating for a short time.

\section{SANITATION}

"Muskrats, like many other rodents, are very clean. They spend a gleat deal of time washing and combing their tur. While working on their houses or building runways, they stop every little while to wash and comb. Upon emerging from the water, a slight shake is sufficient to flick the muddy water and muck from their fur. Excrement is almost always deposited in the water and none is ever found in their nests or houses, which are always sweet and clean. Sometimes a small accumulation $o_{L}$ pellets is found upon a resting platform or feeding raft. When the muskrats are kept in small pens, a pan of water, changed daily, is entirely efficient in keeping the pens sanitary.

"Muskrats are almost careful in keeping any wound clean by constant licking. If the flesh becomes infected, they do not hesitate to gnaw it away. In many cases-evidenced by three-legged, two-legged and even-one-legged muskrats being caught in the marsh-thev have been able to heal legs amputated by traps. In some cases, this simple licking method of healing wounds is not sufficient to preclude infection and we have found that frequent antiseptic baths are most successful in counteracting septic poisoning and complications. In most cases, however, it is sufficient, after a leg has been amputated, to place the muskrat in a cage by itself and by putting a little Dakin's solution in the waterpan each day, the wound quickly heals. Pus sacs occasionally form on the muskrats whose legs have been previously amputated, and when these are removed they make strenuous efforts to lick up the pus.

\section{METHOD USED FOR AMPUTATING LEGS}

"When muskrats-and other animals-caught in traps have broken legs immediate amputation becomes necessary. The following method has been used throughout this work successfully: The muskrat is placed in a small box-a rolled oats box proved very efficient-by capturing it by the tail and lowering head first very quickly into the box. The box is covered quickly beiore the muskrat has time to turn around and climb out. A small wad of cotton is saturated with ether and placed in the box, which is tlien covered tightly. Muskrats "go under" quite readily and usually a very few minutes is sufficient to "put them to sleep." A very good indication as to when sufficient ether has been administered is when the muskrat is quiet but still blinks its eyes. It can then be placed upon the operating table and a cornucopia, made of paper in which is a wad of cotton saturated with ether, is placed over its nose. Care must be taken that too much ether is not given. One person watches and regulates the ether given while the other amputates. Dakin's solution (about 5\%) has been used most successfully both for sterilizing the instruments used and for washing the wounds 
"With scissors, first cut the leg off where the bone is broken. Then with a very fine saw, saw the bone as far above, where the flesh is cut, as possible in order that the muscles can grow over. A clean cut is necessary, as sharp points on the bone cause pus to accumulate later. It is then washed with Dakin's solution. With a needle and thread, two or three stitches are taken to pull the skin together over the end of the bone. All this should be done as quickly as possible and as little blood lost as possible. The ether cap is removed and the muskrat placed in a box on clean grass or excelsior.

"A small pan of water in which a little of Dakin's solution has been placed is put in the box, which is then covered so that it is semidark, but also provided with a circulation of air. In a few hours, if the operation has been successful, the muskrat is recovered and ready to eat. It may be kept in a small cage and fed corn, apple and green food until the leg has healed. The van of water should always contain a small amount of antiseptic in order that the wound can heal easily

\section{BREEDING}

"Although we have found mice or embryos every month of the year, the heaviest breeding takes place from November to April, inclusive. During the trapping season of 1925-26, 600 muskrat carcasses were examined. Of these 323 were females and 41 , or $12 \%$, contained embryos.

"During the 1926-27 season 263 carcasses were examined, of which s9 were females, and of these $21 \%$ to $23 \%$ contained embryos. After the trapping season closes in February there is generally high water in the marshes until about the end of April. During these spring months the rats, now undisturbed by trapping, are very active. Mice can be found in most of the houses during these months. Although the evidence for an extensive breeding season is conclusive, yet the number of times one individual temale breeds annually is by no maens so frequent. One female, for instance, had a litter of young last November and, as yet, has had no more. There is, however, every indication that another litter will appear soon, as this pair has been very active lately, building on their house and making new nests. The period of gestation is more speculative material, according to literature, and by analogy with the gestation period of Microtus, it has been placed at twenty-one days. We have, however, three females which were seen to mate and twenty-one days have passed without young being produced.

"The number of embryos contained in 66 female carcasses varied from one to six-three and four occurring with, by far, the greatest frequency, thus making an average of between three and four to a litter. In 17 iitters of mice found in the field, the numbers ranged from one to five-one, two and three occurring most frequently. This seems to indicate mouse mortality.

"Young mice, weighing only 21 grams, have been found in the nest, blind and hairy. Large embryos have a sparse covering of hair, which: is distinctly visible. The sex can be determined easily before the eyes open and the hair on the bellies become too thick to distinguish the mamae. The mamae range in number from eight to ten. Out of 213 adult and sub-adult female pelts examined, the following had:

8 mammae, $2-2$ pectoral, $2-2$ inguinal........... 177

9 mammae, $3-2$ pectoral, $2-2$ inguinal.......... 32

10 mammae, $3-3$ pectoral, $2-2$ inguinal......... 3

9 mammae, $2-2$ pectoral, $3-2$ inguinal......... 1 
"These pelts were average lots, containing kits, medium and adults. "There were several cases where kits had 9 mammae and we have found mice with 10 , so that the number does not depend upon the age of the muskrat.

"Amputated legs do not hinder muskrats from breeding. It is interesting to note that upon every occasion when mating was observed, the muskrats were partially submerged in water. Before mating, the males and females were both observed to back up against the sides of the pen, leaving an intense odor of musk. This evidently serves as a sign of possession or recognition. We have often noticed these musk-places in the marsh, especially during the winter and spring.

\section{ENEMIES}

"Although injudicious trapping is the greatest enemy of the muskrat, yet there are several animals which include the rat in their diet. The fact that the muskrat is most suspicious and either stays under cover or else very near it, is a great help in eluding animals of prey. Alligators are, perhaps, the muskrats' worst natural enemy, but they have been hunted so extensively during the last few years that they are becoming scarcer and scarcer. Large moccasin snakes have been found to eat young muskrats and they are also capable of entering the houses through the plunge holes. Some evidence of owls taking mice and small kits has been obtained. No direct evidence of hawks killing rats has been found, but trappers insist that they tear the pelts of many rats caught in traps. Minks have been known to kill and eat muskrats.

"Like the Maryland muskrat, this species is also infested by a mite which has been identified by Dr. Ewing of the Smithsonian as Tetragonysus spiniger. Some rats have more than others and even mice in the nests have been found infested with them. However, they seem to cause but little discomfort.

"Surprisingly few endo-parasites have been found so far. Out of ten muskrat specimens sent to Dr. Ward of the University of Illinois, none contained endo-parasites. One specimen, sent to Dr. Manter, now at the University of Nebraska, proved to be a degenerate arachnid. The damage done by endo-parasites is evidently neglible. As for diseases, none has been found so far.

"Of all the climatic conditions which are detrimental to muskrats, drought seems to be the worst. This not only decreases the amount of available water in the marsh, but also affects the vegetation, thus decreasing the amount of rat food. Marsh fires, when set during dry weather, when the water on the marsh is low, are also detrimental. This not only burns the vegetation, thus destroying food and cover, but also destroys many hills and even the rats themselves. However, judicial firing has been witnessed after a heavy rain, when the marshes were quite wet, and no damage was done. The high water prevented the roots of the plants from being burned and the houses were too wet to be destroyed.

"After the hurricane of August 28, 1926, the water was very high over the marshes in the Penchant region. A survey proved that it had not damaged the rat land at all. The rats, in fact, were more active than ever, building their houses higher and digging for roots. The recent storm and resulting very high water has also had no detrimental effects in this region." 


\section{CHAPTER TWENTY-TWO}

\section{'RAT RANCHING}

RTIFICIAL muskrat farming will probably never prove as remunerative as the ranching method. In fact, no less an authority than E. Lee LeCompte, state game warden of Maryland, has made the sweeping statement that: "Artificial muskrat farming has never proved profitable," and recommends that the raising of these valuable fur-bearers should be done on large and unspoiled marshland areas in a natural-or, at least, in a semi-naturalenvironment, and he cites a number of instances of what 'rat ranches in Maryland have produced and earned for' the owners.

Mr. LeCompte recites the experiment of W. A. Gibbs, of Chester, Pa., the inventor and manufacturer of the trap that bears his name, who owns an 800-acre tract in Dorchester County, Maryland, one-third of which was enclosed with a tight board fence set three feet in the ground. This was done to keep the animals wholly enclosed, but it was found that this was not a practicable method of confinement as the animlas gnawed holes through the boards in a very short time in order to satisfy their desire to wander or migrate, and further experiments taught the owner that the muskrats would dig almost to any depth to create a passage under any obstruction which might be set in mucky soil such as that comprising a marsh. Better success was obtained in erecting an enclosure on high marsh land, while other sections not inhabited by the small fur animals were ditched and flooded with water and the 'rat population soon spread and began populating the new territory.

Mr. Gibbs is quoted as saying that previous to his experiments this particular 800 -acre tract had never yielded the trappers more than 700 muskrats in any one season. After fencing and ditching, the catch for one season was 4,025 , and an average for 12 years was in excess of 3,000 a season. The average would have been better had it not been for two or three severe winters, especially that of 
The Fur Animals of Louisiana
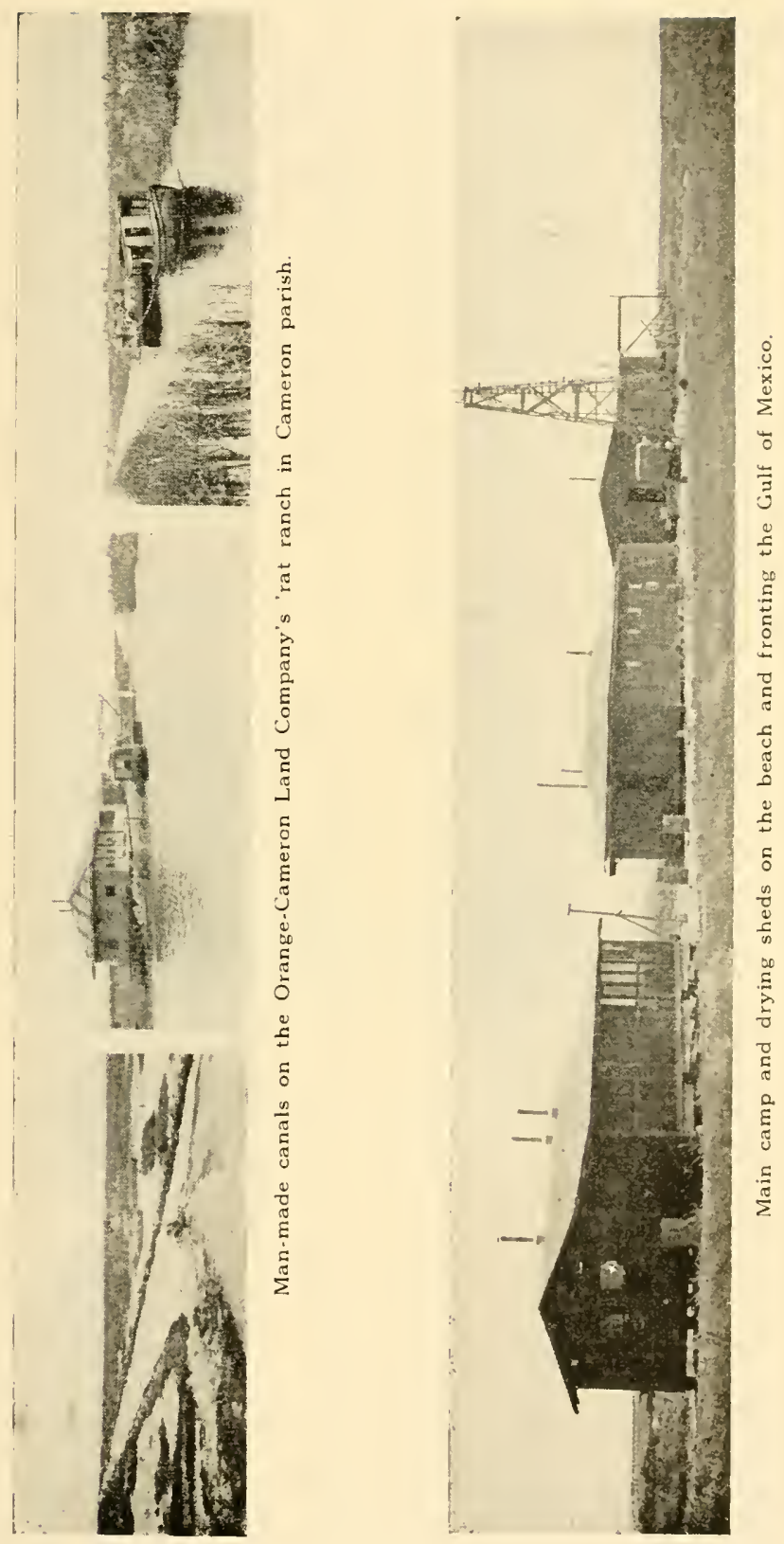
1918, which practically froze most of his muskrats to death, he says.

Game Warden LeCompte states that his reason for claiming that artificial muskrat farming does not pay is "due to the fact the muskrat has never yet shown a profit by being raised in captivity," and cites the Gibbs experiment as a method which does not confine the animals and that the success achieved was due to the ditching, whereby it was possible to flood the area. In fairness to the Maryland official, it must be observed that in 1928 he modified his statement somewhat by calling attention to Mr. Gibbs' success in raising breeding stock in captivity.

From experience in the Louisiana and Texas muskrat producing areas, it is the prediction that the Maryland production can be increased from 3 to 10 times by proper ranch cultivation methods.

While the Maryland authorities do not believe that muskrats can be succesfully raised for their commercial pelts in limited enclosures, there are some evidences at hand to the contrary. They can be "farmed" and a profit realized from the sale of breeder's, but this should be remembered: the smaller the farm the smaller the profits and the more work entailed, although the success achieved by the Mount Forest Musklat Farm in Michigan indicates that the farming of 'rats is possible on a commercial scale if conducted intelligently.

It is well to remember that the production of fur animals in captivity is a comparatively recent enterprise and for that reason is not supported by exhaustive experimental and research data that are enjoyed by similar industries. Cartain phases of fur farming are still in an experimental stage and until something definite is established showing how a healthy profit can be realized from the sale of muskrats on a strictly pelting basis, it must remain, as it is today, a debatable question. Whether or not certain species of fur animals should be farmed depends on pelt values, for it should never be forgotten that the sole purpose of growing fur animals, in captivity or out of it, is to sell the pelts, 


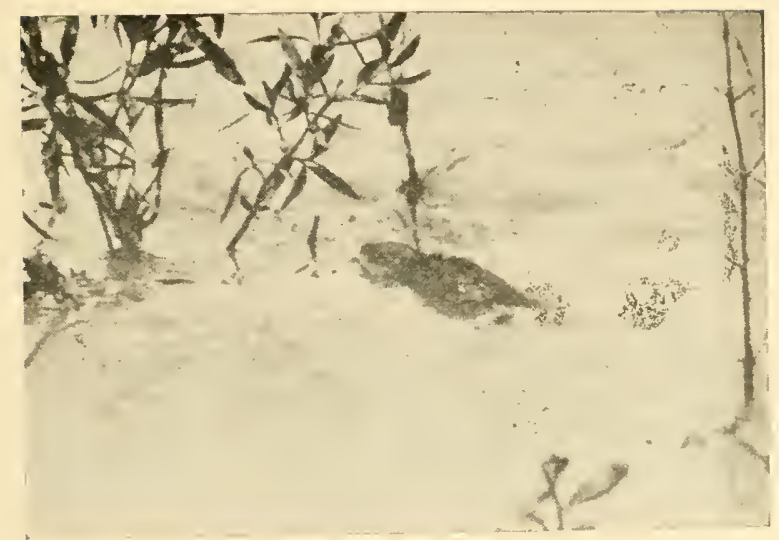

A muskrat swimming to the shelter of the black mangrove bushes. In swimming this animal uses all four feet and frequently brings its tail into play as a scull.

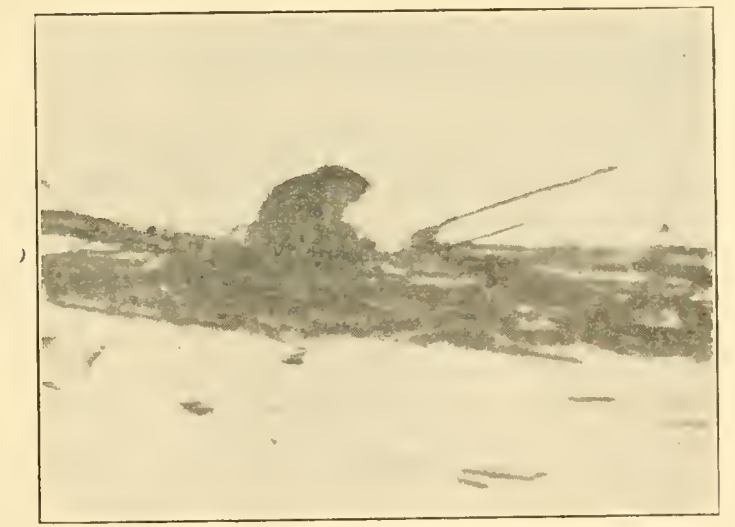

A muskrat "kit" on a raft of its own construction.

and the sale of breeders should only be an incidental adjunct to the main business.

When it becomes stabilized, fur farming will be a commendable and hopeful adjunct to the fur industry and as such should be encouraged by all interested in the fur trade, in the opinion of Frank G. Ashbrook, in charge of the fur resource division of the Bureau of Biological Survey in the United States Department of Agriculture. "That dishonest 
ranchers and companies should have used fur-bearing animals as a means to extract money from persons unfamiliar with the business was only to be expected," he says. "Such a condition is found in many other enterprises. The lack of authentic information concerning the raw fur market and the feeding, breeding, and management of fur-bearers in captivity has made the work of deceiving the novice extremely easy."

Mr. Ashbrook finds that, while much has been said and written about the raising of skunks for profit, that unless the prospective breeder stops to consider the matter carefully he may be seriously misled. He shows that from 1921 to 1923 , the price of skunk pelts on the raw fur markets of New York and St. Louis ranged from a few cents for damaged skins to $\$ 6.20$ for the very best grades, and that the approximate average for all pelts was $\$ 2.19$, with a drop in 1923 to $\$ 1.86$, brought about by a decline in the German and Russian marts, heretofore the chief skunk pelt buyers.

"At present prices the feed for the maintenance of a pair of skunks for a year would probably cost more than two cents a day," he says. "To this must be added the cost of labor connected with the care of the animals and the initial investment in equipment, such as pens, dens, feed dishes, and so on."

The same general conditions are true in the case of raccons, Mr. Ashbrook finds. The highest price obtained in recent years for the raw pelt of a raccoon of exceptionally fine quality was $\$ 10$. The approximate average for all grades for three years was $\$ 3.15$, and a pair of raccoons will eat two or even three times as much as a pair of skunks and this makes their feed cost for the year anywhere from $\$ 14$ to $\$ 21$ and does not include the cost of equipment or labor.

Referring to attempts that are being made to raise muskrats and beavers in confinement, Mr. Ashbrook believes, too, these should be classed as experiments and not considered as established practices, and further observes: "While certain waste lands may be useful for the produc- 
tion of beavers and muskrats, it is believed that these water fur-bearing animals cannot be raised profitably in pens, since all the feed would then have to be supplied to them, thus adding materially to the cost of production. If given adequate protection, both as to the maintenance of their natural habitat and the proper regulation by law of the open and close seasons, muskrats, by their prolificacy, will maintain their numbers."

To those seriously considering going into the muskrat ranching, the figures furnished by Gibbs in his Maryland experiments, as to his area and annual production, are interesting and worth analyzing. In one year he produced 4,205, which indicates 5.25 muskrats to an acre and he had good land and poor in his holdings.

Muskrat marshes in Dorchester, which is the largest producer of this animal of all the Maryland counties, range in value, according to the state's game warden, from \$25 to $\$ 100$ an acre, whereas a score of years ago they would not bring over 50 cents to $\$ 5$ an acre. These Maryland marshes given over to muskrat culture range in size from 200 to 6,000 acres each. Trappers, who usually trap the animal on shares of 50 per cent, are allotted from 100 to 200 acres each, according to the known fertility of the territory. One owner of a 6,000-acre tract pays the trapper 50 cents for each pelt taken and 10 cents for each carcass prepared for the market, and many of his trappers earn under this plan from $\$ 1,000$ to $\$ 1,500$ each winter of about 75 trapping days.

Maryland production of muskrats reported by Mr. LeCompte is about 445,000 from five counties on that state's east shore. Louisiana's production is more than 10 times this amount. The Maryland official also records one tract of land which produced 5,000 muskrats off 1,300 acres, which was not quite 4 to an acre, and calls attention to the fact that taxes are not as high on marsh lands as on arable lands, and cites the instance of one Maryland marsh which in 1916 sold for $\$ 5,000$, brought $\$ 19,800$ seven years later, the increase in realty values being brought about by the heretofore insignificant muskrats inhabiting the marsh. 
In Louisiana a well-known 'rat ranch is located in Cameron parish, in the extreme southwestern section of the state. Roughly, it is 35 miles east to west, and from 14 to 16 miles north and south, containing 163,000 acres of marshland. It was purchased in 1923 for approximately $\$ 3.50$ an acre. In the course of our biological surveys and scientific investigations, Vernon Bailey, chief field naturalist of the Bureau of Biological Survey, made an approximation as to the number of muskrats that could be trapped normally on this tract and not endanger the "seed," or breeding stock, and this was placed at a minimum of 6.75 muskrats to the acre, a very conservative figure, it must be remembered.

At this low figure, it would mean that this tract of land, should only 6 rats to the acre be taken from each of the 163,000 acres, would have an annual production of 978,000 muskrats, to say nothing of mink, otters, raccoons and skunks. Should the owners realize only $\$ 1.25$ a pelt (an absurd and ridiculous price in these days of climbing fur values), the gross income would be over $\$ 1,222,240$ a year. With 40 per cent going to the trappers and an operating overhead of 10 per cent charged, there would be a net of $\$ 611,220$ annually.

Actual production on the Cameron parish lands during the season 1923-24, when 10,000 of these very acres were trapped by an operator named Oscar Jones and his crew, was 226,000 muskrats, to say nothing of more than 1,000 raccoons and mink. This indicates an actual catch of better than $22 \frac{1}{2}$ muskrats to the acre in a normal season.

Another instance of high production occurred in the 1924-25 season in Louisiana. Two men leased a tract of land in the Terrebonne parish section for $\$ 350$ for the season. The tract was "wild land," had not been protected or planted or cultivated, in any manner, shape or form. It had a three-quarter mile frontage on a bayou and ran back exactly one mile, three-quarters of a section, or 480 acres in all. 


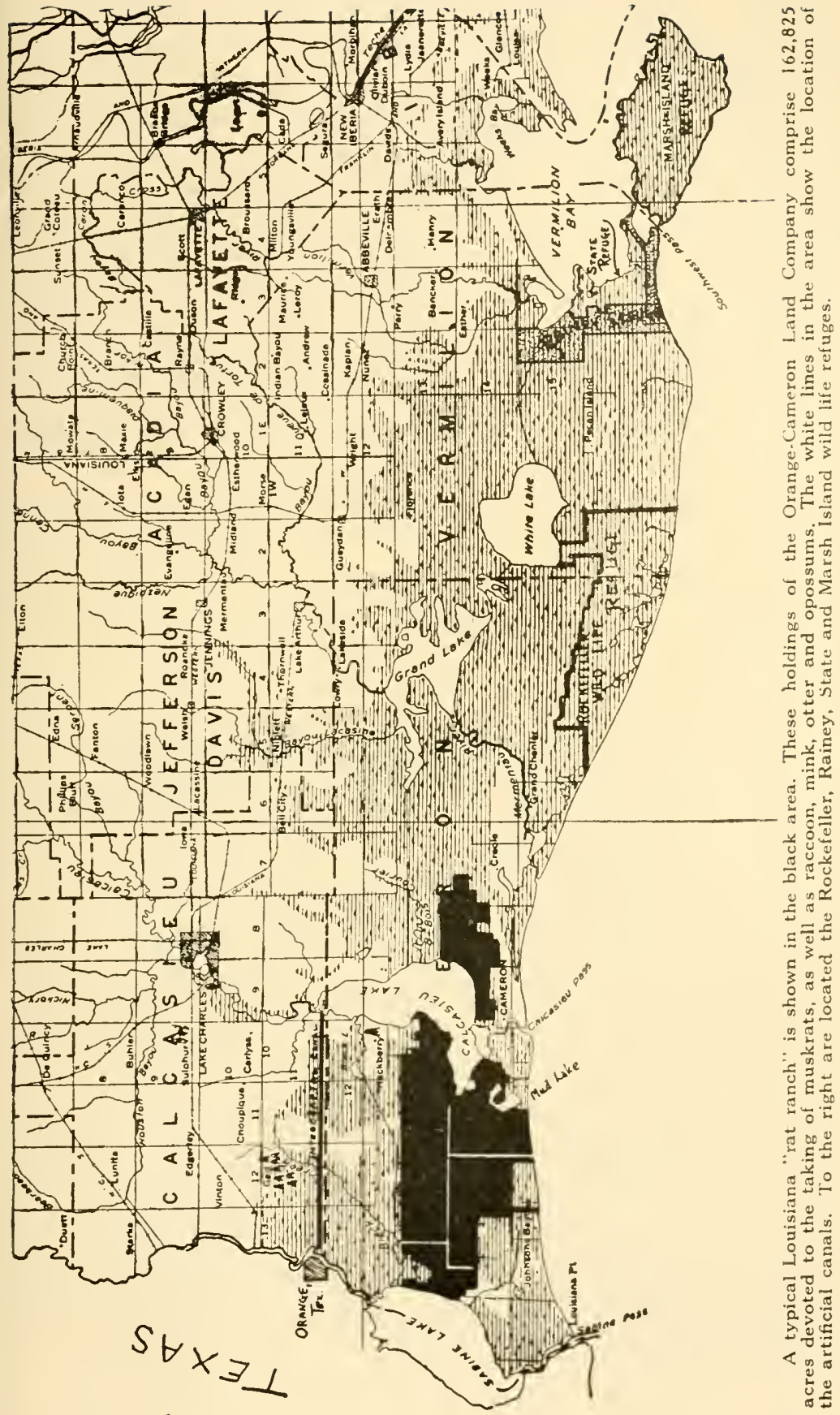


The area was thickly grown with one of the three-cornered grasses, (the leafy three-square rush, Scirpus robustus), with some bulrush, cattail, wild cat grass, and from outward appearances gave every indication of being an ordinary muskrat trapping sector. Just before the opening of the season the two trappers went over the property, but were not at all enthusiastic over the outlook because of what they considered to be a lack of "signs," and they endeavored to dispose of their lease for $\$ 300$, being willing to stand a $\$ 50$ loss and try trapping elsewhere. They were not successful in this and several days after the legal trapping season opened they began running their trap lines and commenced skinning 'rats.

In less than 80 days of trapping, the open season then being 90 days (from November 15 to February 15), and before the legal close season was at hand, the two adult trappers, with three young boys assisting by skinning and curing the pelts, "pulled" their traps and left the marsh.

Being illiterate and unable to count, they could not keep an accurate detail of their catch, but from checks given them by fur buyers it was learned that they received exactly $\$ 14,200$ for their entire winter take of muskrats, which they sold at prices averaging from 74 to 93 cents per pelt.

After the close of the season a survey was made of this particular piece of ground to see if the trappers had left even the grass roots, and found better "signs" on this area than on any other spot of like dimensions in the whole State of Louisiana that particular spring. Naturally, the lease jumped in price for the next season.

This catch must have been in the neighborhood of 17,000 muskrat pelts, or a per acre production of 35 animals. Such trapping, however, would be suicidal to any one investing in lands for the purpose of making a permanent 'rat ranch, and it is merely mentioned to show what has been done on the Louisiana marshlands, although the Delacroix Island region in St. Bernard and Plaquemines parishes duplicated this take the winter of 1926-27. 


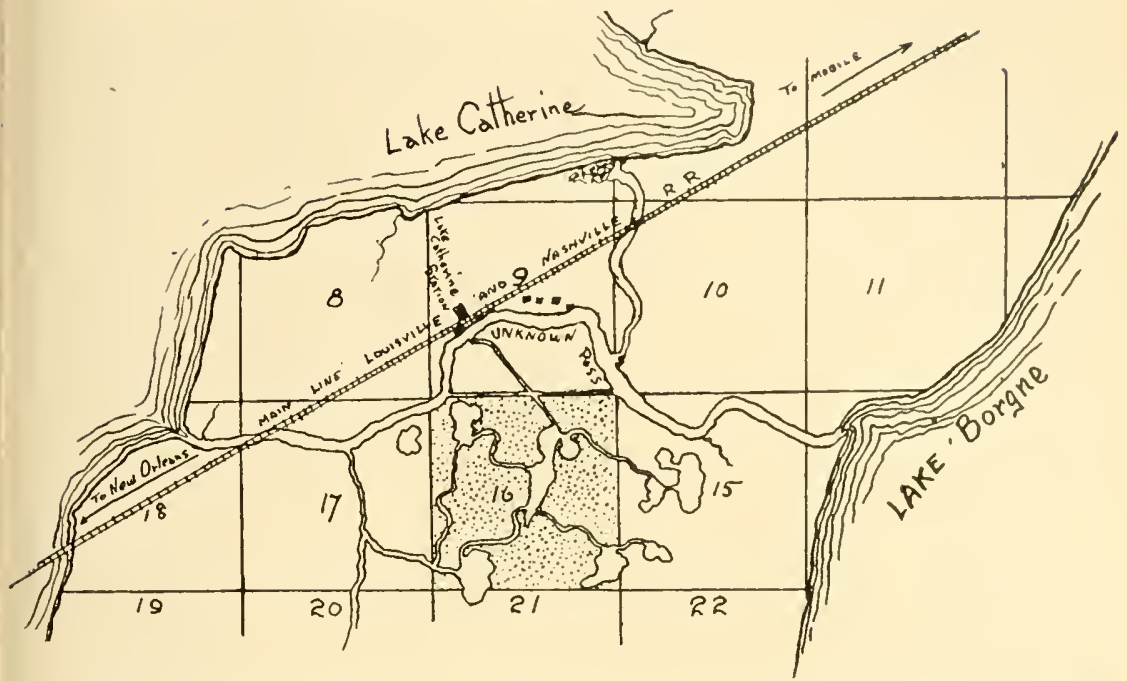

Location of the school section at Lake Catherine, in the Parish of Orleans, where muskrat experimental trapping was carried on in co-operation with the New Orleans Public School Board.

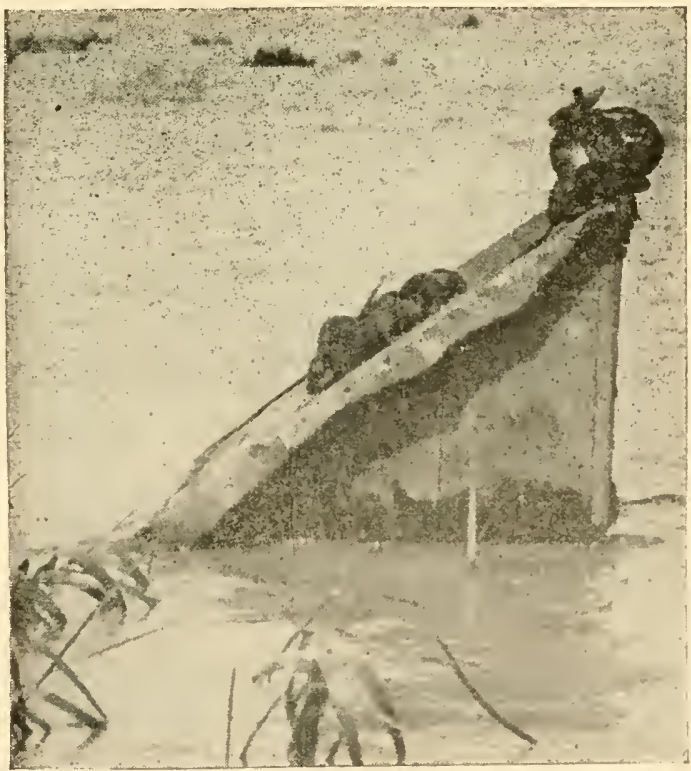

Rabbits and muskrats shared the roof of a shack for several days when their marsh homes were flooded. 
What harm can be done by overtrapping or "skinning" was startlingly brought out by the experience of the McFaddin interests, with holdings below Port Arthur, Texas, where 160,000 muskrats were taken on 9,000 acres the 1924-25 season. This high production on this particular area was caused by drought conditions existing in southeastern Texas the summer of 1924, and the Keith Lake section, where the trapping was done, was the last section to go dry. As a lesult, muskrats migrated to this wet spot in unbelievable numbers. The following season no trapping was done on this tract, for the simple reason there were no musk rats there to be taken!

By giving this land a rest and trapping lightly, C. E. Ward, who directs the operations of the McFaddin interests, built these acres back to normal production and on the total holdings harvested a 100,000 pelt crop in the 1927-28 season.

\section{WHAT IS RAT RANCHING?}

There is as much difference between a fur farm and a 'rat ranch as there is between a New England 40-acre garden truck farm and a Texas beef baron's cattle ranch. On one, the ground is being constantly fertilized, plowed, cultivated, and worked, and a bare living scratched from the holdings. On the other hand, the beef baron secures vast stretches of country, turns loose his cattle, lets them propagate unaided by man, does no plowing, cultivating or planting, and, ever so often, has his round-up of the natural increase, sells his beef, pockets his fat earnings and spends the intervening time between one round-up and the other in luxury and amusements.

So with muskrat farming vs. 'rat ranching. Both can be done, but one is a big money-making proposition, if successful, and the other is not. To be a 'rat rancher proper marsh territory is needed. Proper capital must be subscribed. Proper food plants must grow on the property, or they must be planted if lacking. Muskrats must be introduced if they are not already present. That muskrats can be introduced in localities where they have never been 
set by nature, providing physical conditions are to their requirements, has been conclusively demonstrated and proved by the Imperial Valley irrigation project in Southern California. What has occurred there can best be told by Dr. Joseph S. Dixon, of the Univer'sity of California and bioloigst of the California Game and Fish Commission, who in his "Rodents of the Imperial Valley" 40 showed that, while the muskrat was unknown in 1904, that in 1920 a catch of 20,000 'rats were secured by trappers in a region that was once nothing but an arid desert covered with mesquite, creosote-bush, and such desert flora. With the coming of water came cattails and such grasses that would supply the muskrat with food. Then came the 'rats.

However, what has been written in this chapter anent ranching and farming should not deter anyone sufficiently interested in experimenting in farming muskrats in either quite large outdoor enclosures or in smaller pens. Muskrats can and have been successfully bred in backyards and even in a house. All these animals require are clean quarters, plenty of the right kind of food and water, and attention.

What pecuniary returns come from such a method cannot be prophesied, but it is certain that the person so experimenting will learn many things to his advantage and what he learns may prove of enough interest to spur him on to making a ranching investment. Then, too, the rearing of breeding stock for re-sale should not prove difficult and some side-line income be made.

Raising the muskrat in captivity will have its drawbacks, but what will be learned as to their habits will be worth many of the troubles and disappointments encountered. Even if one has a 'rat ranch of considerable size he would do well to keep a few in an enclosure where he can study these animals, watch their method of living, their reaction to certain foods, and, particularly, watch them at work building their houses and using their feeding platforms, and, especially, noting their reproduction.

4nournal of Mammalogy, vol. 3, No. 3, pp. 136-146. 
This should be done on a unit basis and it has been our practice to recommend an area 100 feet long by 47 feet wide, making the area 1-10th of an acre. To arrive at a per acre estimate all that needs to be done is to multiply by 10. The enclosure should be set on a typical piece of marshland, where it can either receive a natural flooding by water every so often or else be artificially flooded when necessary by damming a stream and raising the water level, or by building levees or dykes so that the nomal rainfall can be retained, or excessive rain waters be drained off by creating spillways or sluice-gates in the dykes.

Directions for building such an experimental enclosure as worked out in Louisiana can be found in the outlines under the illustration of our experimental plots on page 281.

\section{'RAT RANCHING IN MARYLAND}

One learns many things by comparisons. This is as true in the fur business as in any other line of endeavor. As the conditions in the Maryland tide water marshes come nearer duplicating the conditions found in Louisiana coastal marshes, it seems permissible to detail something of the industry in that state, although the habitat of the muskrat in this part of the country bordering the Chesapeake Bay includes sections of Virginia and Delaware and New Jersey have like conditions. Again, in view of the fact that no surveys of these particular marshes have been made, quotations will be given from observations by Mr. E. Lee LeCompte, state game warden for Maryland.*

In this territory the open season for trapping the fur animals is from January 1 to March 15, a season that approximates Louisiana's 75-day period for legally taking the muskrat. In these eastern seaboard states it will be understood by the Louisiana reader that the ice conditions do not permit trapping during the middle of the winter; therefore, it is necessary to set open the dates as they have been designated by the Maryland law. In 1928, it is pointed out that, due to ice conditions, January was a very unsatisfac- 
tory month for the trappers, and the crop of pelts had to be harvested during February and up to March 15, although the state game warden of Maryland believes that trapping, in normal winters, should not be continued too late.

This same official points out that very few states have the so-called "black" muskrat and that they are New Jersey, Delaware, Maryland and Virginia. He claims that Maryland is the only state where the black muskrat averages better than 20 per cent out of every 100 taken, and asserts that in his state the catch usually shows 60 to 65 per cent black muskrats. He estimates that in the 1927-28 season the Maryland trappers averaged from $\$ 1.50$ to $\$ 2.00$ per pelt for the brown 'rat and $\$ 2.50$ to $\$ 3.00$ for the blacks.

Some interesting observances are gleaned from Mr. LeCompte's article. For instance, he says: "Some of the marsh owners have a habit of burning over the marshland during March, claiming that this action makes the grass grow for grazing purposes and hay. I believe that every marshland owner, who has any muskrat area, should burn the houses (or homes) prepared by the muskrat the season before. For instance, all houses found in the marshes in July and August should be destroyed by burning because the muskrat will select an old house, remodel it for the coming season, and, as they are invariably infested with lice, that this will prove a detriment to the young that the mother will litter in the renovated marsh apartment."

The game warden of Maryland hastens to add, however, that he does not approve the burning of marshlands. To the contrary, he says that it is his belief that if the muskrat producing area is not burned over, large quantities of aquatic plants, which form the principal foods of the animals, would be conserved for the coming season. This appears to be very sound advice, whether it is given a trapper or marshland owner in Maryland, Ontario, Manitoba, or Louisiana.

In commenting on the fact that there was not a large catch in his state during the 1927-28 season, the Maryland conservationist said that a great deal of the shortage was caused by "not enough feed on the marshes for the animals 
thereon, for the muskrat is like all other game animalsthey must have cover and sufficient food in their habitat to propagate and increase, as they have a great many natural enemies."

In this same official's estimation, Dorchester county leads in the number of muskrats taken in Maryland. This animal's natural habitat in the state includes all counties bordering the Chesapeake Bay and its tributaries, and muskrats are also found along the streams of western Maryland, but instead of being termed "marsh rabbit" (which is the common market name for our friend the muskrat in that section of the United States), or even marsh muskrat, they are known as "bank 'rats," and, according to Mr. LeCompte, they are harder to trap than the animals found in the tidewater marshes.

It is learned that a great many of the owners of large marsh areas in Maryland do not lease or rent their muskrat marshes, but compensate the trapper who catches the animal at the rate of 50 cents a pelt for every one skinned out, and the trapper, additionally, receives a certain percentage from the sale of the flesh of the carcess, for the muskrat is sold in the big markets of Baltimore and Washington, D. C., under the nome de musquash of "marshrabbit," and is, rightly so, considered a delicacy.

The muskrat industry of Maryland, from what Mr. LeCompte tells us, is a stable one, for, due to the fact that lands upon which this animal is found in greatest numbers are not tillable arable lands and all that they will raise is the muskrat and the foods on which it thrives best. Assessments on this class of land are lower than on land that can be cultivated for agricultural purposes, and, whether the trapper's catch is a large or small one, the purchase of such lands is a profitable undertaking when compared to the amount of money invested, he finds.

\section{MARYland's “BlaCK” Muskrat}

Considerable interest has always been manifest in the so-called black muskrats from the Chesapeake region. These animals are not absolutely black, as seems to be the general 
impression among those interested in the ranching or farming of muskrats, but the term does apply to color of the pelage on the back of the animal, as the belly fur and hairs are lighter, as they are in other 'rats. From the naming of this animal and the knowledge that they are blackish in pelage there has been quite a movement on in late years to secure specimens from Maryland, New Jersey, Delaware and Virginia so that they will cross with lighter colored species in the West and other sections of the country.

It must be borne in mind that the securing of a score of such "black" muskrats and the liberation of them in a natural marsh in Louisiana will not mean that a black strain will be created. It might be that the young of the first mating may show a tendency to darken in pelage, but when these, in turn, mate with the native animals, the preponderance will work against the black, and the resultant young from several matings will bear the normal coloration of the native stock. If black 'rats are mated with black 'rats in confinement it is doubtless true that black young will be produced, although there is a likelihood that some of the young will prove to be of the normal brown color, and selective breeding will have to be resorted to to keep up the dark strain. See page 382 .

This is mentioned merely to point out the fact that to simply import a few dark 'rats to the Louisiana marshes and turn them loose will not mean we will develop a dark strain here. This holds good for experiments in the West $\sim r$ elsewhere.

In the article on Maryland conditions that has been quoted Game Warden LeCompte recalls a statement that he made in 1925 that "artificial muskrat farming did not pay due to the fact that the muskrat had never yet shown any person a profit who had attempted to raise the animal in captivity." At that time he referred to the experience of W. A. Gibbs, the well-known trap manufacturer of Chester, Pa., who has large muskrat marshes in Dorchester county, Md. Since 1925, Mr. LeCompte finds that conditions have changed and that Mr. Gibbs has been diligently working on a method of propagating muskrats in captivity and that his methods are beginning to show results. 
"Mr. Gibbs is trapping these animals in the wild (not ranch raised) and propagating them in captivity. His pens are built of sheet metal and one-inch mesh chicken wire carried into the ground one foot, on hard dry ground well back from the ponds of the marsh, three to four feet in the soft, wet ground where the animals will work up against it.

"The animals are paired and placed in pens to propagate. The diet consists chiefly of apples, the tops and roots of such vegetables as carrots, beets, parsnips, etc. The muskrats are also very fond of the leaves of kale, clover, cabbage, parsley and corn, both stalks and grain. One of the best foods for the muskrat and one which he enjoys the most is the ordinary chicken scratch food.

"The muskrat, being a very clean animal, must be supplied with plenty of fresh, clean water, both to drink and to swim in. If persons propagating them in captivity can have flowing water through the pens at all times it would take care of the water situation, but if not, a swimming tank must be constructed. An ordinary dishpan is large enough for a pen, but the water must be changed often and kept clean and sanitary. These animals are fed four ounces of vegetables and one and one-half ounces of grain per animal per day. They will breed three to five times a season with an average of five to seven to a litter, and the young can be marketed for full-grown animals within six months.

" $\mathrm{He}$ is getting $\$ 20$ to $\$ 25$ a pair for the black and $\$ 15$ to $\$ 20$ for the brown muskrats and cannot fill one-half of the orders he receives."

The above description of the Gibbs methods are interesting, but it must be pointed out that, as yet, Mr. LeCompte's original statement that artificial muskrat farming does not pay, according to the author of this bulletin, still stands good, as Gibbs is making his profits from the sale of breeding stock and not from the farming of muskrats on a strictly pelting basis. The reader, too, is invited to compare the quoted Gibbs methods to those of the Mt. Forest Fur Farms as detailed on page 343. 


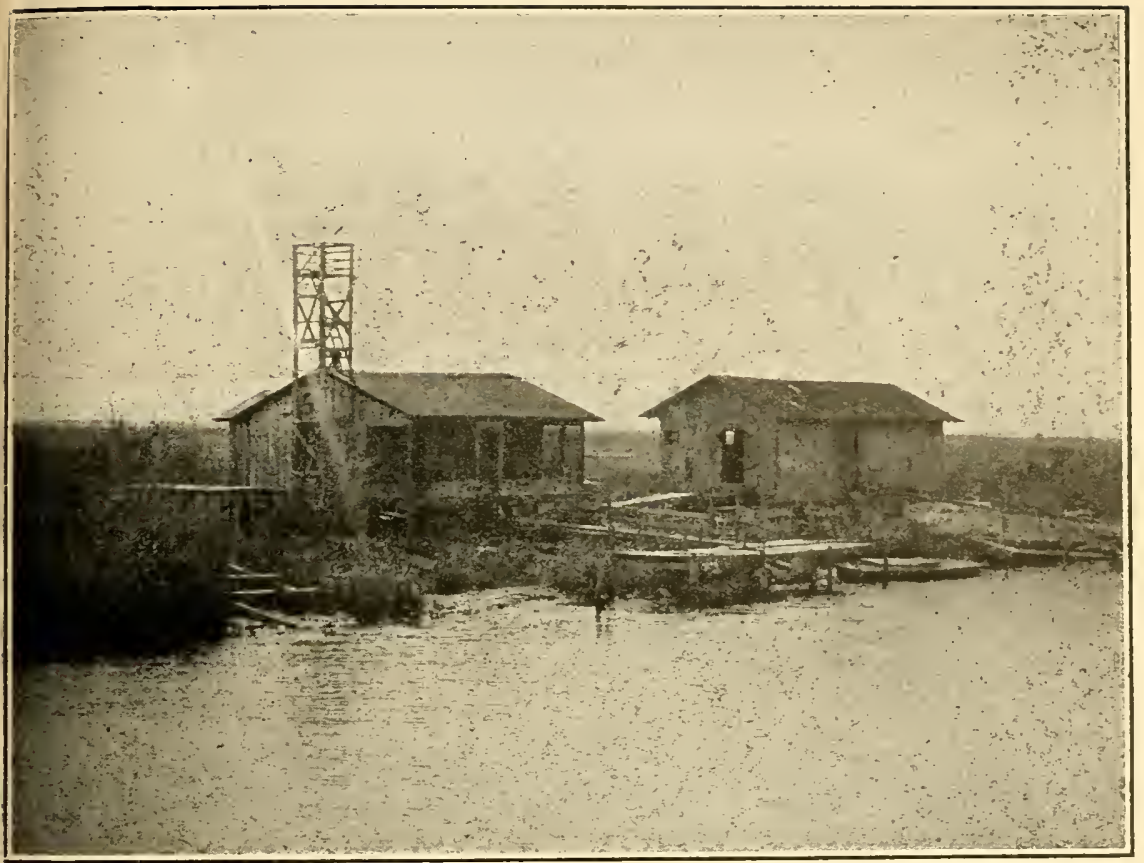

Conservation agent's station and tower on the State Wild Life Refuge in Vermilion Parish.

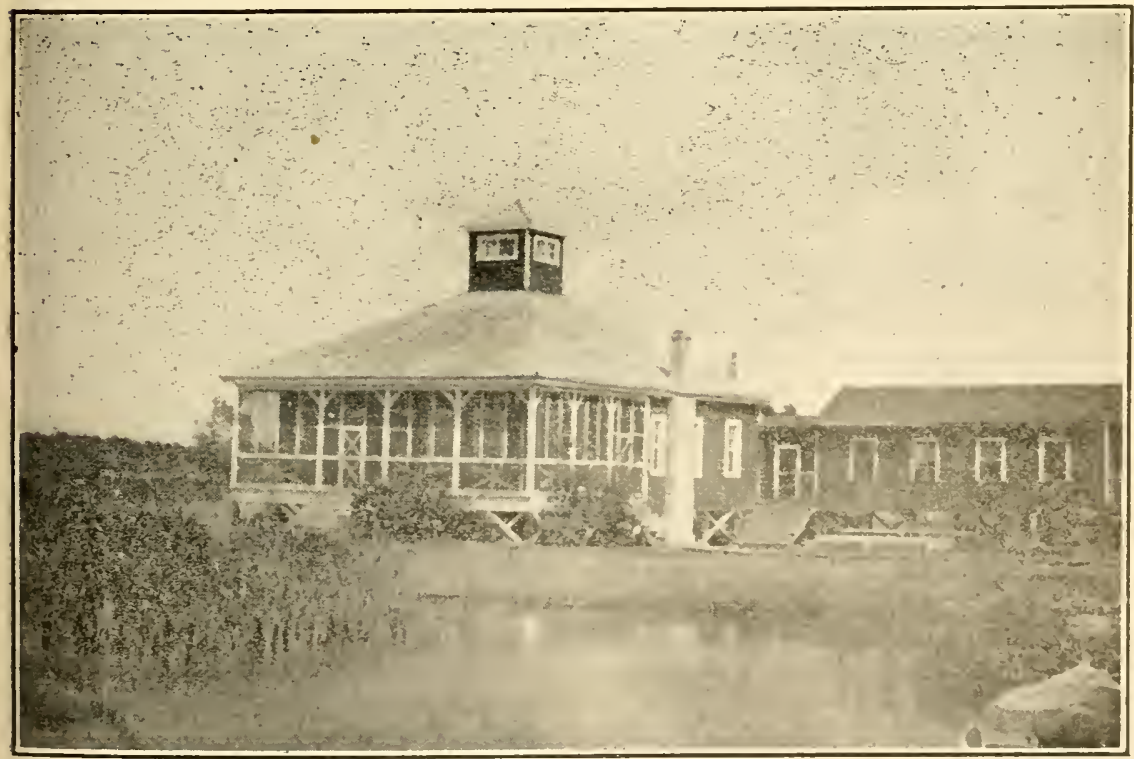

The Pass a la Loutre clubhouse on the State's public shooting grounds at the mouth of the Mississippi River. Here is to be found ducks of all species as well as muskrats, minks, raccoons and otters. 
There is a lesson to be learned from the recital of Maryland muskrat operations, and that is that money is being made in the industry there and under conditions that are not as favorable to ranching, farming, and breeding as are to be found in Louisiana.

\section{Fur Production on Refuges}

Concrete examples of what certain areas of marshland in Louisiana produce will be found in the following figures, which relate to the activities of trappers on the major wild life refuges in our state, viz., Marsh Island, the Rockefeller Foundation Refuge and the Paul J. Rainey Refuge, as well as the Pass a la Loutre Public Shooting Grounds, etc. It might be first explained that the wild life sanctuaries were set aside for the exclusive use of the migratory wild waterfowl of the continent and, as the muskrats devour the rootstalks of the very grasses that provide food for the ducks and geese, it is necessary to keep the animals thinned down or else they would "eat out" the food of the game birds that seek haven on the refuges every winter.

The state, through the department of conservation, places trappers on the state-owned sanctuaries to trap off not only the muskrats but the raccoons, minks and otters as well. On the Rainey Refuge, the National Association of Audubon Societies has leased out the trapping rights to trapping concerns at so much an acre, and has trapped the area with its own force.

On the Marsh Island Sanctuary there are exactly 71,550 acres of land that are trapped, and tables showing the number of animals taken by the trappers, and the average prices secured by them for the pelts sold, are listed below:

\begin{tabular}{|c|c|c|c|}
\hline \multicolumn{4}{|c|}{ Marsh Island, 1923-24 } \\
\hline Muskrats & $\ldots \ldots \ldots \ldots 336,535$ & $\$ .50$ & $\$ 168,267.00$ \\
\hline Raccoons & $\ldots \ldots \ldots \ldots \ldots$ & 3.00 & $2,760.00$ \\
\hline Minks . . & 1,056 & 5.00 & $5,280.00$ \\
\hline & & & $\overline{\$ 176,307.00}$ \\
\hline \multicolumn{4}{|c|}{ Marsh Island, 1924-25 } \\
\hline Muskrats & $\ldots \ldots \ldots 184,546$ & $\$ .75$ & $\$ 138,409.50$ \\
\hline Raccoons & $\ldots \quad 1,121$ & 3.00 & $3,363.00$ \\
\hline \multirow[t]{2}{*}{ Minks . . } & $\ldots \ldots \ldots \ldots \ldots \ldots$ & 5.00 & $7,615.00$ \\
\hline & & & $\$ 149,387.50$ \\
\hline
\end{tabular}




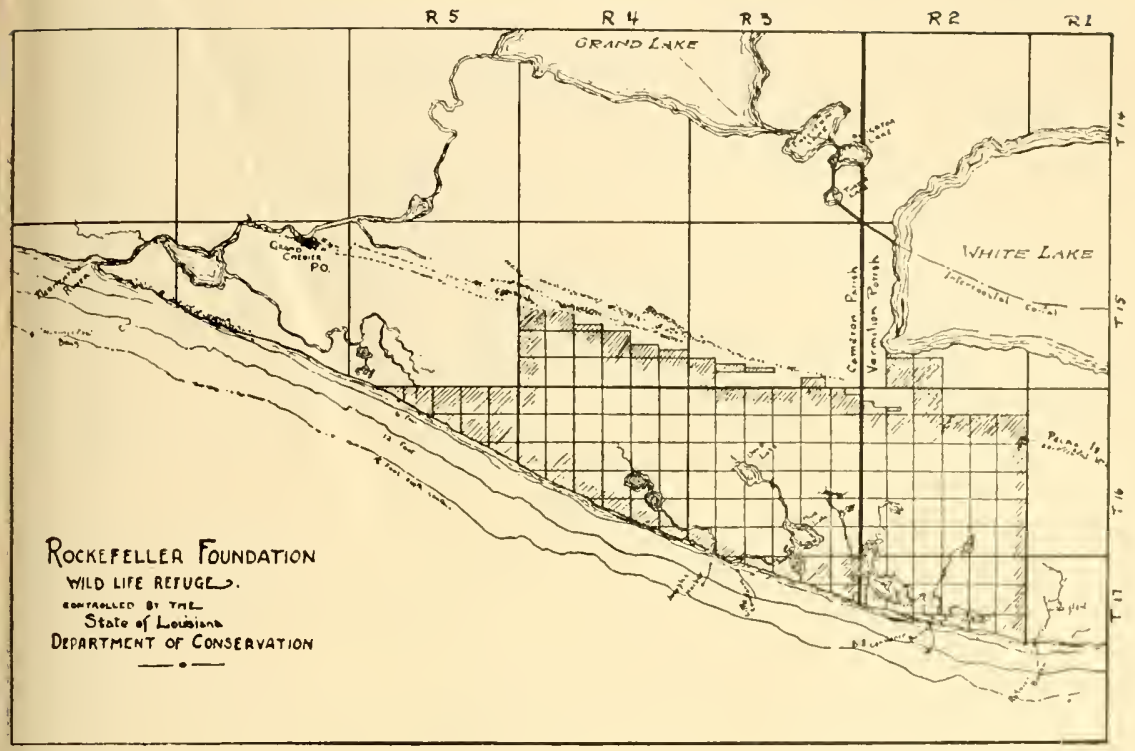

The Rockefeller Wild L.ife Refuge of 86,000 acres lying in Cameron and Vermilion parishes.

These figures show that the trappers took off the sanctuary in the 1923-24 season 4.70 muskrats to an acre, and on the following winter the catch fell off to 2.57 'rats. Due to two drought summers, there was a marked decrease in the catch, but in neither year was the area "skinned," as we have estimated that such areas can contribute 6.75 muskrats per acre without harming the "seed" or breeding stock.

It might be interesting to average what the trappers received per acre for the fur take in the 1923-24 winter. Marsh Island land earned $\$ 2.46$ an acre and the year following, due to the rise in the price of 'rats, the earning capacity of the same area was $\$ 2.35$ an acre, for the value of raccoons and minks are figured the same for both seasons, in spite of the fact that the trappers received better prices than indicated in the tables.

On the Rockefeller Refuge the Jones Brothers, of Grand Chenier, who had the trapping rights on the Cameron end of the sanctuary, consisting of a little more than 60,000 acres, estimate their 1923-24 catch was in excess of 200,000 
muskrats, for which they received from 28 to 46 cents a pelt, or about $\$ 74,000$. Their $1924-25$ catch was only 21,000 'rats, the average price ranging from 65 to 78 cents a pelt, or a little more than $\$ 15,000$ for the season. This made their 1923-24 catch average approximately 4 to an acre and the following year about $1 / 3$ of a 'rat to an acre. It might be here pointed out that the Rockefeller Refuge was severely hit by a two-season drought, as was Marsh Island, and the decrease of animal life was caused more by the elements than by trappers.

The total catch on sanctuaries for the season 1925-26 was as follows:

Marsh Island

Muskrats

Raccoons

Mink

Muskrats

Raccoons

Mink

Muskrats

Raccoons

Mink
48,376

381

499

234

6

2

Rockefeller

367

196

159

A comparison of the figures for seasons 1923-24, 1924-25 and 1925-26 will show that the refuges are rapidly being trapped out and all noxious animals are being removed.

On the Rainey Refuge, which is a tract of approximately 26,000 acres, a leasing system of ridding the lands of the muskrat population was first tried out. From the revenue thus acquired the National Association of Audubon Societies paid the upkeep of the sanctuary.

The lands were leased to a trapping concern for three years at so much an acre, viz., for 1924-25, the price was set at 40 cents; for 1925-26, it brought 50 cents an acre, and for the exclusive trapping privilege of the 1926-27 season, 60 cents an acre was paid. Owing to a non-completion of certain surveys the tract was set officially at 23,490 acres with the proviso of extra land would be included in the price per acre paid. 


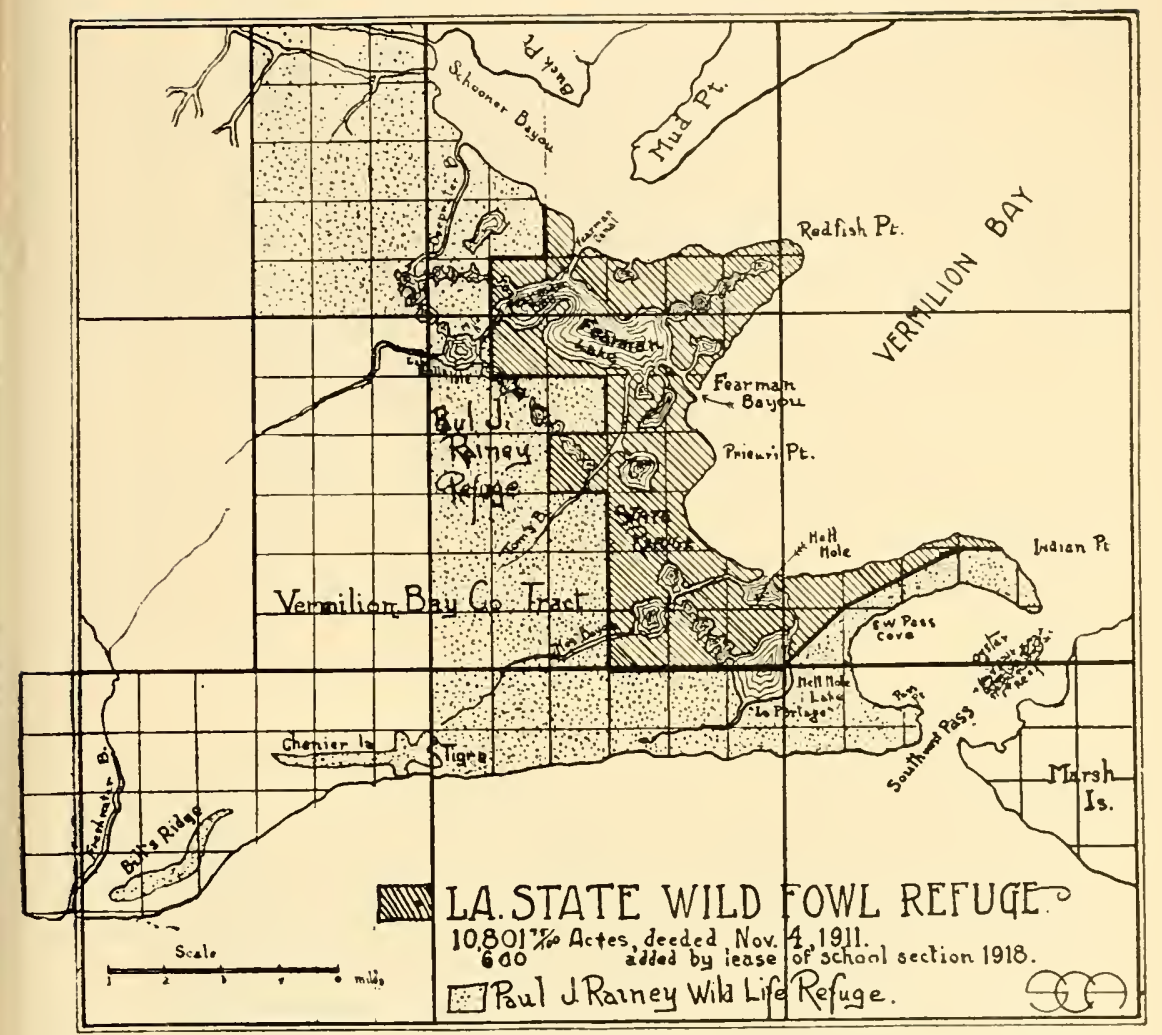

The Louisiana State Wild Life Refuge, in Vermilion parish and, shown by the dotted section, the Paul J. Rainey Refuge, administered by the National Association of Audubon Societies.

This shows that this area served not only its purpose as a refuge for the migratory wild waterfowl but earned the first year approximately $\$ 9,600.00$; the second season, $\$ 12,000.00$, and the next year would have brought in $\$ 14$,400.00 , but trapping was stopped after the first half of the season and only one-half of the rental was paid in. All this without a nickel's output for stocking the fur animals or feeding them throughout the year.

The exact amount of fur taken off the Rainey Refuge property is shown in the following figures furnished by Dick Gordon, superintendent of the refuge, with an estimated valuation to the trappers: 


\begin{tabular}{|c|c|c|c|c|c|c|}
\hline & 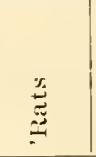 & $\stackrel{\text { 兰 }}{\Xi}$ & 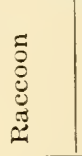 & \begin{tabular}{l}
$\tilde{\Xi}$ \\
\multirow{3}{n}{} \\
0 \\
0 \\
0 \\
0
\end{tabular} & $\frac{\vec{D}}{\Delta}$ & 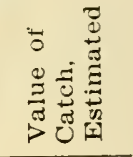 \\
\hline $1924-25$ & 42,000 & 150 & 150 & & & $\$ 31,605.00$ \\
\hline $1925-26$ & 24,416 & 75 & 31 & 14 & & $38,000.00$ \\
\hline $1926-27$ & 5,870 & 282 & 282 & & & $10,272.00$ \\
\hline $1927-28$ & 10,321 & 217 & 257 & 36 & 1 & $14,599.00$ \\
\hline
\end{tabular}

These figures vividly indicate how the muskrat population fell off during the trapping seasons following the two drought years of 1924-25. Indications at the time of this bulletin was printed predict a normal catch of the fur animals for the 1928-29 season, thus providing the advisibility of light trapping when the 'rat population has been reduced.

The Department of Conservation leases out the trapping rights on the State Public Hunting Grounds at one of the mouths of the Mississippi River, called Pass a la Loutre. Here are 23,263 acres of marshland constantly flooded with fresh water from the flow of the mighty Mississippi and is a natural habitat of muskrats, raccoons, minks and otters.

The Delacroix Island territory, from time of the coming of the first white settler, has always had the reputation of being rich in fur animals, fish, oysters, shrimp, wild duck and geese and other forms of wild life. It lies in a fresh water basin which never seems to be affected when other sections of the state are being burned by a drought, and it supports the finest and most extensive stands of three-cornered grasses (Scirpus robustus, olneyi, and americanus) known in Louisiana, so with such favorable food and water conditions it is no wonder that this area has always been, and probably always will be, a paradise for muskrats. 


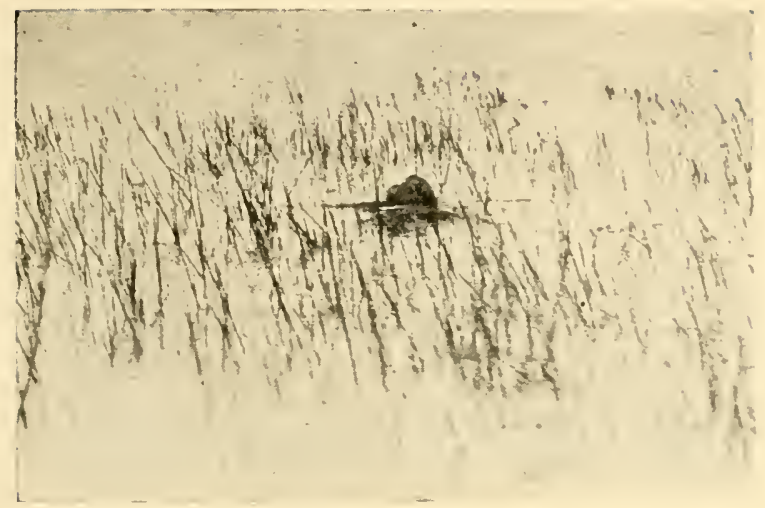

When high water comes muskrats build themselves a raft from stalks of marsh vegetation.

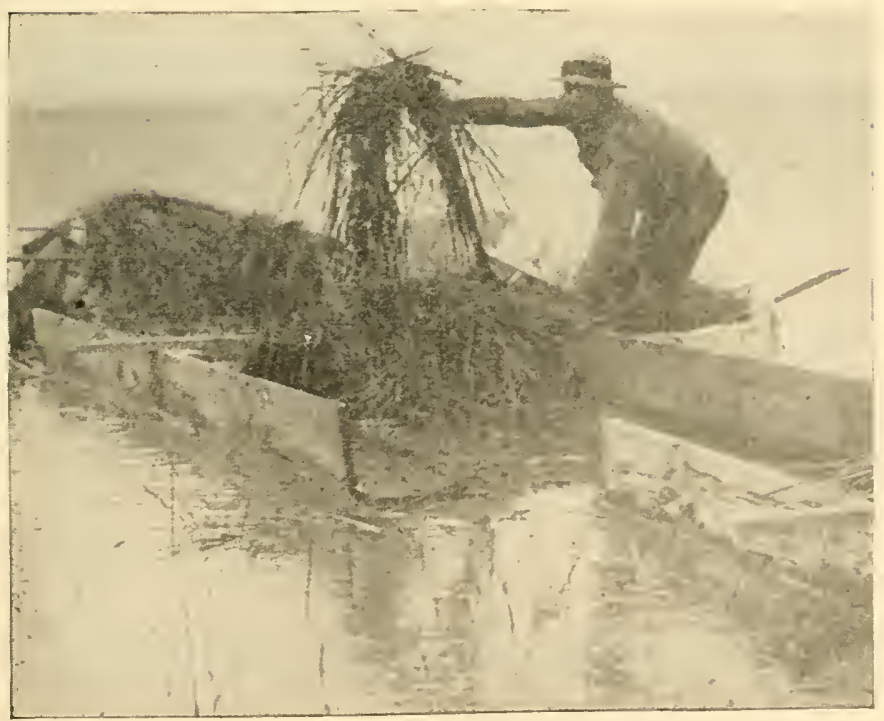

The type of life raft that proved the most efficacious in saving muskrats in the flooded districts. 
In 1922, due to a break in the levee at Poydras, this area was flooded by crevasse water's and the water remained on the land 54 days. In the trapping season of 1922-23, the winter following the inundation, little or no trapping was done. In the 1923-24 season the take of muskrats amounted to 20 per cent of a normal season. In the 1924-25 season the take was approximately 70 per cent. The two following winter trapping seasons, 1925-26 and 1926-27, saw these marshes yield the trappers of the region 100 per cent of fur and better. When the Poydras levee broke in 1922 , a mistake was made by the then conservation department officials in giving trappers permission to shoot the muskrats and when the water inundated the marshes trappers with shotguns killed hundreds of thousands of these refugee fur animals while they were clustered on top of their muskrat hills. In spite of this needless, ill-considered and wanton slaughter, the muskrats so repopulated these marshlands that five years later we find this very area contributing about 80 per cent of the 1926-27 muskrat crop of Louisiana.

In April of 1927 this territory again flooded when an artificial break was made in the levee system at Caernarvon to save New Orleans from a feared crevasse during the high water period of that year. The water remained on the Delacroix Island muskrat marshes approximately 108 days, compared to a 54-day submersion in 1922, but the food grasses came back to their former luxurious abundance soon after the water drained off, as they did five years previously.

During the 1928 flood period strict orders were issued from the Department of Conservation agents, assisted by trappers holding special commissions, and with the cooperation of lessees and land owners, all such violations were kept down and instead of killing the refugees at a time when their furs were of no value, life rafts were built and floated in the crevasse waters and thousands were saved from drowning. 


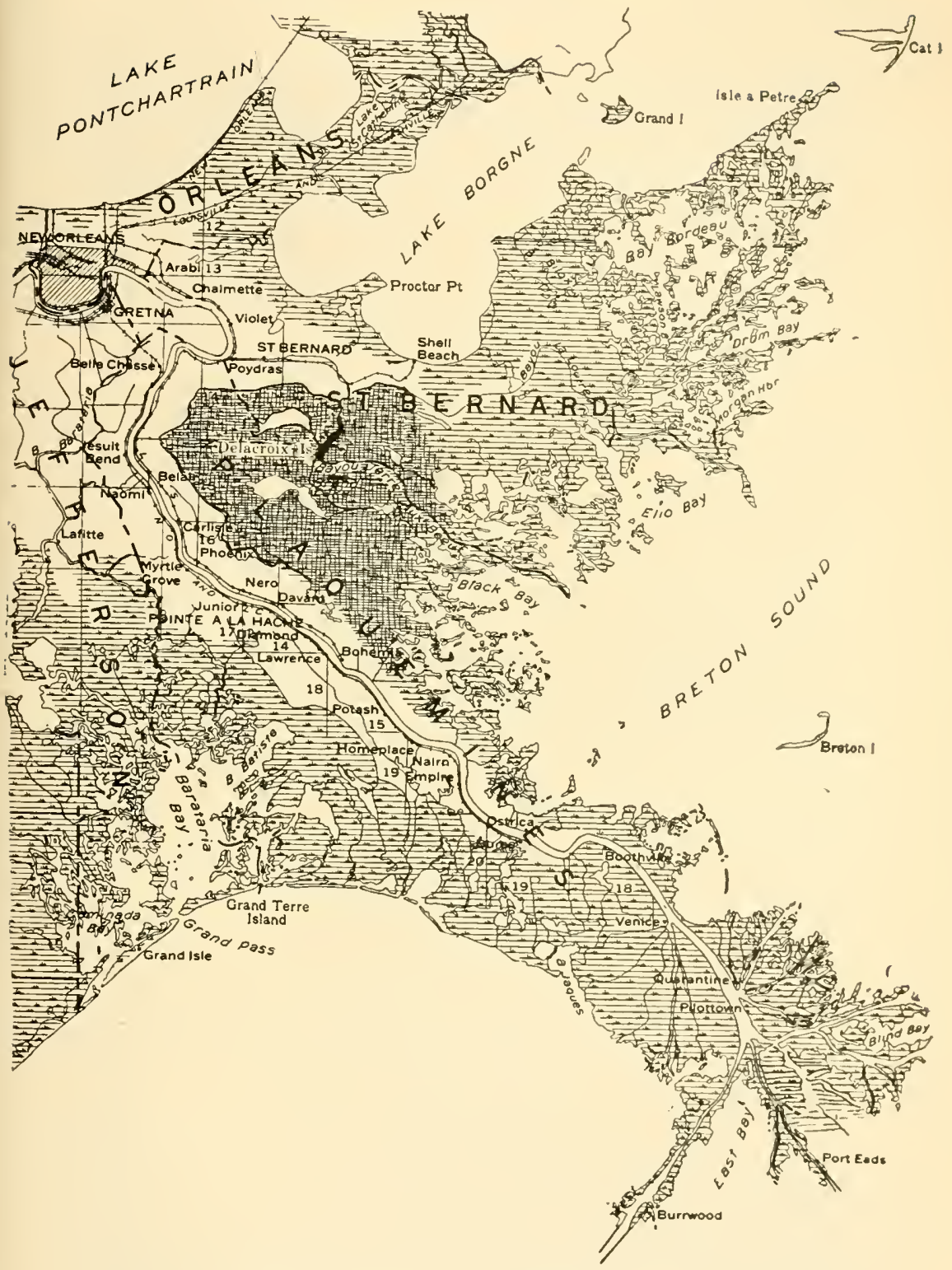

The heavily shaded area indicates the celebrated Delacroix Island marshlands southeast of New Orleans which are undoubtedly the most productive marshes on the North American Continent. 
When this territory was first inundated by the waters from the Caernarvon crevasse the department requested the Reparations Committee of the City of New Orleans to furnish figures as to past yields in this territory. As the books of the fur dealers were closed to the department, blank report forms were sent to all trappers of the region so that they could supply us data, through sworn affidavits, of the number of muskrats taken during the 1926-7 season, the acreage trapped, the prices secured, and to whom sales of pelts were made.

A total of 418 such sworn affidavits were returned and an analysis of the reports proves to be very interesting, as they show that those taking muskrats in the St. Bernard section of the Delacroix Island territory averaged 31.11 pelts to the acre, the figures indicating that 481,053 muskrats had been taken on 15,462 acres.

The sworn reports from the trappers in the Plaquemines parish section showed that 713,939 muskrats had been taken off of 20,174 acres, or an average per acre of 35 pelts.

From these figures it would appear that an abnormally high number of muskrats were taken off this area and might cause those unfamiliar with trapping conditions in this particular territory to doubt the reliability of the figures. A number of instances of high averages per ace, as 73.82 per cent, 60.50 per cent, 64.06 per cent, 64.35 per cent, 71.53 per cent, etc., were reported.

In St. Bernard parish, Richard Acosta \& Sons declare in their sworn affidavits they had a trapping area of 128 acres, in which they took 9,440 rats, or an average of 73.82 per cent. This is the highest average reported.

The lowest average reported on the St. Bernard list is Jordan Freeman. He reports that he took 700 'rats off of 300 acres, which gives him an average of 23 per cent. This is approached only by Felicon Nunez, who reports that he took 150 rats off of 50 acres, an average of 3 to an acre, and John Washington, who trapped 300 acres and secured 650 rats, his average being 2.16 per cent. 
The Fur Animals of Louisiana

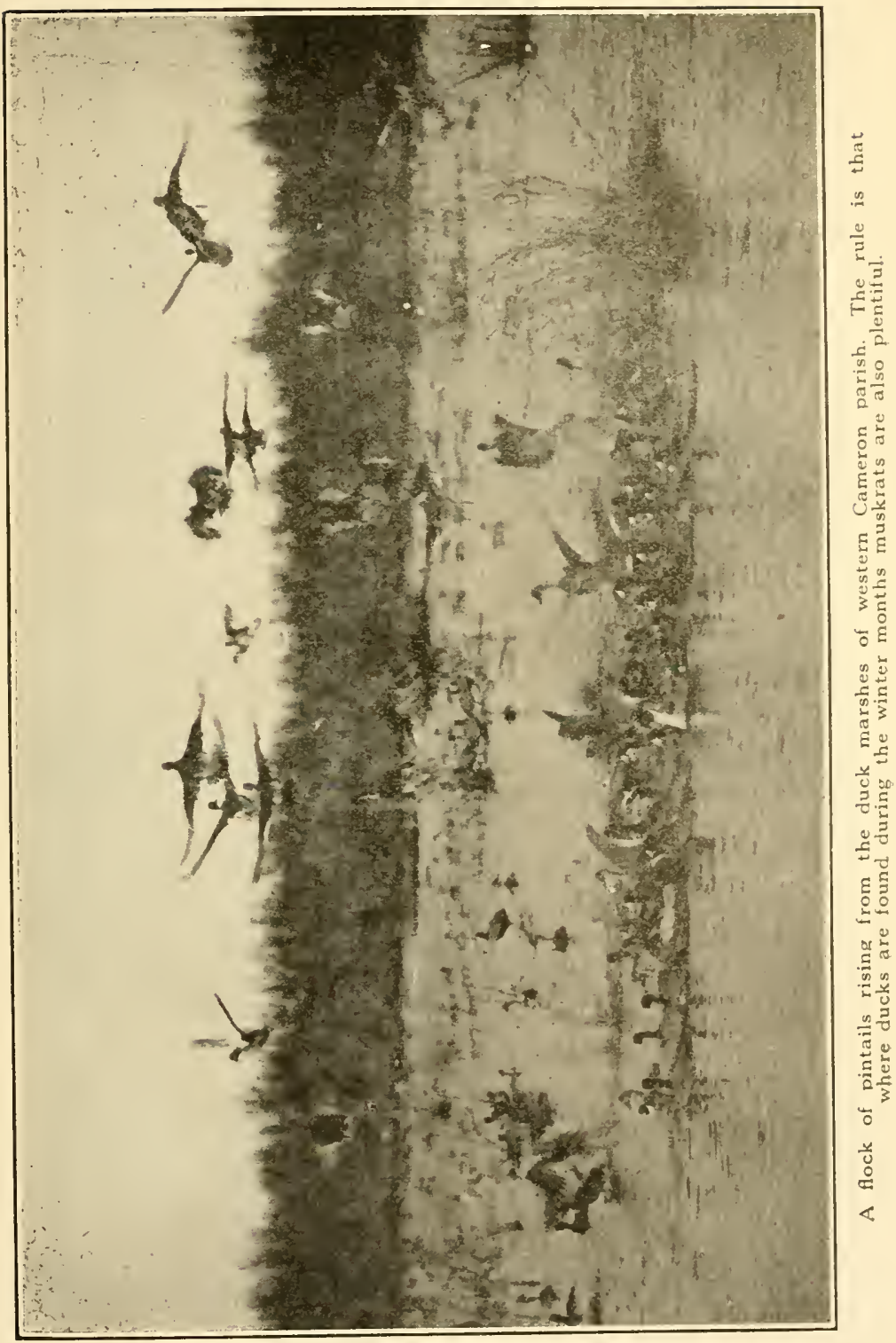


In Plaquemines Parish the sworn affidavits from trappers range collective higher both in take, acreage and percentage per acre. The individual high take in Plaquemines parish is furnished by Alex Ruiz, who claims that on 80 acres he secured 6,000 rats, which was an average of 75 rats to an acre, and the lowest catch reported is that of Roy Mellerine, who reports that on his 60 acres he took 597 muskrats, an average of 9 to an acre.

The following reports are indicative of what was taken on some of the acres:

Stephen Molero, who trapped 180 acres, reports securing 5,060 muskrats, which is an average of 28.11 to the acre. This man is an excellent trapper and a hard worker and as he had a very good piece of territory, I am prepared to believe that his report is quite in line with what he actually did.

The reports of the Roberts brothers is, in my estimation, indicative of what was actually done on this area. Harvey E. Roberts, who had 1,3401/2 acres, secured 22,504 muskrats, which is an average of 16 to an acre. Roberts did not trap himself, but engaged three or four trappers, and his affidavit was on the pooled interest of what these men did.

The report of $\mathrm{P}$. J. Roberts, who trapped 125 acres and secured 2,863 muskrats, an average of 23 to an acre, is in my estimation a very accurate report on what was done on his area, as the Roberts boys had a very good piece of ground.

Mitchell St. Germaine trapped 102 acres and secured 2,754 muskrats, or an average of 11.70 per acre. Considering the type of land that St. Germaine trapped, this would be nearer to an under-statement than an over-statement.

In pointing out these individual efforts on the part of trappers, in the face of sworn affidavits by those most directly concerned, it is not an exaggeration of what was really done on this land the past winter to say that 25 muskrats or more was the average production of these very excellent trapping lands. 


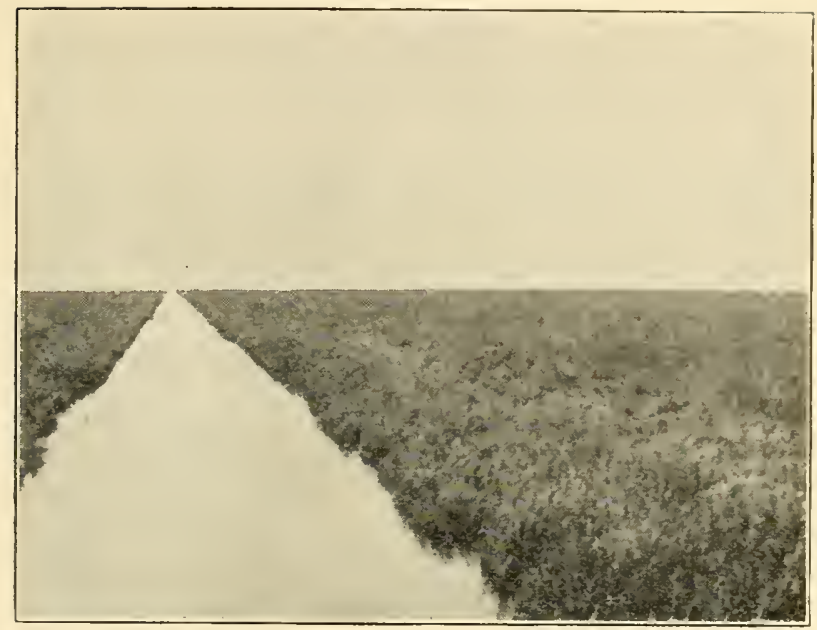

More than forty miles of canals cleave the tract of the OrangeCameron Land Company's 'rat ranch.

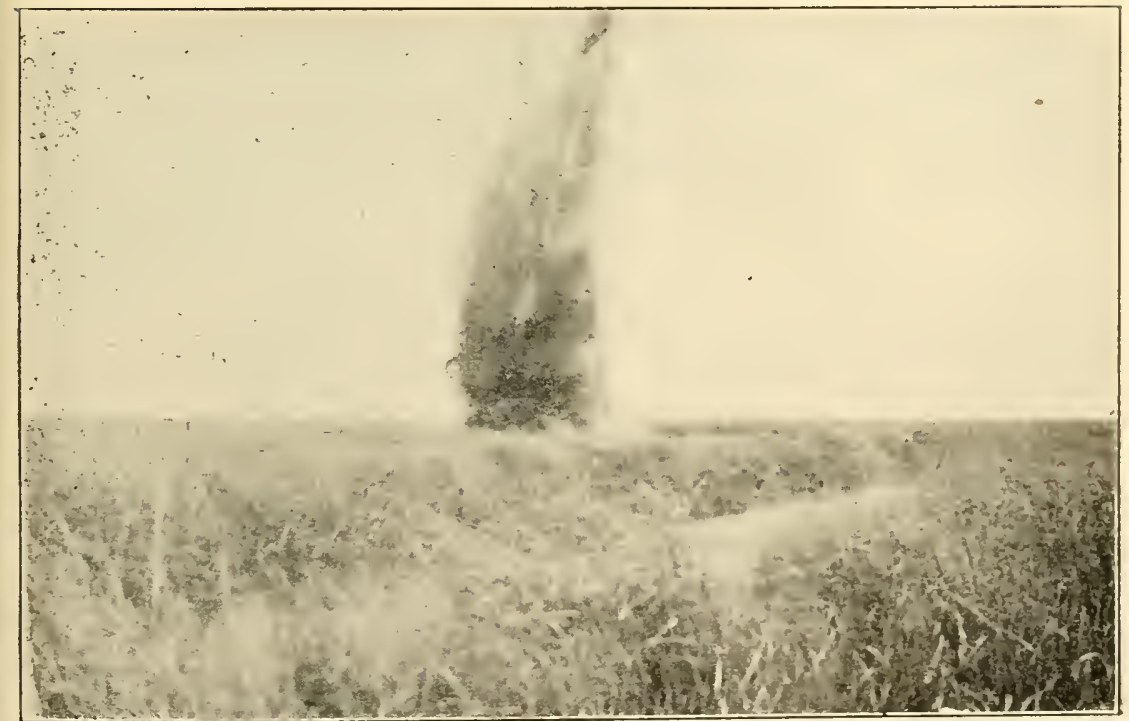

Ditching by dynamite proves to be an efficient and economical method of digging small canals, known in Louisiana as pirogue trails. 
When this very large yield is considered, it might be possible for the layman to conclude that these lands were "skinned" by the trappers, and that the number of muskrats taken was entirely too much to permit a sufficient breeding stock to remain in the marshes for the next winter season, but judging from the myriads of muskrats driven from their habitats by the flood waters when the lands were first inundated it is certain that, in spite of this high take, that the trappers did allow sufficient breeding stock to remain on the marshes to insure as good a take for the coming winter as was taken off of these lands during the season of $1926-27$.

\section{Ditching With Dynamite}

The cost of digging canals through the Louisiana marshes, as has already been pointed out, averages from $\$ 1,000$ to $\$ 1,500$ a mile, depending on width, depth, and the kind of marsh through which the dredge must work. Canals 18 feet wide and 6 feet deep, such as have been exacavated by a local land company, and which have been designated as standard by this department for 'rat ranching, are not necessary in every part of a large acreage given over to the production of muskrats.

Pirogue trials, or narrow-width, shallow canals, will prove a great aid to the 'rat rancher in effectively protecting, patrolling and transporting supplies and collec. tions. They can be dug with effect and with comparative cheapness, as can be proved by the experiments made on the holdings of the land company's tract during the summer of 1927 , when $23 / 4$ miles of pirogue trail was blasted by dynamite at a cost of $\$ 1,635$, or $\$ 75$ a mile, approximately. 


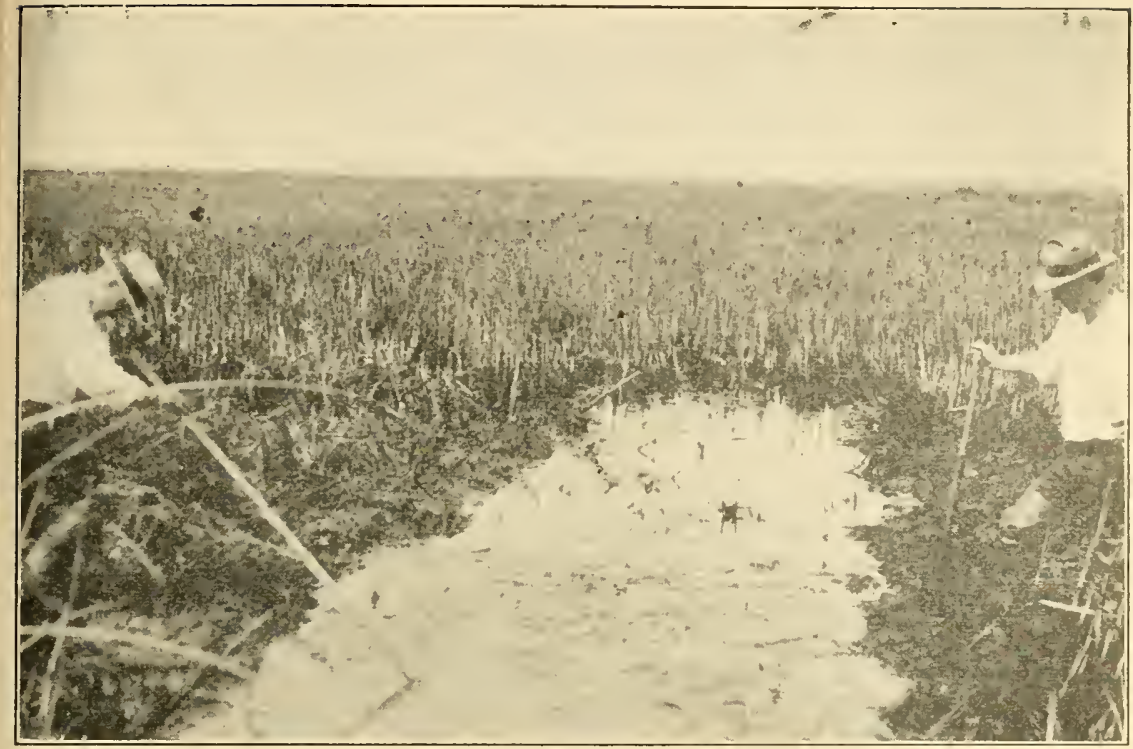

The first blast of dynamite blows out a pirogue trail of sufficient width and depth. The sticks for future explosions are set in the burned grass area at the end of the water hole.

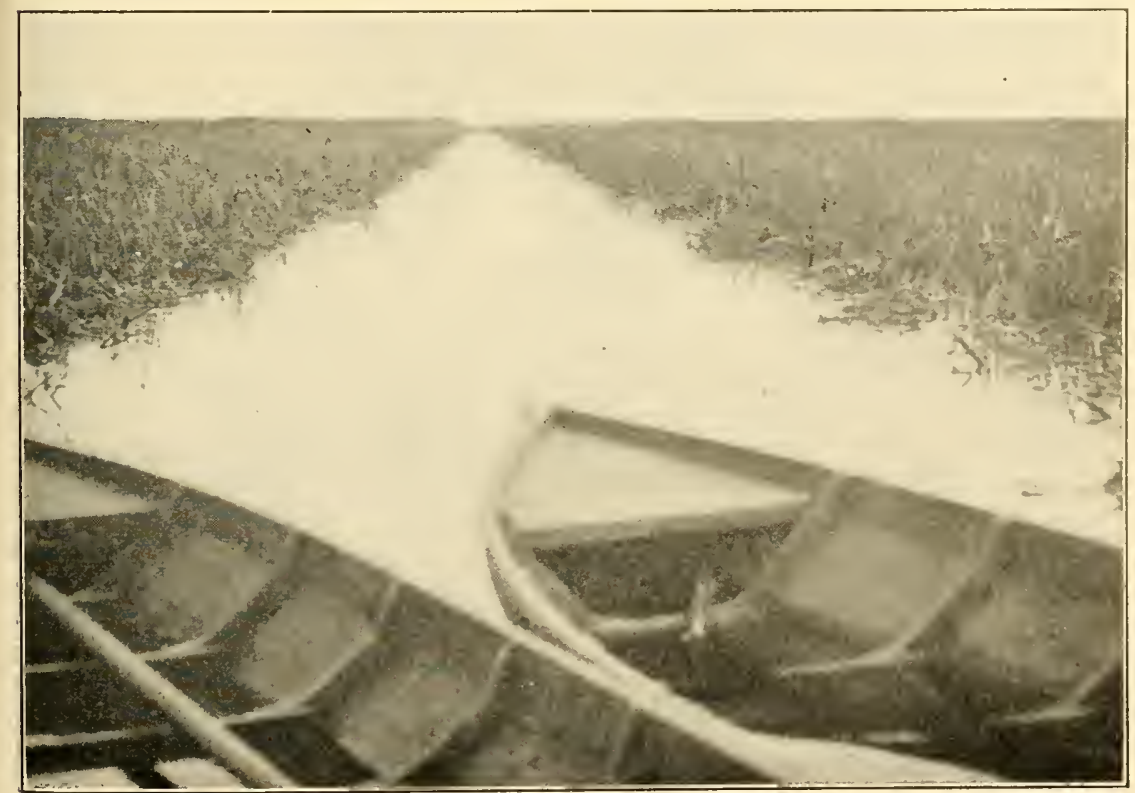

The completed pirogue trail dug with sticks of dynamite as described in the text. 
The ditch thus dug was uniformly 5 feet wide and averaged in depth from 22 inches to 3 feet throughout its length and proved to be adequate for not only pirogues but for skiffs propelled by outboard motors. The explosives used cost $\$ 1,250$ in half-pound sticks, at $\$ 22.50$ per 101 lbs., while the necessary caps and wiring cost $\$ 25$. The bill for labor amounted to $\$ 360$, men employed by the company as guardians being used in the work.

Experiments were made with the propogation of charges until it was decided that an average distance of 20 inches between the half-pound sticks of dynamite threw the marsh dirt and mud clean and clear, and to a proper depth and width. The demonstrator for the dynamite manufacturers advised placing the sticks from 14 to 16 inches apart, but no misses were made with the 20 -inch separation and the explosive cost was thereby reduced.

The longest shot that was made was 380 feet. The half-pound sticks were set into holes made by a shovel handle and spaced 20 inches apart. Every 15 to 20 feet a booster cap was set into a dynamite stick to insure the entire charge being fired.

The experimental shots were made on a marsh that had not been cleared and as a consequence the thick vegetation hindered a clean job being done. A favorable opportunity was taken when the wind was just right and the marsh wet from a rain, and the vegetation was fired. Over this burned area stakes were set by compass and the course of the pirogue trail set. Three charges a day were averaged by the crew and not 10 working days were consumed in completing the task. Due to the fact that the ditch was. dug over the burned marsh very little cleaning was necessary after the shots were fired.

The pirogue trail immediately filled with water and the digging of it has already proved its worth in time and labor saved by the patrol men guarding this tract in the close season, and it will be of decided help to the trappers during the season given over to the taking of fur. 


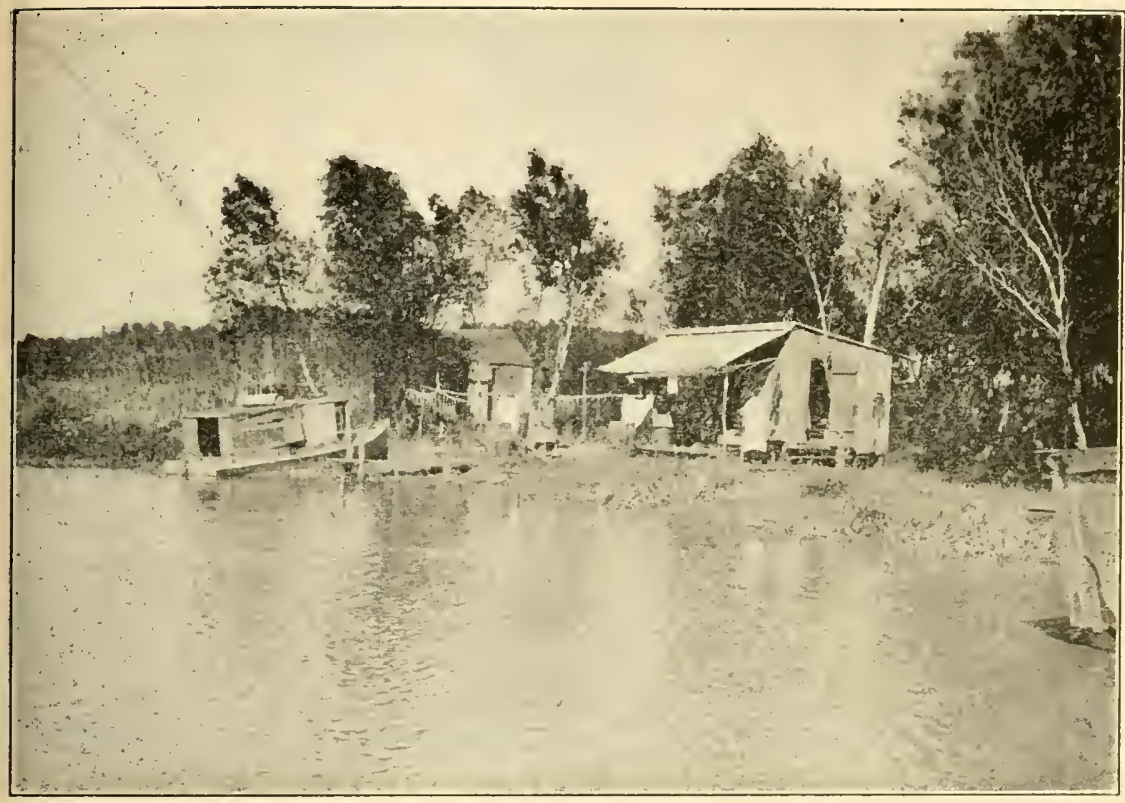

Typical trappers' habitation along a bajou bank. Here the whole family lives during the productive winter months, every member assisting in the catching or drying of the fur pelts.

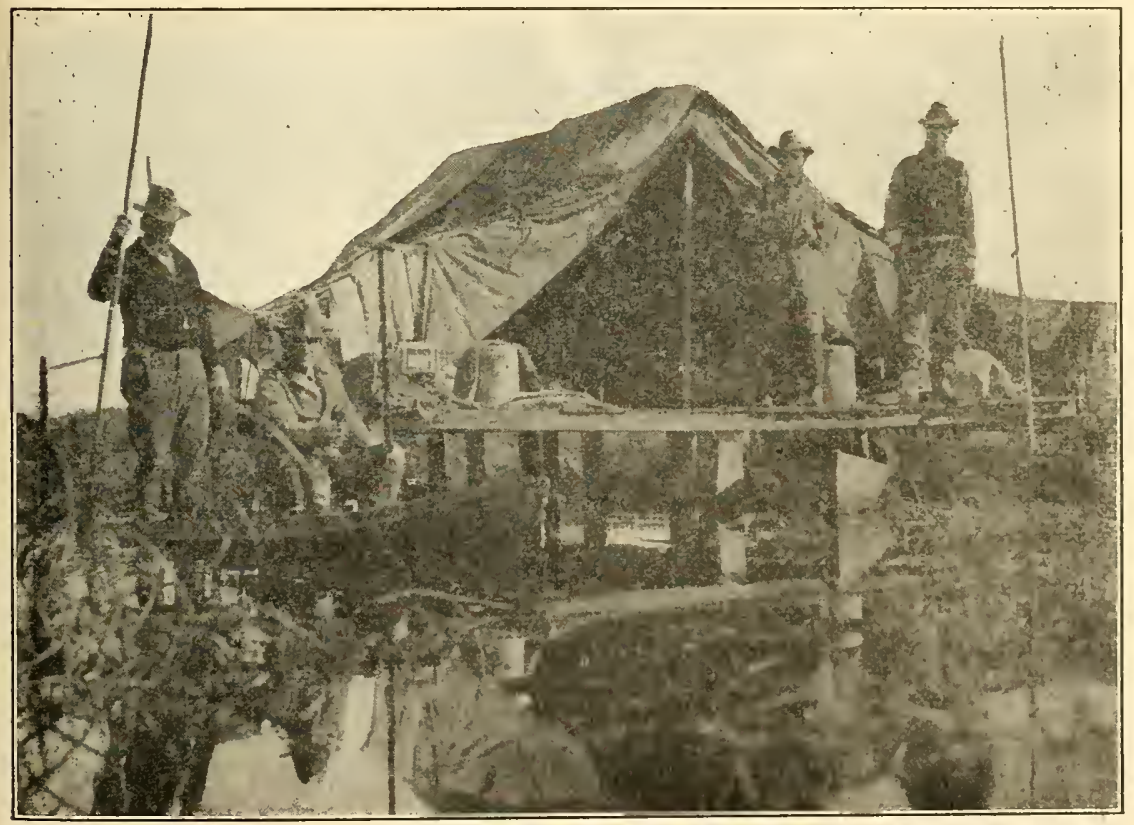

A camp in the marsh, raised alove the water by stilts. All transportation is by pirogue (the craft on the teft ct the : ictuc) which is known as the "Hiver" of the ma:shes. 


\section{TRAPPERS' ASSOCIATIONS}

In the good old days, "free trapping" was all the vogue in the Louisiana marshes, as well as throughout the state. A trapper, if he elected to pursue this vocation, merely bought himself some traps and sallied forth anywhere the fur was to be found and set the traps, skinned his catch, and sold his pelts to the first visiting fur buyer. Then, as the fur crop became more valuable, owners decided to share in this annual harvest and either worked their own lands or leased them out to trappers at so much an acre rental; a few-a very few, however-shared in the value of the take.

Less than six years ago there entered a new element into the business. Fur trapping rights were purchased from marshland owners, who were getting no revenue at all from their lands, and the right to trap the acres were subleased to practical trappers. In other cases, marshlands were purchased outright and the owners went into the fur business. This caused consternation among the "free trappers," and, in a number of instances, open warfare, as the majority of the trappers were decidedly antagonistic to having their free trapping rights taken from them-even by the owners of the lands on which they trapped without even going through the formality of asking for this privilege. The leasing companies and owners went into the courts and invoked the trespass law.

Trappers formed themselves into "protective associations," engaged lawyers and fought the rights of the owners, but the courts upheld the landowners and his right to lease the fur-trapping rights on his own property. Whereupon, the trapping associations did a right-about-face, paid in for membership stock, and in turn secured leasing rights for their members, doing the identical thing the corporation they had been fighting had been doing, and peace prevailed. However, as in most cooperative movements, the trarp ?r's' associations were popular for about one year and then they languished, and today most of them are dead. 


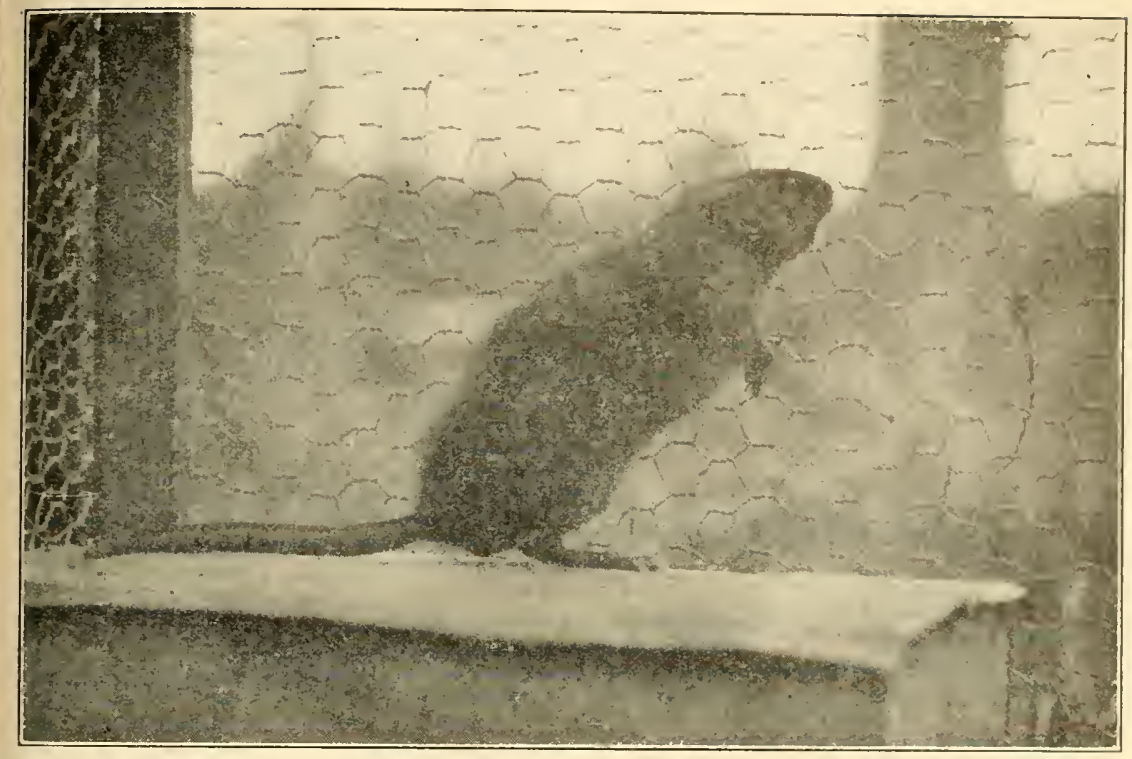

-Photograph by Svihla.

A Louisiana muskrat in breeding pens on the department's experimental fur farm.

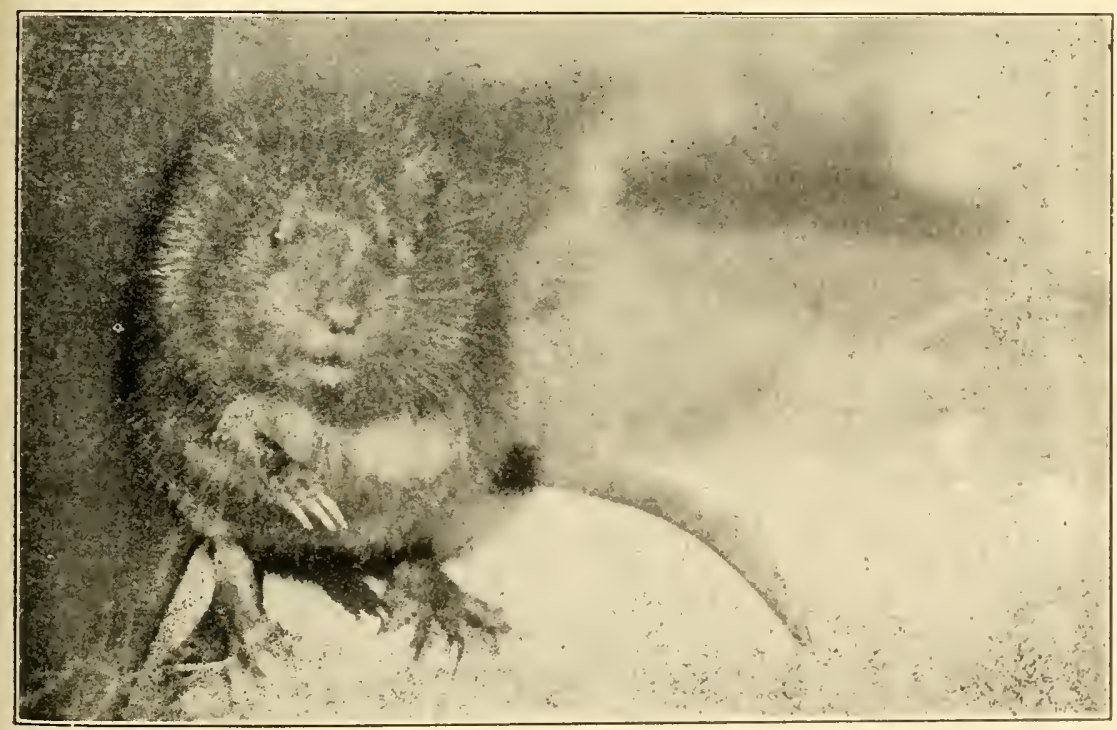

- Photograph by Vernon Bailey.

This three-legged muskrat proves that animals losing a leg in a trap, called locally "wring-offs" do recover from the nound. 
As yet there has been no cooperative selling of the pelts taken by the members of associations, leasing companies or by large landowners, but the subject is being seriously considered as a means of securing better prices and cutting out middlemen's profits.

The 'rat ranching idea is taking strong root in the minds of the trapping fraternity and now efforts are being made by those with foresight to secure tracts of land they can work year after year, in the open season for securing pelts, and in the close season so that they may build up the food and other conditions on their areas. Many trappers have purchased small tracts of land which they work themselves.

While it may be generally stated that all of the muskrat land in the state has been taken up, there is plenty of opportunity for the practical trapper to sublease tracts and conduct his own ranch and thus provide for himself a steady income. What has been done for the 'rat ranches can also be done for many of the other sections of the state where raccoons, opossums, minks, skunks, otters and such upland fur-bearers have a natural habitat in the swamps of cypress, tupelo, and hardwoods still remaining in the state.

\section{Control Methods of BreEding}

\section{Complete Control}

Cement-lined cages or breeding pens approximately $6 \times 10$ feet and wholly covered with wire netting have been advocated for limited area or so-called "backyard" breeding pens for muskrats. Such pens are no doubt practicable, but very and excessively expensive. The Mount Forest Fur Farm method appears much superior. It has been worked out by several breeders in different sections of the country. If one buck is placed among four or five females, greater success will attend breeding and reproduction, but the use of the buck solely for stud purposes, as practiced by the Mount Forest Fur Farm, is undoubtedly the correct procedure for mating. Space should be reserved in such a 


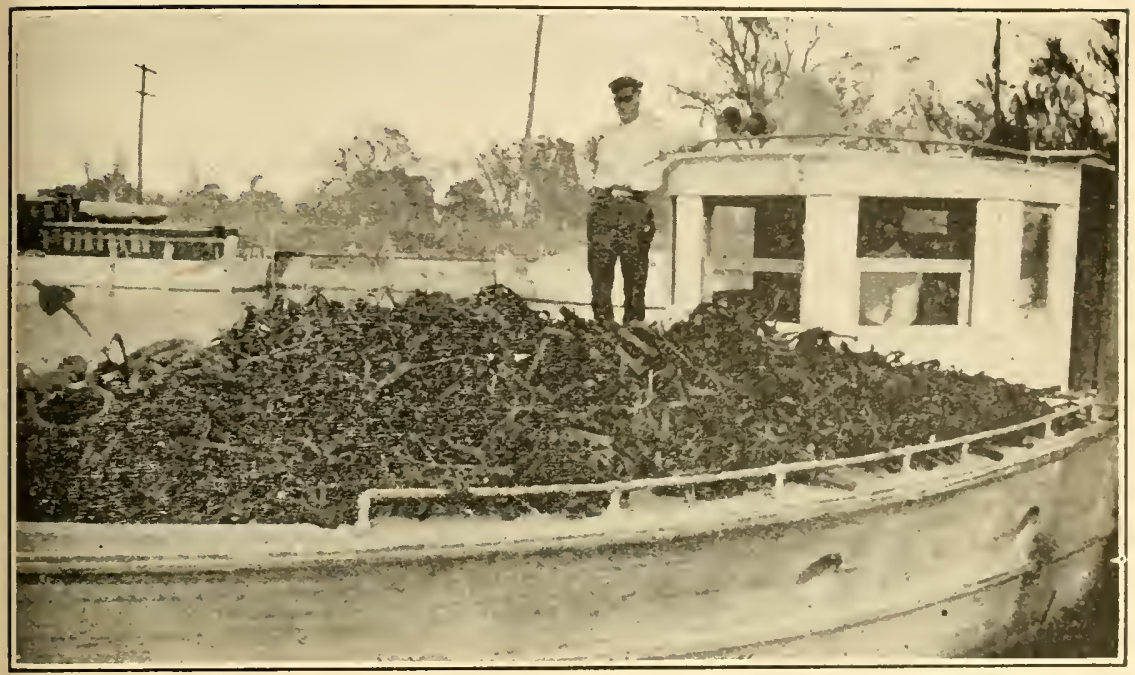

A deckload of 1,250 traps on the Department's patrol boat "Eagle," confiscated because of violations of the trapping laws.

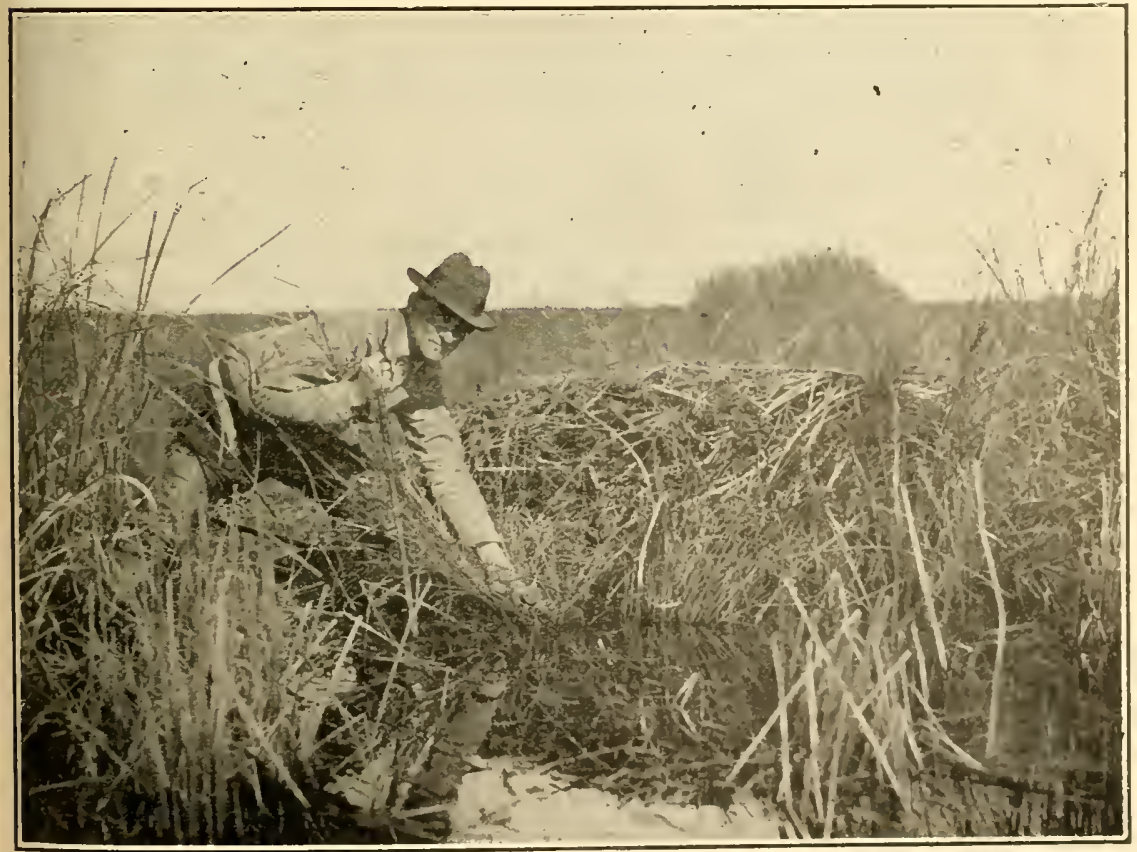

Conservation agent confiscating a trap set nearer than 10 feet of a muskrat house. 
cement-lined enclosure to allow some greens to grow so as to vary the monotony of the diet of rolled oats, apples, turnips, etc., fed the animals and a good-sized bathing pool should be a part of the equipment. If space permits, a series of such pens can be constructed, but emphasis must be placed on the cost of such equipment, a cost that will not be refunded if the animals are raised solely on a pelting basis.

By this "complete control" method data can be kept on breeding habits and, perhaps, the knotty problem of the period of gestation can be untied. As has already been stated, it has not been conclusively proved that the period of gestation of the muskrat in all sections of its range on this North American continent is exactly 21 days, nor do we know to a certainty just how many litters can be produced in the period of a twelve-month.

Dr. Johnson, in his "The Muskrat in New York" says that the exact period of gestation of the muskrat has not, so far as he is aware, ever been determined and points out that some investigators, on the basis of analogy with the common house rat, have suggested that the period of gestation is not more than 21 days.

That distinguished writer, artist and naturalist, Ernest Thompson Seton, gives the period of gestation as "probably 30 days" and our experiments and surveys in Louisiana seem to bear out Seton's figures, although we have arrived at nothing definite or concrete on this moot question.

The most reliable data as to the number of young produced in a litter are furnished by records of embryos contained in the uterine horns. Such records gathered by the Biological Survey naturalists and others indicate a wide variation, i. e., Seton gives the muskrat from 4 to 9 in a litter; Biological Survey data show 3, 6, 8, and even 13 fetuses found in different females. Dr. Vernon Bailey's observations in Montana heading the list with 13 found in one female, June 18, 1895. In the Imperial Valley, Southern California, where muskrats have been introducted in a desert turned into an Eden by artificial irrigation, Dr. Jo- 


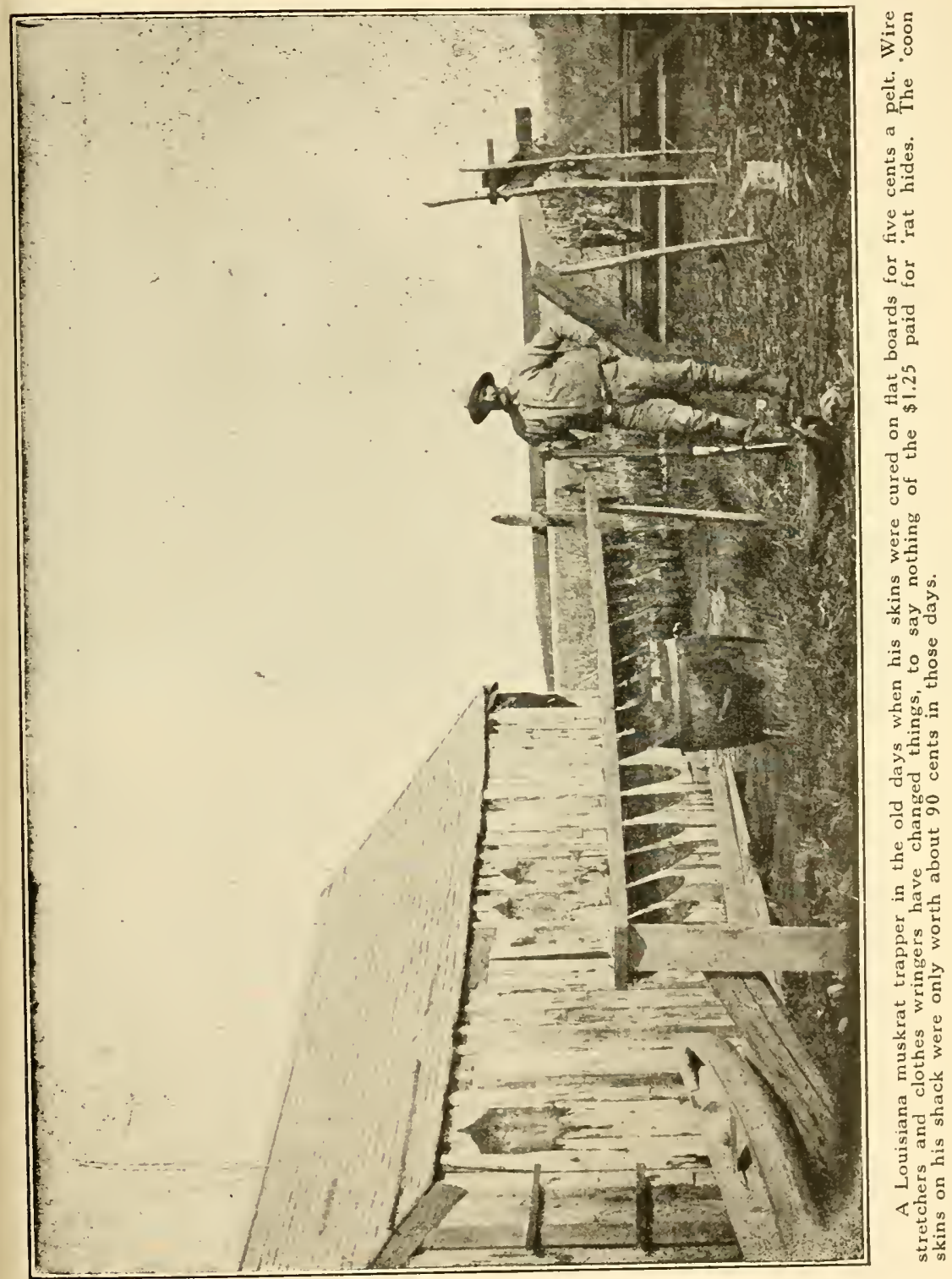




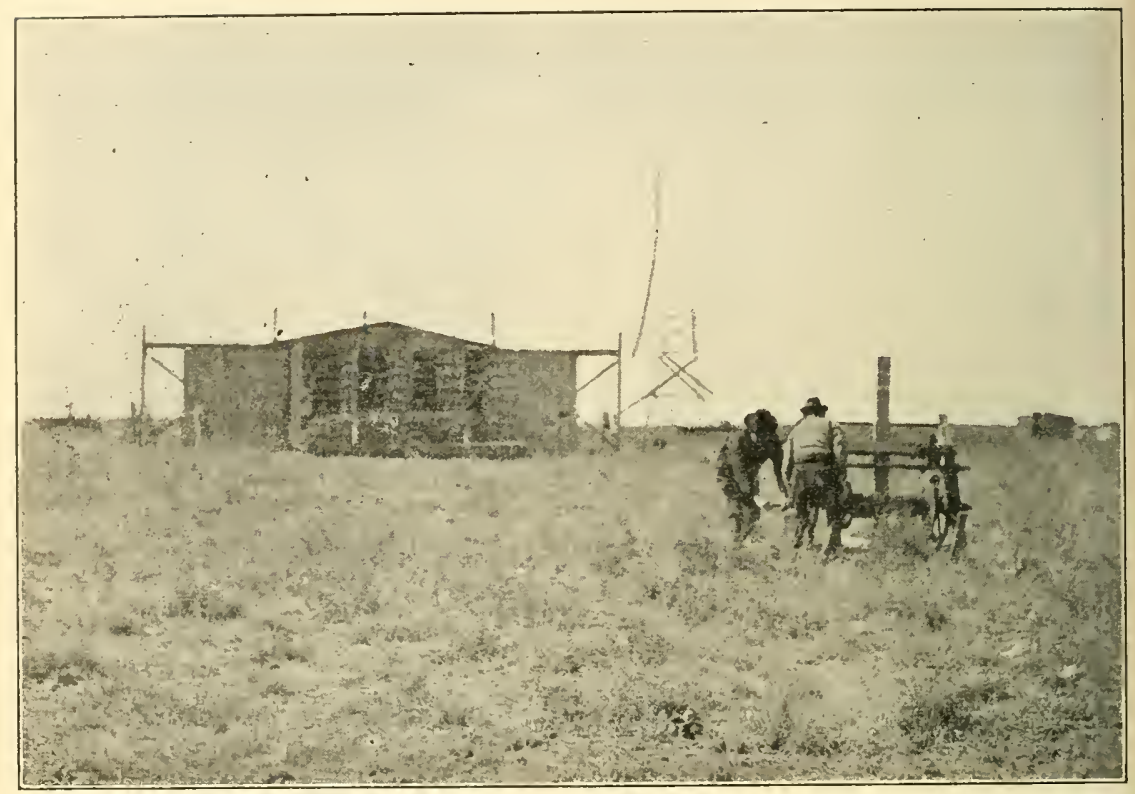

The big drying rack, which runs on rails, is worked in and out of the shed by a windlass and steel cables.

seph S. Dixon found that the average number of embryos in 23 pregnant females to have been 6 , with 3 and 9 as extremes. An exhibition female muskrat, shown by the Mount Forest Muskrat Farm, gave birth to a litter of 16 while in the Detroit offices of this concern, according to Mr. Bangs. The number of litters a season delivered by a female muskrat has aroused as much discussion and debate as has the question of the number of young to a litter David Lantz, of the Bureau of Biological Survey, in 1917, made the assertion that it was a "well-established fact" that muskrats breed from three to five times a year, but supplied no evidence to back the assertion. Other investigators and writers have made similar guesses and statements on this point, and their statements indicate a range from two litters a year to as many as eight. But still no uncontroverted evidence is at hand to prove this definitely -not even from Louisiana. 


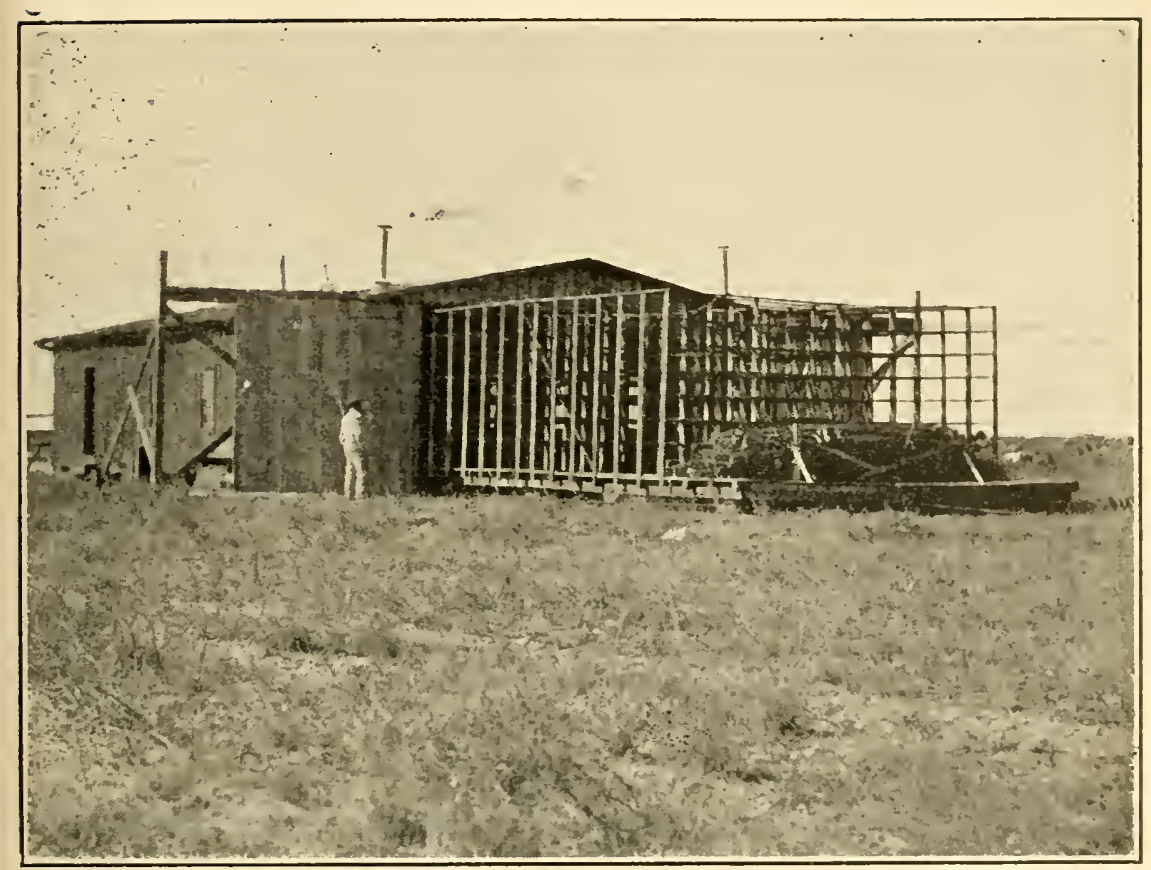

A drying rack on the Orange-Cameron Land Company's 'rat ranch in Cameron parish. This rack can cure 70,000 muskrat pelts at one loading. When the weather is right the whole rack can be windlassed into the open: when the weather is damp, it is run on tracks to the interior of the shed and curing is hastened by artificial heat. This large drying plant has been abandoned in favor of smaller units scattered over the marsh.

Professional-and, usually, unlettered-trappers are as divided on this point as are the savants and trained naturalists, so we must be content with the knowledge that muskrats are prolific breeders, else how are marshes, depleted year after year by vigorous trapping, replenished in population before the opening of another season?

Wherefore, this important matter must remain a question to be answered after 'rat ranching gets into full swing and opportunity has been given practical ranchers to solve not only this problem but to definitely ascertain whether or not the young of the first or spring litters themselves mate and reproduce by fall. 
It is believed that the muskrat in Louisiana has from three to five litters a year. It is known from our embryonic examinations that the females have from 1 to 7 young in a litter, with the average around 4 and 5 . It is known to be a prolific little animal, but just exactly how prolific is only hazard. It is known that certain marshlands that have been apparently "skinned" of their rat population one winter are thickly infested with them the next seasonprovided the muskrats are let alone during the close season. In other words they must not be molested for nine months of the year.

Their amazing multiplication is aided by the rapidity of the growth of the mice, as the baby muskrats are called, for they soon get into the "kit" class when they begin nibbling the grass roots and start shifting for themselves. This is, perhaps, the "dangerous age" for the muskrat family for the "kit" (abbreviation for "kitten") becomes the prey for other children of nature, such as hawks that fly by day, owls by night, and a host of other predacious creatures, such as mink, raccoons, alligators, gars and possibly other large fish.

When the young are born they are not naked, as a number of writers have stated, but are covered with a silken pelage, soft and with a beautiful sheen, giving a hint of the glory of fur and guard hairs to come. They are born with their eyes closed, however, and they remain "blind" for quite a period of time (another question yet to be definitely and positively decided). One did not open its eyes until it was 17 days old, and it was a day or two old, possible older, when it was removed from its birthplace on Marsh Island. This might have been due, it may be only fair to observe, to the fact that it was not fed on its mother's milk.

This period of blindness can be looked upon as a wise provision of nature, for it compels the "mouse" to stick close to home and mother, and not wander forth from the nest, which they will do when their eyes are opened. Young 


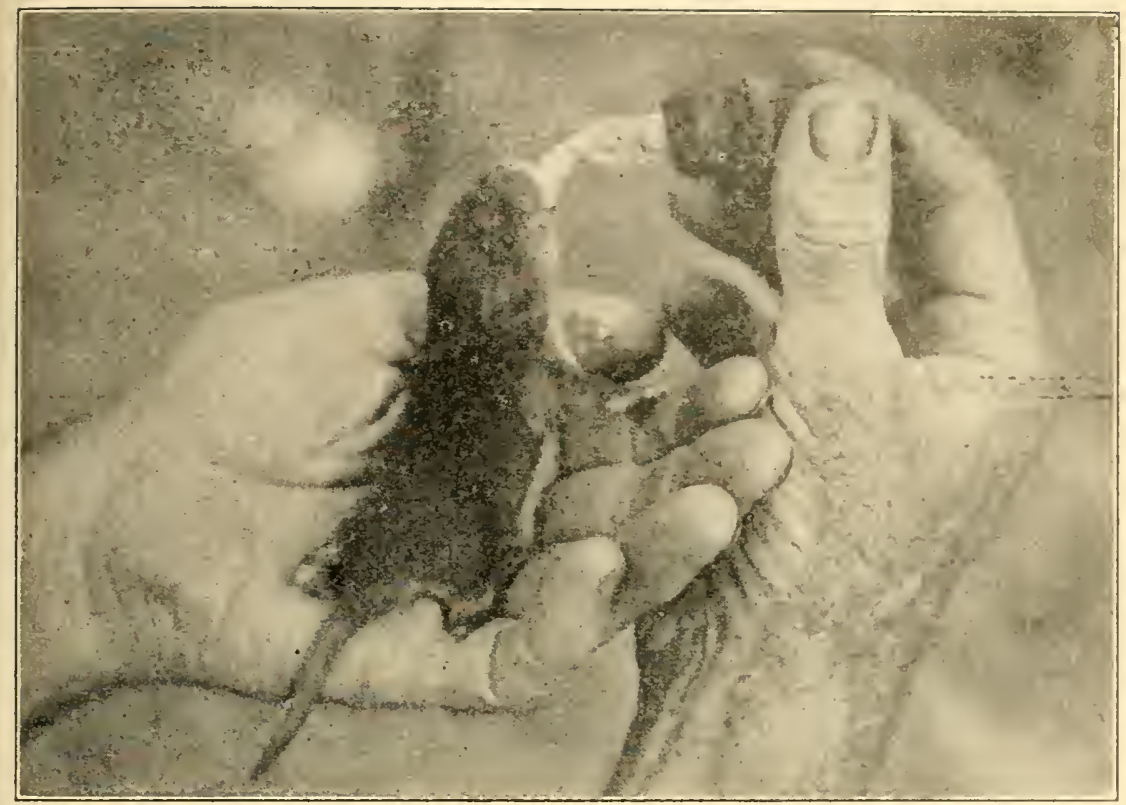

A fountain-pen ink dropper and some diluted pet cream came in handy in raising baby "musk-mice" by hand.

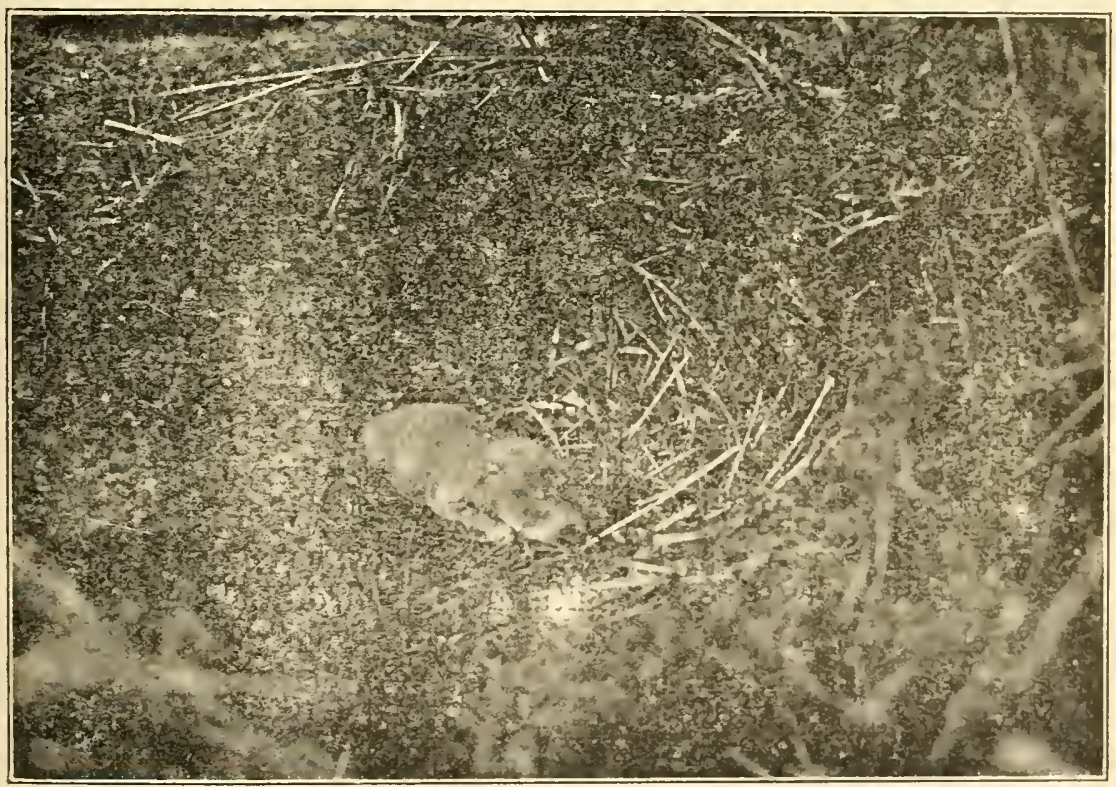

A few days old, its eyes not yet opened, but fully haired with fur that is to make it valuable in a few months. 
muskrats then become very active and make their way through the dive holes and out into the great outdoors to begin their battles of life.

The muskrat is the most prolific breeder that we have among the fur animals. Its rapid increase of numbers is due, perhaps, to the fact that the young of the first litter become sexually mature and mate before they experience their first winter. Some have set the sexual maturity as early as four months, but this, too, remains to be proved, and it seems only reasonable to presume that a muskrat must be six months old to properly function in this regard. Even though they do breed this early in life, it seems quite evident, from our researches, that muskrats do not physically mature or reach a real prime condition, as regards pelage, until they are at least a year old. Therefore, this is another reason for preferring the "ranching" method over the "farming" of them, for it will not be necessary to supply your farm stock with so much food and every expense saved adds just that much to your profits in the enterprise.

\section{INTRODUCTION OF MUSKRATS}

That muskrats can be introduced in localities where they have never existed before has been proved by the Imperial Valley project and the growth of the muskrat population there. In 1905, Dr. E. W. Nelson, former chief of the Bureau of Biological Survey, tells us that four Canadian muskrats were introduced on a nobleman's estate in Bohemia, a section of Germany. Since that time these animals have increased so rapidly that they have not only spread over a large part of Bohemia and into Bavaria and Saxony but into Austria and Moravia as well, and they have become such pests that measures have been prescribed against them by the Agricultural Council of Bohemia. A curious fact in connection with this introduction is that these Bohemia muskrats did not maintain the silky, fine fur of their Canadian ancestors, but developed a coarse, hairy pelage that made them unfit for the fur trade. 


\section{Foods}

The muskrat is mainly, and sometimes in certain localities, wholly a vegetarian. Its food consists of a considerable variety of plants, either growing in or about water. While it has been stated from time to time that this animai varies its normal vegetable diet with fish, clams, crayfish, mussels, eic., cur researches in Louisiana lead us to unhesitatingly declare it, like its cousin the beaver, lives, thrives and dies on plant life.

However, whether or not this mammal occasionally samples animal foods is not important to the 'rat rancher, for to successfully rear these fur animals for their pelts it will be necessary to stock the preserve with vegetable forage and that will be the cniy phase of the matter here considered.

An intensive study of the food problem in Louisiana listed the following items on the menu that nature provides the little fur animal with throughout the year in Louisiana, and the same or closely related species of plant life furnish sustenance for these animals elsewhere on the North American continent. While the cattail is the acknowledged "main" food of the muskrat in New England, Manitoba and elsewhere, in Louisiana the best 'rats are found, and most abundantly, where there is a heavy growth of what is known here as the three-square rush.

The list follows what is believed to be the important foods in the order in which they are named, and not only are "book names" of the plants given but their scientific designation as well, so as to make identification doubly certain. The "folk names" of these muskrat food plants are also included, those in italics being the usual French name applied by the average Acadian trapper to the plant, a few Spanish designations used by the Spanish-speaking trappers of the Delacroix Island section, and the others, in quotation marks, are lccal English terms. 

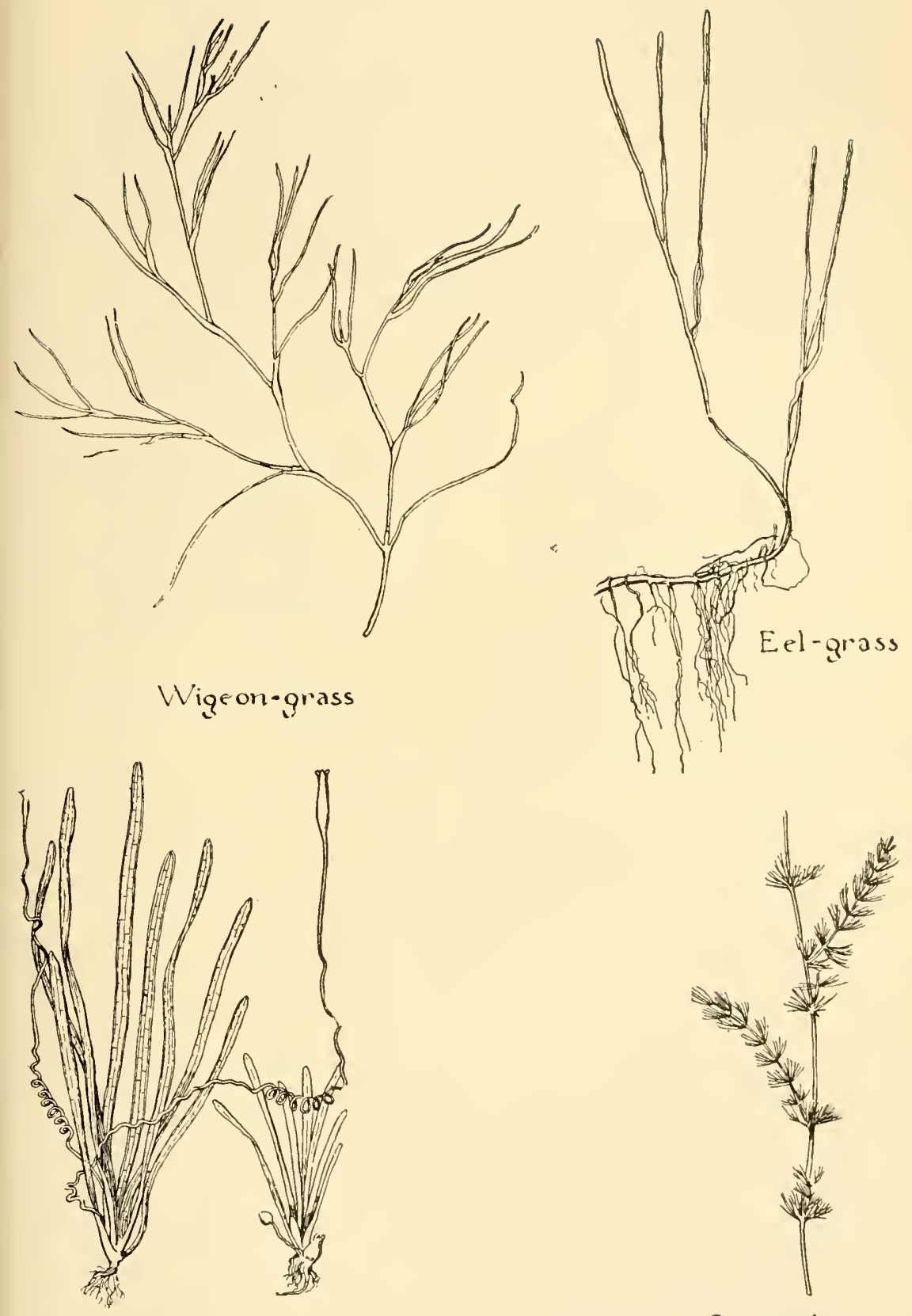

IVild celery

Coontail a diffuse form Muskrats are fond of varying thelr cliet with these plants. 
LeAFy Three-SQuare Club Rush (Scirpus robustus). "Three-cornered grass," "Leafy three-cornered grass," Paille des oie, Paille d'oie, "Goose grass," La canne trois-quarts, "Cocoa grass," "Sweet cocoa," Coco doux. Bayonet Three-Square Club Rush (Scripus olneyi). "Three-cornered grass," Paille des oie, Paille doie, "Bayonet grass," Le jonc trois-quarts, Yerba tres filos.

SAlt THREE-SQUARE Club Rush (Scirpus anericanus). Maritime three-cornered grass.

Giant Bulrush (Scirpus validus). "Bull whip," Jonc rond, "Buggy-whip."

CatTaIL (Typha angustifolia). "Flag grass," Jonc plat, Jone au baril.

Couch Grass (Spartina patents var. juncea). Paille fine, "Payfeen," "Hay grass," "Marsh grass," "Salt meadow grass," "Wire grass," "Needle giass," Seril'o, "Chorook grass."

MaRsh GRASS (Panicum virgatum and P. hemitomum). Paille fine, "Switch grass," "Meadow grass."

Quill Cane (Spartina glabra). "Mar'sh cane," "Hog cane," "Oyster grass," Cannes des cochon, Roseau des cochon, "Small rozo," Herb d'huitre.

NEEDLE GR^SS (Juncus rocmerianus). "Wildcat grass," Paille chat tigre, "Black grass."

Cut Grass (Oryza sativa). Jonc coupant.

Marsh CANE (Phragmites communis). Roseau, "Rozo," "Sea cane," "Small rozo," "Switch cane."

FEATHer Grass (Panicum virgatum). "Switch grass," Cannish, Paille jaune, "Coontail."

Wild DUCK Millat (Chinochloa walteri). "Jungle rice," "Wild rice," Riz de long.

Giant Foxtail (Chaetochloa). Jungle millet.

\section{RECOVERY OF MUSKRats AFter Storms}

It has long been a moot question as to the whys and wherefores of the sudden heavy population of muskrats in a certain area and the almost total absence of these animals in the same haunts the next year. Usually there is an explanation for such absences and shortages. Gulf hurricanes have been a decided factor in such matters, more so have droughts and their accompanying marsh fires.

What has been stated under "Periodic Fluctuations" applies in a general way to the problem, but it would seem best, for a fuller understanding of the matter, to set down 
The Fur Animals of Louisiana

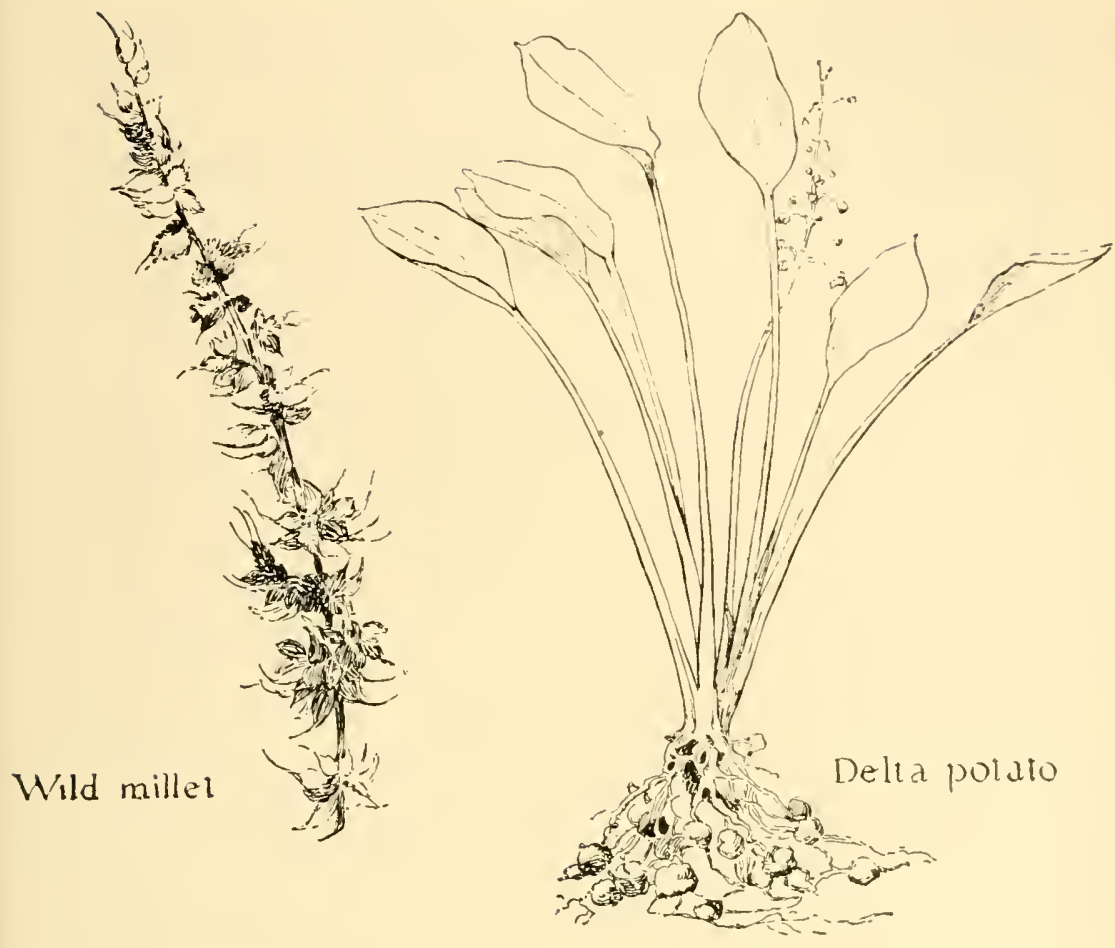

Duckineeds
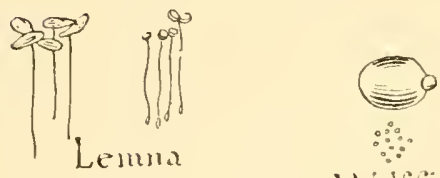

Wolfria

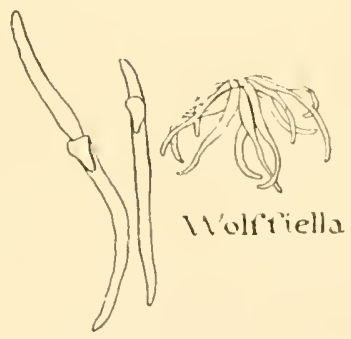

Some Louisiana marsh and water plants used frequently by muskrats for food. 
some known 'rat shortages from known causes, and indicate the length of recovery.

On Marsh Island, now a state wild life refuge, the trapping of muskrats has been an industry for many, many years, and the quality of the muskrat from this territory is so well known that a "Marsh Island 'rat" commands a better price in the fur trade both in Louisiana and in New York.

One sector of this island, consisting of 12,900 acres. was trapped by the Lovell Brother's and their first operation came during the winter of 1915-16. In August of 1915 the entire western Louisiana coast was swept by a gulf hurricane which did considerable damage to the :ity of Galveston and a wave of salt water was swept over Marsh Island, killing muskrats and other fur animals by the thousands. According to J. W. Lovell, there were very few muskrats in the sector apportioned him and his brothers the winter immediately after the hurricane swept the place, and their operations consisted mainly in trapping mink and raccoon, with 12 to 15 trappers working over the marshes and ridges.

When they resumed operations during the season of 1916-17 the Lovell Brothers noticed an increase in the muskrat population, in the low spots of their territory; however, they refrained from trapping them. The following winter of 1917-18 did not show as great an increase of muskrats as they had hoped for, this because of a summer drought in 1917, but they did trap lightly and caught what they considered a very good take, considering the drought and hurricane of two years before.

During the winter of 1918-19 they secured 507 muskrats along Oyster Bayou, but their main operations were for mink and 'coon, and they decided to allow muskrats to increase without molestation on other sections of their territory. The following year, 1919-20, they secured approximately 4,000 muskrats; in the $1920-21$ season the take jumped to nearly 7,000 muskrats; the 1921-22 season netted them about 12,000 'rats; in excess of 18,000 'rats were taken during 1922-23; and their traps delivered 
33,834 muskrats during the winter of $1923-24$, as well as 292 raccoons and 204 mink.

This does not indicate, fairly, the real increase of the muskrat on Marsh Island during the ten years intervening between the disastrous hurricane and the peak year of muskrat production, for the lands trapped by the Lovells does not come within the category of good 'rat land, for it is high and has always been more important for its raccoon and mink catches thereon. But it does show, in a startling manner, the come-back of this fur animal following an inundation when it was commonly prophesied that "every muskrat on the island had been 'drowned' by the salt water!"

It has been found, from reliable figures, that muskrats do build up their own population following a disaster. However, water, and too much of it, was not all the muskrats of Marsh Island had to contend with. The summer of 1924, the summer that followed the record catch of more than 33,000 muskats on the area we have under consideration, was particularly noteworthy for the record drought that occurred. The most prolonged that this section had been visited with for more than a score of years, records indicated, and as a consequence fires that started from other agencies than that of man swept the marshland of the coastal parishes and Marsh Island was not excepted. This lack of water, with the fire and smoke, and drying up of vegetation, was responsible for a marked falling off in the muskrat population, as will be easily discerned by the following figures:

The total take of Marsh Island for 1923-24 was 336535 muskrats, and with 33,824 taken on the Lovell tract. For the trapping season that followed the drought summer of 1924 , the total island talie fell to 184,546 muskrats, while the Lovell trapper's secured only 9,034 of these animals, and the season following, which was preceded by a summer drought in 1925 , the total catch for Marsh Island fell to 48,376 muskrats.

According to J. W. Lovell, the conditions on the area he trapped presented the same aspects in 1926 as they did 
in 1915 immediately following the Gulf hurricane damage, and, judging the future by the past, it seems safe to presume that with a return to normal summer rainfall, which has been the rule since the dry summers of 1924-25-26, that within three years' time the population of muskrats will be back to near normal at least.

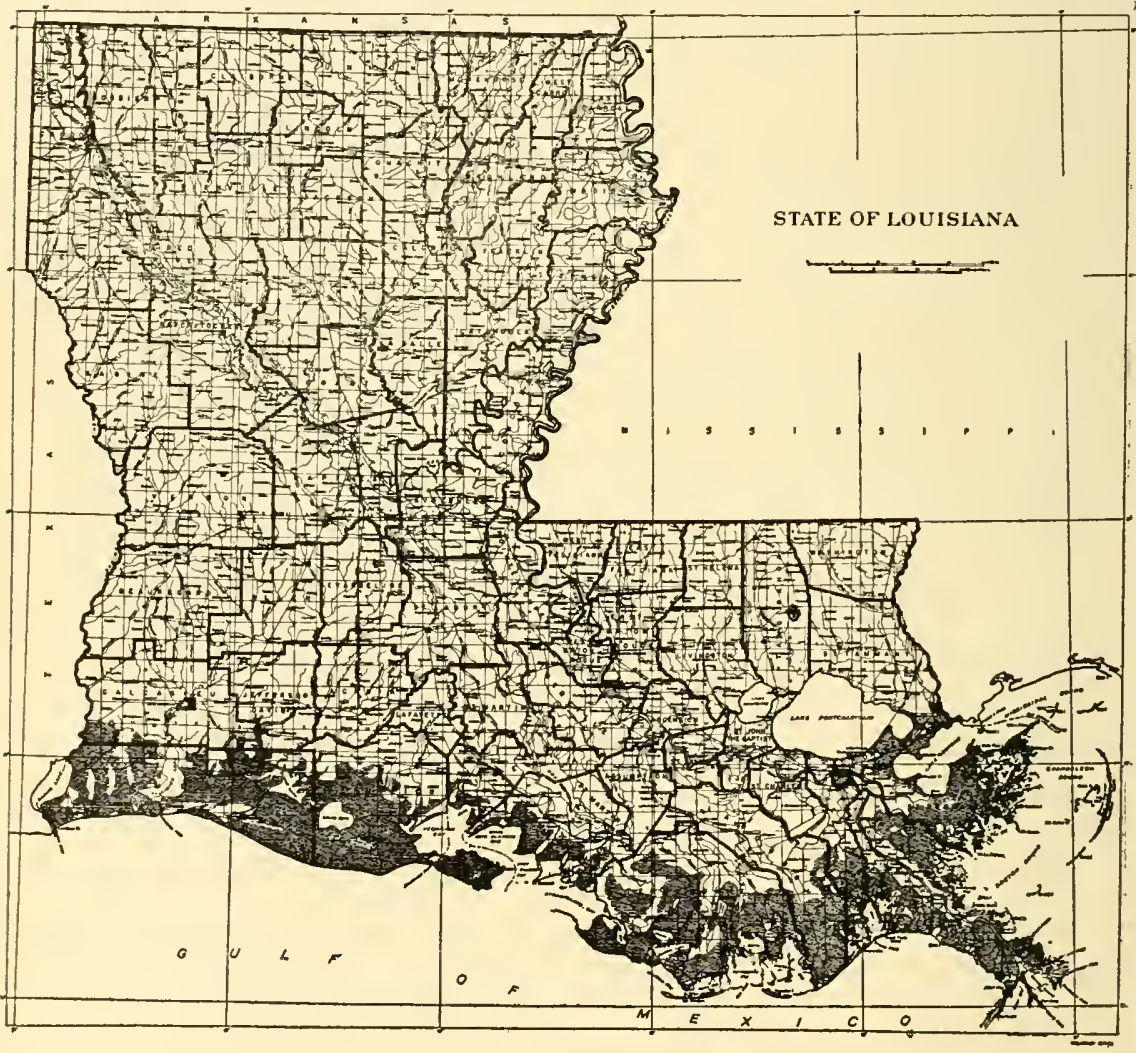

The shaded areas along the Gulf of Mexico show the location of coastal marshes where rat ranching is being practiced on large areas by big trapping concerns. 


\section{CHAPTER TWENTY-THREE}

\section{FUR FARMING OF MUSKRATS}

W

HAT is claimed by some national fur farm publications of this country as "undoubtedly the largest individual muskrat farming concern in the world" is the Mount Forest Fur Farm, located at Mount Forest, Michigan, with offices in Detroit. This concern has al o purc'rased large areas of Louisiana marshland for 'rat ranching. The general manager and originator of this fur farm, Milton S. Bangs, has furnished the data that follows regarding the methods practiced in the pen raising of muskrats on a purely commercial basis at his establishment. A personal visit made by the author to this fur farm in May, 1928, indicated that this concern does all its officers claim for it.

The breeding enclosures now functioning at the Mount Forest Farm prove to be a marked and radical departure from any other enclosure that has been used for fur farming, and it seems best, therefore, to recite the different retaining pens tried and rejected for what was considered by Mr. Bangs and his partner and farm manager, Donald Campbell, as the ultimate and most efficacious for the purposes of their business.

\section{The Mount Forest Fur Farm Methods}

"Our first enclosures were of ordinary wire mesh," explained Mr. Bangs, "but we found that the muskrats, animated by their instinct for the wilds, would continually endeavor to get out of the pens, and through their ceaseless wanderings up and down the wire sides of the pens would scratch their noses and bodies and wear them sore. These wounds became infected and we were constantly cleaning the abrasions with antiseptics and painting them with a preparation known to all druggists as 'new skin,' something all fur farmers should keep on their place.

"This constant attempt to force themselves through the wires of the cages was not only of serious consequence to 
our breeding stock but proved a great nuisance and unnecessary care to those intrusted with the well-being of these animals. However, this is not the only disadvantage we northern breeders found with wire-covered cages-in winter the snow would pile high over the dens, within the pens, covering the food and otherwise proving fatal to our muskrats.

"We tried wire cloth also, but even this fine-meshed wire did not give us what we wanted, consequently $\mathrm{Mr}$. Campbell discarded the wire pens altogether and constructed galvanized iron pens, open at the top save when they are covered during inclement weather, and we found we had solved our problem. Although I realize that you have very long and hot summers in Louisiana, I am quite confident that the galvanized pens will prove the efficacious -provided they are shaded during the middle of the day.

\section{Iron Breeding Pens}

"These galvanized iron pens measure exactly eight feet long, four feet high, and three feet wide. The flooring is also of galvanized iron, a commercial sheet of No. 20 gauge $4 \times 8$ fect being utilized for this purpose. Therefore, each pen will need one $4 \times 8$ and four sheets of $3 \times 8$ iron sheets. the bottom utilizing the large sheet, while the sides use two of the remaining three sheets, the third being cut in half to make the two end pieces.

"Such pens are smooth and free of all obstacles. The sides are too high for them to jump out and we do not place dens, boxes, or other structure on the inside. Such a pen described is suitable for ten families, for we never allow our bucks to remain with the females any longer than is necessary to insure breeding. During the heat of the summer cays or during rain and snow in winter we cover our pens with wooden tops with a small opening left at one end for air.

"When we constructed our first pens of galvanized iron we placed huts on the inside and covered them with sod; later we changed to another type of box, and still another type of den architecture was designed, but later discarded. 
We found that to successfully raise muskrats in pens that wooden dens were not at all necessary, and all we do at Mount Forest is to throw heaps of wet marsh grass in one end of the pen, which is raised several inches above the other end to keep all drainage at the end opposite the nest, and in this grass heap, or house, or hill, or whatever you may want to call it, the females in the pen construct their nest, just as they would do in the wild state-as a matter of fact, we find that the closer we keep to nature in our fur farming the more successful we are in results.

\section{MATing MeThods}

"Our method of mating, I believe, is radically different than has been practiced on other like institutions but which is now being adopted by many others. As has been stated, we keep ten females in our breeding pens. We begin our breeding operations in Michigan as early as possible and about the middle of February, in the morning, we introduce a male in the pen with the females. He immediately serves all ten of them but is allowed to remain with his new companions until the next morning, when he is removed to another pen to perform the same duties. In the first pen another male is introduced and kept there for twenty-four hours, another and another until four males have served the females. This is done to insure breeding taking place and each of the ten females served.

"The males are kept on their course of visiting all of the pens and, of course, only selected and hardy bucks are thus used, in addition to their selection for fur and color of fur. I believe that this is one of our trade secrets which has made our concern as successful as it has proved to be, and, naturally, I recommend it to all breeders of muskrats. After our study 'rats have performed their duties they are returned to what we term the 'bull pen,' where they feed, loaf and await their summons for the next breeding service.

\section{Gestation Periods}

"We have conclusively proved that the period of gestation of our farm-bred muskrats is from 19 to 21 days. As 
may be surmised, we have had exceptional opportunities to note this matter. The exact period of gestation of the muskrat seems to have led to a great deal of surmising and dispute, especially as to the muskrats of the wilds. We have also proved, in our pen breeding, that the young from the first spring litter will themselves reproduce before winter, but the female will not produce as many young in her litter as will a more mature muskrat.

"After our ten females have dropped their litters and the young are from two weeks to eighteen days old, we follow the same procedure just described with the breeding duties, four bucks for one day each serving the females. During our 1926 season we secured four litters of young in the manner just described and the production averaged thirty-four to a breeding female. An average litter from an adult breeding female being ten young.

\section{No SWIMMING WATER}

"While our pens have been described in detail it may be well to say something on. what we consider as one of the greatest problems in muskrat farming-that of water. In our early days we used, as do many breeders today, a receptacle about the size of a bread pan and changed the water twice a day. Being very nocturnal, the muskrats appeared very little during the day and confined their activities in the pens to the darkness, just as they do in the wilds. In the mornings we would find the watering pans filled with refuse, food, excrement and other filth, rendering the water unfit for drinking. Fearful of the health of our breeders, we changed the water frequently, put chemicals in it in an effort to neutralize the effects of the droppings and other undesirable matter from off the fur and feet, when the animals would swim in the pans, but the labor of changing water in several thousand pans is a considerable item when operating on a commercial basis, and we were forced to revolutionize the watering problem.

"Our ranch manager, Don Campbell, adapted the ordinary fountain water pan so used by poultry breeders for 
our muskrats. The fountain is filled by turning it upside down and, when inverted, only water enough to fill a small trough is allowed to fall from the supply. The fountain is hung just high enough for the muskrats to reach and drink from the trough, but adjusted carefully so they cannot get in it and dirty the water.

"Swimming water? We have none, as we have found that 'dry farming' is perfectly feasible and has allowed us to overcome, in our estimation, the last great obstacle in pen raising muskrats."

\section{The Sexing Box}

On the Mount Forest Fur Farm a number of innovations designed by Mr. Campbell, many of which have been adopted and adapted by other breeding concerns, were seen and examined. One of the most noteworthy inventions for the practical muskrat breeders has been Donald Campbell's "sexing box." Having learned from experience, and scarred fingers, the difficulty in accurately determining the sex of a mature 'rat, it became necessary to design some sort of a mechanical contrivance to prevent these animals from sinking their long incisors in his fingers when making an examination of this character. The muskrat is vicious and especially hard to hold when searching out the reproduction organs, and cannot be handled, even with gloves, without bloodshed on the part of the handler. To have a bloodless examination, he constructed a cone-shaped wooden funnel, larger at one end than at the other. Picking a muskrat up by the tail and dropping it head down into the large end of the funnel, he found its parts could be examined without injury either to the subject or the handler. This same idea has been incorporated in a galvanized ir. funnel, equipped with clips and put on the market in a commercial form and under the name of "Nobite" by an Indiana firm, but which was first the author of this bulletin cannot say.

The illustrations show the general form of this very excellent contrivance, which can be constructed by a muskrat breeder at a slight cost and which should be on every fur farmer's place. See page 230 . 


\section{FEEDING THE BREEDERS}

According to $\mathrm{Mr}$. Bangs, the principal food given breeding stock at Mount Forest is "marsh grass" throughout the summer and fall, and during the winter carrots, corn and mash is fed, with a sprinkling of oats. In the spring corn, beets and dried carrots are given the penned animals. Dry corn kernels, off of the cob, are also kept before the breeding muskrats. Feeding costs were not furnished, as the Mount Forest people contract a year in advance with farmers adjacent to their field of operations for the grown feed at so much a ton, and their feeding costs are very low as a result.

"One of the greatest mistakes of the muskrat breeder who raises his animals in pens is that of over-feeding," $\mathrm{Mr}$. Bangs claims. "We have ascertained that muskrats are naturally small eaters, although, like dogs and other animals, they will eat as much as they can if food is constantly at hand. We have also found out that fat muskrats will not breed and drop young any more than will fat foxes or any other animals."

It is claimed by these fur raisers that curiosity of the owner and help has been a contributing factor to many failures experienced by amateur muskrat pen breeders. The Mount Forest experience is that when a nesting heap is opened to see if young are getting along, the disturbance is resented by mothers, so much so at times that they kill their young, and the expert advice they give is "the less attention you give breeding muskrats the greater your production will be."

\section{HANDLING AND SHIPPING}

The handling and shipping of muskrats has, on a commercial farm of the Mount Forest Company's proportions, received considerable and close attention. Mr. Bangs has explained in detail the manner in which they handle their live stock, and it is incorporated here as a piece of very excellent advice to be followed.

"We do not handle our muskrats any more than is absolutely necessary, but when we do we endeavor to handle 


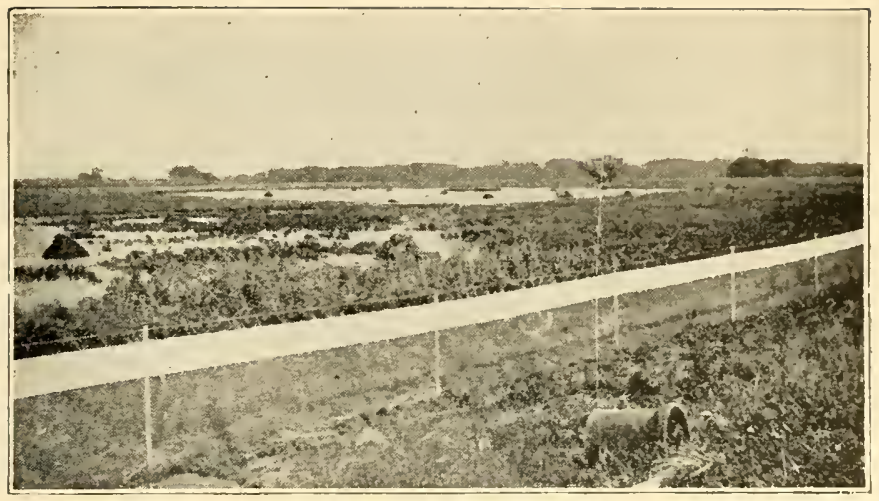

Cood example of well-fenced muskrat marsh according to the Crown method.

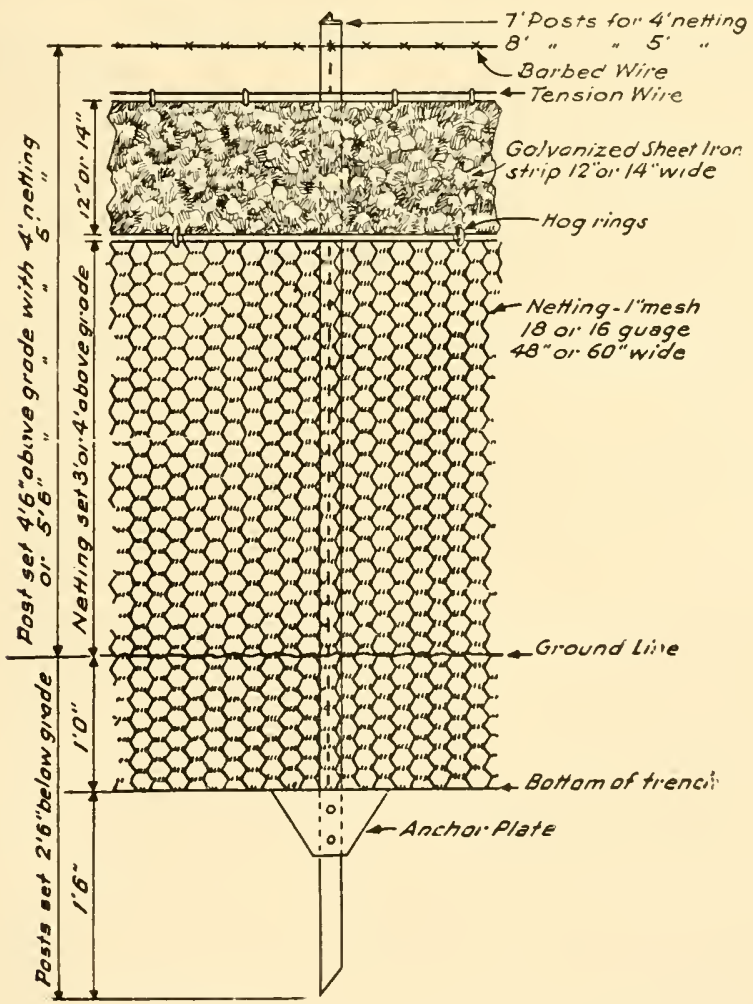

Fence specifications for muskrat farms as worked out by the Crown lron Works Company of Minneapolis, Minn. The galvanized sheet-iros strip used at the top of the fence is useful only in keeping muskrats from climbing out but to keep minks and other predatory animals from climbing in. This company has specialized in fence and pen building material for fur farming purposes and issue helpful circulars on the subject. 
them in a manner that will work a minimum of harm to them and to ourselves. We found in the early days of our business that frequently the muskrat when handling them by the approved manner-that is, by the tail-the animal would turn, and, if I may use the expression, climb up its tail and bite the hand holding it. To prevent this injury we found that by slightly and quickly dropping the rat, still holding fast to the tail, however, it would in turn drop its body and head, an instinctive movement to ease the fall to the ground which it instinctively expected. If it again turns and attempts to repeat the climbing process, go through the same dropping movements.

"In first laying hands on a muskrat one should first shoulder the animal, laying one hand flat on its back just over the forelegs, holding it to the ground so it cannot turn on you, and with the other hand obtain a firm grasp on the tail and then gently lift it in the air. Rough handling of these animals, by the tail or otherwise, is often the cause of death. If we were grabbed by our leg and swung around, our spine would be strained, and the same thing happens to a muskrat if it is handled in a clumsy, awkward manner, and these animals have very weak spines."

The shipping of muskrats calls for care and intelligence, these same fur farmers have ascertained, and have adopted what they call a standard shipping crate. At first wooden crates were used, but, as they had to be built of heavy material, the shipping costs were in excess of what they should be for practical commercial purposes. The crates now used are light and very durable, and are built of wood and wire cloth. They are 40 inches long, 24 inches wide, 8 inches deep, and have 10 compartments. The whole crate holds 10 muskrats and has a shipping weight of about 12 pounds. The crates are made with four wooden partitions running across the width, and the individual compartments are made by having a division of wire cloth in each so as to make two tiers of five compartments, each with a separate door on the top.

Considerable space has been given the matter of commercially raising muskrats in pens in this bulletin, as it is 
recognized that this is a phase of the fur business that has not been followed to any extent in Louisiana and it appears that there is a fertile field here for such experimentation, if not the establishment of commercial farms on a parity with those already in business in the north and east. What has been done by the Mount Forest Fur Farm has been detailed because of the position this concern holds, and its executives have been very obliging and free with a number of matters of their business that are usually religiously guarded as "trade secrets."

\section{PEN BREEDING}

Very little experimentation has been done in Louisiana with the breeding of muskrats in pens; in this regard we are far behind states in the north and in many localities in Canada. For this reason we are very deficient in the knowledge we should have of this chief fur producer. Today, however, there is a pronounced awakening of the value of such experiments and many projects are under way to build up a breeding stock of Louisiana muskrats for sale.

E. A. Arpin, of Gueydan, Vermilion parish, has been experimenting with these animals in pens for some time, but he had his first success in having the animals breed in captivity in the early summer of 1928 . He reports that he has fourteen pairs of Louisiana muskrats and one pair of Colorado 'rats in captivity.

In his experiments Mr. Arpin has followed the pair mating system and has not experimented with polygamous breeding. According to his method, he believes he will be better able to build up his strain "by taking only the best and breeding them to the best of the opposite strain. I this way the poor breeder's can be more quickly eliminated."

His females dropped their young during the latter part of April and the first of May, when the animals were paired he did not state, with the following results:

Female, about 6 or 7 months old....... young Female, young ............... 4 young Female, young ............. y young

Female, old ............... y young

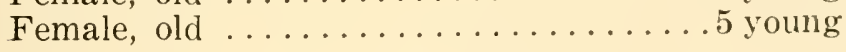


When the litter's were dropped $\mathrm{Mr}$. Arpin did not examine the young as to sex, believing that it would not be good practice to handle the animals, stating: "I know of severa! men who have been unsuccessful in raising muskrats in confinement and, after inquiring into their methods, I found that they invariably had the habit of handling their 'rats to make them tame. This, I believe, was the main cause of their failures. I have, therefore, made it a rule not to handle the 'rats or disturb them any more than is absolutel.' nec essary.

"I feed my animals in tin pans and give them mainly col'n chops and rolled oats. For green food I give them clover. caitarls and water lilies. Every afternoon I give them fresh water and food. In addition to the water pans I supply each coop with a box akout 8 inches high in which I keep fresh water and mud. This gives them a place to play in and tends to keep their drinking water cleaner.

"I notice that in the open type of coop I am using now the 'rats are gradually becoming accustomed to having people about. I have one pair with four young that will come out at feeding time and eat while I am standing close by, but this is true of this one pair only. Some of the others will come out soon after feed is placed in their coops, but will run back in their dens when I approach too close to the pen." 


\section{CHAPTER TWENTY-FOUR}

\section{TRAPPING METHODS}

7 RAPPING in Louisiana is not the highly specialized profession, if the word may be used, it is elsewhere in North America and where the fur is less plentiful. The taking of the fur animals, esspecially the muskrat, is almost a matter of luck, and Vernon Bailey cannot be censured for claiming that the trapping methods in use here are "crude and wasteful of the fur crop, as well as the time and energy of the trappers."

When Mr. Bailey first explored our muskrat marshes he found the traps most generally in use where the Gibto "two-tigger traps," which catch and hold or kill the animal by having the third jaw fly over and strike the body of the animal after the smaller jaws had caught and held it by one foot.

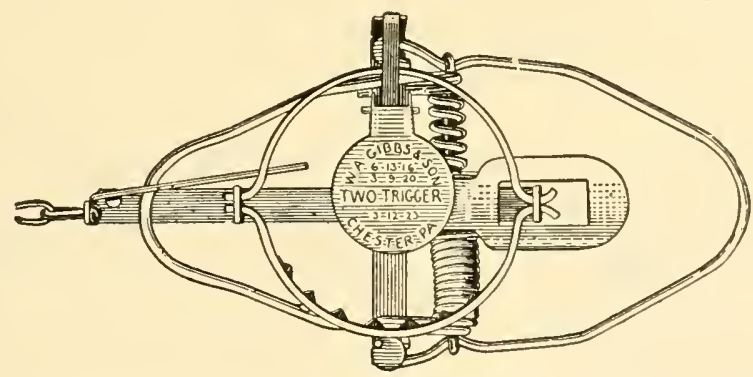

This is the Cibbs "two trigger" trap that catches the animal over the body as well as holding it fast by the leg.

The Gibbs traps have been very popular with the muskrat trappers. Many, however, still prefer the Victor traps, which have done duty in the marshes for generations, and the Nos. 0,1 , and 2 are preferred.

The question of traps is sure to bring up heated arguments on the marsh. Many of the veteran trappers claim that the use of the two-trigger Gibbs trap has been the cause of the present decrease in the Louisiana muskrat population. Other trappers, just as experienced and adept 
in catching the muskrat, heatedly deny that this is so and claim that the "two-trigger trap" catches and holds the animal; therefore, "wring-offs" (when the animal amputates its foot and thus frees itself from the trap) are prevented and the trapper collects the pelt and not the toes of the animal.

The Victor champion counters with the declaration that when the two-trigger bar strikes the muskrat it kills the animal and when it is dead the owls, hawks, grackles and other birds and mammals feed on it, cutting its pelt, and that the trapper collects, and skins out, a "damaged" instead of a top 'rat. There seems to be no end or settlement to the argument, for the trappers continue to buy and use both brands to the exclusion of all other makes.

The Victor line of traps, made by the Animal Trap Co., of Lititz, Penn., have been the veterans in the field, and probably the larger No. 2 trap is more generally used, so that the animal's leg is caught high up where the muscles are heavier and there is less danger of the leg being twisted, the bone broken, or the bruised flesh severed by the strong incisor teeth of the captive.

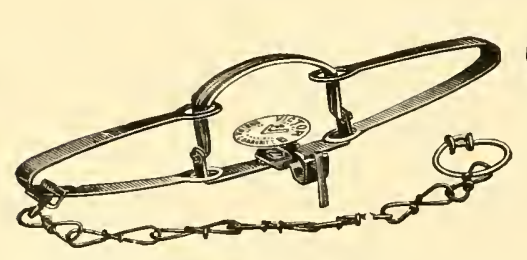

The larger sized, double spring Victors are used to take the larger fur animals, lynx, otter, wolf, etc.

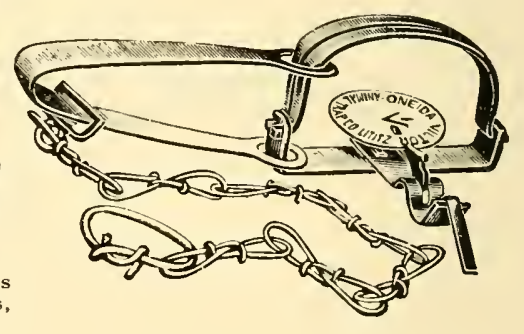

We have found that even in these large traps the feet and leg bones are frequently broken and that the muskrats twist free, either to die of their injuries or to recover as. cripples. In attempting to keep for study animals so taken in two-jawed steel traps, we found it difficult, even with care and antiseptics, to keep them alive, and about $50 \%$ of those thus secured died and the remaining cripples would not breed. 
It would appear that the regular two-jawed trap catches more adults and less mice and kits than the two-trigger trap. This conclusion seems to be borne out by reports from trapping camps where the kit percentage is high coincident with the use of the trap with the killer bar.

"Better traps than any in present use are greatly needed in the muskrat industry, traps that will catch and instantly kill the animals or take them alive, so the valueless young, the unprime and a large percentage of the females can be released unharmed," insists Vernon Bailey, who put his ingenious mind to work while in Louisiana to devise a surefire, "catch-alive" muskrat trap which will be described later.

As W. A. Gibbs, of Chester, Pa., has invented a line of fur animal traps that have differed markedly from the usual forms that have been used for hundreds of years, and as these traps have become so popular in the Louisiana marshes, the inventor was asked to describe his different traps and their use. His "live trap" has been used with some success in our experiments in taking muskrats alive for study and breeding, and they were also used in the Delacroix Island section when a restoration movement was undertaken following the crevasse of 1927. While the Gibbs "live trap" is far from being 100 per cent perfect, it did catch the animals alive and unhurt, and in greater numbers than did any of the other traps experimented with.

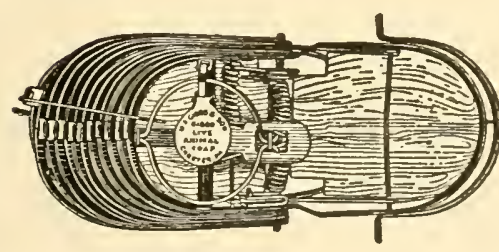

Gibbs Live Trap in set position.

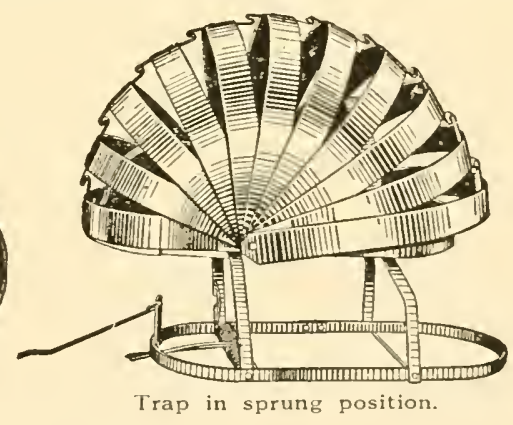

Mr. Gibbs' "no kit" trap, as I dubbed it following experiments with models on the Louisiana marshes, and which he calls his "adult muskrat trap," has in my estima- 


\section{tion the greatest promise of any trap we have yet experi- mented with. The inventor has not placed it on the market in quantities as this is being written, but it would appear if this trap is developed and extensively used, that the problem of how not to catch the mice and kits, but take only the big ones, has been solved. Mr. Gibbs describes his dif- ferent traps as follows:}

The Gibbs "two-trigger" trap was produced for the purpose of stopping the loss by "wringing off" of such animals as mink, muskrat, etc., which has always been common in the type of traps commonly known as steel traps. "Wringing off" is an expression used by trappers in connection with having reference to the amputation of a leg or part of an animal gripped in the jaws of a steel trap. Various trappers have different ideas as to the manner in which an animal accomplishes this result. Some think the animals themselves chew their legs off, while others believe that in struggling in the trap the animal breaks the leg bone and finally severs the skin and ligaments, freeing itself from the trap. Personally, in the case of muskrats, I am positive that this latter is true. Muskrats do not bite themselves under any circumstances or conditions intentionally. They do, however, sometimes cut themselves in striking at a trap that is holding them.

[I differ with Mr. Gibbs in his positive statement that muskrats do not bite themselves free of a trap after the leg is broken.-S. C. A.]

“This loss from 'wringing offs' varies in different localities and under different situations. I found, myself, that in my own marsh it amounted to $28 \frac{1}{2}$ animals in a hundred, and I believe that in Louisiana it must have amounted close to if, not, $50 \%$, and $I$ have been told by various trappers there that it did.

"In addition to saving for the trappers and fur industry the animals that have previously' escaped as above, the 'two-trigger' trap kills most of these animals caught in it quickly, and is, therefore, in a measure humane. It also holds the animals so that they do not cut down the grass and vegetation in the vicinity where the trap is set, and this, coupled with the fact that the animals are quickly killed, makes it more difficult for birds of prey to see them, and, consequently, saves a great deal of damage to pelts from such birds. The surroundings of the place where the trap is set not having been disturbed, the trapper can reset the trap in the same place, making it easier for him to conduct his operations." [Mr. Gibbs and I differ here, too. Our investigations have proved that birds damaging the muskrat pelts only attack dead animals-never the live ones.-S. C. A.]

"There is a wide difference of opinion expressed as to the number of muskrats that recover after having escaped from a trap through the amputation of a leg, but I do not believe that any one who has really paid close attention to the condition of the animals after they do escape, and to the number of animals taken in a succeeding season that have recovered, against those that escaped in the preceding season, would hesitate in the least to state positively that the number is exceedingly small. In my marsh, where I have trapped the same territory year after year and kept records, in one season before I had perfected the 'two-trigger' trap I had 272 wring offs. The next season I caught five animals that had wrung off in the preceding or previous seasons and had recovered. Personally, I do not believe that more 
than $2 \%$ of them lecover." [Unquestionably a correct statement as far as the Louisiana marshes are concerned.-S. C. A.]

"My 'single-grip' traps are, in so far as their accomplishment is concerned, exactly similar to ordinary steel traps. Their only supeeriority over the leaf spring type of traps is that by the use of coil springs, spring breakage (which varies in different localities, but in Louisiana would amount to at least $25 \%$ ) is eliminated. These traps are, however, smaller, easier to set, more flexible and stronger than the ordinary luaf spring traps now on the market.

"The 'adult 'rat' trap. While I do not care to say too much about this trap until it has been proved to those interested that it is what I claim it to be, I believe that everyone will appreciate its value to the marsh owners, trappers, State of Louisiana, if it accomplishes the work which I have developed it to do-namely, to catch only animals of a size large enough to have a worthwhile value to their pelts, and to not catch or injure the very small 'rats which are worthless from a marketable standpoint. This, it seems to me, will take care of the problem of always leaving enough breeding stock in the Louisiana marshes to insure a full crop of 'rats the following season, and if it works out successfully there can be no doubt but that it will be worth millions of dollars annually to the fur industry in that State.

"From my observation when out with trappers in the Louisiana marshes, from $15 \%$ to $30 \%$ of the animals that were being caught had absolutely no commercial value, and if these could have been left in the marshes until the following season, not only would their own value have been saved but by the next season each one of them would have multiplied perhaps by ten.

"My 'live trap' is, of course, a specialty, and its use in its present form will probably be confined to experimental purposes and for use where it is desired to secure animals for sale alive as breeders or for restocking areas for the purpose of muskrat farming.

"My experience in not being able to catch muskrats when I was in Louisiana in July is exactly similar to experiences that I have had in the Maryland marshes. I told the trappers whose marshes I visited that I did not believe we would have any success, but they were so positive in their assurances that I was desirous of making the trips for the purpose of seeing whether there was, perhaps, a difference there as compared to conditions that I was used to, but I found that there was not, and the trappers themselves agreed with me that it is next to impossible to trap animals successfully in such extremely hot weather."

"The humane game trap. There is at the present time a great deal of agitation throughout the country in comnection with the eruelty of the common steel trap, and the development of a humane game trap. We have developed a humane game trap which is safe, practical, adaptable, and cheap; as a matter of fact, it is exactly the same as the steel traps now in use with the exception that it has attached to it an absolutely sealed receptacle which is filled with calcium cyanide, and an animal that is caught in the trap is quickly relieved of its pain and suffering when it bites into the container and applies the effect of the contents to itself.

"While the animals that it is desired to trap will, without exception, bite the containers, this form of trap has the distinct advantage that domestic animals and cattle will not, and it also has the further commendable feature that, upon exposure to the air, the poison gas in the calcium cyanide passes off quiclily and nothing is left that is dangerous. No animal except the one actually trapped will, or can, be affected by the use of the poison in this manner, and it will be 

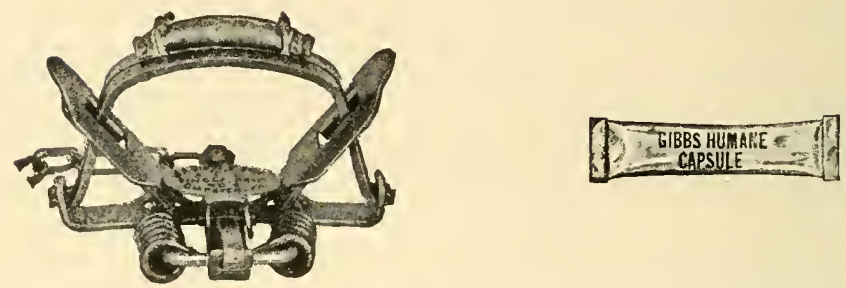

The Gibbs Humane trap is on the left and on the right is the poison capsule which is attached to the jaws of the trap. When the jaws of the trap close on an animal's leg the captive bites at the trap, breaks the capsule and is instantly killed.

noticed that we do not take the animal by the use of poison; we take it with the trap and kill it quickly to relieve its sufferings, with the poison.

"While it will be necessary for the trapper to renew the poison charge after each animal is caught, his saving in the animals that would otherwise escape will make the use of this trap a profitable one for him, instead of an additional expense."

\section{Trapping Muskrats Alive}

The importance of being able to catch muskrats alive for study of habits and eventually for restocking marshes and for selecting fur and breeding animals has been given much thought, but not much has been accomplished.

Vernon Bailey devised a trap, which is shown in the illustrations on the opposite page, but it did not work out as successfully as we hoped it would, having drawbacks noticed in the Gibbs live trap. Metal, it appears, is very objectionable to muskrats, especially in cold weather, and they will not walk on it. Both the Bailey and the Gibbs traps had metal floors. In many of the marshes the water levels are affected by the tide and in both these traps many drowned 'rats are recovered after they have been successfully taken by the action of the trap.

Experiments have been made with a number of manufactured "live traps" but with little or no success. The Crown galvanized box trap will undoubtedly catch and hold a muskrat-if one will go in the trap!-none have been enticed into the contraption yet. Ordinary wooden box traps, barrel traps, and all the old stand-bys of muskrat literature, especially those found in government bulletins, have been tried and found wanting. 


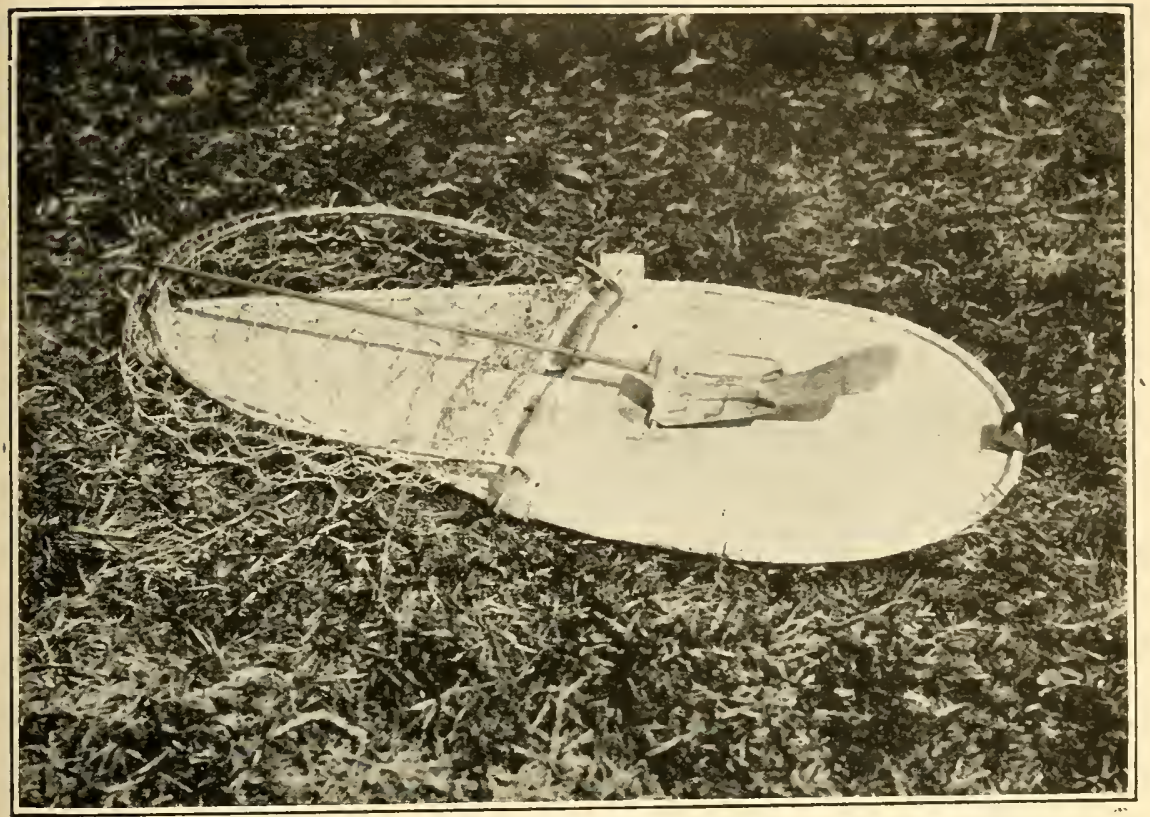

A "catch em alive and unhurt" trap for muskrats invented by Dr. Vernon Bailey, of the U. S. B:ological Survey, which was tried out in our muskrat investigations.

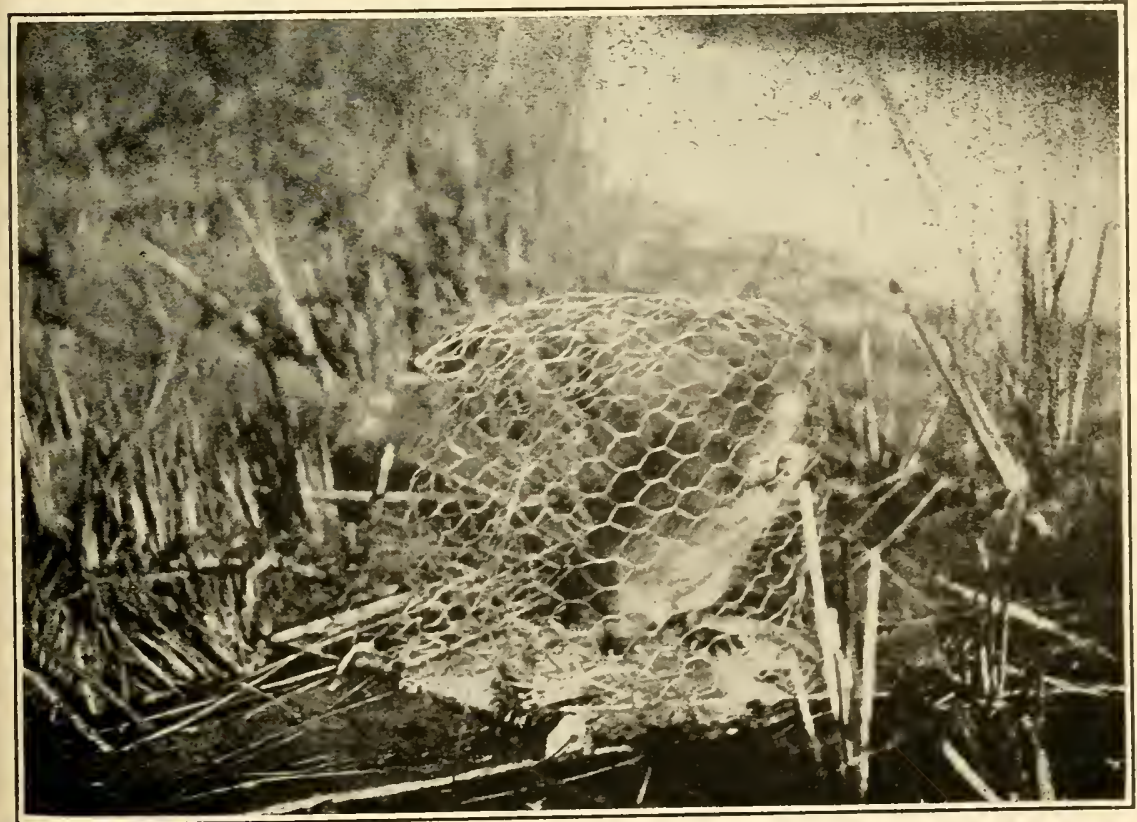

-Photograph by Vernon Bailey.

The Bailey live trap with a muskrat taken by it on the Lake Catherine school section experimental plot. Live traps will solve the problem of securing unhurt specimens for breeding purposes when perfected. 

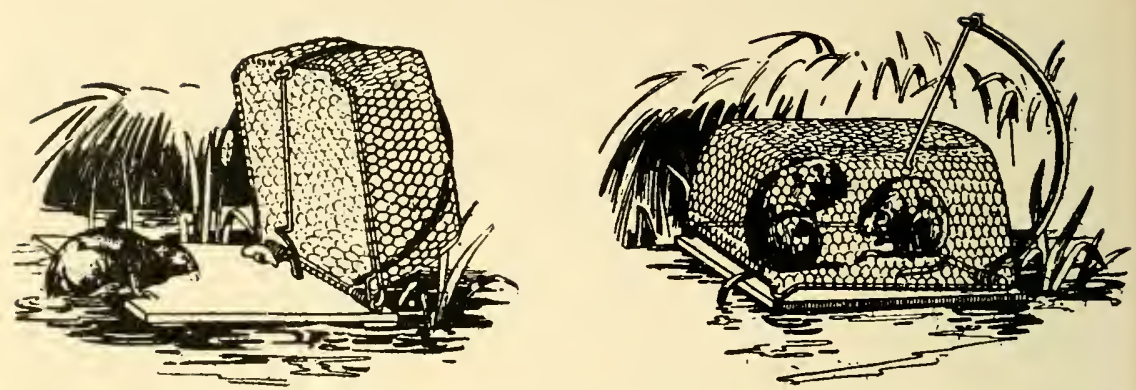

How the Cummins live trap works. This sort of live trap, or one modeled on its general lines, it would appear, would be the most effective for use in muskrat marshes affected by the rise and fall of the tide.

One type of trap, invented by A. P. Cummins, of British Columbia, a game warden in the service of that provincial government, and manufactured by A. I. Johnson \& Co., Ltd., Vancouver, B. C., appeals to the author of this bulletin as the one type of trap that comes nearest to being "the" live trap for Louisiana and other tidal marsh muskrats.

The illustrations show how it sets and works, and attention is especially called to the fact that this trap has a wooden floor-that it floats. Mr. Cummins names his trap "The Humane Trap" and he calls attention to the fact that it will catch and hold minks and other small mammals as well as muskrats.

\section{The inventor describes the trap's use as follows:}

"In muskrat trapping it will be found best to float the trap in rushes or near the bank of a stream or bayou and bait with an apple, parsnip or carrot. Minks can be caught in the same way, but the bai tshould be fish or flesh, fish oil or lure. Any of the smaller fur animals, such as raccoons, foxes, weasels and skunks, can be trapped the Humane way by finding a secluded spot used by these animals. A hole is excavated large enough to take the platform of the trap, letting it down to the level of the ground, covering the flooring with leaves and earth to make it look like the surroundings, and the hole camouflaged with grass and twigs.

"In tidal water's and large marshes the Humane trap is unexcelled as it can be floated and it can be found a necessity to the 'rat ranchers and those who want live muskrats for fur farms. During the pelting season 'rats can be caught, breeding stock selected and turned loose, and the surplus pelted.

"In my trap the animal's pelt is not damaged, as frequently happens when ordinary steel traps are used, and trapped 'rats are frequently ladly bitten by other 'rats when held by the regulation jawed trap. This cannot happen to a muskrat taken in one of my traps. 


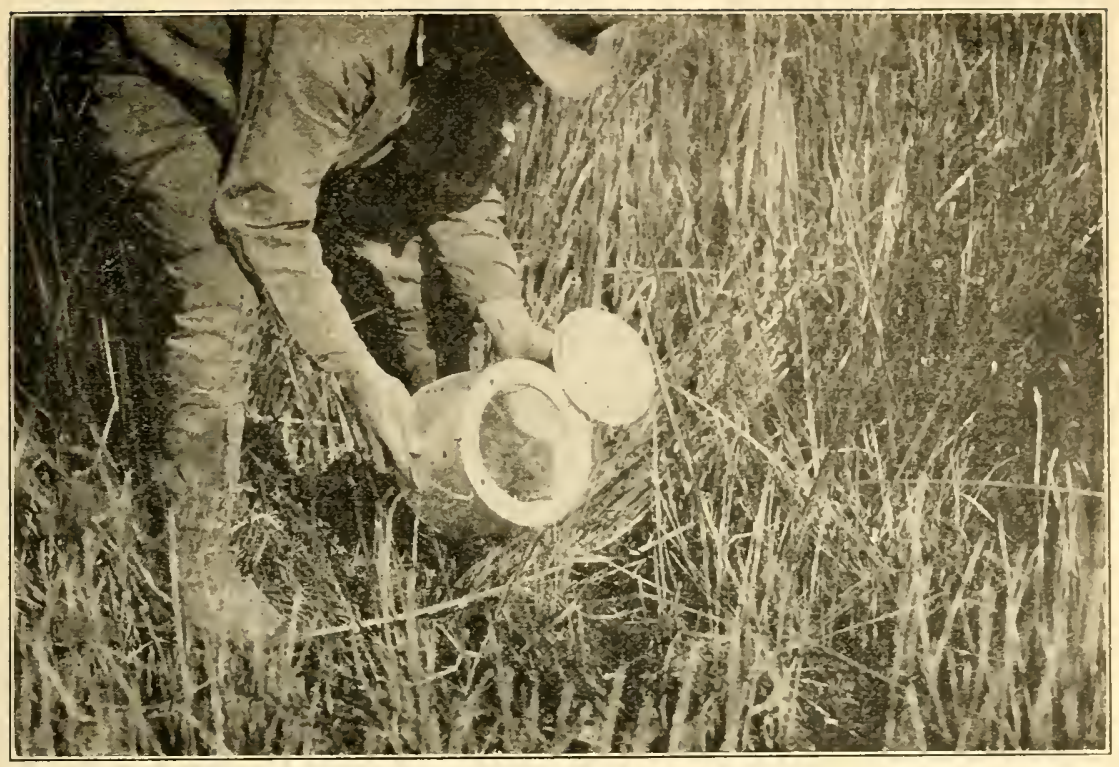

Releasing a live muskrat from a galvanized carrying can in the restoration work carried on by a fur company in St. Bernard parish after the crevasse of 1927.

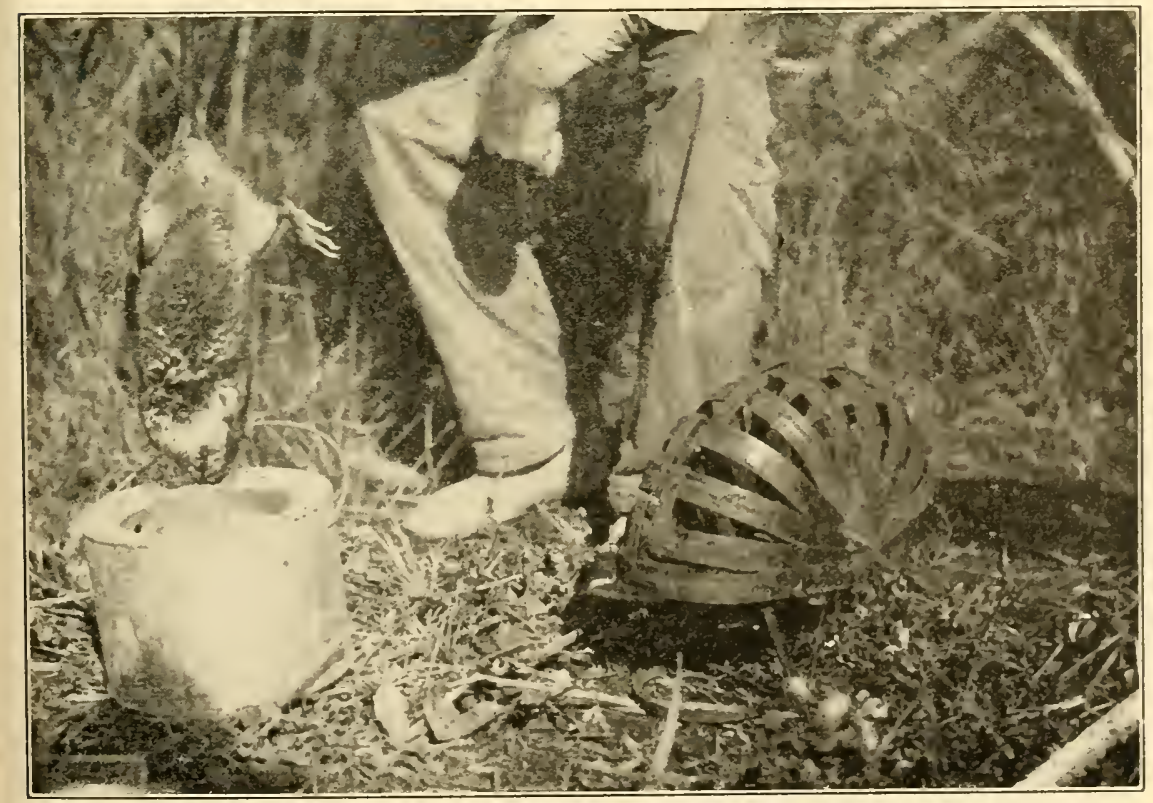

The 'rats were taken in the Gibbs live trap, which is shown closed in the right foreground, and the captive dropped in the special carrying can for transportation to the marshes in St. Bernard parish. 
"My trap is simplicity itself; the platform is of wood and, as it floats, it becomes an attraction to passing animals. Floating logs and pieces of wood are frequently natural resting places for muskrats, and, consequently, they will not hesitate to climb on the plaftorm. Once taken, an animal can be removed by working it into a corner, so that the tail will come under the lower edge of the cage part of the trap; seize the tail, raise the cage, and drop the captive alive and unhurt into a sack."

Mr. Cummins' trap, it will be noticed from the illustration herewith reproduced, can catch two 'rats at a time, if two happen on the platform and bait at the same time. When the cage comes down, the lower edge of the cage cannot smash or otherwise injure the captive's tail, as there is a narrow opening provided for when the cage snaps down.

The halftone illustration on page 363 shows a cage made up by Donald Campbell and it will be noted that it resembles the Cummins trap to a considerable extent. Thd cage is nothing more or less than a galvanized wire dish strainer secured from the $5 \mathrm{c}$ and $10 \mathrm{q}$ stores. It has been used successfully at Port Rowan and should work equally as well in Louisiana marshes. It will be noted that the "pan" on the trap devised at Port Rowan is quite wide and that there is an absence of a top bar and rod to hold the trap open. It, too, needs baiting.

Mr. Cummins' trap cost $\$ 5$. By the time expressage and freight and customs duty is paid, the cost amounts to $\$ 10$ each. Such traps should be built at a cost considerably under $\$ 1$. The Cummins' trap is now being manufactured in the United States by A. B. Delmage, of the Tide Water Fur Farms, West Point, Virginia, and the inventor informs me that it is to be put on the market at $\$ 2.50$ each.

The field for the "sure-fire" live trap is large and experiments should be made of all makes and designs offered until the 100 per cent live trap is found.

\section{A Folding Live Trap From Wisconsin}

Something new in the way of a live trap has just been manufactured by the Folding Trap Company, of Tomahawk, Wis., which is illustrated (p. 364). A sample trap has 


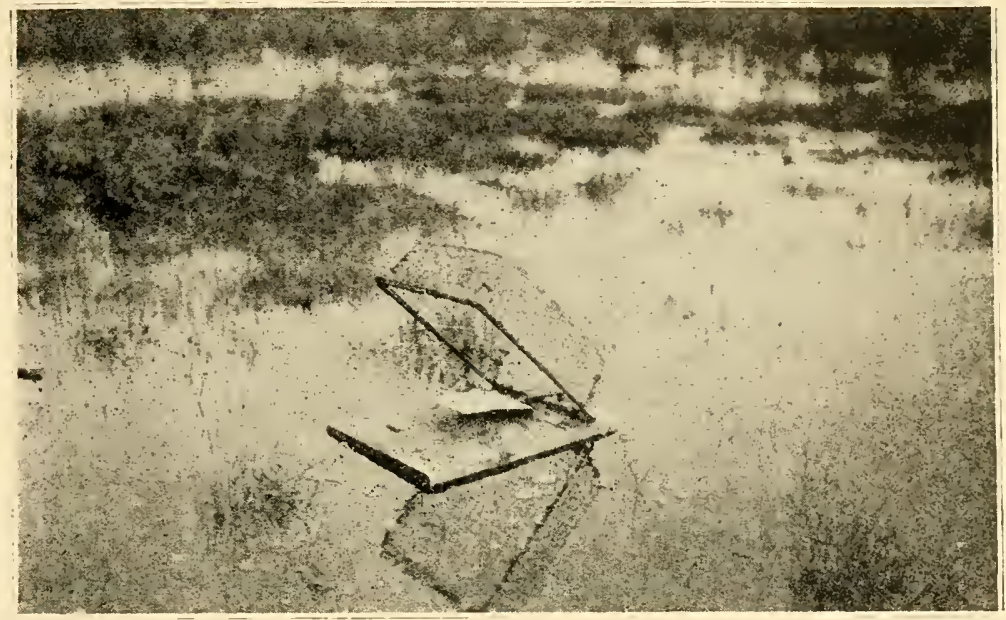

Floating Live Irap in use on the Mount Forest Fur Farm's marsh at Port Rowan, Ontario, Canada. This is an adaptation of the Cummins live trap. It floats and has a very large trip pan. The wire part was made from a dish strainer purchased in a 10 to 25 cent department store. This is unquestionably the typ. of live trap for taking muskrats on tidal marshes but needs development.

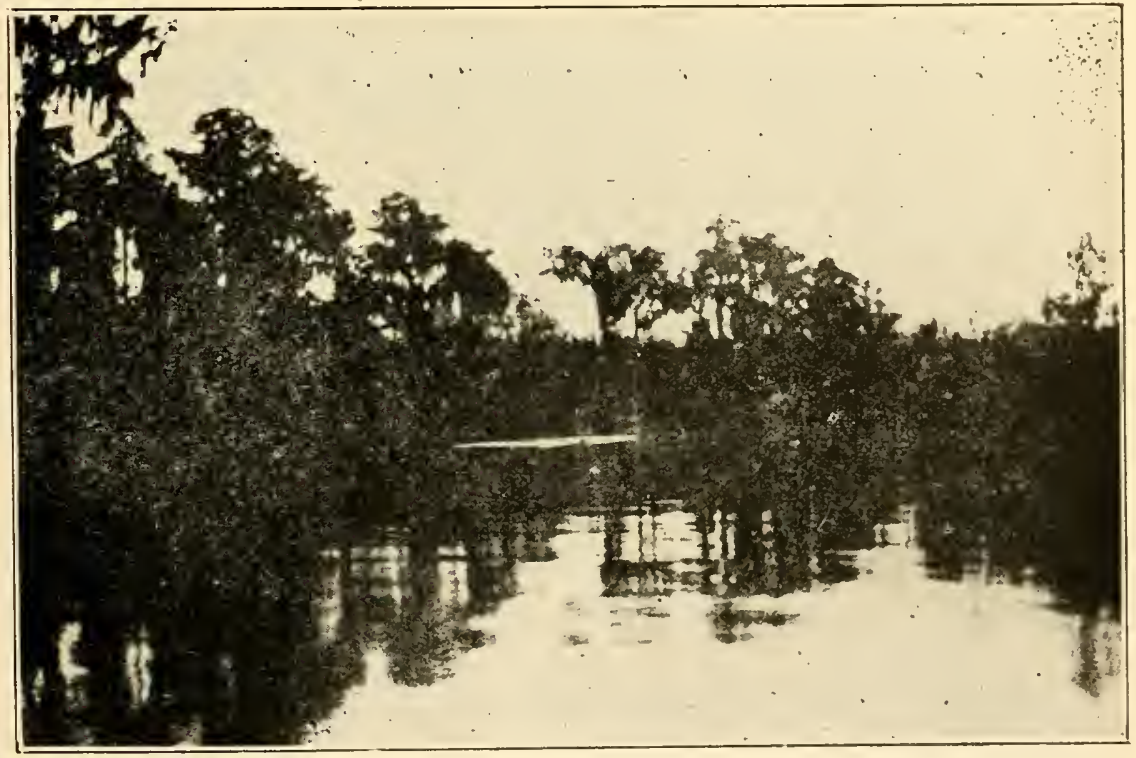

A cypress-lined and moss-hung Louisiana bayou, haunt of many valuable fur animals. 
been sent us for trial, but was received too late to make field experiments and include our results in this bulletin. This trap presents so many marked new departures that it warrants a mention here. While it is of the "box trap" variety, its open wire construction does away with the dark interior that characterizes other box traps, and some animals, especially muskrats, are shy about entering dark interiors not of their own construction.

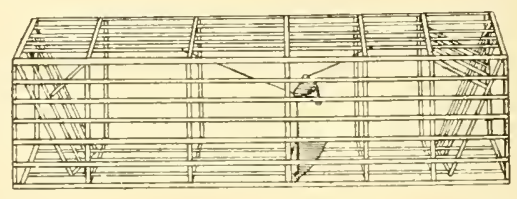

The folding trap is made of zinc-coated wire and is so constructed that it can be folded flat to the thickness of about one-half inch. It is a very light and, when flattened, a trapper should be able to carry 25 or more into the marsh under one arm. It should not take ever a novice more than one minute to unfold and set the trap, as everything about it is very simple and it is evident if a 'rat enter's it will remain inside. The open wire shculd enable a trapper to easily determine the sex of a captive while in the trap. The manufacturers claim this trap will outcatch any other form of box trap and equal in efficiencv the steel trap when properly set, because, when properly $s^{\wedge} t$ and covered with grass, the wire construction is practically invisible, as it is coated with green enamel.

This trap seems to have marked advantages and is worth a trial for all kinds of live trapping as the traps are manufactured in a variety of sizes. The single-door muskrat trap is priced at $\$ 2.50$ with discounts for lots of 12 or more.

\section{Baiting Live Traps}

Live traps need to be baited. excenting, of course. the Gibbs invention, to be successful. and this appears to be the weakness in live trapping muskrats in Louisiana.

Apples, carrots, parsnips. turnips and rolled oats have been urged as good baits for taking the animals else- 
where but, tried out in the Louisiana marshes, they have pioved failures.

Specialists know that there is nothing better for bait than the natural food of the animal. To trap a muskrat with an apple for a lure, we will first have to educate this marsh dweller's palate, for he doesn't know what an apple tastes like, but he does know how succulent and sweet and satisfying the root parts of the three-cornered grasses, the cattails and the bulrushes are-therefore, the sight of an apple is no attraction.

Where appeals to this animal's appetite and stomach fail, we can appeal to other senses and try to capture our rrey by using a scent. A scent is a strong-smelling substance, ce:tain kinds being particularly attractive to ceitain animals, as it arouses their passions and mating instincts.

As an animal, in its native habitat, can usually secure an ample supply of food to satisfy its hunger, trappers were forced to experiment with scent lures and for years fur houses and otiers have sold such scents to trappers in a concentrated form. The usual plan has been to claim such scents are made from very costly and valuable ingredients and oils obtained from the far reaches of the world and which, in consequence, had great alluring power.

All such advertised baits naturally, "are the best," consequently the trapper is called on to pay 75 cents to $\$ 1.00$ for a vial containing only a few ounces of the "rare" liquids.

It must be admitted that many of these prepared scents have proved successful, for they have been concocted from well known and proved formulaes. Far more have proved worthless-why, is a mystery, for it is not necessary to pay dollars for scents and lures that will cost only a few cents if the trapper elects to make up his own.

The following are extensively used and can be secured from druggists: Anise oil, oil of Rhodium, Asafetida, fish oil, used separately or mixed, will probably answer every purpose of a Louisiana trapper. Mink musk and muskrat musk, secured from the scent glands of these animals, are also used. Male musk should be used to attract females. 
Fish oil is easily made and need not be purchased. The body of a fish is cut in small pieces and placed in an uncovered mason jar which is in turn placed in the sun. It is allowed to decay. Soon a fetid, foul-smelling oil forms, which should be poured off carefully from the other matter and corked in small containers. Such fish oil is especially alluring to animals of aquatic habits, especially so to minks.

Scents should never be put on the pan of the trap, but should be placed on a stick above the trap, being arranged so that the animal will have to step on the trap to get to the scented bait. Some good lures are:

Muskrat: A good scent is muskrat musk mixed with a small amount of anise oil and oil of Rhodium.

Skunk: Tainted meat, especially tainted skunk and rabbit, and the animal's own scent may be used. Not being suspicious, skunks are easily caught, and scent lures are not. necessary.

Mink: The best scent is the musk of mink; fish oil frequently does the trick, and a mixture of mink musk and fish oil is an old stand-by.

Raccoon: Fish oil mixed with a few drops of anise oil and a little honey is considered by many trappers to be the scent that gets $\mathrm{Br}$ 'er Coon. Pure fish oil, muskrat musk, anise oil can also be used.

Opossum:Bating with food, bird carcasses, rabbit. meat or carrion, instead of using a scent, seems to be the general practice.

Weasel: Fish oil mixed with anise, oil, asafetida and oil of Rhodium make an attractive lure for this small rare fur animal.

Wild Cat: Fish oil will probably prove to be the best scent.

Otter: Fish oil, mixed with anise oil. 


\section{CHAPTER TWENTY-FIVE}

\section{ECOLOGY OF THE LOUISIANA MUSKRAT LANDS}

B

ECAUSE of the fact that the Louisiana muskrat crop is of immense value to the state and nation, and as enterprises in the farming and ranching of muskrats are being launched in Louisiana, as well as in other states of the Union, any information of a scientific nature on the relation of muskrats, or the other fur animals, to their natural surroundings will be of great value to these commercial enterprises.

\section{Physiography OF LOUISIANA WET LANDS}

The Mississippi alluvial plain extends southward along the eastern border of Louisiana in a broad belt about four hundred miles in length and averaging about fifty miles in width, its lower portion swinging out in the gulf toward the southeast, where it terminates in the present delta of the Mississippi river. On the east side in the state of Mississippi and in the Florida parishes of Louisiana, and on the west side in Louisiana, the more modern alluvial lands are bordered by the loessal or bluff formation. These in turn are bordered on the east and west by the various manifestations of the belted coastal plain, which is young along the coast and grades inland to a maturely dissected peneplain. Extending diagonally across the state from its northwest corner, and joining the Mississippi alluvial plain midway between the Arkansas line and the Gulf, is the broad valley, that of the Ouachita river. East of Alexandria, the Ouachita valley merges with that of Mississippi to form an immense flood plain.

Below the mouth of the Red river, the Mississippi has no tributaries of any importance, but in the broad fanshaped alluvial plain which terminates in the present delta there are numerous important outlets. These, except the Atchafalaya and the present passes at the mouth of the Mississippi have now been dammed by the levee 
builders. The Mississippi itself flows neai the easte $n$ edge of this area, while the Atchafalaya flows near the western edge. The other distributaries, both t.rose abandoned by the river naturally and those closed artificially, originate at the Mississippi or Atchafalaya, and, by branching, spread fan-shaped over the area. That portion of the flood plain which lies west of Morgan City was built originally by the Red river alone and later in combination with the Mississippi, whereas the remainderwas built by the Mississippi alone or later in combination with the Red.

\section{Geological Age}

Geologically speaking, the Louisiana portion of the Mississippi flood plain belongs to the immediate present. Its topography has resulted from a differential building up by sedimentation, and not from upheaval or erosion. Along the main river or its distributaries, present or past, are the natural levees, popularly called "front lands," formed by the deposition of the coarser sediments, whereas the "back lands" differ not only in their lower level but in finer texture, due to an excess of clays. The slope and transition from one to the other, however, is gradual.

Where the level of the back lands dips below the mean ground water level, swamps are formed. These vary from shallow swamps characterized by a variety of hardwoods to the deeper swamps in which only tupelo and cypress grow. Many of these swamps, especially those in the lower region, differ from those associated with the chain lakes already described in that they are not flooded by back waters but are merely catch basins for the high waters which normally overflow the natural levees in times of flood, although today this occurs only when the artificial levees give way. They also catch the rainfall in the alluvial plain, since the drainage is away from the master streams. Some swamps partake of the nature of both types. 


\section{Treeless Marsh LandS}

As we approach the coast the younger wet areas are treeless marsh, and there are many sea level lakes and lagoons resulting from arms of the sea being surrounded but not as yet completely filled with alluvium. The trees, larg.ly cypress, start their growth near the ridge of the master stream and slowly migrate out over the marsh toward some lake or sluggish bayou in the rear. In very young formations, or where the sea water near the coast has prevented the growth of trees, the marsh (fresh or brackish, as the case may be) borders the ridge without the intervening swamp. It is this type of treeless swamp, locally called marsh, that is the typical habitat of the Louisiana muskrat.

In addition to the swamps and marshes of the delta of the Mississippi there are a number of smaller rivers traversing the coastal plain from the Pearl river, on the southeastern boundary of the state, to the Sabine, on the southwest, which exhibit, in miniature, are replicas of the swamps and marshes of the Mississippi.

\section{Westeri PRAIRIE LANDS}

There is still an area of Louisiana wet lands which has not been touched upon as yet. The prairies in the southwest portion of the state, formed by almost modern marine deposit, incline gradually to the sea, becoming more and more marshy as we approach the coast. The mud of the Atchafalaya is at present being carried westward and deposited in a shallow sea, and beach formations, still extant but far inland, indicate that this condition has existed for some time in the past. Because of these wave and wind built beaches, which act as dykes against intrusion by the sea water, the fresh water in the marsh, furnished by rainfall, groundwater seepage, and springs, tends to remain fresh and at a more or less constant level, producing near the coast a permanent marsh of wide expanse, varied only here and there by lakes and by shell or sand ridges sometimes far inland. 
These ridges are the former beaches of lakes, bays or the gulf.

\section{Classification of Louisiana LANDS}

The State of Louisiana contains approximately 46,000 square miles of land and 2,500 square miles of rivers, bayous, lakes, lagoons and land-locked bays. Of this area (291/2 million acres of land and 11/2 million acres of water bottoms) only about nine million acres were classed by the census bureau in 1924 as farm lands, about four million acres of which were in crops.

The wet lands, comprising the swamps and marshes which are not considered as water bottoms, comprise some $81 / 2$ million acres, bringing the area covered with water at some season of the year, to some ten million acres, or nearly one-third of the total area of the state. Under primitive conditions, the area subject to overflow only during excessive floods of the master rivers, would total about fifteen million acres, or nearly one-half of the entire state. Today, when the levees hold, this is reduced to the smaller figure, about.ten million acres, allotted about as follows: Permanent water bottoms, including rivers, bayous, lakes and bays, $1 \frac{1}{2}$ million acres, sea marsh $2 \frac{1}{2}$ million acres, fresh water marsh $13 / 4$ million acres, permanent swamp $11 / 2$ million acres, and hardwood swamp subject to periodic overflow $23 / 4$ million acres.

The state is divided roughly then in three great areas, each occupying at present about one-third of the total, upland forest lands, agricultural lands, and wet lands, each of which is productive of great wealth; the first primarily for its timber and pulp wood (cypress excluded); the second primarily for its crops and pasture lands; and the third for its great wild life, fur and fisheries resources and cypress and associated timber.

\section{The Muskrat Lands}

The muskrat lands of Louisiana comprise a strip of territory of about two and a half million acres lying near or adjacent to the Gulf Coast, but just beyond the tidal 
zone, the animals not thriving where tidal influence is too great but tolerating occasional inundation. These lands are partly of alluvial origin and partly of coastal plain formation. The muskrat territory east of the Atchafalaya river is entirely alluvial in origin. West of the Atchafalaya it is largely of coastal plain formation traversed by strips of alluvial formation adjacent to the streams of that section.

Climatic factors are, of course, similar on both sides of the Atchafalaya river, as these lands lie in approximately the same longitude. There is relatively little difference in the rainfall in the different areas of south Louisiana, although it averages slightly higher in the alluvial section of southwestern Louisiana than in the coastal plain section in the southwest. Periods of drought severely affect muskrats, particularly during the periods when the marsh remains dry for long periods and marsh fires take a heavy toll. These marsh fires do not seem to destroy many of the muskrats by actual burning, since they can seek refuge in the water, in their runways, or in sloughs, lagoons, bayous, or canals which traverse these areas, but by creating adverse alkaline conditions due to potash salts from the burning of the grasses and peaty humus.

\section{ReHabilitation After Droughts}

Subsequent to serious drought periods, it takes a number of years for muskrats to rehabilitate a given area. In some of the alluvial sections of Louisiana, particularly near the mouths of the Atchafalaya and Mississippi rivers and in St. Bernard and Plaquemines parishes, where the marsh in the general vicinity of Delacroix Island is kept relatively fresh by the waters from Lake Pontchartrain and Lake Borgne, which acts as storage reservoirs for the fresh waters of the rivers of the Florida parishes, the rat areas are not as seriously affected by the drought periods.

On the other hand, in the areas between the main rivers, such as in Terrebonne parish in the alluvial sections, or in the coastal plain areas in the western part 
of the state, the toll of muskrat life is severest in extent.

This indicates that it is not the character of the geological formation itself, which is favorable to muskrats and facilitates their survival during the adverse periods, but the amount of fresh water available to prevent the marshes from becoming too saline and to prevent the marsh fires from burning too deeply, thus destroying the nests or rats and creating alkaline conditions adverse to their development, or, rather, directly to the growth of their food plants.

Since climatic factor's are practically identical both in the Mississippi Valley muskrat territory and in the coastal plain muskrat territory, and since the rats exist similarly in two different types of geological formations, we must look to some other common factor which is favorable to their development and determines their. presence in both geological formations.

The muskrat lands, as stated previously, lie near or adjacent to the Gulf Coast and do not extend any great distance inland. In the inland swamps and marshes away from the Gulf Coast there are no muskrats, and examination of these swamps and marshes will show that they are periodically inundated by the Mississippi river or some other silt-bearing stream. Here there is a clay subsoil, with no appreciable layer of peaty humus on top. The rivers in their land-building process, add layer upon layer of silt and clay during every inundation, but there is no layer of vegetable matter of any consequence developing on top of this soil.

\section{The Importance of Peaty Humus}

Along the coast, however, even where there is periodical flooding by the rivers, conditions are such that the salt marsh grasses which thrive in those regions build up a layer of peaty humus from inches to sometimes several feet in thickness. This humus may be as much as $90 \%$ vegetable matter and $10 \%$ mineral matter, the latter consisting of clays and silt, and in some areas a small amount of sea sand. It is in the areas where this peaty formation is best developed that the muskrat seems to thrive best, 
othes: factors being practically equal in the different geolcgical areas of the state. Therefore, since the abundance of muskrats seems to be in the direct proportion to the amount of peat in their habitat, it would seem then that the one outstanding factor of a favorable muskrat environment is the presence of this peat. This peaty formation consists largely of accumulated dead remains of the sedges and grasses characteristic of that region, in which are intermingled the roots of the living plants which form the chief source of food for this mammal.

\section{Plants Forming Peat Lands}

Among the more important plants whose rooting systems built up this peaty formation might be mentioned the three-quare rushes (Scirpus robustus, S. olneyi and S. americanus); the Giant bulrush (Scirpus validus); Saw grass (Cladium effesum); the Cattail (Typha angustafolia); Couch grass (Spartina patens juncea) and a number of others. As to the importance of this layer of peaty humus in protecting the muskrats from adverse conditions there are several distinct benefits that may be derived therefrom. In the first place, it enables the animals to build their under-water runs without difficulty, since it is more easy for them to dig through a spongy layer than through a layer of clay or sand. This spongy layer sustains the underground tunnels of the muskrats and prerents caving. Muskrats in making the runs from the nests dig deeply down from the nest under the water and come up to the surface at a considerable distance from the nest. These efficient water traps (plunge holes) and their radiating subterranean tunnels prevent access of natural enemies of many kinds. 


\section{CHAPTER TWENTY-SIX}

\section{THE DIFFERENT MUSKRAT FURS}

\section{A}

TRADE JOURNAL of New York recently published the following article on the different qualities of muskrat pelts and their compartive points of value, which is reproduced here as an unbiased and authoritative review of the different muskrat furs, in which the Louisiana pelt does not suffer by comparison:

At present musklat is used in only two ways: in its natural coloring, and dyed black to imitate seal skin, says the Fur Trade Review article. For the past few years muskrat, in its natural color, has been used to a great extent because it lends itself particularly well to the making of jacquettes and sport coats. Its rich and varied coloring can be worked up effectively into stripes and designs for garments of this type. The fur is full and soft, with a fine lustre, and the pelt is strong and serviceable.

The muskrats in common use can be divided into four classifications, viz., natural black, northern, southern tops and southern. All of them are of a distinctive brown color, varying in depth of shade from very dark brown with black top hairs, to a light brown with black top hairs. The underfur varies from dark gray to light slate gray.

Natural Black'Rats.-Of all the muskrats that are used in the natural state, the natural black 'rat is by far the finest in appearance and quality. Its full, heavy top hair and uniform, charcoal-black coloring make it so distinctive that it can be easily recognized in the manufactured garment. Because of its superior quality and the fact that the skins are never over-plentiful, owing to the limited catch, the natural black muskrat always brings a higher price, both in skins and garment, than any other 'rat. The best black 'rats come from New Jersey and Maryland, respectively, and some are found in parts of Delaware and Pennsylvania.

Southern Tops. - The next most desirable 'rat for use in the natural color, and which is used most extensively, is 


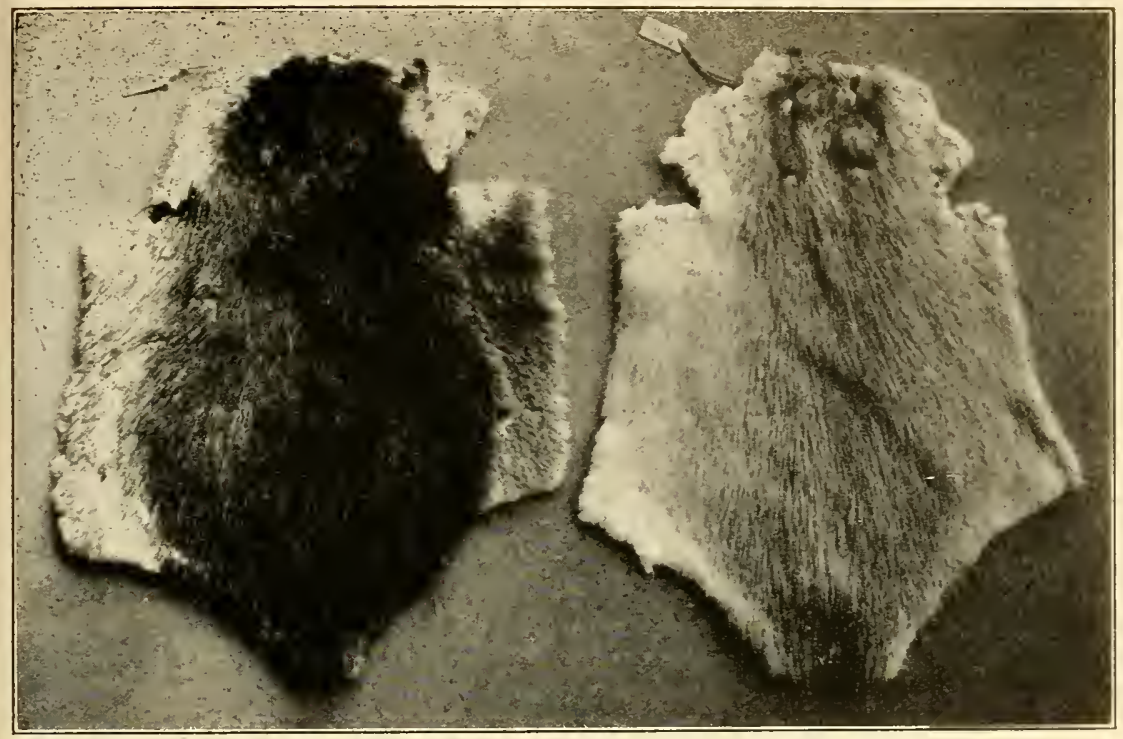

The muskrat pelts from St. Bernard parish. The skin on the left is the typical shade and color but the skin on the right is of a light fawn or "champagne" color. This color is evidently not an albino as the animals bearing this color of fur do not exhibit the pink eyes of the normal albinistic animals. Quite a number of "champagne" pelts are taken each winter from certain circumscribed territories.

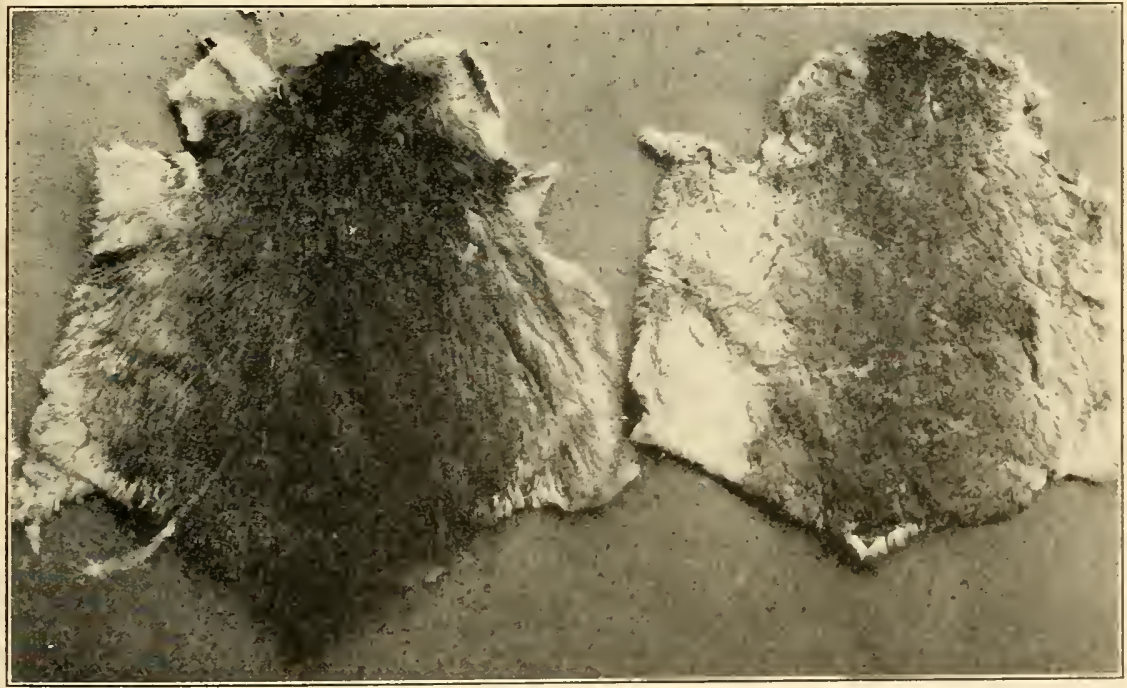

On the left is a typical prime Plaquemines parish muskrat taken in the middle of winter. Note its long and rich guard hairs and full-furred belly that make it a top. On the right is a summer pelt from the same territory: It is without guard hairs, the fur is scarce and flat: The two pelts illustrate the necessity of taking only prime pelts and in the colder months of the year. 
what is known as the Southern Top 'Rat. Compared with the uniformed blackness of the natural black 'rat, the southern tops are varied and lighter in color. Southern tops are found in western Louisiana and a few in eastern Texas, and are distinguishable from the other southe. 'rats by their longer top hair, fuller fur and darker color.

Southern 'Rats.-The skins of all other southern 'rats are very flat and of a bluish-brown color. They are also used in their natural state for coats and coat linings, though sometimes they are dyed for Hudson seal. As such, the pelt loses its strength, wears poorly and does not look satisfactory. The leather of the southern 'rat is stronger than that of the northern 'rat, from which most Hudson seal is made.

Northern 'Rats.-Northern rats, on the other hand, have a weaker leather than the southerns, but their silkier, heavier underfur makes them particularly adaptable for Hudson seal. When the top hairs are plucked and sheared, the full underfur dyed black, it appears rich and beautiful. The natural color of the northern 'rat is reddish brown.

The northern 'rats, found in the northern part of New York state, are considered the best in quality and durability and the largest in size. Almost as good as these are the 'rats from Michigan, Wisconsin and some parts of Minnesota. Illinois and Indiana yield large muskrats which have a very heavy pelt, but are not full in fur. A good quality 'rat is also obtained from some of the New England states, especially Maine and Vermont. They are large and possess a fine, silky hair.

Canadian 'Rats.-Canadian 'rats are the poorest of all 'rats in wearing quality. This is due to the fact that in cold weather they absorb their own fat for food, which thins the pelt and impoverishes the fur to some extent. The silkiness of the hair does not compensate for the tenderness of the pelts. From only one section of Canada come 'rats strong enough in pelt for Hudson seal, and they are the better qualities found around Rice lake, in Ontario. Others are sometimes used for Hudson seal, but they must be selected from among the best skins. The rest are made 


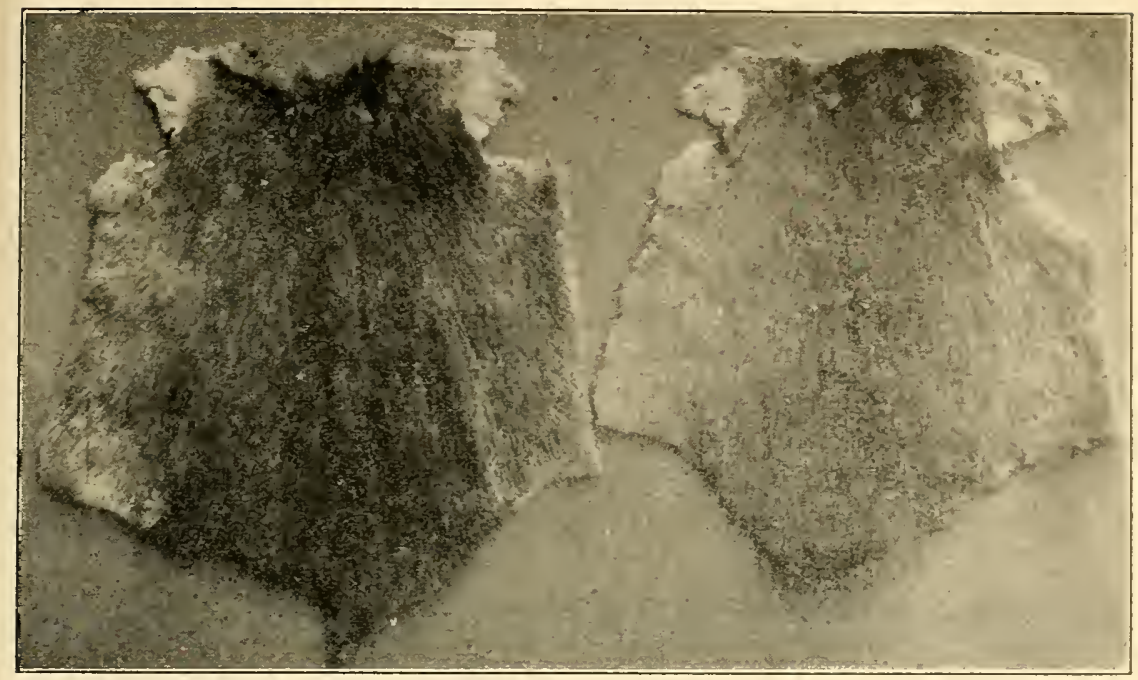

The muskrat pelt on the left, from Cameron parish, Louisiana, is the so-called "Texas "rat" of the fur trade. It is contrasted in size and color with a skunk from the central section of the coastal muskrat marshes.

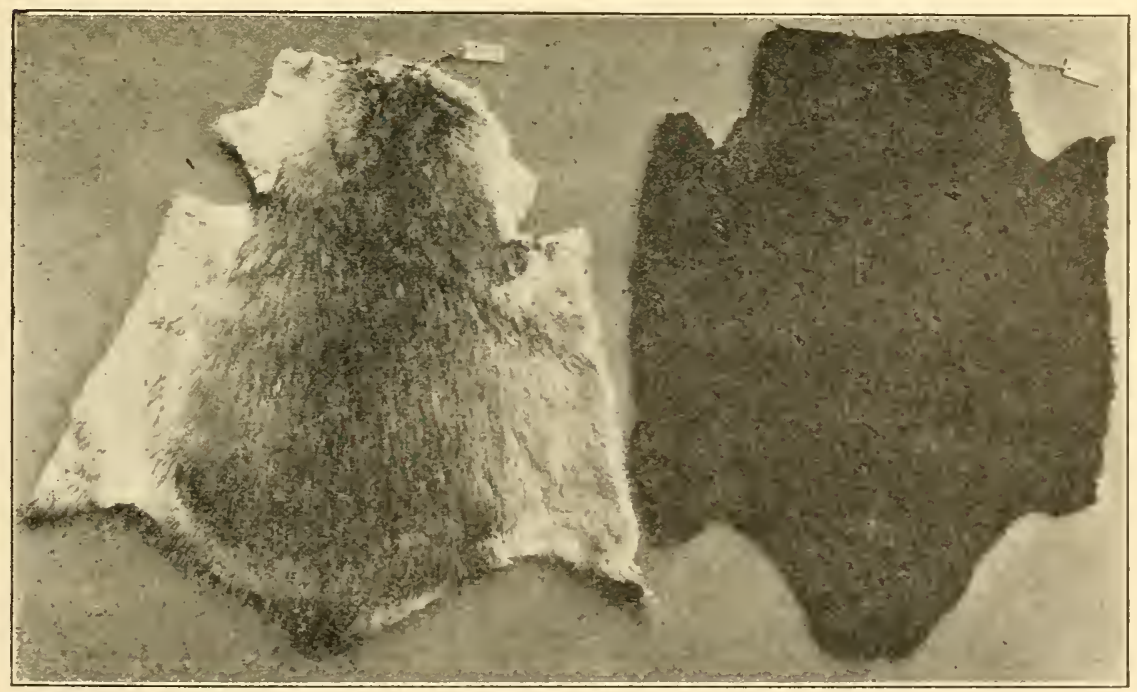

The pelt on the left, taken in Terrebonne parish illustrates the three grades of fur secured from a Louisiana muskrat, the back, which gives the "beige" fur: the sides, furnishing the "golden muskrat;" and the belly skin from which the "silver muskrat" is secured. On the right is a Louisiana muskrat pelt plucked, sheared and dyed which makes it a "Hudson Seal," or as it is now called by the furriers "Seal-dyed muskrat. 
up in natural color and the poor grades are used for coat linings.

Alaskan 'Rats.-Thousands of 'rats are produced every year in Alaska, but so far the fur trade has found very little use for them because of their weak pelts and the fact that from 50 to 60 per cent of them are "shots". They are similar to the Canadian 'rats in quality, and larger than the southern United States 'rats in size. Alaska traders claim that if these 'rats were carefully selected and graded and offered to the trade for what they are, at least 25 per cent of them could be used successfully for Hudson seal, and good use could be made of the remainder for trimmings and linings.

Muskrats, unlike most fur-bearing animals, reach their prime in the spring. At that time the fur is richest and fullest, and the pelt is firm and supple. Fall 'rats, though stronger in leather, are very poor in fur and are the least desirable.

Manufacturing.-Years ago the natural muskrat was used chiefly for lining men's fur coats. But its natural beauty and practicability have made it very desirable for women's daytime coats, and it is growing increasingly in favor for their purpose.

Formerly, the most beautiful effects in natural muskrat coats were obtained by "letting-out" the skins and working them in stripes, to imitate mink. This is still done with fine dark skins, especially with the heavy natural black 'rats. The labor entailed in this process makes it prohibitive on anything but the best skins, in as much as the additional cutting and sewing increase the cost almost 100 per cent. For this reason new methods have been devised to get a similar effect from the natural pelts. They are split in half and worked diagonally, in herring bone and diamond patterns, and in many other original and unique way. This does not involve nearly as much labor as the "let out" skins, and in many cases is just as attractive. Natural black 'rats are also worked set up square, as are southern 'rats. The latter, as a matter of fact, cannot be "let out" because the flat fur woud reveal every cut and seam. 


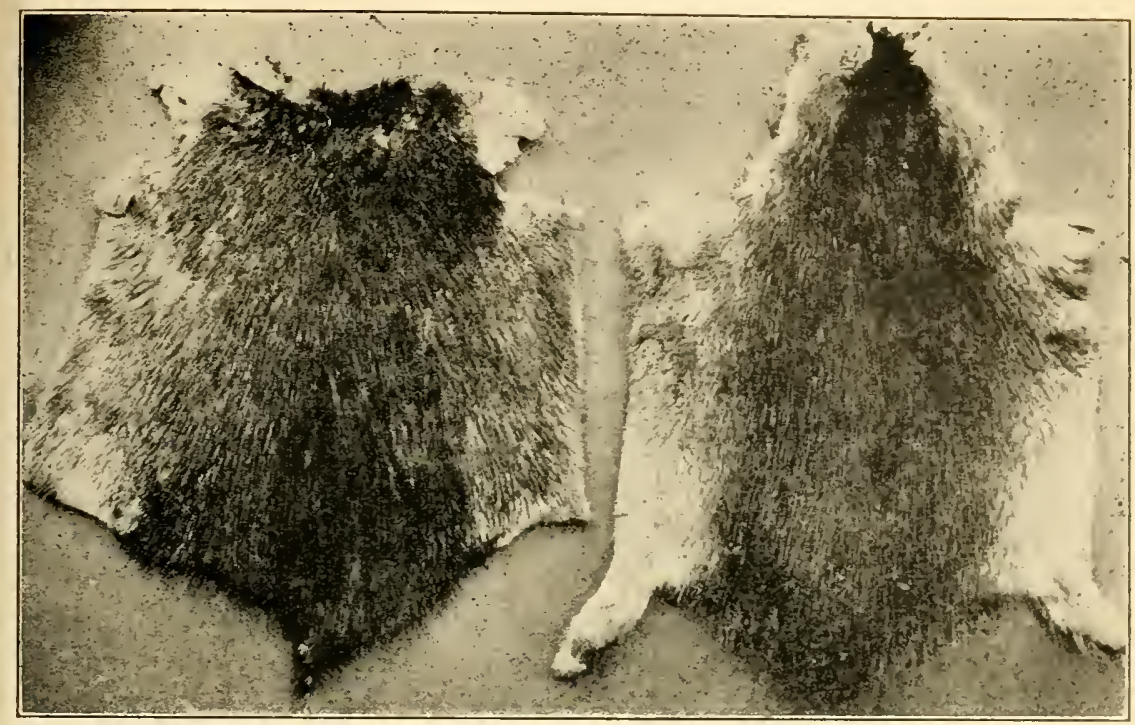

On the left is a typical pelt of a Cameron parish muskrat pelt photographed with a skin of F. z. macrodon from Maryland, the so-called "black muskrat" of the Eastern sea. board marshes. The heavy, beautiful and glossy-black guard hairs of the back being responsible for the designation of "black "rat" as the animal's fur is not jet black through. out its pelage.

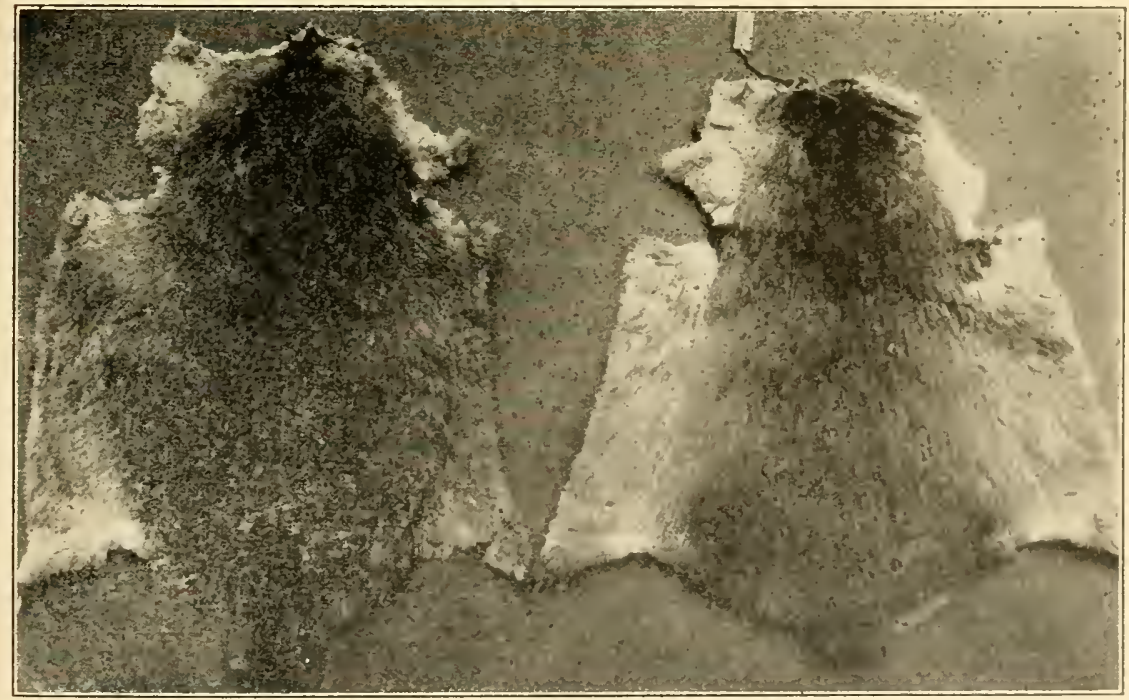

The pelt on the left is from a Nevada muskrat, F. $z$. mergens, contrasted with a typical terrebonne parish muskrat. Our muskrats average larger and have better color and guard hairs than have the Western animals. 
In working a natural muskrat coat the bellies are usually cut away. The more of the belly that is eliminated the cleaner cut the coat is considered. For Hudson seal, however, the entire skin is used.

"Silver 'Rat."-The recent popularity of light shades in furs have brought muskrat bellies into use as a fur in itself. They have been introduced to the trade as "silver 'rat". The hair of the belly is softer and silkier than that of the back, and its pale grayish tan color makes it quite desirable for light spring jacquettes. More labor is required in the making of a coat of muskrat bellies, because of the small size of the pieces, than on the natural muskrat coat, and for this reason "silver 'rat" coats cost as much as, if not more than, the ordinary muskrat coat.

\section{Variations in Muskrat Color Patterns}

It is a well known fact to scientists who have studied the muskrat that the color of the pelage differs widely with different forms and species. The range of color is from light tawny shades to dark brown, which sometimes is almost black, but the prevailing color is a rich reddish brown. Sports in color are frequently seen, especially in Louisiana, and we have records of albinism, in which the 'rat's coat is a pure white, with the accompanying pink eyes, of course, and we have frequently met with a muskrat fur that is a wonderful rich fawn, or "champagne" color, one such pelt being reproduced in the upper illustration on page 373 .

According to Harry J. LaDue, editor of the American Fur Breeder,* known as an authority of considerable importance in silver fox and pen muskrat breeding, the outstanding occurrences in variations from the type colors in muskrats seem to occur in such isolated sections as certain sections of Labrador, Nevada and along the Atlantic seaboard. He believes that isolation is rather an important factor in the dominance of variations in the wild state "because breeding becomes more or less a natural form of line breeding in an isolated section and variations obtain a greater foothold and increase accordingly."

*LaDue, H. J., American Fur Breeder, Sept., 1928. 
Muskrat pelts from widely scattered localities all seem to have one common color for the base of the underfur. and that color is slate blue, according to Mr. LaDue, who says he has noted this in skins he has handled from Nevada, Wisconsin and Maryland. In examining a skin from Virginia he found it offered an interesting contrast, in that the underfur was tipped with light blue which ran into a wide band of creamy white at the base.

"The tips of the guard hairs, especially the tips of the underfur, showed a wide difference. The Nevada pelts had almost red guardhairs, the darkest hairs being found in a narrow band down the back bone. The underfur tips on these pelts were almost a lilac shade and showed a decided lilac after the guard hairs were plucked. Pelts from Wisconsin had red guard hairs along the sides and a broad band of rich, dark brown guard hairs down the back. The tips of the guard hairs were quite dark and when laid flat gave an appearance of being black. The tips of the under fur of Wisconsin pelts were uniformly a rich reddish-brown."

The Maryland and Virginia pelts Mr. LaDue examined were from the so-called "black muskrat". It is interesting to note that this gentleman calls attention to the same fact I have always pointed out to those in the South who have wanted to experiment with the "black" muskrat-that it is not black.

"Many persons not familiar with the true color of the black muskrat have been disappointed after receiving their breeding stock," says Mr. LaDue, "because they expected a jet black 'rat and instead got a 'rat with a brownish-black back and sides and a creamy white belly.

"On cross examination the tips of the guard hairs of the Maryland and Virginia black 'rat pelts do not appear to be much darker than the tips of guard hairs of the pelts from Wisconsin. However, the band of dark guard hair is much broader on the Atlantic Coast muskrat and the red-tipped guard hairs, which seem to be present in all three widely scattered specimens, did not extend very far up from the belly. 
"The reason the Maryland and Virginia so-called 'black' muskrat pelts look black is, in our estimation, because the tips of the underfur underneath the dark guard hairs, are almost as dark as the guard tips. The pelt, consequently, looks dark no matter whether the guard hairs are standing upright or lying flat."

This proves to $\mathrm{Mr}$. LaDue that there is a color inheritance that goes with the dark-tipped underfur-the why and wherefore of which would be interesting to solve-and he believes that pen breeders of muskrats will be those who will solve the matter from a genetic standpoint.

A collection of muskrat pelts from the different sections of the Louisiana coastal marshes, from the Pearl river to the Sabine, shows almost as much difference in the color of guard hairs, and underfur color as in the muskrats the Minnesota editor examined from Labrador, Nevada and Wisconsin, and Maryland and Virginia.

In Louisiana there is a so-called "black" muskrat. It is the same animal the local fur trade sell the eastern manufacturers as a "Texas 'rat," and occurs principally in Cameron parish. It has size, plus color, that differs from other muskrats in Louisiana, although it feeds on the same kinds of food.

The value of a muskrat coat, therefore, depends on the darkness of the skins, the number of skins used, the sections from which they come and the amount of labor that has been put into the making of the garment. When only the dark centers of the skin are used, more skins are naturally required to make the coat than when the skins are trimmed close to the head and down into the belly fur.

Hudson "Seal" is the favorite and most popular camouflage of the fur trade. While it is true that in this day of "truth in furs," as is now practiced by the reputable furriers of this country, that woman is beginning to know more about the zoology of the pelt she is wearing, and now a skunk is a skunk instead of a "Fitch;" and a rabbit is becoming a rabbit in spite of attempts to make it a "Cony," a "Chinchellette," an "Electric Mole," a "Sealette" or a score of other misleading names. 


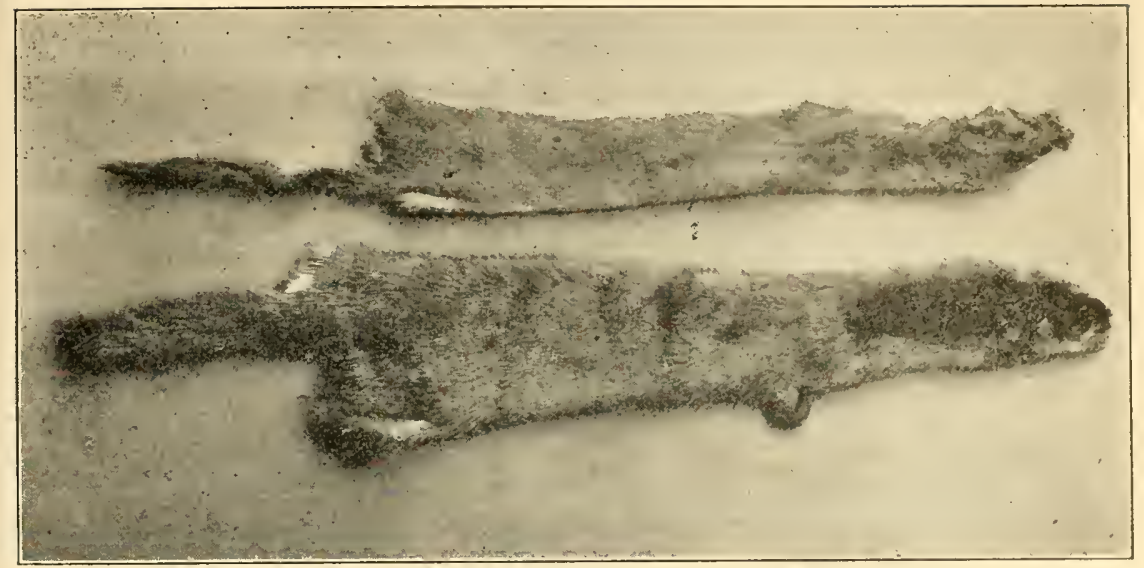

A Louisiana weasel upper, contrasted with a typical mink from the swamp sections of St. James parish. This photograph shows the pelage of the backs and it should be noted that a portion of the mink's tail has been lost having the effect of shortening the comparative length.

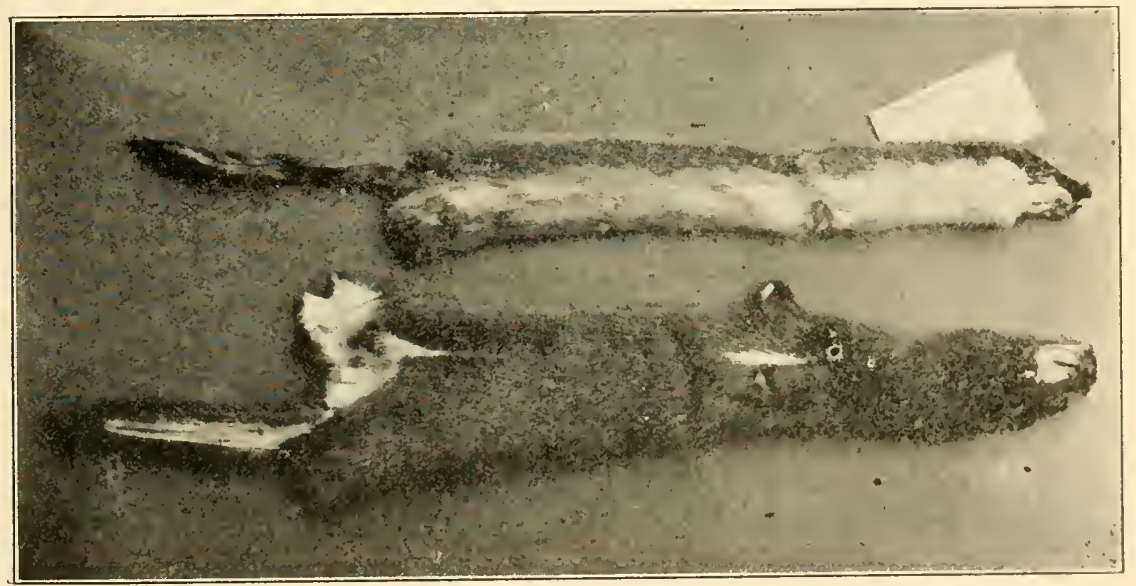

The under parts of the weasel and mink are vividly illustrated in this photograph. Note that the mink, lower, has a small white area on the belly and chest while the belly white of the weasel extends practically the length of the body. 
Today reputable fur garment advertiser's brand a Hudson Seal article a "Seal-dyed Muskrat," just exactly what. it is, and, in parentheses the ancient name. But it is quite possible that long usage of the term Hudson Seal will continue and, as many muskrats from this state are used in its manufacture, it will not be out of place to describe how Hudson Seal is produced.

While it is now known in a general way that muskrat skins that have been plucked, sheared and dyed black become this article of commerce, few are aware of the various processes through which a raw 'rat pelt must pass in order to emerge a "seal".

As many as eighteen separate and distinct operations, all of which call for expert handicraft and precise mechanical equipment, are required because this manufacturing process has graduated from a plain dyeing operation into. a scientifically and exact procedure.

The raw pelts are received by the tanning and dyeing establishments in the same form the trapper prepared them, cased and with the fur on the inside. They are first perforated near the edge with a number so as to mark one shipper's merchandise from another's and then the skin. are "half dressed," a term used in the fur industry to indicate a treatment preparatory to the dyeing process, but which is commonly and incorrectly identified with tanning. Today, muskrat skins are dressed in a manner quite superior to the antiquated crude method of tanning or dressing handed down from the Indians, and a great percentage of the value of the finished Hudson Seal product depends on the initial dressing which has been evolved to an art by the major fur dyeing and fur finishing plants of this country, and an art that calls for the best kind of craftsmanship. This dressing process is carefully supervised so that when completed in the half dressing the muskrat is left with a pliable pelt and with no injury to the fur.

The operation consists of inserting the pelts in a mechanical contrivance known as a "kicking" machine. By kicking it is not meant that the pelts are subjected to anything remotely resembling harsh treatment but merely that 


\section{H. A. REICH}

METHOD OF CUTTING FUR SKINS AND PRODUCT THEREC
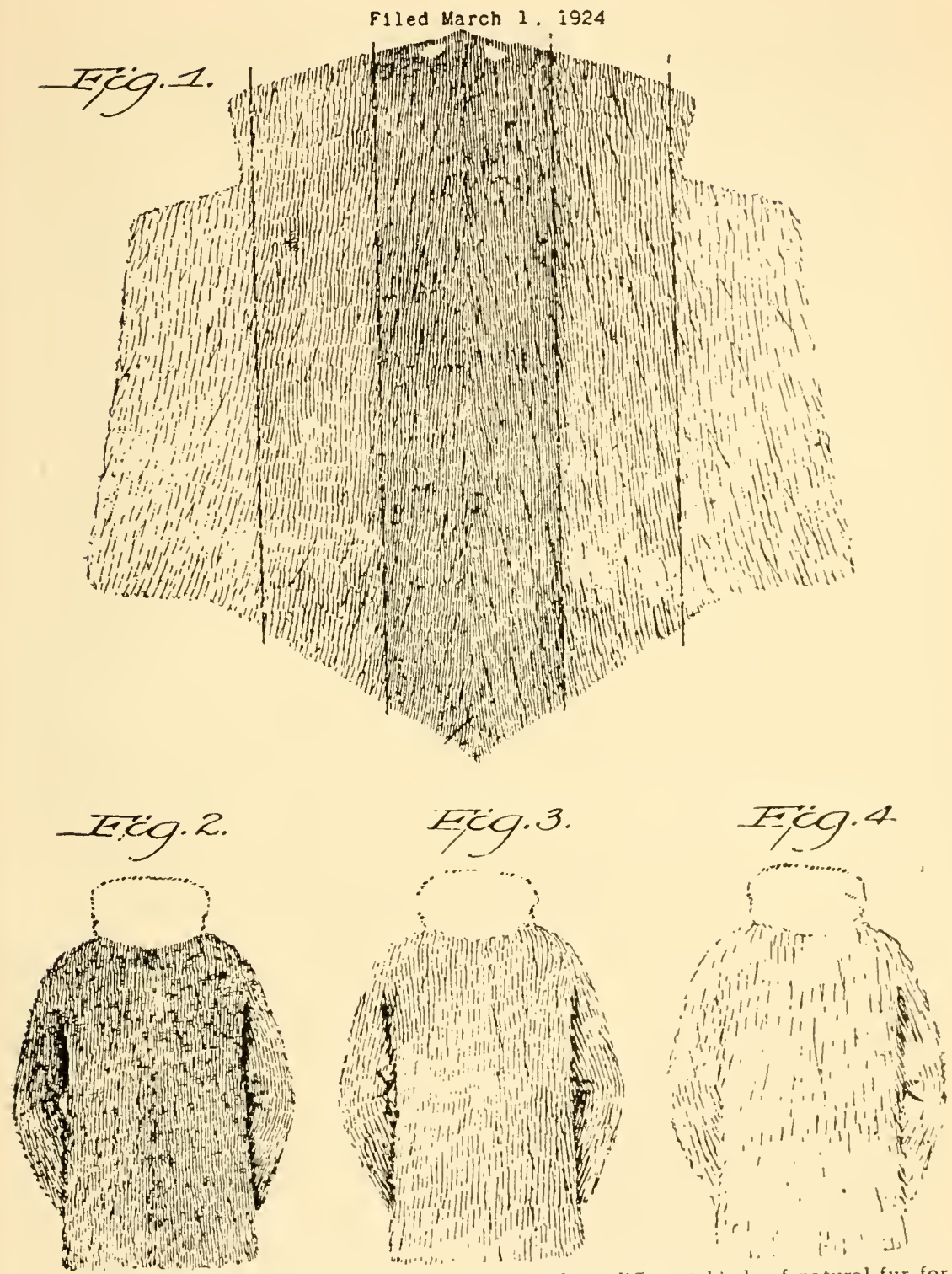

a minds of natural fur for (har garment-making, according to the Reich patents. The center strip either side of the back back, furnishing the "beige" or "groton skins; the two strips onufactured; and the two furnish the skins from which "golden muskrat" coats are manufactured" and the two furnish the skins from the belly skin, from which the "silver muskrat" garments are manufactured. In making a muskrat coat the strips are accurately cut, matched for color and shade, and then stitched together by the garment-maker. As the Louisiana muskat furnishes "beige," "golden," and "silver" fur, it is frequently referred to as a "theige" or back fur, the article" "rat. Figures 2, 3 and 4 show garments made 
the necessary chemical compounds and ingredients are driven into the pores of the skin; the term"kicking" was evidently derived from the ancient methods employed by the Indians, who had a habit of treading their skins with: their feet when tanning.

After the muskrat skin has passed through the kicking. process it is split through the belly lengthwise, which leaves: the pelt practically square of form and quite different from the "cased" appearance it has when handled as a rew pelt. This splitting leaves intact the back of the pelt, which contains the best part of the fur, and facilitates the handlingof the skin in all subsequent processes.

Next the muskrat skins must be cleaned and for this operation they are placed in a hug drum, which is revolved at a given speed. The skin has now been completely dressed with the exception of a "fleshing" process which is not done at this stage of the operations so as to permit superflous layers of flesh and grease to remain on the skin and act as absorbents for impurities and superfluities which attach themselves to the skins during the subsequent dyeing processes. After being drummed, the skins are turned over to skilled help, who mend all natural rips and who cut off paws and frayed edges to eliminate possibilities of tearing later on. A number of skins, during this examination, are rejected, and those determined as suitable for Hudson seal are passed on for further treatment.

The next treatment consists of "plucking." This consists of placing the skins before an odd-looking machine which has a whirling wheel equipped with a circular blade. This machine removes from the pelage such guard hairs that would otherwise detract from the appearance of the fur. The skins are next "sheared." Shearing is done by special machines equipped with large blades running lengthwise and they shear the hairs of the fur side of the muskrat pelt so that all will be of a uniform depth. This being a very important operation, the blades of this machine are set and gauged to a nicety so that, while the fur is cut down, a sufficient amount of fur of a desirable softness and depth. remains. 
This accomplished, the muskrat skins so treated are immersed in huge dyeing vats, where the chemicals act upon the lower part of the hairs. While being dyed the skins are also subjected to mixing. This first dyeing is lighter in tone and hue to the dyeing received in subsequent operations, this being done so as to accentuate a difference between the colors of the dyes and that a coveted lustrous effect be secured.

After the initial dyeing the skins are placed in a horizontal centrifuge, a machine resembling somewhat a huge bass drum, and in this appliance the skins are revolved at a very high speed. Due to the centrifugal force thus created, all superfluous liquids in the pelts are thrown off and, when this extractor is stopped and the skins removed, it is found that the pelts are not only practically dry but thoroughly pliable and very susceptible to the dyeing process which follows.

Before securing this second dyeing the muskrat skins are removed to a drying room, which is heated to an even, predetermined temperature and with fans keeping this heated air in constant circulation, the skins dry evenly. A drum, containing an amount of sawdust, next receives the skins and through this drumming operation the skins are revolved in the sawdust, which cleans the fur and pelt of all foreign matter which might have accumulated in previous operations, and it might be added that the drumming operation is repeated at the finish of all subsequent operations to insure a thoroughly cleaned pelt leaving the establishment.

Hand-applied black dye and dye applied by certain mechanical contrivances follow so as to give the finished product a solid, velvety and lustrous black demanded in the better grade of Hudson seal by the trade and the women who still yearn for a black fur in this day of the more bizarre effects and a demand for the natural color of the pelage of wild animals.

After the dyeing processes have ended, the skins are finally fleshed to remove any particles of flesh or grease from the pelt side of the skin. In this operation a special 
fleshing blade is required and it removes all excess grease, flesh and extraneous matter accumulated during the processes the muskrat skin has been subjected to during its conversion from a lowly 'rat to a stylish "seal".

After being drummed, the skins are unhaired-that is, the long, stiff guard hairs which escaped the initial shearing process are removed by a revolving blade which insures an evenly surfaced fur and again sheared to make the finished fur one of velvety evenness, and the operation is ended save for packing and returning the skins to the manufacturing furrier, who cuts the small pelts into strips, sews them together, and models the garment that is placed on sale in fur shops as, if the retailer follows the truth in advertising prescribed by his own trade, "Seal-dyed Muskrat (Hudson Seal)." 


\section{CHAPTER TWENTY-SEVEN}

\section{GRADING FUR PELTS}

O ACCOUNT of confusion among many trappers, fur merchants and conservation officials and agents as to the meaning of the terms "prime" and "unprime" and "legal" and "illegal" when applied to raw pelts of fur animals, the biological survey of the United States Department of Agriculture has made the following explanation of these terms, which is out of place at the beginning of a chapter on the grading of fur pelts.

Primeness is determined by examining the skin side, which, if the pelt is fresh, should be fairly white or cream colored, and show some "life" when handled. Black or blue spots in the skin indicate that it is unprime. Skins turn yellow with age and lose their firmness. The outside of a prime fur should be perfectly and evenly furred all over, both on the back and on the belly, with the fur reasonably long, lustrous and silky. There should be no rubbed spots or defects. A trapper cannot tell whether a pelt is prime before he skins the animal, however, for the outside appearance is not conclusive evidence in the matter.

"Legal" and "Illegal," on the other hand, relate specifically to furs taken in open and close seasons-purely a question of date. If a fur animal is trapped after the opening of the season, then it is taken legally, and the skin is termed legal, although on examination it may be unprime. An animal caught after the close season, on the other hand, regardless of the condition of the pelt, is taken illegally.

A frequent defect in the fur laws of the various states, and this was long the case in Louisiana, is that the open season is so long as to permit trapping before the pelts are prime in fall and after breeding is in progress in the spring. The only application, then, that "unprime" could have to the law would be to unprime skins taken in close season. These, as well as all other's taken in close season, would be illegal. 


\section{Grading Fur Pelts}

Every trapper cannot expect to be a fur grader, but it is very necessary that he know something about the manner in which furs are graded by the raw pelt dealers, as grading the pelts of fur animals determines their value in the marketing. What follows is a concensus of opinion as to what constitutes furs as the fur market men view the skins sent them by the trapper.

It is hardly necessary to say here that some experienced graders judge pelts in one way and other professionals differ in their methods of judging, and what is set down in this chapter is written more as a desire to acquaint the trapper-reader with a brief outline of what the graders look for when handling a fur pelt so as to fix a price on it, rather than attempt to set what might be construed a "standard grade" for Louisiana furs.

\section{Prime Pelts}

There are two kinds of skins," prime" and "unprime," that are sent into the fur market by the man who takes the animal in his traps and the price the trapper receives depends first of all on this first classification. A prime skin must have a bright, healthy, reddish flesh-colored pelt and on the other side it must be very well furred with no rubbed spots, cuts or holes. The skin must have been properly stretched to come within this rating and in size must come up to what constitutes a full-grown adult animal.

\section{UNPRIME PELTS}

A pelt is usually classed as an unprime skin when the pelt side exhibits sufficient characteristics to grade them as such. A pelt that falls into this classification is usually bluish, instead of being reddish flesh-colored, and graders usually refer to such skins as "blue." Unprime pelts are frequently graded as Nos. 2's, 3's or 4's, according to size and the quantity of fur shown on the opposite side of the skin.

The blue pelt, however, almost invariably denotes that the animal was taken at a time of the year when 


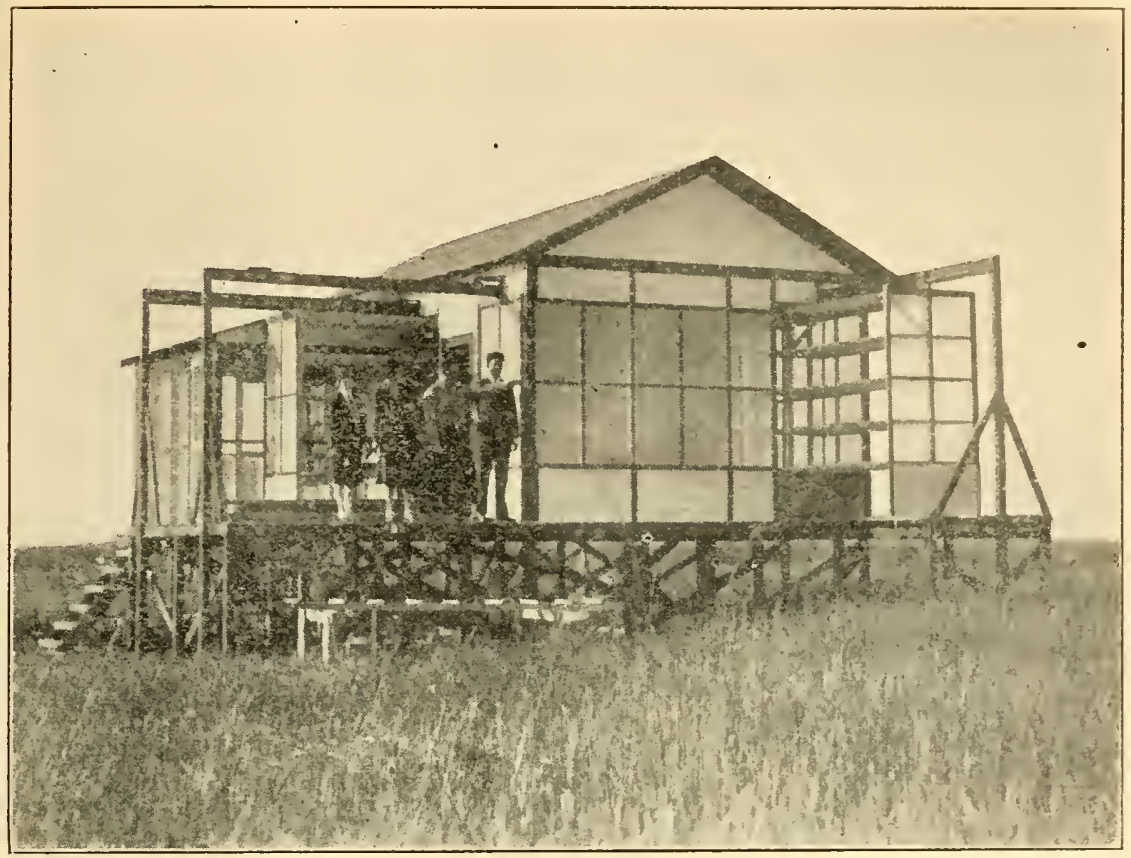

Modern fur drying house erected by the Mt. Forest Fur Farm on their Plaquemines parish 'rat ranch. The transparent sides of the structure are of celloglass, a treated cloth that admits light but keeps water out when it is raining, and when the atmosphere is dry the racks are run out by aid of the overhead rails.

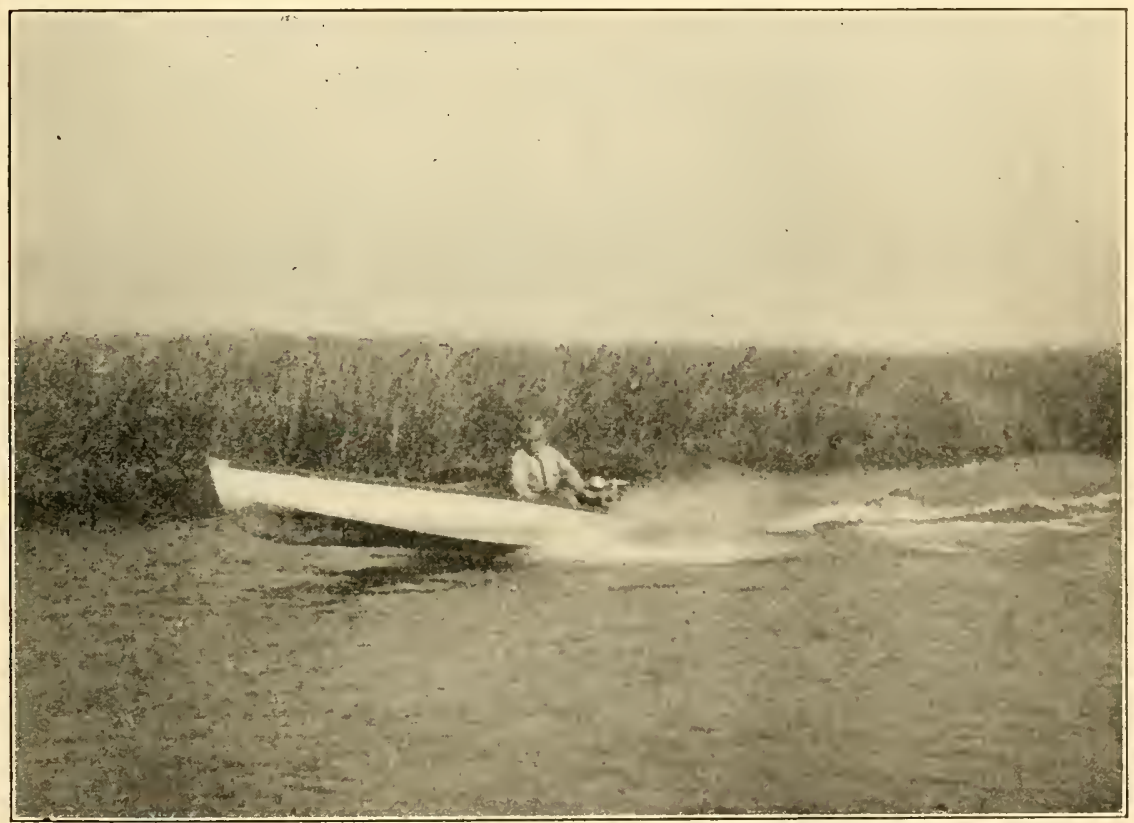

Shallow-draught speed boats made of metal and high-powered out board motors permit the big rat ranchers to adequately guard their fur marshlands. 
the pelage was not at its maximum growth and, therefore, an unprime skin is an unseasonable one. This shows a very excellent reason for the state laws that exact open and close seasons for the fur animals of Louisiana.

While it is true that blue-pelted skins are sometimes laken off of animals trapped in midwinter, this marking of the pelt is quite likely to be due to an unhealthy condition of the fur-bearer.

As a general rule, furs caught late in the season, which means early in the spring, have a shedded and rubbed pelage and then they become what is termed, in the parlance of the fur trade, "Springy," and as a consequence grade off in value. When out-o-season skins exhibit prime looking pelts, but on curing become dry and brittle, it will be noticed that the fur is flat, rubbed, and has a tendency to fall out. Such skins are graded 2's, 3's and much lower, according to the condition of the pelage.

\section{Pelt AND PELAGE}

In the foregoing the words pelts and pelage have been used to describe various conditions of the skins of fur animals. The "pelt" is the flesh or inside of the hide that is taken from the fur animal, while the "pelage" is the growth on the outside of the hide, which in most skins is the mixture of hair and fur that give the animal its protection in life and its value in the fur market. In grading furs both the pelt and the pelage must be considered.

The color of the fur on a skin that goes into the market has a decided effect on the price that it will bring the trapper. This is especially true with muskrats, mink, raccoon, and otter skins. With opossum, skunk, wolf and fox pelts the profusion of pelage is the contributing factor in grading. With the furs of the first-named division, the general rule is that the darker pelage skins bring the better prices. Mink possessing a silky, glistening ("alive," the experienced grader and furrier call such fur) will always bring a higher price that a brown mink, irrespective of size. Dark colored and heavily furred raccoons will always average higher in price than like animals 


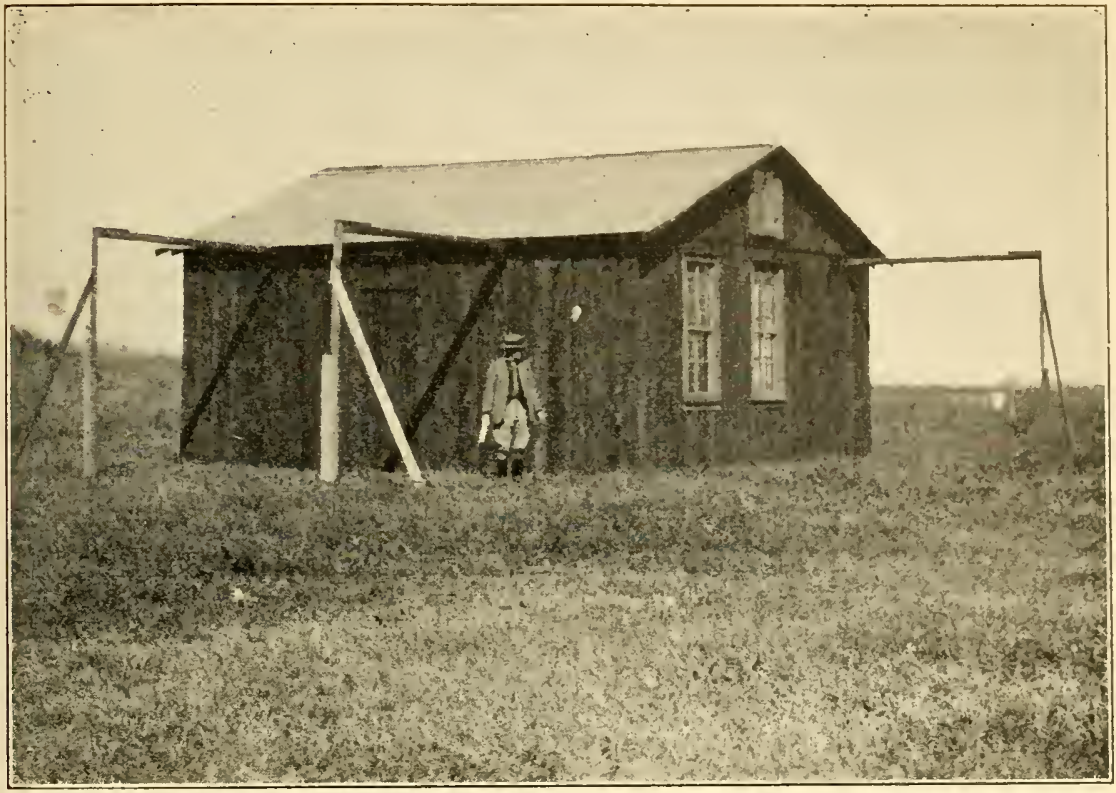

Drying shed on the Louisiana Coast Land Company's holdings in Vermilion parish. The house is closed with the racks inside for drying pelts in wet weather.

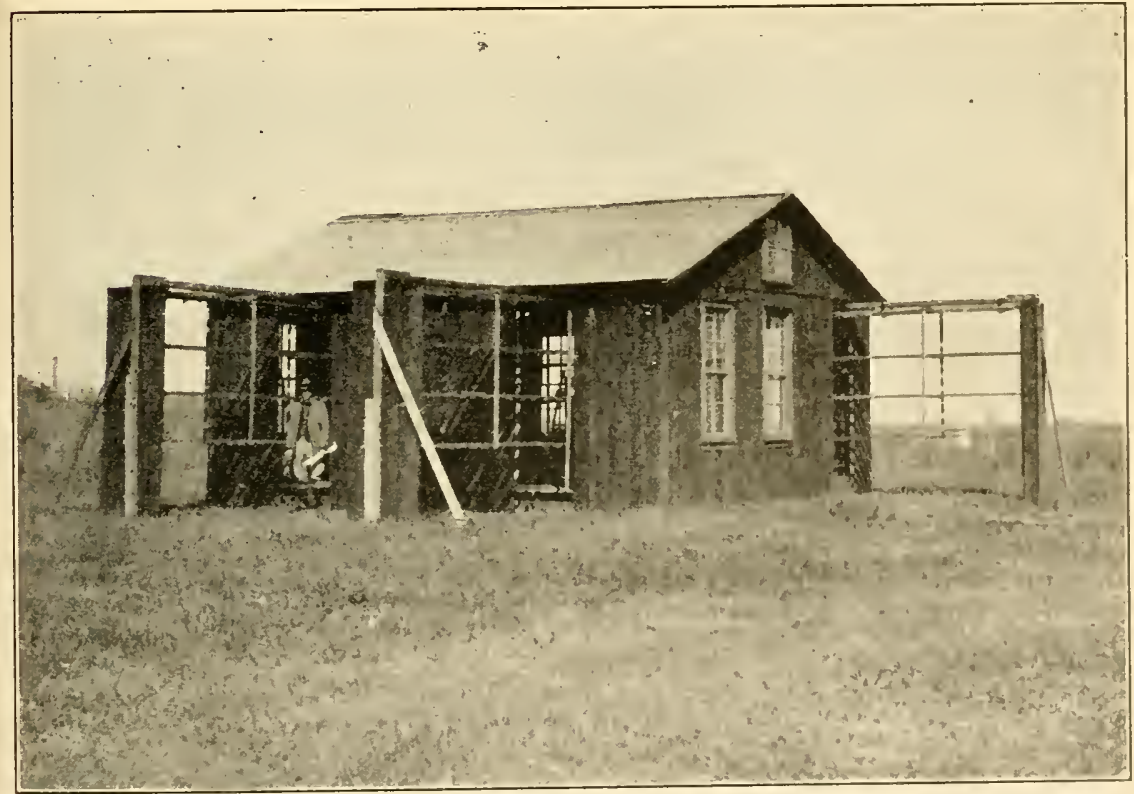

The same house with the drying racks extended for drying muskrat pelts in dry weather. This type of dryer is being adopted throughout the coastal muskrat marshes of Louisiana by the larger rat ranchers. 
which are just ordinary 'coons, and the swamp 'coon is always a better animal than the marsh, or "Salt water" coon, as the latter is usually yellowish or "rusty," a pelage condition due largely to the fact that the marsh 'coons become "burnt" from the sun, whereas the swamp raccoons have the shade of the swamp tree growth to protect its fur from the bleaching effects of the sun's rays.

\section{OPOSSUM FUR}

Good No. 1 opossum skins deep with fur can either be used in the natural state or they can be dyed in splendid imitation of skunk and other kinds of fur, and, therefore, can be sold at a price much under the genuine article that it is made to resemble.

For this reason it is necessary for a No. 1 'possum to be prime with underfur deep and fully developed, free of so-called "weakspots" and of full size. If the underfur is skimpy, with the long, coase guard hairs predominating, the skin cannot serve any very useful fur purpose, and it is graded a No. 2, 3, or 4, according to condition and size.

Opossum pelts are never graded as largely by the pelt as are other fur animals, principally because of the large amount of fat that remains on the skin, the depth and quality of the underfur are the principal items to be considered in grading them for the fur market. 'Possums trapped early in the fall or in the spring when they have begun to shed are usually of little value and this fur animal should be trapped in the middle of the winter.

In preparing the opossum for the fur market it should be skinned so that it can be dried cased with the pelage on the inside and the pelt outside of the stretcher.

\section{RACCOON FUR}

The raccoon has a skin that has come into such prominence in the fur world of late as to cause its value as a raw pelt to mount rapidly and, as this state is the foremost producer of this fur animal and because it occurs uniformly throughout Louisiana, it has become a factor in the returns earmed by trappers here every winter. 


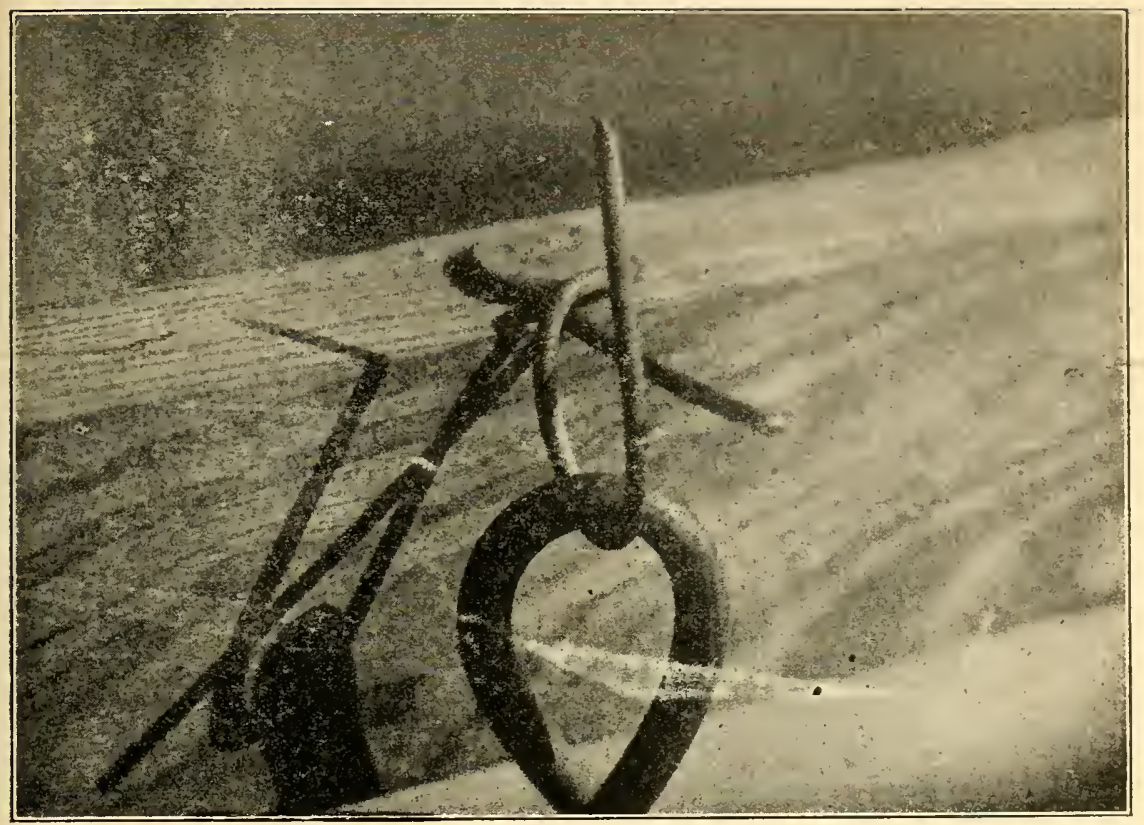

A simple and effective way to keep wire pelt stretchers from blowing off drying frames when high winds are blowing. A short piece of galvanized wire, bent as shown in the photograph, and held in place by a roofing nail does the trick.

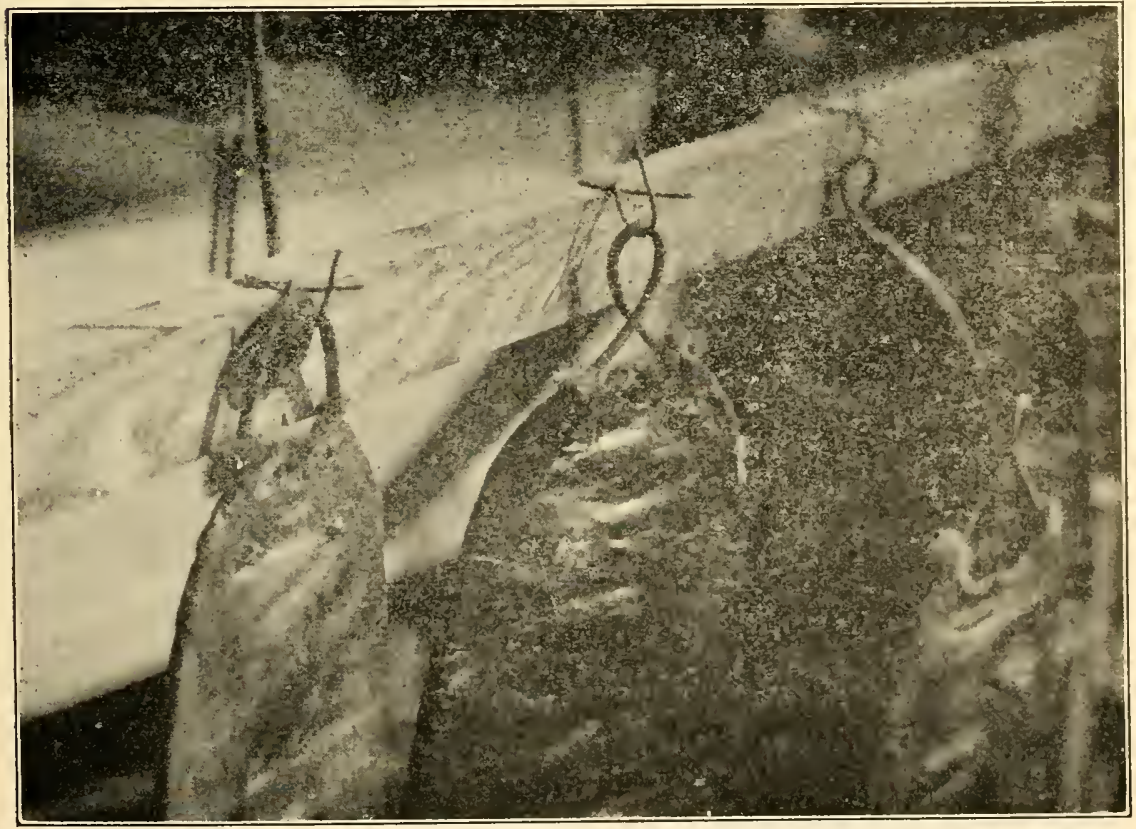

This method of securing stretchers to the drying racks was evolved by Elmer and Bobby Bowman, veteran trappers of Cameron parish. 
Primeness of pelt is a very important factor in grading this fur and any tendency toward bluishness will naturally bring down its value in the eyes of the raw fur dealer. The condition of the pelage, its depth and color and markings are so carefully scrutinized by the grader, as the raccoon is one of the few fur animals that are cured stretched open and should never be cased when dried. The manner in which the skin has been handled in stretching it for drying also affects its grading. For this reason the 'coon skin should be stretched absolutely square, as shown in the accompanying illustration.

Prime 'coon skins, with good dark color, size and shape, and density of fur, would be graded extra large No. 1's, medium No. 1's, and small No. 1's, or No. 2, No. 3, No. 4.

Any pale, reddish or rusty-sometimes termed "yellow"-laccoon skin, irrespective of size or thickness of pelage, even though exhibiting a prime pelt, would not be graded a No. 1 of any sort.

Raccoons must never be trapped late in the winter, as they have a tendency to get "springy" very early, and this lowers the grading considerably. A reddish spot on the back of the neck is usually the sign of a late-caught 'coon and the color markings have a tendency to become faded.

What has been written above under color should be studied again in obtaining an idea as to raccoon grading.

\section{OTTER FUR}

In the consideration of an otter and the price its pelt will bring, it must be remembered that sizes of otter's taken vary considerably, as does the underfur and guard hairs and the color of the pelage. The color of the fur of the otters taken in Louisiana are seldom very uniform, some being very dark brown, while other are light enough to be termed almost yellow.

Just what causes this wide range of color is not known, but it is safe to presume the temperature of the water habitat has something to do with it, as it is a fact that otters from the hot climates of Mexico and Central 


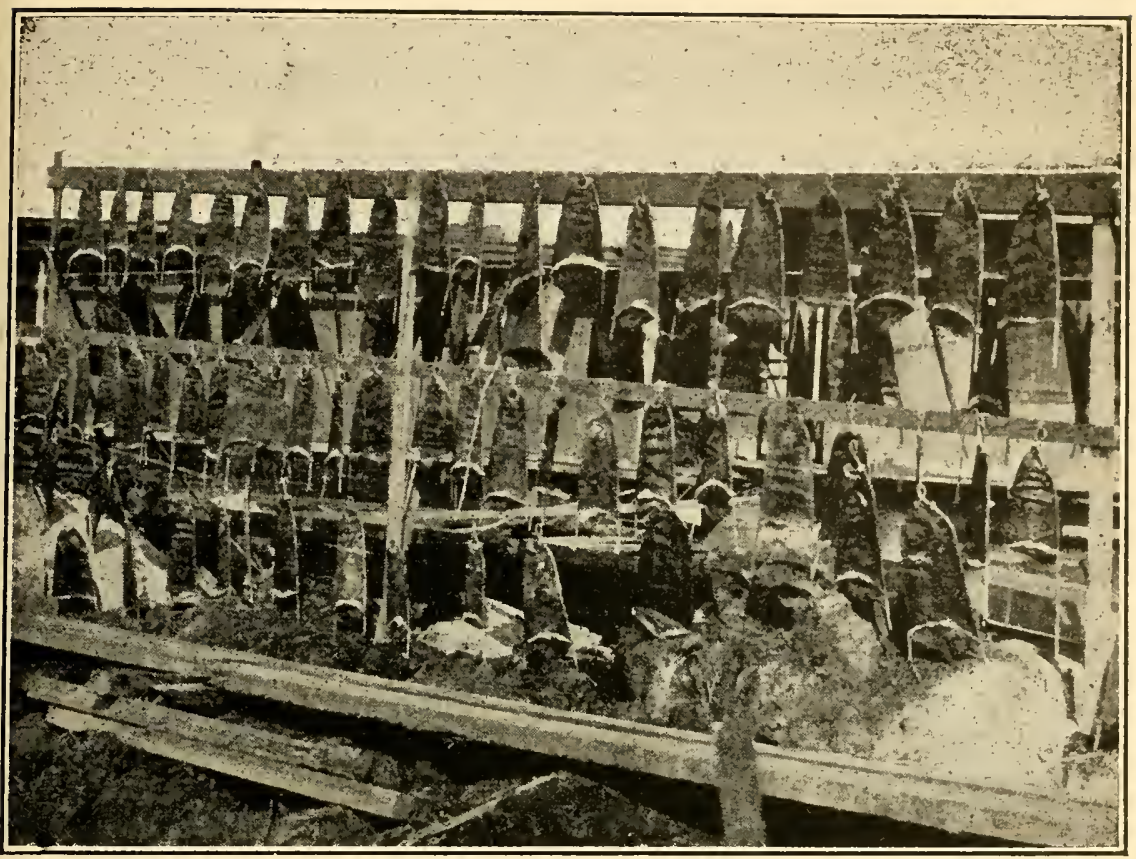

Muskrat pelts, which sold for $\$ 1.45$ a pound, being cured in the open air.

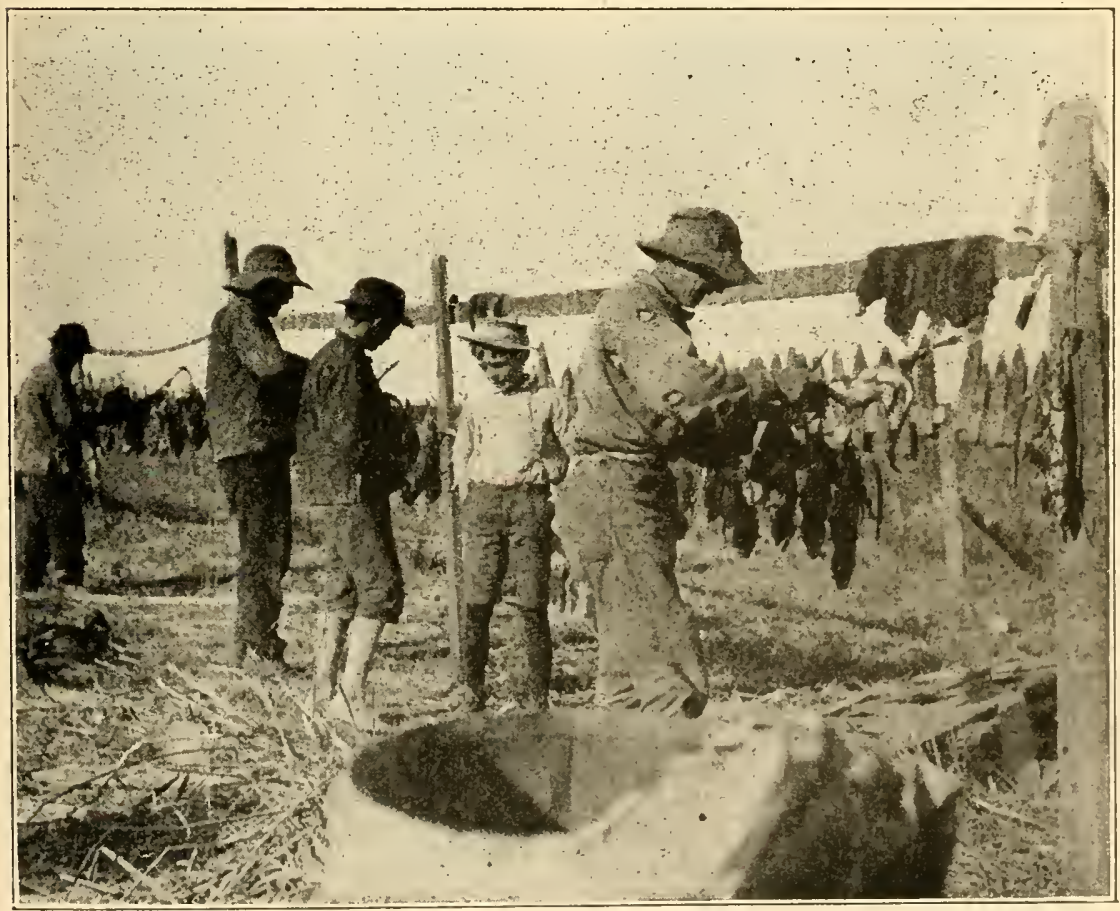

A trapper's camp and catch of muskrats in the coastal region. 
America are very poor in quality and color. In Louisiana, otters from the very mouth of the Mississippi, such as Pass a la Loutre, are very good in color, size and density of pelage, as these waters always run cool, even in the hot summer months.

To grade as a No. 1, an otter skin must be prime and flesh-colored, full furred all over the body, as well as rich brown in color. An otter skin that is well furred, but which shows an unprime pelt, will be graded as a No. 2 . It is quite certain that a skin with a dark blue pelt will be flat as to fur and light as to color, and graders will only consider as a No. 3 or even a No. 4 and pay accordingly.

Otter skins show at times a decided tendency to be "singed", as a slight curling of the ends of the fur and hairs is termed, and regardless of size and primeness of pelt or other qualities will never grade above a No. 2 or No. 3.

The otter must be cased, like a muskiat, mink, opossum and skunk, when prepared for the drying board and, while it should be well stretched for this operation, the trapper should guard against over-stretching in an endeavor to increase its size.

\section{SKUNK FUR}

Skunk skins are graded first of all as prime or unprime and when this is determined attention is paid to the pelage. Dark blue or black-splotched pelts are graded as "poor skins" and, more frequently, termed "trash," and the trapper paid accordingly. The primeness of the pelt decided, the grader classifies the skin into one of four divisions: Black, Broad stripe, Short stripe, Narrow stripe.

To be graded a "black" the skunk skin should be entirely black of pelage with the exception of a white patch, sometimes called a "star," on the head, or it may have a short, narrow stripe of white, which does not extend beyond the neck. This is the most valuable pelt.

A "broad stripe" has two very wide streaks of white hair, which extend the full length of the body. This is the least valuable pelt.

For a skunk skin to be called a "narrow stripe," the white markings must extend in a narrow width along each 

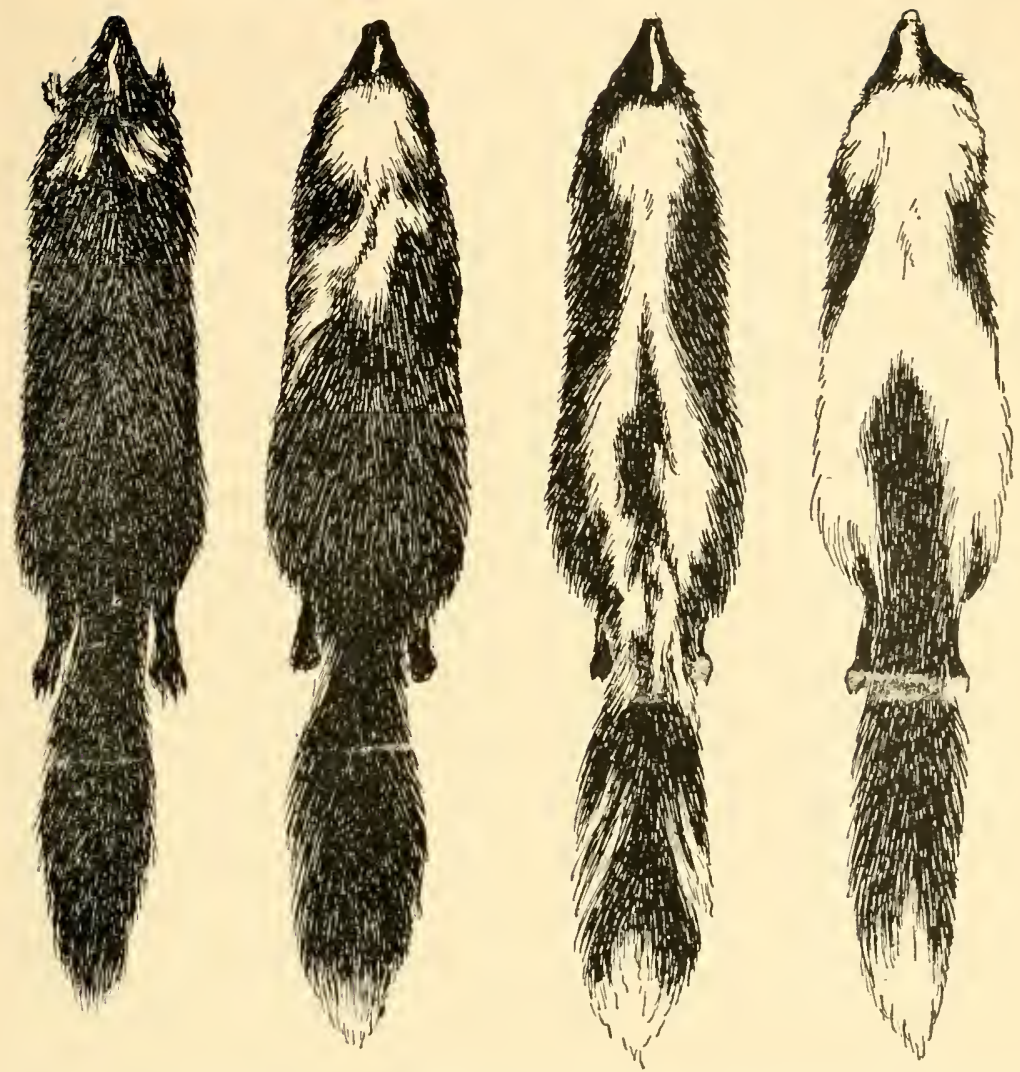

Four grades of skunk pelts. On the left is a black skin, showing very little white; next is the so-called "star" pelt, then a narrow stripe and, on the right, a broad-stripe. in the market the more black on a skunk pelt the more money it will earn the trapper.

side of the back, while a "short stripe" skin is one in which the narrow white markings do not extend the full length of the animal's body. These two skunk skins grade between the blacks and the broad-stripes.

Formerly a skunk skin was graded down according to the amount of white hair the animal developed, as the white parts were cut out by the furrier in fashioning a garment and only the black hairs and furs used. When cutting was resorted to, the whole skin was dyed black, but this robbed the fur of its chief beauty, a rich, glossy, alive black. Of late years the use of the whole skunk skin with white as well as black pelage for collars, flounces, 
etc., has been popular with furriers and for certain modish fur garments. Broad-stripes have brought almost as much as short stripes, when used for collars or silver and golden muskrat coats and jacquets.

The designation of Nos. $1,2,3,4$, etc., is never used in grading skunk furs.

\section{WOLF}

A wolf skin, like that of the opossum, is seldom graded oy size or the appearance of the pelt. According to some graders and dealers, the value of wolf skin is determined by quality of the fur and the best prices are paid for skins possessing a soft and silk-like pelage. Skins which have long hairs with little or no fur are limited to uses in the fur industry and therefore do not command a price, regardless of the size of the skin. This holds good for skins with a good quantity and quality of fur, but which also possess a coarse mane down the back, as this must be cut out by the furrier when preparing the tanned skin for manufacturing use.

The color of a wolf's pelage is not to be taken into consideration when grading the skin because it is almost invariably dyed before being made into garments. Nor is size an important factor in determining the value for, as stated before, coase and thinly furred skins are not worth nearly as much as the better and softer furred specimens.

As with other unprime pelts, the wolf skins are always graded No. 2's or No. 3's or even lower, depending on damage, rubbed or other like factors.

The wolf skin should always be cased when prepared for drying and never stretched out like a raccoon skin.

\section{GRAY FOX}

To grade as a No. 1 fox the skin must be prime of pelt with the entire outer side covered with a full coat of fur. A No. 2 skin is usually unprime of pelt, but possessing a full pelage of fur, while prime pelts, with slightly rubbed fur, or if slightly damaged, will also grade a No. 2. Any badly rubbed or poorly furred skin is graded as No. 3. Skins 
that all are hair or damaged fall into the No. 4 category.

Usually, foxes trapped in the early fall are blue pelted and, as a consequence, very thinly furred, being consequently of little or no value, while late-caught gray foxes, although prime pelted, and usually "springy," or, at least, badly rubbed, and the trapper, therefore, cannot expect anything but a poor price for a poor skin.

The fox must be cased when prepared for the drying operation or it is not worth while to send it to a dealer.

\section{"CiveT"}

The little striped skunk, or "civet," as those in the fur" trade persist in calling this diminutive brother of the common skunk, when considered by the fur grader, falls into one of the three grades: $1,2,3$.

In contradistinction to the grading of the common skunk by the amount of white found in the pelage, no attention is paid to the white markings of the little spotted skunk, but to grade as a No. 1 the pelt must be prime and the pelage well furred. A No. 2 is usually well furred, but with a bluish pelted skin, while the No. 3's are those skins which are dark blue of pelt and with thinly furred pelage.

The little striped skunk must be cased after it is skinned off the body and well cleaned of fat.

\section{MUSKRats}

Muskrats from Louisiana are usually referred to in the trade as "Southern 'Rats" and in grading them no numerals are used, but special designations have become established in the fur trade. While it is true that color plays an important part in determining the price that is paid the trapper, the dark, furred and reddish colored pelts command the best prices.

The following classification usually determines the value:

"Tops," "Mediums," "Seconds," "Flats," and "Kits" and "Damaged." It is quite true that when these Louisiana muskrats reach the eastern market and offerings are made at such sales as the New York Fur Auction Company and 
other companies put on, that selected lots are placed on the block as "Extra Large and Large No. 1's," etc., still the Louisiana trapper never sells his catch in this manner, but confines his trading to Tops, Mediums, Seconds, Flats and Kits and Damaged, or sells his entire catch to the fur buyer at so much a "round" or "by the nose," as the expressions go, when a sale is consummated by the trapper receiving, say, $\$ 1.05$ each for every muskrat in his collection and no attempt is made to grade the catch.

A muskrat to be graded a "Top" must be prime of pelt, of good size, heavily furred and of good color as to fur. Little attention is paid, as a rule, to the color of the belly. A "Medium" will have to grade very much like a "Top," but will not come up to the higher priced skin as to size.

A muskrat "Second" is usually a skin with an unprime pelt, or it may be a prime pelt having a lack of dense fur, or the guard hairs may lack "life" or be noticeably rubbed.

When the muskrat skin is termed a "Flat" it is because it is so lacking in underfur as to feel flat when the fingers are passed over the pelage, or it may also be deficient in guard hairs, and the pelt denotes its unprime condition. A flat usually proves to be a skin taken from an animal trapped so early in the season that its winter pelage has not had time to develop, but which, if it were taken in the middle of winter, would have become a Top and would have been worth double the amount received for it as a Flat.

"Kits" and "Damaged" denote a collection of muskrat skins taken from half-grown animals (the word being derived and shortened from the term "Kitten," such as applied to the young of domestic cats), while the "Damaged" term is applied to all classes of skins that have been damaged by knives when skinned, by hawks, blackbirds, other muskrats, while held fast in the traps before the trapper markes his round to collect his catch of the night before. "Mice" or baby muskrats frequently are taken in the traps and such skins are placed in the "Kits" and "Damaged" collection.

When a trapper finds a large percentage of kits and mice in his traps it is invariably an indication that his area is being trapped too hard, or that he is placing his traps 


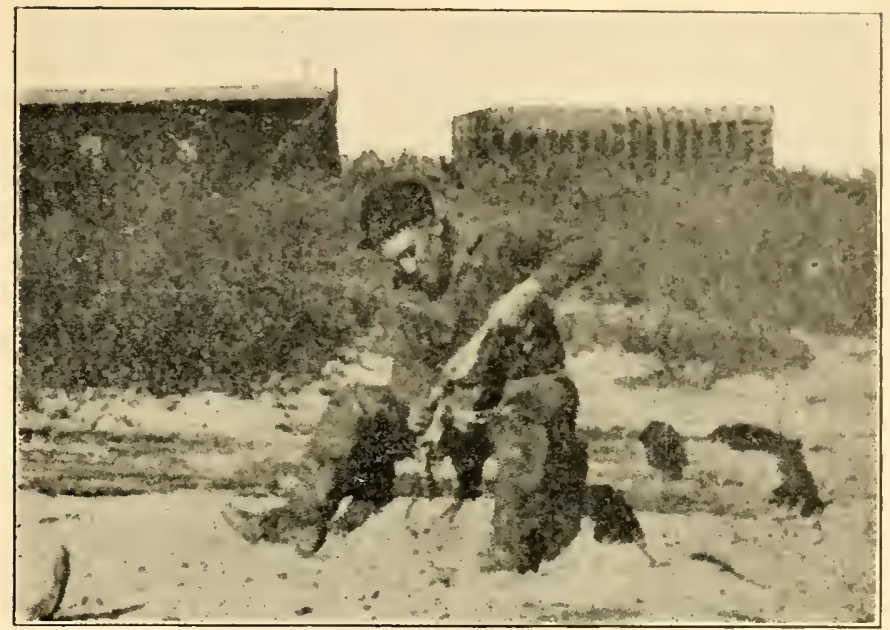

Irapper skinning a muskrat. Note the big drying rack in the back. ground with thousands of pelts being cured.

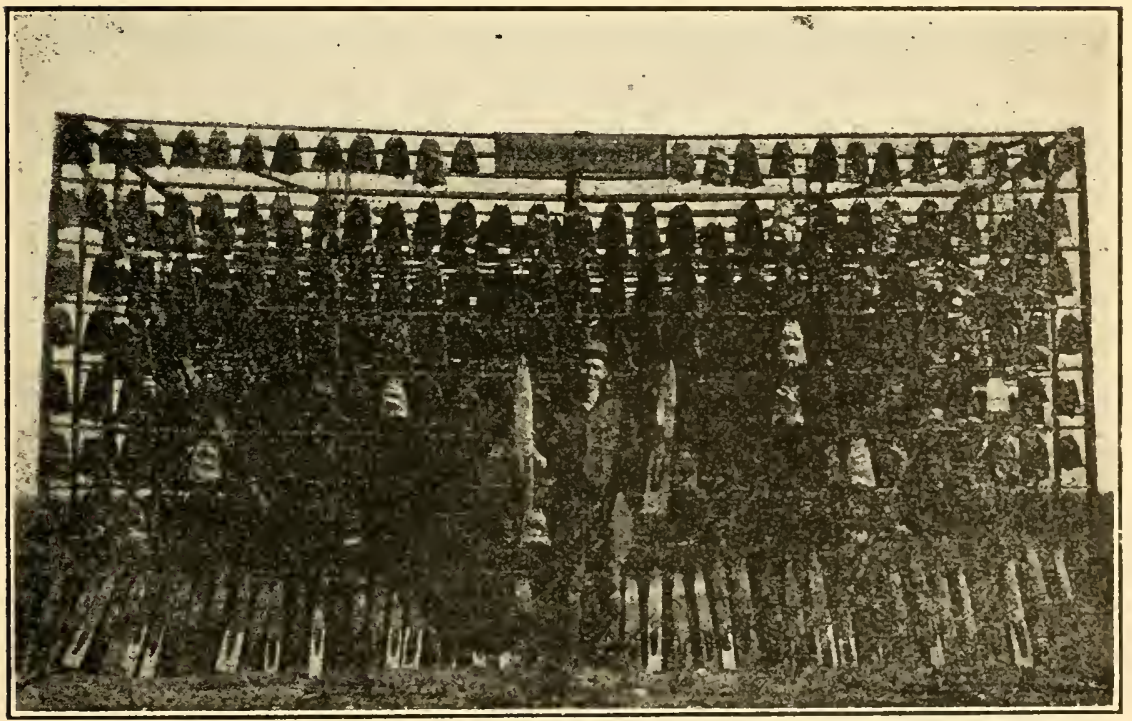

Curing 70,000 muskrat pelts, to say nothing of $47 \mathrm{mink}$ skins, at one operation on a rat ra* $\mathrm{cn}$. 
too close to a house or "hill," and the remedy is obvious. He should change his trap line or he is violating the Louisiana law by setting his traps closer than 10 feet of a house.

The muskrat, to bring the best price, should never be trapped before December 15, nor later than February 15; should be skinned carefully, washed, run through a ringer, cased on a wire stretcher, and dried in the shade with the pelt side out. Drying by artificial heat, such as near a stove, or curing in the sun's rays does not produce the raw pelt that comes from curing in the shade with a brisk north wind blowing.

\section{WILD CAT}

The baby lynx, or "wild cat," to bring a top price when offered for sale, must have a prime pelt and be well furred. If it possesses these it can be graded a No. 1. As a rule, the grader determines that a No. 2 is a skin that is well furred, but whose pelt is unprime, or the article may be prime of pelt but is slightly damaged as to pelage, or the hairs may show a tendency to shed. The No. 3's and No. 4's ar'e usually flat, thinly furred skins, graded as to size.

The wild cat must be cased to cure it and never opened for the drying operation.

\section{BEAVER}

While it is strictly against the law to trap a Louisiana beaver, or to buy or sell the skin of one, a few words as to how a beaver is graded may not prove out of place here.

The same general methods of grading beaver skins are followed as in the grading of other fur animals. The primeness and size of the pelt and the thickness, depth, quality and color of the under fur determines the value placed on it by the raw pelt dealer.

Like the raccoon, the beaver should be stretched open and not cased. But in stretching for curing, the beaver skin should not be dried square, a round or oval shape being demanded by the fur trade.

Don't trap a Louisiana beaver, or a conservation agent will get you! 


\section{CHAPTER TWENTY-EIGHT}

\section{SKINNING, CURING AND SHIPPING FURS}

HEN a trapper has succeeded in taking an animal in his trap the next operations are the preparation of the skin so that it can be handled by the fur trade; namely, the skinning the pelt off the carcass; its drying, so that it may be properly "cured;" and the packing and shipping of the collection of skins that the trapper may have accumulated by his endeavors in the woods and mar'shes.

There are two ways of skinning and curing a fur animal, depending on the species. It is either dried "open" or" "cased". The raccoon, beaver and bear should always have their skins taken off the body open, that is, so the entire skin can be stretched flat on a board.

The alternate way is to case the skin. All skins of the muskrat, mink, otter, weasel, opossum and skunks should be cased and placed on stretchers, with the pelt side out and the pelage or fur inside. In other words, the animal's skin is turned inside out for this operation. While the skins of the fox, wildcat and wolf are also cased, they should be dried on a stretcher with the fur on the outside.

The accompanying illustrations of the different Louisiana skins will show the proper methods of curing or drying better than written words.

\section{How to Prepare an Open Pelt}

To take the skin off a raccoon open, the trapper should cut the skin down the belly, down the back of the hind legs, and then on the inside of the fore legs. Aided by a sharp knife, the skin should be torn from the flesh, working from the belly to the back, removing the tail bone from its covering, cutting the skin on the lower side if necessary. Care should be exercised in skinning the head skin, which should never be cut off, as it depreciates the value of the pelt. 
When a raccoon has been properly skinned, place the pelt on a suitably sized drying board and with all the nails that are necessary, nail the pelt to the curing board with the pelage against the board and the pelt on the outside so. that the air can dry it. It is very important to strecth a 'coon skin square when preparing it for the curing operation, just as is shown in the accompanying illustration.

Before skinning any animal, if the fur is dirty, bloody or caked with dried mud, it should be washed until the pelage is cleaned. Allow the fur to dry. An easy way to do this is to hang the animal up by the nose or fore feet so. that the excess water can drain off in the direction the fur. lies. After it has dried, the skinning operation can begin.

Never use salt, alum, ashes or other preparation on a pelt when curing it. Simply let it dry in the open air, in a shady spot, if possible. Never dry a fur pelt by a fire or in the sun. Another caution to be observed in handling pelts after they have been cured, or while they are going through this process, is in not allowing them to become wet. or even damp.

\section{To CASE A PELT}

To skin a cased animal the trapper should begin by cutting around the heels of the hind legs with a sharp skinning. knife. The skin from one heel to the other should be slit, and, in skinning the muskrat and opossum, a cut should be made around the tails, as there is no fur or hair on them; there is, consequently, no need of saving them.

With the other fur animals, mink, otter, skunk and weasel, fox and wolf, the tails must be saved. This is done by slitting the skin on the bottom side about one-third of the way down and removing the tail bone. This accomplished, the skin should be worked down over the body, using the skinning knife when necessary to sever adhering flesh. This can best be accomplished by suspending the carcass from some object by the hind legs. The use of a skinning "gambrel" will hold the carcass in such a way as to permit the trapper to use both hands in the operation allowing him to pull the skin and cut at the same time. 


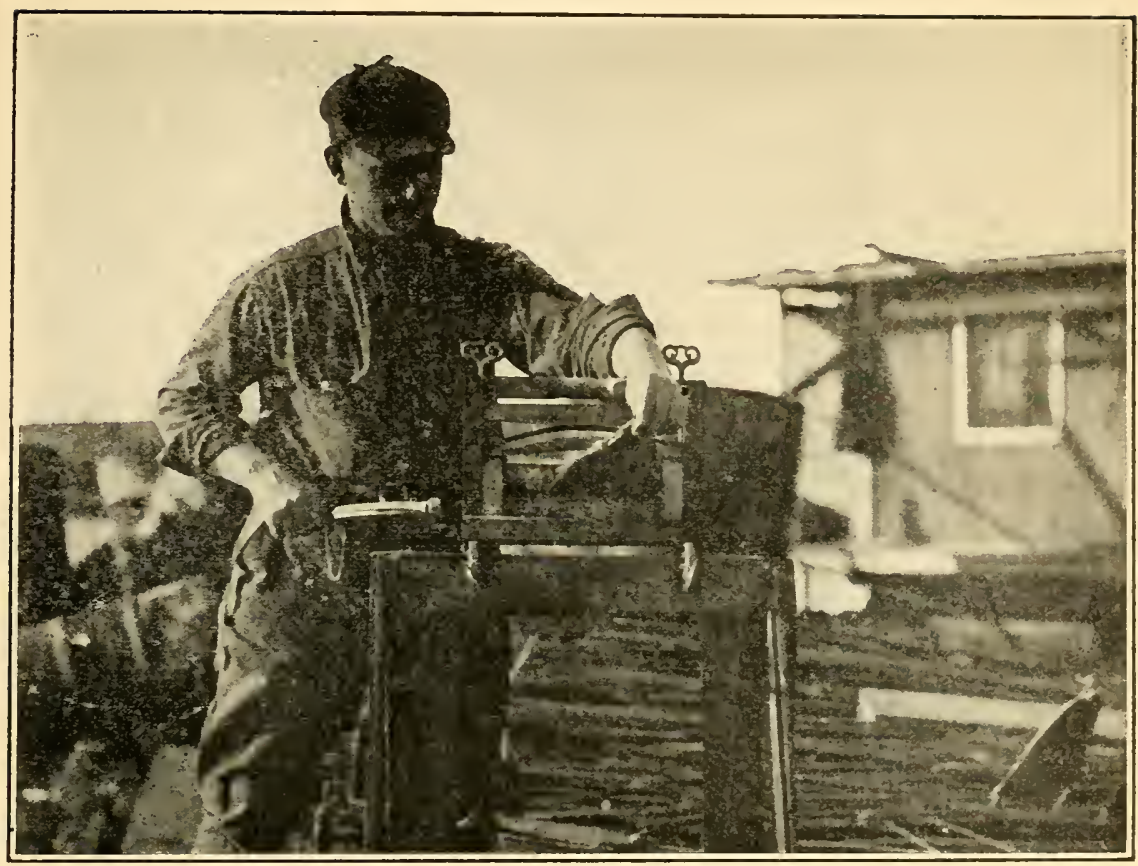

A Louisiana innovation. An ordinary clothes wringer is used to clean off the fats, meats and water on a freshly skinned muskrat pelt before it is stretched and hung up to cure.

When the shoulders are reached it will be found that the skinning knife will be needed to sever the muscles from the skin, and when the head is reached, care should be exercised in cutting about the eyes, ears and nose so as not to tear the skin or to leave large holes.

If the skinning process has been done properly there will be little need of "fleshing," as the operation of removing the surplus flesh and fat from the hide after it has been removed from the carcass is called. It is well to take pains and extra time in removing all fat, as otherwise the pelt will "burn," which will cause the fur to loosen.

\section{DRYING OR CURING}

The skinning accomplished, the pelt must be placed on a stretching board or wire frame. While stretching boards have been used for many years by the trapping fraternity 
to dry their furs, the inexpensive and more efficacious wire stretchers have superseded wood, especially in the curing of muskrat skins. Wire stretchers can be adjusted quickly for any sized pelt and a space is provided for a circulation of air between fur sides, thus hastening the curing. When the pelt has dried sufficiently the wire frame needs only to be compressed and the dried skin slips off without sticking, tearing or otherwise damaging the hide.

Large cased skins, such as the otter's, still have to be cured on boards, for wire frames will not permit a proper stretching, and provision must be made for nailing the split tail skin out flat. In Louisiana most of the mink skins are still dried on boards, as are some larger skunk skins. In placing a pelt on any kind of a stretcher the sides of the skin must fit over the edges of the stretcher.

Some trappers make a mistake in overstretching a fur animal's skin; the reason for so doing is an endeavor to try and make a "large" out of a "medium" or a medium out of a "small". This practice usually does more damage than good, as overstretching causes a skin to become thin and it will then fall off in grading when the fur buyer comes around.

\section{Storing Cured Pelts}

When a pelt has been cured, and three or four days in proper dry weather is usually sufficient time for this necessary operation, the skins should be removed from the stretchers, strung on wires or cord and placed out of reach of rats and mice. The stringing of pelts should be done so that they do not lie too closely packed, for contact sometimes leads to "sweating," which is very damaging.

In packing furs for shipment they should be placed pelt to pelt, never pelt to fur, and wrapped securely in burlap sacking. Before wrapping, the owner's name and address and number and kinds of skins should be written on a tag and securely affixed to the skins, and again the wrapped package should carry his name, address and an itemized list of the contents on a tag. 


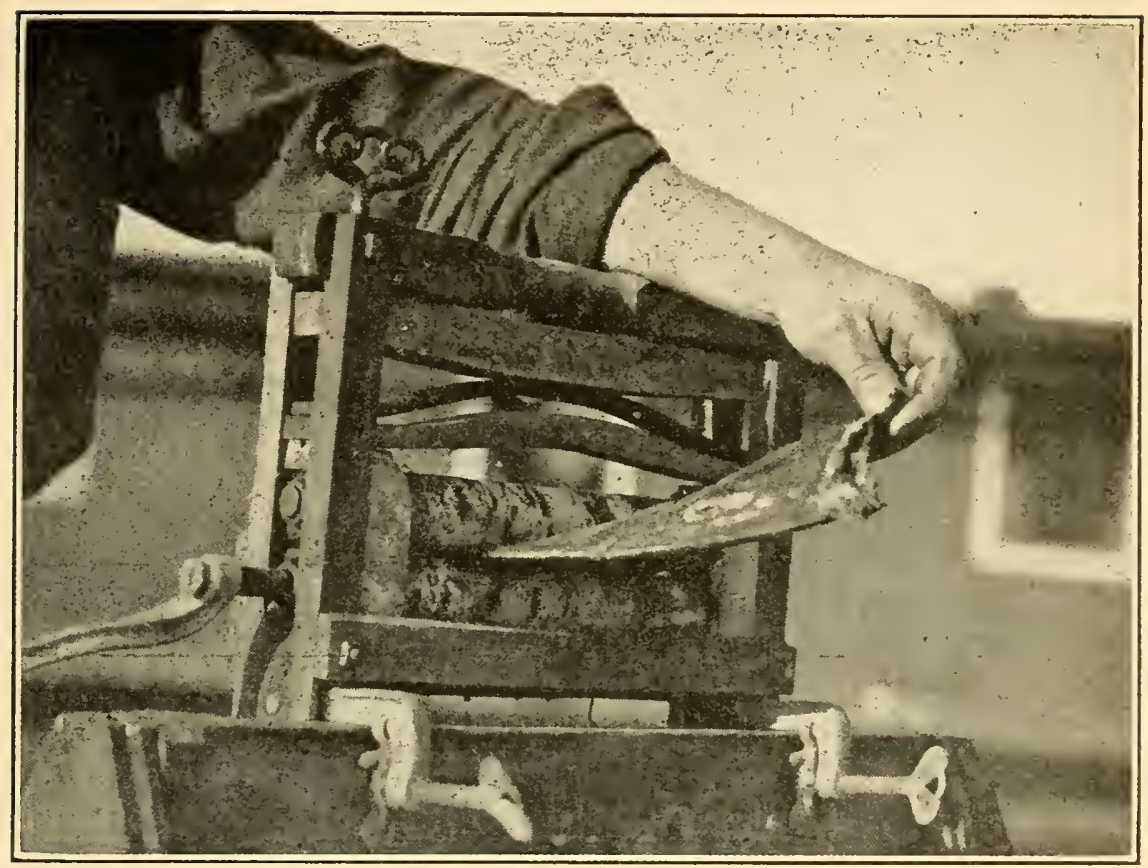

The use of the clothes wringer for cleaning muskrat pelts before they are hung up to cure is becoming universal in the Louisiana marshes and is recommended by this department.

In Louisiana all shipments of furs, whether sent by parcel post or express, should carry an official shipping tag issued by the Department of Conservation, which not only provides for the trapper's name and address but a list of skins contained in the shipment, a detachable section mailed to the Department of Conservation at New Orleans. A special shipping tag must be used, and if the consignment is to be sent out of the state the fur tax must first be paid or the furs are liable to confiscation by the Department's conservation agents. 


\section{APPENDIX}

\section{COMPARATIVE TAKES OF FUR ANIMALS}

I $T$ IS BELIEVED that many readers of this bulletin will be interested in knowing how the fur take in Louisiana compares with the production of furs in other sections of the North American continent. So that such matters can be studied by those interested, the tables that follow have been secured from authoritative sources and are in every way offiicial.

\section{Louisiana}

\begin{tabular}{|c|c|c|c|c|c|c|}
\hline & $1924-25$ & $1925-26$ & $1926-27$ & $1827-28$ & $1928-29$ & $1929-30$ \\
\hline Muskrat . & $6,236,165$ & $3,613,765$ & $3,036,749$ & $2,858,834$ & $5,105,374$ & $6,269,556$ \\
\hline Opossum. & 287,180 & 198,490 & 356,184 & 339,210 & 518,295 & 309,363 \\
\hline Raccoon . & 145,810 & 128,516 & 127,882 & 103,544 & 153,914 & 105,381 \\
\hline Mink. . & 84,201 & 51,447 & 43,896 & 67,284 & 99,844 & 69,680 \\
\hline Otter . ...... & 2,110 & 2,024 & 2,554 & 1,190 & 3,048 & 1,147 \\
\hline Skunks ...... & 14,752 & 30,866 & 27,671 & 22,348 & 38,940 & 27,034 \\
\hline Miscel. Pelts . & 947 & 1,058 & 1,095 & 1,072 & 2,655 & 1,877 \\
\hline Total & $6,791,265$ & $4,026,166$ & $3,596,031$ & $3,393,482$ & $5,922,070$ & $6,784,338$ \\
\hline Value. & $\$ 6,490,340$ & $\$ 5,528,982$ & $\$ 6,932,107$ & $\$ 5,125,363$ & $\$ 8,734,538.50$ & $\$ 4,681,111.75$ \\
\hline
\end{tabular}

The remark is frequently made that "while it may be true the great muskrat output of Louisiana does give that state the lead in numbers of pelts of all kinds that go into the market, the value of Louisiana's fur take is so much less than the furs taken in the more northern states."

Let us see if this is so. Quoting from the United States Biological Survey and the Canadian Dominion figures and from the year book of the National Association of the Fur Industry, we find the following figures interesting, to say the least: 
Value of Catch, 1924-25

United States

LOUISIANA

$\$ 6,490,340$

Michigan . ......... 3,000,000

Pennsylvania . ...... 2,500,000

Minnesota . .........2, 2,399,200

Tennessee . ........2, 2,000,000

Alaska . . . . . . . . 1,657,448

New York . ......... 1,500,000

Arkansas . .......... 1,500,000

Wisconsin . ........ 1,341,000

Texas . ............ 1,000,000

Maryland ............ 500,000

Kansas ............. 250,000

Oregon ............ 250,000

Virginia ........... 200,000

Vermont ........... 150,000
Canada

Ontario . ..........\$3,406,868.

Quebec . ............2,272,095

Alberta . ..........2, 2,030,974

N. W. Territory . . . . 1,780,666

Manitoba . ......... 1,589,078

British Columbia . .... 1,403,769

Prince Edward Island . . 326669

Yukon Territory ...... 309,549

Nova Scotia ........ 271,753

New Brunswick . ...... 246,091

All of which rather abruptly disposes of that argument as to the value of the pelts that come out of Louisiana each year.

"The United States, including Alaska, has been produring approximately seventy million dollars worth of pelts a year for several years past. Our seventy million-dollar production compares with Canada's fifteen millions and Russia's thirty-five millions. The last, however, includes all countries tributary to Moscow and should perhaps be better termed the Soviet's. These figures are approximate; those for the United States may be several millions too high, those for Canada and Russia are low, as the native trappers and their families use large quantities, points out David C. Mills, director of the National Association of the Fur Industry, in a recent article.*

"This comparison is astonishing because the United States appears in it as such a large producer. There are various reasons for this. For example, the Mississippi Basin is, as it always has been, an ideal section for wild life, with plenty of cover, plenty of water, plenty of food. For some of the animals, such as the opossum and the muskrat, we might add plenty of good company, for they exist in very large numbers.

*Mills, David C., The International Fur Trade, Journal of Home Economics, vol. 18 , No. 11, p. 625 . 
"Louisiana alone produces from four to six million muskrat pelts a year and under her wise administration of muskrat conservation laws there may reasonably be expected a ten-million skin collection in the course of time. From fourteen to seventeen million muskrats are taken each year in the United States.

"While trapping has been carried on throughout the entire Basin for several generations, and in some parts two hundred years, the smaller fur bearers have been able to hold their own by reason of first, their fecundity, and second, the extermination of their larger natural enemies. For example, the muskrats in Louisiana have multiplied as the alligators have been reduced in numbers.

"Another reason for the great collection of American furs each year is the fact that there are more trappers here than eleswhere. The population is greater per square mile here than in Canada or Siberia. Furthermore, our trappers are better equipped for their work than the inhabitants of the far north and other less advanced sections."

\section{FUR Prices From 1915 To 1928}

To give the reader a comprehensive idea of the gradual rise of the prices the Louisiana trappers received for their fur takes during the past dozen years the following table has been compiled:

\begin{tabular}{|c|c|c|c|c|c|c|c|c|}
\hline & 1915 & 1917 & 1918 & 1923 & 1925 & 1926 & 1928 & 1929 \\
\hline Muskrat & .08 & .15 & .25 & .50 & .83 & 1.20 & 1.25 & .60 \\
\hline Opossum. & .30 & .35 & .90 & 1.0 & .90 & .85 & 1.00 & .75 \\
\hline Raccoon. & 1.25 & 1.25 & 2.00 & 3.00 & 4.00 & 5.25 & 6.00 & 3.50 \\
\hline Mink...... & 1.33 & 1.45 & 1.75 & 5.00 & 5.00 & 5.50 & 8.00 & 4.00 \\
\hline Skunk . .... & .20 & 1.15 & .75 & .90 & 1.25 & 1.10 & 1.25 & .60 \\
\hline Otter . . . . & 6.00 & 6.00 & 8.00 & 10.00 & 15.00 & 15.00 & 20.00 & 15.00 \\
\hline
\end{tabular}

It should be borne in mind that these prices are the average the trappers received and not the highest given them by fur buyers for choice skins. For instance, during the past three years the price of Louisiana top 'rats soared to $\$ 1.85, \$ 2.55$, and even to $\$ 3.00$ when the pelts reached the New York markets-but the trappers did not get these 
fancy prices. In all of the figures given in this bulletin an effort has been made to strike averages and at prices received by the man who severed the product from the soil.

\section{A Final Comparison}

In comparing the total fur take of Canada with that of Louisiana, a table, "Fur Production of Canada," being found on an adjoining page, it seems quite fair to point out that the 1926-27 catch of the Dominion shows that our northern cousins include a variety of pelts from animals that do not appear in our lists, including farm raised animals.

For instance, their catch of 4,289,233 animals is swelled by the inclusion of a number of game animals, such as bears, rabbits, caribou, deer, moose, mountain goats and sheep, squirrels, as well as more than a thousand domestic cats! And their numbers are considerable. More than a million rabbits are included!

Were we to subtract the following:

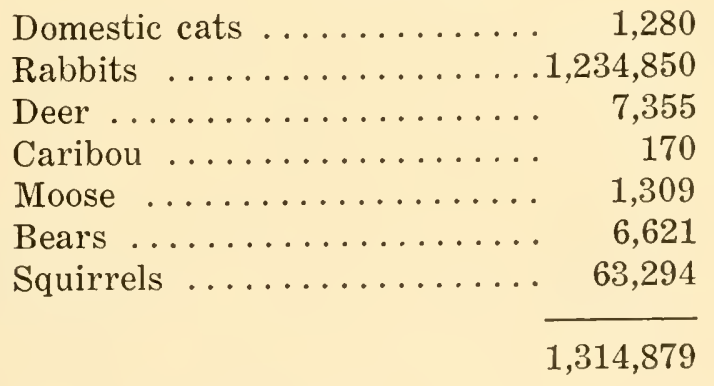

the Canadian production would amount to $2,974,354$ real fur animals, compared to Louisiana's production for the same season of $3,596,031$ pelts.

Due to the inclusion of many of the more valuable per pelt fur animals the total value of the Canadian fur crop exceeds that of Louisiana considerably, but subtropical Louisiana exceeds in the value of her fur crop that of any of the Dominion's provinces or territories, as a study of the table of fur value on page 409 will demonstrate. 
The comparative figures included in this section of our bulletin on the Fur Animals of Louisiana have been reproduced more for the sake of awakening in our own people an appreciation and realization of the remarkable value of the great natural resource that has been give us than any other reason, and it is the hope of the author that it will awaken a conservation and economic endeavor to keep such an industry with us as long as possible.

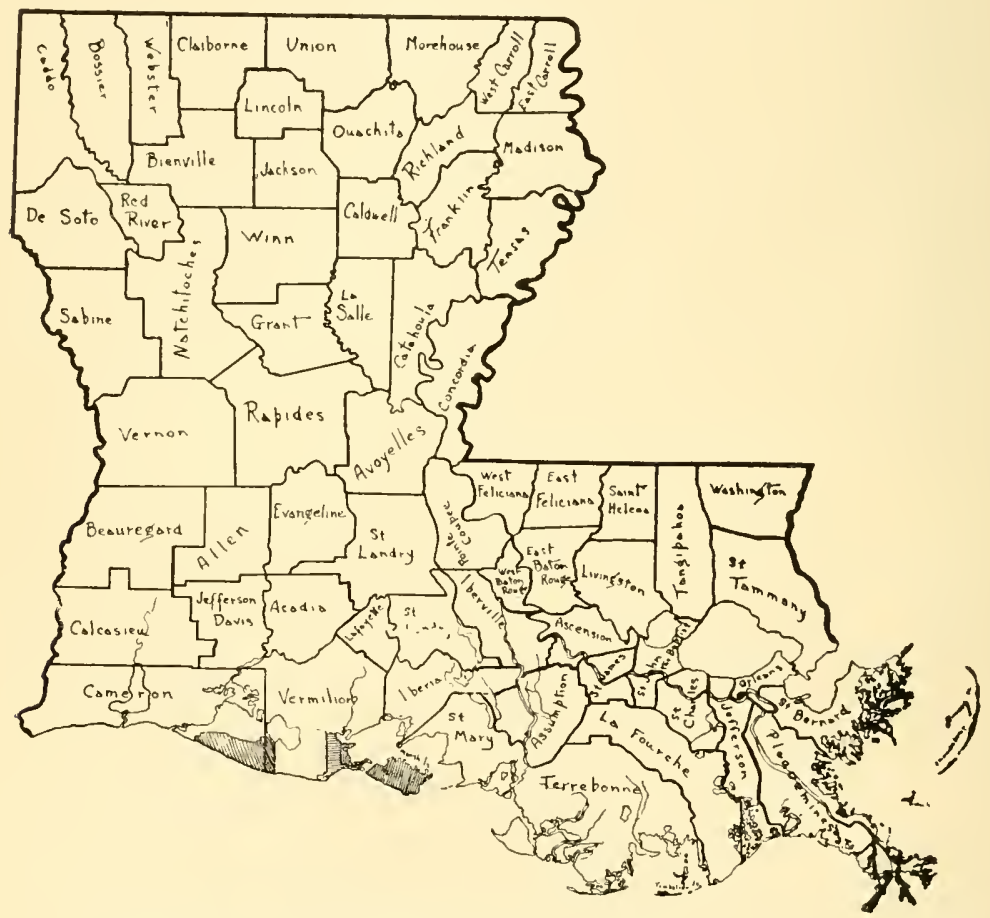

An outline map of Louisiana, showing the different parishes mentioned in this bulletin. The shaded areas along the Gulf Coast show the location of Marsh Island, Rockefeller, State and Rainey Wild Life Refuges. 


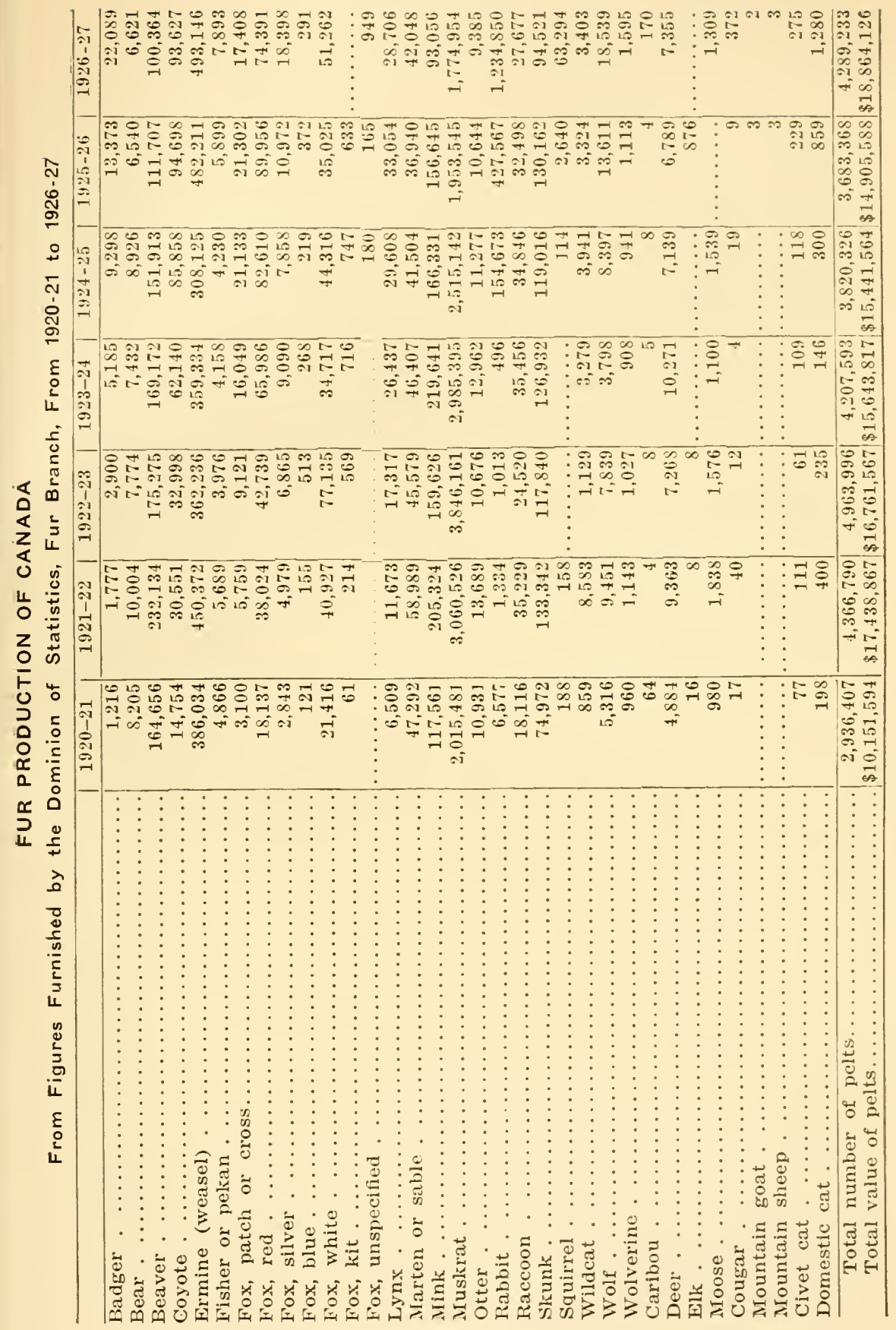




\section{Department of Conservation of Louisiana}

FUR TAKE IN THE DIFFERENT CANADIAN PROVINCES

\begin{tabular}{|c|c|c|}
\hline Ontario & $\begin{array}{l}\text { Season } \\
1923-24\end{array}$ & $\begin{array}{l}\text { Season } \\
1924-25\end{array}$ \\
\hline Badger & 28 & \\
\hline 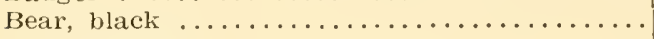 & 1,079 & 2,014 \\
\hline Bear, grizzly $\ldots \ldots \ldots \ldots \ldots \ldots \ldots \ldots \ldots \ldots \ldots \ldots \ldots \ldots \ldots \ldots \ldots$ & 4 & \\
\hline 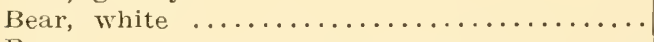 & 14 & 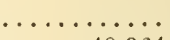 \\
\hline 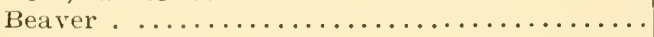 & 54,346 & 48,364 \\
\hline 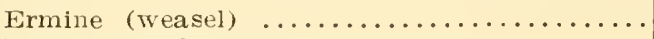 & 54,904 & 34,365 \\
\hline Fisher or pekan $\ldots \ldots \ldots \ldots \ldots \ldots \ldots \ldots$ & 1,949 & 1,936 \\
\hline 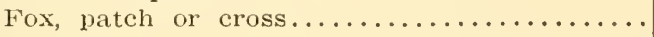 & 1,085 & 2,601 \\
\hline 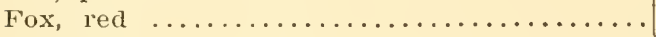 & 18,643 & 22,198 \\
\hline 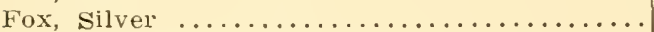 & 409 & 433 \\
\hline 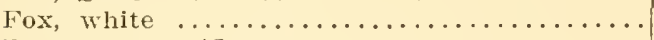 & 355 & 974 \\
\hline 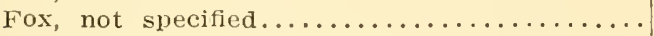 & & 61 \\
\hline 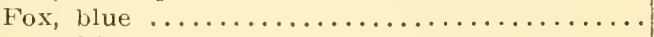 & 2 & \\
\hline 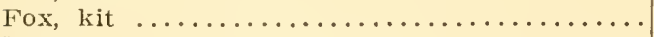 & 18 & $\cdots \cdots$ \\
\hline 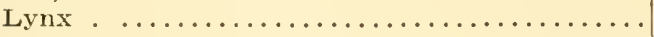 & 2,154 & 2,200 \\
\hline 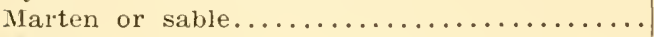 & 4,491 & 3,125 \\
\hline 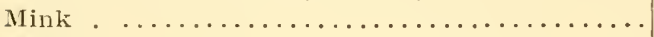 & $\$ 9,143$ & 68,138 \\
\hline 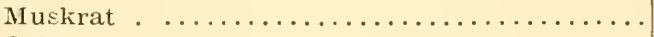 & 638,899 & 534,739 \\
\hline 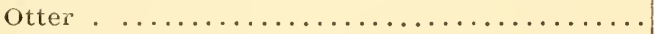 & 5,148 & 4,522 \\
\hline Rabbit,$\ldots \ldots \ldots \ldots \ldots \ldots \ldots \ldots \ldots \ldots \ldots \ldots \ldots$ & 388 & ....... \\
\hline 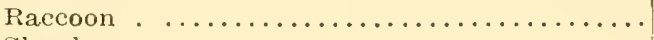 & 25,413 & 22,157 \\
\hline 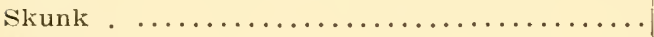 & 65,464 & 67,100 \\
\hline 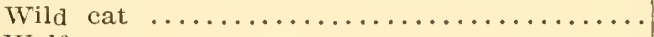 & 12 & $\ldots \ldots \ldots$ \\
\hline 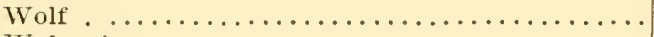 & 609 & 1,984 \\
\hline 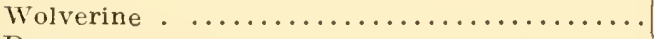 & 2 & \\
\hline 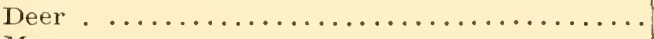 & 4,533 & \\
\hline Moose $\ldots \ldots \ldots \ldots \ldots \ldots \ldots \ldots \ldots \ldots$ & 45 & \\
\hline Total number of pelts............. & 969,137 & 816,919 \\
\hline 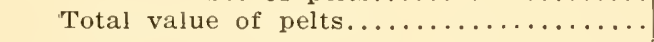 & $\$ 3,781,989.00$ & $\$ 3,406,868.00$ \\
\hline Prince Edward Island & $\begin{array}{l}\text { Season } \\
1923-24\end{array}$ & $\begin{array}{l}\text { Season } \\
1924-25\end{array}$ \\
\hline Beaver . ........ & & 13 \\
\hline Ermine (weasel) $\ldots . . \ldots \ldots \ldots \ldots \ldots$ & 173 & 342 \\
\hline 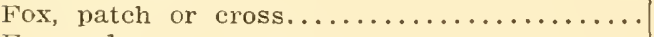 & 131 & 135 \\
\hline 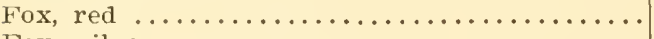 & 35 & 20 \\
\hline Fox, silver $\ldots \ldots \ldots \ldots \ldots \ldots \ldots \ldots \ldots \ldots \ldots \ldots \ldots \ldots \ldots \ldots$ & 4,433 & 2,957 \\
\hline Mink ........... & 90 & 181 \\
\hline Muskrat . ..... & 1,277 & 884 \\
\hline Raccoon . .... & 40 & 66 \\
\hline Skunk : ....... & 14 & 64 \\
\hline Domestic eat $\ldots \ldots \ldots \ldots \ldots \ldots \ldots \ldots \ldots \ldots \ldots$ & & \\
\hline 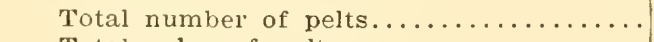 & 6,193 & 4,664 \\
\hline 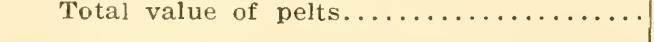 & $471,772.00$ & $326,669.00$ \\
\hline
\end{tabular}


FUR TAKE IN THE DIFFERENT CANADIAN PROVINCES (Continued)

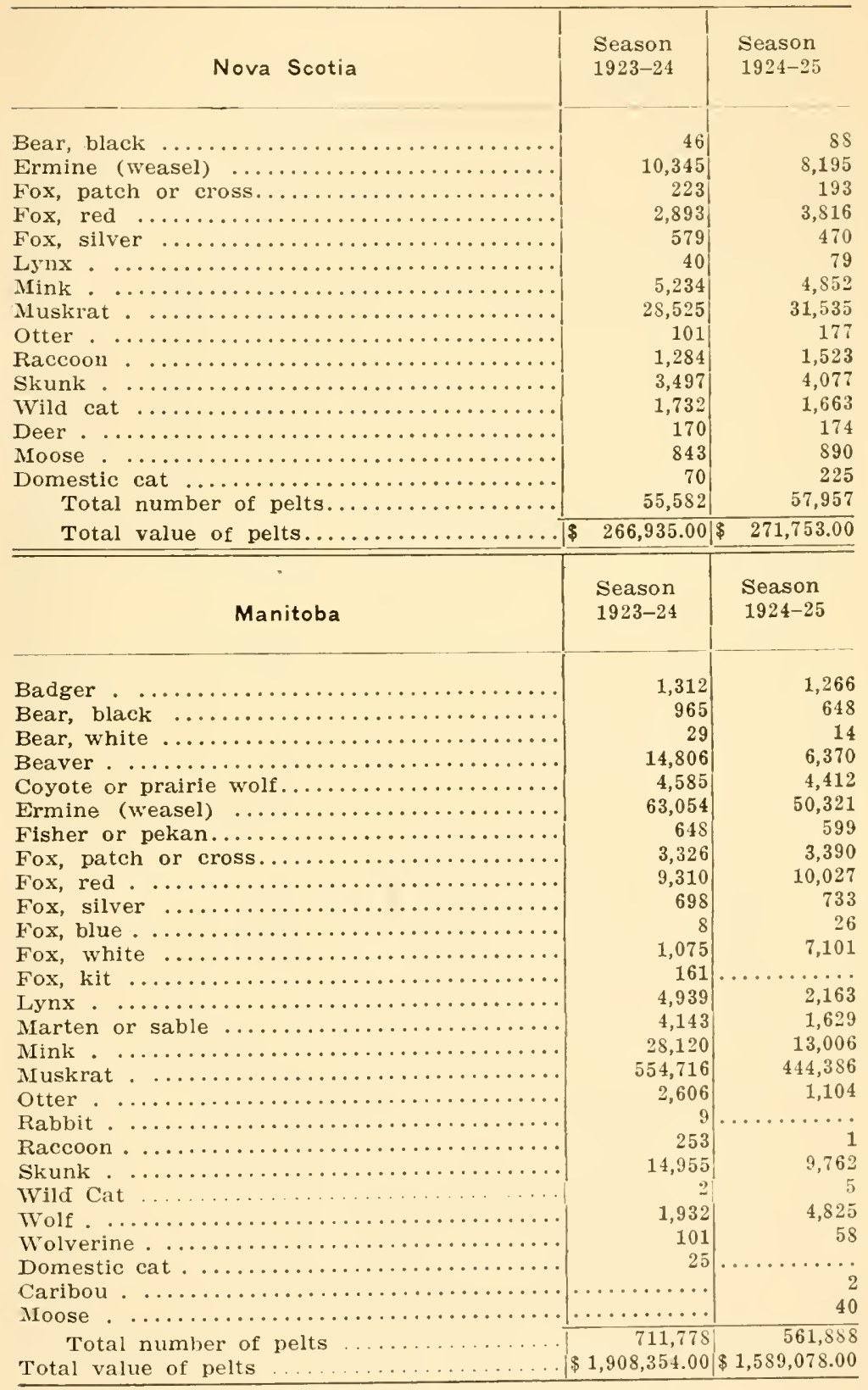


FUR TAKE IN THE DIFFERENT CANADIAN PROVINCES (Continued)

\begin{tabular}{|c|c|c|}
\hline New Brunswick & $\begin{array}{l}\text { Season } \\
1923-24\end{array}$ & $\begin{array}{l}\text { Season } \\
1924-25\end{array}$ \\
\hline Bear, black & 82 & 192 \\
\hline 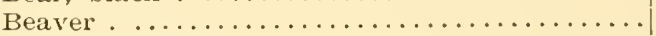 & 12 & 20 \\
\hline Ermine (weasel) $\ldots \ldots \ldots \ldots \ldots \ldots \ldots \ldots \ldots$ & 18,008 & $9, \pm 70$ \\
\hline 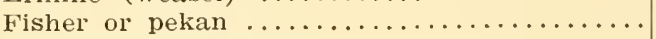 & 56 & 67 \\
\hline 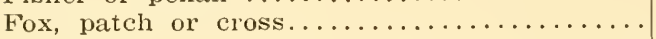 & 145 & 125 \\
\hline 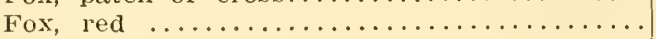 & 4,074 & 4,003 \\
\hline 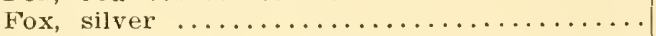 & 1,016 & 729 \\
\hline 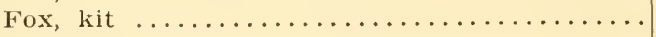 & 10 & … \\
\hline 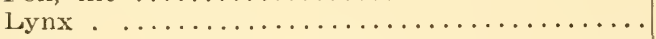 & 16 & \\
\hline 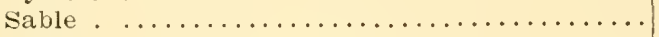 & 197 & 177 \\
\hline 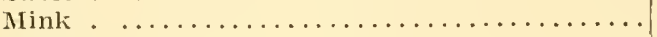 & 3,270 & 2,823 \\
\hline 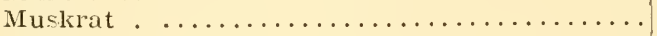 & 16,503 & 18,314 \\
\hline 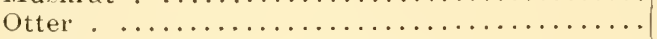 & 103 & 105 \\
\hline 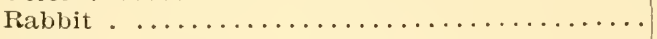 & 55 & \\
\hline Raceoon .... & 1,163 & 1,567 \\
\hline Skunk ...... & 4,931 & 6,017 \\
\hline Wild cat... & 1,488 & 2,154 \\
\hline 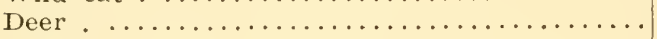 & 1,003 & 1,461 \\
\hline 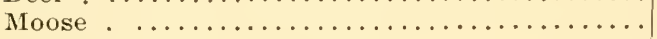 & 147 & 395 \\
\hline Domestic cat & 51 & 61 \\
\hline Total number of pelts.............. & 52,330 & 47,680 \\
\hline 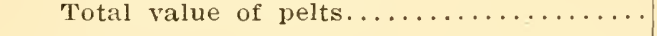 & $248,547.00$ & $246,091.00$ \\
\hline
\end{tabular}


FUR TAKE IN THE DIFFERENT CANADIAN PROVINCES (Continued)

\begin{tabular}{|c|c|c|}
\hline Quebec & $\begin{array}{l}\text { Season } \\
1923-24\end{array}$ & $\begin{array}{l}\text { Season } \\
19-4-25\end{array}$ \\
\hline Badger.$\ldots \ldots \ldots \ldots \ldots \ldots \ldots \ldots \ldots \ldots \ldots \ldots \ldots \ldots \ldots \ldots$ & 10 & 1 \\
\hline 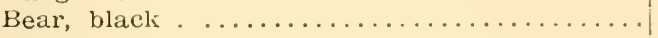 & 964 & 1,199 \\
\hline Bear, white $\ldots \ldots \ldots \ldots$...... & 25 & 51 \\
\hline 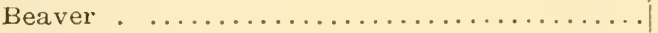 & 44,785 & 41,869 \\
\hline Ermine (weasel) $\ldots \ldots \ldots \ldots \ldots \ldots \ldots \ldots$ & 42,867 & 22,136 \\
\hline 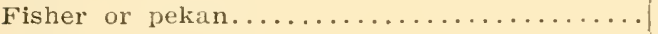 & 675 & 802 \\
\hline 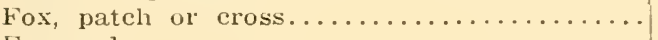 & 1,046 & 1,043 \\
\hline Fox, red $\ldots \ldots \ldots \ldots \ldots \ldots \ldots \ldots \ldots$ & 7,896 & 11,162 \\
\hline 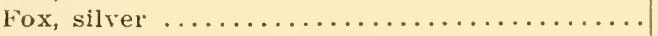 & 333 & 245 \\
\hline 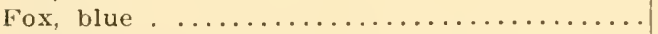 & 133 & 38 \\
\hline Fox, white $\ldots \ldots \ldots \ldots \ldots \ldots \ldots \ldots \ldots \ldots \ldots \ldots \ldots \ldots \ldots$ & 14,361 & 4,606 \\
\hline Fox, kit $\ldots \ldots \ldots \ldots \ldots \ldots \ldots \ldots \ldots \ldots \ldots \ldots \ldots \ldots \ldots \ldots \ldots$ & 81 & $\ldots \ldots \ldots$ \\
\hline Fox, unspecified $\ldots \ldots \ldots \ldots \ldots \ldots \ldots$ & $\ldots \ldots \ldots$ & 110 \\
\hline 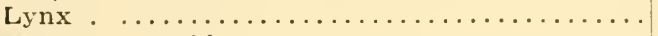 & 1,593 & 3,239 \\
\hline 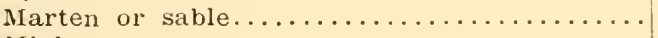 & 10,449 & $\$, 977$ \\
\hline 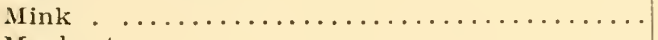 & 22.306 & 21,609 \\
\hline 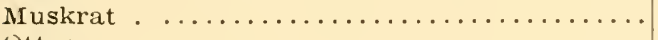 & $1 \div 8,26:$ & 164,645 \\
\hline 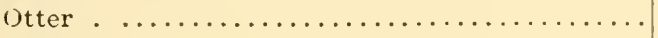 & 3.015 & 3,460 \\
\hline Raccoon.$\ldots \ldots \ldots \ldots \ldots \ldots \ldots \ldots \ldots \ldots$ & $2,5+3$ & 3,201 \\
\hline 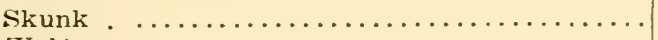 & $i \tilde{z}, 810$ & 15,186 \\
\hline Wolt W. $\ldots \ldots \ldots \ldots \ldots \ldots \ldots \ldots \ldots \ldots \ldots \ldots \ldots$ & 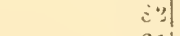 & 101 \\
\hline Wolverine.$\ldots \ldots \ldots \ldots \ldots \ldots \ldots \ldots \ldots$ & 21) & 15 \\
\hline 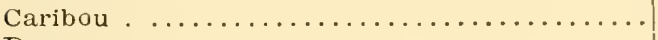 & 2 & 5 \\
\hline Deer.$\ldots \ldots \ldots \ldots \ldots \ldots \ldots \ldots \ldots \ldots \ldots \ldots \ldots$ & 4,555 & 5,464 \\
\hline 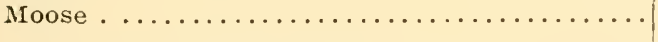 & 37 & 177 \\
\hline 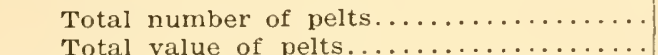 & 351,881 & $\begin{array}{r}309,341 \\
297 \cdot 09500\end{array}$ \\
\hline 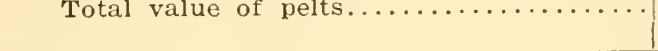 & $2,075,801.00$ & $\$ 2,272,095.00$ \\
\hline
\end{tabular}


FUR TAKE IN THE DIFFERENT CANADIAN PROVINCES (Continued)

\begin{tabular}{|c|c|c|}
\hline Saskatchewan & $\begin{array}{l}\text { Season } \\
1923-24\end{array}$ & $\begin{array}{l}\text { Season } \\
192 \pm-25\end{array}$ \\
\hline Badger.$\ldots \ldots \ldots \ldots \ldots \ldots \ldots \ldots \ldots \ldots \ldots \ldots \ldots$ & 2,043 & 5,008 \\
\hline 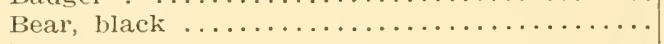 & $\$ 47$ & 847 \\
\hline 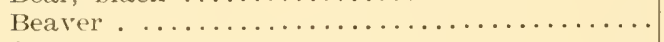 & 6,083 & 5,001 \\
\hline 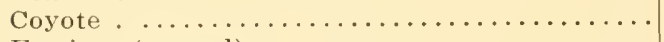 & 21,536 & 31,009 \\
\hline 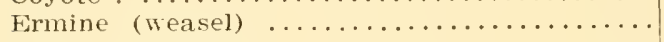 & 82,437 & 87,816 \\
\hline 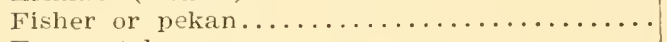 & 90 & 48 \\
\hline 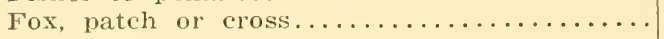 & 2,199 & 2,379 \\
\hline 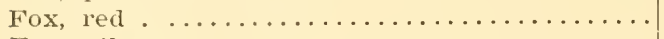 & 6,921 & 7,810 \\
\hline 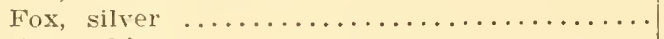 & 342 & 368 \\
\hline 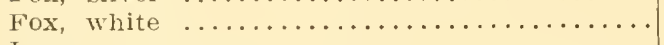 & 56 & 179 \\
\hline 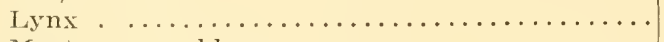 & 1,614 & 1,022 \\
\hline 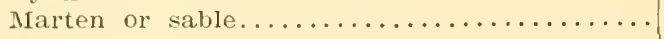 & 2,241 & 1,767 \\
\hline 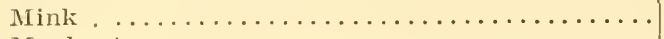 & 13,953 & 6,625 \\
\hline 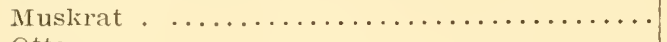 & $1,006.863$ & 856,829 \\
\hline 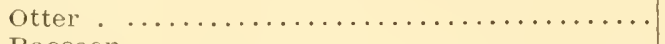 & 592 & 516 \\
\hline 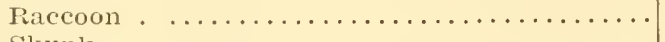 & $\ldots \ldots \ldots \ldots$ & \\
\hline 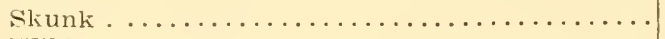 & 13,787 & 9,117 \\
\hline 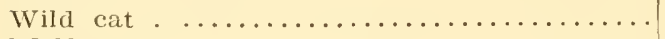 & 2 & \\
\hline 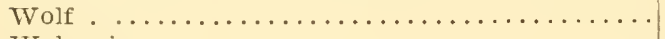 & 136 & 115 \\
\hline Wolverine $\quad \ldots \ldots \ldots \ldots \ldots \ldots \ldots \ldots \ldots \ldots \ldots \ldots \ldots \ldots \ldots$ & 63 & 54 \\
\hline 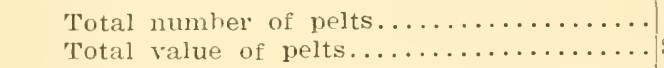 & $\begin{array}{r}1,161,805 \\
\$ 1,927,914.00\end{array}$ & $\begin{array}{r}1,016,5 \geqslant 7 \\
\$ 1,804,052.0\end{array}$ \\
\hline & & \\
\hline
\end{tabular}


FUR TAKE IN THE DIFFERENT CANAD:AN PROVINCES (Cont.nueci)

\begin{tabular}{|c|c|c|}
\hline Alberta & $\begin{array}{l}\text { Season } \\
1923-24\end{array}$ & $\begin{array}{l}\text { Season } \\
1924-25\end{array}$ \\
\hline$\ldots \ldots \ldots \ldots \ldots \ldots \ldots \ldots \ldots \ldots \ldots$ & $1,77 \mathrm{~s}$ & 3,008 \\
\hline lear, blac. & 1,368 & 1,363 \\
\hline 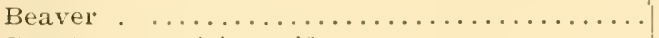 & 20,057 & 18,747 \\
\hline 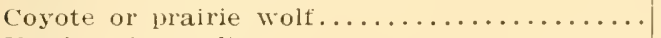 & 32,315 & 42,665 \\
\hline Ermine (weasel) $\ldots \ldots \ldots \ldots \ldots \ldots \ldots \ldots \ldots$ & 57,962 & 60,150 \\
\hline 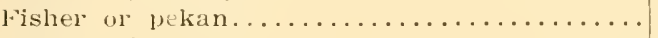 & 83 & 78 \\
\hline 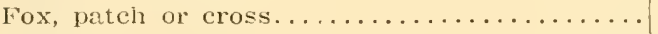 & 5,767 & 7,416 \\
\hline Fox, red $\ldots \ldots \ldots \ldots \ldots \ldots \ldots \ldots \ldots \ldots$ & 11,511 & 14,184 \\
\hline 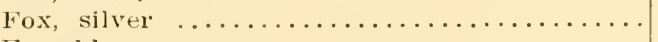 & 768 & 1,179 \\
\hline Fox, blue $\ldots \ldots \ldots \ldots \ldots \ldots \ldots \ldots \ldots$ & $\ldots \ldots$ & 1 \\
\hline Fox, white $\ldots \ldots \ldots \ldots \ldots \ldots \ldots \ldots \ldots \ldots \ldots \ldots \ldots \ldots$ & 48 & 47 \\
\hline 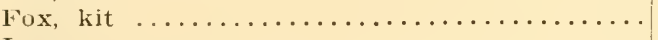 & 444 & 747 \\
\hline 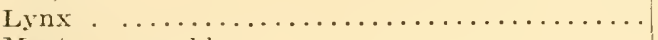 & 7,374 & 7,006 \\
\hline Marten or sable $\ldots \ldots \ldots \ldots \ldots \ldots \ldots \ldots$ & 3,568 & 3,046 \\
\hline 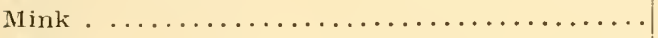 & 20,294 & 11,928 \\
\hline 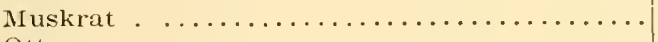 & 331,144 & 271,633 \\
\hline 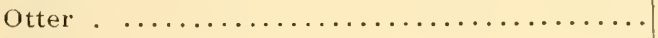 & 367 & 352 \\
\hline 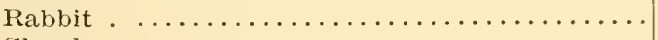 & 44 & 152,673 \\
\hline 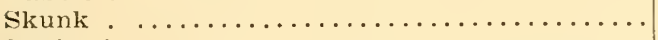 & 7,733 & 6,470 \\
\hline Squirrel $\ldots \ldots \ldots \ldots \ldots \ldots \ldots \ldots \ldots$ & $\ldots \ldots$ & 114 \\
\hline 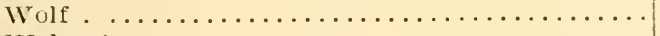 & 184 & 283 \\
\hline Wolverine.$\ldots \ldots \ldots \ldots \ldots \ldots \ldots \ldots \ldots \ldots$ & 220 & 255 \\
\hline Caribou.$\ldots \ldots \ldots \ldots \ldots \ldots \ldots \ldots \ldots \ldots$ & 3 & 1 \\
\hline Deer.$\ldots \ldots \ldots \ldots \ldots \ldots \ldots \ldots \ldots \ldots \ldots$ & 10 & 40 \\
\hline 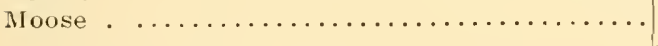 & 28 & 37 \\
\hline 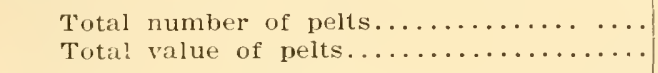 & $\begin{array}{r}503,070 \\
\$ 1,970,013.00\end{array}$ & $\begin{array}{r}603,483 \\
\$ 2,030,474.00\end{array}$ \\
\hline
\end{tabular}




\section{FUR TAKE IN THE DIFFERENT CANADIAN PROVINCES (Continued)}

\begin{tabular}{|c|c|c|}
\hline Northwest Territories & $\begin{array}{l}\text { Season } \\
1923-24\end{array}$ & $\begin{array}{l}\text { Season } \\
1924-25\end{array}$ \\
\hline 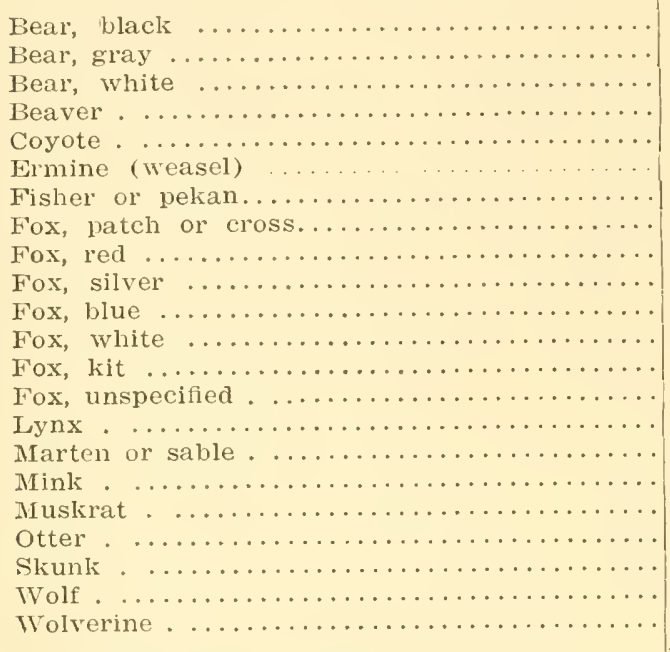 & $\begin{array}{r}285 \\
4 \\
344 \\
4,933 \\
17 \\
2,767 \\
24 \\
655 \\
1,745 \\
99 \\
125 \\
17,719 \\
2 \\
2 \\
1,300 \\
9,782 \\
15,703 \\
108,632 \\
155 \\
136 \\
323 \\
110\end{array}$ & $\begin{array}{r}329 \\
2 \\
391 \\
4,698 \\
\ldots \ldots \ldots \\
2,759 \\
46 \\
1,653 \\
4,664 \\
230 \\
151 \\
30,624 \\
\ldots . \\
7 \\
2,444 \\
11,069 \\
10,015 \\
79,034 \\
164 \\
35 \\
422 \\
101\end{array}$ \\
\hline 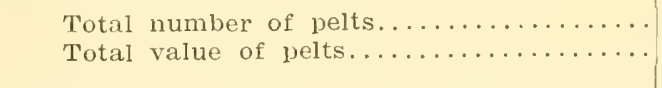 & $\begin{array}{r}164,903 \\
\$ 1,529,376.00\end{array}$ & $\begin{array}{r}148,885 \\
\$ 1,780,665.00\end{array}$ \\
\hline Yukon Territory & $\begin{array}{l}\text { Season } \\
1923-2 \frac{1}{1}\end{array}$ & $\begin{array}{l}\text { Season } \\
1924-25\end{array}$ \\
\hline 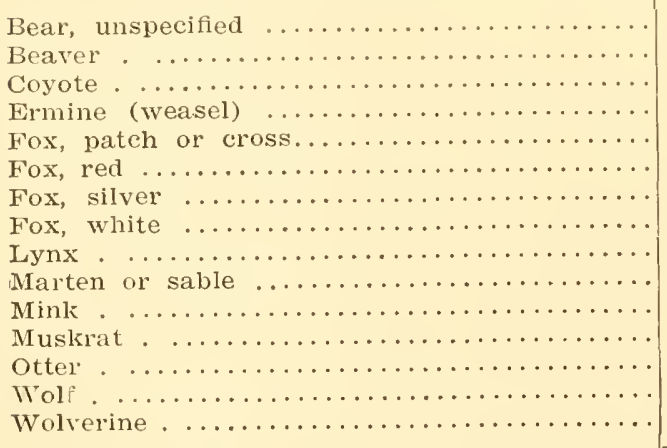 & $\begin{array}{r}330 \\
2,581 \\
371 \\
1,689 \\
528 \\
1,749 \\
111 \\
1,080 \\
2,526 \\
1,170 \\
2,578 \\
34,904 \\
78 \\
168 \\
207\end{array}$ & $\begin{array}{r}199 \\
2,792 \\
519 \\
1,248 \\
544 \\
2,488 \\
156 \\
783 \\
3,757 \\
147 \\
2,578 \\
20,929 \\
82 \\
181 \\
213\end{array}$ \\
\hline 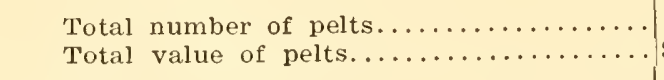 & $\begin{array}{r}50,070 \\
\$ \quad 347,079.00\end{array}$ & $\begin{array}{r}36,616 \\
309,549.00\end{array}$ \\
\hline
\end{tabular}




\section{FUR TAKE IN THE DIFFERENT CANADIAN PROVINCES} (Continued)

\begin{tabular}{|c|c|c|}
\hline British Columbia & $\begin{array}{l}\text { Season } \\
1923-24\end{array}$ & $\begin{array}{l}\text { Season } \\
1924-25\end{array}$ \\
\hline 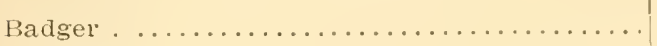 & 14 & 15 \\
\hline 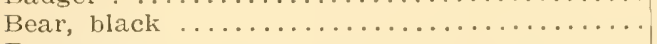 & 1,017 & 1,529 \\
\hline 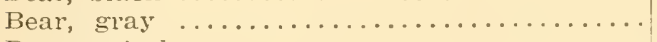 & 12 & 19 \\
\hline Bear, grizzly $\ldots \ldots \ldots \ldots \ldots \ldots \ldots \ldots$ & 17 & 41 \\
\hline Beaver $\quad \ldots \ldots \ldots \ldots \ldots \ldots \ldots$ & 21,509 & 24,039 \\
\hline Coyote.$\ldots \ldots \ldots \ldots \ldots \ldots \ldots \ldots \ldots \ldots$ & 3,333 & 7,236 \\
\hline Ermine (weasel) $\ldots \ldots \ldots \ldots \ldots \ldots \ldots \ldots$ & 25,128 & 31,323 \\
\hline 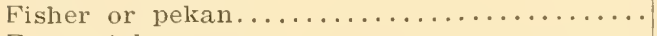 & 633 & 654 \\
\hline Fox, patch or cross $\ldots \ldots \ldots \ldots \ldots \ldots \ldots \ldots$ & 944 & 1,654 \\
\hline Fox, red $\ldots \ldots \ldots \ldots \ldots \ldots \ldots \ldots \ldots \ldots$ & 1,209 & 2,238 \\
\hline Fox, silver $\ldots \ldots \ldots \ldots \ldots \ldots \ldots \ldots \ldots \ldots \ldots \ldots \ldots \ldots$ & 302 & $35 s$ \\
\hline Fox, blue $\ldots \ldots \ldots \ldots \ldots \ldots \ldots \ldots \ldots$ & $\ldots \ldots \ldots$ & 3 \\
\hline 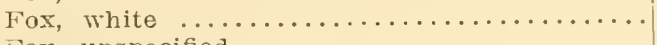 & 23 & 2 \\
\hline Fox, unspecified $\ldots \ldots \ldots \ldots \ldots \ldots \ldots \ldots$ & $\ldots \ldots .$. & $\begin{array}{r}2 \\
-78\end{array}$ \\
\hline 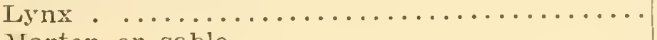 & 4,881 & 7,638 \\
\hline Marten or sable $\ldots \ldots \ldots \ldots \ldots \ldots \ldots \ldots \ldots$ & 10,366 & 11,567 \\
\hline Mink $\ldots \ldots \ldots \ldots \ldots \ldots \ldots \ldots$ & 18,950 & 24,536 \\
\hline Muskrat.$\ldots \ldots \ldots \ldots \ldots \ldots \ldots \ldots \ldots \ldots \ldots$ & 85,670 & $92,21 \pm$ \\
\hline Otter.$\ldots \ldots \ldots \ldots \ldots \ldots \ldots \ldots \cdots \cdots \cdots \cdots$ & 767 & 795 \\
\hline 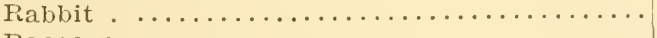 & $\ldots \ldots \ldots$ & 2,000 \\
\hline 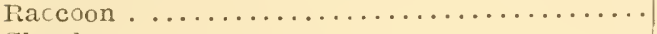 & 4,760 & 6,327 \\
\hline Skunk.$\ldots \ldots \ldots \ldots \ldots \ldots \ldots \ldots \ldots \ldots$ & $605^{-}$ & 1,188 \\
\hline 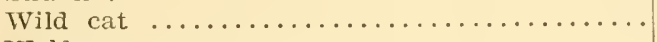 & 43 & 116 \\
\hline 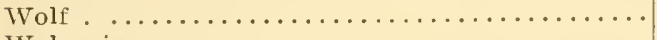 & 361 & 486 \\
\hline Wolverine $\ldots \ldots \ldots \ldots \ldots \ldots \ldots \ldots \ldots \ldots \ldots$ & 184 & 237 \\
\hline Cougar $\ldots \ldots \ldots \ldots \ldots \ldots \ldots \ldots$ & $\cdots$ & 19 \\
\hline Panther.$\ldots \ldots \ldots \ldots \ldots \ldots \ldots \ldots \ldots \ldots \ldots$ & $4]$ & $\ldots \ldots \ldots$ \\
\hline Civet cat.$\ldots \ldots \cdots \cdots \cdots \cdots \cdots \cdots \cdots \cdots$ & 109 & $11 \mathrm{~s}$ \\
\hline Domestic cat $\ldots \ldots \ldots \ldots \ldots \ldots \ldots \ldots \ldots$ & $\cdots \cdots$ & 12 \\
\hline 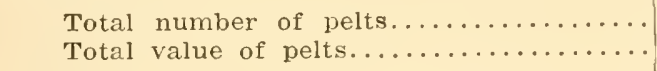 & $\begin{array}{r}180,844 \\
\$ 1,116,037.00\end{array}$ & $\begin{array}{r}216,366 \\
\$ 1,403,769.00\end{array}$ \\
\hline
\end{tabular}


FUR ROYALTIES IN CANADA

\begin{tabular}{|c|c|c|c|c|c|c|c|c|c|c|}
\hline Species & 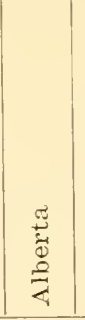 & 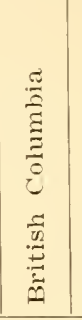 & 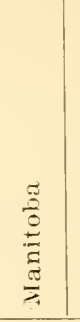 & 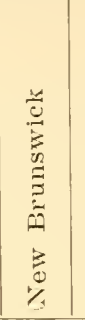 & 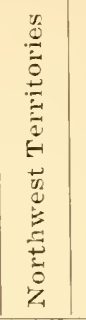 & 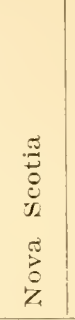 & $\stackrel{\mathscr{\Xi}}{\leftrightarrows}$ & $\frac{0}{0}$ & 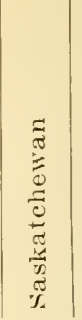 & $\begin{array}{l}\Xi \\
0 \\
\frac{1}{3} \\
0\end{array}$ \\
\hline ear.... & $\$ .40$ & $\$ .40 \$$ & $\$ .40 \$$ & $\$ .60 \$$ & $\$ .40 \$$ & & $\$ .40$ & $\$ .60 \mid$ & $|\$ .40|$ & \\
\hline lar bear & 2.00 & $\ldots$ & $\ldots$ & 1.50 & $2.00 \mid$ & & & $1.00 \mid$ & $|\ldots|$ & \\
\hline er ... & 1.00 & 1.00 & 1.00 & & 1.00 & & 1.00 & 1.00 & 1.00 & \\
\hline isher . . . . . . . & $|1.50|$ & 1.50 & 1.50 & 2.00 & 1.50 & & 1.50 & 2.00 & 1.50 & 2.00 \\
\hline Fox, cross $\ldots \ldots \ldots$ & 1.50 & 1.50 & 1.50 & 1.75 & 1.50 & 1.50 & 1.50 & 1.75 & 1.50 & 2.00 \\
\hline Fox, red .......... & .75 & .75 & .75 & .75 & .75 & .75 & .75 & .75 & .75 & 1.0 \\
\hline Fox, silver ........ & 5.00 & 5.00 & 5.001 & 10.00 & 5.00 & $\ldots$ & 5.00 & 10.00 & 5.00 & 3.0 \\
\hline Fox, white ..... & 1.50 & $\ldots$ & 1.50 & 1.75 & 1.50 & $\ldots$ & 1.50 & 1.75 & $\ldots$ & 1.0 \\
\hline Fox, ordinary ..... & $\ldots$ & $\ldots$ & $\cdots$ & $\ldots$ & $\ldots$ & $\ldots$ & .50 & & $\cdots$ & .. \\
\hline Fox, bastard ....... & & $\ldots$ & $\ldots$ & .50 & $\cdots$ & & $\ldots$ & .50 & & \\
\hline $\mathrm{nx} . \ldots \ldots \ldots \ldots$ & .75 & .75 & .50 & .50 & .75 & 1.00 & .50 & .50 & .75 & 1.0 \\
\hline Marten. & 1.00 & 1.00 & .75 & 1.00 & 1.00 & $\ldots$ & 1.00 & 1.00 & 1.00 & 1.0 \\
\hline $11 \mathrm{n} \cdot \cdots \cdots \cdot \cdots$ & .25 & .25 & .25 & $\ldots$ & .25 & .40 & .25 & .40 & .25 & .25 \\
\hline Muskrat ........ & .05 & .05 & .05 & .05 & .05 & .05 & .05 & .05 & .05 & .05 \\
\hline Raccoon .......... & $\ldots$ & .10 & $\ldots$ & .15 & $\ldots$ & .20 & .10 & .15 & $\ldots$ & $\ldots$ \\
\hline kunk . ......... & .10 & .10 & .10 & .10 & .10 & .15 & .10 & .10 & .10 & \\
\hline easel ........... & .03 & .03 & .05 & .05 & .03 & .03 & .05 & .05 & .05 & .0 \\
\hline Wolverine . .... & $\ldots$ & .50 & .25 & $\ldots$. & $\ldots$. & $\cdots \cdot$ & .40 & .50 & .50 & .40 \\
\hline otter . ......... & 1.00 & 1.00 & 1.00 & 1.50 & 1.00 & 1.00 & 2.00 & 2.00 & 1.00 & .75 \\
\hline Fox, tarmed .... & $\ldots$ & 1.50 & $\ldots$ & .50 & $\ldots$ & $\ldots$. & $\ldots \ldots$ & $\cdots$ & $\ldots$. & \\
\hline olf.$\ldots \ldots \ldots$ & $\ldots$ & $\ldots$ & .10 & $\cdots$ & $\ldots$ & & & .70 & .25 & \\
\hline oyote. & & & $\ldots$ & $\cdots \cdot$ & $\ldots$. & & & $\ldots$ & .25 & \\
\hline Fox, blue .......... & $\cdots \cdot$ & $\cdots$ & 1.50 & 1.75 & 2.50 & & & 1.75 & & \\
\hline Badger . .......... & .... & ... & .05 & & & $\ldots$ & & $\ldots$. & .25 & \\
\hline Fox, black ..... .. & & & $\ldots$ & $5.00 \mid$ & 5.00 & & 5.00 & 5.00 & 5.00 & 3.0 \\
\hline
\end{tabular}

\section{ROYALTIES COLLECTED 1926}

Alberta, 70,000.00; British Columbia, \$56,045.13; Manitoba, $\$ 72,000.00$; New Brunswick, $\$ 8,595.59$; Northwest Territories, no collections until 1929; Nova Scotia, $\$ 5,80000$; Ontario, $\$ 55,970.70$; Quebec, $\$ 103,402.10$; Sasliatchewan, $\$ 55,600.00$; Yulion, $\$ 12,128.95$. 


\section{LIST OF REFERENCES}

The following bibliography was used in compiling data for the purposes of this bulletin:

Ahrens, Albert M.

1922. Fur Facts." St. Louis.

ANTHONY, H. E.

1928. "Field Book of North American Mammals." New York.

ARthur, Stanley Clisby

1914-1928. Biennial Reports of the Conservation Commission and of the Department of Conservation of Louisiana. New Orleans.

AsHBROOK, Frank G.

1927-1928. "Mink Raising," U. S. Dept. of Agriculture Leaflet 8-L. "Fur Farming for Profit." New York.

Audubon, John James, and Bachman, John

1846. "The Viviparous Quadrupeds of North America."

BAILEY, VERNON

1927. "Beaver Habits and Experiments in Beaver Culture." Technical Bulletin No. 21, U. S. Dept. of Agriculture. "Habits of Meadow Mice." Journal of Agricultural Research,. Vol XXVII.

BANGS, OUTRAM

1895. "Notes on North American Mammals." Proceedings Boston Society Natural History, Vol. XXVI. Pp. 541-542.

Bossu, N. (Captain in the French Marines)

1771. "Travels Through That Part of North America Formerly Called Louisiana." Translated by John Reinhold Foster, 2 Vols., London.

BushNelL, David I.

1909. "The Choctaw of Bayou Lacombe, St. Tammany Parish." Bulletin No. 48, Smithsonian Institution, Washington, D. C. 
1927. "Drawings by A. DeBatz in Louisiana 17321735," 6 plates, Smithsonion miscellaneous collection, Vol. 80, No. 5 .

Byington, Cyrus

1915. "A Dictionary of the Choctaw Language." Smithsonian Institution, Bureau of American Ethnology, Bulletin No. 46.

Chambers, Henry E.

1925. "Mississippi Valley Beginnings." de Charlevoix, P. F. X.

1721. "History and General Description of New France." French Historical Collection of Louisiana.

COATES, R. H.

1927. "Fur Production of Canada, Seasons 1923 to 1927." D o m i n i o n Bureau Statistics, Fur Branch, Ottawa.

Coues, Elliot

1877. "Fur-Bearing Animals. A Monograph of North American Mustelidae." U. S. Geological Survey of the Territories. Publication No. 8.

Cram, W. E.

1923. "The Tussel on Tide Water Creek." Journal of Mammalogy, Vol. 4, pp. 22.

DEARBORN, NED

1920. "The Maintenance of the Fur Supply." U. S. Dept. of Agriculture, Biological Survey, Circular No. 135.

DitMaRs, RAYMOND LEE

1908. "The Reptile Book." New York.

DIXON, JOSEPH SCATTERGOOD

1922. "Rodents and Reclamation in the Imperial Valley." Journal of Mammalogy, Vol. 3, No. 3.

Dumont de Montigny, Butel

1753. "Memories Historiques sur La. Louisiane." 2 Vols. Paris.

du Pratz, Le Page

1758. "Historie de La Louisiana." 3 Vols. Paris. 
French, B. F.

"Historical Collections of Louisiana." 1846 , 1850, 1853, 1869, 1875.

GrinNELl, JOSEPH and Storer, TrACY IRWIN

1921. "Animal Life of the Yosemite," University of California

GRAVIER JACQUES

1700. "Journal of the Voyage of Father Gravier." Jesuit Relations, Vol. LXV. 145-153.

HALL, E. RAYMOND

1927. “A New Weasel from Louisiana." Proceedings Biological Society of Washington, D. C. Vol. 40, pp. 193-194.

1927. "An Outbreak of House Mice in Kern County, California." University of California Publications in Zoology, Vol. 30, No. 7.

Hartman, Carl GotTFried

1921. "Breeding Habits, Development, and Birth of the Opossum," Smithsonian Institution Annual Report, 1921, pp. 347-363, Washington, D. C.

1928. "The Breeding Season of the Opossum, Journal of Morphology and Physiology, Vol. 46, No. 1, Philadelphia, Pa.

Heuser, Chester H. and Hartman, Carl G.

1928. "Notes on the Breeding Habits of the Opossum," Journal of Mammalogy, Vol. 9.

HODGSON, ROBERT G.

1927. "Successful Muskrat Farming," Fifth Edition.

Fur Trade Journal of Canada, Toronto.

HOLLISTER, NED

1911. "A Systematic Synorsis of the Muskrats." U. S. Dept. of Agriculture, Bureau of Biological Survey, North American Fauna No. 32.

Howell, Arthur H.

1901. "Revision of the Skunks of the Genus Chincha." U. S. Dept. of Agriculture, North American Fauna No. 20. 
1906. "Revision of the Skunks of the Genus Spilogale." U. S. Dept. of Agriculture, North American Fauna No. 26.

1909. "Notes on the Distribution of Certain Mammals in the Southeastern United States." Proceedings Biological Society, Washington, D. C. Vol. XXII.

Hornaday, William T.

1910. "The American Natural History." New York. JACKSON, V. W.

1925. "Fur and Game Resources of Manitoba."

1927. "Rat Ranching in Manitoba." Northern Fur Trade, Winnipeg, Man.

Jesuit Relations and Allied Documents

1897-1901. Edited by Ruben Gold Thwaites, 73 vols., Cleveland.

Johnston, Charles Eugene

1925. "The Muskrat in New York; Its Natural History and Economics." Roosevelt Wild Life Bulletin, Vol 2, No. 2.

LADUE, HARRY J.

1928. "American Fur Breeder," Vol. 1, No. 2, St. Peter, Minn.

LA HARPE, BERNARD DE

1831. "Journal Historique de l'Establissement des Francois a la Louisiana," Nouvelle-Orleanes.

LA Honton Louis DE D., BARON DE

"New Voyages to North America."

LANTZ, DAVID E.

1910. "The Muskrat." U. S. Department of Agriculture, Farmers' Bulletin No. 396.

1917. "The Muskrat as a Fur Bearer, with Notes on Its Use as Human Food." U. S. Department of Agriculture, Farmer's' Bulletin No. 869.

1917. "Economic Value of North American Skunks." U. S. Department of Agriculture, Farmers' Bulletin 587. 
Laut, Agnes C.

1921. "The Fur Trade of America." New York.

LECOMPTE, E. LEE

1925. "The Muskrat Industry in Maryland." State Game Department of Maryland, Baltimore.

MARgry, PiERRE

1879. "Decouvertes et Establissements des Francais dans l'Ouest et dans le Sud de l'Amorique Septentrionale. (1614-175\%.)" 6 Vols. Paris.

Miller, GERRIT S., JR.

1924. "List of North American Recent Mammals." U. S. National Museum, Bulletin 128, Washington, D. C.

Mills, David C.

1926. "The International Fur Trade." Journal of Home Economics, Vol. 18, No. 11, p. 625.

Mitchell, P. Charles

1912. "The Childhood of Animals." New York. Nelson, EdWard W.

1918. "Wild Animals of North America." National Geographic Society, Washington, D. C.

ReEse, A. M.

1915. "The Alligator and It's Allies." New York.

SAGARD-THEODAT, GABRIEL

1636. "History of Canada." Paris.

SCHMIDT, KARL P.

1922. "The American Alligator." Leaflet No. 3, Field Museum Natural History. Chicago.

SETON, ERNEST THOMPSON

1909. "Life Histories of North American Animals." 2 Tols. New York.

Smith, Captaine JoHN

1612. "A Map of Virginia. With a Description of the Countrey, the Commodities, People, Government, and Religion."

Stone, Witmer and Cram, W. E.

1913. "American Animals." 1 Vol. New York. 
SURRY, N. M. MILLER

1916. "The Commerce of Louisiana During the French Regime, 1699-1763." Studies in History, Economics and Public Law, Columbia University, New York, Vol. LXXI, No. 1.

SWANTON, JOHN R.

1909. "Indian Tribes of the Lower Mississippi Valley and Adjacent Coast of the Gulf of Mexico." Smithsonian Institution, Bureau of American Ethnology, Bulletin No. 43.

1912. "A Dictionary of the Biloxi and Ofo Languages" Smithsonian Institution, Bureau of American Ethnology, Bulletin No. 47.

VIOSCA, PERCY, JR.

1925. "Louisiana Wet Lands and the Value of Their Wild Life and Fishery Resources." Department of Conservation, Technical Paper No. 6 . 


\section{A SYSTEMATIC LIST OF THE FUR ANIMALS OF LOUISIANA}

In our modern system of classification and scientific naming of our wild life the lowest forms are placed first in a systematic list. When the scientific name of an animal is written the genus and species name is used, as Didelphis virginiana, which is bestowed on the common opossum of the eastern United States. But as there are other forms of this mammal the species is split and those that differ slightly are called subspecies and our very common gulf opossum falls in this class and as a subspecies of the Virginia animal it has been named Didelphis virginana pigra. Therefore, when there are subsptcies it is necessary to repeat the species name of the typical animal and the first-named opossum becomes Didelphis virginiana virginiana. Frequently scientific names are abbreviated, as D. v. virginiana. Scientific usage prescribes that the name of the original describer of the form appears, but when the author's name is set in parentheses it indicates that the seientific name as first set down has been changed because of a rule of priority or some other law observed by naturalists.

Although measurements today ale usually made by the metric system, those in the following list appear in inches, and tenths of inches, as it is believed that readers of this bulletin will more readily comprehend the sizes, for most of us are accustomed to thinking in inches and not in millimeters. To convert millimeters into inches: $25 \mathrm{~mm}$. equal 1 inch. Total length means the distance, in a straight line, flom the tip of the nose to the tip o tise tail, but must not inclide the hail of the tal. Tie length of the tail vertebrate should be taken from the root of the tail to the fleshy tip of the tail. An accurate method of securing the tail measurement is to bend the tail upwards at right angles from the back and measure from the base to the last bit of skin on the tail. The length of the hind foot should be taken from the edge of the neel to the tip of the longest claw. In taking this measurement the foot is extended and kept flat, so that the curvature of the toes is straightened out. These are the methods recommended by H. E. Anthony in his recent field book of North American mammals.

For the purposes of identification it should be remembered that mammals vary in size, in color, and in the measurements or proportions of paits, and that the lengths given are average measurements of the different species. There is always a wide variation in the color of a coat of a mammal and frequently pure white, or albino, specimens are seen, and the black or me'anistic, phase is infrequently found.

The following descriptions and scientific determinations, and ranges are set down with the knowledge that our Louisiana mammals, particularly our fir animals, have not received the scientific attention they deserve.

\section{OPOSSUMS}

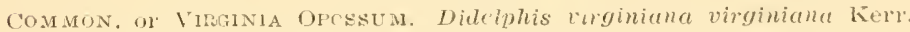

Measurements.-Total length, 33 inches; taii vertebrate, 12.5 inches; hind foot, 3 inches.

Range.-From the Great Lakes southward to Oklahoma, northern Texas, and neally to the Gulf Coast; east to the lower Hudson valley and Long Island. This is the common opossum found in Louisiana away from the Gulf Coast marshes and swamps.

1) scription.-The pelage is composed of very long guard hairs and short, sof $\mathrm{c}$ underfur. The guard hairs are a mixture of white and black, the white hairs very long and exceeding the black in length. 
The hair on the head is yellowish-white in color; cheeks whitish: sooty black about top of head and eyes; ears with yellow spot on upper erge, rest of eas black. The sexes are alike in color, but the femase possesses a marsupial pouch, a fur-lined opening along the lower abdomen.

GulF Opossum. Didelphis virginiana pigra Bangs.

Measurements.-Total length, 31 inches; tail veltebrate, 14 inches; hind foot, 2.7 inches.

Range-Florida, the lower coast of Georgia, and the low Gulf coast belt as far as wtstern Louisiana (Miller). This form is numerous up to and inciuding eastern Texas along the Gulf, where it may melge with another form.

Description.-This is a small, dark form when contrasted with the Virginia orossum. It has a longer tail than the Virginia species, but its body measulemuts will average smaller.

TExas Oposstrm. Didelphis mesamericana texensis (Allen).

Mcasurements.-Total length, 31 inches; tail vertebrate, 15 inches; hind foot, 2.7 inches.

Range.-Coast legion of Texas from Nueces Bay soutinard, and fiom the lower Rio Grande Valley as far up the valley at least as Del Rio, Val Verde county (Miller). This may or may not prove to be the long-tailed opossum that has been taken in eastern Texas and southwestern Louisiana, and its inclusion in this list is only provisional.

Description.- A large op ssum occurring in two coior phases, according to Anthony, one being a gray phase, quite similar in appearance to the Virginia opossum, and a black phase in which the longer guard hairs are black instead of white the Virginia opossum has the white guard hairs longer than the black. The Texas opossum has the pelage on the top of the head to the nose dusky; dusky stripe from ear through eye to nose; tail black for basal half, rest flesh colored. Guide for identification should be: exceedingly long tail, black guard hairs longer than white, and blackish co or of tail for jalf its length where it joins the body.

\section{RACCOON}

RACCOON. Procyou lotor lotor (Linnaeus).

Measurements.-Total length, approximately 30 inches; tail vertebrate 10 inches; hind foot, 2.5 inches.

Range.--Eastern North America from Canada about 50 degrees latitude south to Gulf coast.

Description.-See chapter on Raccoon.

\section{RING-TAILED CAT}

Ring-TAILED CAT. Fassariscus astutus flavus Rhoads.

Measurements. - Total length, 32 inches; tail vertebrate, 17 inches; hind foot, 2.S inches. Females will average smaller.

Range--- Wrestern half of Texas north to Colorado and southern Utah and west through New Mexico and Arizona. Scattered records as far east as Louisiana and Alabama (Anthony). The Louisiana records of occurrence not definite; see chapter on Raccoon and this anima!, which also gives description. 


\section{WEASEL}

1.OU1SIAXA WEASEL. Mustela noveboracensis arthuri Hall.

Measurements. - Total length, male 15 inches, female 14.5 inches; tail vertebrate, 4.5 inches; hind foot, 1.7 inches. The female is always smaller.

Range.-Louisiana only; may be found also in Mississippi. Records in Louisiana include St. James, Ascension, Assumption, West Feliciana, st. Helena, and Plaquemines parishes. Full range yet to be established.

D. scription.-See chapter on Weasel.

\section{MINK}

Lovisiana MINK. Mustela rison vulgivaga (Bangs).

Measurements.-Total length, 24.5 inches; tail vertabrate, 7.5 inches; hind foot, 2.9 inches. Females are noticeably smaller.

Range.-Coast of Louisiana and Mississippi. North in the Mississippi river bottoms to northern Louisiana (Miller).

Description.-See chapter on Mink.

\section{OT'TER}

('AROI INA OTTER. Latra canadensis latazina (F. Cuvier).

Measurements.-Total length, 45 inches; tail vertebrate, 18 inches.

Range.-Found in southeastern states, North and South Carolina; limit of range unknown (Anthony).

Description.-The jdentification of the otter found in Louisiana is only provisional. Skulls from Cameron parish examined by E. Reymond Hall indicate that our otter represents a form intermediate in size between $L$. c. lataxinc and $L$. c. vaga, but Dr. Hall believes that until further research is made that the Louisiana otter should stand as named above.

\section{SKUNKS}

Littile SPotted SkUNK ("Civet Cat"). Spilogale indianola Merriam.

Measurements.-Total length, males, from 17.6 to 21 inches; tail vertebrate, 6.6 to 8.2 inches; hind foot, 1.8 to 2 inches. Females are slightly smaller than the males.

Ringe-Coast region of Texas and Louisiana; south to Victoria, Tamaulipas, Mexico (Howell). This skunk is found in Calcasieu, Jefferson, Jefferson Davis, Terrebonne, Lafourche, Livingston, Iberville, Allen, Cameron, East and West Feliciana, and Vernon parishes. The Louisiana distribution has not been thoroughly worked out.

GUIF STRIPED SKUNK. Mephitis elongata (Bangs).

Measurements.--Tutal length, 28 inches; tail vertebrate, 12.6 inches; hind foot, 3 inches.

Range.-Florida to North Carolina, and in the mountains to West Virginia; West on the Gulf coast to the Mississippi river (Howell). It would appear from our researches that the Mississippi river is not the western limit of this species, so its range in Louisiana as given is merely provisional.

D.:scription.-Size medium, with sexes abolıt equal; tail very long, marker with white on the sides, and with a long white pencil; markings on back variable but white stripes usually very broad ( Howell). 
LOUISIANA STRIPED SKUNK. Mephitis mesomelas mesomelas Lichtenstein.

Measurements.-Total length, 23 inches; tail vertebrate, 9 inches; hind foot, 2.5 inches. Sexes vary but little in size.

Range.-Wtst side of Mississippi Valley from southern Louisiana to Miscouii; westward along the coast of Texas to Matagorda Island; and up the Red River Valley as far at least as Wichita Falls (Howell).

Description.-Small in size, variable in color, Howell finds; tail short usually entirely black; white stripes may or may not reach to tail. Not much difference in size between sexes.

\section{FOX}

GRAY Fox. Uroeyon einereoargenteus floridanus Rhoads.

Measurements.-Total length, 36 inches; tail vertebrate, 10.5 inches; hind foot, 5 inches.

Range.-Found from Florida west to eastern Texas, according to Anthony. Whether we have in Louisiana, in the northern part of the state, of course, the typical $U$. c. cinereoargenteus remains to be proved.

Description.-The Gulf coast gray fox is described by Anthony as being smaller than the typical eastern species, with harsher pelage and shorter ears, tail and hind foot, the underparts are fulvous. The eastern form, whose southern limits meet the northern range of floridanus, is given a length of 40 inches; tail vertebrate, 12 inches; hind foot, 5 inches. Sixes should average same size.

\section{WOLF}

Gray Wolf. Canis floridanus Miler.

Measurements.-Total length, males 64 inches, females 56 inches; tail vertebrate, male: 16 inches, females 12 inches; hind foot, malis and females, 10 inches.

Range-Found in Florida; limits of range unknown (Anthony).

Deseription.-Our wolf is identified as $C$. florilcenus on the authority of Dr. Hartley H. T. Jackson, U. S. Biological Survey, after an examination of two skulls from Beauresard $i$ a ist. Dr sucison points out that his identification is only provisio..... Uur wo f resembles the eastern timber wolf, C. lyacon, in general cranial characters, the pelage is a light buffy gray mixed with black on the upperparts; rusty red on muzzle, legs and feet. There is also a black phase, also typical of the wolf from Florida. See chapter on Wolf.

\section{WILD CAT}

BAY LYNX. Lynx ruffus floridanus (Rafinehque).

Measurements.-Total length, 39 inches; tail vertebrate, 7 inches; hind foot, 7.5 inches. Males average larger than females.

Range.-According to Anthony, this subspecies is found in Florida, north to Georgia, west to Louisiana. It has a uniform distribution throughout the state.

Description.-Siee cliapter on Wild Cat.

\section{BEATER}

BeAver. Castor canadensis earolinensis Rhodes.

Measurements.-Total length, 45 inches; scaly portion of tail, 11 by 6.3 inches; hind foot, 7.4 inches.

Range.-Given by Anthony as North Carolina, south to northern Florida and the Gulf of Mexico, west to eastern Texas. In Louisiana found 
today only in certain parts of East Feliciana, St. Helena, Eust Baton Rouge and I.ivingston palishes. See map on page 161 .

1). scription.-The so-called Carolina beaver is larger than the typicul canadensis, and has a relatively broader tail; the pelage, accordins to Anthony, is bright hazel on the back, brigtening to cimnamonrufous on the rump. The type beaver of the sorth is given a length of 43 inches, with a tail measuring 16 by 4.5 inches broad, and a i-inch hind foot. The identitication of $C$. c. carolinensis for the Louisiana beaver is only provisional.

\section{MUSRAT}

Louisiana Muskrat. Fibcr rivalicius (Bangs).*

Measurements. - Total length, 22 inches; tail verteblate, 10 inches; hind foot, 2.9 inches.

Range-Gulf coast only of Louisiana; west, from High Island, Tex. : east to Pascagoula, Miss. (possibly to Mobile Bay, Ala.); north in Louisiana to north shore of Lakes Pontchartrain and Maurepas, up Mississippi river in scatteled localities, principally rice fields, to Pointe Coupee parish; in western Louisiana, rice fields in Allen parish.

Description.- See chapters on Muskrat.

* Ondatra rivalica of some authors. 

A P P E N D I X 



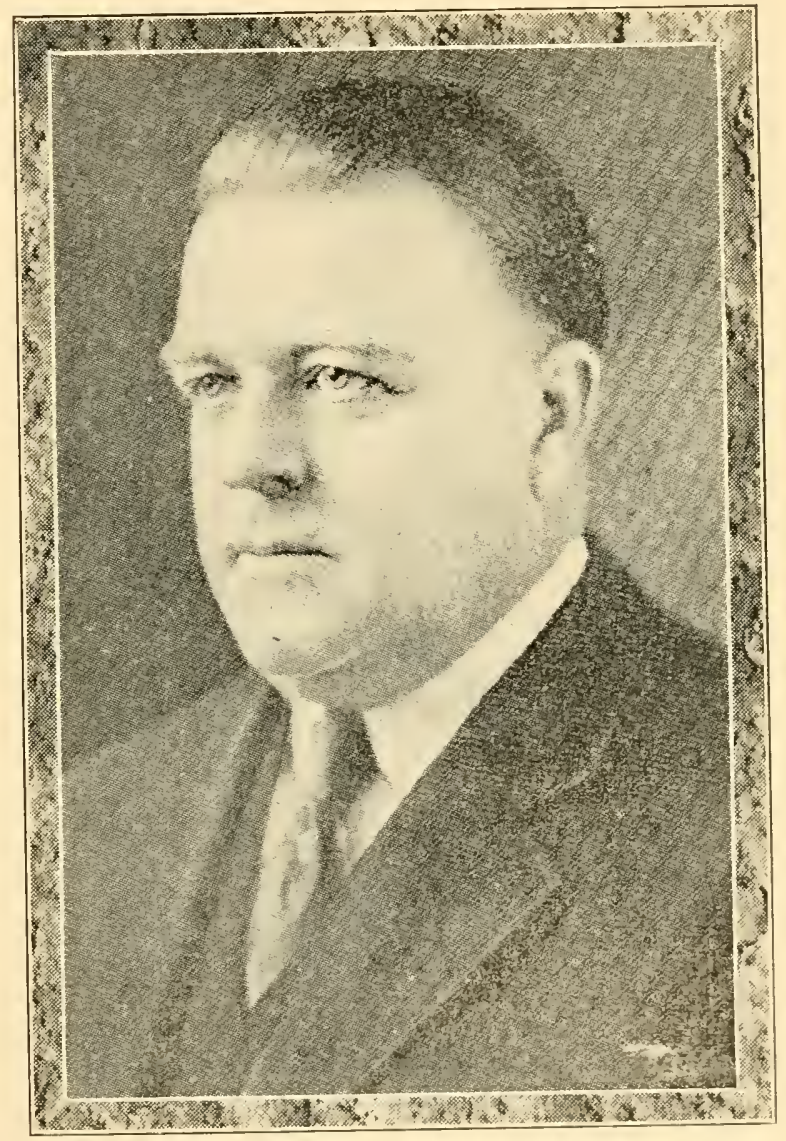

HON. EDWARD A. MCILHENNY

Father of Louisiana Wild Life Refuges 



\section{The Greating of the Wild Life Refuges in Louisiana}

I.

\section{The Louisiana State Wild Life Refuge}

T N MARCH, 1910, I was in a sporting goods store in New Orleans looking over some fishing tackle. The clerk serving me, called me by name, and at once a man standing at the counter near me, turned to me and said, "Are you Mr. McIlhenny of Avery Island?" On being assured that I was, he said, "I am Charles Willis Ward, of Michigan, and I have been wanting to meet you for a long time, to learn at first hand how you have accomplished the protection of the wild life in Louisiana, for which you are famous."

This was my first meeting with Mr. Ward, who was destined to be of such great assistance in establishing the Louisiana Wild Life Sanctuary.

During our conversation at this first meeting, I learned of Mr. Ward's interest in birds, plants, shooting, and fishing. Recognizing in him a kindred spirit-for all my life these subjects had interested me more than any others-I asked him to come to Avery Island and spend a week-end with me. Mr. Ward told me he was camping on Wolf River, back of Pass Christian, Mississippi, and would be very glad to accept my invitation, as soon as he felt well enough. He explained that he was just recovering from a severe illness, and was under the care of a trained nurse.

I had quite forgotten about Ward, when he arrived at Avery Island, about three weeks later. I took him to my house expecting he would stay two days at most, but he was so fascinated with the bird and plant life, and the fishing, that he remained two weeks. Mr. Ward was greatly impressed with my building and protecting the Egret and Heron colony on Avery Island, which at the time of his visit contained about 15,000 pair of nesting birds. This "Heronry" started by me in an artificial pond in 1893, with a few pair of Egrets, in an effort to save this bird from extermination, and later as a duck sanctuary, had proven a wonderful success, and demonstrated the fact that year 
after rear if given proper protestion and environment, migratory birds would return to the protected area.

This little experiment in conservation by me was the first demonstration of the wild life sanctuary idea for migratory birds in the world, and was the object lesson on which the wild life refuge plan has been built.

During Mr. Ward's visit with me, we together visited a 54,000-acre block of land on the south side of Vermilion Bay, which I had under lease from the Orange Land Company for the purpose of protecting the ducks and geese during their winter sojourn in Louisiana. On this property I had maintained a warden service during the winter, and it had become a famous winter resort for great numbers of wild fowl. Mr. Ward was very anxious to buy this property, and before the year was out he and I bought it jointly. As scon as we had title to this property, I used my best efforts to close it to all shooting, with the exception of a couple of thousand acres, which I proposed we should keep for our personal shooting grounds. Mr. Ward would not agree to this, but I finally got him to agree to set aside 13,000 acres of the best of the property for a wild life sanctuary. The locating of the 13,000 acres he left entirely to me, and I selected that portion having in its area the greatest amount of duck-feed growing ponds, and the great goose-graveling beach at Hell Hole.

As soon as the location of the 13,000 acres had been determined and a survey made, I at once took up with the Board of Commissioners for the Protection of Birds, Game, and Fish, (the Department of Conservation not then having been created), the question of acceptance of the proposed wild life refuge, and on the 25th of July, 1911, the Board of Commissioners for the Protection of Birds. Game, and Fish, adopted a lengthv resolution appointing "Frank M. Miller, President of said board to accept the contemplateri deed of gift."

On November 4, 1911, a little more than a year after we purchased the Vermilion Bay propertv. Mr. Ward and I donated to the State of Louisiana the 13,000 acres now known as the Louisiana State Wild Life Sanctuary-the proportion of the gift being three-fourths by Ward and one-fourth by McIlhenny. This was the first wild life refuge in the world, privately donated, for the public good. 
II.

\section{MARSH ISLAND}

I realized that if the migratory wild life of the Mississippi Valley was to be preserved for all time, a much greater area of winter feeding and resting ground must be provided for permanent refuges.

During the summer of 1911 , I quietly got together options on Marsh Island, a long strip of wonderîul duck and geese country lying between Vermilion Bay and the Gulf of Mexico, in Iberia Parish, Louisiana. The acquiring of the ontions to purchase this property required a very large amount of detail work, and occupied almost my entire time from early summer until late fall. First, the numerous individuals who owned the property had to be incluced to sell their lands, at a price at which I could feel justified in making the attempt to raise the purchase price. Second, the various titles to the different parcels of land had to be perfected. This in itself seemed almost impossible, and but for the able assistance of $\mathrm{Mr}$. John Dymond, $\mathrm{Jr}$., and $\mathrm{Mr}$. A. Giffen Levy, this part of the work would never have been accomplished. Third, to have a proper survey of the property made, as no actual survey had ever been made and the boundary, as afterwards proven, must have been located by guess.

By the middle of December, 1911, all troubles had been overcome, and as Mr. C. W. Ward had come South for the winter, I laid my plan for this additional refuge before him, and he at once agreed to join me in putting up the necessary cash to procure an option on this property.

This being accomplished, and a six months option being secured, I left for the North to lay before my many sportsmen friends my plan for acquiring this great tract of land for a permanent wild life refuge. Reaching Chicago on January 8, 1912, in twelve days I secured pledges amounting to $\$ 38,000.00$, with the promise of considerably more. I then went to New York and at once got in touch with $\mathrm{Mr}$. Wm. T. Hornaday, who was at that time greatly interested in the conservation of our wild life. Mr. Hornaday kindly gave me a letter of introduction to $\mathrm{Mr}$. Robert W. DeForest. On January 25, 1912, by special appcintment, I met Mr. Robert W. DeForest and Mr. Henry W. DeForest, and went fully into the advisability of establishing this great wild life sanctuary in Louisiana. These gentlemen at once thought favorably of the plan and promised to give me their assistance. They brought the matter to the attention of Mrs. Russell Sage, and after numerous conferences, and at her request, a thorough investigation of 
the adaptability of the property for the conservation of wild life was ordered, and Mr. George Byrd Grinnell was sent to Louisiana to make the investigation. Mr. Grinnell arrived at Avery Island on March 4 and spent four days going over the Marsh Island proposition.

Gi March 18, I was advised by wire by Mr. DeForest that Mr. Grinnell had reported favorably. I at once went to New York where arrangements were made for the purchase of Marsh Island in its entirety, by Mrs. Sage. All those who had pledged their support to aid in the purchase were relieved of their pledges, and on the 22nd of July, 1912, Mrs. Sage paid the purchase price for Marsh Island, leaving the title of the property in my name until it was decided what body politic should finally receive it.

The property purchased by Mrs. Sage was:

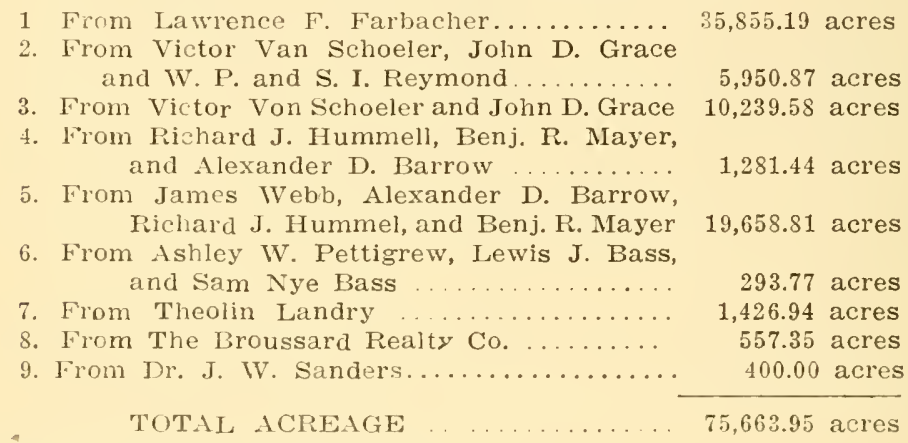

for the price of $\$ 162,980.02$.

On August 12, 1913, I, acting as agent for Mrs. Russell Sage, tendered Marsh Island to the Conservation Commission of Louisiana, for a period of five years, to be used as a wild life refuge, which tender was duly accepted, and Marsh Island was placed under the control of the State of Louisiana.

\section{III.}

\section{The Rockefeller Foundation Wild Life Refuge}

Shortly after I acquired Marsh Island for Mrs. Russell Sage, a large body of land, 86,000 acres, lying in the Western Vermilion and Eastern Cameron Parishes bordering the Gulf of Mexico for many miles, was brought to my attention.

I knew the land quite well, having hunted ducks and geese over various sections of it and I knew it was highly 
adaptcd for a winter feeding and resting refuge for migratory wild fowl, and I determined, if possible, to secure wis land, also, as a permanent wild life refuge.

On Uctober 12, 1912, assisted by Messr's. Sol Wexler and John E. Bouden, Jr., I paid $\$ 8,000.00$ for an option on this property, subject to the examination of the title. $\mathrm{Mr}$. John Dymond, Jr., and Mr. A. Giffen Levy undertook this title examination, and they having approved the title, I secured an additional option for six months, on December 11,1912 -by the payment of $\$ 20,000.00$ in cash-to purchase the property.

I at once went North to again call on my sportsmen friends for assistance, and met with the same hearty response, securing pledges for a little more than $\$ 45,000.00$ in less than two months, Mrs. Russell Sage again nobly coming to the front with a donation of $\$ 5,000.00$. Before this option expired I had secured pledges sufficient to warrant my purchasing the property. As I could not use any of the pledge money until all the purchase price had been raised, I bought the property in my own name on June 12 , 1913 , paying $\$ 27,500.00$ in cash, and giving vendors' lien notes for $\$ 185,000.00$, thus completing the purchase price of $\$ 212,500.00$.

Through the able assistance of Messrs. Robert W. and Henry W. DeForest, the merits of my wild life refuge plan were brought to the attention of of the Rockefeller interests, and after many conferences and much correspondence, Mr. Star J. Murphy, attorney for the Rockefeller interests, was instructed to investigate the merits of the proposition. Mr. Jerome D. Green, secretary of the Rockefeller Foundation, was sent to Louisiana for this purpose in the early fall of 1913, spending six days in a most thorough investigation. On his return North, Mr. Green reported favorably on the project, and I was called to New York for a conference. Several months were spent in perfccting this deal, before the Rockefeller Foundation purchased the 86,000 acres for a perpetual wild life refuge, paying for it $\$ 212,000.00$ cash, on the 20th of May, 1914 .

In order to have the wild life on this great sanctuary afforded immediate protection, I urged the Rockefeller Foundation to place its control in the hands of the Conservation Commission of Louisiana. On May 27, 1914, the Rockefeller Foundation passed a resolution offering full control of this property to the Conservation Commission of Louisiana, for a period of five years. There was some local opposition to the Commission taking over this land and giving it protection, but at a meeting of the full Com- 
mission at my house on Avery Island, on September 24, it was decided to accept the offer of the Rockefeller Foundation, and on September 25, 1914, the Conservation Commission of Louisiana, by proper resolution formally accepted the care of this great wild life refuge, for a period of five years.

The Conservation Commission of Louisiana now had under its management three great tracts of land dedicated for perpetual wild life protection, a total of $174,663.95$ acres. All but 13,000 acres, (being that donated to the State by C. W. Ward and E. A. McIlhemny), was held for a limited time only.

MIy next problem was to have the Sage Foundation and the Rockefeller Foundation deed these lands to the State of Louisiana. This was a more difficult problem than securing the purchase of the lands, but it was finally decided that such a donation was proper, and on December 15, 1919. I wired from New York to Mr. M. L. Alexander, Commissioner of Conservation, that both the Sage Foundation and Rockefeller Foundation had decided to make the gift to the State, and confirmed this information by letter from Avery Island on December 18, 1919, and before the New Year, the deeds to the State were signed and delivered, and Louisiana became the owner of one of the largest and most important wild life refuges in the world.

The cost of these properties to the several donors at the time of purchase, was $\$ 407,480.00$. The value of the properties today, based on the annual fur catch, is $\$ 2,183,-$ 287.00 , acquired at no cost to the State of Louisiana.

(Signed) E. A. MCIllhenNy.

Avery Island, Louisiana, April 4th, 1930. 




